\title{
分子科学アーカイブス
}

\author{
AC0008
}

\section{学部学生のための量子化学講義ノート 後編}

安積 徹 著

公開日 2008 年 1 月 11 日 第 1 版

分子科学会編集委員会は、優れたテキストを分子科学アーカイブスとして公 開しますが、その内容の一切の責任は著者にあります。読者からの貴重なご 意見は、（edit-office@j-molsci.jp）で随時受け付けております。ご意見は編 集委員会から著者にお伝えし、テキストの内容に反映していきます。

著者紹介

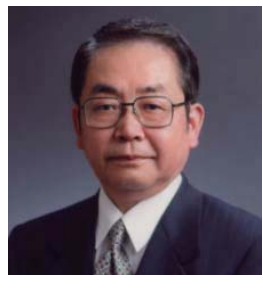

安積 徹（あづみとおる）

所属：東北大学名誉教授 国際教養大学特任教授

専門分野: 分子分光学. 光化学・ スピン化学 


\section{CHAPTER 12}

\section{時間に依存した摂動論}

時間に依存した摂動が系に掛かる場合はいろいろある。例えば，分子に電磁波が照 射される場合には，電磁波自体が時間について振動しているので，摂動も時間に依存 することになる. 分子と電磁波の相互作用は, 吸収スペクトル始め多くの分光学の実 験の基礎理論として非常に重要である. 本章ではこのような理論を発展させるために 必要な，時間に依存した摂動論を学習する。

\section{1 時間に依存した摂動論}

全ハミルトニアン $H(t)$ を

$$
H(t)=H_{0}+H^{\prime}(t)
$$

と表す. $H_{0}$ は time-independent であり,かつ， $H_{0}$ についての eigenvalue と eigenfunction はすでに求まっているものとする。 $H^{\prime}(t)$ が時間に依存した摂動を表す.

全ハミルトニアン $H(t)$ についての時間に依存した Schrödinger equation は，すでに

Section 4.3 で述べたように

$$
H(t) \Psi(t)=-\frac{\hbar}{i} \frac{\partial \Psi(t)}{\partial t}
$$

で与えられる。この式をこのまま解くことが出来れば何の問題もないのであるが，一 般には解けないことが多い.そこで， $H_{0}$ についての eigenvalue と eigenfunction を用い てH(t)についての eigenvalue と eigenfunction を求めよう, というのがこれから学習す る方法である。すなおち，通常の摂動論と同じ考えに基づいているが，ただ異なるの は，時間に依存した Schrödinger equation を用いるということである.

さて， $H_{0}$ の解は求まっているわけで，式(10.1.7)と同様，その eigenvalue を $E_{n}{ }^{0}$, 
eigenfunction を $\psi_{n}^{0}$ とする.

$$
H_{0} \psi_{n}^{0}=E_{n}^{0} \psi_{n}^{0}
$$

$H_{0}$ は時間に依存しないから，その eigenfunction も時間に依存しない形で上のように 表せるわけである。しかし， $H_{0}$ を形式的に時間に依存すると見なして（すなわち， 時間について一定な $H_{0}$ と考えて） $H_{0}$ についての time dependent Schrödinger equation を考えることは出来る。この場合の eigenfunction を $\psi_{n}{ }^{0}(t)$ のように表して，時間の関 数であることを示すことにしよう。

$$
H_{0} \psi_{n}{ }^{0}(t)=-\frac{\hbar}{i} \frac{\partial \psi_{n}^{0}(t)}{\partial t}
$$

$H_{0}$ があらわに時間を含まない場合は直ちに次のような解が求まる.

$$
\psi_{n}{ }^{0}(t)=\psi_{n}{ }^{0} \exp \left(-\frac{i}{\hbar} E_{n}{ }^{0} t\right)
$$

式(12.1.2)の解 $\Psi(t)$ を求めるために, それを式(12.1.5)の $\left\{\psi_{n}{ }^{0}(t)\right\}$ の完全系で展開する.

$$
\begin{aligned}
\Psi(t) & =\sum_{n} c_{n}(t) \psi_{n}{ }^{0}(t) \\
& =\sum_{n} c_{n}(t) \psi_{n}{ }^{0} \exp \left(-\frac{i}{\hbar} E_{n}^{0} t\right)
\end{aligned}
$$

この式を式(12.1.2)に代入する.

$$
\begin{aligned}
& \sum_{n} c_{n}(t) H_{0} \psi_{n}{ }^{0}(t)+\sum_{n} c_{n}(t) H^{\prime}(t) \psi_{n}{ }^{0}(t) \\
& =-\frac{\hbar}{i} \sum_{n} \frac{d c_{n}(t)}{d t} \psi_{n}{ }^{0}(t)-\frac{\hbar}{i} \sum_{n} c_{n}(t) \frac{d \psi_{n}{ }^{0}(t)}{d t}
\end{aligned}
$$

式(12.1.4)より，左辺の第 1 項と右辺の第 2 項とが等しいから,

$$
\sum_{n} c_{n}(t) H^{\prime}(t) \psi_{n}^{0}(t)=-\frac{\hbar}{i} \sum_{n} \frac{d c_{n}(t)}{d t} \psi_{n}^{0}(t)
$$

この式の両辺に左から $\psi_{m}{ }^{0}(t)$ *を掛けて全空間について積分する. 右辺については $n=m$ の時にのみ值を持つので, 次式を得る. 


$$
\sum_{n} c_{n}(t) \int \psi_{m}{ }^{0}(t) * H^{\prime}(t) \psi_{n}{ }^{0}(t) d \tau=-\frac{\hbar}{i} \frac{d c_{m}(t)}{d t}
$$

すなわち

$$
\begin{aligned}
\frac{d c_{m}(t)}{d t} & =-\frac{i}{\hbar} \sum_{n} c_{n}(t) \int \psi_{m}{ }^{0}(t) * H^{\prime}(t) \psi_{n}{ }^{0}(t) d \tau \\
& =-\frac{i}{\hbar} \sum_{n} c_{n}(t)\left[\int \psi_{m}{ }^{0} * H^{\prime}(t) \psi_{n}{ }^{0} d \tau\right] \exp \left\{-\frac{i}{\hbar}\left(E_{n}{ }^{0}-E_{m}{ }^{0}\right) t\right\} \\
& =-\frac{i}{\hbar} \sum_{n} c_{n}(t) H^{\prime}{ }_{m n}(t) \exp \left\{-\frac{i}{\hbar}\left(E_{n}{ }^{0}-E_{m}{ }^{0}\right) t\right\}
\end{aligned}
$$

ここで

$$
H_{m n}^{\prime}(t)=\int \psi_{m}^{0} * H^{\prime}(t) \psi_{n}^{0} d \tau
$$

とおいた。すなわち $H^{\prime}{ }_{m n}(t)$ の integrand に現れる wavefunction は, 時間の因数を除い たものであることに注意したい。

式(12.1.10)は，展開係数 $c_{n}(t)$ に関する連立微分方程式である. この連立微分方程式 を解くことは，現実に遭遇する困難はいろいろあろうが，原理的には係数が求まり， 式(12.1.6)によって正しい time dependent wavefunction が求まることになる.

なお，ここで一つだけ注意したいことは，式(12.1.10)は正確な式であるということ である.もしも式(12.1.10)を正確に解くことが出来れば，それを用いて表した式 (12.1.6)は正確な式ということになる. Chapter 10 で学習した time independent perturbation theory では, 展開を入の何次かで打ち切るという近似が最初から最後まで ついてまわったが，ここではそのような気持ちの悪い近似は入って来ない。では，正 確な解がいつでも求まるかというと, 現実問題としては式(12.1.10)が正確に解けるこ とはほとんどあり得ない。もつとも大きな問題は，多くの場合，完全系は無限個の wavefunction よりなっているので，式(12.1.10)は無限元の連立微分方程式ということ になる．特殊な場合を除いて，無限級数を有限の項で打ち切るということをせざるを 得ないのは time dependent perturbation theory でも存在するむずかしさである。この "truncation"の問題は，摂動論において多くの場合に避けられない大変むずかしい問題 である。 


\section{2 二準位系についてのモデル計算}

式(12.1.10)は一般には, 多元連立微分方程式であるので, それを解くのは容易では ない，そこで本節では，まず，比較的簡単に解が得られる系として仮想的な二準位系 のモデルについて時間に依存した摂動論を解いてみよう.

ここで採用するモデル系は，まず第 1 に 2 準位系であるということで，すなわち， 2 つの状態だけで完全系をなすという場合である。（ $\operatorname{spin} \frac{1}{2}$ の系を除いては現実にはあ り得ない仮想的なモデル系である.）もう1つ近似を導入し，ここでは 1 次の摂動エ ネルギーがゼロになる場合を考える。すなわち，

$$
H^{\prime}{ }_{11}(t)=H^{\prime}{ }_{22}(t)=0
$$

ここでは一応「仮定」として取り扱うが，非常に多くの場合（すなわち，摂動の八ミ ルトニアン $H^{\prime}(t)$ が座標系に対して完全に対称でない限り)，このことは現実に成り立 つ.

式(12.1.10)は式(12.2.1)が成り立つ限り, 次のような簡単な式となる.

$$
\begin{aligned}
& \frac{d c_{1}(t)}{d t}=-\frac{i}{\hbar} c_{2}(t) H^{\prime}{ }^{\prime}(t) \exp \left[-\frac{\mathrm{i}}{\hbar}\left(E_{2}{ }^{0}-E_{1}{ }^{0}\right) t\right] \\
& \frac{d c_{2}(t)}{d t}=-\frac{i}{\hbar} c_{1}(t) H^{\prime}{ }_{21}(t) \exp \left\{-\frac{\mathrm{i}}{\hbar}\left(E_{1}{ }^{0}-E_{2}{ }^{0}\right) t\right\}
\end{aligned}
$$

以下, perturbation は $t=0$ でかかり, その後時間的に変動しない場合を考える. $H^{\prime}(t)$ を図 12.2 .1 に模式的に示す. 


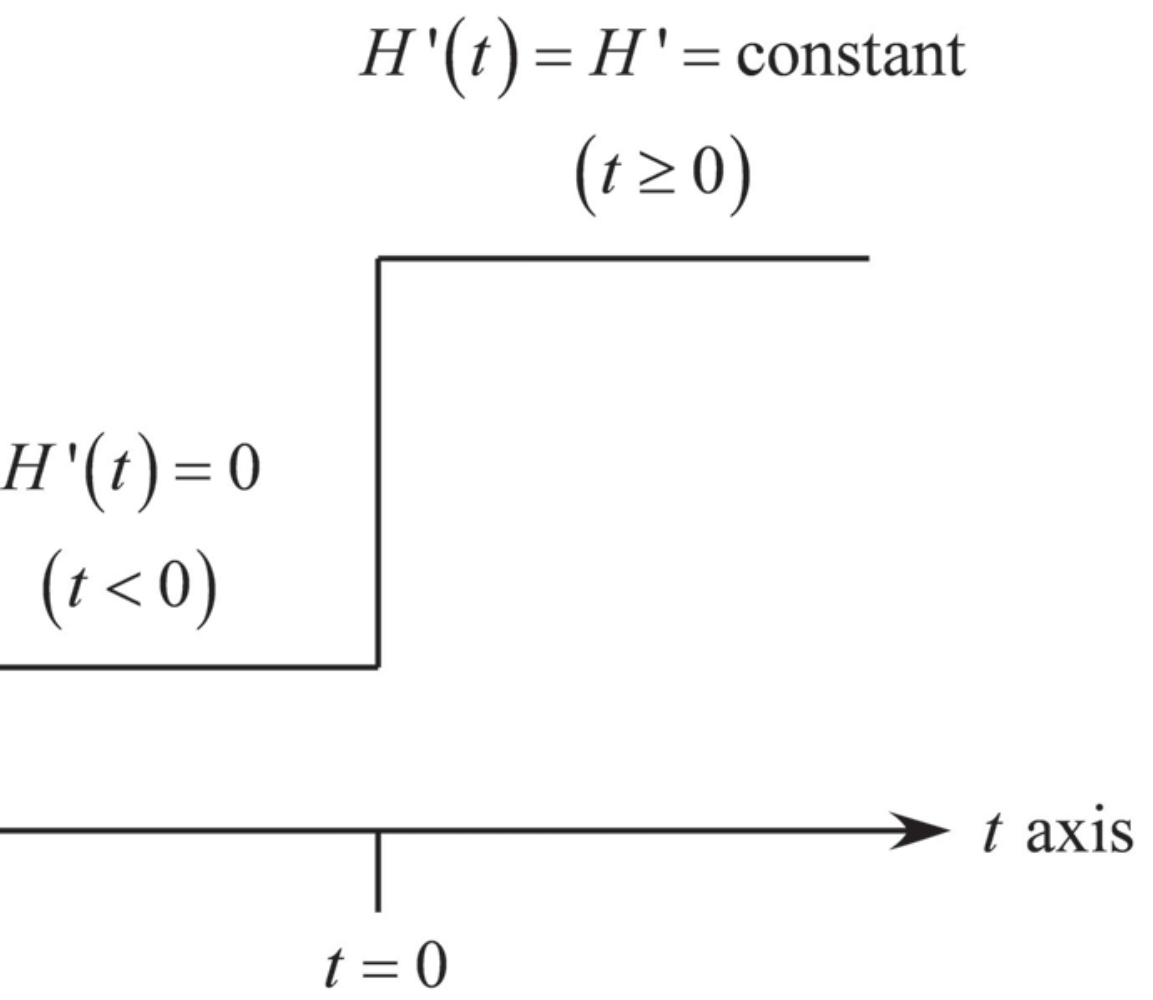

図 12.2.1 時間に依存する摂動

$t>0$ の領域を考えるので，摂動は時間的に変化しない．従って通常の，時間に依存 しない摂動論を用いて解くことが出来るわけであるが，その問題を形式的に，時間に 依存する摂動論で解いてみよう。また，ここでは $H^{\prime}$ をHermitian でかつ real であると 考える。従って

$$
H^{\prime}{ }_{12}(t)=H^{\prime}{ }_{21}(t)=V
$$

更に,

$$
E_{2}{ }^{0}-E_{1}^{0}=\Delta E
$$

とおくと式(12.2.2)は次のようになる.

$$
\begin{aligned}
& \frac{d c_{1}(t)}{d t}=-\frac{i}{\hbar} c_{2}(t) V \exp \left(-\frac{i}{\hbar} \Delta E t\right) \\
& \frac{d c_{2}(t)}{d t}=-\frac{i}{\hbar} c_{1}(t) V \exp \left(+\frac{i}{\hbar} \Delta E t\right)
\end{aligned}
$$

この解を求める方法はいろいろあるが，もつとも初歩的には，第 1 の式を $t$ について 微分し，得られた式に第 2 の式を代入する方法がある. こうして次のような 1 元 2 次 
微分方程式が 2 つ得られる.

$$
\begin{aligned}
& \frac{d^{2} c_{1}(t)}{d t^{2}}+\frac{i \Delta E}{\hbar} \frac{d c_{1}(t)}{d t}+\frac{c_{1}(t) V^{2}}{\hbar^{2}}=0 \\
& \frac{d^{2} c_{2}(t)}{d t^{2}}-\frac{i \Delta E}{\hbar} \frac{d c_{2}(t)}{d t}+\frac{c_{2}(t) V^{2}}{\hbar^{2}}=0
\end{aligned}
$$

初期条件として, $t=0$ にて状態は純粋に $\psi_{1}^{0}$ にある, 寸なわち $c_{1}(0)=1, c_{2}(0)=0$ と いう場合を考える。このような初期条件のもとで式(12.2.6)の解は次のようになる.

$$
\begin{aligned}
& c_{1}(t)=\left(\cos \frac{W}{\hbar} t+i \frac{\Delta E}{2 W} \sin \frac{W}{\hbar} t\right) \exp \left(-\frac{i \Delta E}{2 \hbar} t\right) \\
& c_{2}(t)=-i \frac{V}{W} \sin \frac{W}{\hbar} t \exp \left(+\frac{i \Delta E}{2 \hbar} t\right)
\end{aligned}
$$

ただし，

$$
W=\sqrt{\left(\frac{\Delta E}{2}\right)^{2}+V^{2}}
$$

我々に興味あるのは $c_{1}(t), c_{2}(t)$ そのものよりもむしろそれらを二乗したもの，すなわ ち，時刻 $t$ において $\psi_{1}^{0}$ および $\psi_{2}^{0}$ を見出す確率である. 特に, $t=0$ で存在しなかった $\psi_{2}^{0}$ の時間発展 $P_{2}(t)$ は

$$
\begin{aligned}
P_{2}(t) & =\left|c_{2}(t)\right|^{2}=\left(\frac{V}{W}\right)^{2} \sin ^{2} \frac{W}{\hbar} t \\
& =\frac{4 V^{2}}{\Delta E^{2}+4 V^{2}} \sin ^{2} \frac{\sqrt{\Delta E^{2}+4 V^{2}}}{2 \hbar} t
\end{aligned}
$$

また，当然のことながら， $\psi_{1}^{0}$ の存在確率は

$$
P_{1}(t)=1-P_{2}(t)
$$

である。

以下, エネルギー差 $\Delta E$ の異なったいくつかの場合について $P_{2}(t)$ をもう少し詳しく 吟味してみよう。

（a ）まず，ゼロ次のエネルギーが縮退している場合，すなわち $\Delta E=0$ の場合を考 
える.

上述したように, $H^{\prime}(t)$ は $t>0$ の範囲では time-independent であるから, まず time independent perturbation theory を用いて解いてみよう。 $\Delta E=0$ であるから縮退系への perturbation theory を用いなければならない。解くべき secular equation は

$$
\left|\begin{array}{cc}
H^{\prime}{ }_{11}-E & H^{\prime}{ }^{\prime} \\
H^{\prime}{ }_{21} & H^{\prime}{ }_{22}-E
\end{array}\right|=0
$$

であるが，式(12.2.1)および式(12.2.3)より式(12.2.11)は

$$
\left|\begin{array}{cc}
-E & V \\
V & -E
\end{array}\right|=0
$$

となり，摂動エネルギー $E$ は

$$
E= \pm V
$$

が得られる. wavefunction は容易に次のように求まる.

$$
\begin{aligned}
& E=+V \text { の場合 } \psi=\frac{1}{\sqrt{2}}\left(\psi_{1}^{0}+\psi_{2}^{0}\right) \\
& E=-V \text { の場合 } \psi=\frac{1}{\sqrt{2}}\left(\psi_{1}^{0}-\psi_{2}^{0}\right)
\end{aligned}
$$

以上のことを図 12.2 .2 に示す. 


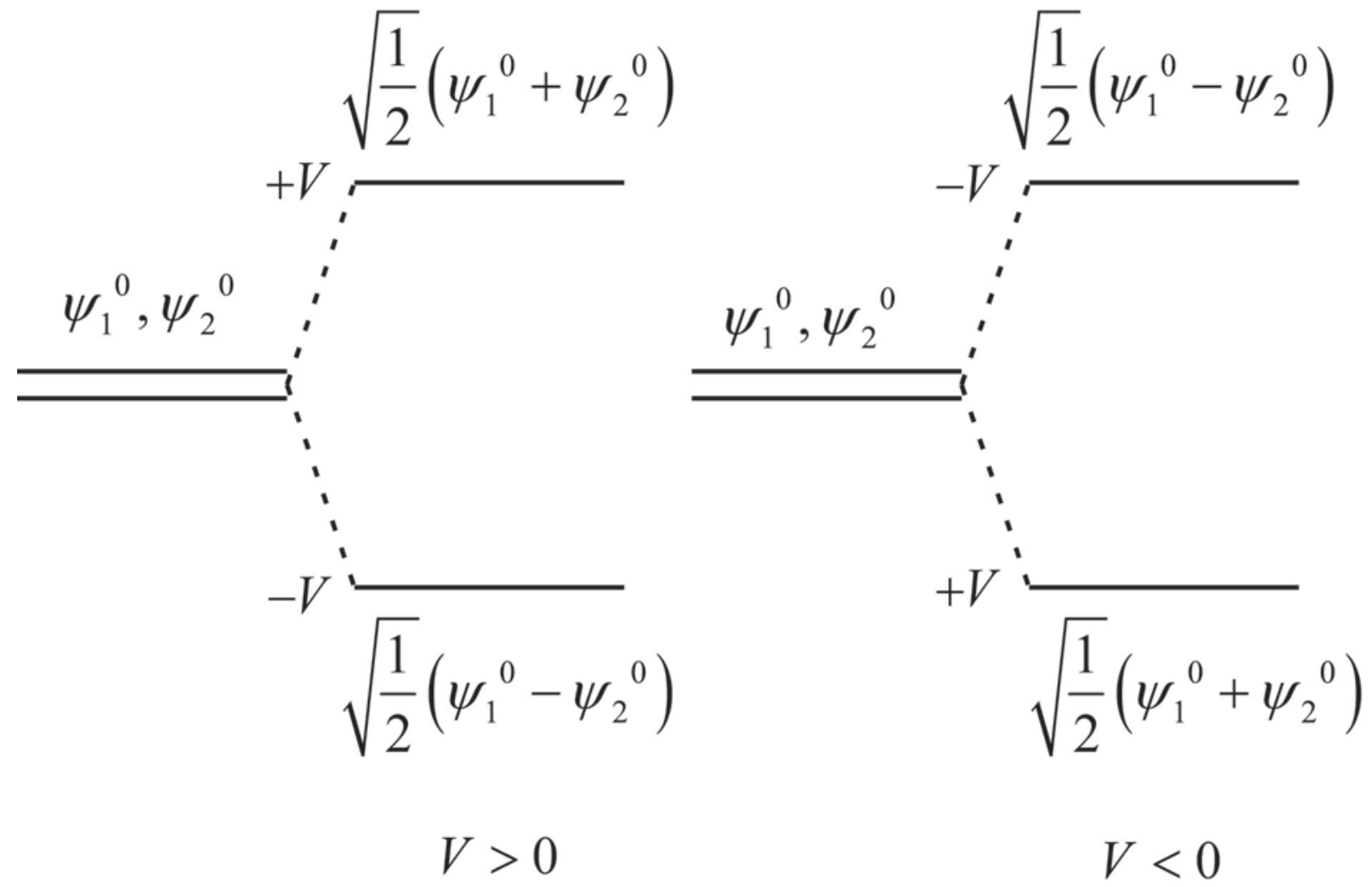

図 12.2.2 $\Delta E=0$ の場合の time-independent perturbation theoryによる解 $V>0$ および $V<0$ の場合

次に，この系を time-dependent perturbation theory を用いて解いてみよう。 $\Delta E=0$ を式 (12.2.9)に代入することによって

$$
P_{2}(t)=\sin ^{2} \frac{V}{\hbar} t
$$

となる.また，当然のことながら，

$$
P_{1}(t)=\cos ^{2} \frac{V}{\hbar} t
$$

$\psi_{1}^{0}(t)$ の存在確率 $P_{1}(t)$ および $\psi_{2}^{0}(t)$ の存在確率 $P_{2}(t)$ を $t$ についてプロットしたもの を図 12.2.3a および㘠 $12.2 .3 b$ に示す。 


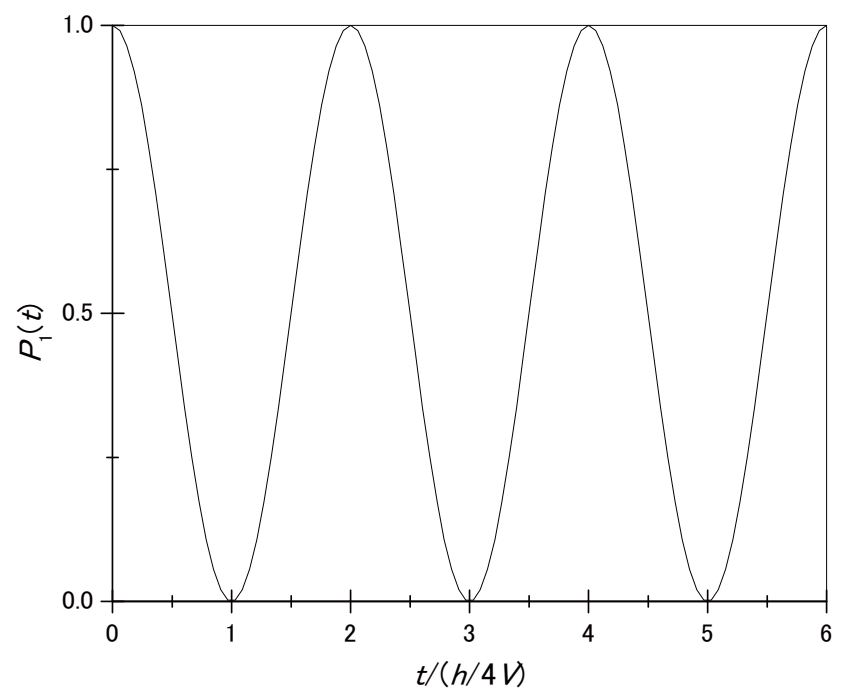

図 12.2.3a $\Delta E=0$ の場合の $P_{1}(t)$

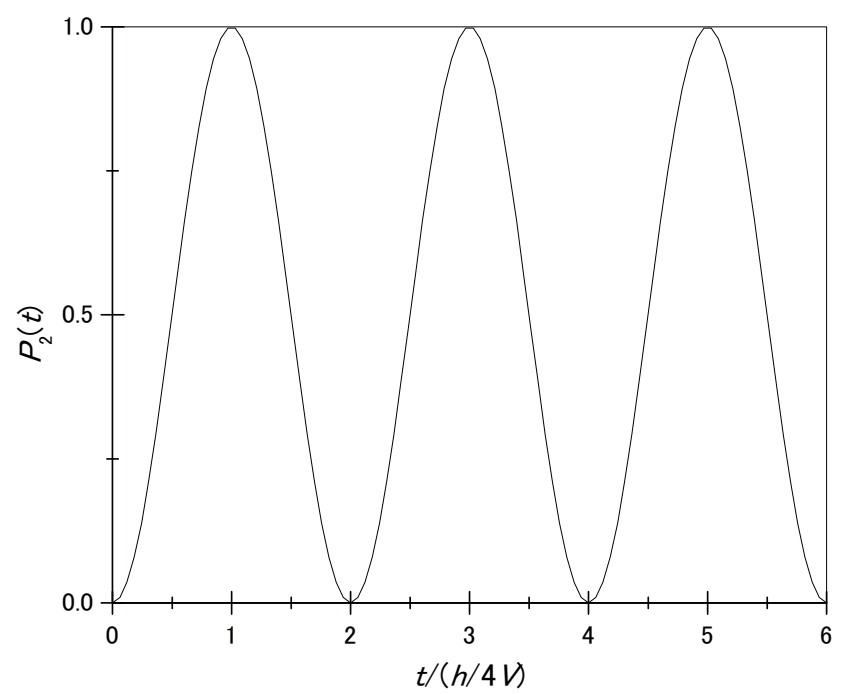

図 12.2.3b $\Delta E=0$ の場合の $P_{2}(t)$ 
図 12.2.3 からも分かるように, $t=0$ で純粋に $\psi_{1}^{0}$ にあった系は, $t=\frac{h}{4 V}$ で純粋な $\psi_{2}^{0}$ に変ってしまう，そしてまた $t=\frac{h}{2 V}$ で純粋な $\psi_{1}^{0}$ に戻って来る．そして再びこの変化 を繰り返す.このように，系の状態は $\psi_{1}{ }^{0}$ と $\psi_{2}{ }^{0}$ の間を行ったり来たりしている.

$t$ が $\frac{h}{4 V}$ の偶数倍であれば系は純粋な $\psi_{1}^{0}$ にあり, また, $t$ が $\frac{h}{4 V}$ の奇数倍であれば系 は純粋な $\psi_{2}^{0}$ にある. $t$ が $\frac{h}{4 V}$ の整数倍でない時, 系は $\psi_{1}^{0}$ でも $\psi_{2}{ }^{0}$ でもなく,$\psi_{1}^{0}$ と $\psi_{2}^{0}$ とが混じり合った状態にある。

以上, $t>0$ の範囲で time-independent な perturbation が掛かった時の問題を，2つの 異なった方法, すなわち, time-independent perturbation method と time-dependent perturbation method の 2 つの方法で解いてみた. time-independent method では, 図 12.2.1 のようにもともと縮退していた準位が 2 つに分裂するという描像が得られた。もとも とあったゼロ次の状態というものはもはや存在せず, この 2 つの線形結合した状態の みが存在する。一方, time-dependent method では図 12.2.2 に示すように，2つのゼロ 次関数の間を行ったり来たりしているという描像が得られた。この 2 つの描像は一見 全く異なっているように見えるが，実は全く同一のものを異なった視点から見ている だけのもので本質的には同じものである. 物質や現象を理解する場合, どちらの考え 方で考えても全く同じことである.

図 12.2.1 に示した例では, $t=0$ で掛けられた摂動がその後ずっと存在すると考えた が，次に $t=0$ から掛け始めた摂動を $t=\frac{h}{4 V}$ で打ち切ることを考えよう。この時間領域 の中で $P_{1}(t)$ および $P_{2}(t)$ は図 12.2.3 と同じように変化し, $t=\frac{h}{4 V}$ で丁度 $P_{1}=0, P_{2}=1$ と なり, $\psi_{1}^{0}$ と $\psi_{2}^{0}$ とが入れ替ったことになる.この時点で摂動は切れるから, その後は $\frac{d c_{1}(t)}{d t}=\frac{d c_{2}(t)}{d t}=0$ で時間変化はない, すなわち以後ずっと $P_{1}=0, P_{2}=1$ が保たれる.

このように摂動を与える時間幅を調節することによって 2 つ準位の分布数を反 転することが出来る。このようなことは, NMR（Nuclear Magnetic Resonance，核磁気 共鳴）の分野でよく使われる技術である.

$(\mathrm{b})$ 次に $\Delta E \neq 0$ の場合を考えてみよう。この場合のありさまを， $\frac{2 V}{\Delta E}$ の值が 1.0 
の場合， 0.5 の場合， 0.25 の場合の 3 つの場合について図 12.2.4に示す.
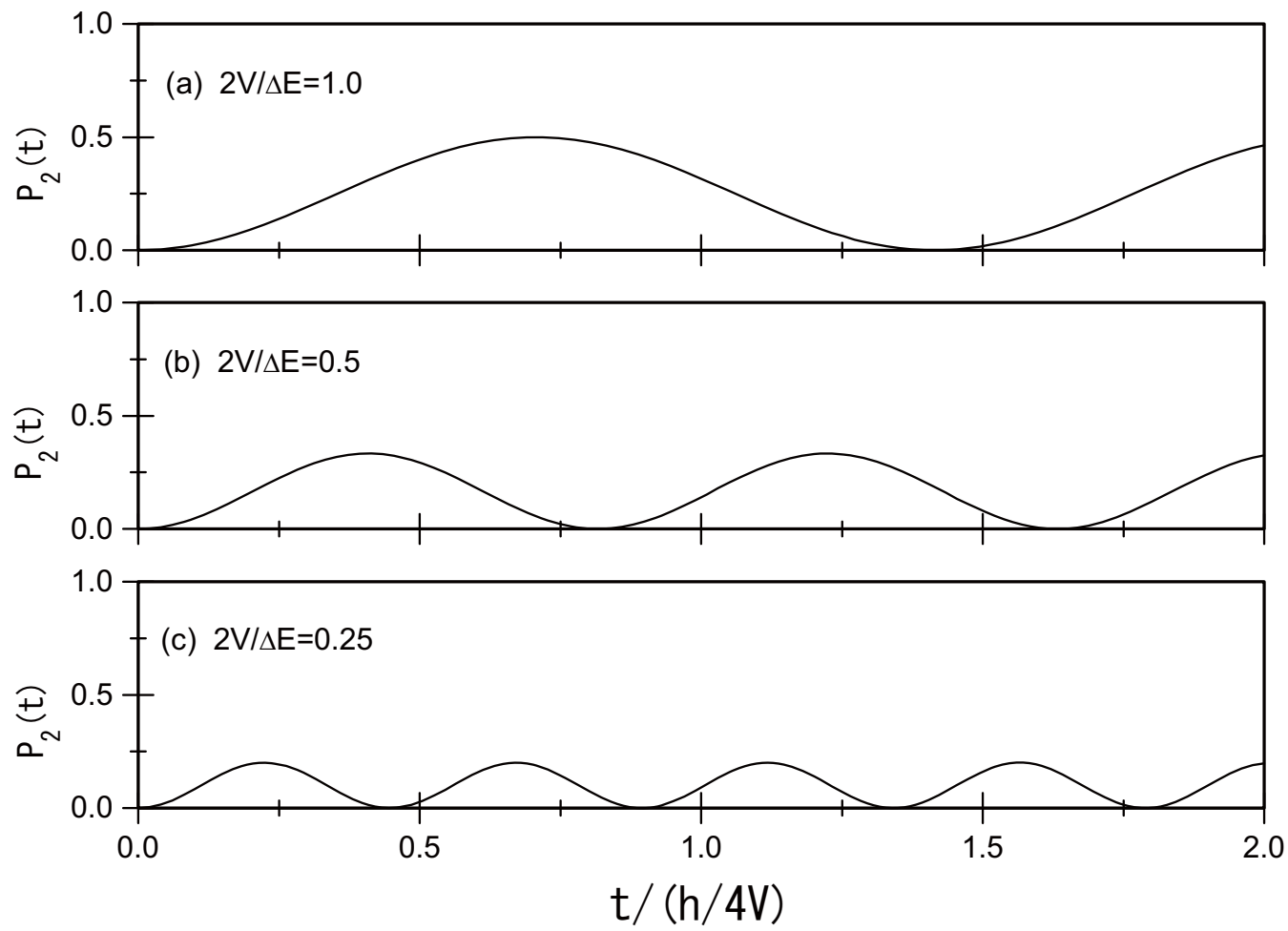

図 12.2.4 $\Delta E \neq 0$ の場合の $P_{1}(t)$ および $P_{2}(t)$.
a) $\frac{2 V}{\Delta E}=1.0$, b) $\frac{2 V}{\Delta E}=0.5$
c) $\frac{2 V}{\Delta E}=0.25$

式(12.2.9)から分かることであるが，図 12.2.4 でも明らかなように $\frac{2 V}{\Delta E}$ が小さくなるに つれて，(1)遷移の確率が小さくなり，かつ，(2)行ったり来たりの頻度が大きくなる. $\frac{2 V}{\Delta E}$ が更に小さくなり

$$
\frac{2 V}{\Delta E}<<1
$$

という条件が成り立つ場合を考える。この場合式(12.2.9)は

$$
P_{2}(t)=\left(\frac{2 V}{\Delta E}\right)^{2} \sin ^{2} \frac{\Delta E}{2 \hbar} t
$$


となる．この場合も当然 $\Delta E$ が大きくなるにつれ，より速く振動し，また，それと同 時に $P_{2}(t)$ の振幅は小さくなる. 寸なわち $\psi_{2}{ }^{0}$ への移行はごくわずかしか起らない. (図 $12.2 .4)$

\section{3 分子の共鳴}

前節で述べたことを念頭において, 化学における重要な概念である分子の共鳴につ いて復習してみよう。ベンゼンは $2 つ の$ Kekule 構造 $\psi_{\mathrm{A}}$ と $\psi_{\mathrm{B}}$ が resonance したもので ある，という考え方はもう何回も学習していることであろう。

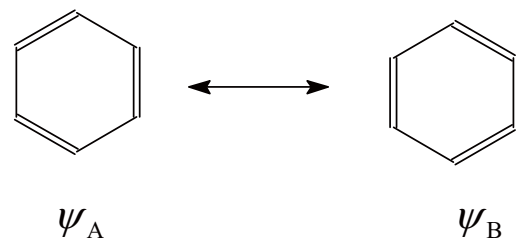

このことは式(12.3.1)のように表わされるのが普通であるが, この両向き矢印は何を意 味するのであろうか?2つの Kekule 構造 $\psi_{\mathrm{A}}$ と $\psi_{\mathrm{B}}$ の間を行ったり来たりしているの か，それとも $\psi_{\mathrm{A}}$ と $\psi_{\mathrm{B}}$ の中間のものがただ 1 つ存在するというのであろうか?実は， このどちらの考え方も正しい，ということを前節で述べたわけである.

2 つの Kekule 構造の間には何らかの相互作用があるはずで, この相互作用の八ミ ルトニアンを摂動 $H^{\prime}$ で考える. 前節で述べたように, time-independent perturbation で 考える方法と time-dependent perturbation で考える方法と 2 つる. time-independent perturbation によると(図 12.2.2), resonanceによって状態のエネルギーは $|V|$ だけ安定化 する.この $|V|$ が resonance energy であることは周知のことであろう. 一方， time-dependent perturbation によると（図 12.2.3），2つの Kekule 構造 $\psi_{\mathrm{A}}$ と $\psi_{\mathrm{B}}$ の間を行 ったり来たりしている．行って戻って来る時間を周期ということにすると，周期は 
$\frac{h}{2|V|}$ で与えられることは図 12.2 .3 からも明らかであろう.片方からもう片方へ移る時 間 (hopping time) は $\frac{h}{4|V|}$ で与えられることにする.そうすると，この周期又は hopping time は resonance energy と関係づけられることが分かる. resonance energy が大きいと いうことは行って戻って来る時間が短いということである。ではこの周期またはその 半分の hopping time は, ベンゼンの場合, 具体的にどの位であろうか? それで resonance energy の大きさを調べてみよう. resonance energy の求め方はいろいろある. 実験的に はベンゼンの生成熱と $\mathrm{C}-\mathrm{H}, \mathrm{C}-\mathrm{C}, \mathrm{C}=\mathrm{C}$ の結合エネルギーから求める方法や水素化の エンタルピーから求める方法などがある. 又, 理論的に計算で求める方法もないわけ ではない。ここでは水素化のエンタルピーを比較してみよう。

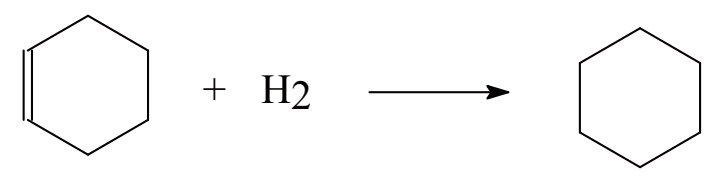

cyclohexene

cyclohexane

$$
\Delta H^{0}=-119 \mathrm{~kJ} / \mathrm{mol}
$$

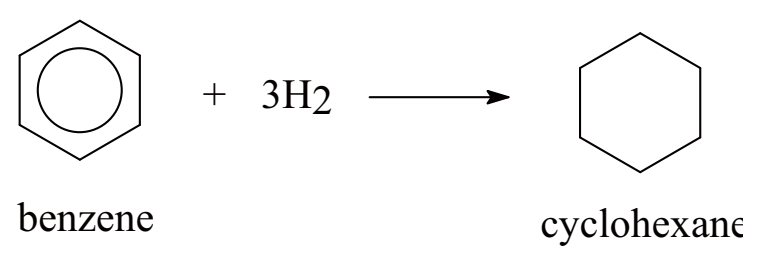

$$
\Delta H^{0}=-206 \mathrm{~kJ} / \mathrm{mol}
$$

この $\Delta H$ の data より

resonance energy $=(119 \times 3-206) \mathrm{kJ} / \mathrm{mol}=151 \mathrm{~kJ} / \mathrm{mol}$

従って，行ったり来たりの周期は

$$
\frac{h}{2 V}=\frac{6.626 \times 10^{-34} \mathrm{Js}}{2 \times \frac{151 \times 10^{3} \mathrm{~J}}{6.02 \times 10^{23}}}=1.32 \times 10^{-15} \mathrm{~s}
$$

ということになる. hopping time はこの半分で $6.6 \times 10^{-16} \mathrm{~s}$ となる. 
ではここの時間を実際に実験で測定することが出来るであろうか?それには原理的 な困難がある. benzene の 2 つ Kekule 構造は現実に存在しない仮想的なものである. Kekule 構造の 1 つは, 1,3,5-cyclohexatriene ではない. 後者は C-C の長さと C=C の長 さが異なる分子である. Kekule 構造はすべての炭素－炭素結合の長さが等しい，正六 角形の骨格で，電子だけがそれぞれの構造式で表されるようなものであり，現在の所 存在しないし, 将来もこういうものが見出されることはないものと思われる. 仮想的 な Kekule 構造が存在しない以上，実験的に周期を測定することは出来ないわけであ る.

\section{胥Problem 12.3.1}

excimer 蛍光と言われるものがある。一口で言うと励起状態で二量体を作ったもの からの蛍光ということになるが，pyrene（構造式は図の中に示してある）を例にとっ て説明しよう。図 12.3.1 は, pyreneの蛍光の濃度変化を示したものである.

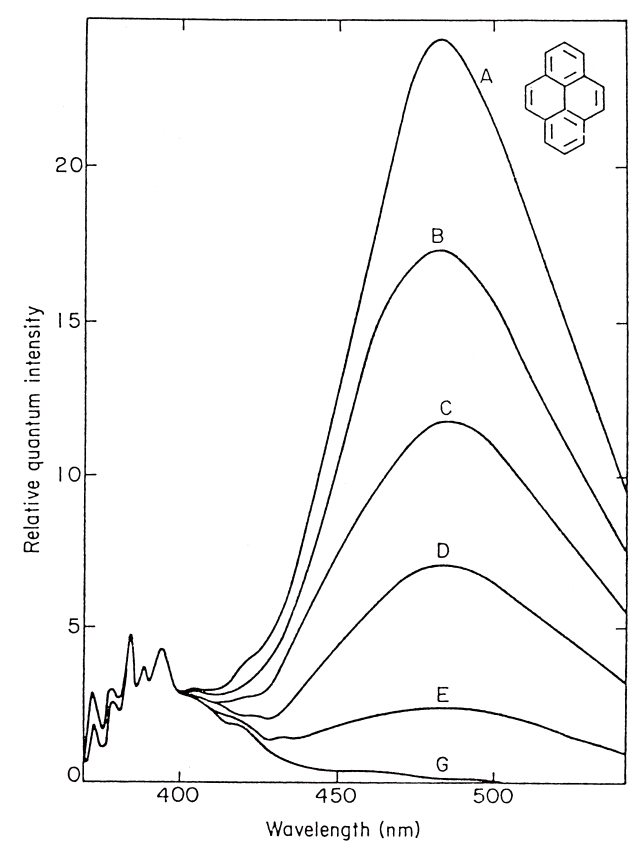

図 12.3.1 pyrene の cyclohexane 溶液の蛍光スペクトルの濃度変化. A: $10^{-2} M$, B: $7.75 \times 10^{-3} M, \mathrm{C}: 5.5 \times 10^{-3} M, \mathrm{D}: 3.25 \times 10^{-3} M, \mathrm{E}: 10^{-3} \mathrm{M}, \mathrm{G}: 10^{-4} \mathrm{M}$

濃度が小さい時には蛍光は $372 \mathrm{~nm}$ からはじまる構造のあるスペクトルを示し，こ れは pyrene 自身の蛍光である.濃度が大きくなるにつれて長波長側に構造のない幅広 
いバンドが表われて来る．そのピークは $480 \mathrm{~nm}$ にある．濃度が大きくなって現れる ものといえばまず会合体（例えば二量体）を考えるのが普通であるが，吸収スペクト ルには濃度変化がないという実験事実から, 基底電子状態では会合していないと判断 される. そこで励起状態でのみ二量体 (dimer)を作っていると考えられる. excited state の dimer ということで"excimer"という言葉が提案され，広く使われている. A という pyrene 分子の基底状態の wavefunction $を \psi_{0}{ }^{\mathrm{A}}$, 励起状態の wavefunction を $\psi_{1}{ }^{\mathrm{A}}$ と表わす と,この excimer 状態は

$$
\psi_{0}{ }^{\mathrm{A}} \psi_{1}^{\mathrm{B}} \leftrightarrow \psi_{1}^{\mathrm{A}} \psi_{0}{ }^{\mathrm{B}}
$$

という resonance で示される，見方を変えれば励起エネルギーが分子 A と B の間を hoppingしていると考えられる.

monomer 蛍光の波長 $372 \mathrm{~nm}$ と excimer 蛍光の波長 $480 \mathrm{~nm}$ の差が，上記 resonance による安定化と考えて（註：この考え方はかなり大雑把で無理があるが，取り敢えず そう考えて）励起エネルギーの hopping の時間を求めてみよ.

\section{4 多準位系における二準位近似}

前節でも述べたように，式(12.1.10)は一般に多元連立微分方程式で，それを解くこ とは不可能ではないかもしれないが，実にむずかしい，前節では二準位系について解 いたが，この節では，多準位系のまま，以下の近似を導入して解いてみよう。

ここで考える近似は，まず第 1 に， $t=0$ では $\psi_{\mathrm{i}}^{0}$ のみがあったとする.（initial state の意味でi という subscript をつけている)。すなわち

$$
\begin{aligned}
& c_{\mathrm{i}}(0)=1 \\
& c_{j}(0) \neq 1 \quad \text { for } \quad j \neq \mathrm{i}
\end{aligned}
$$

第 2 の近似として, perturbation は十分に短い時間内に起ると考える.この近似のもと では， $c_{j}(t)$ を $c_{j}(0)$ と置き換えていいと考えられる．この近似を採用寸ると，注目 している状態 $\psi_{\mathrm{f}}^{0}$ （final state という意味で subscript のf をつけている）の時間発展は 次式で表される. 


$$
\begin{aligned}
\frac{d c_{\mathrm{f}}(t)}{d t} & =-\frac{i}{\hbar} \sum_{n} c_{n}(0) H_{\mathrm{f} n}^{\prime}(t) \exp \left\{-\frac{i}{\hbar}\left(E_{n}{ }^{0}-E_{\mathrm{f}}{ }^{0}\right) t\right\} \\
& =-\frac{i}{\hbar} c_{\mathrm{i}}(0) H_{\mathrm{f} i}^{\prime}(t) \exp \left\{-\frac{i}{\hbar}\left(E_{\mathrm{i}}^{0}-E_{\mathrm{f}}{ }^{0}\right) t\right\} \\
& =-\frac{i}{\hbar} H_{\mathrm{fi}_{\mathrm{i}}}^{\prime}(t) \exp \left\{-\frac{i}{\hbar}\left(E_{\mathrm{i}}^{0}-E_{\mathrm{f}}{ }^{0}\right) t\right\}
\end{aligned}
$$

この式を $t$ について 0 から $t$ まで積分する. $c_{\mathrm{f}}(0)=0$ であるから, $c_{\mathrm{f}}(t)$ は次式のよ うに時間発展をする。

$$
c_{\mathrm{f}}(t)=-\frac{i}{\hbar} \int_{0}^{t} H_{\mathrm{fi}_{\mathrm{i}}}^{\prime}(t) \exp \left\{-\frac{i}{\hbar}\left(E_{\mathrm{i}}^{0}-E_{\mathrm{f}}{ }^{0}\right) t\right\} d t
$$

ここで扱った近似では，上述したように $t=0$ では系は純粋に $\psi_{\mathrm{i}}^{0}$ にあったものが，い ろいろな状態に移行していくわけであるが，そのうちの 1 つの状態として $\psi_{\mathrm{f}}{ }^{0}$ に着目 する限り，式(12.4.3)のように，あたかも $\psi_{\mathrm{i}}^{0}$ と $\psi_{\mathrm{f}}^{0}$ との 2 準位しか存在しないようにみ える式が得られた.これは, 摂動が十分に弱く短い時間内に作用するので, $\psi_{\mathrm{i}}^{0}$ から $\psi_{\mathrm{f}}^{0}$ への直接的な移り変りのみを考えればよいという近似に基づいている.

この近似が成り立つ範囲内では, $H^{\prime}(t)$ の具体的な関数形が与えられれば式(12.4.3)

に基づき， $c_{\mathrm{f}}(t)$ を求めることが出来る.

一例としてまず，図 12.2.1に示したような

$$
H^{\prime}(t)=H^{\prime}=\text { const } \quad t \geq 0
$$

という摂動を考える。ここでも $H^{\prime}$ は real で Hermitian であるから，

$$
H_{\text {if }}^{\prime}(t)=H_{\text {fi }}^{\prime}(t)=V
$$

更に

$$
E_{\mathrm{f}}^{0}-E_{\mathrm{i}}^{0}=\Delta E
$$

とおくと，式(12.4.3)は次のようになる. 


$$
\begin{aligned}
c_{\mathrm{f}}(t) & =-\frac{i}{\hbar} V \int_{0}^{t} \exp \left(\frac{i}{\hbar} \Delta E t\right) d t \\
& =\frac{V}{\Delta E}\left\{\exp \left(\frac{i}{\hbar} \Delta E t\right)-1\right\}
\end{aligned}
$$

従って

$$
\left|c_{\mathrm{f}}(t)\right|^{2}=\left(\frac{2 V}{\Delta E}\right)^{2} \sin ^{2} \frac{\Delta E}{2 \hbar} t
$$

となり，式(12.2.17)と同じ式が得られる。すなわち，式(12.4.4)のような摂動の場合に

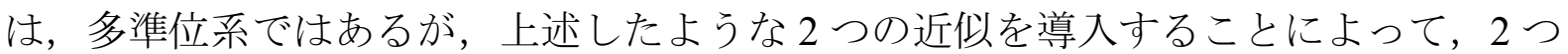
の準位しかない場合と同じ結果が得られたことになる.

もう 1 つの例として

$$
H^{\prime}(t)=H^{\prime}\left(1-e^{-k t}\right)
$$

の関数形で時間変化する perturbation を考える. $t>>\frac{1}{k}$ の時間で $H^{\prime}(t)$ は $H^{\prime}$ に収束す るが，この時刻での係数 $c_{\mathrm{f}}(t)$ はどうなるであろうか. 式(12.4.9)を式(12.4.3)に代入す ることにより次の式を得る.

$$
c_{\mathrm{f}}(t)=-\frac{i}{\hbar} H^{\prime}\left[\frac{\exp \left(i \frac{\Delta E}{\hbar} t\right)-1}{i \frac{\Delta E}{\hbar}}+\frac{\exp \left\{-\left(k-i \frac{\Delta E}{\hbar}\right) t\right\}-1}{k-i \frac{\Delta E}{\hbar}}\right]
$$

ここで

$$
\lambda=\frac{k \hbar}{\Delta E}
$$

とおくと

$$
c_{\mathrm{f}}(t)=-\frac{i}{\hbar} H^{\prime}\left[\frac{\exp \left(i \frac{k}{\lambda} t\right)-1}{i \frac{k}{\lambda}}+\frac{\exp \left\{-\left(k-i \frac{k}{\lambda}\right) t\right\}-1}{k-i \frac{k}{\lambda}}\right]
$$

これより final state の時間発展は次の式で得られる. 


$$
\begin{aligned}
P_{\mathrm{f}}(t) & =c_{\mathrm{f}}(t)^{*} c_{\mathrm{f}}(t) \\
& =\left(\frac{H^{\prime}}{\Delta E}\right)^{2} \frac{1}{1+\lambda^{2}}\left\{\begin{array}{l}
1+2 \lambda^{2} \\
-2 \lambda^{2} \cos \frac{k t}{\lambda}-\left(2-e^{-k t}\right) e^{-k t} \\
-2 \lambda\left(1-e^{-k t}\right) \sin \frac{k t}{\lambda}
\end{array}\right\}
\end{aligned}
$$

図 12.4.1に $P_{\mathrm{f}}(t)$ の時間変化を, $H^{\prime}(t)$ の時間変化と共に示す. 図 12.2.1の $t=0$ で急激 に perturbation が掛かった場合と比べて，今回は perturbation がゆっくりと立ち上がっ ているが， $P_{\mathrm{f}}(t)$ の時閒変化の概略は大差がない， $\lambda$ が小さくなるにつれて，すなわ ち，エネルギー差 $\Delta E$ が大きくなるにつれて， $P_{\mathrm{f}}(t)$ の振動がより激しくなり，かつ， $P_{\mathrm{f}}(t)$ の最大值は小さくなることは, 図 12.2.1 でも見られた傾向である. 

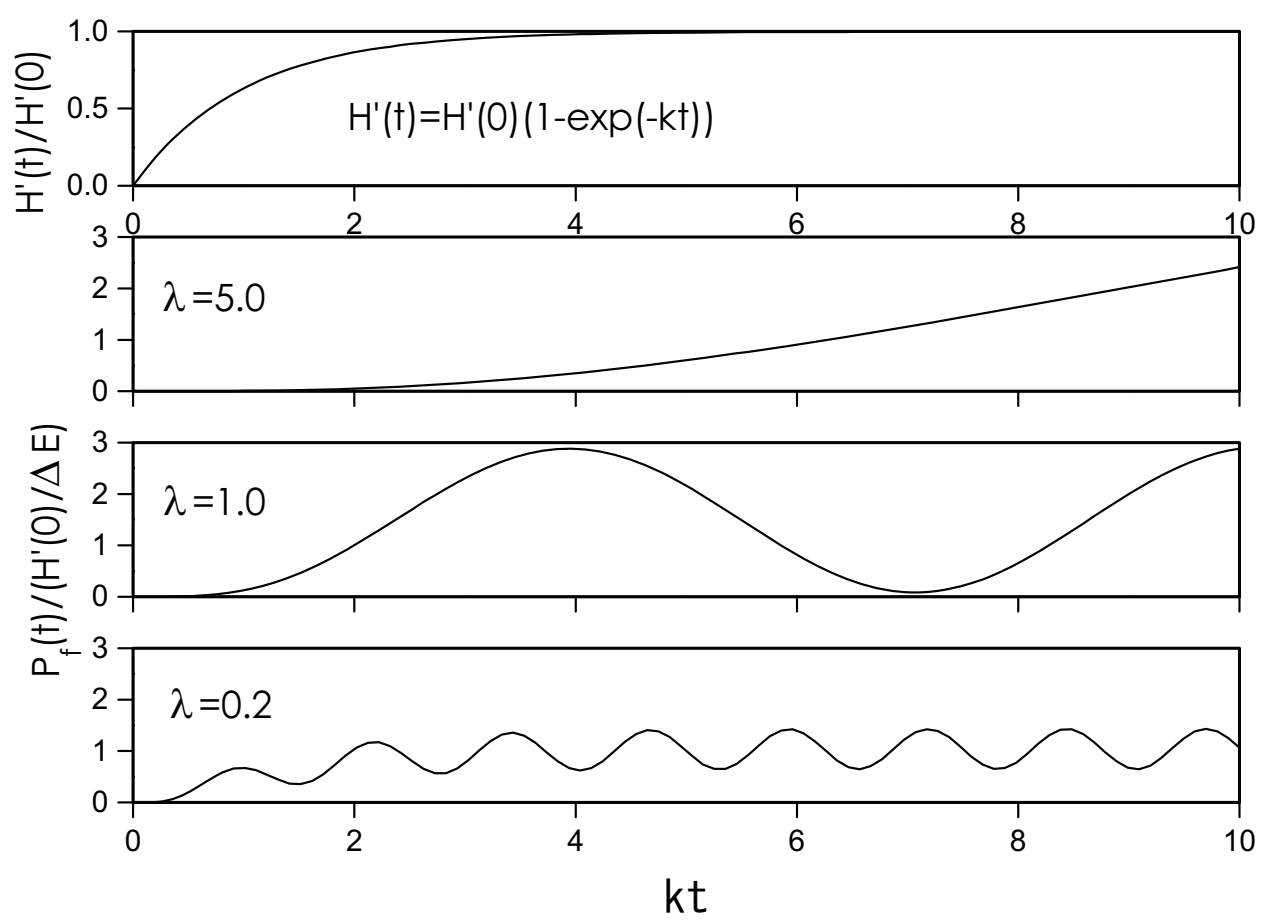

図 12.4.1 式(12.4.7)の形の摂動が加えられた場合の $P_{\mathrm{f}}(t)$ の時間変化 縦軸は $\frac{P_{\mathrm{f}}(t)}{H^{\prime}(0) / \Delta E}$, ただし $\lambda=\frac{k \hbar}{\Delta E}$

次に, $\Delta E$ が更に大きく, $\lambda \ll 1 の$ 条件が成り立ち, 更に, 時間が十分に経過して $t>\frac{1}{k}$ が成り立つ場合を考えてみよう。この場合には式(12.4.10)は

$$
c_{\mathrm{f}}(t)=-\frac{H^{\prime}}{\Delta E} \exp \left(i \frac{\Delta E}{\hbar} t\right)
$$

となるが，これは，二乗すれば 1 になる時間に依存した phase factor $\exp \left(i \frac{\Delta E}{\hbar} t\right)$ を除 いて，二準位系での時間に依存しない摂動論における波動関数についての一次の補正 係数(10.1.23) と完全に同じである.このように, perturbation がゆっくりと掛けられる 時は, time-independent perturbation を用いても実質的には変りがないことが多い. 
胥Problem 12.4.1

この節で行った近似のもとで

$$
H^{\prime}(t)=H^{\prime}(0) \cos 2 \pi v t
$$

の場合の $c_{\mathrm{f}}(t)$ を求めよ. 


\section{CHAPTER 13}

\section{電磁波の吸収と放出}

原子や分子の量子状態を実験的に調べるのにもつともよく使われるのが電磁波と 分子（または原子）との相互作用を観測する分子分光学である. 分子分光学は多岐に わたるが，その中でも電磁波の吸収と放出はもっとも基本的なものである. 物質に色 がついているのはその物質が可視部の光を「吸収」するからである。一方，ネオンサ インの赤い色も蛍光灯の光もすべて物質から光が「放出」したものである．可視部の 光の吸収や放出は日常生活のいたるところで見ているものであるが，電磁波の波長に よっていろいろな種類の分光学が存在する.X 線領域の電磁波の吸収や放出もある し，また，ESRやNMR はそれぞれマイクロ波やラジオ波の吸収（時には放出）であ る.このようにいろいろな種類の分光学があり，それらを学習することは非常に大切 なことである。このChapter では，そのうちのごく一部として，電磁波吸収と放出の 基礎理論を学習する。主として用いる理論は Chapter 12 で学習した time-dependent perturbation theory である.

なお，以下の話では，おおまかにいって，可視部近辺の波長領域の光を頭に入れな がら話を進めていく。しかし，本質的には，波長に関係なくごく一般的に成り立つも のであり，X線分光学にも ESR にも NMRにも，多少の手直しをすれば適用出来る.

電磁波の吸収や放出は分子と電磁波との相互作用を考えることによって理解出来 る. 分子と電磁波との相互作用を量子論的に取り扱う最も良い方法は，分子も電磁波 も共に量子論的に取り扱う方法であり，これは quantum electrodynamics とか quantum field theory と言われる.しかしこの方法は今の段階で学習するにはちょっと advanced すぎる。ここでは，原子や分子の方は量子論的に扱い，電磁波の方は古典的な波とし て取り扱うことにする。

\section{1 電荷をもった粒子と電磁波との相互作用のハミルトニアン}

電磁波というのは，その進行方向に垂直に電場 $E$ と磁場 $B$ が振動している波であ る. 電場の振動方向と磁場の振動方向とは常に垂直である。もし，電場の振動がある 平面内に限られていればその電磁波は「平面偏光」していると言う。多くの場合，単 に「偏光している」（polarized）と表している。この場合，特に断らない限り，偏光の 方向は電場 $E$ の方向であるが，場合によっては磁場 $B$ の方向のこともある， $z$ 軸方向 へ進行する偏光した電磁場をある瞬間に写真に写したとすると図 13.1.1のようにな る. 


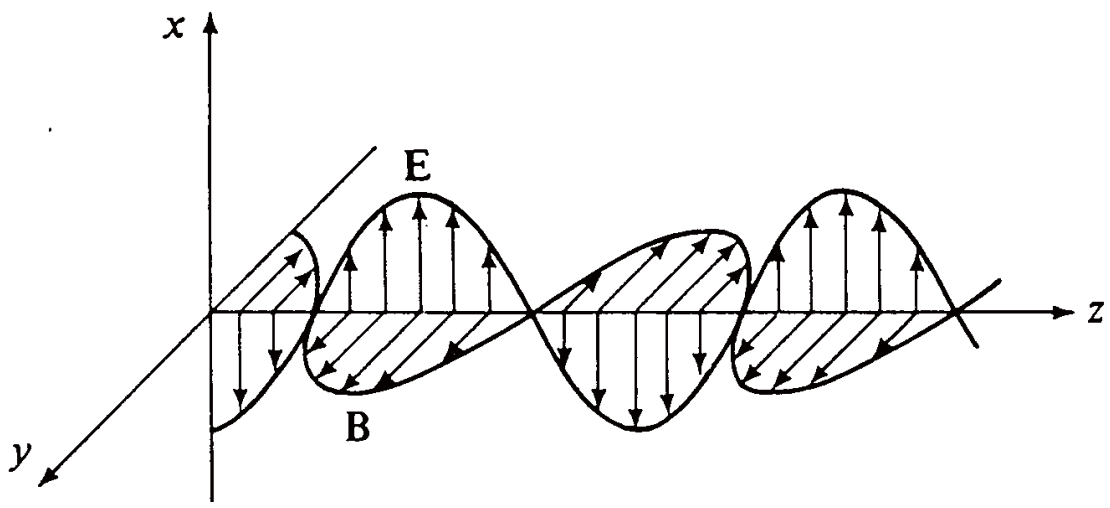

図 13.1.1 $z$ 方向に進行する平面偏光した電磁波

電磁波はその波長 (又は振動数)により，いくつかの異なった名前で呼ばれている. 図 13.1.2 はそれぞれの大まかな領域を示している.

\section{FREQUENCY/Hz}

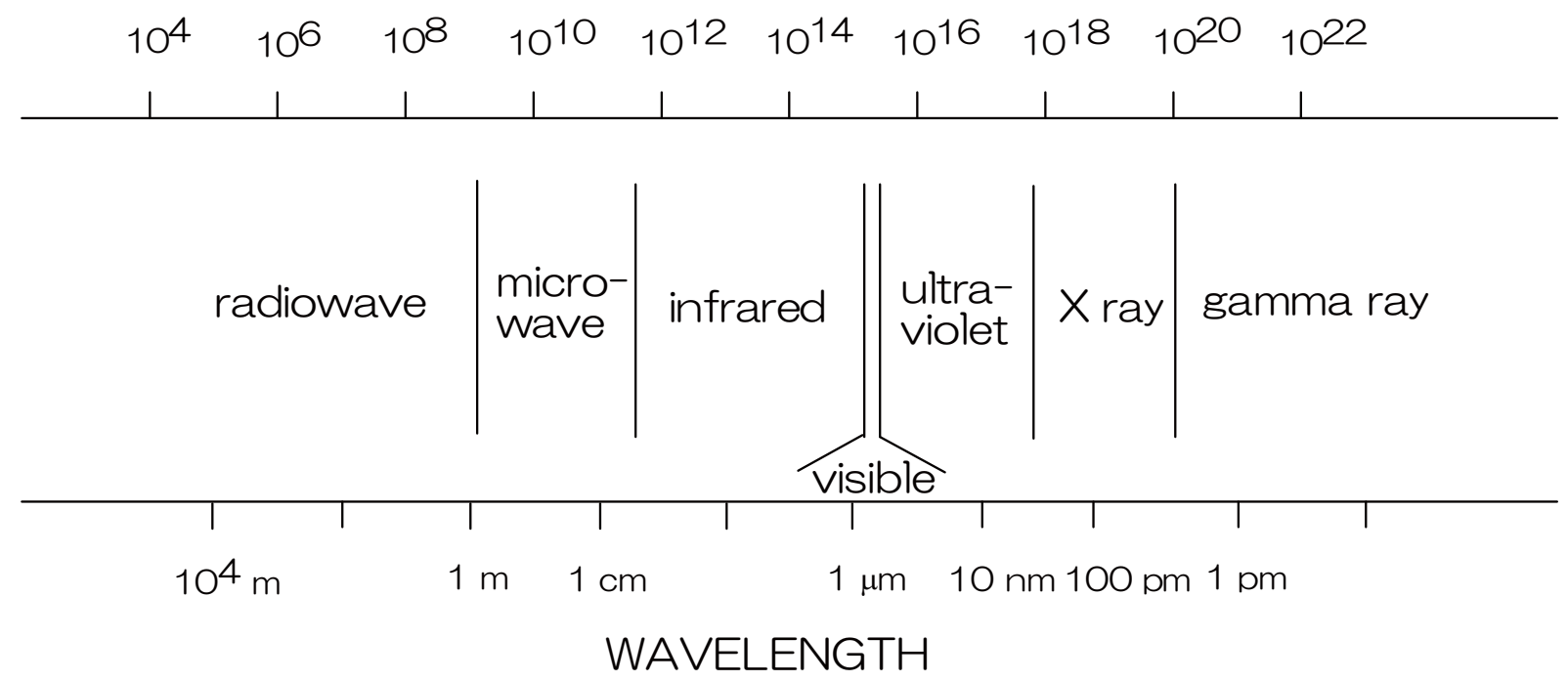

図 13.1.2 電磁波の振動数または波長による分類

我々が通常「光」というと主として赤外線，可視光，紫外線の領域のことを暗黙に意 味している. 周波数がもつと小さいものとしてマイクロ波, ラジオ波と呼ばれている ものがあり，反対に周波数が大きいものとしてX線やガンマ線がある。このように便 宜上，異なった名前が付けられてはいるが，全て，電磁波であり，本質的には同じも 
のである，当然，どの波長の電磁波でも理論は共通であるはずであるが，近似を導入 する段階で微妙に異なって来る．上にも述べたが，本 lecture noteでは，以下，特に断 らない限り，可視部領域位の「光」を想定して議論を進めることにする.

電磁波が分子（又は原子）に照射した時の影響を摂動のハミルトニアンとして表す ことを考える。これが与えられれば, すでに学習した time dependent perturbation theory を用いて始状態や終状態の時間変化を求めることが出来るわけである.

電磁波と分子との相互作用の八ミルトニアンはいろいろな教科書に与えられてい る，そこで，本 lecture noteでは，摂動のハミルトニアンの導出は省略し，結果だけを 示すことにする.

原子または分子に電磁波が照射した時に新たに加わる摂動八ミルトニアンは次式 で与えられる。(例えば Eyring, Walter, Kimball, "Quantum Chemistry" page 108-110。こ の教科書では cgs 単位系を用いているが，それをSI 単位系に変換したのが次式であ

る.）（SI 単位系については Appendix 1 を参照のこと.）

$$
H^{\prime}=-\frac{e}{m_{e}} \sum_{j} \boldsymbol{A}_{j} \boldsymbol{p}_{j}+\sum_{j} \frac{e^{2}}{2 m_{e}}\left|\boldsymbol{A}_{j}\right|^{2}
$$

ここで $\boldsymbol{A}$ は vector potential で電磁波の持っている磁束密度 $\boldsymbol{B}$ と

$$
\boldsymbol{B}=\nabla \times \boldsymbol{A}=\operatorname{rot} \boldsymbol{A}
$$

という関係にある. $e$ は電気素量, $m_{e}$ は電子の質量, $\boldsymbol{p}_{j}$ は $j$ 番目の電子についての運 動量演算子である.

式(13.1.1)の第 2 項目は電磁波が弱い時には, 小さいものの二乗であるから無視出 来る. もっとも, laser のような強い光源を用いての実験では, 第 2 項目も非常に重要 な役割を持つわけであるが，そのような特殊の場合があることを承知の上で，以下の 話ではあえて第 2 項目を無視して，第 1 項目のみを考えることにしたい. 寸なわち， laser 場などの強い電磁波のない場合を想定し，以下は

$$
H^{\prime}=-\frac{e}{m_{e}} \sum_{j} \boldsymbol{A}_{j} \boldsymbol{p}_{j}
$$

を用いることにする.

放Problem 13.1.1

式(13.1.4)は J という dimension を持つことを確かめよ。（ヒント：磁束密度 $B$ の dimension は T (テスラ）である. 従って式(13.1.2)より vector potential の dimension は $\mathrm{Tm}$ (テスラ・メーター) である.） 


\section{2 電磁波の捸動 - 誘導吸収と誘導放出}

Section 13.1 で述べたように，電磁波による摂動ハミルトニアンは，電磁波が強く ない場合,

$$
H^{\prime}(t)=-\frac{e}{m_{e}} \sum_{j} \boldsymbol{A}_{j} \boldsymbol{p}_{j}
$$

で表される.ここで vector potential $\boldsymbol{A}$ は, 当然, 電磁波の持っている振動数で振動し ているわけで, $\boldsymbol{A}_{j}$ の $x, y, z$ 成分 $A_{x j}, A_{y j}, A_{z j}$ は次のように表される.

$$
\begin{aligned}
& A_{x j}=A_{x j}{ }^{0} \cos 2 \pi v t \\
& A_{y j}=A_{y j}{ }^{0} \cos 2 \pi v t \\
& A_{z j}=A_{z j}{ }^{0} \cos 2 \pi v t
\end{aligned}
$$

振動数 (frequency) $v$ の代りに, それを $2 \pi$ で割った角振動数（angular frequency） $\omega$ を 用いることがしばしばある，単なる置き換えに過ぎないが，よく用いられる表し方で もあり，又以下分かるように，場合によっては $v$ を用いた式よりも

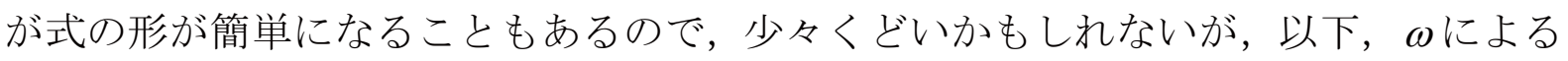
表示も併記することにする. 式(13.2.2)は当然, 次式のようになる.

$$
\begin{aligned}
& A_{x j}=A_{x j}{ }^{0} \cos \omega t \\
& A_{y j}=A_{y j}{ }^{0} \cos \omega t \\
& A_{z j}=A_{z j}{ }^{0} \cos \omega t
\end{aligned}
$$

\section{【註】:}

$v$ も $\omega$ もく用いられるが，どちらかというと電子スペクトルや振動スペクトルの 分野ではvがより popularであり，ESR やNMRの分野では $\omega$ がより popularである. しかし最近は，NMRやESR で研究された手法を電子スペクトルの分野でも研究する ことが出来るようになり，その際，ESRやNMRでの習慣をそのまま引きずって電子 スペクトルの分野でもしばしば $\omega$ が用いられる。vの単位は Hz， $\omega$ の単位は Hz/radian

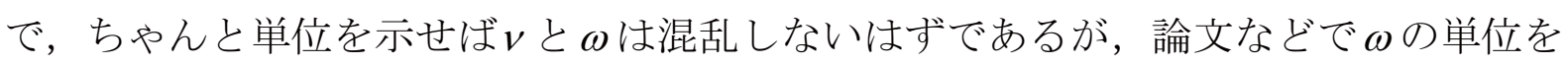
radian を省略して単に $\mathrm{Hz}$ と書いてしまう研究者もいて，分かりづらく厄介なことも ある。論文の值を自分で計算してみると，どうしてもほぼ 6 倍の因子（正確には $2 \pi の$ 因子）だけ異なって悩むなんていうことがよくある. 自分が論文を書く時になったら こういうことも注意してほしい.

以後, 話を簡単にするため, しばらくの間, $z$ 軸方向に進行し $x$ 軸方向に直線偏光 した電磁波を考える。この場合，式(13.2.1)の摂動ハミルトニアンは次のようになる. 


$$
\begin{aligned}
H^{\prime}(t) & =-\frac{e}{m_{e}} \sum_{j} A_{x j}{ }^{0} p_{x j} \cos 2 \pi v t \\
& =-\frac{e}{m_{e}} \sum_{j} A_{x j}{ }^{0} p_{x j} \frac{1}{2}\left(e^{i 2 \pi v t}+e^{-i 2 \pi v t}\right)
\end{aligned}
$$

または

$$
H^{\prime}(t)=-\frac{e}{m_{e}} \sum_{j} A_{x j}{ }^{0} p_{x j} \frac{1}{2}\left(e^{i \omega t}+e^{-i \omega t}\right)
$$

この式で表される時間に依存した摂動が原子または分子の系に与えられた場合を時 間に依存した摂動論を用いて考えていく.

さて，時間に依存した摂動[式(13.2.3)]を Chapter 12 で学習した time-dependent perturbation method を用いて取り扱うのであるが，具体的にどうしたらいいであろう か. 一般には準位の数は無限個あるわけで, 式(12.1.10)の無限元の連立微分方程式を 解くことは不可能である。そこで practical な意味で取り得る方法は次の 2 つうちの いずれか 1 つかないことになる. 第 1 は，式(12.4.3)を用いる方法であり，この方法 が取られることが多い。この方法は perturbation が弱く，かつ，時間が短い範囲内で のみ考えるという近似に基づいていることは Section 12.4 で詳述した通りである。も う 1 つの方法は，光の吸収や放出に直接関与している 2 つ準位のみを考え，その 2 つの準位のみで完全系をなしていると仮に考えてしまって解くという方法である. 2 元連立微分方程式ならなんとか解くことが出来よう．最近のコヒーレント分光法で は，こういった取り扱いをするのが普通である。第 2 の方法はしばらく後で学習する ことにして，当面は第 1 の方法で推し進めることにする.

$t=0$ で系は initial state $\psi_{\mathrm{i}}^{0}$ にあるとする. $t=t$ で final state $\psi_{\mathrm{f}}^{0}$ にある確率は式 (12.4.3)で与えられる.

$$
c_{\mathrm{f}}(t)=-\frac{i}{\hbar} \int_{0}^{t} H_{\mathrm{fi}}^{\prime}(t) \exp \left\{+\frac{i}{\hbar}\left(E_{\mathrm{f}}{ }^{0}-E_{\mathrm{i}}{ }^{0}\right) t\right\} d t
$$

ここで

$$
\begin{aligned}
H_{\mathrm{fi}}^{\prime}(t) & =\int \psi_{\mathrm{f}}^{0} * H^{\prime}(t) \psi_{\mathrm{i}}^{0} d \tau \\
& =\int \psi_{\mathrm{f}}^{0} *\left\{-\frac{e}{m_{e}} \sum_{j} A_{x j}{ }^{0} p_{x j} \frac{1}{2}\left(e^{i 2 \pi v t}+e^{-i 2 \pi v t}\right)\right\} \psi_{\mathrm{i}}^{0} d \tau \\
& =H_{\mathrm{fi}}^{\prime} \frac{1}{2}\left(e^{i 2 \pi v t}+e^{-i 2 \pi v t}\right)
\end{aligned}
$$

さらに 


$$
H_{\mathrm{fi}}^{\prime}=\int \psi_{\mathrm{f}}^{0} *\left(-\frac{e}{m_{e}} \sum_{j} A_{x j} p_{x j}\right) \psi_{\mathrm{i}}^{0} d \tau
$$

とおいた。また，

$$
\Delta E=E_{\mathrm{f}}^{0}-E_{\mathrm{i}}^{0}
$$

または

$$
\omega_{\mathrm{fi}} \hbar=E_{\mathrm{f}}^{0}-E_{\mathrm{i}}^{0}
$$

とおくと，式(13.2.4) と式(13.2.5) より

$$
\begin{aligned}
c_{\mathrm{f}}(t) & =-\frac{i}{\hbar} H_{\mathrm{fi}}^{\prime} \int_{0}^{t} \frac{1}{2}\left[\exp \left\{\frac{i}{\hbar}(h v+\Delta E) t\right\}+\exp \left\{\frac{i}{\hbar}(-h v+\Delta E) t\right\}\right] d t \\
& =-\frac{1}{2} H_{\mathrm{fi}}^{\prime}\left[\frac{\exp \left\{\frac{i}{\hbar}(\Delta E+h v) t\right\}-1}{\Delta E+h v}+\frac{\left.\exp \left\{\frac{i}{\hbar}(\Delta E-h v) t\right\}-1\right]}{\Delta E-h v}\right]
\end{aligned}
$$

または

$$
c_{\mathrm{f}}(t)=-\frac{1}{2} \frac{H_{\mathrm{fi}}^{\prime}}{\hbar}\left[\frac{\exp \left\{i\left(\omega+\omega_{\mathrm{fi}}\right) t\right\}-1}{\omega_{\mathrm{fi}}+\omega}+\frac{\exp \left\{i\left(\omega-\omega_{\mathrm{fi}}\right) t\right\}-1}{\omega_{\mathrm{fi}}-\omega}\right]
$$

以後, $\Delta E=\hbar \omega_{\mathrm{fi}}$ が正の場合と負の場合とに分けて考えよう.

（a） final state $の$ energy が initial state $の$ energy より高い場合，すなわち

$$
\Delta E=E_{\mathrm{f}}{ }^{0}-E_{\mathrm{i}}^{0}>0 \quad\left(\text { または } \omega_{\mathrm{f} i}>0\right)
$$

の場合，式(13.2.8)の第 2 項は分母がゼロの近辺で非常に大きくなり得るので，式 (13.2.8)の第 1 項は十分に無視出来る. 従って

$$
c_{\mathrm{f}}(t)=-\frac{1}{2} H_{\mathrm{fi}}^{\prime} \frac{\exp \left\{\frac{i}{\hbar}(\Delta E-h v) t\right\}-1}{\Delta E-h v}
$$

すなわち 


$$
\begin{aligned}
P_{\mathrm{f}}(t) & =\left|c_{\mathrm{f}}(t)\right|^{2} \\
& =\left(H^{\prime}{ }_{\mathrm{fi}}\right)^{2} \frac{\sin ^{2}\left\{\frac{(\Delta E-h v) t}{2 \hbar}\right\}}{(\Delta E-h v)^{2}} \\
& =\left(H_{\mathrm{fi}}^{\prime}\right)^{2} \frac{\sin ^{2}\left\{\frac{\left(E_{\mathrm{f}}{ }^{0}-E_{\mathrm{i}}{ }^{0}-h v\right) t}{2 \hbar}\right\}}{\left(E_{\mathrm{f}}{ }^{0}-E_{\mathrm{i}}{ }^{0}-h v\right)^{2}}
\end{aligned}
$$

または

$$
\begin{aligned}
P_{\mathrm{f}}(t) & =\left(\frac{H_{\mathrm{f} i}^{\prime}}{\hbar}\right)^{2} \frac{\sin ^{2}\left\{\frac{1}{2}\left(\omega-\omega_{\mathrm{fi}}\right) t\right\}}{\left(\omega-\omega_{\mathrm{fi}}\right)^{2}} \\
& =\left(\frac{H_{\mathrm{fi} i}^{\prime} t}{2 \hbar}\right)^{2}\left[\frac{\sin \left\{\frac{1}{2}\left(\omega-\omega_{\mathrm{fi}}\right) t\right\}}{\frac{1}{2}\left(\omega-\omega_{\mathrm{fi}}\right) t}\right]^{2}
\end{aligned}
$$

$t=0$ で initial state $\psi_{\mathrm{i}}^{0}$ にある分子へ電磁波が照射されると，それより高いエネルギー の final state $\psi_{\mathrm{f}}^{0}$ の存在確率は式(12.2.10)のような時間発展をしていく. 時間発展のあ

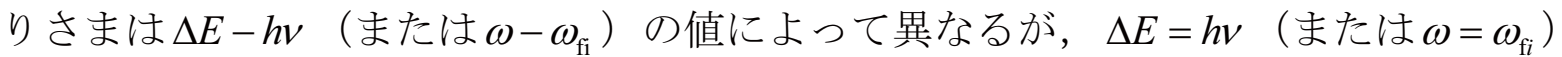
の近辺では initial state から final stateへの「遷移」が起る. この場合 $E_{\mathrm{f}}{ }^{0}-E_{\mathrm{i}}{ }^{0}=\Delta E=\omega_{\mathrm{fi}} \hbar$ に相当するエネルギーは電磁波によって供給されるわけである，すなわち，電磁波は 分子によって「吸収」される。これが電磁波の吸収である。電磁波が照射されて始め て電磁波の吸収が起るわけで，電磁波の誘導吸収（induced absorption または stimulated absorption）という言葉で表される.

（b） final state $の$ energy $E_{\mathrm{f}}^{0}$ が initial state $の$ energy $E_{\mathrm{i}}^{0}$ よりも低い場合，すなおち

$$
\Delta E=E_{\mathrm{f}}^{0}-E_{\mathrm{i}}^{0}<0 \quad\left(\text { または } \omega_{\mathrm{fi}}<0\right)
$$

の場合， $|\Delta E|=h v$ の近辺で（すなおち， $\omega=\omega_{\mathrm{fi}}$ の近辺で）式(13.2.8)の第 2 項は第 1 
項に比べて無視出来る。すなわち

$$
\begin{aligned}
c_{\mathrm{f}}(t) & =-\frac{1}{2} H_{\mathrm{fi}}^{\prime} \frac{\exp \left\{\frac{i}{\hbar}(\Delta E+h v) t\right\}-1}{\Delta E+h v} \\
P_{\mathrm{f}}(t) & =\left|c_{\mathrm{f}}(t)\right|^{2} \\
& =\left(H_{\mathrm{fi}}^{\prime}\right)^{2} \frac{\sin ^{2}\left\{\frac{(\Delta E+h v) t}{2 \hbar}\right\}}{(\Delta E+h v)^{2}} \\
& =\left(H_{\mathrm{fi}}^{\prime}\right)^{2} \frac{\sin ^{2}\left\{\frac{\left(E_{\mathrm{f}}{ }^{0}-E_{\mathrm{i}}^{0}+h v\right) t}{2 \hbar}\right\}}{\left(E_{\mathrm{f}}{ }^{0}-E_{\mathrm{i}}^{0}+h v\right)^{2}}
\end{aligned}
$$

または

$$
\begin{aligned}
P_{\mathrm{f}}(t) & =\left(\frac{H_{\mathrm{fi}}^{\prime}}{\hbar}\right)^{2} \frac{\sin ^{2}\left\{\frac{1}{2}\left(\omega+\omega_{\mathrm{fi}}\right) t\right\}}{\left(\omega+\omega_{\mathrm{fi}}\right)^{2}} \\
& =\left(\frac{H_{\mathrm{fi}}^{\prime} t}{2 \hbar}\right)^{2}\left[\frac{\sin \left\{\frac{1}{2}\left(\omega+\omega_{\mathrm{fi}}\right) t\right\}}{\frac{1}{2}\left(\omega+\omega_{\mathrm{fi}}\right) t}\right]^{2}
\end{aligned}
$$

$t=0$ で energy の高い initial state にある分子一電磁波が照射されると, それより低いエ ネルギーの final state 一式(13.2.12)のような時間発展をしながら「遷移」を起す。この 場合，分子は $E_{\mathrm{f}}{ }^{0}$ と $E_{\mathrm{i}}{ }^{0}$ との差にに相当するエネルギーを「放出」する．これが電磁波 の放出である，後で学習する「自然放出」と異なり，電磁波の照射によって始めて電 磁波の放出が起こるわけで特に「誘導放出」(induced emission または stimulated emission）という言葉が与えられている.

以上みて来たように，誘導吸収の場合と誘導放出の場合，final state の時間発展は， $\Delta E=E_{\mathrm{f}}{ }^{0}-E_{\mathrm{i}}{ }^{0}=\omega_{\mathrm{fi}} \hbar$ の符号の違いを考慮に入れれば実質的に同じ式である. そこで， 以下，誘導吸収の場合の式，式(13.2.10)に従ってもう少し詳しく吟味してみよう. まず式(13.2.10)をプロットした図を図13.2.1に示す. 


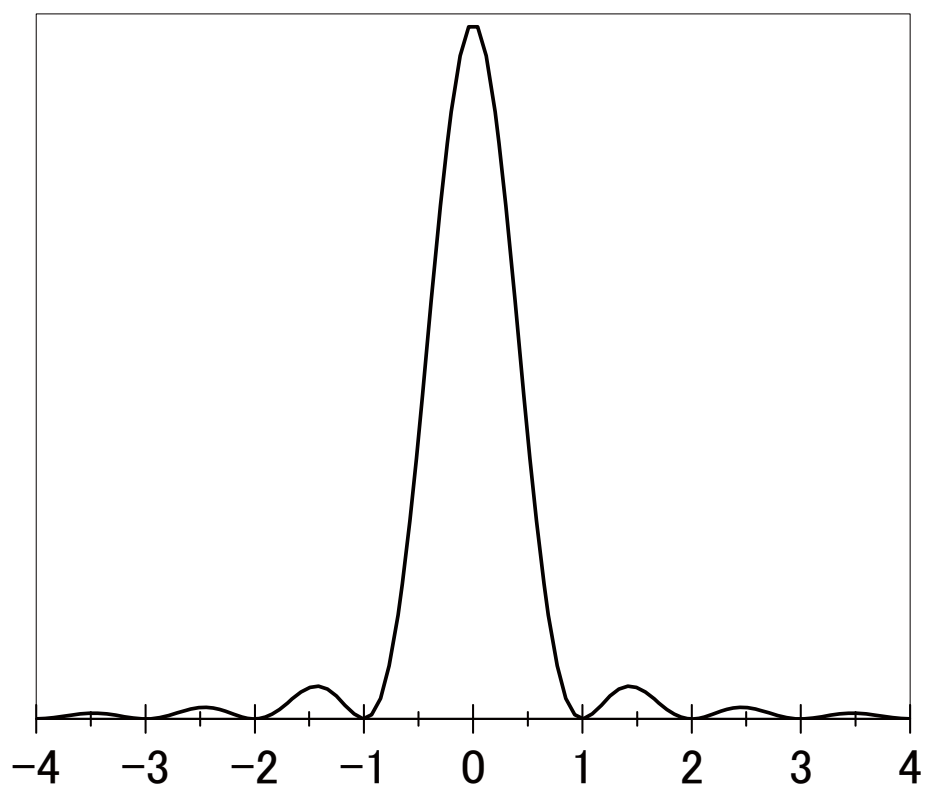

図 13.2.1 $P_{\mathrm{f}}(t)$ と $\Delta E-h v$ との関係.

困の縦軸は $\frac{P_{\mathrm{f}}(t)}{\left(\frac{H_{\mathrm{fi}}^{\prime} t}{2 \hbar}\right)^{2}}$, 横軸は $\left(\frac{E_{\mathrm{f}}{ }^{0}-E_{\mathrm{i}}{ }^{0}-h v}{h}\right) t=\frac{t}{2 \pi}\left(\omega_{\mathrm{fi}}-\omega\right)$

$h v=E_{\mathrm{f}}{ }^{0}-E_{\mathrm{i}}{ }^{0} \quad$ (または $\left.\omega=\omega_{\mathrm{fi}}\right)$ が成り立つ所，すなわち共鳴条件が正確に満される 所で $P_{\mathrm{f}}$ は極大を示す.しかし，ここから少々離れてもやはり誘導吸収や誘導放出は起 こり得ることに注目すべきである。この問題は次の節でもう少し詳しく吟味する.

必Problem 13.2.1

図 13.2.1 に示されるスペクトルの時間依存性をより具体的にプロットしてみよ.波 長 $500 \mathrm{~nm}$ に鋭い吸収があるとし，吸収スペクトルを横軸は波長にとり，300 nmから $700 \mathrm{~nm}$ までの範囲でスペクトルを描け。時間は，スペクトルの形が変わる時間帯に 
ついていくつか選ぶこと.

\section{3 遷移速度 - Fermi の黄金則}

式(13.2.10)［および式(13.2.12)］に着目して, final state を見出す確率 $P_{\mathrm{f}}(t)$ の時間依 存性を吟味してみよう。図 13.2.1 では，横軸はエネルギーに時間をかけたものとなっ ているので，そのままでは時間発展のありさまがよく分からない．横軸をエネルギー にし，いろいろな時間についてプロットすればより分かりやすいであろう.

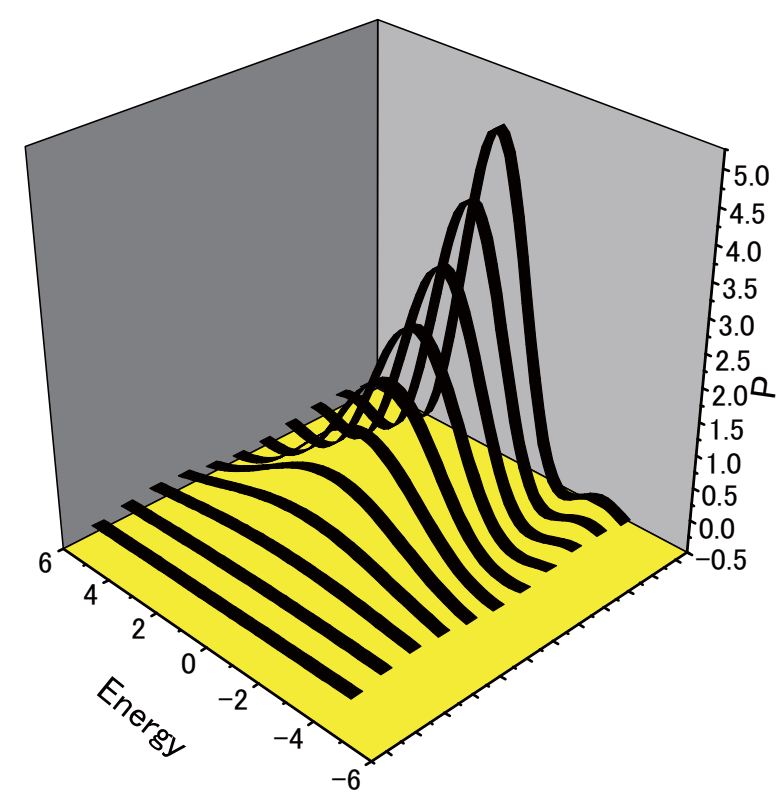

図 13.3.1

$\left(13.2 .10^{\prime}\right)$ に基づく $P_{\mathrm{f}}(t)$ の時間発展. Energy の軸は $\left(\omega-\omega_{\mathrm{fi}}\right)$. 縦軸は, $\frac{P_{\mathrm{f}}(t)}{\left(\frac{H_{\mathrm{fi}}^{\prime} t}{2 \hbar}\right)^{2}}$. 手前 から奥に向かって, $t=\frac{0.2}{\left(\omega-\omega_{\mathrm{fi}}\right)}, \frac{0.4}{\left(\omega-\omega_{\mathrm{fi}}\right)}, \frac{0.6}{\left(\omega-\omega_{\mathrm{fi}}\right)}, \ldots$ と時間発展している.

図 13.3.1 をみると, 時間発展と共に $P_{\mathrm{f}}(t)$ の $\frac{1}{2}\left(\omega-\omega_{\mathrm{fi}}\right)$ についての幅がだんだんと小 
さくなることが(このことは図 13.2.1 からも明らかではあるが) 視覚的によく分かる. $P_{\mathrm{f}}(t)$ の $t$ 依存性は，もちろん $\omega-\omega_{\mathrm{fi}}$ の值によって異なる. 図からも分かるように, 正 確に共鳴条件が満たされる場合，すなわち

$$
h v=E_{\mathrm{f}}^{0}-E_{\mathrm{i}}^{0}
$$

または

$$
\omega=\omega_{\mathrm{fi}}
$$

が正確に満たされる場合には，式(13.2.10)は

$$
P_{\mathrm{f}}(t)=\frac{1}{4}\left(\frac{H_{\mathrm{f}}^{\prime} t}{\hbar}\right)^{2}
$$

となる. すなわち, final state を見出す確率は $t^{2}$ に比例して大きくなるということを示 しているが, それはありそうにもないことである.というのは, 式(13.3.2)に従う限り， 遷移の確率 $P_{\mathrm{f}}(t)$ が時間と共にどんどん大きくなっていき，ついに 1 を越えてしまう. 考え方のどこかに間違いがあったわけである.

ぞこに間違いがあるかというと，まず第 1 に気が付くことは，この式は式(12.4.3) の近似式を用いて導き出したということである. 式(12.4.3)は, perturbation が弱く, かつ時間が十分に小さいという条件下で近似的に導出した式である．従って $t$ の大き な所まで適用出来ないことは明らかである。そこでまず $t$ があまり大きい所は考えな いことにして，遷移速度 $W_{\mathrm{i} \rightarrow \mathrm{f}}$ を求めてみる。

$$
\begin{aligned}
W_{\mathrm{i} \rightarrow \mathrm{f}} & =\frac{d P_{\mathrm{f}}(t)}{d t} \\
& =\frac{1}{2}\left(\frac{H_{\mathrm{fi}}^{\prime}}{\hbar}\right)^{2} t
\end{aligned}
$$

たとえ ルの強度が時間と共にどんどん大きくなることを示していて, 現実にはとてもありそ うもない. やはり理論のどこかに本質的な間違いがあるのであろう．上の取り扱いに おける最も重要な問題点は, 式(13.3.1)に示した正確な共鳴条件があり得ないというこ とである，正確な共鳴条件が成り立つためには，照射する電磁波が十分よい単色光性 を持っていないといけない. どの程度の単色性が必要かというと, 図 13.2.1 から大体 分かるように，照射する電磁波のエネルギー幅が，中央のピークの幅の中に十分に入 っていればよい。すなわち 


$$
\left|\frac{E_{\mathrm{f}}^{0}-E_{\mathrm{i}}^{0}-h v}{\hbar}\right|<<\frac{\pi}{2 t} \approx \frac{1}{t}
$$

または

$$
\left|\omega-\omega_{\mathrm{fi} i}\right|<<\frac{1}{t}
$$

が成り立てばよいということになる。ここで $t$ は電磁波を照射する時閒である。とこ ろが時間 $t$ 内にエネルギーを $\frac{\hbar}{2 t}$ 以上に精度よく決めることは不確定性原理から不可

能である. すなわち, 式(13.3.4)を満たすような単色性のよい光というものは存在しな い. 更に現実の分子系では，多数の分子の間での相互作用があるため， final state の近 辺に $E_{\mathrm{f}}{ }^{0}$ とほんのわずかだけエネルギーが異なる多くの状態が存在する。（相互作用が あるとエネルギーが少し変ることは，例えば摂動論からも理解出来よう。）これらの 理由で，共鳴条件からはずれた所でも光の吸収（および発光）が起こり得る，という ことを考慮しないといけない. すなわち, $P_{\mathrm{f}}(t)$ を $E_{\mathrm{f}}{ }^{0}-E_{\mathrm{i}}{ }^{0}-h v$ のある範囲内で積分す る必要がある。このように積分した確率を $\overline{P_{f}(t)}$ という記号で表すことにする。

$$
\overline{P_{\mathrm{f}}(t)}=\left(H_{\mathrm{fi}}^{\prime}\right)^{2} \int^{\text {band }} \frac{\sin ^{2}\left\{\frac{\left(E_{\mathrm{f}}{ }^{0}-E_{\mathrm{i}}{ }^{0}-h v\right) t}{2 \hbar}\right\}}{\left(E_{\mathrm{f}}{ }^{0}-E_{\mathrm{i}}{ }^{0}-h v\right)^{2}} d\left(E_{\mathrm{f}}{ }^{0}-E_{\mathrm{i}}{ }^{0}-h v\right)
$$

または

$$
\overline{P_{\mathrm{f}}(t)}=\left(\frac{H_{\mathrm{fi}}^{\prime}}{\hbar}\right)^{2} \int^{\mathrm{band}} \frac{\sin ^{2}\left\{\frac{1}{2}\left(\omega-\omega_{\mathrm{fi}}\right) t\right\}}{\left(\omega-\omega_{\mathrm{fi}}\right)^{2}} d\left(\omega-\omega_{\mathrm{fi}}\right)
$$

ここで, 積分の範囲は入射電磁波のバンド幅にとる。このバンド幅を正確に見積も るのはむずかしい，不確定性による幅もあるし，光源の実験的条件にもよる。（例え ば，連続光を分光して単色光を得ているとすると，用いた分光器の分解能や分散等の 能力によるし, 又いわゆる単色光といわれている laser 光の場合でもある有限のエネ ルギー幅を持っており，その幅はそれぞれの laserによって異なる.）しかし，その幅 を正確に知らなくても式(13.3.4)は計算出来る.このことを述べる前にもう1つ大切な ことがある。

以上は，入射した電磁波の不確定性又は実験上の制約によるエネルギー幅の中に final state がただ 1 つだけ存在する場合の取り扱いである. 原子が真空中にただ 1 個存 
在する場合にはこういう状態に近いであろうが，現実の系，特に原子でなくて分子に なると，あるエネルギー幅の中に存在する状態はかなり沢山ある．どうしてそうなる のかというと，例えば溶液中の分子を考えると，1個 1 個の分子が溶媒のつき方など 少しずつ異なり，溶媒との相互作用のために， 1 個 1 個の分子のエネルギーが少しず つ異なる. 更に，原子でなくて分子の場合には，分子を構成している原子が振動によ って刻々その相対位置を変えている。こういうことによっても少しずつ異なるエネル ギー状態がたくさん存在寸るのである. そして，与えられた入射電磁波の幅の中に存 在する final state の数は非常に多くなる. それらの final state 1 つ 1 つ個別に認識す

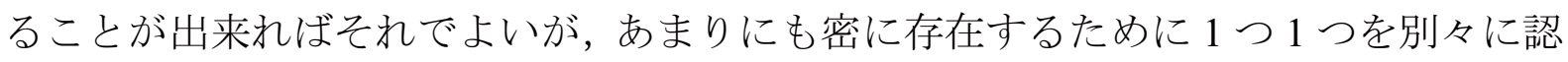
識することはとうてい出来ない，そこで我々は，final stateをまとめてあるエネルギー 幅の中に，何個の final state がつまっているか，ということで考える．この final state のつまり方を示す量として density of states $\rho_{\mathrm{N}}\left(E_{\mathrm{f}}{ }^{0}\right)$ というものを定義する． $\rho_{\mathrm{N}}\left(E_{\mathrm{f}}{ }^{0}\right)$ は，エネルギー $E_{\mathrm{f}}{ }^{0}$ の所で，エネルギー幅 $d E_{\mathrm{f}}{ }^{0}$ の中に final state が何個存在するかを示 す量である. subscript の $\mathrm{N}$ は density of states を state の数（Number）で表すという意 味である。

以上述べたように, final state が多数存在することを考慮して式(13.3.5)を書き直す.

$$
\overline{P_{\mathrm{f}}(t)}=\left(H_{\mathrm{fi}}^{\prime}\right)^{2} \int^{\text {band }} \frac{\sin ^{2}\left\{\frac{\left(E_{\mathrm{f}}^{0}-E_{\mathrm{i}}^{0}-h v\right) t}{2 \hbar}\right\}}{\left(E_{\mathrm{f}}{ }^{0}-E_{\mathrm{i}}{ }^{0}-h v\right)^{2}} \rho_{\mathrm{N}}\left(E_{\mathrm{f}}{ }^{0}\right) d\left(E_{\mathrm{f}}{ }^{0}-E_{\mathrm{i}}^{0}-h v\right)
$$

積分の範囲を正確に知ることはほとんど不可能であることは上述した通りである が，式(13.3.6)の integrand は図 13.2.1 または図 13.3.1 からも明らかなように

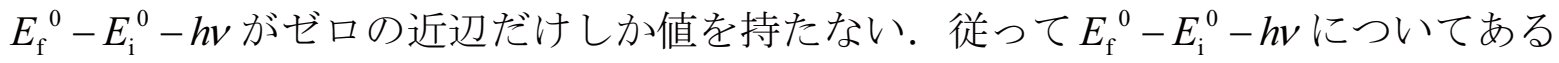
限られたバンド幅内について積分する代りに, いて積分しても積分の值は実質的に同じになるであろう。こういう考えに基づき， 


$$
\begin{aligned}
\overline{P_{\mathrm{f}}(t)} & =\left(H_{\mathrm{fi}}^{\prime}\right)^{2} \int_{-\infty}^{+\infty} \frac{\sin ^{2}\left\{\frac{\left(E_{\mathrm{f}}{ }^{0}-E_{\mathrm{i}}^{0}-h v\right) t}{2 \hbar}\right\}}{\left(E_{\mathrm{f}}{ }^{0}-E_{\mathrm{i}}^{0}-h v\right)^{2}} \rho_{\mathrm{N}}\left(E_{\mathrm{f}}{ }^{0}\right) d\left(E_{\mathrm{f}}{ }^{0}-E_{\mathrm{i}}^{0}-h v\right) \\
& =\left(\frac{H_{\mathrm{fi}}^{\prime} t}{2 \hbar}\right)^{2+\infty} \int_{-\infty}^{+\infty} \frac{\sin ^{2}\left\{\frac{\left(E_{\mathrm{f}}{ }^{0}-E_{\mathrm{i}}^{0}-h v\right) t}{2 \hbar}\right\}}{\left(\frac{E_{\mathrm{f}}{ }^{0}-E_{\mathrm{i}}^{0}-h v}{2 \hbar}\right)^{2}} \rho_{\mathrm{N}}\left(E_{\mathrm{f}}{ }^{0}\right) d\left(E_{\mathrm{f}}{ }^{0}-E_{\mathrm{i}}^{0}-h v\right)
\end{aligned}
$$

ここで

$$
x=\frac{\left(E_{\mathrm{f}}^{0}-E_{\mathrm{i}}^{0}-h v\right) t}{2 \hbar}
$$

と変数を変換する.

$$
\overline{P_{\mathrm{f}}(t)}=\frac{\left(H_{\mathrm{fi}}^{\prime}\right)^{2} t}{2 \hbar} \rho_{\mathrm{N}}\left(E_{\mathrm{f}}{ }^{0}\right) \int_{-\infty}^{+\infty} \frac{\sin ^{2} x}{x^{2}} d x
$$

ここで

$$
\int_{-\infty}^{+\infty} \frac{\sin ^{2} x}{x^{2}} d x=\pi
$$

という関係があるので式(13.3.7)は

$$
\overline{P_{\mathrm{f}}(t)}=\frac{\left(H_{\mathrm{fi}}^{\prime}\right)^{2} \pi t \rho_{\mathrm{N}}\left(E_{\mathrm{f}}{ }^{0}\right)}{2 \hbar}
$$

となる。

遷移速度 $W_{\mathrm{i} \rightarrow \mathrm{f}}$ は $P_{\mathrm{f}}(t)$ を時間について微分したものである.すなわち

$$
W_{\mathrm{i} \rightarrow \mathrm{f}}=\frac{d P_{\mathrm{f}}(t)}{d t}
$$

従って

$$
W_{\mathrm{i} \rightarrow \mathrm{f}}=\frac{\pi}{2 \hbar}\left(H_{\mathrm{fi}_{\mathrm{i}}}^{\prime}\right)^{2} \rho_{\mathrm{N}}\left(E_{\mathrm{f}}{ }^{0}\right)
$$

のように，時間を含まない形として得られた。この式は非常に有用で，Fermi の黄金 則（Fermi's golden rule）としてよく知られている. 


\section{【蛇足】：}

念のため, (12.3.13)の dimension を確かめておこう。 $H_{\mathrm{fi}}^{\prime}$ はエネルギーの dimension, $\rho_{\mathrm{N}}\left(E_{\mathrm{f}}{ }^{0}\right)$ は単位エネルギー幅の中の状態の数であるから, その dimension はエネルギ

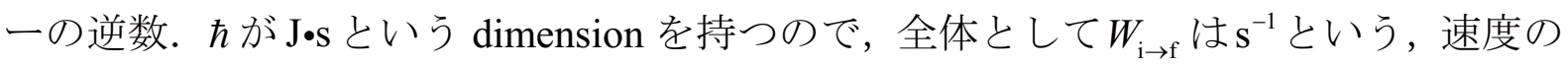
dimension を持っていることが確かめられる.

式(13.3.13)は state density を単位エネルギー当りの state の数 $\rho_{\mathrm{N}}\left(E_{\mathrm{f}}{ }^{0}\right)$ で表した。分 光学の分野ではしばしば，エネルギーをJ単位でなく, そのエネルギーを持つ電磁波 の周波数 $v$ の単位で表す. state density を, 単位周波数当りの state の数 $\rho_{\mathrm{N}}\left(v_{\mathrm{f}}^{0}\right)$ (これ を frequency density of states と言う) で表すと式(13.3.13)は

$$
W_{\mathrm{i} \rightarrow \mathrm{f}}=\frac{1}{4 \hbar^{2}}\left(H_{\mathrm{f} i}^{\prime}\right)^{2} \rho_{\mathrm{N}}\left(v_{\mathrm{f}}^{0}\right)
$$

となる.この形の Fermi's golden ruleもしばしば用いられる.

\section{4 遷移双極子モーメント}

前節で Fermi の黄金則（式(13.3.13)および式(13.3.14)）を導いたので，それを用い て遷移速度を具体的に求めることが出来るはずであるが，実は式(13.3.13)の中の $H_{\mathrm{fi}}^{\prime}$ という積分の求め方をまだ学習していなかった。この節では $H^{\prime}{ }_{\mathrm{fi}}$ の計算方法を学習し よう。 $H_{\mathrm{fi}}^{\prime}$ はすでに式(13.2.6)で定義してある.念のため繰り返し記す.

$$
H_{\mathrm{fi}}^{\prime}=\int \psi_{\mathrm{f}}{ }^{0} *\left(-\frac{e}{m_{e}} \sum_{j} A_{x j}{ }^{0} p_{x j}\right) \psi_{\mathrm{i}}{ }^{0} d \tau
$$

この式を出す時, 簡単のため, $x$ 軸方向に直線偏光した光のみを考えた. それで式 (13.4.1)には $x, y, z 3$ つの成分があるべきところ， $x$ 成分しか書いてないわけである. 話を簡単にするためにしばらくこの近似を続けて，最後に，yおよび $z$ 成分について も考えることにしよう。 
式(13.4.1)に現れる vector potential の振幅 $A_{x j}{ }^{0}$ に着目しよう。これは分子中の $j$ 番目 の電子が感ずる入射電磁波の vector potential の $x$ 成分の振幅である. 当然，分子中の それぞれの電子が感ずる電磁波の potential は少しずつ異なるはずである. しかし，も し電磁波として可視部の光を考えると, その光の波長は数百ナノメーター, 寸なわち $10^{-7} \mathrm{~m}$ のオーダーであり, 分子の大きさ $\left(10^{-10} \mathrm{~m}\right.$ のオーダー) に比べてはるかに大 きい. 従って, 分子中の電子は全て等しい vector potential を感ずると考えてよからう. 可視部の光でなく, 赤外線光であると更に波長が長くなり, ESR で用いるマイクロ波 では波長は $\mathrm{cm}$ のオーダーとなる. NMR で用いるラジオ波は, ラジオのアンテナの大 きさからも分かるように，もっと長い波長である，才なわち，全ての電子が等しい vector potential を受けるという考え方はますます正しいことになる，反対に電磁波の 波長をどんどん短くしていって，X線の領域になると，これは，もう波長が分子の大 きさと同じ位になってしまう(それだからこそX線解折により原子の配列を決めるこ とが可能なのである！)。こういう場合は，当然各電子の感ずる vector potential は異な るわけである，以下では話を簡単にするために，X線のような極端に波長の短い電磁 波は考えずに，せめて紫外部の光よりも波長の長い電磁波を問題にすることにする.

こういう場合， $A_{x j}{ }^{0}$ は $j$ に依存しないと考えられる。従って式(13.4.1)は

$$
\begin{aligned}
H_{\mathrm{fi}}^{\prime} & =\int \psi_{\mathrm{f}}^{0} *\left(-\frac{e}{m_{e}} A_{x}^{0} \sum_{j} p_{x j}\right) \psi_{\mathrm{i}}^{0} d \tau \\
& =-\frac{e}{m_{e}} A_{x}^{0} \int \psi_{\mathrm{f}}{ }^{0} *\left(\sum_{j} p_{x j}\right) \psi_{\mathrm{i}}^{0} d \tau
\end{aligned}
$$

となる。（ここで subscript i, f, $j$ など似ている文字を使ってしまったが，混乱しない ようにしてほしい，念のため繰り返して述べると i 一方， $j$ は分子中の $j$ 番目の電子という意味である.)

式(13.4.2)に従って $H_{\mathrm{fi}}{ }_{\mathrm{fi}}$ を求めることが出来るわけであるが，これは $p_{x}$ という運動 量 operator に関する積分である。これを計算するには，wavefunction を微分しなけれ ばいけないが，出来ることなら，そういうややこしい計算は避けたい，そこで，本質 的なことではないが，しばしば次のようにして運動量についての行列要素を座標につ いての行列要素に変換して用いる．以下考えることは， $p$ という運動量 operator に関 する計算を $x$ という座標 operator に関する演算に変換することである. notation の混雑 をさけるため, この変換を行う間, 電子の番号を示寸 $j$ という subscript を省くことに する.まず, $p$ と $x$ との交換関係に着目し, 次の式を得る. 


$$
\begin{aligned}
{\left[p_{x}{ }^{2}, x\right] } & =p_{x}\left[p_{x}, x\right]+\left[p_{x}, x\right] p_{x} \\
& =-2 i \hbar p_{x}
\end{aligned}
$$

Hamiltonian $H$ は $p$ についは $\frac{p^{2}}{2 m_{e}}$ という形を含んでおり，その他の全ての部分は座 標 $x$ と可換であるから

$$
\begin{aligned}
{[H, x] } & =\frac{1}{2 m_{e}}\left[p_{x}^{2}, x\right] \\
& =-\frac{i \hbar}{m_{e}} p_{x}
\end{aligned}
$$

すなわち

$$
p_{x}=\frac{i m_{e}}{\hbar}(H x-x H)
$$

従って

$$
\int \psi_{\mathrm{f}}^{0} * p_{x} \psi_{\mathrm{i}}^{0} d \tau=\frac{i m_{e}}{\hbar} \int \psi_{\mathrm{f}}^{0} *(H x-x H) \psi_{\mathrm{i}}^{0} d \tau
$$

となるが，ここで

$$
H \psi_{\mathrm{i}}^{0}=E_{\mathrm{i}}^{0} \psi_{\mathrm{i}}^{0}
$$

および

$$
x \psi_{\mathrm{i}}^{0}=\sum_{k} \psi_{k}^{0} \int \psi_{k}^{0} * x \psi_{\mathrm{i}}^{0} d \tau
$$

という関係に着目すると，式(13.4.6)は次のようになる。

$$
\int \psi_{\mathrm{f}}{ }^{0} * p_{x} \psi_{\mathrm{i}}^{0} d \tau=\frac{i m_{e}}{\hbar}\left(E_{\mathrm{f}}{ }^{0}-E_{\mathrm{i}}{ }^{0}\right) \int \psi_{\mathrm{f}}{ }^{0} * x \psi_{\mathrm{i}}^{0} d \tau
$$

式(13.4.9)の関係を用いて式(13.4.2)を書き換える.

$$
\begin{aligned}
H_{\mathrm{fi}}^{\prime} & =-\frac{e}{m_{e}} A_{x}{ }^{0} \frac{i m_{e}}{\hbar}\left(E_{\mathrm{f}}^{0}-E_{\mathrm{i}}^{0}\right) \int \psi_{\mathrm{f}}^{0^{*}}\left(\sum_{j} x_{j}\right) \psi_{\mathrm{i}}^{0} d \tau \\
& =-\frac{i}{\hbar} A_{x}^{0}\left(E_{\mathrm{f}}{ }^{0}-E_{\mathrm{i}}^{0}\right) \int \psi_{\mathrm{f}}{ }^{0^{*}}\left(\sum_{j} e x_{j}\right) \psi_{\mathrm{i}}^{0} d \tau
\end{aligned}
$$

ここで

$$
\int \psi_{\mathrm{f}}^{0^{*}}\left(\sum_{j} e x_{j}\right) \psi_{\mathrm{i}}^{0} d \tau=e X_{\mathrm{fi}}
$$

とおくと 


$$
H_{\mathrm{fi}}^{\prime}=-\frac{i}{\hbar} A_{x}^{0}\left(E_{\mathrm{f}}^{0}-E_{\mathrm{i}}^{0}\right) e X_{\mathrm{fi}}
$$

となる。

式(13.4.12)は，電子の片寄りのために生ずる電子双極子演算子に関する行列要素で あり，電子遷移双極子モーメント（electronic transition dipole moment）と言われる量で ある。以上のようにして, 運動量 operator に関する行列要素を計算する代りに, 電子 双極子モーメントを計算すればよいということになり，もちろん考え方にもよるが， 計算は多少簡単になる。

この結果を式(13.3.13)に代入すると，遷移速度 $W_{\mathrm{i} \rightarrow \mathrm{f}}$ は

$$
\begin{aligned}
W_{\mathrm{i} \rightarrow \mathrm{f}} & =\frac{\pi}{2 \hbar}\left|-\frac{i}{\hbar} A_{x}^{0}\left(E_{\mathrm{f}}{ }^{0}-E_{\mathrm{i}}{ }^{0}\right) e X_{\mathrm{fi}}\right|^{2} \rho_{\mathrm{N}}\left(E_{\mathrm{f}}{ }^{0}\right) \\
& =\frac{\pi}{2 \hbar^{3}}\left[A_{x}{ }^{0}\left(E_{\mathrm{f}}{ }^{0}-E_{\mathrm{i}}{ }^{0}\right)\right]^{2}\left|e X_{\mathrm{fi}}\right|^{2} \rho_{\mathrm{N}}\left(E_{\mathrm{f}}{ }^{0}\right)
\end{aligned}
$$

繰り返しことわって来たように，今までは，電磁波が $x$ 軸方向に直線偏光していると 仮定して来た. 現実の電磁波は, $x, y, z$ す心゙ての偏光成分を持っているから式(13.4.13) を一般に拡張し, 次式を得る。

$$
W_{\mathrm{i} \rightarrow \mathrm{f}}=\frac{\pi}{2 \hbar^{3}}\left(E_{\mathrm{f}}{ }^{0}-E_{\mathrm{i}}{ }^{0}\right)^{2}\left[\left(A_{x}^{0}\right)^{2}\left|e X_{\mathrm{fi}}\right|^{2}+\left(A_{y}{ }^{0}\right)^{2}\left|e Y_{\mathrm{fi}}\right|^{2}+\left(A_{z}^{0}\right)^{2}\left|e Z_{\mathrm{fi}}\right|^{2}\right] \rho_{\mathrm{N}}\left(E_{\mathrm{f}}{ }^{0}\right)
$$

また state density を周波数単位で表した式(13.3.13)を用いると

$$
W_{\mathrm{i} \rightarrow \mathrm{f}}=\frac{1}{4 \hbar^{4}}\left(E_{\mathrm{f}}{ }^{0}-E_{\mathrm{i}}{ }^{0}\right)^{2}\left[\left(A_{x}^{0}\right)^{2}\left|e X_{\mathrm{fi}}\right|^{2}+\left(A_{y}{ }^{0}\right)^{2}\left|e Y_{\mathrm{fi}}\right|^{2}+\left(A_{z}^{0}\right)^{2}\left|e Z_{\mathrm{fi}}\right|^{2}\right] \rho_{\mathrm{N}}\left(v_{\mathrm{f}}{ }^{0}\right)
$$

であるが，ついでのことに $E_{\mathrm{f}}^{0}, E_{\mathrm{i}}^{0}$ も周波数単位で表し，かつ

$$
h v_{\mathrm{fi}}^{0}=E_{\mathrm{f}}^{0}-E_{\mathrm{i}}^{0}
$$

のように新しく $v_{\mathrm{fi}}$ という notation を導入する。この結果

$$
W_{\mathrm{i} \rightarrow \mathrm{f}}=\frac{1}{4 \hbar^{2}}\left(v_{\mathrm{fi}}\right)^{2}\left[\left(A_{x}^{0}\right)^{2}\left|e X_{\mathrm{fi}}\right|^{2}+\left(A_{y}{ }^{0}\right)^{2}\left|e Y_{\mathrm{fi}}\right|^{2}+\left(A_{z}^{0}\right)^{2}\left|e Z_{\mathrm{fi}}\right|^{2}\right] \rho_{\mathrm{N}}\left(v_{\mathrm{f}}{ }^{0}\right)
$$

を得る。

等方的な試料の場合には

$$
\left(A_{x}^{0}\right)^{2}=\left(A_{y}{ }^{0}\right)^{2}=\left(A_{z}^{0}\right)^{2}=\frac{1}{3} A^{2}
$$


とおいてよいので，式(13.4.17)は次のようになる.

$$
W_{\mathrm{i} \rightarrow \mathrm{f}}=\frac{1}{12 \hbar^{2}} v_{\mathrm{fi}} A^{2}\left|e R_{\mathrm{fi}}\right|^{2} \rho_{\mathrm{N}}\left(v_{\mathrm{f}}^{0}\right)
$$

ここで

$$
\left|e R_{\mathrm{fi}}\right|^{2}=\left|e X_{\mathrm{fi}}\right|^{2}+\left|e Y_{\mathrm{fi}}\right|^{2}+\left|e Z_{\mathrm{fi}}\right|^{2}
$$

とおいた。

\section{【注意】：}

現実の電磁波が $x, y, z$ 寸心゙ての偏光成分を持っている，というのは，ありそうもな いことのように思えるかもしれない，仮に電磁波が $z$ 方向に進行していたとすると， 偏光は $x$ および $y$ 方向に限られ， $z$ 方向の偏光成分はない。このように考えると，上 で述べたことはおかしく思われるかもしれない. しかし，この節で定義した $x, y, z$ 軸 は，今まではっきりとは述べて来なかったが，空間固定の軸でなく，分子固定の軸な のである. 分子が空間中にきちんと並んだ特別に作られた配向試料について実験する のでない限り，分子固定の軸からみれば一般の電磁波はすべての偏光面を持っている と見なしてよいであろう。もう少し正確にいうと，空間固定の $Z$ 軸方向に進行する電 磁波の vector potential の成分 $A_{X}{ }^{0}$ と $A_{Y}{ }^{0}$ が，それぞれ空間固定の $X, Y$ 軸と分子固有の 軸 $(x, y, z)$ との方向余弦の成分に分けられ, それでもって分子固有の軸でみた vector potential の成分 $A_{x}{ }^{0}, A_{y}{ }^{0}, A_{z}{ }^{0}$ は決められるわけである. この段階では $A_{x}{ }^{0}, A_{y}{ }^{0}, A_{z}{ }^{0}$ はも ちろん等しいというわけではない，しかし，溶液系のように，系の中にある分子がお 互いにばらばらの方向を向いているとすると, 平均として, $A_{x}{ }^{0}, A_{y}{ }^{0}, A_{z}{ }^{0}$ の 3 方向が 等しいと見なすことは出来よう。こういう場合には，式(13.4.18)のようにおくことが 出来る。こういうふうにおけるのは，あくまで系の中に分子が等方的にばらまかれて いることを仮定しているわけで，結晶のように特定の方向に配向した試料については 成り立たない，量子化学は本来，分子 1 個について取り扱うものであるが，場合によ ってはこのように，統計的な概念が導入される場合もあるわけである. 
[Coffee Break］運動量演算子に関する積分と座標に関する積分

式(13.4.9)は，運動量演算子に関する積分が座標に関する積分で置き換えられるこ とを示しており，実にありがたい式である，wavefunction の形にもよるが，多くの場 合, wavefunction を微分するのは厄介であり, 座標に関する積分ですむことは便利で ある.ただ，この式は， wavefunction が Hamiltonian $H$ の正確な eigenfunction になっ ている場合のみ成り立つ（このことは式の導出過程を見れば明らかであろう.）こと を忘れてはならない. 水素原子以外の原子や分子では正確な eigenfunction を求めるこ とは出来ず，必ず何らかの近似に基づいて wavefunction を求めるわけで，そういう場 合は決して, 式(13.4.9)の両辺は等しい值を与えない. 分子軌道法を用いて遷移モーメ ントを求めている論文で，座標 operator を用いた計算値と運動量 operator を用いた計 算值を併記していることがよくあるが，両者は一致していない，ただ，両者が近いと いうことは wavefunction がそれだけ真の eigenfunction に近いということを示すわけ で，そういう check のためにも，両者をそれぞれ計算することは意味のあることであ る.

放Problem 13.4.1

a-particle-in-a-box の wavefunction について式(13.4.9)の両辺を別々に計算することに よってこの式を確かめよ.

\section{5 電気双極子遷移の選択則}

前節でみたように, initial state $\psi_{\mathrm{i}}^{0}$ と final state $\psi_{\mathrm{f}}{ }^{0}$ との間の双極子遷移が可能であ るためには，それが吸収であろうと放出であろうと，または spontaneous な過程であ ろうと stimulated な過程であろうと，とにかく

$$
\begin{aligned}
& e R_{\mathrm{fi}}=e X_{\mathrm{fi}}+e Y_{\mathrm{fi}}+e Z_{\mathrm{fi}} \\
& =\int \psi_{\mathrm{f}}{ }^{*}\left[e \sum_{j}\left(x_{j}+y_{j}+z_{j}\right)\right] \psi_{\mathrm{i}}^{0} d \tau
\end{aligned}
$$

という「遷移モーメント」が值を持つ必要がある。

遷移モーメントがどの位の大きさであるかは，1つ1つの場合について具体的に計 算してみる必要があるが，水素原子の場合とか, harmonic oscillator の場合とか, 
a-particle-in-a-box の場合とか，いくつかの典型的な系については，少なくともこれこ れの条件では遷移モーメントがゼロでなく有限な值を持つ，という法則を導くことが 出来る。そのような法則を選択則（selection rule）という。以下，二三の場合につい て選択則を導いてみよう。

（1）調和振動子の場合

$$
\begin{aligned}
& \int{\psi_{m}}^{*}(x) x \psi_{n}(x) d x \\
& =\frac{1}{\sqrt{\beta}} \int \psi_{m}^{*}(\xi) \xi \psi_{n}(\xi) d \xi \\
& =\frac{1}{\sqrt{2 \beta}} \int \psi_{m}^{*}(\xi)\left(b+b^{+}\right) \psi_{n}(\xi) d \xi \\
& =\frac{1}{\sqrt{2 \beta}}\left(\sqrt{\frac{n}{2}} \delta_{n-1, m}+\sqrt{\frac{n+1}{2}} \delta_{n+1, m}\right)
\end{aligned}
$$

以上の関係から選択則として

$$
\Delta n= \pm 1
$$

を得る。

（2）水素原子の場合

まず $z$ 軸方向に直線偏光した光（ $z$ 偏光）の場合を考えよう.

$$
\begin{aligned}
& \int \psi_{n^{\prime}, l^{\prime}, m^{\prime}}{ }^{*} z \psi_{n, l, m} d \tau \\
& =\int R_{n^{\prime} l} r R_{n l} r^{2} d r \int \Theta_{l^{\prime} m^{\prime}} \cos \theta \Theta_{l m} \sin \theta d \theta \int \Phi_{m^{\prime}}{ }^{*} \Phi_{m} d \phi \\
& =\left\langle R_{n^{\prime} l^{\prime}}|r| R_{n l}\right\rangle\left\langle\Theta_{l^{\prime} m^{\prime}}|\cos \theta| \Theta_{l m}\right\rangle\left\langle\Phi_{m^{\prime}} \mid \Phi_{m}\right\rangle
\end{aligned}
$$

であるが，動径部分の積分 $\left\langle R_{n^{\prime} l^{\prime}}|r| R_{n l}\right\rangle$ については $n, n^{\prime}, l, l^{\prime}$ の゙うういう組み合せでも ゼロになるということはない。角度部分の積分については，

$$
\cos \theta \Theta_{l, m}=\sqrt{\frac{(l-m+1)(l+m+1)}{(2 l+1)(2 l+3)}} \Theta_{l+1, m}+\sqrt{\frac{(l-m)(l+m)}{(2 l-1)(2 l+1)}} \Theta_{l-1, m}
$$

という recursion formula を用いて考えるのがよい. 式(13.5.3)は $\Theta_{l, m}$ に $\cos \theta$ をかけると $l$ の 1 つ大きい $\Theta_{l+1, m}$ と $l$ の 1 小さい $\Theta_{l-1, m}$ との線形結合で表されることを示してお り，たとえ係数は覚えていなくてもこのことだけを覚えているだけでいろいろな selection rule を導くことが出来るという便利な式である. 結局 $\left\langle\Theta_{l^{\prime} m^{\prime}}|\cos \theta| \Theta_{l m}\right\rangle$ は 
$l^{\prime}=l \pm 1$ が成り立つ時にのみゼロでないことが分かる. $\left\langle\Phi_{m^{\prime}} \mid \Phi_{m}\right\rangle$ についは当然 $m=m^{\prime}$ のときのみ值を持つ. 以上, $z$ 偏光の場合の selection rule は

$$
l^{\prime}=l \pm 1, \quad m^{\prime}=m
$$

とまとめることが出来る.

次に $x$ 軸方向に直線偏光した光（ $x$ 偏光）の場合を考えよう.

$$
\begin{aligned}
& \int \psi_{n^{\prime}, l^{\prime}, m^{\prime}}{ }^{*} x \psi_{n, l, m} d \tau \\
& =\left\langle R_{n^{\prime} l^{\prime}}|r| R_{n l}\right\rangle\left\langle\Theta_{l^{\prime} m^{\prime}}|\sin \theta| \Theta_{l m}\right\rangle\left\langle\Phi_{m^{\prime}}|\cos \phi| \Phi_{m}\right\rangle
\end{aligned}
$$

であるが， $\theta$ についての積分を吟味するには次の recursion formula が便利である.

$$
\sin \theta \Theta_{l, m}=-\sqrt{\frac{(l+m+1)(l+m+2)}{(2 l+1)(2 l+3)}} \Theta_{l+1, m+1}+\sqrt{\frac{(l-m)(l-m-1)}{(2 l-1)(2 l+1)}} \Theta_{l-1, m+1}
$$

または

$$
\sin \theta \Theta_{l, m}=\sqrt{\frac{(l-m+1)(l-m+2)}{(2 l+1)(2 l+3)}} \Theta_{l+1, m-1}-\sqrt{\frac{(l+m)(l+m-1)}{(2 l-1)(2 l+1)}} \Theta_{l-1, m-1}
$$

この recursion formula より $\left\langle\Theta_{l^{\prime} m^{\prime}}|\sin \theta| \Theta_{l m}\right\rangle$ は $l^{\prime}=l \pm 1, m^{\prime}=m \pm 1$ が成り立つ時にのみ值

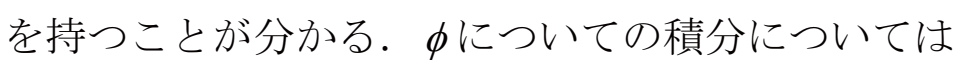
$\left\langle\Phi_{m^{\prime}}|\cos \phi| \Phi_{m}\right\rangle=\frac{1}{2}\left\langle\Phi_{m^{\prime}}\left|e^{i \phi}+e^{-i \phi}\right| \Phi_{m}\right\rangle$ より $m^{\prime}=m \pm 1$ がゼロにならないための条件とな る。これらをまとめて,$x$ 偏光の場合には,

$$
l^{\prime}=l \pm 1, \quad m^{\prime}=m \pm 1
$$

の時にのみゼロでないという結果が得られる.

最後に $y$ 軸方向に直線偏光した光（ $y$ 偏光）の場合には

$$
\begin{aligned}
& \int \psi_{n^{\prime}, l^{\prime}, m^{\prime}}{ }^{*} y \psi_{n, l, m} d \tau \\
& =\left\langle R_{n^{\prime} l^{\prime}}|r| R_{n l}\right\rangle\left\langle\Theta_{l^{\prime} m^{\prime}}|\sin \theta| \Theta_{l m}\right\rangle\left\langle\Phi_{m^{\prime}}|\sin \phi| \Phi_{m}\right\rangle
\end{aligned}
$$

となるが，この場合の selection rule も式(13.5.8)で与えられることは直ちに分かるであ ろう. 以上 3 つの場合をまとめて, 水素原子の場合の選択則として

$$
\Delta l= \pm 1, \quad \Delta m= \pm 1
$$

を得る. 


\section{必Problem 13.5.1}

a-particle-in-a-box の wavefunction についての選択則を導け.

定Problem 13.5.2

$1 s \rightarrow 2 p$ 遷移の transition moment を求めよ. $2 p$ のつの状態については，real な wavefunction $p_{x}, p_{y}, p_{z}$ を用い $1 s \rightarrow 2 p_{x}, 1 s \rightarrow 2 p_{y}, 1 s \rightarrow 2 p_{z}$ の各遷移についてそれぞれ $x$ 偏光, $y$ 偏光, $z$ 偏光の光が入射した時の $\mid$ transition moment $\left.\right|^{2}$ を求めよ. 単位は SI 単位系で数值的に求めよ. 次の表を埋める形でまとめよ.

\begin{tabular}{|c|l|l|l|}
\hline & $1 s \rightarrow 2 p_{x}$ & $1 s \rightarrow 2 p_{y}$ & $1 s \rightarrow 2 p_{z}$ \\
\hline$x$-polarized & & & \\
$y$-polarized & & & \\
$z$-polarized & & & \\
\hline
\end{tabular}

\section{6 誘導吸収および誘導放出に関する Einstein の $B$ 係数}

式(13.4.19)で与えられた $W_{\mathrm{i} \rightarrow \mathrm{f}}$ をもう少し使いやすい形にする，そのためには電磁気 学を用い，例えば vector potential の部分を電磁波の持っているエネルギーに換算し， 更にこのエネルギーおよび frequency density of states $\rho_{\mathrm{N}}\left(v_{\mathrm{f}}^{0}\right)$ などより，新しく周波数 $v_{\mathrm{fi}}$ における energy density of states $\rho\left(v_{\mathrm{fi}}\right)$ を定義する.（subscript のNがついていない） この式の導出は，例えば Atkins, "Molecular Quantum Mechanics"の page 442-443 に載っ ているのでここではその結果を引用するにとどめる. 最終的に, 式(13.4.19)に代るべ き式として次式を得る。

$$
W_{\mathrm{i} \rightarrow \mathrm{f}}=\frac{1}{4 \pi \varepsilon_{0}} \frac{2 \pi}{3 \hbar^{2}}\left|e R_{\mathrm{fi}}\right|^{2} \rho\left(v_{\mathrm{fi}}\right)
$$

更に 


$$
B_{\mathrm{fi}}=\frac{1}{4 \pi \varepsilon_{0}} \frac{2 \pi}{3 \hbar^{2}}\left|e R_{\mathrm{fi}}\right|^{2}
$$

をEinstein のB係数という。 $B$ 係数を用いると

$$
W_{\mathrm{i} \rightarrow \mathrm{f}}=B_{\mathrm{fi}} \rho\left(v_{\mathrm{f} i}\right)
$$

と表される。これが stimulated absorption および stimulated emission についての遷移速 度を示す式である。明らかなように, stimulated absorption と stimulated emissionの速 度はお互いに等しい。

\section{7 自然放出に関する Einstein $の ~ A$ 係数}

もつともエネルギーの低い量子状態，すなわち基底状態（ground state）を $\psi_{\mathrm{g}}$, そ のエネルギーを $E_{\mathrm{g}}$ とする. ある 1 つの励起状態 $\psi_{\mathrm{e}}$ を考え, そのエネルギーを $E_{\mathrm{e}}$ とし よう。我々が通常の実験系で取り扱うのはこのような分子が多数集まった系である が，例えば，系が絶対零度に冷却されていれば，全ての分子は基底状態にある．有限 な温度では，励起状態にある分子も少しはある，平衡状態において励起状態にある分 子の数 $N_{\mathrm{e}}{ }^{0}$ と基底状態にある分子の数 $N_{\mathrm{g}}{ }^{0}$ (平衡状態という意味で superscript 00 をつ けている）との関係は統計力学で学習する分布則によって決まるわけである. 粒子の 種類によって Fermi-Dirac の統計に従う場合や Bose-Einstein の統計に従う場合等ある が，分子の数が多い場合は，よほど特殊な場合以外は Boltzmann 統計で示される.す なわち，

$$
\begin{aligned}
\frac{N_{\mathrm{e}}{ }^{0}}{N_{\mathrm{g}}{ }^{0}} & =\frac{\exp \left(-\frac{E_{\mathrm{e}}}{k T}\right)}{\exp \left(-\frac{E_{\mathrm{g}}}{k T}\right)} \\
& =\exp \left(-\frac{E_{\mathrm{e}}-E_{\mathrm{g}}}{k T}\right) \\
& =\exp \left(-\frac{h v_{\mathrm{eg}}}{k T}\right)
\end{aligned}
$$

で示される。ここで $T$ は温度， $k$ は Boltzmann 定数である.ただし簡単のため, ここ では $\psi_{\mathrm{e}} お よ ひ ゙ \psi_{\mathrm{g}}$ いずれにも縮退がないとしている. 
さて, $h v_{\mathrm{ge}}$ のエネルギーを持つ電磁波がこの物質系に照射されると, 電磁波の吸収 が起こり， $\psi_{\mathrm{g}}$ にある分子のうちの一部は $\psi_{\mathrm{e}}$ 一遷移する．当然，遷移が起こった瞬間 には $N_{\mathrm{e}}$ が平衡状態の時よりちょっとだけ大きくなるが，Boltzmann 分布からはずれた そのような分布は不安定で，直ちにもとの平衡状態に戻ろうとする，その時に，外か ら電磁波が入射されなくても電磁波を放出寸る過程があり，そのような電磁波の放出 を自然放出（spontaneous emission）という。この自然放出の速度を $A_{\mathrm{eg}}$ とおき，それは Einstein の $A$ 係数と言われている. $\psi_{\mathrm{g}}$ からの誘導吸収によって $\psi_{\mathrm{e}}$ へ移る分子数は

$$
N_{\mathrm{g}} B_{\mathrm{eg}} \rho\left(v_{\mathrm{eg}}\right)
$$

である。一方， $\psi_{\mathrm{e}}$ からの誘導放出および自然放出によって $\psi_{\mathrm{g}}$ へ移る分子数の和は

$$
N_{\mathrm{e}}\left[B_{\mathrm{eg}} \rho\left(v_{\mathrm{eg}}\right)+A_{\mathrm{eg}}\right]
$$

である．平衡状態ではこの 2 つが等しいから，

$$
N_{\mathrm{e}} B_{\mathrm{eg}} \rho\left(v_{\mathrm{eg}}\right)=N_{\mathrm{e}}\left[B_{\mathrm{eg}} \rho\left(v_{\mathrm{eg}}\right)+A_{\mathrm{eg}}\right]
$$

式(13.7.1)と式(13.7.2)より

$$
\exp \left(-\frac{h v_{\mathrm{eg}}}{k T}\right)=\frac{B_{\mathrm{eg}} \rho\left(v_{\mathrm{eg}}\right)}{A_{\mathrm{eg}}+B_{\mathrm{eg}} \rho\left(v_{\mathrm{eg}}\right)}
$$

または

$$
\rho\left(v_{\mathrm{eg}}\right)=\frac{\frac{A_{\mathrm{eg}}}{B_{\mathrm{eg}}}}{\exp \left(\frac{h v_{\mathrm{eg}}}{k T}\right)-1}
$$

ただし

$$
B_{\mathrm{ge}}=B_{\mathrm{eg}}
$$

を用いた。輻射の density of states $\rho\left(v_{\mathrm{eg}}\right)$ は，正確にはそれぞれの系について実験で求 めるしかそれを知る方法はないが，大体の目安をつけるために黒体輻射の式でもって 
代用してみよう. Planckによって与えられた式(1.1.3)，すなわち

$$
\rho\left(v_{\mathrm{eg}}\right)=\frac{8 \pi h v_{\mathrm{eg}}^{3}}{c^{3}} \frac{1}{\exp \left(\frac{h v_{\mathrm{eg}}}{k T}\right)-1}
$$

を式(13.7.4)に代入することにより，次式を得る.

$$
\frac{A_{\mathrm{eg}}}{B_{\mathrm{eg}}}=\frac{8 \pi h v_{\mathrm{eg}}{ }^{3}}{c^{3}}
$$

式(13.6.2)を用い, 結局, $A, B 2$ つの係数はまとめて次のように与えられる.

$$
\begin{aligned}
& A_{\mathrm{eg}}=\frac{1}{4 \pi \varepsilon_{0}} \frac{32 \pi^{3} v_{\mathrm{eg}}^{3}}{3 c^{3} \hbar}\left|e R_{\mathrm{ge}}\right|^{2} \\
& B_{\mathrm{ge}}=B_{\mathrm{eg}}=\frac{1}{4 \pi \varepsilon_{0}} \frac{2 \pi}{3 \hbar^{2}}\left|e R_{\mathrm{eg}}\right|^{2}
\end{aligned}
$$

二三の仮定を用いて得た式ではあるが，式(13.7.6)はなかなか含蓄のある式である. spontaneous emission と stimulated emission の速度の比は $v^{3}$ に比例するので, 振動数 $v$ の 減少と共に急激に小さくなる. 我々がいつも実験室で見ているように, 可視部や紫外 部の光の領域では，自然放出による蛍光や燐光が非常に容易に見られるが，NMRの ラジオ波の領域では, $v$ がずっと小さくなり, 自然放出はほとんどなく, 観測される 放出はすべて誘導放出によるものである. maser（マイクロ波の誘導放出に基づく） が作られてから laser（光の誘導放出に基づく）が作られるまでかなりの年数が必要で あったこともうなずける。また，X線 laser が作られればどんなにかすばらしいこと だろうと人々が待ち望んでいるのになかなか作られないということも納得がいくと 思う。

计 Exercise 13.7.1

$1000 \mathrm{~K}$ の温度の $\mathrm{H}$ 原子の集団の $3 p \rightarrow 2 s$ 遷移について stimulated emission および spontaneous emission の速度をそれぞれ計算せよ。

\section{【解】 :}

Einstein $の A$ coefficient および $B$ coefficient は式(13.7.7)および式(13.7.8)で与えられ る.まず transition moment $R$ の二乗を求める. 例えば $z$ 成分については $3 p_{0} \rightarrow 2 s$ のみ が許容であるから 


$$
\begin{aligned}
z_{3 p, 2 s} & =\int \psi_{3,1,0}^{*} z \psi_{2,0,0} d \tau \\
& =\left\langle R_{31}|r| R_{20}\right\rangle\left\langle\Theta_{10}|\cos \theta| \Theta_{00}\right\rangle
\end{aligned}
$$

ここで $\rho=\frac{r}{a_{0}}$ とおくと（ $a_{0}$ は Bohr radius $)$

$$
\begin{aligned}
& R_{31}=\frac{4}{81 \sqrt{6}} \frac{1}{\sqrt{\left(a_{0}\right)^{3}}}\left(6 \rho-\rho^{2}\right) e^{-\frac{\rho}{3}} \\
& R_{20}=\frac{1}{2 \sqrt{2}} \frac{1}{\sqrt{\left(a_{0}\right)^{3}}}(2-\rho) e^{-\frac{\rho}{2}}
\end{aligned}
$$

より

$$
\begin{aligned}
\left\langle R_{31}|r| R_{20}\right\rangle & =\int R_{31} r R_{20} r^{2} d r \\
& =\left(a_{0}\right)^{4} \int R_{31} R_{20} \rho^{3} d \rho \\
& =\frac{a_{0}}{81 \sqrt{3}} \int_{0}^{\infty}\left(\rho^{6}-8 \rho^{5}+12 \rho^{4}\right) e^{-\frac{5}{6} \rho} d \rho
\end{aligned}
$$

積分公式を用いて積分を計算する。

$$
\left\langle R_{31}|r| R_{20}\right\rangle=\frac{2^{10} \times 3^{4}}{\sqrt{3} \times 5^{6}} a_{0}
$$

一方，式(13.5.3)より

$$
\left\langle\Theta_{10}|\cos \theta| \Theta_{00}\right\rangle=\sqrt{\frac{1}{3}}
$$

従って

$$
Z_{3 p, 2 s}=\left\langle\psi_{3,1,0}|z| \psi_{2,0,0}\right\rangle=\frac{2^{10} \times 3^{3}}{5^{6}} a_{0}
$$

すなわち

$$
\left|Z_{3 p, 2 s}\right|^{2}=\frac{2^{20} \times 3^{6}}{5^{12}} a_{0}^{2}
$$

$x$ 方向および $y$ 方向成分についても同様に求まるからそれら各成分についてそれぞれ 計算してもよいが， atomのような中心対称性を持つ場合については

$$
\left|X_{3 p, 2 s}\right|^{2}=\left|Y_{3 p, 2 s}\right|^{2}=\left|Z_{3 p, 2 s}\right|^{2}
$$

は明らかである。（例えば Problem 13.5.2 を参考.）従って

$$
\left|R_{3 p, 2 s}\right|^{2}=3\left|Z_{3 p, 2 s}\right|^{2}
$$

となる。結局 


$$
\left|e R_{3 p, 2 s}\right|^{2}=\frac{2^{20} \times 3^{7} \times e^{2} a_{0}^{2}}{5^{12}}=6.7485 \times 10^{-58} \mathrm{C}^{2} \mathrm{~m}^{2}
$$

$3 p$ と $2 s$ とのエネルギー差は

$$
v_{3 p, 2 s}=\frac{h c R}{h}\left(\frac{1}{4}-\frac{1}{9}\right)=\frac{5}{36} c R
$$

Rydberg constant $R=1.097373 \times 10^{5} \mathrm{~cm}^{-1}$ を代入し,

$$
v_{3 p, 2 s}=4.5692 \times 10^{14} \mathrm{~s}^{-1}
$$

式(13.7.7), 式(13.7.8)に代入し,

$$
\begin{aligned}
& A=6.739 \times 10^{7} \mathrm{~s}^{-1} \\
& B=1.1435 \times 10^{21} \mathrm{~m}^{3} \mathrm{~J}^{-1} \mathrm{~s}^{-2}
\end{aligned}
$$

一方, $\rho$ は式(13.7.5)で与えられる. 計算すると

$$
\rho=1.782 \times 10^{-23} \mathrm{~m}^{-3} \mathrm{Js}
$$

従って spontaneous emission $の$ rate は

$$
B=2.04 \times 10^{-2} \mathrm{~s}^{-1}
$$

\section{8 レーザー}

laser という言葉は, light amplification of stimulated emission of radiation の頭文字をと って作られた．最初の laser が作られたのは1960年のことであるが，それ以来，数々 の laser が作られ，いろいろな所で利用されている.

$\psi_{\text {high }}$ と $\psi_{\text {low }}$ という2つの状態を考えよう。 $\psi_{\text {high }}$ の energy $E_{\text {high }}$ は $\psi_{\text {low }}$ の energy $E_{\text {low }}$ よりも高いとする.これらの状態の population を $N_{\text {high }}$ および $N_{\text {low }}$ とすると, 熱平衡状 態では Boltzmann 分布則により $N_{\text {low }}>N_{\text {high }}$ である.この場合， $E_{\text {high }}-E_{\text {low }}$ に相当する エネルギーを持つ電磁波が照射されると, stimulated absorption は stimulated emission によって減らされ，結局，吸収の強度は $N_{\text {low }}-N_{\text {high }}$ に比例することになる。

もし，何らかの方法で， $N_{\text {high }}>N_{\text {low }}$ という条件すなわち population inversion が達 成出来たとする。（このような状態は熱平衡から大きくずれており，もしもこの $2 つ$ の状態間に無理矢理 Boltzmann 分布則を適用すると $\frac{N_{\text {high }}}{N_{\text {low }}}=\exp \left(-\frac{E_{\text {high }}-E_{\text {low }}}{k T}\right)>1$ より, 
温度を負にとらなければならなくなり， "negative temperature"の状態ということもあ る. 勿論, 非平衡状態において，仮に Boltzmann 分布を仮定したらこうなるという話 であり，本来ならそもそも Boltzmann 統計が従うべき系でないものに無理やり

Boltzmann 分布を当てはめただけである. 従って熱力学の第三法則と矛盾するのはど うしてか，などと悩む必要はない.）この場合， $E_{\text {high }}-E_{\text {low }}$ に相当する電磁波が照射さ れると, stimulated emission が stimulated absorption を凌駕し, 結局, emission が出て来 ることになる。これが laserの基本的原理である.

以上で分かるように, laser emission を起こさせるためにはまず, population inversion を起こさなければならない，それから光を増幅させる手段が必用である。これらのこ とを，最初に作られた laserである ruby laser を例として説明しよう。

ruby はアルミナ $\mathrm{Al}_{2} \mathrm{O}_{3}$ の結晶の, $\mathrm{Al}^{3+}$ の一部が $\mathrm{Cr}^{3+}$ で置き換えられたものである. このような結晶の電子状態は, $\mathrm{Cr}^{3+}$ の状態が $\mathrm{Al}_{2} \mathrm{O}_{3}$ という結晶場の中でどうなるかは いわゆる「結晶場の理論」で理解出来る。主な状態を図 13.8 .1 に示す.

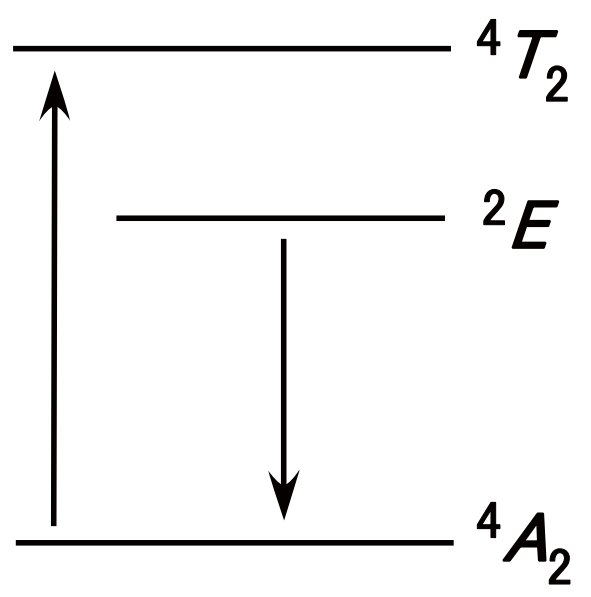

図 13.8.1 $\mathrm{Cr}(\mathrm{III})$ の電子状態

この図で, $A_{2}, T_{2}, E$ は群論でいうところの既約表現の記号であり，このことについ ては Chapter 17 で学習する。また，左肩についている 4 とか 2 の数字はそれぞれ spin の多重度の quartet と doublet を示しているがこれらについては, Chapter 14 で学習す る. 従ってこれらを学習してない現在は何のことかは分からないかもしれないが，と りあえず，状態の性質を示す記号だと理解しておけばよかろう。 
ruby laser というのは, ruby の結晶の棒で, そのまわりに Xe のフラッシュランプが おいてあり，このフラッシュランプで $\mathrm{Cr}^{3+}{ }^{3}{ }^{4} A_{2}$ 基底状態から ${ }^{4} T_{2}$ 励起状態へ励起出 来るようになっている. ruby 結晶の棒の両端は光学的に磨いて，メッキをし，この棒 の中で光が反射するようになっている，この場合，一方の端では，光は完全に反射さ れるようにし，もう 1 つの端では，ごくわずかの光は外に出て行くようにしてある. さて，フラッシュランプの光が照射されると，rubyの結晶は緑色の光を吸収し，（だ から ruby は赤い色を呈するのである ! ) ${ }^{4} A_{2}$ 基底状態は ${ }^{4} T_{2}$ 励起状態に励起される. ${ }^{4} T_{2}$ 励起状態は容易にエネルギーを無輻射的に失い， ${ }^{2} E$ 励起状態となる. ${ }^{2} E$ 励起状態は， 一部 spontaneous emission を出して基底状態に失活するが，それは（spin 多重度が異な る状態間の遷移であるため）遅い過程であり，なかなかその population は減らない。

フラッシュランプの光がある時間継続しているとその間にどんどん ${ }^{4} A_{2} \rightarrow{ }^{4} T_{2} \rightarrow{ }^{2} E$

の遷移が起こり，ついに， ${ }^{4} A_{2}$ と ${ }^{2} E$ の間に population inversion が起こることになる.

（すなわち， negative temperature が実現することになる.）上述したように ${ }^{2} E$ 状態は spontaneous emission を出すが，この emission はあらゆる方向に出ている. laser rod の 軸方向に出ている光も，その垂直方向に出る光もあるが，このうち，後者は，ruby の 結晶の棒，すなわち laser rod の外に出てしまってもはや再び戻って来ることはない. しかし， laser rodの軸方向に出た光は，両端の鏡の間で反射して， laser $\operatorname{rod} の$ 結晶中 を何回も往復することになる. population inversion が起こっているから，この光によ って, stimulated emission が生じるが，この光も又， laser rodの中を往復し，それが又 stimulated emission を生む. こういうことの繰り返しにより, ついに, 非常に強い光と

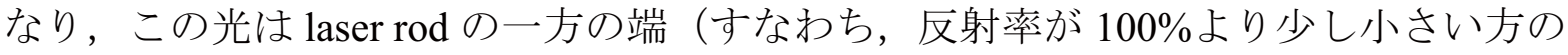
端）から外に出ることになる。

以上説明したように，2 枚の鏡の間を光が往復することを繰り返す間に光の増幅が 起こるわけであるが，この間に光はまず単色光性がよくなり，かつ， coherent（位相 が揃うこと）になり，そして強度が大きくなる．もちろん，光の進行方向も限られ， 方向性がよくなる. laser はこのように，1）方向性がよい 2) 単色性がよい 3) coherent 4）強度が大，という大きな特徵を持っており，この特徽を生かして，現在，いたる 所で利用されている. 分光学者も光化学者も, 昔から強い光を求め続けて来た. 科学 者でなくても強い光を望んでいた．ゲーテだって死の直前，"mehr Licht"と叫んだとい う。㐌テ以来の人類の夢は laser という形でかなえられたといえるだろう.

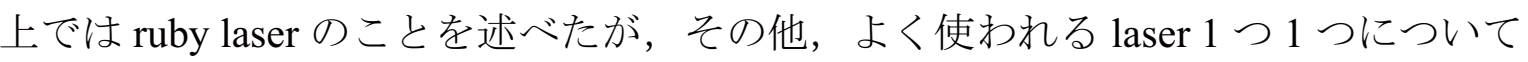
その原理を述べることは意味のあることであると思う。しかし，もう少し，電子状態 
について学習した後でないと原理を理解することは出来そうもないので，もう1つだ け，ヘリウムーネオンレーザーについて簡単に紹介し， laserの解説を終らせることに する.

He-Ne laser はガラス管の中に He を約 1 Torr (約 $100 \mathrm{~Pa}$ ), Ne を約 0.1 Torr (約 $10 \mathrm{~Pa}$ ) の圧力で入れたものである.（注：Torr は水銀柱 $1 \mathrm{~mm}$ に相当する圧力の単位で，SI 単位系ではないが，水銀柱の圧力計で圧力を測っている実験者には直感的に分かりや すいということで，しばしばこの単位がよく用いられている.）ガラス管の中には電 極が封入されていて，電気的放電が連続的に行われている，ガラス管の両側には，上 述した ruby laser の場合と同じく，1つは完全反射の，もう 1 つは部分反射の鏡がおい てある．放電によって He 原子は励起されるが，高い励起状態は直ちに $3(1 \mathrm{~s}, 2 \mathrm{~s})$ の状 態に失活する。（左肩の 3 は, spin の triplet という意味, Chapter 14 を参照）この状態 は， He 原子の基底状態 $1 s^{2}$ との間で双極子遷移が許されていない $(2 s \rightarrow 1 s$ の遷移で $\Delta l=0$ であるから禁制であるが，更に spin 禁制）ので，基底状態に失活寸ることはな い，その代り， $\mathrm{Ne}$ との衝突によってそのエネルギーを $\mathrm{Ne}$ の基底状態に与える．それ により, $\mathrm{Ne}$ は $1 s^{2} 2 s^{2} 2 p^{5} 4 s$ で表わされる励起状態となる。こういう過程により作られ た $1 s^{2} 2 s^{2} 2 p^{5} 4 s$ という励起状態は, 光を発し, それより低い励起状態 $1 s^{2} 2 s^{2} 2 p^{5} 3 p$ に落 ちる．ところが，いったん $1 s^{2} 2 s^{2} 2 p^{5} 3 p$ 状態が作られると，更に，エネルギーの低い $1 s^{2} 2 s^{2} 2 p^{5} 3 s$ に非常に速い速度で失活寸る。（図 13.8.2）

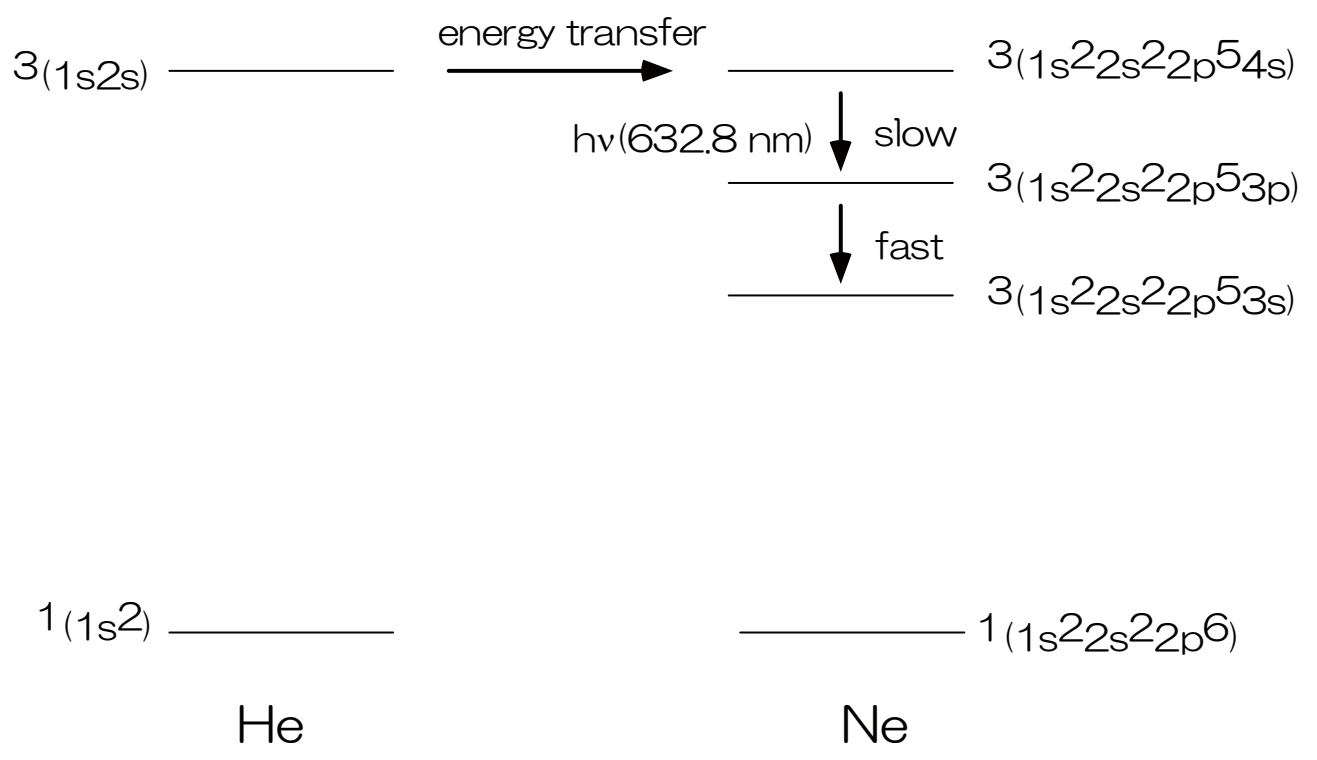

図 13.8.2 He-Ne laser

放電による $\mathrm{He}$ の励起は定常的に行われているから， $\mathrm{Ne} の 1 s^{2} 2 s^{2} 2 p^{5} 3 p$ 状態の 
population はどんどん増加し，その上の $1 s^{2} 2 s^{2} 2 p^{5} 4 s$ 状態との間に population inversion が起こることになる。（すなわち negative temperature が得られる.）そしてこの間のエ ネルギー差に相当する電磁波（632.8 nm の光）を laser 光として出すことになる．以 上が He-Ne laser の簡単な説明である。

\section{¿3 Problem 13.8.1}

He-Ne laser についての上述の説明で，population inversion が起こるには， $1 s^{2} 2 s^{2} 2 p^{5} 4 s \rightarrow 1 s^{2} 2 s^{2} 2 p^{5} 3 p$ の遷移が遅く $1 s^{2} 2 s^{2} 2 p^{5} 3 p \rightarrow 1 s^{2} 2 s^{2} 2 p^{5} 3 s$ の遷移が速い, と いうことがもつとも重要であった。そのことを納得するために，それぞれの遷移につ いて dipole transition moment の二乗を求め, その比較（比をとる）をしてみよ. transition moment の計算にあたっては， $1 s^{2} 2 s^{2} 2 p^{5}$ という配置は全ての 3 つの状態に共通である から，これら9つの電子は $\mathrm{Ne}$ の原子核にくつついていて（実際はそんなことはない が）あたかも原子核の電荷が +1 で電子がそれぞれ $4 s, 3 p, 3 s$ にあるような原子（すな わち水素類似原子）とみなすという，思い切った近似を用いることにせよ。

\section{9 コヒーレント分光}

Section 13.2 以降，前節まで，電磁波の perturbation を式(12.4.3)の近似式を用いて取 り扱った。繰り返し述べて来たように，この近似とは，まず第 1 に perturbation が十 分に弱いということであり，又第 2 には時間の短い領域にのみに限る，という近似で ある.この近似をはずして，もっと一般的な解を求めようとすると式(12.1.10)の連立 微分方程式を解かなければいけない。念のため，式(12.1.10)を再録しよう。

$$
\frac{d c_{m}(t)}{d t}=-\frac{i}{\hbar} \sum_{n} c_{n}(t) H^{\prime}{ }_{m n}(t) \exp \left[-\frac{i}{\hbar}\left(E_{n}{ }^{0}-E_{m}{ }^{0}\right) t\right]
$$

ここで

$$
H^{\prime}{ }_{m n}(t)=\int \psi_{m}{ }^{0} * H^{\prime}(t) \psi_{n}{ }^{0} d \tau
$$

式(13.9.1)は一般には無限元の連立微分方程式となるので解くことは出来ない. そこで 我々は, initial state $\psi_{\mathrm{i}}^{0}$ と final state $\psi_{\mathrm{f}}^{0}$ の 2 つの state だけで完全系を成していると仮 定する.この仮定のもとでは，式(13.9.1)は二元連立一次微分方程式となるので何とか 解けそうである。

以下，式(12.2.1)と同じく 


$$
H_{\mathrm{ii}}^{\prime}(t)=H_{\mathrm{ff}}^{\prime}(t)=0
$$

の場合を考える．この場合式(13.9.1)は次のようになる．

$$
\begin{aligned}
& \frac{d c_{\mathrm{i}}(t)}{d t}=-\frac{i}{\hbar} c_{\mathrm{f}}(t) H^{\prime}{ }^{\prime}(t) \exp \left[-\frac{i}{\hbar}\left(E_{\mathrm{f}}{ }^{0}-E_{\mathrm{i}}{ }^{0}\right) t\right] \\
& \frac{d c_{\mathrm{f}}(t)}{d t}=-\frac{i}{\hbar} c_{\mathrm{i}}(t) H^{\prime}{ }_{\mathrm{fi}}(t) \exp \left[-\frac{i}{\hbar}\left(E_{\mathrm{i}}{ }^{0}-E_{\mathrm{f}}{ }^{0}\right) t\right]
\end{aligned}
$$

$H^{\prime}{ }_{\text {if }}(t), H^{\prime}{ }^{\prime}(t)$ は式(13.2.5)で与えられるように

$$
\begin{aligned}
& H_{\mathrm{if}}^{\prime}(t)=\frac{1}{2} H_{\mathrm{if}}^{\prime}\left(e^{i \omega t}+e^{-i \omega t}\right) \\
& H_{\mathrm{fi} i}^{\prime}(t)=\frac{1}{2} H_{\mathrm{fi}}^{\prime}\left(e^{i \omega t}+e^{-i \omega t}\right)
\end{aligned}
$$

ここで式(13.2.6)で与えられるように

$$
H_{\mathrm{fi}}^{\prime}=\int \psi_{\mathrm{f}}^{0} *\left(-\frac{e}{m_{e}} \sum_{j} A_{x j}{ }^{0} p_{x j}\right) \psi_{\mathrm{i}}^{0} d \tau
$$

であるから wavefunction を realにとる限り

$$
H_{\text {if }}^{\prime}=H^{\prime}{ }_{\mathrm{fi}}
$$

となる. 更にこれら相互作用も角振動数の単位で表し，

$$
\beta=\frac{H_{\mathrm{f} i}^{\prime}}{\hbar}=\frac{H_{\mathrm{if}}^{\prime}}{\hbar}
$$

のように表すことにする．また式(13.2.7')と同じく 2 つの間のエネルギー差も角振動 数単位で表し,

$$
\omega_{\mathrm{fi}}=\frac{E_{\mathrm{f}}^{0}-E_{\mathrm{i}}^{0}}{\hbar}
$$

とおく．結局式(13.9.4)は

$$
\begin{aligned}
& \frac{d c_{\mathrm{i}}(t)}{d t}=-i c_{\mathrm{f}}(t) \frac{\beta}{2}\left[\exp \left\{i\left(\omega-\omega_{\mathrm{fi}}\right) t\right\}+\exp \left\{-i\left(\omega+\omega_{\mathrm{fi}}\right) t\right\}\right] \\
& \frac{d c_{\mathrm{f}}(t)}{d t}=-i c_{\mathrm{i}}(t) \frac{\beta}{2}\left[\exp \left\{i\left(\omega+\omega_{\mathrm{fi}}\right) t\right\}+\exp \left\{-i\left(\omega-\omega_{\mathrm{fi}}\right) t\right\}\right]
\end{aligned}
$$

となる. 右辺のうちの $\exp \left\{i\left(\omega-\omega_{\mathrm{fi}}\right) t\right\}$ および $\exp \left\{-i\left(\omega-\omega_{\mathrm{fi}}\right) t\right\}$ は光の振動数以上の速 い振動数で変化する関数であるから, それよりずっとゆっくりした時間領域での議論 には省略してしまってよい. この近似のもとでは式(13.9.9)は 


$$
\begin{aligned}
& \frac{d c_{\mathrm{i}}(t)}{d t}=-i c_{\mathrm{f}}(t) \frac{\beta}{2} \exp \left\{i\left(\omega-\omega_{\mathrm{fi}}\right) t\right\} \\
& \frac{d c_{\mathrm{f}}(t)}{d t}=-i c_{\mathrm{i}}(t) \frac{\beta}{2} \exp \left\{-i\left(\omega-\omega_{\mathrm{fi}}\right) t\right\}
\end{aligned}
$$

これを解く方法はいろいろあろうが，第 2 番目の式を $t$ で微分すると次のような一元 二階微分方程式が得られる.

$$
\frac{d^{2} c_{\mathrm{f}}(t)}{d t^{2}}+i\left(\omega-\omega_{0}\right) \frac{d c_{\mathrm{f}}(t)}{d t}+\left(\frac{\beta}{2}\right)^{2} c_{\mathrm{f}}(t)=0
$$

初期条件として $t=0$ で $c_{\mathrm{i}}(0)=1, c_{\mathrm{f}}(0)=0$ とすると，解は次のように求まる.

$$
\begin{aligned}
& c_{\mathrm{i}}(t)=\exp \left\{\frac{i\left(\omega-\omega_{0}\right) t}{2}\right\}\left\{\cos \frac{\Omega t}{2}-\frac{i\left(\omega-\omega_{0}\right)}{\Omega} \sin \frac{\Omega t}{2}\right\} \\
& c_{\mathrm{f}}(t)=\frac{i \beta}{\Omega} \exp \left\{\frac{i\left(\omega-\omega_{0}\right) t}{2}\right\} \sin \frac{\Omega t}{2}
\end{aligned}
$$

ここで

$$
\Omega=\sqrt{\left(\omega-\omega_{0}\right)^{2}+\beta^{2}}
$$

final state の存在確率 $P_{\mathrm{f}}(t)$ は $\left|c_{\mathrm{f}}(t)\right|^{2}$ で与えられる.すなわち

$$
P_{\mathrm{f}}(t)=\left(\frac{\beta}{\Omega}\right)^{2} \sin ^{2} \frac{\Omega t}{2}
$$

$t=0$ で $P_{\mathrm{f}}(t)=0$ であったが時間の発展と共に増加し $t=\frac{\pi}{\Omega}$ で $P_{\mathrm{f}}(t)=\left(\frac{\beta}{\Omega}\right)^{2}$ となる. その 後は $t=\frac{2 \pi}{\Omega}$ で $P_{\mathrm{f}}(t)=0$ になるまで減少し, これを永久に繰り返すことになる. $t=0$ と $t=\frac{\pi}{\Omega}$ の間では入射光を吸収し， $t=\frac{\pi}{\Omega}$ と $t=\frac{2 \pi}{\Omega}$ の間では光を放出し，以後 $\frac{2 \pi}{\Omega}$ の周期 で吸収と放出を繰り返す。

このように，時間に対して振動する $P_{\mathrm{f}}(t)$ は，(13.3.11)で求めた時間に対して一次に 増加する $P_{\mathrm{f}}(t)$ と全く異なる関係であることに注目したい. 理論の取り扱い方によっ 
て，かくも大きな違いが見られるのである.

では式(13.9.14)で与えられた式を実験的に確かめることが出来るであろうか? そ ういう実験はなかなか難しい. まず入射する光の位相が完全に揃っていないといけな い. 又, 入射光は十分によい単色光でなくてはいけない，一昔前まではこんな実験が 可能となるとはとても思えなかったのであるが，科学技術の進歩は有難いもので，今 ではそういう実験が出来るようになった。

図 13.9.1 にマイクロ波領域でのこのような過渡現象の例を示寸，Rhのトリスビピ リジン錯体の三重項励起状態のスピン蕉位間の遷移を観測したものである.このよう に， $\frac{2 \pi}{\Omega}$ に相当する周期で吸収と放出を繰り返す現象は nutation（章動）と言われ，電 磁波と物質との coherent な相互作用の効果を直接的に示している. 図の実験結果は, 式(13.9.14)で期待されるような永久に振動する関数とはなっておらず，時間と共に振 幅が減少していく，それは，上述の理論的取り扱いには含まれていなかった緩和の効 果によるものであるが，詳しいことは省略したい.

ここで紹介した実験は coherent spectroscopy と言われるものの一例で, 最近の技術 革新によって可能となった分野で，いろいろな形の coherent spectroscopy がこれから も更に発展するであろう。

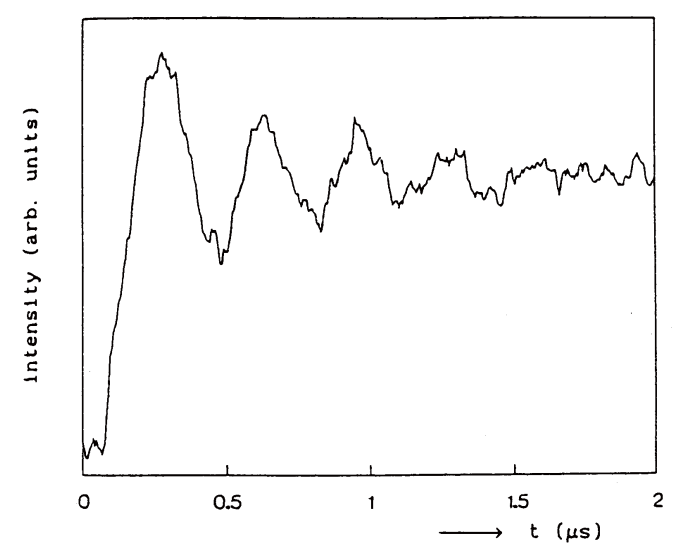

図 13.9.1

$\mathrm{Ru}(\mathrm{pby})_{3}\left(\mathrm{ClO}_{4}\right)_{3}$ の三重項状態のスピン準位間にみられる nutation.

マイクロ波の周波数は $2320 \mathrm{MHz}$. 


\title{
CHAPTER 14
}

\author{
電子スピン
}

電子スピンのことを知らないで現在の化学を論ずることは到底出来ない. それほど 電子スピンという概念は重要であるが，それを量子化学のカリキュラムの中のどこで 学習したらいいかはなかなかむずかしい. 現存する多くの教科書では原子構造の章の 中で始めて導入する，というのは，原子構造をより厳密に考えていこうとすると，ど うしても，それまで無視して来たスピンのことをちやんと考えなくてはならないとい う現実にぶつかるからである。例えば，Chapter 16 で学習するように，3 電子系の Li 原子の基底状態のエネルギーを変分法を用いて計算すると, 実験值よりもエネルギー が低いという，変分原理に反する奇異な結果になってしまう。そこで始めてスピンと いう概念を導入する，というのが多くの教科書の方法である。しかし，実を言うと， 何も 3 電子系までいかなくても， 1 電子系の $\mathrm{H}$ 原子でさえ, 励起状態を考える限りス ピンの概念なしには解釈がつかないのである．例えば $\mathrm{H}$ 原子の $2 p \rightarrow 1 s$ の発光スペク トルが 2 本に分裂しているという，いわゆるスペクトルの微細構造は，スピンの概念 を導入して始めて説明される. 更に現代の化学におけるスピンの重要性は原子構造や 原子スペクトルの解釈だけにあるのではない. スピンを実験的に捕える ESR の装置 はどこの大学にもあるし，化学反応に対するスピンの効果も重要である. 今や, spin chemistry ともいうべき新しい分野が生まれつつあると言ってもよい.

こうした，化学全般における重要性の観点からも，スピンのことはもつと早く学習 してもいいと思う。スピンというものが，古典力学ではどうしても理解出来ないもの である，という点から，量子力学の本論に入る前にまず spinのことを勉強するのはい いことであろう。そして, おそらく, 軌道角運動量 $\boldsymbol{L}$ について学習したすぐ後に, ス ピン角運動量について学習するのもよさそうに思う。現に本講義では，ごく初期の

Section 2.2 で Stern-Gerlachの実験のことを述べたが，実の所これはスピンに関連した 問題であったのである。ただ，角運動量のことをChapter 5 で学習した時，すぐそれ に続いてスピン角運動量に発展させることをためらったのは軌道角運動量のように きちんとした定義がスピン角運動量については得にくく理解しにくいためである. そ んなことで, 本講義でも, 今まで延び延びとなってしまったが, 原子構造について学 習する前にはじうしてもスピンのことを学習せざるを得なくなってしまった.

歴史的には，スピンというものは1925 年に, Uhlenbeck と Goudsmitにより, 原子 スペクトルの 2 重線を解決するために導入されたものである.しかし，その 3 年前に なされた Stern と Gerlachの実験が実はスピンに関した実験であったのである. Stern と Gerlach の実験についてはすでに Section 2.2 で詳述したが，このことに関してごく 
簡単に復習することから始めよう。

\subsection{Stern-Gerlach $の$ 実験}

1922 年に発表された Stern-Gerlachの実験は, Ag 原子が磁気モーメントを持ってい るかどうかを調べる目的でなされたものである．Ag の粒子を不斎磁場の中に入射し 通過させると，不斎磁場の方向がどうあろうとも，Ag 粒子の軌跡はいつも2つに分 れる. 念のため, 図 2.2.4 を再び示す。この実験結果はこの当時としては信じがたい ことであったに違いない.

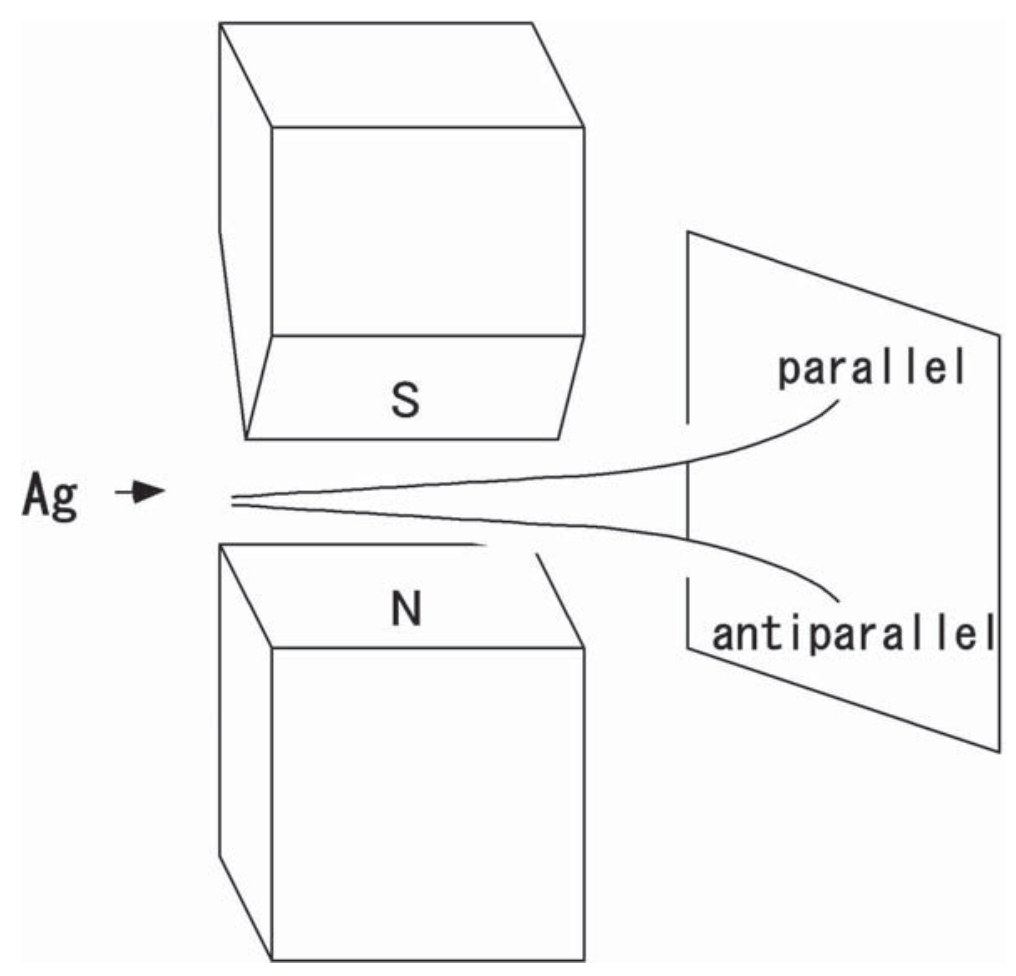

図 14.1.1 Stern-Gerlach の実験

(図 2.2.4 と同じもの)

Section 2.2 では, 「古典論の立場からは Ag 粒子の描く軌跡は, 図 2.2.3(b)のように, 連続的になるはずであるのに, 2 つしか分かれないというのは理解しにくい.」とい う観点から量子化の話を導入した。しかし，この段階まで学習した現在ではもう諸君 は，量子化ということも十分分かっているし，更に，軌道角運動量による量子化とい 
うことも分かっているので, Section 2.2 よりはちょっとばかり進んだ立場で

Stern-Gerlachの実験を考えてみよう.

当時すでに原子の軌道角運動量 $\boldsymbol{L}$ については十分な理解がなされていて, 多くの原 子スペクトルがこの考えを用いて理解されていた．例えばある 1 つの $L$ に相当するス ペクトル線が磁場によって $2 L+1$ 個に分裂するということも分かっていた (Zeeman 効 果)。そういう観点からみると, 粒子を直接不斉磁場の中に通過させれば軌跡は $2 L+1$ 個に分れるであろうことは容易に考えつく. Stern-Gerlach の実験では 2 つしか分れ

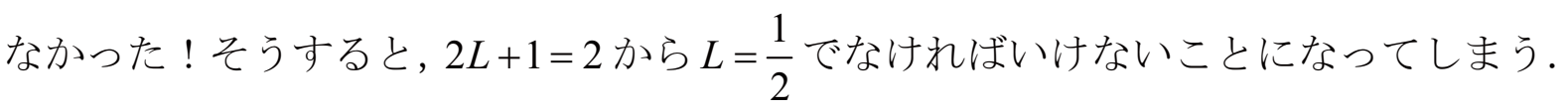
今までは整数であると思っていた $L$ という量子数が半整数であるとは！

現在の我々の知識によれば， $L$ につてはよく分かる。 $\mathrm{Ag}$ 原子の電子配置は $1 s^{2} 2 s^{2} 2 p^{6} \ldots 4 d^{10} 5 s$ である. 最外殼の $5 s$ 以外はすべて閉殼であるから角運動量を持たな い. $5 s$ についても $L=0$ であるからやはり角運動量はない. 従って，原子全体として $\mathrm{Ag}$ は軌道角運動量を持たない，すなわち， $L=0$ であることは自明である.

Stern-Gerlach の見出した磁気モーメントは，軌道角運動量以外の何か他の原因による ものである.それが今から学習する spin というものにあるわけであるが, Stern-Gerlach の時代にはそのことは分からなかったのである.

\subsection{Uhlenbeck と Goudsmit $の$ spin 仮説}

1920 年代の始め, 世の物理学者や分光学者はスペクトルで実験的に見出された微 細構造の解釈について悩んでいた。 寸なわち，それまで 1 本と思われて解釈されてい たスペクトル線が分光器の発達によって実は2本に分かれていることに気がついたわ けである。例えば，卑近な例では $\mathrm{Na}$ の発光スペクトルの D 線がある。これは $\mathrm{Na}$ 原 子の $1 s^{2} 2 s^{2} 2 p^{6} 3 p$ の励起状態から $1 s^{2} 2 s^{2} 2 p^{6} 3 s$ の基底状態へ遷移する時の発光線とし て解釈されていた。しかし，分解能のよい分光器で調べると，この Na の D 線は $589.76 \mathrm{~nm}$ と $589.16 \mathrm{~nm}$ の 2 つ線から構成されている. 2 つのスペクトル線の間隔は 波数にして $17 \mathrm{~cm}^{-1}$ となる。このような分裂は, その当時の理論では解釈出来ないも のであった，そういう時代に，Uhlenbeck と Goudsmit の 2 人が，以下に述べる画期的 な仕事をしたわけである。

1925 年, Uhlenbeck と Goudsmitは，電子スピンの仮説によって，それまで説明出 来なかったスペクトルの分裂が満足に説明出来ることを示した。（G. E. Uhlenbeck, Goudsmit, Naturwissenshaften, $\underline{13}, 953$ (1925); Nature, 117, 264 (1926).) 彼らが提唱した電 子スピンの仮説は次のように要約される.

（1）電子は spin angular momentum $S$ を持ち，その空間上ある方向 $u$ への成分に相 
当する operator $S_{u}(u=x, y, z$, etc. $)$ はただ 2 つの eigenvalue $\frac{\hbar}{2}$ と $-\frac{\hbar}{2}$ を持つ.（ここ で， $u$ は $x, y, z$ 方向のみならず空間中の任意の方向を代表していると考えてよい)

（2）電子のスピン磁気モーメント（spin magnetic moment）の $u$ 方向の成分は（SI 単位系で $)-\frac{e}{m_{\mathrm{e}}} S_{u} \quad(u=x, y, z)$ という Hermitian operator で示される.ここで $e$ は電 気素量, $m_{\mathrm{e}}$ は電子の質量である。

（3） spin angular momentum の operator $S_{u}$ は orbital angular momentum $L_{u}$ と同じよ うな交換関係を満たす。すなわち

$$
\begin{aligned}
& {\left[S_{x}, S_{y}\right]=i \hbar S_{z}} \\
& {\left[S_{y}, S_{z}\right]=i \hbar S_{x}} \\
& {\left[S_{z}, S_{x}\right]=i \hbar S_{y}}
\end{aligned}
$$

この仮説が出された当時のことを考えてみると，仮説（3）は，従来の $L_{u}$ に関する交 換関係の常識的な拡張であり，あまり問題はありそうもないが仮説（1）と（2）は， 従来の理論の常識からみて, はなはだ奇異なものと思われたであろう。すなわち，(1） の仮説は半整数の量子数の導入という，それまでなかった奇異な仮説である。（2）の 仮説は更に理解しにくかったであろう。というのは，軌道角運動量 $L_{u}$ にるる磁気モー メントの operator は $-\frac{e}{2 m_{\mathrm{e}}} L_{u}$ であった。（下記註を参照.）仮説（2）は，それまでの軌 道角運動量についての常識からすると 2 倍の大きさとなっている.

\section{【註】：}

電子の運動によって生ずる magnetic moment が上述のような值となることは電磁気 学の教科書に書いてある通りであるが，念のために復習しておこう。

電子が半径 $r$ の円周上を速さvで回っているとする. Law of Biot-Savartにより, magnetic moment $\boldsymbol{\mu}$ は current $\times$ area で表される.電子は, 軌道を単位時間内に $\frac{\boldsymbol{v}}{2 \pi r}$ 回 回る.従って

$$
\text { current }=-\frac{e v}{2 \pi r}
$$

となる. 一方 


$$
\text { area }=\pi r^{2}
$$

である。従って

$$
\boldsymbol{\mu}=-\frac{e v \boldsymbol{r}}{2}
$$

となる。一方, orbital magnetic moment $\boldsymbol{L}$ は

$$
\boldsymbol{L}=m_{\mathrm{e}} \boldsymbol{v} r
$$

である.かくして $\boldsymbol{\mu}=-\frac{e}{2 m_{\mathrm{e}}} \boldsymbol{L}$ を得る。

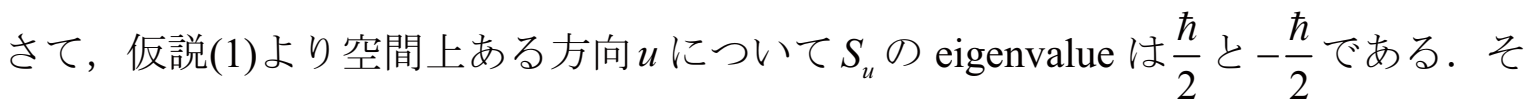
こで我々は, $z$ 軸方向の成分 $S_{z}$ についての eigenfunction を定義することにする，すな わち, operator $S_{z}$ についての eigenvalue が $\frac{\hbar}{2}$ のものを $\alpha,-\frac{\hbar}{2}$ のもを $\beta$ で表すこと にする。すなわち

$$
\begin{aligned}
& S_{z} \alpha=\frac{\hbar \alpha}{2} \\
& S_{z} \beta=-\frac{\hbar \beta}{2}
\end{aligned}
$$

こうして spin function $\alpha$ および $\beta$ に対する $S_{z}$ の作用を定義してしまうと， $S_{x}$ および $S_{y}$ の作用も一義的に決められる。この過程は Problem 14.2.1 で行うこととし，以下結 果のみをまとめておこう。

$$
\begin{aligned}
& S_{+}=S_{x}+i S_{y} \\
& S_{-}=S_{x}-i S_{y}
\end{aligned}
$$

と定義すると次式が得られる.

$$
\begin{aligned}
& S_{+} \alpha=0 \\
& S_{+} \beta=\hbar \alpha \\
& S_{-} \alpha=\hbar \beta \\
& S_{-} \beta=0
\end{aligned}
$$

または上式を書き換えて次式を得る. 


$$
\begin{aligned}
& S_{x} \alpha=\frac{\hbar \beta}{2} \\
& S_{x} \beta=\frac{\hbar \alpha}{2} \\
& S_{y} \alpha=\frac{i \hbar \beta}{2} \\
& S_{y} \beta=-\frac{i \hbar \alpha}{2}
\end{aligned}
$$

\section{乞 Problem 14.2.1}

式(14.2.4)または式(14.2.5)を次のようにして証明せよ.

Step 1 交換関数の仮定より次の式を証明せよ.

$$
\begin{aligned}
& S_{+} S_{-}=S^{2}+\hbar S_{z}-S_{z}^{2} \\
& S_{-} S_{+}=S^{2}-\hbar S_{z}-S_{z}^{2} \\
& S_{z} S_{+}=S_{+}\left(S_{z}+\hbar\right) \\
& S_{z} S_{-}=S_{-}\left(S_{z}-\hbar\right)
\end{aligned}
$$

Step 2 step 1 で求めた関係式より

$$
S_{z} S_{+} \alpha=\frac{3 \hbar S_{+} \alpha}{2}
$$

であることを示せ.これより， $S_{+} \alpha$ は固有值 $\frac{3 \hbar}{2}$ を持つ $S_{z}$ の固有関数であるか, また は $S_{+} \alpha=0$ であるかのいずれかである．前者はスピン仮説に反する（どうしてか考え

よ）ので後者が成り立たなければならない。このような議論により次式を証明せよ.

$$
\begin{aligned}
& S_{+} \alpha=0 \\
& S_{-} \beta=0
\end{aligned}
$$

Step 3 上述したことより次式を証明せよ.

$$
\begin{aligned}
& S^{2} \alpha=\frac{3 \hbar^{2} \alpha}{4} \\
& \boldsymbol{S}^{2} \beta=\frac{3 \hbar^{2} \beta}{4}
\end{aligned}
$$

Step 4 step 2 と同様な方法で $S_{+} \beta$ は $\alpha$ の何倍か, また $S_{-} \alpha$ は $\beta$ の何倍か，すなわち

$$
\begin{aligned}
& S_{+} \beta=c_{+} \alpha \\
& S_{-} \alpha=c_{-} \beta
\end{aligned}
$$


と表されることを示せ.

Step 5 以上の結果を用い次式を証明せよ.

$$
c_{+} c_{-}=\hbar^{2}
$$

Step $6 S_{x}, S_{y}$ は Hermitian operator であるという仮定を用い，かつ， $\alpha$ および $\beta$ は規 格化されていると考えて次式を証明せよ.

$$
\begin{aligned}
& c_{+}=c_{-}{ }^{*} \\
& c_{-}=c_{+}{ }^{*}
\end{aligned}
$$

Step 7 以上のことより $c_{+}$および $c_{-}$の一般的な解を求めよ。（ $c_{+} ， c_{-}$にはここで考え た以外の制限，例えば実数とするなどの制限を設けないものとする)

\section{【注意】:}

この問題では，式(14.2.5)および式(14.2.6)の導出を目的としている．従って，当然 のことながら，これから証明しようとする式を用いないように. 用いてよいのはスピ ン仮説とそれに基づく定義式(14.2.2)のみである.

¿̧Problem 14.2.2

次の式を証明せよ。

$$
\begin{aligned}
& S_{x} S_{y}+S_{y} S_{x}=0 \\
& S_{y} S_{z}+S_{z} S_{y}=0 \\
& S_{z} S_{x}+S_{x} S_{z}=0
\end{aligned}
$$

\section{胥Problem 14.2.3}

$S$ の成分, $S_{x}, S_{y}, S_{z}$ はいずれも $\boldsymbol{S}^{2}$ と可換，すなわち

$$
\left[S_{x}, S^{2}\right]=\left[S_{y}, S^{2}\right]=\left[S_{z}, S^{2}\right]=0
$$

であることを証明せよ。

\section{3 スピン仮説による Stern-Garlach の実験の解釈}

Uhlenbeck と Goudsmit のスピン仮説は, それまでどうしても説明することが出来な かったスペクトル線の分裂を説明する，ということで提唱されたものである。しかし， 
この問題に入る前に, この仮説が出された時より 3 年前になされた Stern-Gerlach の実 験が，実はこのスピン仮説でよく説明出来ることを示そう.

前節で述べたスピン仮説（1）によると，空間上のある方向 $u$ に対して $S_{u}$ は $\frac{\hbar}{2}$ と $-\frac{\hbar}{2}$ という 2 つだけの eigenvalue を与える。これは Stern-Gerlach の実験で, どのような方 向に磁場をかけてもただ 2 つの結果（Section 2.2 では"parallel"と"antiparallel" と名付け た）を与えるということに対応している．Ag 原子はその電子のために spin angular momentum をもっていて， $u$ 方向に不斉磁場をかけるという Stern-Gerlach の実験は， operator $S_{u}$ で示されると考えられる. 同様に, $u$ 方向の磁気モーメントは $-\frac{e}{m_{e}} S_{u}$ とい う operator で示される.このように考えてみると, Stern-Gerlach の実験, および Section 2.2 で述べたいくつかの思考実験は満足に説明出来る. 以下，このことを具体的に考 えてみよう。それで諸君は以下を読む前にまず Section 2.2 を復習し, 図を参考にしな がら以下を学習してほしい。

オーブンで熱せられて出て来た Ag 原子は， $\alpha$ spin を持つものと $\beta$ spin を持つも のが半々あると考えられる。（これは統計力学の問題である。もし，オーブン中で銀 を熱する時に磁場がかけられていなければ， $\alpha$ spin を持つ $\mathrm{Ag}$ 原子の数と $\beta$ spin を持 つ $\mathrm{Ag}$ 原子の数とは完全に一致している.） $\alpha$ ののは

$$
S_{z} \alpha=\frac{\hbar \alpha}{2}
$$

$\beta$ のものは

$$
S_{z} \beta=-\frac{\hbar \beta}{2}
$$

のように振る舞う。このそれぞれが parallel, antiparallel として, 不斉磁場によって別 の方向に曲げられるわけである.すなわち, parallel と antiparallel とは, それぞれ, eigenvalue が $\frac{\hbar}{2}$ おび- $\frac{\hbar}{2}$ を持つものに相当する。磁気モーメントの $z$ 成分は eigenvalue の- $\frac{e}{m_{\mathrm{e}}}$ 倍であるから parallel, antiparallel それぞれについて

$$
\mp \frac{e \hbar}{2 m_{\mathrm{e}}}=\mp \mu_{\mathrm{B}}
$$

となる。

次に, 図 2.2.5に示した $2 つ の$ Stern-Gerlachの装置を組み合わせた実験を考えてみ よう。念のため, 図 2.2.5 を図 14.3.1 として再び示しておく.この実験では, 最初の Stern-Gerlach の装置で parallel になったもののみを第 1 の Stern-Gerlach の装置に導入 すると，全ての Ag 原子が parallel になる，というものであった。この結果は spin 仮 
説で次のように解採される.

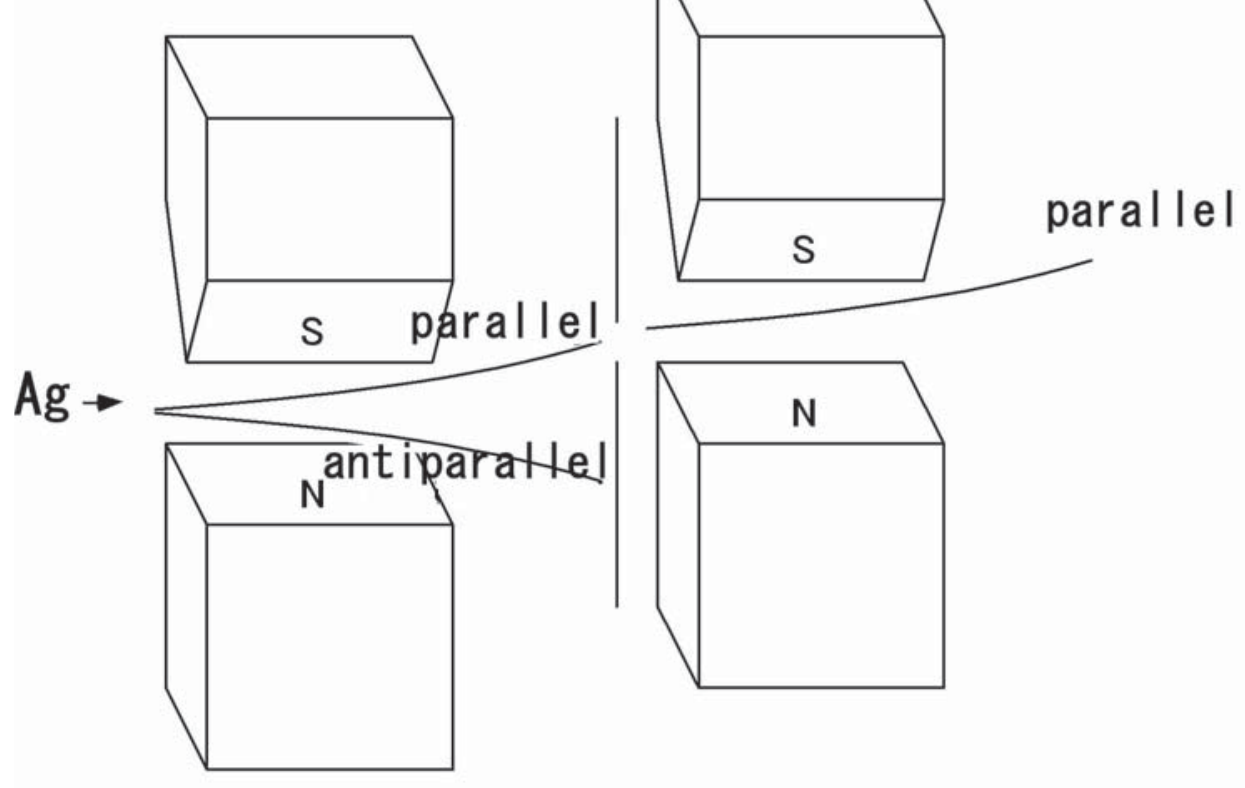

図 14.3.1Ｓtern-Gerlach の実験を 2 回続けて行う（その 1）

(図 2.2.5 と同じもの)

第 1 の $z$ 軸方向の不斉磁場で parallel となったもの，すなわち $\alpha$ spin のものだけを 取り出し, もう一度 $z$ 方向の不斉磁場にかけるわけである.この 2 番目の実験は $S_{z} \alpha$ と いう式でもって示される実験である。結果は

$$
S_{z} \alpha=\frac{\hbar \alpha}{2}
$$

の式から分かるように $\alpha$ spin は $S_{z}$ の eigenfunctionになっているから 100\%の確からし さで parallel ということが分かる.

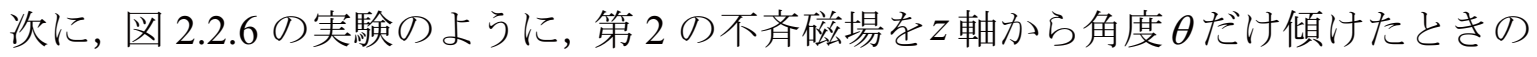
ことを考えてみよう。 


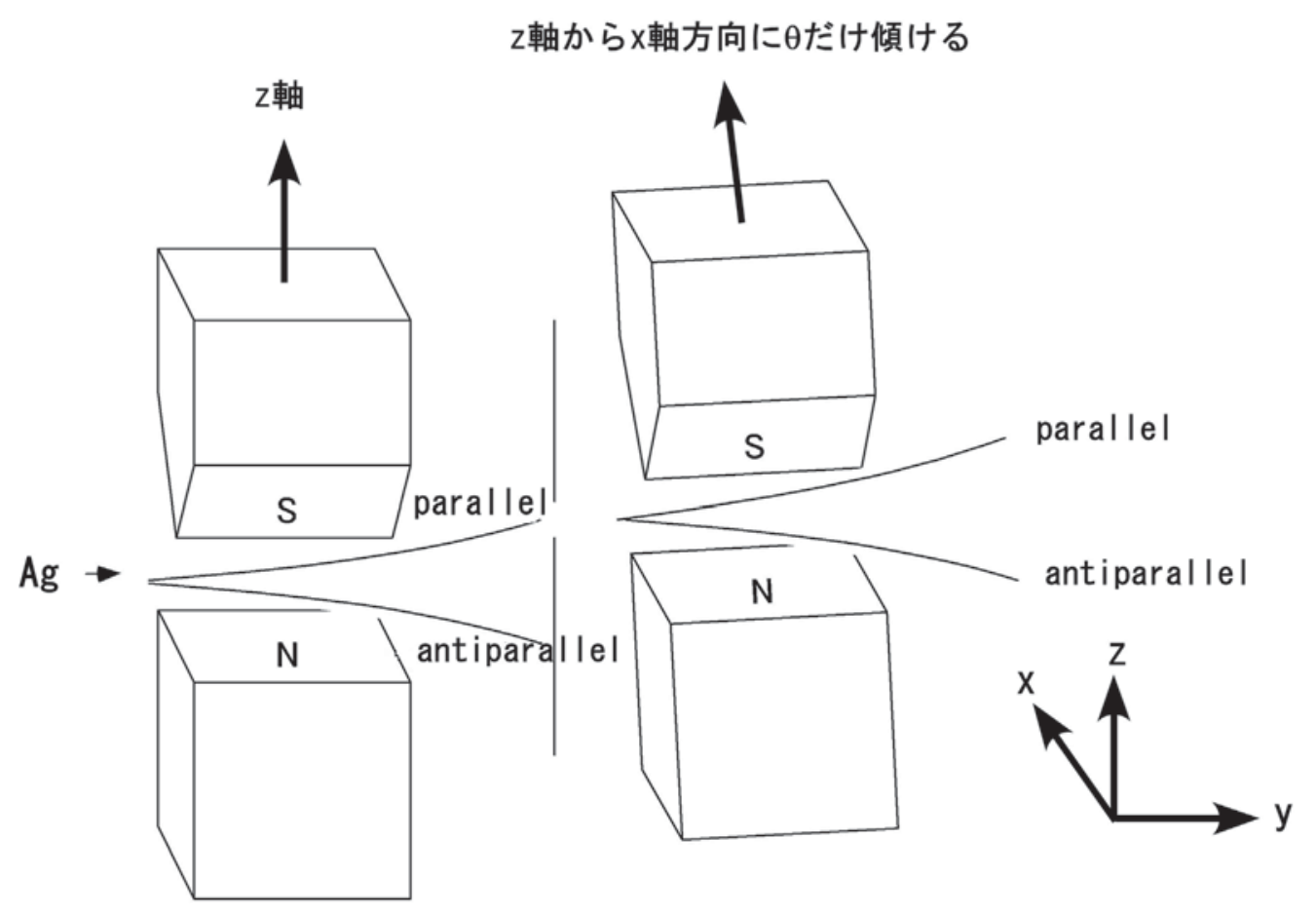

図 14.3.2 Stern-Gerlach の実験を 2 回続けて行う（その 2）（図 2.2.6 と同じもの）

この実験では，第 1 の不斉磁場で parallel となったものだけを取り出して，第 1 の 不斉磁場とは $\theta$ だけ傾いた第 2 の不斉磁場に通す. そうすると, 前回の $\theta=0$ の場合と 異なり, parallel と antiparallel の両方の成分が出て来るというものであった. そして parallel に出て来る $\mathrm{Ag}$ 原子の数は全体の $\cos ^{2} \frac{\theta}{2}$ で, antiparallel に出て来る $\mathrm{Ag}$ 原子の 数は全体の $\sin ^{2} \frac{\theta}{2}$ である.この実験結果は次のように解釈される. 第 2 の不斉磁場に よる実験は operator $\cos \theta S_{z}+\sin \theta S_{x}$ に相当する. $\alpha$ spin にこの operator を作用させる と

$$
\left(\cos \theta S_{z}+\sin \theta S_{x}\right) \alpha=\left(\frac{\hbar}{2} \cos \theta\right) \alpha+\left(\frac{\hbar}{2} \sin \theta\right) \beta
$$

となる.すなわち, $\alpha$ spin はこの operator の eigenfunction にはなっていない. それ故, 第 2 の不斉磁場による結果はある時には parallel になり，またある時には antiparallel になり，1回毎に異なり得るのである。こういう場合には，数多くの実験による平均 值が expectation value として与えられるだけである. expectation value は

$$
\left\langle\alpha\left|\cos \theta S_{z}+\sin \theta S_{x}\right| \alpha\right\rangle=\frac{\hbar}{2} \cos \theta
$$


となる. 磁気モーメントの磁場方向 $u$ の成分を与える operator は $S_{u}$ に $-\frac{e}{m_{\mathrm{e}}}$ をかけたも のであるからその expectation value は

$$
-\frac{e}{m_{\mathrm{e}}} \frac{\hbar}{2} \cos \theta=-\mu_{\mathrm{B}} \cos \theta
$$

となり, 式(2.2.6)ですでにみた通りである.

\section{【注】 :}

式(14.3.5)で spin 関数についての積分を実行している， $\alpha$ spin, $\beta$ spin が規格直交 系をな寸ということを暗黙に認めてしまっているが，この点については次の section で学習してほしい.

\section{4 スピンの数学的表現}

今まで述べて来たことで, 1 電子のスピン関数 $\alpha$ と $\beta$ についてはだいたい理解出来 たであろう.今までのことをまとめると次のようなことになる. どちらも operator $S^{2}$ の固有関数である. (式(14.2.7)） $\boldsymbol{S}^{2}$ と $S_{z}$ とが交換可能であるから $\alpha, \beta$ は $S_{z}$ の固有 関数である. $S_{z}$ の固有值が $\frac{\hbar}{2}$ のものが $\alpha,-\frac{\hbar}{2}$ のものが $\beta$ である. すなわち

$$
\begin{gathered}
S_{z} \alpha=\frac{\hbar \alpha}{2} \\
S_{z} \beta=-\frac{\hbar \beta}{2}
\end{gathered}
$$

こう考えてみると, operator $\boldsymbol{S}^{2}$ および $S_{z}$ は, 少なくとも形式的にはすでに学習した orbital angular momentum operator $\boldsymbol{L}^{2}$ および $L_{z}$ とほぼ同様に考えてよさそうだという ことになる．交換関係も同じだし，こう考えて一見よさそうにも思える.

\section{【補】:}

具体的には

$$
L_{z} Y_{l, m}=\hbar m Y_{l, m}
$$

の式で, 形式的に $m= \pm \frac{1}{2}$ をとると（ $Y_{l, m}$ は $m$ が整数の場合しか定義されていないこと を承知の上で，仮にそうおくと） 


$$
\begin{aligned}
& L_{z} Y_{l, \frac{1}{2}}=\frac{\hbar}{2} Y_{l, \frac{1}{2}} \\
& L_{z} Y_{l,-\frac{1}{2}}=-\frac{\hbar}{2} Y_{l,-\frac{1}{2}}
\end{aligned}
$$

となるので, これをみると $\alpha$ というのは $Y_{l, \frac{1}{2}}$ みたいなもので, $\beta$ というのは $Y_{l,-\frac{1}{2}}$ みたい なもんだな，とも思える。更に

$$
\begin{aligned}
L_{ \pm} Y_{l, m} & =\sqrt{l(l+1)-m(m \pm 1)} \hbar Y_{l, m \pm 1} \\
& =\sqrt{(l \pm m+1)(l \mp m)} Y_{l, m \pm 1}
\end{aligned}
$$

の式で，再び形式的に $m= \pm \frac{1}{2}$ とし，更に $l=\frac{1}{2}$ とすると

$$
\begin{aligned}
& L_{+} Y_{\frac{1}{2}, \frac{1}{2}}=0 \\
& L_{-} Y_{\frac{1}{2}, \frac{1}{2}}=\hbar Y_{\frac{1}{2},-\frac{1}{2}} \\
& L_{+} Y_{\frac{1}{2},-\frac{1}{2}}=\hbar Y_{\frac{1}{2}, \frac{1}{2}} \\
& L_{-} Y_{\frac{1}{2},-\frac{1}{2}}=0
\end{aligned}
$$

となる．これと式(14.2.4)と比べると，形式的には $\alpha$ とは $Y_{\frac{1}{2}, \frac{1}{2}}, \beta$ とは $Y_{\frac{1}{2},-\frac{1}{2}}$ みたいなも のに相当するんだなと思える.しかし，こういった形式的な比較は，いろいろな点で 破綻を生ずる。むずかしいことは， $\boldsymbol{S}$ という operator を座標で定義することが出来な いことであろう。，場合には例えば

$$
L_{z}=-i \hbar\left(x \frac{\partial}{\partial y}-y \frac{\partial}{\partial x}\right)
$$

のように，空間座標 $x, y, z$ で定義される。または

$$
L_{z}=-i \hbar \frac{\partial}{\partial \phi}
$$

のように極座標でも定義される。しかし，スピンの operatorについてはそういう定義 を与えることが出来ない， $S$ の定義はSection 15.2 のスピン仮説に述べたものしかな い. そこに物理的イメージがつかみにくい難点があろう.

ではスピン関数というものをもう少し見てみよう.今まで我々はwavefunction $\psi$ を 空間座標 $x, y, z$ の関数と見なして来た。 それでは，スピン関数はどういう座標の関数 なのであろうか. これは $x, y, z$ 以外の第 4 の座標としての「スピン座標」 $\sigma$ の関数で 
ある.ただし， $\sigma$ は， $x, y, z$ のような連続な変数とは異なり,$\frac{1}{2}$ と $-\frac{1}{2}$ のつの值し か取り得ない変数である. spin wavefunction を $\psi$ でなく $\rho$ と表すことにし，それはス ピン座標 $\sigma$ の関数ということで $\rho(\sigma)$ と書こう. (スピンの波動関数をどういう記号で 表すかということで特に一般的な習慣があるわけではない， $\psi$ とか $\phi$ を用いてもいい が，いつも ややфではまぎらわしいのでここでは仮に $\rho$ という記号を用いることにし たまでである． $\rho$ という記号が広く一般的に用いられているというわけではない.) $\psi(x, y, z)$ が， $x, y, z$ を決めればある值として定まるのと同様な意味で， $\rho(\sigma)$ の值 ものが与えられればある值として定まる． $\alpha$ というものは $\sigma=\frac{1}{2}$ の時に 1 であり， $\sigma=-\frac{1}{2}$ の時 0 であるような関数と定義される. 寸なわち

$$
\begin{aligned}
& \alpha(\sigma)=1 \quad \text { for } \quad \sigma=\frac{1}{2} \\
& \alpha(\sigma)=0 \quad \text { for } \quad \sigma=-\frac{1}{2}
\end{aligned}
$$

同様に spin function $\beta$ は, 次のように定義される.

$$
\begin{array}{ll}
\beta(\sigma)=0 \quad \text { for } \quad \sigma=\frac{1}{2} \\
\beta(\sigma)=1 \quad \text { for } \quad \sigma=-\frac{1}{2}
\end{array}
$$

spin function がこのように座標 $\sigma$ の関数として与えられたので，2つの spin function $f(\sigma)$ と $g(\sigma)$ との間のスカラー積も容易に定義出来る. 寸なわち

$$
\int f^{*}(\sigma) g(\sigma) d \sigma=f^{*}\left(\frac{1}{2}\right) g\left(\frac{1}{2}\right)+f^{*}\left(-\frac{1}{2}\right) g\left(-\frac{1}{2}\right)
$$

例えば式(14.4.1)を用いて

$$
\int \alpha^{*} \alpha d \sigma=\alpha^{*}\left(\frac{1}{2}\right) \alpha\left(\frac{1}{2}\right)+\alpha *\left(-\frac{1}{2}\right) \alpha\left(-\frac{1}{2}\right)=1
$$

または，しばしば用いられる bracket notation を用いて

$$
\langle\alpha \mid \alpha\rangle=1
$$

このことを我々は「規格化されている」という言葉で表している，同様に 


$$
\int \alpha^{*} \beta d \sigma=\alpha^{*}\left(\frac{1}{2}\right) \beta\left(\frac{1}{2}\right)+\alpha *\left(-\frac{1}{2}\right) \beta\left(-\frac{1}{2}\right)=0
$$

または

$$
\langle\alpha \mid \beta\rangle=0
$$

であるが，これを通常「 $\alpha$ と $\beta$ とは直交している」という言葉で表している.

これまでは, wavefunction を空間座標のみの関数として表して来たが，上述したス ピン座標にも依存すると考える。 $\psi(x, y, z, \sigma)^{*} \psi(x, y, z, \sigma) d x d y d z$ は体積素片

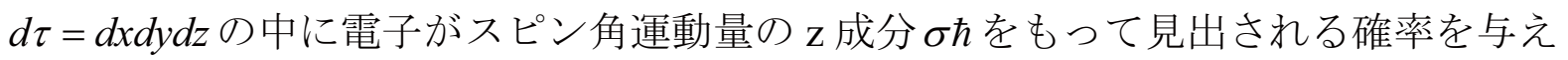
る. $\psi$ の規格化は当然

$$
\iiint\left\{\psi\left(x, y, z, \frac{1}{2}\right) * \psi\left(x, y, z, \frac{1}{2}\right)+\psi\left(x, y, z,-\frac{1}{2}\right) * \psi\left(x, y, z,-\frac{1}{2}\right)\right\} d x d y d z=1
$$

で与えられる。

これまで, wavefunctionのスピン座標依存性を無視して来たが，それはスピン座標 まで含めた wavefunction が

$$
\psi(x, y, z, \sigma)=\psi(x, y, z) \rho(\sigma)
$$

のように，空間座標のみの関数（spatial wavefunction） $\psi(x, y, z)$ とスピン座標のみの 関数（spin wavefunction） $\rho(\sigma)$ との積で表される場合を扱っていたことになる.

例えば，水素原子の波動関数

$$
\psi_{n \ell m}=R_{n \ell}(r) \Theta_{\ell, m}(\theta, \phi)
$$

は $\ell$ にいて $0,1,2, \ldots, n-1$ の $n$ 個, $m$ について $-\ell,-\ell+1, \ldots, \ell の 2 \ell+1$ 個の, 合わせて $n^{2}$ 個の wavefunction が縮退しているが， spin まで考えると $\psi_{n \ell m} \alpha と \psi_{n \ell m} \beta$ があり，合わせ て $2 n^{2}$ 個の wavefunction が縮退していることになる.とはいっても, spatial wavefunction と spin wavefunction とは完全には独立でなく, ある程度の相互作用があるのが現実で あり，実はこの相互作用こそが Uhlenbeck と Goudsmit が解決したスペクトル線の分裂 を与えるものなのである。この点に関しては Section 14.6 で述べる.

\section{5 一般のスピン関数}


今までは 1 個の電子の取り得るスピンとして $\alpha$ および $\beta$ の 2 つスピンのみを考え て来たが，2 個以上の電子からなる系では，それぞれのスピンの組み合せで新しいス ピン関数が得られる. 一般にスピン関数 $\rho\left(S, M_{\mathrm{s}}\right)$ は量子数 $S$ と $M_{\mathrm{s}}$ にって定義され

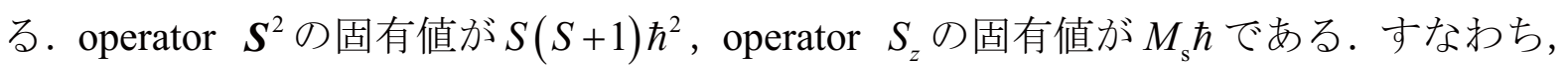

$$
\begin{aligned}
& S^{2} \rho\left(S, M_{\mathrm{s}}\right)=S(S+1) \hbar^{2} \rho\left(S, M_{\mathrm{s}}\right) \\
& S_{z} \rho\left(S, M_{\mathrm{s}}\right)=M_{\mathrm{s}} \hbar \rho\left(S, M_{\mathrm{s}}\right)
\end{aligned}
$$

$S_{+}$および $S_{-}$の作用も，Chapter 5 でLについて出したのと全く同じように，(又は

Problem 14.2.1 $S=\frac{1}{2}$ の場合に行ったのと同じように）求めることが出来る. 全く同 じ考え方で式を導出するのであるから, 当然と言えば当然であるが， $L_{ \pm}$の作用と形式 的には全く同じである。すなわち

$$
S_{ \pm} \rho\left(S, M_{\mathrm{s}}\right)=\sqrt{S(S+1)-M_{\mathrm{s}}\left(M_{\mathrm{s}} \pm 1\right)} \hbar \rho\left(S, M_{\mathrm{s}} \pm 1\right)
$$

が得られる。

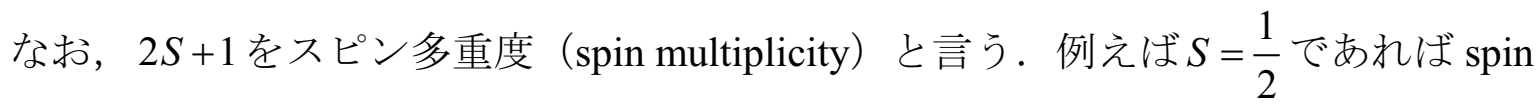
multiplicity は2，S=1であれば spin multiplicity は 3 である. そして，一般に spin multiplicity の值そのものの代りに，次のような言葉で表わされる.

$$
\begin{aligned}
\text { spin multiplicity } & =2 & & \text { spin doublet } \\
& =3 & & \text { spin triplet } \\
& =4 & & \text { spin quartet } \\
& =5 & & \text { spin quintet } \\
& =6 & & \text { spin sextet }
\end{aligned}
$$

々 Exercise 14.5.1

2 電子系のスピン関数を $\boldsymbol{S}^{2}$ および $S_{z}$ の固有関数となるように求めよ.

\section{【解】 :}

$1 つ 1 つ の$ 電子について $\alpha$ および $\beta$ の 2 通りがあり得るから, 2 電子系では $2 \times 2=4$ 通りがあり得る. 寸なわち，考えられる spin wavefunction として， 


$$
\begin{aligned}
& \alpha \alpha=\alpha(1) \alpha(2) \\
& \alpha \beta=\alpha(1) \beta(2) \\
& \beta \alpha=\beta(1) \alpha(2) \\
& \beta \beta=\beta(1) \beta(2)
\end{aligned}
$$

ここで，例えば $\alpha(1)$ というのは 1 という電子が $\alpha$ spin を持つということを示すこと とする. いちいち(1)とか(2)とかを書くのが面倒な場合，式(14.5.3)の左辺のように簡 単に示すことも出来る。

さて, spin operator は, 次のように各電子についての和と考える.

$$
S_{u}=S_{u}(1)+S_{u}(2) \quad(u=x, y, z)
$$

ここで $S_{u}(1)$ というのは，1 という電子の spin function にのみ $S_{u}$ という operator を作用 させることを示している. 当然

$$
\begin{aligned}
& S_{+}=S_{+}(1)+S_{+}(2) \\
& S_{-}=S_{-}(1)+S_{-}(2)
\end{aligned}
$$

例として $\alpha \alpha$ に $S_{z}$ を作用させてみよう。

$$
\begin{aligned}
S_{z} \alpha \alpha & =S_{z}(1) \alpha(1) \alpha(2)+S_{z}(2) \alpha(1) \alpha(2) \\
& =\left[S_{z}(1) \alpha(1)\right] \alpha(2)+\alpha(1)\left[S_{z}(2) \alpha(2)\right] \\
& =\frac{\hbar}{2} \alpha(1) \alpha(2)+\frac{\hbar}{2} \alpha(1) \alpha(2) \\
& =\hbar \alpha(1) \alpha(2)
\end{aligned}
$$

すなおち， $\alpha \alpha$ は operator $S_{z}$ の固有関数であり，その固有值はちであることが分かる.

もう 1 つの例として $\alpha \beta$ に $S_{z}$ を作用してみよう.

$$
\begin{aligned}
S_{z} \alpha \beta & =S_{z}(1) \alpha(1) \beta(2)+S_{z}(2) \alpha(1) \beta(2) \\
& =\left[S_{z}(1) \alpha(1)\right] \beta(2)+\alpha(1)\left[S_{z}(2) \beta(2)\right] \\
& =\frac{\hbar}{2} \alpha(1) \beta(2)-\frac{\hbar}{2} \alpha(1) \beta(2) \\
& =0
\end{aligned}
$$

すなおち， $\alpha \beta$ は $S_{z}$ の固有関数であり，その固有值はゼロであるということが出来る.

式(14.5.3)の残りの 2 つの spin function についても同様に作用してみる. その結果,

$$
\begin{aligned}
& S_{z} \beta \alpha=0 \\
& S_{z} \beta \beta=-\hbar \beta \beta
\end{aligned}
$$


となることが分かるであろう。

式(14.5.6)から式(14.5.9)をまとめてみると, 次のように言うことが出来よう. 式 (14.5.3)の 4 つの spin function はすべて operator $S_{z}$ の固有関数であり, その固有值は,

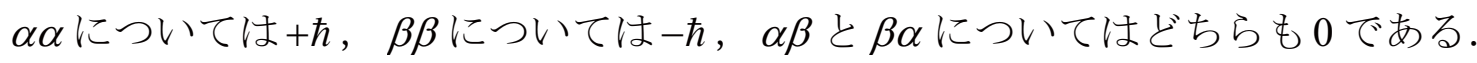

それでは式(14.5.3)の $4 つ の$ spin function が $S^{2}$ の固有関数となっているであろうか. 実際に， $S^{2}$ を作用してみよう。

例として， $\alpha \alpha$ に的作用してみよう.

$$
\begin{aligned}
\boldsymbol{S}^{2} \alpha \alpha & =\left[\frac{1}{2} S_{+} S_{-}+\frac{1}{2} S_{-} S_{+}+S_{z}^{2}\right] \alpha \alpha \\
& =\frac{1}{2} S_{+}\left[S_{-} \alpha \alpha\right]+\frac{1}{2} S_{-}\left[S_{+} \alpha \alpha\right]+S_{z}\left[S_{z} \alpha \alpha\right] \\
& =\frac{\hbar}{2}\left\{S_{+} \beta(1) \alpha(2)+S_{+} \alpha(1) \beta(2)\right\}+\hbar\left[S_{z} \alpha \alpha\right] \\
& =\frac{\hbar^{2}}{2}\{\alpha(1) \alpha(2)+0+0+\alpha(1) \alpha(2)\} \hbar^{2} \alpha \alpha \\
& =2 \hbar^{2} \alpha \alpha
\end{aligned}
$$

もう 1 つ例として $\alpha \beta$ に $\boldsymbol{S}^{2}$ を作用してみよう.

$$
\begin{aligned}
S^{2} \alpha \beta & =\left[\frac{1}{2} S_{+} S_{-}+\frac{1}{2} S_{-} S_{+}+S_{z}{ }^{2}\right] \alpha \beta \\
& =\frac{1}{2} S_{+}\left[S_{-} \alpha \beta\right]+\frac{1}{2} S_{-}\left[S_{+} \alpha \beta\right]+S_{z}\left[S_{z} \alpha \beta\right] \\
& =\frac{\hbar}{2}\left\{S_{+} \beta(1) \beta(2)+S_{-} \alpha(1) \beta(2)\right\} \\
& =\frac{\hbar^{2}}{2} \times 2[\alpha \beta+\beta \alpha] \\
& =\hbar^{2}(\alpha \beta+\beta \alpha)
\end{aligned}
$$

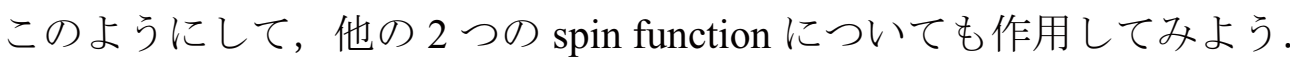
結果は,

$$
\begin{aligned}
& \boldsymbol{S}^{2} \beta \alpha=\hbar^{2}(\alpha \beta+\beta \alpha) \\
& \boldsymbol{S}^{2} \beta \beta=2 \hbar^{2} \beta \beta
\end{aligned}
$$

式(14.5.10)から式(14.5.13)までの結果から分かるように， $\alpha \alpha$ と $\beta \beta$ は共に $\boldsymbol{S}^{2}$ の固有 関数である. そして固有值は, どちらも $2 \hbar^{2}$ である. しかし， $\alpha \beta$ と $\beta \alpha$ とは $\boldsymbol{S}^{2}$ の固有 值になってはいない.

そこで上述したように，我々は，式(14.5.3)の組み合せにより $\boldsymbol{S}^{2}$ の固有関数を作ら 
なければならない。このように，ある operator の固有関数を求める方法はすでに繰り 返し学習している。すなわち, 我々は式(14.5.3)の4つの spin function を basis function とし， $\boldsymbol{S}^{2}$ という operatorについての行列要素からなる matrix を対角化すればよい. 具 体的には,

$$
\left[\begin{array}{cccc}
\left\langle\alpha \alpha\left|\boldsymbol{S}^{2}\right| \alpha \alpha\right\rangle & \left\langle\alpha \alpha\left|\boldsymbol{S}^{2}\right| \alpha \beta\right\rangle & \left\langle\alpha \alpha\left|\boldsymbol{S}^{2}\right| \beta \alpha\right\rangle & \left\langle\alpha \alpha\left|\boldsymbol{S}^{2}\right| \beta \beta\right\rangle \\
\left\langle\alpha \beta\left|\boldsymbol{S}^{2}\right| \alpha \alpha\right\rangle & \left\langle\alpha \beta\left|\boldsymbol{S}^{2}\right| \alpha \beta\right\rangle & \left\langle\alpha \beta\left|\boldsymbol{S}^{2}\right| \beta \alpha\right\rangle & \left\langle\alpha \beta\left|\boldsymbol{S}^{2}\right| \beta \beta\right\rangle \\
\left\langle\beta \alpha\left|\boldsymbol{S}^{2}\right| \alpha \alpha\right\rangle & \left\langle\beta \alpha\left|\boldsymbol{S}^{2}\right| \alpha \beta\right\rangle & \left\langle\beta \alpha\left|\boldsymbol{S}^{2}\right| \beta \alpha\right\rangle & \left\langle\beta \alpha\left|\boldsymbol{S}^{2}\right| \beta \beta\right\rangle \\
\left\langle\beta \beta\left|\boldsymbol{S}^{2}\right| \alpha \alpha\right\rangle & \left\langle\beta \beta\left|\boldsymbol{S}^{2}\right| \alpha \beta\right\rangle & \left\langle\beta \beta\left|\boldsymbol{S}^{2}\right| \beta \alpha\right\rangle & \left\langle\beta \beta\left|\boldsymbol{S}^{2}\right| \beta \beta\right\rangle
\end{array}\right]
$$

という 4 次の matrix を対角化すればよい。しかし，ここでちよっと量子力学における 基本定理を思い出してみると，なにも式(14.5.14)の 4 次の matrix を対角化する必要は ないということに気が付くであろう。この定理というのは，すでにさんざん学習した 次のようなものである。（Section 4.4 参照）

定理：

2 つの Hermitian operator $A$ および $B$ が交換可能，すなわち $[A, B]=0$ であるとする. $\psi_{1}, \psi_{2}$ が operator $A$ の固有関数であり，その固有值がそれぞれ $a_{1}$ おび $a_{2}$ であるとす る.すなわち, $A \psi_{1}=a_{1} \psi_{1}$ および $A \psi_{2}=a_{2} \psi_{2}$. このような場合， $a_{1}$ と $a_{2}$ が等しくなけ れば $\int \psi_{1} * B \psi_{2} d \tau=\left\langle\psi_{1}|B| \psi_{2}\right\rangle=0$ である.

この定理を, 現在の我々の問題に当てはめてみよう. $S_{z}$ と $\boldsymbol{S}^{2}$ とは交換可能である. 更に, $S_{z}$ も $\boldsymbol{S}^{2}$ も Hermitian である. 式(14.5.3)の $4 つ の$ spin function はすべて $S_{z}$ はつい ての固有関数である.しかし, 固有值は $\alpha \alpha$ についての ある。上の定理を用いると， $\alpha \alpha$ あ $\beta \beta$ も $\boldsymbol{S}^{2}$ という operatorにより，他の spin function との行列要素を持たない. $\alpha \beta$ と $\beta \alpha$ はゼロという等しい固有值を持っている.すなわ ち, operator $\boldsymbol{S}^{2}$ によって行列要素を持つのは $\alpha \beta, \beta \alpha$ の spin function の間だけである. こういうわけで, 我々は, 式(14.5.14)の代りに $\alpha \beta$ と $\beta \alpha$ を basis function とする 2 次の matrix を対角化すればいいことになる．実はこのことは，すでに式(14.5.10)および式 (14.5.13)において $\alpha \alpha$ と $\beta \beta$ の 2 つはどちらもこのままで $\boldsymbol{S}^{2}$ の固有関数となっている ということに表れている. 
上述したような理由で，我々は，次のような matrix を対角化すればよいことにな る.

$$
\left[\begin{array}{ll}
\left\langle\alpha \beta\left|S^{2}\right| \alpha \beta\right\rangle & \left\langle\alpha \beta\left|S^{2}\right| \beta \alpha\right\rangle \\
\left\langle\beta \alpha\left|S^{2}\right| \alpha \beta\right\rangle & \left\langle\beta \alpha\left|S^{2}\right| \beta \alpha\right\rangle
\end{array}\right]=\left[\begin{array}{ll}
\hbar^{2} & \hbar^{2} \\
\hbar^{2} & \hbar^{2}
\end{array}\right]
$$

上式の右辺は式(14.5.11)および式(14.5.12)に左から $\alpha \beta$ または $\beta \alpha$ をかけて積分するこ とによって容易に得られる. 固有值を $x$ とすると secular determinant

$$
\left|\begin{array}{cc}
\hbar^{2}-x & \hbar^{2} \\
\hbar^{2} & \hbar^{2}-x
\end{array}\right|=0
$$

を解いて,

$$
x=0 \text { および } x=2 \hbar^{2}
$$

を得る. spin function は常法により $x=0$ については $\frac{1}{\sqrt{2}}(\alpha \beta-\beta \alpha), x=2 \hbar^{2}$ について $\frac{1}{\sqrt{2}}(\alpha \beta+\beta \alpha)$ となることが直ちに分かるであろう.

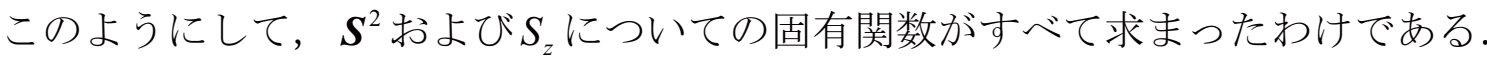
$S_{z}$ についての固有值が $M_{\mathrm{S}} \hbar$ でり, かつ, $S^{2}$ についての固有值が $S(S+1) \hbar^{2}$ であるよ うな spin function を $\rho\left(S, M_{\mathrm{S}}\right)$ という記号で表すことにしよう。このような表し方によ ると，上で求めた結果は次のようにまとめられる.

$$
\begin{aligned}
& \rho(0,0)=\frac{1}{\sqrt{2}}(\alpha \beta-\beta \alpha) \\
& \rho(1,1)=\alpha \alpha \\
& \rho(1,0)=\frac{1}{\sqrt{2}}(\alpha \beta+\beta \alpha) \\
& \rho(1,-1)=\beta \beta
\end{aligned}
$$

式(14.5.18)は， $S=0$ であるから， $2 S+1=1$ で一重項（singlet）の spin function と言わ れる. 式(14.5.19)の 3 つは $S=1$ であるから， $2 S+1=3$ で三重項 (triplet) の spin function と言われる。

さて，2つの電子からなる系の持つスピンは， $S=0$ および $S=1$ ということは分か ったが，それだけのことは上のような面倒な計算を行わなくても角運動量の合成によ り簡単に分かる. 角運動量の合成についてはすでに Section 5.6 で学習したが，重要な ことは次の定理に要約される. 
定理：

2 つの $\operatorname{spin} S_{1}$ と $S_{2}$ との合成により得られる $\operatorname{spin} S$ は,

$$
S_{1}+S_{2}, S_{1}+S_{2}-1, S_{1}+S_{2}-1, S_{1}+S_{2}-2, \ldots,\left|S_{1}-S_{2}\right|
$$

だけの可能性がある.

この定理を適用すると， $S_{1}=\frac{1}{2}, S_{2}=\frac{1}{2}$ であるから，全系のスピンは $\frac{1}{2}+\frac{1}{2}=1$ と $\frac{1}{2}-\frac{1}{2}=0$ の 2 つである. $\operatorname{spin} S$ であれば $M_{\mathrm{S}}$ は $S, S-1, \ldots,-S$ の $2 S+1$ 個の值を取り 得る.こういうことで, 式(14.5.18)および式(14.5.19)に示される $S$ および $M_{\mathrm{S}}$ を持つ spin function が得られることは前もって分かっていたわけである.

\section{定Problem 14.5.1}

式(14.5.18)の右辺に直接 $S_{z}$ および $S^{2}$ を作用し，式(18.5.1)および式(18.5.2)を用いる ことにより，式(14.5.18)がこれら operator の固有関数であり，かつ固有值がどちらに ついてもゼロであることを示せ.

\section{放Problem 14.5.2}

同様に式(14.5.19)のそれぞれの右辺に直接 $\boldsymbol{S}^{2}$ を作用させることにより，いずれの spin function も $\boldsymbol{S}^{2}$ の固有関数であり，固有值が $2 \hbar^{2}$ であることを示せ．さらに， $S_{z}$ を 作用させ，3つの spin function がそれぞれ固有值 $\hbar, 0,-\hbar$ に相当する $S_{z}$ の固有関数で あることを示せ.

\section{论Problem 14.5.3}

式(14.5.18)の右辺に $S_{+}$および $S_{-}$を作用することにより，次の式を証明せよ.

$$
\begin{aligned}
& S_{+} \rho(0,0)=0 \\
& S_{-} \rho(0,0)=0
\end{aligned}
$$

\section{放Problem 14.5.4}

式(14.5.19)の右辺に直接 $S_{+}$およびを作用させることにより，次の式を証明せよ. 


$$
\begin{aligned}
& S_{+} \rho(1,1)=0 \\
& S_{+} \rho(1,0)=\sqrt{2} \hbar \rho(1,1) \\
& S_{+} \rho(1,-1)=\sqrt{2} \hbar \rho(1,0) \\
& S_{-} \rho(1,1)=\sqrt{2} \hbar \rho(1,0) \\
& S_{-} \rho(1,0)=\sqrt{2} \hbar \rho(1,-1) \\
& S_{-} \rho(1,-1)=0
\end{aligned}
$$

\section{巧Problem 14.5.5}

式(14.5.21)および式(14.5.22)を用いて式(14.5.19)に対する $S_{x}$ および $S_{y}$ の作用を求め よ.

\section{拧Problem 14.5.6}

3 電子系のスピン関数を $\boldsymbol{S}^{2}$ および $S_{z}$ の固有関数となるように求めよ。（ヒント： Exercise 14.5.1 と同じように行う. $\alpha_{1} \alpha_{2} \alpha_{3}, \alpha_{1} \alpha_{2} \beta_{3}, \ldots, \beta_{1} \beta_{2} \beta_{3}$ の 8 個の basis function を 考え， $\boldsymbol{S}^{2}$ および $S_{z}$ について対角化する．最高 3 次の matrix を対角化すればよい．な お， $S=\frac{1}{2}, M_{\mathrm{S}}= \pm \frac{1}{2}$ の spin function の形については，ある程度の任意性があることも 解いていけば分かるであろう。

\section{6 スペクトルの微細構造 - 二重線の解釈}

Uhlenbeck と Goudsmit の功績により, スペクトルに現れる分裂が始めて解釈された のであるが,ここではそのことを簡単に述べよう。ここでいうスペクトル線の分裂で, 多くの化学者によく知られているのはおそらく $\mathrm{Na}$ の D 線であろう. 高速道路のトン ネル内の照明にも使われ，又，実験室では施光計の光源に使われる $\mathrm{Na}$ のランプのス ペクトルは, 注意深く見ると $589.76 \mathrm{~nm}$ と $589.16 \mathrm{~nm}$ との 2 本のスペクトル線よりなっ ている.この線はもともと $\mathrm{Na}$ の $3 p \rightarrow 3 s$ 間の遷移によるもので，これが 2 本に分れ る理由は，少なくとも今まで学習して来た理論では分からない.

このスペクトルの分裂は，Uhlenbeck と Goudsmit が仮説として導入した spin によ る角運動量と, すでに学習して来た軌道角運動量との相互作用（spin orbit interaction） 
によってもたらされるのである，そこでまず，この種の相互作用の大きさをもっとも 簡単な系である水素類似原子について求めることから始める.

原子においては，核の周りを電子が自転しながら回っている（spin というのはこ こで述べた自転のことである）この系を力学的に考えるに当り，我々は動いている電 子の上に立って核を眺めてみることにする. 寸なわち, このような座標変換によって， 自転している電子の周りを核が回っていると考えることが出来る.（図 14.6.1)

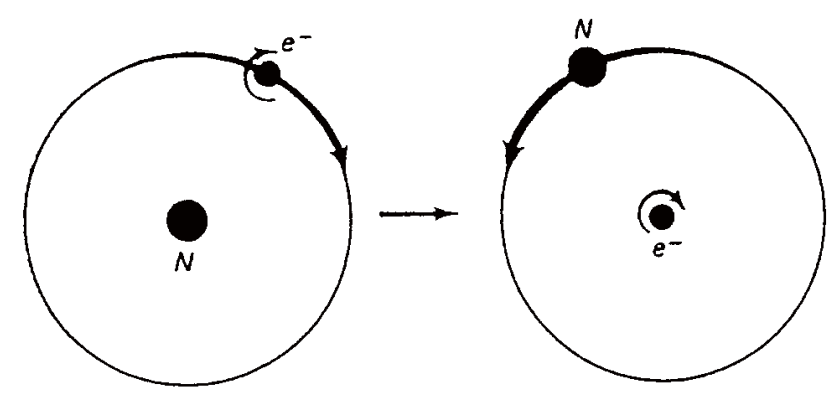

図 14.6.1 spin-orbit interaction を考えるにあたっての座標変換.

$Z e$ の電荷を持つ核が速度 $\boldsymbol{v}$ で電子の周りを回っていると $\boldsymbol{i}=\mathrm{Zev}$ の電位が生ずる. 中心の, 電子の存在寸る位置における磁場 $H$ は Biot-Savar't Law により次のように書 ける。

$$
\begin{aligned}
H & =\frac{\boldsymbol{i} \times \boldsymbol{r}}{4 \pi r^{3}} \\
& =\frac{\mathrm{Z} e}{4 \pi r^{3}} \boldsymbol{v} \times \boldsymbol{r} \\
& =\frac{\mathrm{Z} e}{4 \pi r^{3}} \frac{1}{m_{\mathrm{e}}} \boldsymbol{p} \times \boldsymbol{r} \\
& =-\frac{\mathrm{Z} e}{4 \pi r^{3}} \frac{1}{m_{\mathrm{e}}} \boldsymbol{L}
\end{aligned}
$$

磁束密度 $\boldsymbol{B}$ は

$$
\boldsymbol{B}=\mu_{0} \boldsymbol{H}
$$

で与えられる，又，電子スピンの持つ磁気モーメントを表す演算子は

$$
\boldsymbol{\mu}=-\frac{e}{m_{\mathrm{e}}} \boldsymbol{S}
$$

である．結局，相互作用の Hamiltonian $H_{\mathrm{so}}$ は 


$$
H_{\mathrm{so}}=-\boldsymbol{\mu} \boldsymbol{B}
$$

は式(14.6.1)と式(14.6.4)より

$$
\begin{aligned}
H_{\text {so }} & =\frac{Z e}{4 \pi r^{3}} \frac{1}{m_{\mathrm{e}}} \mu_{0} \frac{e}{m_{\mathrm{e}}} \boldsymbol{L} \boldsymbol{S} \\
& =\frac{1}{4 \pi \varepsilon_{0}} \frac{\mathrm{Z} e^{2}}{m_{\mathrm{e}}{ }^{2} c^{2}} \frac{1}{r^{3}} \boldsymbol{L} \boldsymbol{S}
\end{aligned}
$$

この取り扱いには相対論的な考えは入っていないが，相対論を取り入れた正しい相互

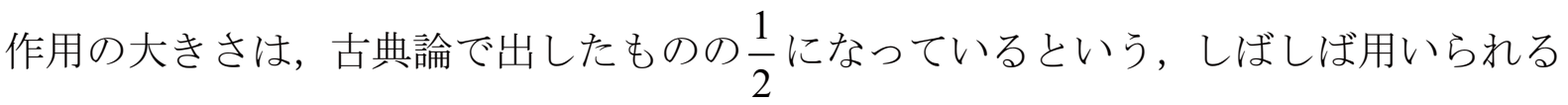
インチキ方法がある。そのインチキを認めると（それがそんなにインチキでもないこ とは後述するが)

$$
H_{\mathrm{so}}=\frac{1}{4 \pi \varepsilon_{0}} \frac{\mathrm{Z} e^{2}}{2 m_{\mathrm{e}}{ }^{2} c^{2}} \frac{1}{r^{3}} \boldsymbol{L S}
$$

となる.ここで

$$
\xi(r)=\frac{\hbar^{2}}{4 \pi \varepsilon_{0}} \frac{Z e^{2}}{2 m_{\mathrm{e}}{ }^{2} c^{2}} \frac{1}{r^{3}}
$$

とおくと

$$
\begin{aligned}
H_{\mathrm{so}} & =\frac{\xi(r)}{\hbar^{2}} \boldsymbol{L} \boldsymbol{S} \\
& =\frac{\xi(r)}{\hbar^{2}}\left(L_{x} S_{x}+L_{y} S_{y}+L_{z} S_{z}\right) \\
& =\frac{\xi(r)}{\hbar^{2}}\left(L_{z} S_{z}+\frac{1}{2} L_{+} S_{-}+\frac{1}{2} L_{-} S_{+}\right)
\end{aligned}
$$

となる. Hamiltonian が spin angular momentum $\boldsymbol{S}$ と orbital angular momentum $\boldsymbol{L}$ との積 で表され，スピン軌道相互作用（spin-orbit interaction）と言われている.

この spin-orbit interaction によって, $\mathrm{H}$ 原子の $2 p$ 軌道に 1 個の電子が入っている励 起状態がどのようになるかを調べてみよう。水素原子の波動関数の空間部分は $R_{n l}(r) Y_{l m}(\theta, \phi)$ で与えられるが, $2 p$ 軌道であるから $n=2, l=1$ で $m=1,0,-1$ の 3 つの 状態が縮退しているというのが今まで学習して来たことである. 新しく導入した spin 関数は $m_{\mathrm{s}}=\frac{1}{2}$ の $\alpha$ また $m_{\mathrm{s}}=-\frac{1}{2}$ の $\beta$ である. 従って, 軌道部分の 3 とスピン部分 の 2 つの組み合せで 6 つの wavefunction が考えられる.空間部分の wavefunction の $m$, およびスピン部分の wavefunction の $m_{s}$ を除いた量子数（ $n$ および $l ）$ は $6 つ の$ wavefunction について共通であるから， notation を省略化して， space $\times$ spinの全波動 
関数を $\psi\left(m, m_{\mathrm{s}}\right)$ で表すことにする。この notation を用いると，

$\psi\left(1, \frac{1}{2}\right), \psi\left(1,-\frac{1}{2}\right), \psi\left(0, \frac{1}{2}\right), \psi\left(0,-\frac{1}{2}\right), \psi\left(-1, \frac{1}{2}\right), \psi\left(-1,-\frac{1}{2}\right)$ の つの wavefunction があり，外部からの摂動がない限りこれらはすべて縮退している。スピン軌道相互作 用によってこの energy がどうなるかは，縮退系への摂動論を適用すればよい。すなわ ち，上述した $6 つ の ~ w a v e f u n c t i o n ~ を ~ b a s i s ~ f u n c t i o n ~ と し て ， ~ H_{\mathrm{so}}$ に対して対角化を行え ばよい。

各行列要素の計算は難なくに行うことが出来る．Hamiltonian

$$
H_{\mathrm{so}}=\frac{\xi(r)}{\hbar^{2}}\left(L_{z} S_{z}+\frac{1}{2} L_{+} S_{-}+\frac{1}{2} L_{-} S_{+}\right)
$$

の各項の作用を吟味してみよう. 第 1 項の $L_{z} S_{z}$ の項は basis function に作用しても $m$ お よび $m_{\mathrm{s}}$ 共に変らない. 第 2 項の $L_{+} S_{-}$は $m_{\mathrm{s}}$ を 1 つ下げ $m$ を 1 つ上げる. 反対に第 3 項 の $L_{-} S_{+}$は $m_{\mathrm{s}}$ を 1 つ上げ $m$ を 1 つ下げる.こういうことから，計算する前から必然的 にゼロとなる行列要素が直ちに分かる.

\begin{tabular}{|c|c|c|c|c|c|c|}
\hline$\psi\left(1, \frac{1}{2}\right)$ & $\psi\left(1, \frac{1}{2}\right)$ & $\psi\left(1,-\frac{1}{2}\right)$ & $\psi\left(0, \frac{1}{2}\right)$ & $\psi\left(0,-\frac{1}{2}\right)$ & $\psi\left(-1, \frac{1}{2}\right)$ & $\psi\left(-1,-\frac{1}{2}\right)$ \\
\hline$\psi\left(1,-\frac{1}{2}\right)$ & 0 & 0 & 0 & 0 & 0 & 0 \\
\hline$\psi\left(0, \frac{1}{2}\right)$ & 0 & & & 0 & 0 & 0 \\
\hline$\psi\left(0,-\frac{1}{2}\right)$ & 0 & 0 & 0 & 0 & 0 & 0 \\
\hline$\psi\left(-1, \frac{1}{2}\right)$ & 0 & 0 & 0 & & 0 & 0 \\
\hline$\psi\left(-1,-\frac{1}{2}\right)$ & 0 & 0 & 0 & 0 & 0 & \\
\hline
\end{tabular}

上図で影をつけた所が值を持ち得るわけで，そのうち対角項（対角線上にある項）の 6 要素は $L_{z} S_{z}$ により, それ以外の 4 要素は $L_{+} S_{-}$または $L_{-} S_{+}$により值を持つわけである. 
これだけの見通しをつけておけば計算は極めて簡単である. $\boldsymbol{L}$ や $\boldsymbol{S}$ の作用は寸でに学 習した（Lについては式(5.3.30)と式(5.4.9)， $\boldsymbol{S}$ については式(14.2.2)および式(14.2.4)） が，念のため，必要な部分をまとめておこう。

$$
\begin{array}{ll}
L_{z} \psi\left(m, m_{s}\right)=m \hbar \psi\left(m, m_{s}\right) & \\
L_{+} \psi\left(m, m_{s}\right)=\sqrt{2} \hbar \psi\left(m+1, m_{s}\right) & (m=-1 \text { or } 0) \\
L_{-} \psi\left(m, m_{s}\right)=\sqrt{2} \hbar \psi\left(m-1, m_{s}\right) & (m=0 \text { or } 1) \\
S_{z} \psi\left(m, m_{s}\right)=m_{s} \hbar \psi\left(m, m_{s}\right) & \\
S_{+} \psi\left(m,-\frac{1}{2}\right)=\hbar \psi\left(m, \frac{1}{2}\right) & \\
S_{-} \psi\left(m, \frac{1}{2}\right)=\hbar \psi\left(m,-\frac{1}{2}\right) &
\end{array}
$$

以上の関係から $H_{\mathrm{so}}$ の作用は直ちに求まる，積分はスピン部分は $\sigma$ 座標について, 空 間部分は $r, \theta, \phi$ にいて行う。結局, $H_{\mathrm{so}}$ に関する行列は次のようになる.

$$
H_{\mathrm{so}}=\left[\begin{array}{cccccc}
\frac{1}{2} \zeta_{21} & 0 & 0 & 0 & 0 & 0 \\
0 & -\frac{1}{2} \zeta_{21} & \sqrt{\frac{1}{2}} \zeta_{21} & 0 & 0 & 0 \\
0 & \sqrt{\frac{1}{2}} \zeta_{21} & 0 & 0 & 0 & 0 \\
0 & 0 & 0 & 0 & \sqrt{\frac{1}{2}} \zeta_{21} & 0 \\
0 & 0 & 0 & \sqrt{\frac{1}{2}} \zeta_{21} & -\frac{1}{2} \zeta_{21} & 0 \\
0 & 0 & 0 & 0 & 0 & \frac{1}{2} \zeta_{21}
\end{array}\right]
$$

ただし

$$
\zeta_{21}=\int R_{21}(r) \xi(r) R_{21}(r) r^{2} d r
$$

この行列を対角化すると固有值として

$$
\begin{aligned}
E^{(1)} & =\frac{1}{2} \zeta_{21} & & \text { 四重縮退 } \\
& =-\zeta_{21} & & \text { 二重縮退 }
\end{aligned}
$$


が得られる。これが求むべき 1 次の摂動エネルギーである。すなわち，もともと6 重 に縮退していたものが 4 重縮退と 2 重縮退の 2 つに分裂し, その分裂の大きさが $\frac{3}{2} \zeta_{21}$ ということになる．この分裂が 1920 年代前期の分光学者を悩ませたスペクトルの分 裂であり, Uhlenbeck と Goudsmit との功績により始めてその原因が明かとなったもの である。

必Problem 14.6.1

$R_{21}(r)$ として水素類似原子の wavefunction（表 9.3.1）を用い $\zeta_{21}$ をZの関数として 求めよ.

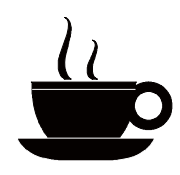

[Coffee Break $]$ スピンの発見に伴うドラマ

この lecture noteではまず最初に Stern-Gerlach の実験を紹介することによって spin のことを導入した。しかし，折々触れたように， spin という考え方は Stern-Gerlachの 実験後, 3 年も経ってから Uhlenbeck と Goudsmitによって始めて提唱されたものであ る.ここではspin という概念が発表されるまでにいたるいろいろな人の関与するドラ マを紹介しよう。全ての科学上の偉大な発見がそうであるように，スピン発見もほん のわずか何かが異なっていれば別の人の功績になっていたと思われる.

Uhlenbeck と Goudsmit が spinのことを考えるよりも半年位前に，ほとんど同じこ とを考えた人がいた。それはアメリカからドイツに留学して来た Kronig といら若い 学徒である. 1925 年 1 月 7 日, 日本であったら正月気分のまだ抜け切らないこの時期 に，Kronigはドイツの Tubingen という町にやって来た。この時のことを，Kronig 自 身次のように回想している. (R. Kronig, in "Theoretical Physics in the Twentieth Century", Interscience)

"On 7 January 1925, at the age of 20 and inexperienced in many ways, I arrived in the small and picturesque German university town of Tubingen, taking lodgings at the Hotel zum Goldenen Ochsen. I had gone there as traveling fellow of Columbia University with the intention of visiting Lande and Gerlach, who held chairs in theoretical and experimental physics, respectively, at the university, and of meeting Back. At the Institute of Physics I was kindly received by Lande with the remark that I was coming at a very opportune moment since he was expecting Pauli the following day. In fact Pauli had written him a long and very interesting 
letter, which he gave me to read."

この文に出て来る Lande というのは, "Lande interval rule"で知られる Lande であり, Gerlach はもうおなじみの名前である. Back というのは, Zeeman 効果で, Paschen-Back effect と言われる仕事をした人である。こういう人々の仕事に興味があって Kronig は アメリカから留学して来たわけである。

Lande は Kronig を迎えると，「あなたは丁度良いところに来ました。というのは， 明日 Pauli が訪ねて来るところです.」と言って Pauli から来た手紙を見せてくれた. この手紙の中で Pauli は，1つの電子は 4 つの量子数によって性格づけられなければ ならないという，彼がすぐ後で出す論文の骨子を述べていた。

この当時は, いろいろな人が異なった量子数を考え出し, それでもって原子のスペ クトルを理解しようとしていたが，アルカリ金属のスペクトルの分裂など，どうして も理解出来ないことがあって，困っていた．Pauli の考えた 4 つの量子数というのは, 今の言葉で言えば $n, l, j, m_{j}$ であり,$j$ は $l+\frac{1}{2}$ と $l-\frac{1}{2}$ のいずれか, そして $m_{j}$ は $j, j-1, \ldots,-j$ の值を取り得るというものであった．Kronig は，この考えの重要性に

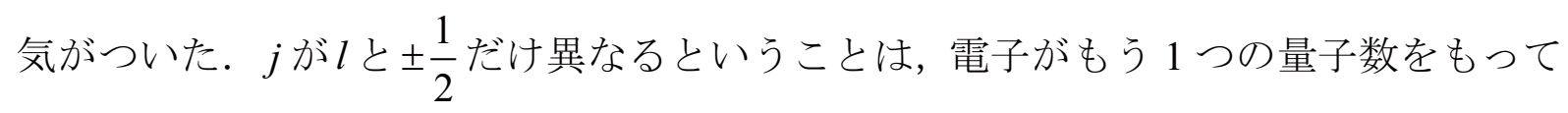
いることを意味するであろうと考えた．そしてこの量子数が出て来る由来を考えて， それは電子が自転することによるものではなからうかと考えた．そしてこの問題を更 に深く突っ込み，スペクトルの分裂があることを説明することが出来た．更にこの分 裂の大きさを計算してみた。（この計算については，この lecture noteでも Section 14.6 で簡単に取り扱っている.）ところが，残念なことに，計算值は実測の分裂の 2 倍の 大きさを示していた。しかしこのことについて Kronig はあまり気にしなかったよう だ. Lande も Kronig の考えを聞いて非常に興味を示し，二人共Pauli に会うのを待ち こがれた。（Kronigはこれだけの仕事を一晚のうちにやってしまったらしい.）Kronig は次の日, すなわち 1 月 8 日に, Tubingenの町に来た Pauli に自分の考えを述べてみ た. Pauli は,

"Das ist ja ein ganz witziger Einfall, aber so ist die Natur schon nicht." と否定的な意見を述べ，それ以上の興味を示さなかったらしい. Lande は

"Ja, wenn der Pauli das sagt, dann wird as schon nicht stimmen."

と述べてこの話は終ってしまったらしい. (der Pauli と定冠詞つきの人名で話されて いる Pauli という人はそれほど偉大であったのだろう.）

その後, Kronig は Copenhagen に行って, Heisenberg とか Kramers などの著名な人々 に自分の考えを話した。 しかし，人々の反応は冷たく，Kronigの考え方に否定的であ ったという. Kronig は計算結果が 2 倍になってしまうことの他，いくつかのむずかし さも分かって来たので，この考えをそれ以上吟味することは諦めてしまったようであ 
る.

そしてその年の 10 月，オランダの Leiden 大学の Goudsmit と Uhlenbeck による

Ersetzung der Hypothese vom unmechanischen Zwang durch eine Forderung bezuglich des inneren Verhaltens jedes einzelnen Elektrons.

という題の論文が Naturwissenschaften という雑誌に彼らの師である Ehrenfest の推薦に よって出された. [G. E. Uhlenbeck and S. Goudsmit, Naturwissenschaften 13, 953 (1925)]

この当時の多くの科学雑誌は, 現在とは異なり, 誰でも論文を投稿することが出来 るわけではなかった。すでに功績のある，ある限られた人しか論文を出せなかったよ うである。そこで若い人はどうしたかというと，自分の師など，すでに功績のある著 名人に頼んで，その人が論文に責任を持つという形でのみ論文を出すことが出来た.

Uhlenbeck と Goudsmit の論文は, Ehrenfestの暖かい思いやりによって日の目を見たと いうわけである。

岩波の理化学事典によると, Uhlenbeck は 1900 年生まれ, Goudsmit は 1902 年生ま れというから，1925 年には 2 人はそれぞれ 25 歳および 23 歳であったことになる.

この頃 Goudsmit は Leiden 大学の Ehrenfest の研究室でスペクトル線の解釈などを行 っていたようである. Goudsmit 自身の回想 [S. Goudsmit, Delta 15, 177 (1972)] による と，Goudsmit があまりすぐれた理論家でないことを Ehrenfest は見抜いたようで，週 に 3 日間 Amsterdam（今なら Amsterdam は Leiden から汽車で 1 時間位で行ける。そ の頃には，どの位かかったのであろうか）の Zeeman の所で非常勤助手として働くこ とを勧めたようである。Zeeman 効果で名の知られているこの有名な物理学者の助手 を勤めることで Goudsmit のスペクトルに対する知識は深くなったようだ.

このちょっと前, Uhlenbeck はローマにいて, ローマ在住のオランダ人の子供達を 教えるために，学業を中断していたらしい，その後 Ehrenfest の研究室に加わった. その頃までに Uhlenbeck は古典力学は十分勉強していたけれども，ローマに行ってい たために，新しい物理学のことはほとんど知らなかったという。そこで Ehrenfest は ある日 Goudsmitにこう言ったという。「君は少しUhlenbeck と一緒に仕事をすると良 かろう。そうすると彼は新しい原子構造やスペクトルについて学ぶことが出来るか ら」と.Goudsmit の回想には，Ehrenfest の意図は「たとえ新しいことに対する知識は なくても物理に対して，より深い洞察力を持った Uhlenbeck と一緒に仕事をすれば君 も少しは真の物理を学習出来るだろう」という思いやりだったらしいと述べられてい る。とにかく，こんな次第で，Uhlenbeck と Goudsmitは一緒に仕事を始めたわけであ る.

2 人が一緒に仕事を始めた頃, Goudsmit が Lande, Heisenberg, Paschen といった著名 な人のことを話すと，Uhlenbeck は「それはいったいどういう人だね」という位，何 も知らなかったという。しかし，Goudsmit が彼の考えている新しい量子数のことを話 した時，Uhlenbeck は「君はことの重大性を認識していないのではないか。これは電 
子が 4 番目の自由度を持っている. 寸なわち, 電子が自転しているという, 非常に重 要なことを示しているんだよ」といった具合に，物事の本質を見抜く力は優れていた らしい.

こうして 2 人の努力によって一応スペクトルの分裂のことは, 定性的には説明出来 た． 2 人にとって何とも幸運であったことは，定量的な計算をしなかったことと，彼 らの師が Pauli でなくて Ehrenfest であったことだ。 Ehrenfest は，「これは非常にいい 仕事であるか，又はまったくナンセンスであるか，どちらかだ。しかし，とにかくこ れを論文として Naturwissenschaften に投稿しよう」と薦めたとのことである.彼らは, 始めは論文にすることを考えていなかったが, Ehrenfest のすすめもあったので論文を 書き上げ，Ehrenfestに渡した． Ehrenfest は，2，3のコメントの後でこう言ったとい う.

"...und dann werden wir Herrn Lorentz fragen."

こういうわけで彼らは Lorentzに意見を求めた。 (Lorentz は Leiden 大学で Ehrenfest の前任の教授であった。すでに退官していたが，毎週月曜日にはLeiden 大学に来るこ とになっていた.）Lorentzは，なかば疑問を持ちながらも「考えましょう」と言って くれた。そして次の週の月曜日，Lorentzはいくつかの計算結果を示してくれた.

Uhlenbeck と Goudsmit の 2 人には難解な箇所もあったが，どうもスピンという概念に はいろいろな難しい点があることは明らかに思われた。

そこでUhlenbeck はこわくなって, Ehrenfestの所に行き，「あの論文は間違ってい ます。論文は送らないでください」とお願いした。これに対して Ehrenfest は次のよ うに答えたという。

"Ich habe Ihlen Brief schon langst abgesandt; Sie sind beide jung genug um sich eine Dummheit leisten zu können!"

(B. L. van der Waerden, in "Theoretical Physics in the Twentieth Century, Interscience) とに かくこういうことで論文は出版されてしまった.

この論文が出された次の日，彼らはHeisenberg から手紙をもらった。この手紙の中 でHeisenberg は「このidea を発表するのにどれほどの勇気がいったか，私には想像も つきません」といった表現で，彼らの勇敢な論文のお祝いを述べた後，「あなた方は あの"2"という因子をどうやって除いたのですか」と質問している．Goudsmit にとつ ては「いったい"2"という因子とは何なのだろう」と皆目, 解らなかったらしい。こ のあたりのことは Goudsmit 自身の言葉が生き生きとして感じがはっきりするので, 次に引用しておく.

"The piece was sent off and published. The very next day I had a letter from Heisenberg in which he wrote of our "courageous paper." I must say I had no idea that courage was needed to publish it. I wasn't in the least courageous. I still have Heisenberg's letter, if you don't believe me. And in it he gives a formula. But I hadn't a clue what it meant. Further on he says: "How did you manage to get rid of 
the factor of 2?" What factor of 2? I hadn't the foggiest notion. The formula just sat there, without derivation.

As I said, the spin fitted exactly into the formalism of the whole business. But, of course, what we really ought to have done was to calculate how big the fission would be. If you believed there was a spin, then it could be in this direction or in that. And you would ask what the difference in energy would be and did that in fact come out right? We already had the formulas, but was it possible to derive them?"

もっとも Uhlenbeck の方は，"2"という因子のことは気がついて，いろいろ悩んでいた らしいが。

$$
\text { こんなことがあって，2 人はちよっとがっかりしたみたいだが，折りも折り }
$$

年 12 月), Lorentzの 50 歳の誕生パーティーが開かれ, Bohr, Einstein, Rutherford, Curie 夫人などが Leiden に集まった。BohrやEinstein などは毎日毎日 Ehrenfest の家 で Uhlenbeck や Goudsmit と共に spinのことについて討論したということである。こ のすぐ後, Uhlenbeck, Goudsmit の第 2 の論文が"Spinning Electrons and the Structure of Spectra"という題でイギリスの Nature 誌に出た.

この論文で初めて"spin"という言葉が導入された。また，この論文では，計算結果 は実測の 2 倍になっていることも述べてある.

" ... it leads, in a preliminary calculation, to width of the spin doublets just twice

as large those required by observation."

しかしその後が面白い.

"It must be remembered, however, that we are here dealing with problems which

for their final solution require a closer study of quantum mechanics."

このような考え方は，なかなか大切ではなからうか.

この論文の終りに，著者はBohr に討論をしてもらったことのお礼を次のように述 べている.

"In conclusion, we wish to acknowledge our indebtedness to Prof. Niels Bohr for an enlightening discussion, and for criticisms which helped us distinguish

between the essential points and the more technical details of the new interpretation."

特に終りの方の, essential point と technical details とを区別するのにBohrの批判が役 に立った，というあたり，いいことを言っているなという感じである．更に，この論 文の終りに，Bohr が Uhlenbeck と Goudsmitの説を支持する旨のコメントを書いてい る.この文の中で，

"... this hypothesis throws new light on many of the difficulties which have puzzled the workers in this field during the last few years. Indeed, it opens up a very hopeful prospect of our being able to account more extensively for the 
properties of elements ..."

とほめたたえている。(こういうおほめの言葉が論文に載るというのも今の時代から 考えると面白い.）

Bohr がこのように, Uhlenbeck, Goudsmit の説に傾き始めたのを知っても Pauli はが んとして，それを認めなかったようである。事実，Pauli は Bohrに対しても spin hypothesis を受け入れることの危険性を警告し続けたという.

ところで, Uhlenbeck, Goudsmit よりも前に spinのことを考えた Kronig は，どうし たであろうか. 自分が半年も前に考えた末，捨ててしまったidea が他の人によって発 表され，又大きな反響を受けているのを見て，「しまった」と思ったろうか?ちょっ と不思議なことは，1926 年の 4 月号の Nature 誌に, Kronig は, Uhlenbeck, Goudsmit の論文を攻撃する文を書いている。 "Spinning Electrons and the Structure of Spectra"とい う, Uhlenbeck, Goudsmit と全く同じ題名のこの論文で, Uhlenbeck, Goudsmit の論文を 攻撃し, その最後は次のような文で締めくくっている.

"The new hypothesis, therefore, appears rather to effect the removal of the family ghost from the basement to the sub-basement, instead of expelling it definitely from the house."

ghost なんていう言葉が出て来るあたりいかにも西欧風だが，この論文を見ると何か もの悲しくなる．もう少し，他人の意見を受け入れる気持ちがほしいように思う。も つとも 21 歳という若さなら，これ位の厳しさも当然かもしれないが.

年をとってきて, Kronig はこの論文のことを少しは恥しいと思ったのではなかろう か. 上に引用した回想録（"Theoretical Physics in the Twentieth Century"）の中で, Kronig はこの論文のことを次のように述べている.

"In view of this complete volte face of the leading physicists in the matter of quantum mechanical strain, the only thing remaining for me to do was to call attention to all the difficulties still in the way of the proposed explanation."

さて, Kronigの痛烈な批判が印刷されたのは 1926 年 4 月 17 日付の Nature 誌であ るが，実はその 1 週間前の 1926 年 4 月 10 日付の Nature 誌に Thomas の論文が印刷さ れている. [L. H. Thomas, Nature, 117, 550 (1926)] この論文で, Thomas は今までの計算 結果が実験值の 2 倍になったのは, 計算における座標の変換(本 lecture note の図 14.6.1 に示したような座標変換) が間違っていたからである，ということを示したのである. 相対論を正しく取り入れて計算すると, 計算值は従来の計算值の 2 分の 1 に, すなわ ち，実験と完全に一致する值になるというのである．この論文は，1926 年 2 月に， Bohrのいた Copenhagen で書かれている.この論文で著者は,

"The interpretation of the fine structure of the hydrogen lines proposed by Messrs.

Uhlenbeck and Goudsmit now no longer involves any discrepancy."

と結んでいる。これで全てが解決したわけである。あの Pauli もこの Thomas の論文を 
みて，とうとう spin hypothesis を受け入れることになったようである. Pauli は,ノー ベル賞受賞講演で，このことを次のように述べている.

"Although at first I strongly doubted the correctness of this idea because of its classical mechanical character, I was finally converted to it by Thomas' calculation on the magnitude of doublet splitting."

以上で spin に関する熾烈な争いは終りとなる。本 lecture note で式(14.6.5)に「相対

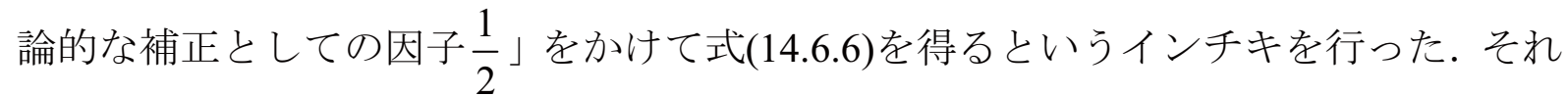
がそれほどインチキでないことはThomas の仕事によってほぼ正当化される。この

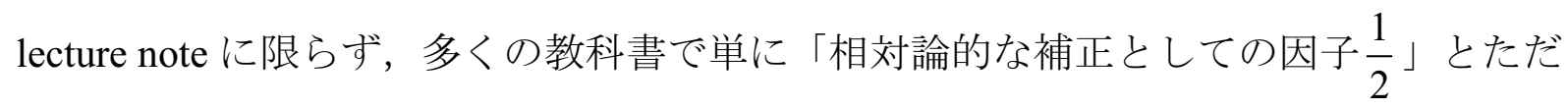
一言で述べられていることも，実は上述したような激しいドラマがあったわけであ る.

話を Kronig と Uhlenbeck, Goudsmit のことに戻すと，ほとんど同じ idea を持ってい ながらほんのちょっとしたきっかけで一方はそれを捨ててしまい，一方は大胆にそれ を発表した，その差によって後世の評価も大きく異なってしまったわけであるが，こ の差はじうして出来たのであろうか. Uhlenbeck と Goudsmitにとって幸運だったこと は，彼らの師が Pauli でなかったことであった。一方，もし Kronig が Ehrenfest のもと にいたならば，Ehrenfest は間違いなく，Kronig をはげまして論文を書かせていただ ろうと思う。上で引用した Goudsmit の回想録[Delta, 15, 177 (1972)]の中に, 1926 年 3 月，Thomas から Goudsmit にあてた手紙（もちろん手書き）のコピーがのせてある. 手書きの手紙は，Thomasの人となりも想像出来て楽しいが，読みにくいと思うので， 以下にタイプし直しておく.

25 March 1926

\section{Dear Goudsmit}

Many thanks for your letter which I was happy to receive this morning. I hope you will be able to understand my English as well as I yours! You have asked me many questions and told me nothing about yourself.

I think you and Uhlenbeck have been very lucky to get your spinning electron published and talked about before Pauli heard of it. It appears that more than a year ago Kronig believed in the spinning electron and worked out something; the first person he showed it to was Pauli. Pauli ridiculed the whole thing so much that the first person became also the last and no one else heard anything of it. Which all goes to show that the infallibility of the Deity does not extend to his self-styled visor on earth. 
この手紙にも，あなた方が Pauli に話す前に論文を出してしまったことは lucky で ある，ということが書かれている。

Ehrenfest は彼自身も物理学の分野で多くの功績を上げたが, 自分自身には非常にき びしく,ついに自分の物理学に行き止まりを感じて自殺をしてしまったというほどの 人である。それでも弟子の仕事に

"Sie sind beide jung genug um sich eine Dummheit leisten zu können!"

と言って励ましたことを考えると，教育者というものはかくあるべきかな，という思 いがする. Ehrenfest の教育者としての功績はすばらしかったらしく，いろいろなこと が言い伝えられている，例えば，次のようなことも伝わっている．Fermi という名前 が物理学で占める重要性について否定する人はいないであろう。岩波の理化学事典を 見ると, 本 lecture note でも扱った Fermi's golden rule の他にも, Fermi の統計とか数頁 にわたって Fermi の名前のつく項目が出て来る。これだけ偉大な人でも，ある時，物 理がいやになって物理をやめようと悩んだらしい。その時ある人が，一度 Ehrenfest を訪礼てから決心をしたらいい，と言ってくれたという。 Ehrenfest を訪ねた Fermi は 再び物理学が好きになって，あれだけ大きな功績を残したという。Fermi に物理学を 続けさせたというだけでも Ehrenfest の功績は大きいが, Uhlenbeck と Goudsmit の 2 人を spin 発見に導いた功績もそれ以上のものであろう。

なお，spin 仮説に反対し続けた Pauli はノーベル賞を受賞しているが，Uhlenbeck も Goudsmit もノーベル賞を受賞していない。これだけ大きな功績を残したにしては おかしいな，と思うのだが。この当時の人々はあまりたいした功績と思っていなかっ たのであろうか?

\section{7 電子スピンと磁場との相互作用 - 電子スピンについての Zeeman 効果}

電子スピンは上で学習したように磁気モーメントを持っているので, 当然のことな がら磁場との相互作用がある。一般に，角運動量と磁場との相互作用をZeeman 効果 といい，軌道角運動量 $\boldsymbol{L}$ と磁場との相互作用については，Exercise 10.2.2でもちよっ と述べたが，それと同じようにスピン角運動量 $S$ につても同様な Zeeman 効果があ る. 以下，電子スピンに関するZeeman 効果の相互作用について考えよう.

Section 14.2 で学習したように，1個の電子の持つスピン磁気モーメント $\boldsymbol{\mu}$ は

$$
\boldsymbol{\mu}=-\frac{l}{m_{\mathrm{e}}} \boldsymbol{S}
$$

といら演算子で示される. 磁場がかけられた時, その磁束密度を $\boldsymbol{B}$ とすると, 相互作 用のエネルギーはー $\boldsymbol{\mu B}$ であるから，Zeeman 効果の Hamiltonian は 


$$
\begin{aligned}
H_{\text {Zeeman }} & =-\boldsymbol{\mu} \boldsymbol{B} \\
& =\frac{e}{m_{\mathrm{e}}} \boldsymbol{B} \boldsymbol{S} \\
& =\frac{2 \mu_{\mathrm{B}} \boldsymbol{B} \boldsymbol{S}}{\hbar}
\end{aligned}
$$

ここで

$$
\mu_{\mathrm{B}}=\frac{e \hbar}{2 m_{e}}
$$

は Bohr magneton である.

ほとんど静止している電子がただ 1 個真空中に存在し, そこに磁場がかかった場合 の Hamiltonian は式(14.7.2)で与えられるが，より一般的な場合への拡張を考え，式 (14.7.2)を次のように表しておく.すなおち

$$
\begin{aligned}
H_{\text {Zeeman }} & =\frac{g \mu_{B} \boldsymbol{B} \boldsymbol{S}}{\hbar} \\
& =\frac{g \mu_{B}\left(B_{x} S_{x}+B_{y} S_{y}+B_{z} S_{z}\right)}{\hbar}
\end{aligned}
$$

ここで式(14.7.2)そのものであれば $g=2$ であるが，相対論的補正を行うと，相互作用 していない（このことを英語で"free"という言葉で表している）電子，すなわち free electron について $g=2.0023$ 位の值となる.この $g$ は free electron についての Landeの g-factor と言われている. 分子の中の電子では，色々な相互作用のため $g$ が 2.0023 よ りも大きくなることも多々あり，このことがまた，分子中の電子の振舞いを研究する 重要な手がかりの 1 つになるわけであるが, 当分 $g$ は大体 2 位の大きさであると理解 しておいてよいであろう。こうして Hamiltonian が与えられればその効果はたちどこ ろに計算出来る。磁場がない時には，spin 系は縮退しているから，Zeeman 効果は縮 退系への摂動論でもって考えることが出来る.

まず $\operatorname{spin} \frac{1}{2}$ の系を考えよう。この場合， $\alpha$ spin と $\beta$ spin とがあるが，それらは 磁場がない時には縮退している。そこで $H_{\text {Zeeman }}$ の効果を, 2 重縮退系についての摂動 論で考える. Hamiltonian (14.7.4)で，まず磁場の方向が分からないといけないが，こ こでは仮に磁場が $z$ 軸方向にかけられているとしよう。（原子の場合には完全に isotropic であるから，磁場の方向を $z$ 軸と定義すればよい，分子の場合には，分子内 の軸が問題であり，分子が規則的に配向しているような試料を用いるにせよ，または， 分子がランダムに配向しているような試料を用いるにせよ，いずれにしても磁束密度 の $x, y, z$ 成分 $B_{x}, B_{y}, B_{z}$ をきちんと与えて計算しないといけない. ) 磁場が $z$ 軸に平行に 
かけられた場合

$$
H_{\text {Zeeman }}=\frac{g \mu_{\mathrm{B}} B_{z} S_{z}}{\hbar}
$$

となる．この場合，Zeeman 効果による摂動エネルギーは

$$
\left[\begin{array}{cc}
\left\langle\alpha\left|H_{\text {Zeeman }}\right| \alpha\right\rangle & \left\langle\alpha\left|H_{\text {Zeeman }}\right| \beta\right\rangle \\
\left\langle\beta\left|H_{\text {Zeeman }}\right| \alpha\right\rangle & \left\langle\alpha\left|H_{\text {Zeeman }}\right| \alpha\right\rangle
\end{array}\right]=\left[\begin{array}{cc}
\frac{g \mu_{\mathrm{B}} B_{z}}{2} & 0 \\
0 & -\frac{g \mu_{\mathrm{B}} B_{z}}{2}
\end{array}\right]
$$

という matrix を対角化することによって得られる。もつとも式(14.7.6)をみると，もう すでに始めから対角化されている。従って, spin eigenfunction $\psi_{1}, \psi_{2}$ と eigenvalue は 次のようになる.

$$
\begin{array}{ll}
\psi_{2}=\alpha: & E_{2}=E_{0}+\frac{g \mu_{\mathrm{B}} B_{z}}{2} \\
\psi_{1}=\beta: & E_{1}=E_{0}-\frac{g \mu_{\mathrm{B}} B_{z}}{2}
\end{array}
$$

ここで $E_{0}$ は磁場がない時のエネルギーである。このように，摂動エネルギーは与えら れた磁場の大きさに比例する.

完Exercise 14.7.1

$\operatorname{spin} \frac{1}{2}$ の系で，磁場が $x$ 軸方向にかけられた時の eigenfunction および eigenvalue を 求めよ.

\section{【解】：}

$$
H_{\text {Zeeman }}=\frac{g \mu_{\mathrm{B}} B_{x} S_{x}}{\hbar}
$$

を用いて，2 次の matrix を対角化し，結果は次のようになる.

$$
\begin{array}{ll}
\psi_{2}=\frac{1}{\sqrt{2}}(\alpha+\beta): & E_{2}=E_{0}+\frac{g \mu_{\mathrm{B}} B_{x}}{2} \\
\psi_{1}=\frac{1}{\sqrt{2}}(\alpha-\beta): & E_{1}=E_{0}-\frac{g \mu_{\mathrm{B}} B_{x}}{2}
\end{array}
$$

放Exercise 14.7.2

式(14.7.7)で与えられる spin $\frac{1}{2}$ の系のZeeman 分裂の大きさ（すなわち 
$\left.E_{2}-E_{1}=g \mu_{\mathrm{B}} B\right)$ を $B=1 \mathrm{~T}$ の場合につき，1） $\mathrm{J}$ 単位，2）波数 $\mathrm{cm}^{-1}$ 単位，および3） 周波数単位で求めよ.ただし $g=2$ としてよい.

\section{【解】:}

物理定数の表から

$$
\mu_{\mathrm{B}}=9.274 \times 10^{-24} \mathrm{~J} / \mathrm{T}
$$

従って

$$
\begin{aligned}
\Delta E & =g \mu_{\mathrm{B}} B \\
& =2 \times\left(9.274 \times 10^{-24} \mathrm{~J} / \mathrm{T}\right) \times(1 \mathrm{~T}) \\
& =1.9549 \times 10^{-23} \mathrm{~J}
\end{aligned}
$$

波数単位では

$$
\frac{\Delta E}{h c}=0.933 \mathrm{~cm}^{-1}
$$

周波数単位では

$$
\frac{\Delta E}{h}=27.99 \mathrm{GHz}
$$

以上のように, $1 \mathrm{~T}$ の分裂が, 波数単位で約 $1 \mathrm{~cm}^{-1}$, 周波数単位で約 $30 \mathrm{GHz}$ である. この数字は覚えておくと何かと便利である.

spin $\frac{1}{2}$ の系についてのZ Zeeman 分裂は以上見て来た通りであるが, spin $\frac{1}{2}$ 以外の系 についても考え方は全く同じである.

例えば $S=1$ ，すなわち三重項スピン系について考えてみよう。三重項スピン系の spin function は, 式(14.5.19)で求めたように

$$
\begin{aligned}
& \rho(1,1)=\alpha \alpha \\
& \rho(1,0)=\frac{1}{\sqrt{2}}(\alpha \beta+\beta \alpha) \\
& \rho(1,-1)=\beta \beta
\end{aligned}
$$

Hamiltonian は, 磁場が $z$ 軸方向にかけられたとして

$$
H_{\text {Zeeman }}=\frac{g \mu_{\mathrm{B}} B_{z} S_{z}}{\hbar}
$$

であるが，ここで spin operator $S_{z}$ は 2 スピン系の operator であるので, 式(14.5.4)のよ 
うに

$$
S_{z}=S_{z}(1)+S_{z}(2)
$$

であることに注意すべきである。そこで，例えば

$$
\rho(1,1)=\alpha(1) \alpha(2)
$$

に $S_{z}$ を作用する場合

$$
\begin{aligned}
S_{z} \alpha(1) \alpha(2) & =S_{z}(1) \alpha(1) \alpha(2)+S_{z}(2) \alpha(1) \alpha(2) \\
& =\left[S_{z}(1) \alpha(1)\right] \alpha(2)+\alpha(1)\left[S_{z}(2) \alpha(2)\right] \\
& =\frac{\hbar}{2} \alpha(1) \alpha(2)+\frac{\hbar}{2} \alpha(1) \alpha(2) \\
& =\hbar \alpha(1) \alpha(2)
\end{aligned}
$$

のように演算する。または，すでに式(14.5.19)を求めた時に明らかにしたように $\rho(1,1)=\alpha(1) \alpha(2)$ における左辺の括弧内の数字の第 2 番目の"1"は2 スピン系全体とし て $M_{s}=1$ ということであるから，この結果を用いれば，直ちに上の式の結果が得られ る.このようにして得られる対角化すべき 3 次の matrix は次のようになる.

$$
\left[\begin{array}{ccc}
g \mu_{\mathrm{B}} B & 0 & 0 \\
0 & 0 & 0 \\
0 & 0 & -g \mu_{\mathrm{B}} B
\end{array}\right]
$$

このように始めから対角形となっているので, eigenfunction と eigenvalue は直ちに次 のように求まる.

$$
\begin{array}{ll}
\psi_{3}=\alpha(1) \alpha(2) & E_{3}=g \mu_{\mathrm{B}} B_{z} \\
\psi_{2}=\frac{1}{\sqrt{2}}\{\alpha(1) \beta(2)+\beta(1) \alpha(2)\} & E_{2}=0 \\
\psi_{1}=\beta(1) \beta(2) & E_{1}=-g \mu_{\mathrm{B}} B_{z}
\end{array}
$$

\section{政Problem 14.7.1}

spin $\frac{1}{2}$ の系について, 磁場が $y$ 軸方向にかかった時の eigenfunction と eigenvalue を 求めよ. 


\section{放Problem 14.7.2}

spin $\frac{1}{2}$ の系について, 磁場の方向の方向余弦が $l, m, n$ あ゙あ場合の eigenfunction, eigenvalue を求めよ。そして, Zeeman 分裂の大きさは磁場の大きさのみに依存し, 方 向によらないことを示せ。

\section{¿ 2 Problem 14.7.3}

spin 1 の系で, 磁場が $x$ 軸にかけられた場合の eigenfunction と eigenvalue を求めよ.

\section{¿ 2 Problem 14.7.4}

上の問題で, 磁場が $y$ 軸方向の場合を求めよ.

\section{خ2 Problem 14.7.5}

上の 2 つの問題を一般的な形で考えよ. 寸なおち, 磁場の方向余弦が $l, m, n$ とし て, eigenfunction と eigenvalue を求めよ。

\section{党}

[Coffee Break] 磁束密度の単位 : テスラ

磁束密度の単位が Tesla といってもなかなか感じがつかめないかもしれない. 自然 界に存在する磁場, 人工の磁場について, 主なものを図 14.7.1にまとめておく.（こ

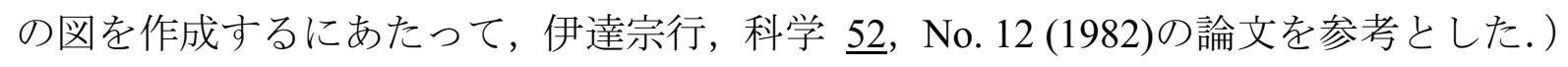




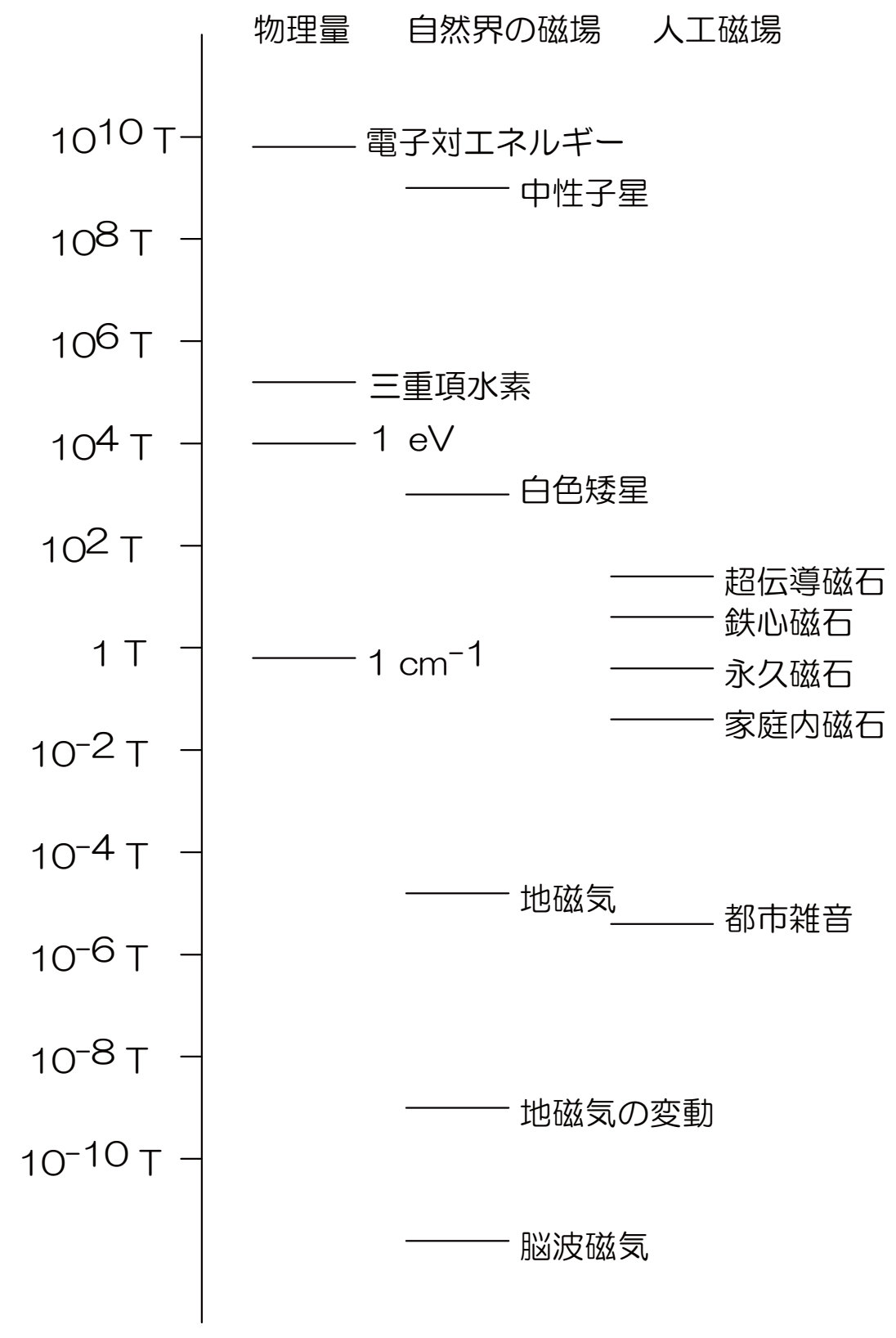

図 14.7.1 種々の磁場の大きさ

図から分かるように，磁場という物理量について現在の人知の及ぶ範囲は $10^{-14} \mathrm{~T}$ から $10^{10} \mathrm{~T}$ までのほぼ $10^{24} \mathrm{~T}$ の範囲の世界である。

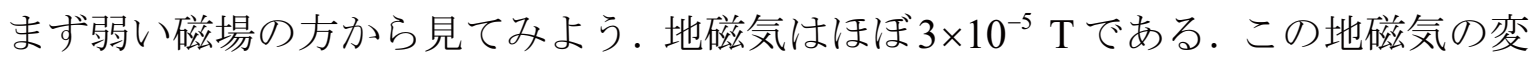
動は約 $10^{-9} \mathrm{~T}$ 程度である。一昔前まではこのあたりが弱磁場の測定限界であったらし いが, 最近ではスクイドと呼ばれる超電導センサーを用いる測定で $10^{-14} \mathrm{~T}$ 位まで測定 可能となっている，そういう非常に小さな磁場でも測定出来るようになったために， 現在では人体内，例えば脳に流れる電流によって生ずる微弱な磁場をさえ測定出来 
る.困で分かるように，これらは $10^{-10} \mathrm{~T} か ら 10^{-12} \mathrm{~T}$ の範囲にある。

電車が走ったり，モーターを動かしたりして発生する磁気的な都市雑音は，約 $10^{-7} \mathrm{~T}$ のオーダーである.

次にもう少し強い磁場を見てみよう. 家庭内で見られる磁石, 例えば電源のブレー カー，テレビなどの内蔵マグネットなどは $10^{-2} \mathrm{~T} か ら ~ 10^{-1} \mathrm{~T}$ の範囲である。永久磁石 のもっとも強いもので1 T のオーダーである. 鉄心にコイルを巻き付けた電磁石でも そうは変わらず，せいぜい 2 - $3 \mathrm{~T}$ である. 鉄心のコイルで限界があるのは強磁性体の 飽和現象のためである.これ以上の強磁場を得ようとすると鉄の代わりに，鉄，コバ ルトの合金や，サマリウム，コバルトの合金などを用いると多少は良くなる．しかし $\log$ スケールで示された図 14.7.1 ではほとんど差はみられない位である。電磁石の場 合にはコイルに大電流を流せばそれだけ大きな磁場が得られるということになるは ずであるが，そうなるとジュール熱によってコイルが駄目になったりするし，第一， 冷却だけで大変なことになる，文献を見ていると，Bitter Magnet というものを使って いる場合がまれにあるが，これはMIT の Bitter という人が中心になって作った大電流 の電磁石のことで $20 \mathrm{~T}$ を越す磁場が作られたということである.

この場合, 川の水でコイルのジュール熱を冷やし, 又電力だけで 10 メガワットを 消費したという。私が学生の頃，まだ電力事情もよくなかった時であったが，金研の 大型電磁石が動き出すと, 仙台市中の電灯がちょっと暗くなるということがあって, その時のことを思い出すと，このBitter Magnet なるもののすさまじさを想像出来る.

このジュール熱の問題を解決したのが超電導線を用いる超電導磁石である. 超電導 線をまいたコイル全体を液体へリウムで泠却する。超電導であるから抵抗はゼロで, ジュール熱の発生はないわけである。しかもジュール熱による損失がないから，超電 導状態になってからコイルを短絡し，外部から電流の供給をやめても永久に電流は流 れ続けるわけで，永久磁石と同じようになってしまう。私自身も自分でコイルを巻い て作ったことがあるがズブの素人が初めて作って，5 Tが楽に得られた。市販されて いるものは，ほぼ15 T位まで得られる。超電導磁石に用いられる超電導は現在の所, 液体ヘリウムで泠却しなければならない. 最近は, 常温超電導体のことが大きなニュ 一スとなっているが, これで超伝導線を作るということまではなっていない.しかし， 将来それが可能となれば科学技術上の大革命である.

これ以上, 強い磁場を求めるには，パルス磁場を用いることになる．大電流をごく 短時間だけ流し，パルス的に強磁場を得るわけである。例えば，パルス幅が $10^{-6} \mathrm{~s} の$ 時間なら $300 \sim 500 \mathrm{~T}$ が得られるという。

なお，図の中に $1 \mathrm{~cm}^{-1}$ とか $1 \mathrm{eV}$ とか記してあるのはゼーマン効果のエネルギー $g \mu_{B} B$ がそれぞれその位のエネルギーに相当することを示したものである. $1 \mathrm{~T}$ の磁場 が波数 $1 \mathrm{~cm}^{-1}$ に相当するエネルギーに対応する。「 $1 \mathrm{~T}$ で $1 \mathrm{~cm}^{-1} 」$ 覚えやすい数字であ 
ろうから覚えておいて損はない換算係数である.

\section{8 電子スピン共鳴}

電子 1 個，すなわち spin $\frac{1}{2}$ の系に，Bという大きさの磁場がかかっている場合を 考える.式(14.9.7)などで学習したように

$$
\Delta E=g \mu_{\mathrm{B}} B
$$

だけの大きさに分裂した $2 つ の$ 状態がある。この状態と外界（すなわち溶媒など）と の熱のやりとりが十分に行なわれているならば，2つの状態にある分子の数，すなわ ち, population は Boltzmann 分布則によって与えられる. 寸なわち, 式(14.8.1)のよう に, energy の低い方について 1, 高い方について 2 という subscript をつけると, population の比 $\frac{N_{2}}{N_{1}}$ は

$$
\frac{N_{2}}{N_{1}}=\exp \left(-\frac{\Delta E}{k T}\right)
$$

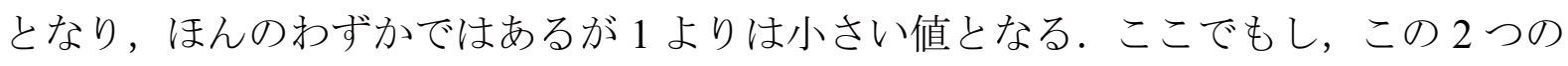
状態間の電磁波の吸収を伴う遷移が量子力学的に許されるならば（すなわち選択則が 許容ならば）丁度電磁波の周波数 $v$ が

$$
h v=\Delta E=g \mu_{B} B
$$

で示される条件を満たした時に電磁波の誘導吸収が起こる，磁場が $1 \mathrm{~T}$ 以下位の大き さでは, 式(14.8.3)の条件を満たす $v$ を持つ電磁波はマイクロ波に相当する.こうして， マイクロ波の吸収を測定することによってスピン状態間のエネルギー差を求める実 験方法を電子スピン共鳴法という。

式(14.8.3)に従ってゼーマン分裂の大きさと，与えるマイクロ波のエネルギーが一 致するところを見出せばいいわけであるので，この場合，（1）マイクロ波の周波数を 一定にしておいて磁場の大きさを変化させて丁度共鳴する場所を見つける方法と, 反 対に，(2）磁場の大きさは一定にしておいてマイクロ波の周波数を変化させていって 共鳴の場所を見つける方法と $2 つ$ 考えられる. 実験の装置の面からは，マイクロ波の 周波数を変えるのはそれほどむずかしくはないが，そのマイクロ波を効率よく，すな わち損失をなるべく少なくして試料まで導くのは至難の業である。それで，通常は， 与えるマイクロ波の周波数は一定にしておいて, 磁場を変化させる方法がとられてい て, これが通常の電子スピン共鳴装置（electron spin resonance spectrometer）である. この時，与えるマイクロ波の周波数によって L-band，S-band，X-band，Q-band 等次の ように名前が付けられている. 


$$
\begin{array}{ll}
v=30 \sim 40 \mathrm{GHz} & \text { Q-band spectrometer } \\
v=12 \sim 18 \mathrm{GHz} & \text { J-band spectrometer } \\
v=8 \sim 12 \mathrm{GHz} & \text { X-band spectrometer } \\
v=4 \sim 8 \mathrm{GHz} & \text { C-band spectrometer } \\
v=2.6 \sim 4 \mathrm{GHz} & \text { S-band spectrometer } \\
v=1 \sim 2.6 \mathrm{GHz} & \text { L-band spectrometer }
\end{array}
$$

それぞれの spectrometerについて merit と demerit があるので，使い分けるのが望まし いが，予算の関係上それほど自由にならないのが現実の世界である。

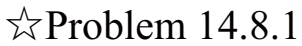

$\operatorname{spin} \frac{1}{2}, g=2$ の系を考える. Q-band, X-band, L-band それぞれの装置で，共鳴条件 の起こる磁束密度の大きさを求めよ。

\section{9 「共鳴」および「非共鳴」の測定方法について}

ESR というのは，上述したように，2つのスピン間のエネルギー差 $\Delta E$ を測定する 手段である。この方法で我々は"resonance"という言葉を用いて来たが， resonance とい うユニークな測定法をもう少し詳しく吟味してみよう。

ある物理量 一 例えばここの例ではエネルギー差一を測定するのに大きく分けて 2つの方法が考えられる.1つはエネルギー差と何らかの関係で結びつけられる物理 量を測定し，その物理量から換算して，エネルギ一差を求める方法である。これは， 以下に詳述する resonant method ではなく, nonresonant method と呼ばれる。もう1つ は上で述べた電磁波の吸収を測定する方法であり， resonant method と呼ばれる.

resonant method では（1）まず第 1 に，電磁波により 2 つ状態間の遷移を誘起する.

（2）次にその結果として生ずる変化を「検出（detect）」する.この方法の特徴は, 変化を「detect」するだけで十分であり，「測定（measure）」の必要はないということ である．後はその変化が detect された時の電磁波のエネルギーをみればよいだけであ る。すなわち，我々が夕なければいけないのは，電磁波の吸収があるかないか，それ だけである。連続的に変化する量を定量的に「測定」するわけではないから，「detect」 するのは実に容易である。この resonant method が正確な「測定」を必要とする nonresonant method に比べてずっと簡単であり，また精度が良いことは明らかである。

以下に resonant method と nonresonant method の差をはっきりさせるために，二三の 例をあげ，2つの方法論を比較してみよう。 
(1) Stern-Gerlach type experiment でAg 原子の持っている magnetic moment を測定す る.

a) Nonresonant method

これは chapter 2 で詳しく述べたように，Stern と Gerlach が最初に試みたことであ る。すなわち，Ag 原子をある速度で inhomogeneous magnetic field の中を通す。

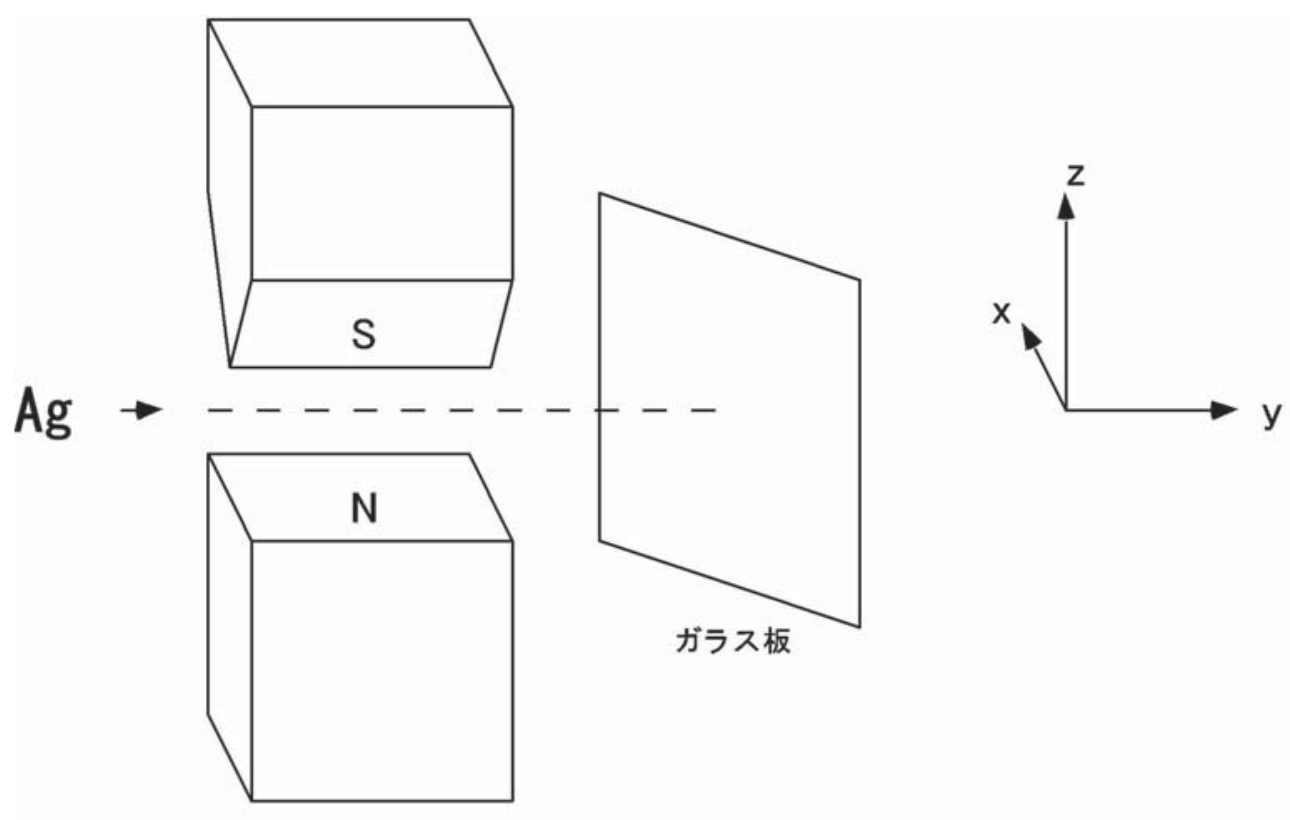

困 14.9.1 （図 2.2.2 と同じもの）

この実験で（1） $\mathrm{Ag}$ 原子の速度，（2）磁束密度の勾配，（3）不斉磁場からガラス板ま での距離，（4）2つの spot 間の距離が分かれば magnetic moment は計算出来るはずで ある。しかし実際上はあまり精度は望めない。

b) Resonant method

次に Section 2.2 で述べた double Stern-Gerlach Experiment と似た実験装置を考える. ただし，2つの同じ向きの inhomogeneous magnetic field の中間に，1つの homogeneous magnetic field を掛けられるようにする. 

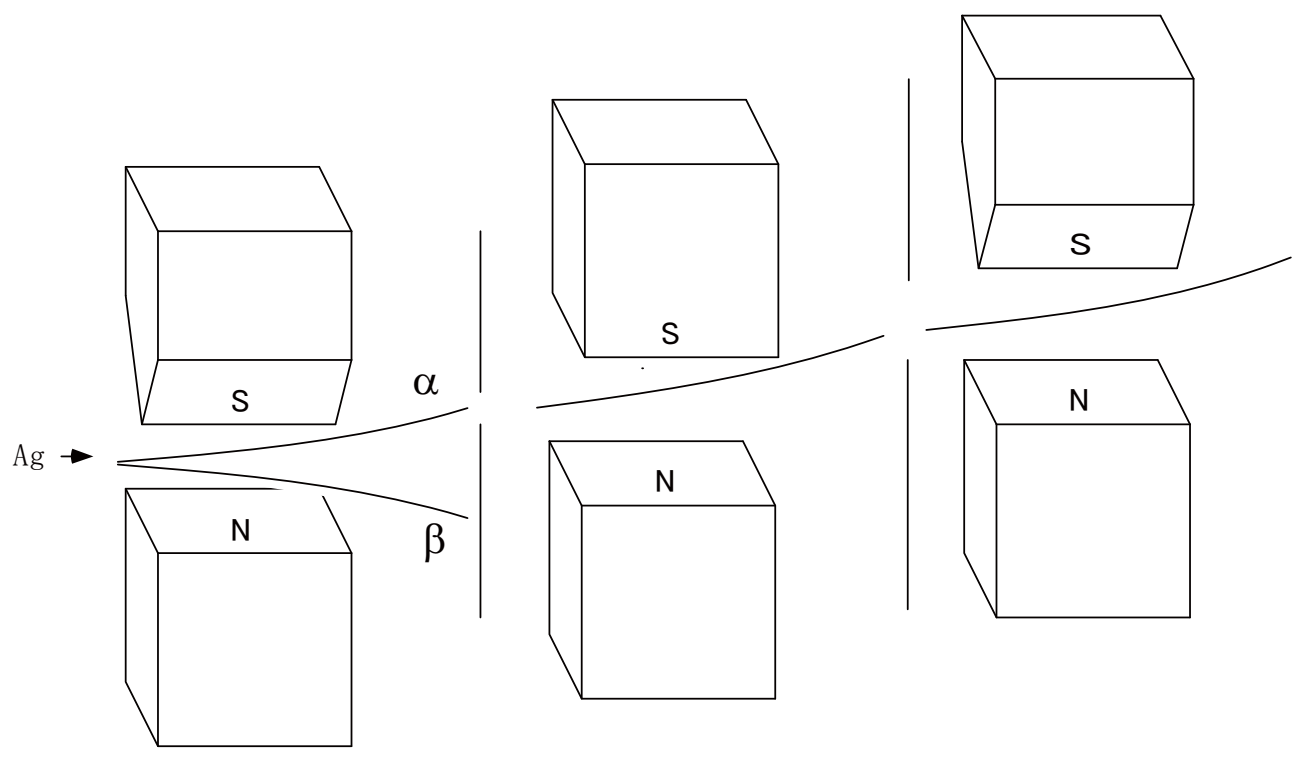

図 14.9 .2

まず，中央の homogeneous magnetic field をゼロにしておく. Section 2.2 で述べたよう に，最初の inhomogeneous magnetic fieldによって $\alpha$ となった原子のみを， 2 番目の inhomogeneous magnetic field に通すと全て $\alpha$ となる．原子の来るべき所に detectorを おいておけば，原子の数を数えることが出来る.

次に中央の homogeneous magnetic field をある大きさ $B$ に保ち, 更に, 強い microwave をここで試料に当てる. homogeneous magnetic fieldにより， $\alpha$ と $\beta$ とのエネルギーが $g \mu_{\mathrm{B}} B$ だけ分裂することはすでに学習した。しかし系には当然 $\alpha$ しかないわけである. ここに magnetic field により作られたエネルギ一差 $g \mu_{\mathrm{B}} B$ と microwave の持っているエ ネルギー $h v$ が丁度等しくなった時に $\alpha$ から $\beta$ への遷移が起こる. すなわち，理想的 な場合には， $\alpha$ spin を持った原子のうちの半分は $\beta$ spin を持つようになる。 $\beta$ spin となった原子は最後の inhomogeneous magnetic fieldによって反対方向に曲げられる. 従って, detectorで感ずる原子の数は急激に減少する。この時のマイクロ波の周波数 $v$ を調べれば, $g \mu_{\mathrm{B}} B=h v$ より $\mathrm{Ag}$ 原子の持っている magnetic moment の值は直ちに求ま る.この実験では, detectorの感ずる原子の数が急激に減少する点を"detect"するだけ で十分である。 


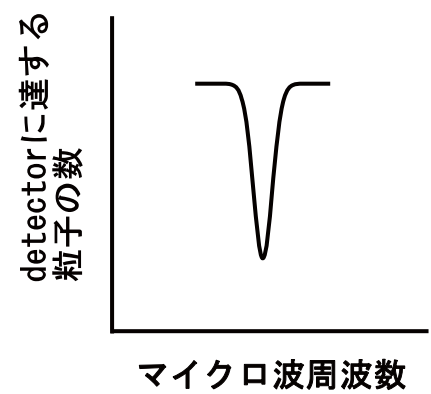

図 14.9 .3

上のような図で，縦軸の目盛を見る必要はない。ただ変化が急激に起こるマイクロ波 周波数さえ detect 出来ればいいわけである.（a）で述べた nonresonant の方法に比べて 簡単で，しかも精度がいいことは直ちに分かるであろう。

（2）水素原子の ${ }^{2} P_{1 / 2}(2 p)$ 状態と ${ }^{2} S_{1 / 2}(2 s)$ 状態とのエネルギー差を求める.

水素原子の基底状態では， 1 個の電子が $1 s$ orbitalにあり， ${ }^{2} S_{1 / 2}(1 s)$ と呼ばれる. 電 子が $2 s$ orbital に励起されれば ${ }^{2} S_{1 / 2}(2 s), 2 p$ orbital に励起されれば ${ }^{2} P_{1 / 2}(2 p)$ である. 初歩的な教科書では， $2 s$ orbital と $2 p$ orbital とは同じエネルギーにとられているの で，2つの励起状態 ${ }^{2} S_{1 / 2}(2 s)$ と ${ }^{2} P_{1 / 2}(2 p)$ とは同じエネルギーを持つように思えるが， 実際には差がある。（この原因は， electron と radiation field との interaction による.） 各 state および configuration を schematic に書くと次の図のようになる. 


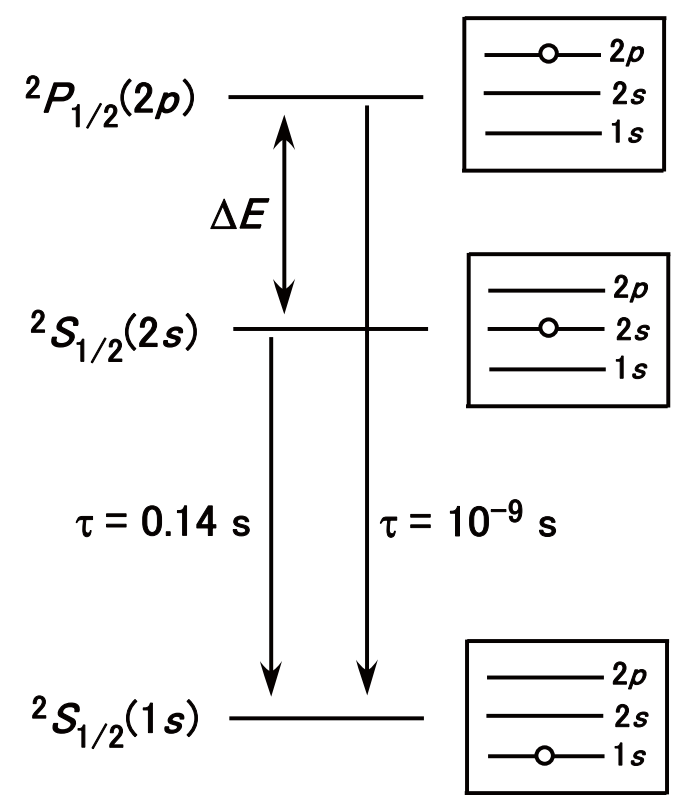

図 14.9 .4

今, 水素原子の beam を作り,それに高電圧をかけると一部の hydrogen atom ${ }^{2} P_{1 / 2}(2 p)$ や ${ }^{2} S_{1 / 2}(2 s)$ になる. beam の先に detector を置いておく.（この detector は励起した水素 原子がぶつかった時だけ，二次電子を出すものである.）

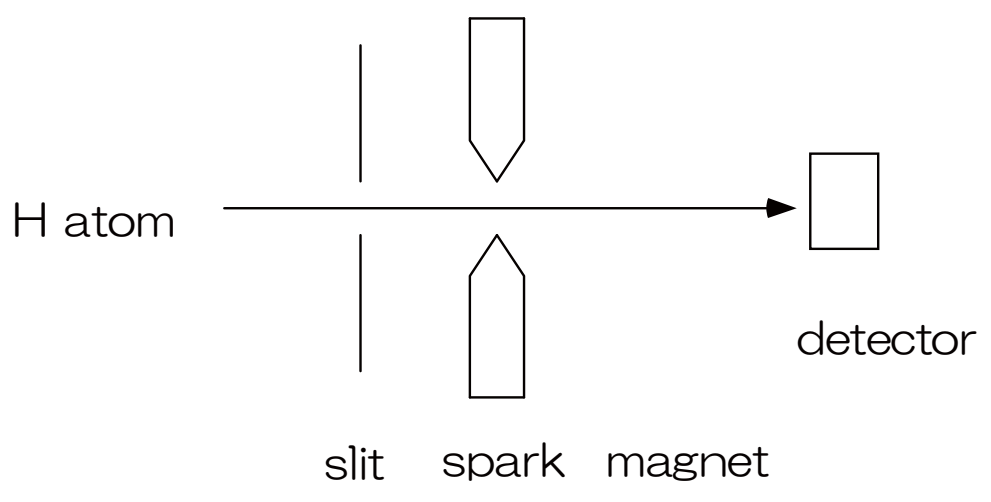

図 14.9.5

さて，2つの励起状態のうち, ${ }^{2} P_{1 / 2}(2 p)$ は基底状態 ${ }^{2} S_{1 / 2}(1 s) へ 10^{-9} \mathrm{~s}$ という短い時 間内に発光を伴って落ちてしまう。従って, detectorに届くことは出来ない. 一方, 
${ }^{2} S_{1 / 2}(2 s)$ は $0.14 \mathrm{~s}$ という長い寿命を持つのでゆうゆうと detector まで飛んで行ける.

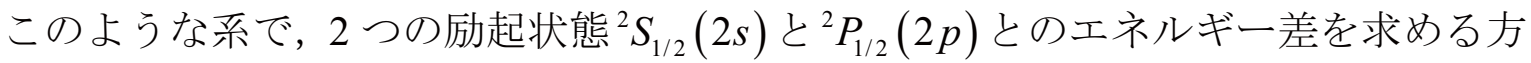
法を resonant および nonresonant の2つの方法で考えてみよう.

1) Nonresonant method

スパークで励起状態を作った後，(少なくとも $10^{-9} \mathrm{~s}$ 以上時間がたつ位粒子が飛ん でから) homogeneous magnetic field をかける.

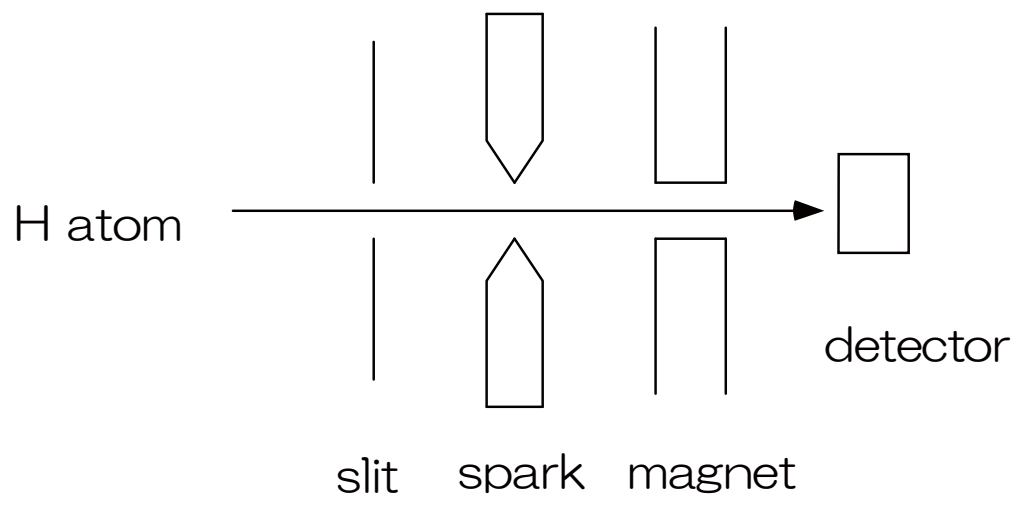

図 14.9 .6

$\mathrm{H}$ atom は spin $\frac{1}{2}$ を持っているから当然Zeeman 分裂が起こる.しかし Zeeman 分裂は spin 系のみでなく, 軌道角運動量を持っている系についても起こる. その結果として, magnetic fieldにより, ${ }^{2} S_{1 / 2}(2 s)$ と ${ }^{2} P_{1 / 2}(2 p)$ とが混じりあう。すなわち magnetic field を通る直前は， ${ }^{2} S_{1 / 2}(2 s)$ であった $\mathrm{H}$ atom は magnetic field を通った後は，

$$
\psi=c_{1}\left|{ }^{2} S_{1 / 2}(2 s)\right\rangle+c_{2}\left|{ }^{2} P_{1 / 2}(2 p)\right\rangle
$$

のように，2つの状態の混じりあいとして表現出来る．このような状態 の寿命 $\tau$ は,

$$
\frac{1}{\tau}=\frac{1}{0.14 \mathrm{~s}} c_{1}^{2}+\frac{1}{10^{-9} \mathrm{~s}} c_{2}^{2}
$$


で示される.すなわち, ほんのわずかの mixing でも寿命は, $0.14 \mathrm{~s}$ から大きく外れる.

（例えば $c_{2}=0.01$ で $\tau=10^{-5} \mathrm{~s}, \quad c_{2}=0.001$ で $\tau=10^{-3} \mathrm{~s}$. )

この混じりあいの係数 $c_{1}$ および $c_{2}$ は magnetic field の大きさと, 2 つの状態間のエネ ルギー差 $\Delta E$ の関数として表される.すなわち, mix した状態の寿命は $\Delta E$ の関数とし て示される. detectorで感ずる励起された $\mathrm{H}$ atom の数は, 従って $\Delta E$ の関数として表 される. 従って magnetic field の大きさ, magnetic field から detector の距離, $\mathrm{H}$ atom $の$ 速度が分かっていれば detector の感ずる励起 $\mathrm{H}$ atom の数より， $\Delta E$ が計算出来るわけ である。しかし考えただけでも，精度高い実験の難しさが分かるであろう。

\section{2) Resonant method}

Resonant method では magnetic field と同時に強い電磁波を与える. 電磁波の振動数 $v$ が磁場をかけた時のエネルギー差 $\Delta E^{\prime}$ と $h v=\Delta E^{\prime}$ で示される resonance condition が成 り立つ時に, ${ }^{2} S_{1 / 2}(2 s) \rightarrow{ }^{2} P_{1 / 2}(2 p)$ への吸収が起る. 従って, ${ }^{2} S_{1 / 2}(2 s)$ の数は急激に減 少する. 磁場の強さを一定に保ち, 電磁波の周波数を変え, detector の感ずる excited $\mathrm{H}$ atom の数が急激に減少することを"detect"すれば，それで測定は終りである.

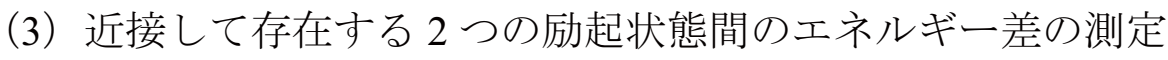

エネルギー的に近接して存在する 2 つの励起状態間のエネルギー差を知りたいこ とがしばしばある(図 14.9.7).

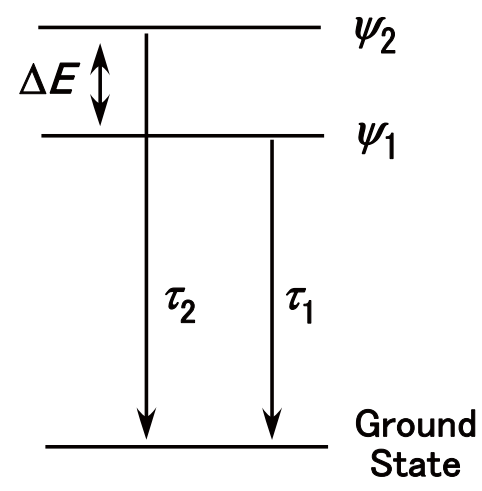

図 14.9.7 2 つの熱分布している準位が $\Delta E$ の間隔で存在し, それぞれの準位の 本質的な寿命が $\tau_{1}$ および $\tau_{2}$ であるとき，見掛けの寿命の温度変化の測定から $\Delta E$ を求めることが出来る. 
例えば第 1 ，および第 2 の励起一重項状態間のエネルギー差など，多くの物性を支配 寸るのでそれを知ることは非常に重要である。しかし，このような場合，従来もっぱ ら nonresonant な方法で扱って来た。、いいろな nonresonant method が現実に使われて いるが，その 1 つは次のようなものである. $\psi_{1}, \psi_{2}$ それぞれについての寿命を $\tau_{1}, \tau_{2}$ と しよう。この 2 つの励起状態が Boltzmann 分布している時は, この 2 つの状態からの 蛍光, 又は燐光の寿命 $\tau$ は次の式で示される.

$$
\frac{1}{\tau}=\frac{\frac{1}{\tau_{1}}+\frac{1}{\tau_{2}} \exp \left(-\frac{\Delta E}{k T}\right)}{1+\exp \left(-\frac{\Delta E}{k T}\right)}
$$

ここで $\Delta E$ は $\psi_{2}$ のエネルギーと $\psi_{1}$ のエネルギーの差である. $k$ は Boltzmann constant, $T$ は温度である．従って温度を変えて $\tau$ を測定し，上式に合うように $\Delta E を$ 決めるこ とが出来る。しかし，このような温度変化より $\Delta E$ を求める方法はあまり精度がよく ない.

resonant method としてもっとも直接的なのは， $\psi_{1}$ から $\psi_{2}$ への吸収を測定すること である. $\Delta E$ の大きさによって，いろいろな波長の電磁波が考えられるが，現実にい ろいろな電磁波でもって測定されている. nonresonant の方法に比べるとはるかに精度 がよいことは明らかであろう。 


\title{
CHAPTER 15
}

\author{
核スピン
}

Chapter 14 で述べたように, Uhlenbeck と Goudsmit の功績により電荷-eを持ってい

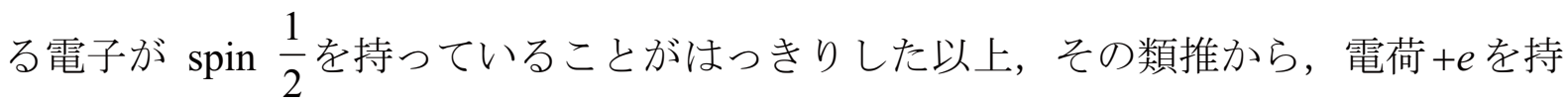

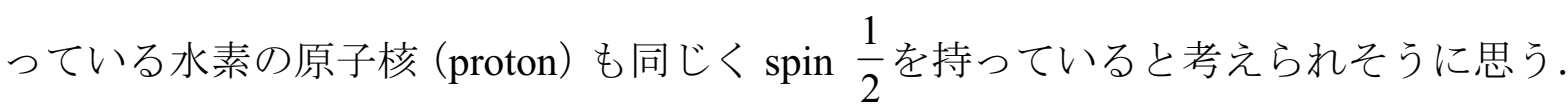
ただ，そう考えてみたところで，それを実験的に示さないうちは，科学とは言えない． それではどうやって実験で証明したらいいであろうか.

現代に生きる諸君は，言うまでもなく，NMR という，化学教室の学生の大部分の 人が毎日のように測定しているスペクトルが核スピン状態間の遷移であることを知 っている。しかし，その NMR が始めて見つかったのは 1946 年のことである。では， 1946 年になって始めて核スピンの存在が実験的に示されたのか, というとそうではな い. 核スピンの発見は，その 20 年ほど前，電子スピンの発見の数年後にすでになさ れていた。ここでは 1920 年代に戻って, どういう実験から核スピンの存在が証明さ れたのかの歴史をみてみよう。

Chapter 14 で詳しく学習したように，電子スピンは，電子スペクトルに見られた分 裂を解釈するために考えられたわけである。もし proton に核スピンがあったら，同様 に電子スペクトルの分裂に現れるだろうか?答は no である。すでに述べたように， 電子は磁気モーメント

$$
\mu_{\mathrm{B}}=\frac{e \hbar}{2 m_{\mathrm{e}}}
$$

を持っていた。このことからの類推でいくと, protonの核スピンの持っている磁気モ 一メントは, 大雑把には, protonの質量を $m_{\mathrm{p}}$ として, $\frac{e \hbar}{2 m_{\mathrm{p}}}$ の大きさで符号は反対であ ると考えられる. protonの質量は, 電子のそれの約 2000 倍であるから, proton の磁気 モーメントは電子の磁気モーメントの約 2000 分の 1 といらふうに考えられる. スペ クトルに現れる分裂の大きさは，磁気モーメントの大きさで決まるから，核スピンに よるスペクトルの分裂の大きさは，電子スピンによる分裂の大きさの約 2000 分の 1 と考えられる.

電子スペクトルに見られる分裂はどの位であろうか? 原子番号が大きい原子ほど 分裂も大きくなるが，例えば，すでに Chapter 14 で述べたように，Naの D 線は $589.76 \mathrm{~nm}$ と $589.16 \mathrm{~nm}$ の 2 本で，この間の分裂は波数単位で $18 \mathrm{~cm}^{-1}$ である。この分 
裂の 2000 分の 1 ， 寸なおち $0.01 \mathrm{~cm}^{-1}$ 程度の分裂があったとしても，とても電子スペ クトルの観測にはかからない.

そもそも， 1 本の線スペクトルの幅が $0.01 \mathrm{~cm}^{-1}$ に比べてずっと大きいからである. スペクトルの幅を決める要素はいろいろあるが，例えば気体のスペクトルの場合に は, 分光器に向かって運動している粒子と, 分光器から離れていく粒子とがあり, そ のためのドップラー効果による energy の広がりだけで $0.1 \mathrm{~cm}^{-1}$ 位ある. 現在では，ド ップラー効果を除いてスペクトルを観測する方法（Doppler-free spectroscopy）もある が，核スピンが発見された 1920 年代にはとてもそんな実験が出来るはずがない.

ではどんな実験から核スピンのことが分かったかというと，全く意外なことに，そ れは熱容量の実験からヒントが得られたのである。

ここで，「意外なことに」という表現を用いたが，このことについては多少の説明 が必要であろう。実は, 歴史を振り返ってみると, 量子力学の発展に熱容量の実験の 果たして来た役割は無視出来ない. 例えば, 固体のモル熱容量が低温では Dulong-Pettit の法則の3R（ $R$ は gas constant）より小さくなるという実験を解釈するのに， Einstein や Debye が振動の energy の量子化ということを取り入れたことはすでに Chapter 1 で

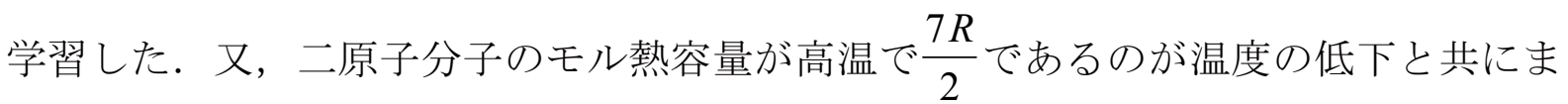

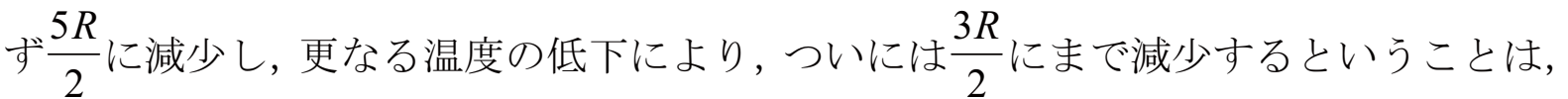
振動や回転の energy の量子化ということで説明がついたわけである.

こういうふうに，熱容量の大きさは量子化した energy 準位を反映しているから， 核スピンがあったとすると，その量子化した energy が熱容量に現れてもよさそうに思 うかもしれない。しかし，そう簡単にはいかないことがちょっと吟味してみれば明ら かとなる。

まず，磁場が完全にゼロであればスピン系は縮退しているわけで，このような場合 にはいくら温度を下げても熱容量には変化が現れない，現実には，積極的に磁場をか けなくても，分子中の電子の運動のためにわずかながら磁場が生じ，このための Zeeman 分裂が起り得る. 従って量子化された energy level が複数個あり，この energy 差と温度とが同じ位になれば熱容量にその効果が現れることになる. 現在の科学で は，大体 $10^{-3} \mathrm{~K}$ 位の極低温で，そのようなことが実験的に見つかっている。しかし絶 対零度に限りなく近い温度での物性測定は, 非常に限られた研究室でやっとこの頃可 能になったばかりであり，電子スピンが発見された 1920 年代には想像もつかないよ うな実験であった。電子スピンを熱容量の点から調べるのに $10^{-3} \mathrm{~K}$ の低温が必要であ るから，電子スピンの $\frac{1}{2000}$ の磁気モーメントしか持たない核スピンがもしあったと してもそれを熱容量で調べるには $10^{-6} \mathrm{~K}$ の低温が必要ということになる。現在では, 
確かに，東北大学の物理教室を含むごくごく限られた研究室で，そのような極低温で 物性測定がなされていることは確かではあるが，大部分の科学者にとっては $10^{-6} \mathrm{~K} と$ いう温度は夢のまた夢でしかない，そういう訳であるので，歴史的に，核スピンの存 在が 1920 年代に熱容量の実験から分かった，ということは，どう考えても意外に思 えるであろう。

それでは熱容量の実験から核スピンの存在が明らかとなったのはどういうことで あろうか．次の節では，このあたりの歴史を振り返ってみることにする.

なお, 核スピンの問題を量子化学のカリキュラムの中でどの程度学習したらいいか についてはいろいろな考え方があると思う。今まで出版された量子化学の教科書で は，核スピンの問題はあまり扱われていない。しかし，現在の化学における核スピン の重要性を考えると, 核スピンの問題はどこかできちんと学習しておく必要があると 思う。どうして核スピンのことが化学にとって重要かというと, 核スピンの状態によ って反応性も異なるし，もちろん，物性も異なる。 又，ひとたび研究実験を始めれば， 大部分の学生諸君は核スピン状態間の遷移である NMR スペクトルを，毎日毎日測定 するであろう。毎日測定しないとしても，卒業までにNMR スペクトルを測定しない 学生は皆無に近いであろう。それほど重要な NMRの基礎理論をどこで学習するだろ うか. 有機化学のカリキュラムの中でも当然学習する。しかし，時間の制限もあり， 非常に定性的な話で終っているようである。NMR スペクトルの解析には不可欠な spin-spin coupling の問題にしても，いわゆる AX 型のスペクトルは定性的な話で理解 出来ようが， $\mathrm{AB}$ 型のスペクトルとなると，とたんに理解が難しくなるのではなかろ うか。しかし，実のところそんなに難しい話ではないのである。量子化学をここまで 学習して来た諸君にとっては，この段階で核スピンやNMRの問題を学習すると，非 常に簡単に全ての理解が得られるように思う。そういうわけで，本 lecture note でも， ある程度の space を核スピンについて費やすことになると思う。

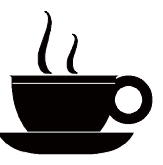

[Coffee Break] 電荷を持たない粒子もスピンを持つ

マイナスの電荷を持っている粒子が運動することによって磁気モーメントが生ず ることはSection 14.2 でも述べたように明らかであり，このことを電子 spin と結びつ けて考えたわけである。そういう観点から，プラスの電荷を持っている核がスピンを 持つであろう，ということを上に考えたのであるが，電荷を持っていない粒子は絶対 にスピンを持たないか，というとそうでもないのでややこしいことになる．実は中性 子も核スピンを持っているのである。このことは，Chapter 14 で考えたようなビオサ バールの法則に基づいた簡単なモデルによる類推からは理解出来ないことである.ど 
うして中性子に核スピンがあるのか，というもっともな疑問には，ここでは納得のい くような答えを出すことが出来ないことをお許し願いたい.

\section{$15.1 \quad H_{2}$ の遠赤外スペクトルと核スピンとの関係}

$\mathrm{H}_{2}$ 分子の定容モル熱容量 $C_{\mathrm{v}}$ は $6000 \mathrm{~K}$ 以上の高温では $\frac{7 R}{2}$ である. しかし，温度の 低下と共に $C_{\mathrm{v}}$ は小さくなり, 図 15.1 .1 に示すように, $300 \mathrm{~K}$ 近似では $\frac{5 R}{2}$, そして, 絶対零度近くでは $\frac{3 R}{2}$ となる.

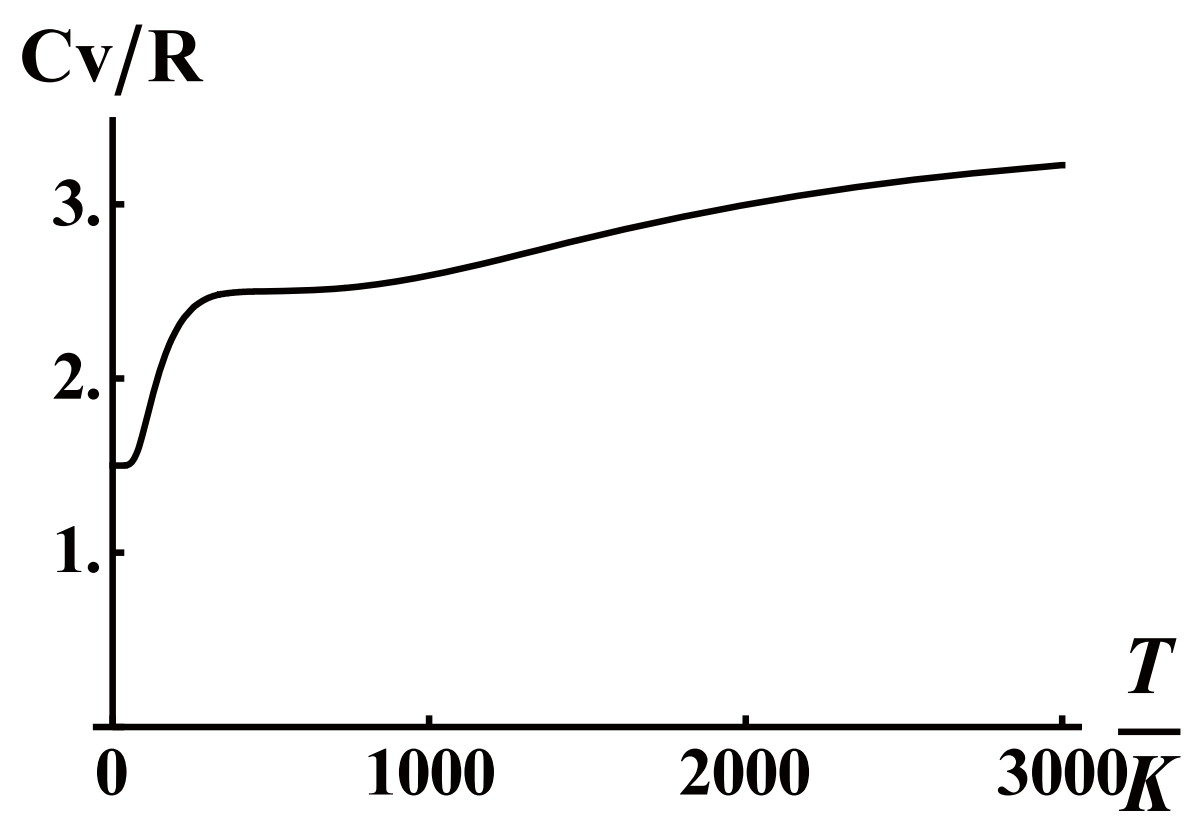

図 15.1.1 $\mathrm{H}_{2}$ の定容熱容量 $C_{\mathrm{v}}$ の温度変化

この熱容量曲線を考えてみよう。断熱近似（Chapter 18 で学習する）のもとでは 2 原子分子の全 energy $\varepsilon_{\text {total }}$ は並進の energy $\varepsilon_{\text {trans }}$, 回転の energy $\varepsilon_{\text {rot }}$, 振動の energy $\varepsilon_{\text {vib }}$, 電子状態の energy $\varepsilon_{\text {elec }}$ の和で表される．従って熱容量は 


$$
\begin{aligned}
\left(C_{\mathrm{v}}\right)_{\text {total }} & =\left(\frac{d \varepsilon_{\text {total }}}{d T}\right)_{V} \\
& =\left(C_{\mathrm{v}}\right)_{\text {trans }}+\left(C_{\mathrm{v}}\right)_{\text {rot }}+\left(C_{\mathrm{v}}\right)_{\text {vib }}+\left(C_{\mathrm{v}}\right)_{\text {elec }}
\end{aligned}
$$

このうち, 電子状態に関しては最低の励起状態の energy は紫外線領域よりも短波長に あるので（水素は無色であることから分かるであろう.）数千度以下の温度範囲では $\varepsilon_{\text {elec }}$ は温度に依存するはずがない，従って

$$
\left(C_{\mathrm{v}}\right)_{\text {elec }}=0
$$

並進の energy は量子化されておらず温度 $T$ では 1 モルあたり $\frac{3}{2} R T$ で与えられる. 従ってモル熱容量は（式が複雑になるのを避けるためここでは定容モル熱容量を単に $C_{\mathrm{v}}$ と表すことにする.）温度に無関係に

$$
\left(C_{\mathrm{v}}\right)_{\text {trans }}=\frac{3}{2} R
$$

と与えられる。

振動については，2 原子分子の振動数を $v$ とすると量子化した振動 energy は

$$
E_{n}=\left(\frac{1}{2}+n\right) h v
$$

であることはすでに学習した，振動に関する partition function は

$$
\begin{aligned}
(p . f .)_{\mathrm{vib}} & =\sum_{n=0}^{\infty} \exp \left(-\frac{E_{n}}{k T}\right) \\
& =\frac{\exp \left(-\frac{h v}{2 k T}\right)}{1-\exp \left(-\frac{h v}{k T}\right)}
\end{aligned}
$$

となる. partition function が分かれば熱容量は

$$
\left(C_{\mathrm{v}}\right)_{\mathrm{vib}}=\frac{\partial}{\partial T}\left[R T^{2} \frac{\partial}{\partial T} \ln (p . f .)_{\mathrm{vib}}\right]
$$

を用いて直ちに計算出来る. 観測されている振動数 $v \quad\left(\tilde{v}=\frac{v}{c}=4159 \mathrm{~cm}^{-1}\right)$ を用いて 計算すると図 15.1.2のようになる. 


\section{$\operatorname{Cv}($ vib)/R}

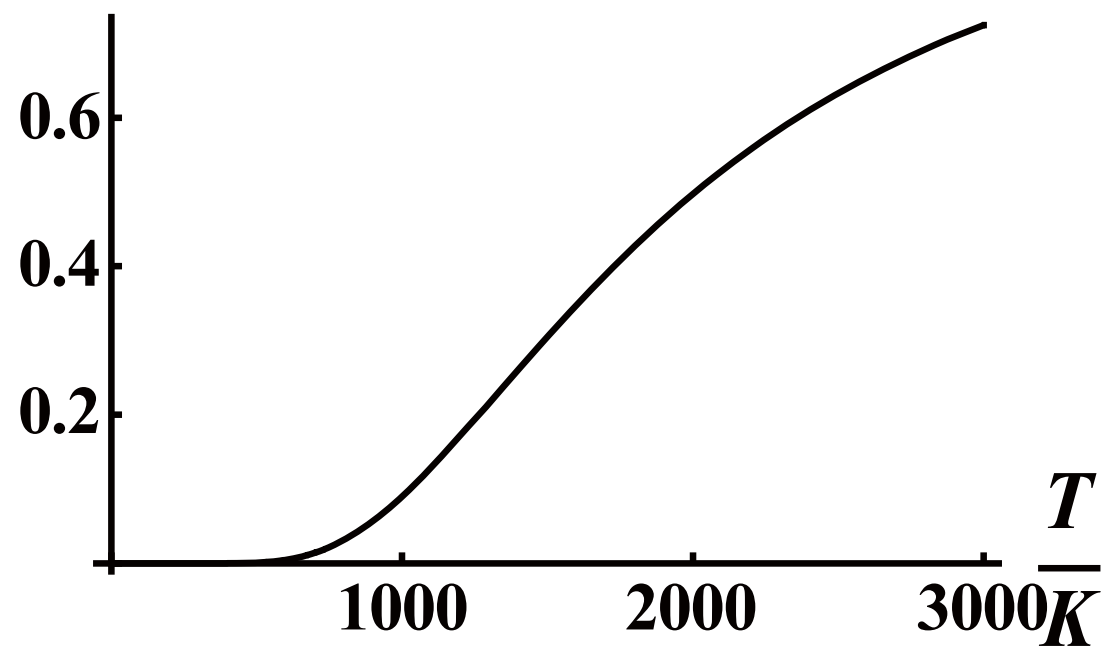

図 15.1.2 振動に関する $\mathrm{H}_{2}$ のモル熱容量の温度変化（計算値）

このようにして, 熱容量についての並進 energy の寄与と振動 energy の寄与とが分 かったので，これらの結果を図 15.1.1.に示した実験值から引くと残りは回転の寄与 で，図15.1.3が得られる. 


\section{$\operatorname{Cv}($ rot $) / R$}

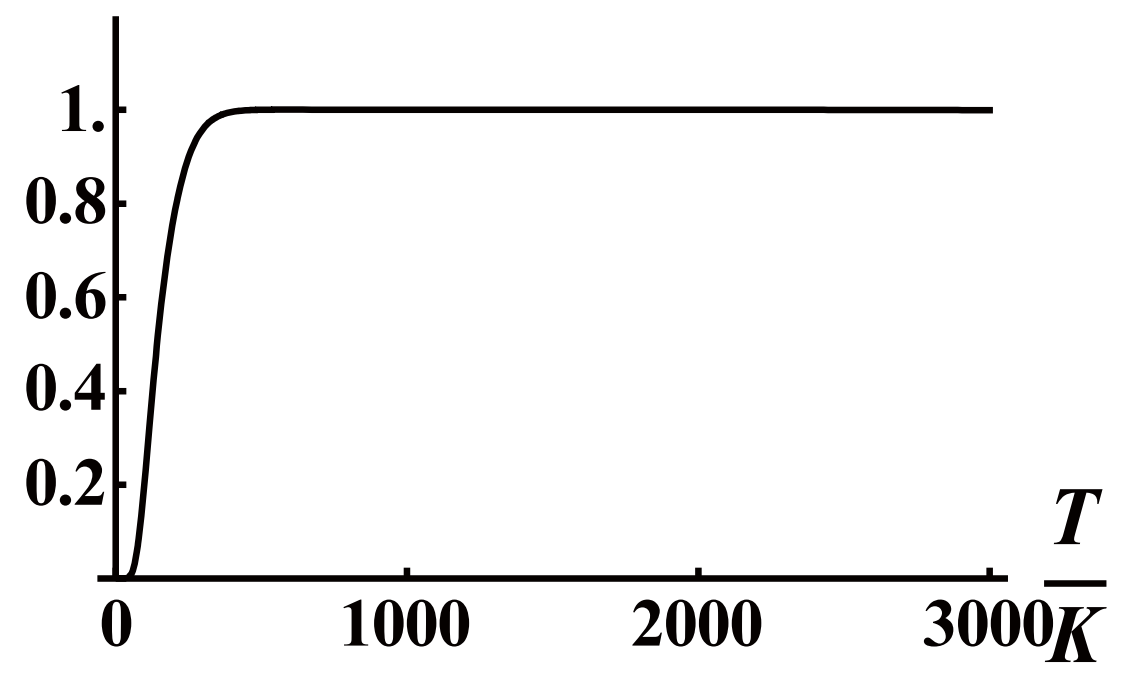

図 15.1.3 回転に関する $\mathrm{H}_{2}$ のモル熱容量の温度変化

図 15.1.1 に示した実験值から図 15.1.2 に示した振動の寄与, および並進の寄与 $\left(\frac{3}{2} R\right)$ を差し引いた值

以上明らかになったように，図 15.1 .1 の温度変化における $\frac{7 R}{2}$ から $\frac{5 R}{2}$ の低下は, 振動の自由度の凍結に, また $\frac{5 R}{2}$ から $\frac{3 R}{2}$ へ低下は, 回転の自由度の凍結による. 最 後に残った $\frac{3 R}{2}$ は量子化していない並進運動に起因するものである.

では, $\frac{5 R}{2}$ から $\frac{3 R}{2}$ へ $C_{\mathrm{v}}$ の変化（すなわち図 15.1 .3 に示した温度変化）をもう少し 定量的に吟味してみよう。量子論によると，剛体の回転体に対する energy は，量子数 jについて,

$$
E_{j}=\frac{\hbar^{2}}{2 I} j(j+1)
$$

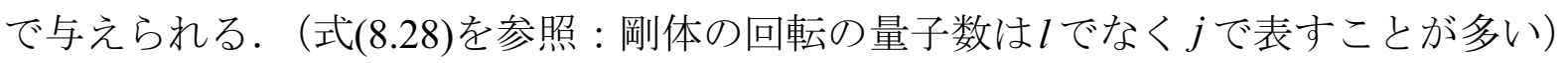
この状態は， $2 j+1$ 重に縮退している。ここで $I$ は回転の慣性モーメントである．式 (15.1.7)により回転に関する分配関数（partition function）は次式で与えられる. 


$$
\begin{aligned}
(p . f .)_{\text {rot }} & =\sum_{j=0}^{\infty}(2 j+1) \exp \left(-\frac{E_{j}}{k T}\right) \\
& =\sum_{j=0}^{\infty}(2 j+1) \exp \left[-\frac{j(j+1) \hbar^{2}}{2 I k T}\right] \\
& =\sum_{j=0}^{\infty}(2 j+1) \exp \left[-\frac{j(j+1) \theta_{\mathrm{rot}}}{T}\right]
\end{aligned}
$$

ここで

$$
\theta_{\text {rot }}=\frac{\hbar^{2}}{2 I k}
$$

は回転に関する特性温度である。また $k$ は Boltzmann constant， $T$ は温度である。

モル熱容量 $C_{\mathrm{v}}$ は式(15.1.8)を用いて, 次式により計算出来る.

$$
\left(C_{\mathrm{v}}\right)_{\mathrm{rot}}=\frac{\partial}{\partial T}\left[R T^{2} \frac{\partial}{\partial T} \ln (p . f .)_{\mathrm{rot}}\right]
$$

現在では， $\mathrm{H}_{2}$ については結合距離が分かっているから，慣性能率が計算出来，式 (15.1.10)は容易に求まる。計算結果は図 15.1.4のようになる. 


\section{$\operatorname{Cv}(\operatorname{rot}) / R$}

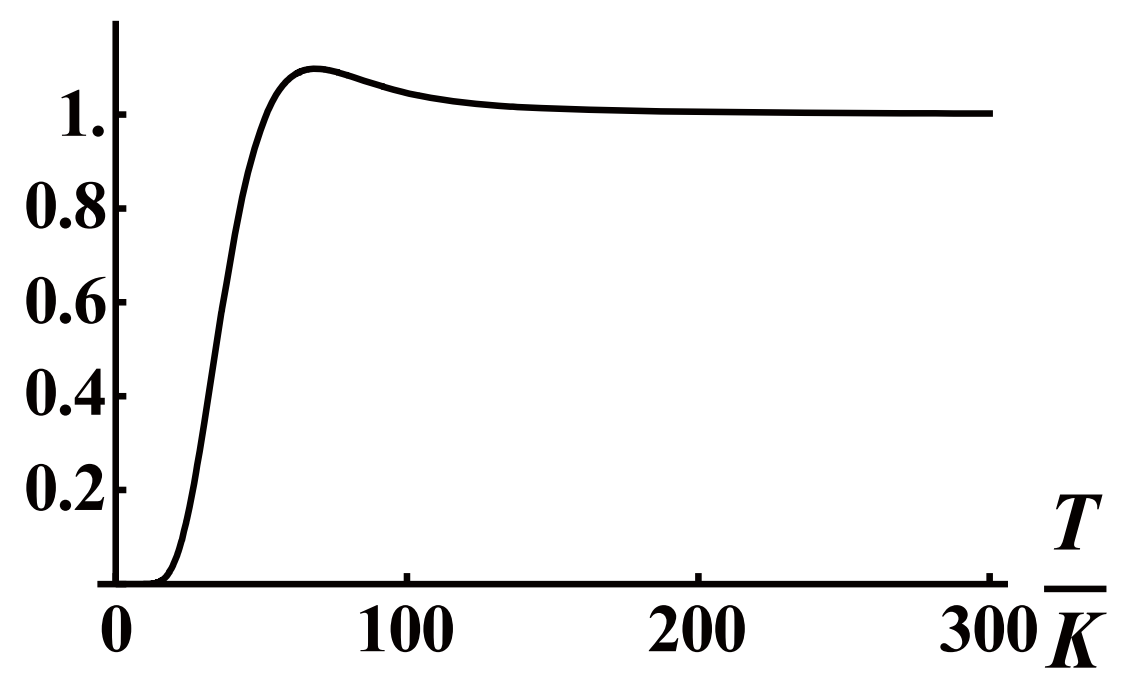

図 15.1.4 式(15.1.10)による $\frac{\left(C_{\mathrm{v}}\right)_{\mathrm{rot}}}{R}$ の $T$ に関する計算值

$\theta_{\text {rot }}$ は式(15.1.9)によると， $\mathrm{H}_{2}$ について，85 K 位である.図 15.1.4 の計算結果は大 まかには，図 15.1.3に示した温度変化の実験值をほぼ再現している。すなおち，温度 の低下と共に回転運動が凍結し， $\left(C_{\mathrm{v}}\right)_{\mathrm{rot}}$ が $R$ からゼロへ低下することを，定性的には， 説明しているように思える.

この方法は一般の異種原子からなる二原子分子の $C_{\mathrm{v}}$ の温度をよく説明する。しか し, $\mathrm{H}_{2}$ 分子についてはよく吟味すると, 図 15.1.4 の計算值は図 15.1.3 の実験結果と 食い違う。計算では， $T=\theta_{\mathrm{rot}}$ すなわち $T=85 \mathrm{~K}$ 位で， $C_{\mathrm{v}}$ が極大值を示す．しかし実験 ではこのような極大は存在しない。この実験と計算との食い違いの原因を究明しよう とした人の中にあの有名な Hund がいたが，Hund がそういうことを考えた時代は，ま だ 2 つの $\mathrm{H}$ 原子間の距離さえ測定されておらず, 従って $\mathrm{H}_{2}$ の慣性モーメントの值も 分かっていなかったので，今からみると正しくない解釈を与えている。 [F. Hund, Z. Physik, $\underline{42}, 93$ (1927)] 
理論と実験との上述の不一致が解決されたのは，遠紫外領域の $\mathrm{H}_{2}$ のスペクトルの 解析にヒントを得たのであった. しかも, そのスペクトルを解析したのは, Copenhagen のBohrの研究室に留学していた堀健夫という日本人である.

1926 年から 1927 年にかけて Hori は (漢字を用いると敬称を用いないといけないよ うに思える．他の人達と同じように，敬称なしで述べることにする.） $\mathrm{H}_{2}$ 分子の電子 遷移に付随してみられる回転構造を解析していた. Hori はいろいろな励起状態と基底 状態との間のスペクトルを解析したようだが, ここではその代表として, 基底状態 $\Sigma_{g}^{+}$ と励起状態 $\Sigma_{u}{ }^{+}$との間の電子遷移を考えよう。 $\left(\Sigma_{g}{ }^{+}\right.$とか $\Sigma_{u}{ }^{+}$は点群の $\mathrm{D}_{\infty \mathrm{h}}$ の既約表現 の記号であり，それぞれの状態が，その既約表現の基底になっていることを示してい る.） $\Sigma_{g}{ }^{+} \leftrightarrow \Sigma_{u}{ }^{+}$の電子遷移に付随する回転構造の選択則は,

$$
\Delta j= \pm 1
$$

である.（この選択則は水素原子における選択則 $\Delta j= \pm 1$ を思い出せば，容易に理解出 来よう.）すなわち, $\Sigma_{\mathrm{g}}{ }^{+}$の $j$ という回転状態と, $\Sigma_{\mathrm{u}}{ }^{+}$の $j+1$ または $j-1$ という回転状 態との間の遷移だけが許容となる.

ところで, Hori の実験によると, 基底状態で偶数の $j$ が関与するスペクトルの系列 は，同じく基底状態で奇数の $j$ が関与するスペクトルの系列よりもずっと弱い．だい たい強度比は，1 対 3 ということであった。（図 15.1.5)

Hori はこの実験結果とその解析を

Über die Analyse des Wasserstoffbandenspectrums im aussersten Ultraviolett という題で，Z. Physik 44, 834 (1927) に発表しているが，この論文をまとめていた時 に, アメリカの Michigan 大学から来た Dennison という人にその原稿を見せた.

Dennison は Hori のスペクトルを見て, 上述したモル熱容量の異常な温度変化の問 題を解決してしまったのである。そしてそのことはまさしく, protonがスピンを持っ ていること,そして proton は Fermi 粒子である, ということを示していたわけである. そのことは次の Section で述べよう.

かくして電子スピンの発見の 1925 年から 2 年遅れた 1927 年に, proton の核スピン の存在が実験的に証明されたのである. 


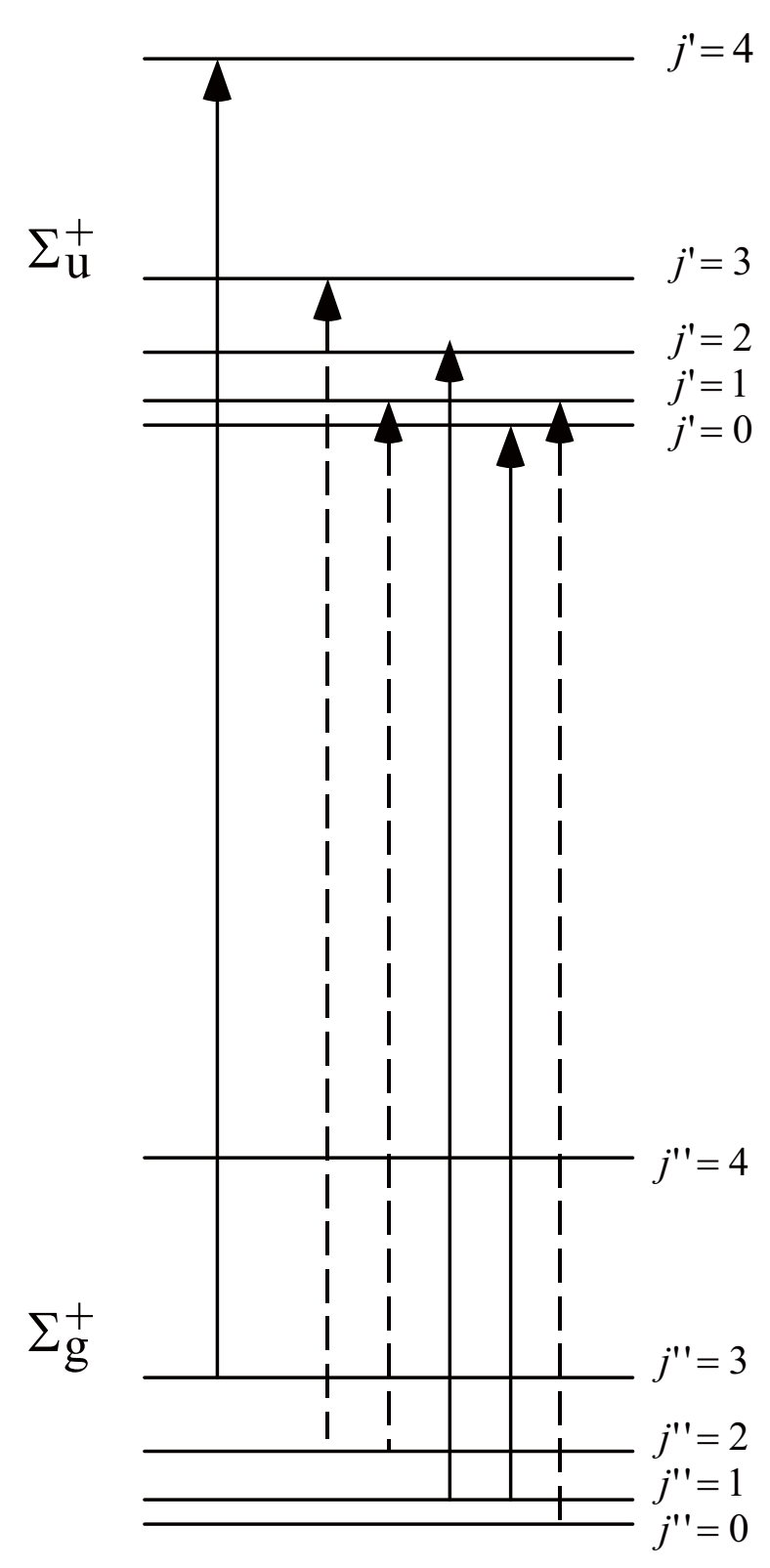

図 15.1.5 Hori の解析した $\mathrm{H}_{2}$ のバンドスペクトルの回転構造の模式図.

図では振動の準位は省略してある. 直線で示した遷移が点線で示した遷移の約 3 倍の強度で観測された. 2 つの電子状態間の energy 差は約 $1000 \mathrm{~cm}^{-1}$. 回転状態 $j^{\prime \prime}=0$ と $j^{\prime \prime}=1$ との間は約 $60 \mathrm{~cm}^{-1}$. ここでは電子基底状態における回転量子数を $j^{\prime \prime}$ ，励起状態におけるそれを $j^{\prime}$ で示している. 
[Coffee Break] 赤い波動関数?

回転は英語で"rotation"，ドイツ語で"Rotation"，どこの国の言葉でも回転の波動関 数は $\psi_{\mathrm{rot}}$, その energy は $E_{\mathrm{rot}}$, 回転による熱容量は $\left(C_{\mathrm{v}}\right)_{\mathrm{rot}}$ のように表す。ドイツ語の 論文の抄録で， $\psi_{\text {rot }}$ や $E_{\text {rot }}$ などの記号を，赤い wavefunction，赤い energy と訳している 場合があった，確かにドイツ語で rot は英語の red に相当するが，科学論文などでは， こういう間違いを犯したくないものだ。

\section{2 核スピンの影響一オルソ水素とパラ水素}

Dennison は $\mathrm{H}_{2}$ の熱容量の温度変化および Hori の見出した遠赤外線領域のスペク

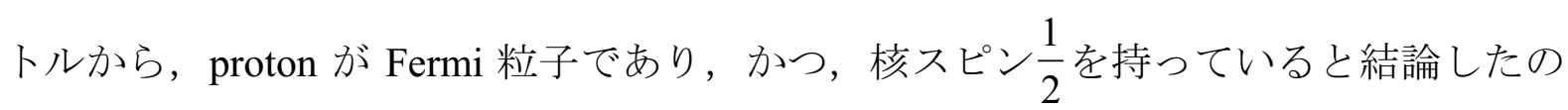
であるが，話が多少ややこしくなるので，ここではこの結論を先取りして，その帰着 するところを考えてみよう。

すなわち， $\mathrm{H}_{2}$ 分子を構成する proton は核スピン $\frac{1}{2}$ を持ち，かつ Fermi 粒子である という前提にたって話を進める。

$\mathrm{H}_{2}$ 分子を性格づける全波動関数は, 電子状態の波動関数 $\psi_{\mathrm{elec}}$, 振動の波動関数 $\psi_{\mathrm{vib}}$, 回転の波動関数 $\psi_{\text {rot }}$ の他に，核スピンの波動関数 $\psi_{\text {nucl spin }}$ の積で表される.

$$
\psi=\psi_{\text {elec }} \psi_{\text {vib }} \psi_{\text {rot }} \psi_{\text {nucl spin }}
$$

proton は, Fermi 粒子である.すなわち, 2 つの protonの交換によって全波動関数 $\psi$ は, 符号を変えなくてはいけない。（antisymmetric でなければいけない.）このことを調べ るために, 式(15.2.1)の右辺を構成している4つの波動関数のそれぞれについて吟味し てみよう。

まず，電子状態の波動関数 $\psi_{\text {elec }}$ について考えよう. $\mathrm{H}_{2}$ 分子は点群 $\mathrm{D}_{\infty \mathrm{h}}$ に属する. 群論については chapter 17 で学習するので，それまではあまり完全には理解出来ない 
かもしれないが，簡単に essence を述べておこう．基底状態はこの点群の既約表現 $\Sigma_{g}{ }^{+}$ に，今問題としている電子励起状態は $\Sigma_{u}{ }^{+}$に属する． $\mathrm{D}_{\infty \mathrm{h}}$ の指標表（例えば Eyring, Walter, Kimball, page 205）の必要な所だけを表 15.2.1に載せておく.

表 15.2.1 $\mathrm{D}_{\infty \mathrm{h}}$ の指標表の一部

\begin{tabular}{|c|cccccc|}
\hline & $E$ & $2 C_{\phi}$ & $\sigma_{v}$ & $i$ & $2 S_{\phi}$ & $C_{2}$ \\
\hline$\Sigma_{g}^{+}$ & 1 & 1 & 1 & 1 & 1 & 1 \\
$\Sigma_{u}^{+}$ & 1 & 1 & -1 & -1 & -1 & -1 \\
\hline
\end{tabular}

$\mathrm{D}_{\infty \mathrm{h}}$ の対称操作のうち，2つの proton の交換に相当するのは $\sigma_{v}$ および $C_{2}$ である.

表から分かるように, 基底状態 $\Sigma_{g}{ }^{+}$は, これらの対称操作，すなわち $2 つ の$ proton の 交換に対して symmetric，励起状態 $\Sigma_{u}{ }^{+}$は antisymmetric である.

次に振動の波動関数 $\psi_{\mathrm{vib}}$ を考えよう. 振動の波動関数は, その振動量子数にかかわ らず，2 つの核の間の距離だけの関数である. 従って, 核の交換については当然 symmetric である.

次に回転の波動関数 $\psi_{\mathrm{rot}}$ を考えよう。 $\psi_{\mathrm{rot}}$ は量子数 $j$ と $m$ によって性格づけられ， 次式で与えられる.

$$
\psi_{\text {rot }}=Y_{j, m}(\theta, \phi) \quad m=j, j-1, \ldots,-j
$$

式(15.2.2)において，2つの proton を交換することは $\theta$ を $\pi-\theta$ に，かつ $\phi$ を $\pi+\phi に$ 置き換えることに相当する. ここで,

$$
Y_{j, m}(\pi-\theta, \pi+\phi)=(-1)^{j} Y_{j, m}(\theta, \phi)
$$




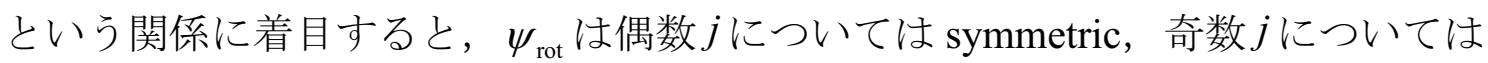
antisymmetric ということが分かる.（このことは水素原子の波動関数について $j=0$ の $s$ 軌道， $j=2$ の $d$ 軌道が symmetric であり， $j=1$ の $p$ 軌道， $j=3$ の $f$ 軌道が antisymmetric であることを思い起こせば容易に理解出来よう.)

最後に $\psi_{\text {nucl spin }}$ について考えてみよう.1 個の protonの核スピンを電子スピンの場合 と同様に(ただし核スピンという事がはっきりするように subscript の $\mathrm{N}$ をけて) $\alpha_{\mathrm{N}}$ ， $\beta_{\mathrm{N}}$ とする. 2 つの電子スピンについて Section 14.5 で式(14.5.18), 式(14.5.19)を導いた

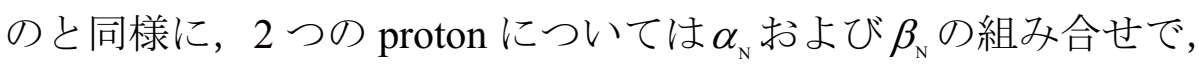
$\sqrt{\frac{1}{2}}\left\{\alpha_{\mathrm{N}}(1) \beta_{\mathrm{N}}(2)-\beta_{\mathrm{N}}(1) \alpha_{\mathrm{N}}(2)\right\}$ が singlet, $\quad \alpha_{\mathrm{N}}(1) \alpha_{\mathrm{N}}(2), \quad \sqrt{\frac{1}{2}}\left\{\alpha_{\mathrm{N}}(1) \beta_{\mathrm{N}}(2)+\beta_{\mathrm{N}}(1) \alpha_{\mathrm{N}}(2)\right\}$, $\beta_{\mathrm{N}}(1) \beta_{\mathrm{N}}(2)$ のつの spin function が triplet として得られる. 直ちに分かるように, 2 つの protonの交換に対して singlet は antisymmetric, triplet は symmetric である.

以上吟味したように，式(15.2.1)の右辺を構成する 4 つの波動関数は，振動量子数 によらず必ず symmetric である $\psi_{\mathrm{vib}}$ を除いてはいずれも，それぞれの量子数によって， protonの交換に対して symmetric になったり， antisymmetric になったりする. それを 表 15.2.2 にまとめておく.

表 15.2.2 2つの protonの交換に関する対称性

wavefunction

$$
\begin{gathered}
\psi_{\text {elec }} \\
\psi_{\text {rot }} \\
\psi_{\text {nucl spin }}
\end{gathered}
$$

symmetric

$\Sigma_{g}^{+}$

even $j$

triplet antisymmetric

$$
\Sigma_{\mathrm{u}}^{+}
$$

odd $j$

singlet 
全波動関数 $\psi$ が $2 つ の$ protonの交換に対して antisymmetric でなければいけないと いうことから $\psi_{\text {elec }}, \psi_{\text {rot }}, \psi_{\text {nucl spin }}$ の組み合せは, 次のような場合のみが許される。

（a）全核スピンが 0, すなわち singlet の場合

基底状態 $\Sigma_{g}{ }^{+}$では, 偶数 $j$ の $\psi_{\text {rot }}$

励起状態 $\Sigma_{u}+$ では, 奇数 $j の \psi_{\text {rot }}$

（b）全核スピンが 1, すなわち triplet の場合

基底状態 $\Sigma_{g}^{+}$では, 奇数 $j$ の $\psi_{\text {rot }}$

励起状態 $\Sigma_{u}^{+}$では, 偶数 $j$ の $\psi_{\text {rot }}$

この結果は実に重要である。我々は，量子論に従って，回転の量子数 $j$ は，0，1，2， $3 ， \ldots$... 1 つおきに変化すると考えて来た。（例えば式(15.1.8)）しかし，基底状態のこ

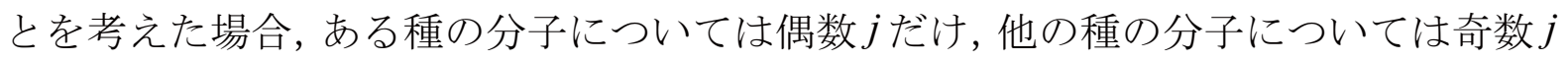
だけしか許されないのである。すなわち， $\mathrm{H}_{2}$ 分子には 2 種類があることになる.上 述（a）の全核スピンが 0 のものを，パラ水素（para hydrogen），(b）の全核スピンが 1 のものを，オルソ水素（ortho hydrogen）という言葉で表す.

前節で $\mathrm{H}_{2}$ の回転によるモル熱容量を計算した時は， $\mathrm{H}_{2}$ に 2 種類あることは考え ていなかったわけである.そこで ortho- $\mathrm{H}_{2}$ と para- $\mathrm{H}_{2}$ とが 2 種類混在しているという モデルで $C_{\mathrm{v}}$ を計算してみよう。

partition function を計算するに当り，jに関する多重度 $2 j+1$ の他に，核スピンに関 する多重度 [para（すなわち singlet）で1, ortho（すなわち triplet）で3]をも考慮し なければいけない，そこで我々は，式(15.1.8)の代りに式(15.2.4)を得る.

$$
\begin{aligned}
&(p . f .)_{\mathrm{rot}}= \sum_{j=0,2,4, \ldots}(2 j+1) \exp \left\{-\frac{j(j+1) \theta_{\mathrm{rot}}}{T}\right\} \\
&+3 \sum_{j=1,3,5, \ldots}(2 j+1) \exp \left\{-\frac{j(j+1) \theta_{\text {rot }}}{T}\right\}
\end{aligned}
$$

Dennison は Hori がスペクトルの解析から求めた慣性能率 $I$ を用いて, 式(15.2.4)を 計算してみた。式(15.2.4)に基づいた計算值は図 15.2.1の"equilibrium"と記した曲線の ようになった。図 15.2.1 には，比較のため，更に，式(15.1.8)に基づく計算值（"naive" と記している）および図 15.1.3 に示した「実験值」（"experimental"と記している）を 


\section{$\operatorname{Cv}(\operatorname{rot}) / R$}

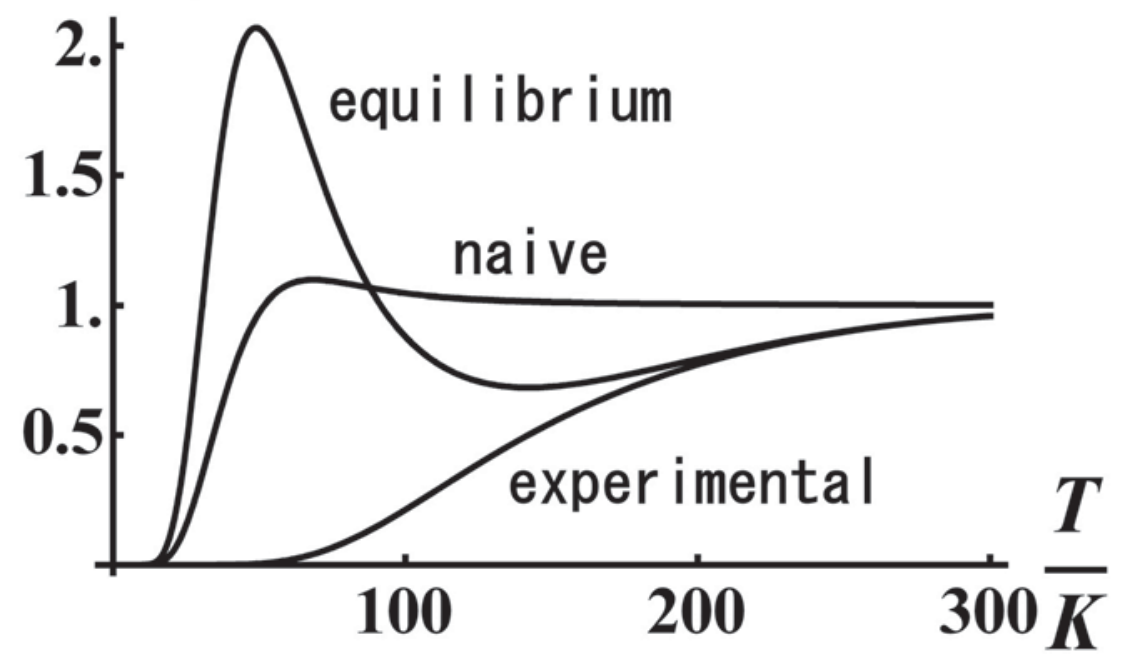

図 15.2.1 $\mathrm{H}_{2}$ の定容モル熱容量の温度変化一計算值と実験值との比較 （"naive"は式(15.1.8)の partition function に基づいて計算したもの， "equilibrium"は式(15.2.4)の partition function に基づいて計算したもの， "experimental"は図 15.1.3に示した「実験值」で，図 15.1.1の測定值から 並進の寄与と振動の寄与を差し引いたもの.

図 15.2.1 から明らかなように，実験值からのずれは以前にもましていっそう悪く なってしまった。しかし，解決は意外に近いところにあったわけである．Dennisonの 解決を述べる前に，式(15.2.4)の由来をもう少し考えてみよう.

式(15.2.4)は ortho- $\mathrm{H}_{2}$ と para- $\mathrm{H}_{2}$ とがあらゆる温度で熱平衡にあるという考えに基づ いている.この 2 種類の $\mathrm{H}_{2}$ がどの位の割合で存在するかは相当する partition function の比で与えられる.

$$
\frac{\left[\mathrm{o}-\mathrm{H}_{2}\right]}{\left[\mathrm{p}-\mathrm{H}_{2}\right]}=\frac{3 \sum_{j, \text { odd }}(2 \mathrm{j}+1) \exp \left\{-\frac{j(j+1) \theta_{\mathrm{rot}}}{T}\right\}}{\sum_{j, \text { even }}(2 \mathrm{j}+1) \exp \left\{-\frac{j(j+1) \theta_{\mathrm{rot}}}{T}\right\}}
$$


この式の示すように, $\mathrm{o}-\mathrm{H}_{2}$ と $\mathrm{p}-\mathrm{H}_{2}$ の割合は, 温度の関数である.計算の結果を図 15.2.2 に示寸.

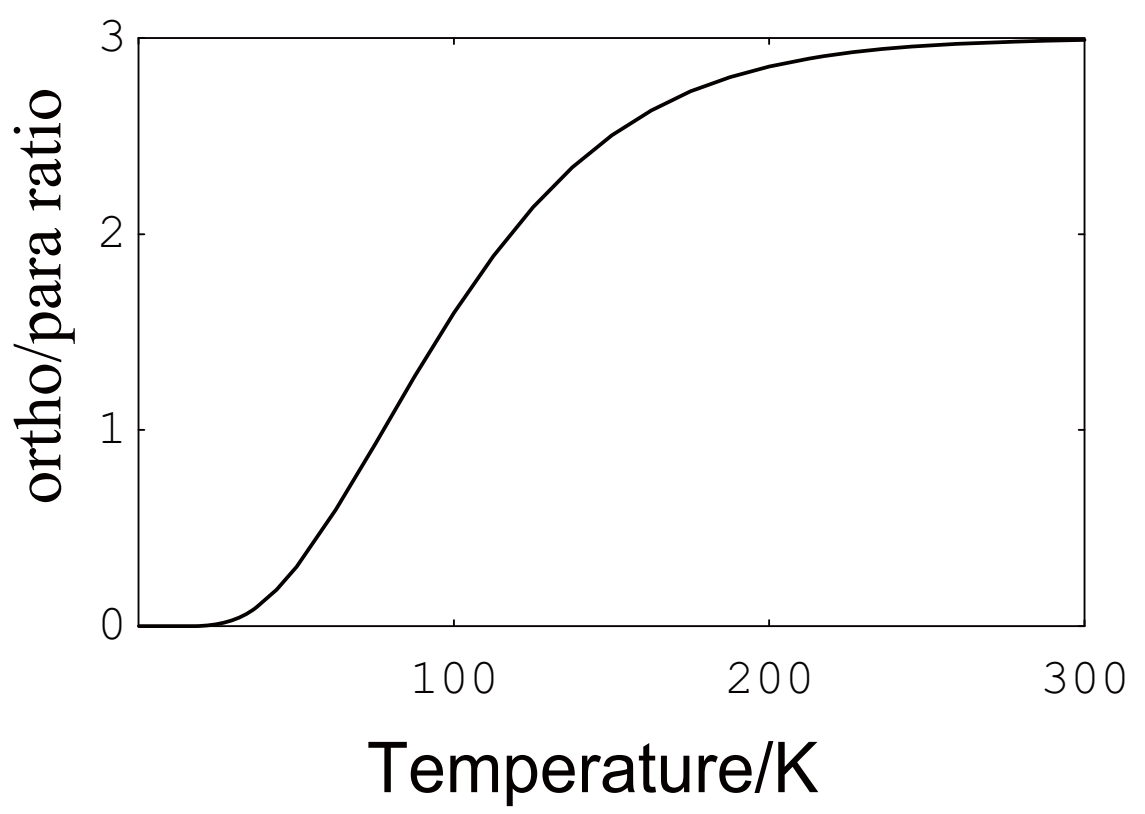

図 15.2.2 o- $\mathrm{H}_{2}$ と $\mathrm{p}-\mathrm{H}_{2}$ の分子数の比 -2 種類の $\mathrm{H}_{2}$ が熱平衡にある場合

図 15.2.2 が示すように, 常温では, ほとんど 3 対 1 の比になっている. Hori の実験 で $\Sigma_{g}{ }^{+}$の奇数 $j$ を含む遷移が $\Sigma_{g}{ }^{+}$の偶数 $j$ を含む遷移の 3 倍の強度で得られたという事 実はまさしくこのことを示しているのである.

念のために, 図 15.1.5 を ortho- $\mathrm{H}_{2}$ と para- $\mathrm{H}_{2}$ に分けて図 15.2.3 に示寸. Hori のスペ クトルは，図15.2.3に示された 2 つの種類の $\mathrm{H}_{2}$ が 3 対 1 の割合で混合していたもの として満足に説明されたのである. 


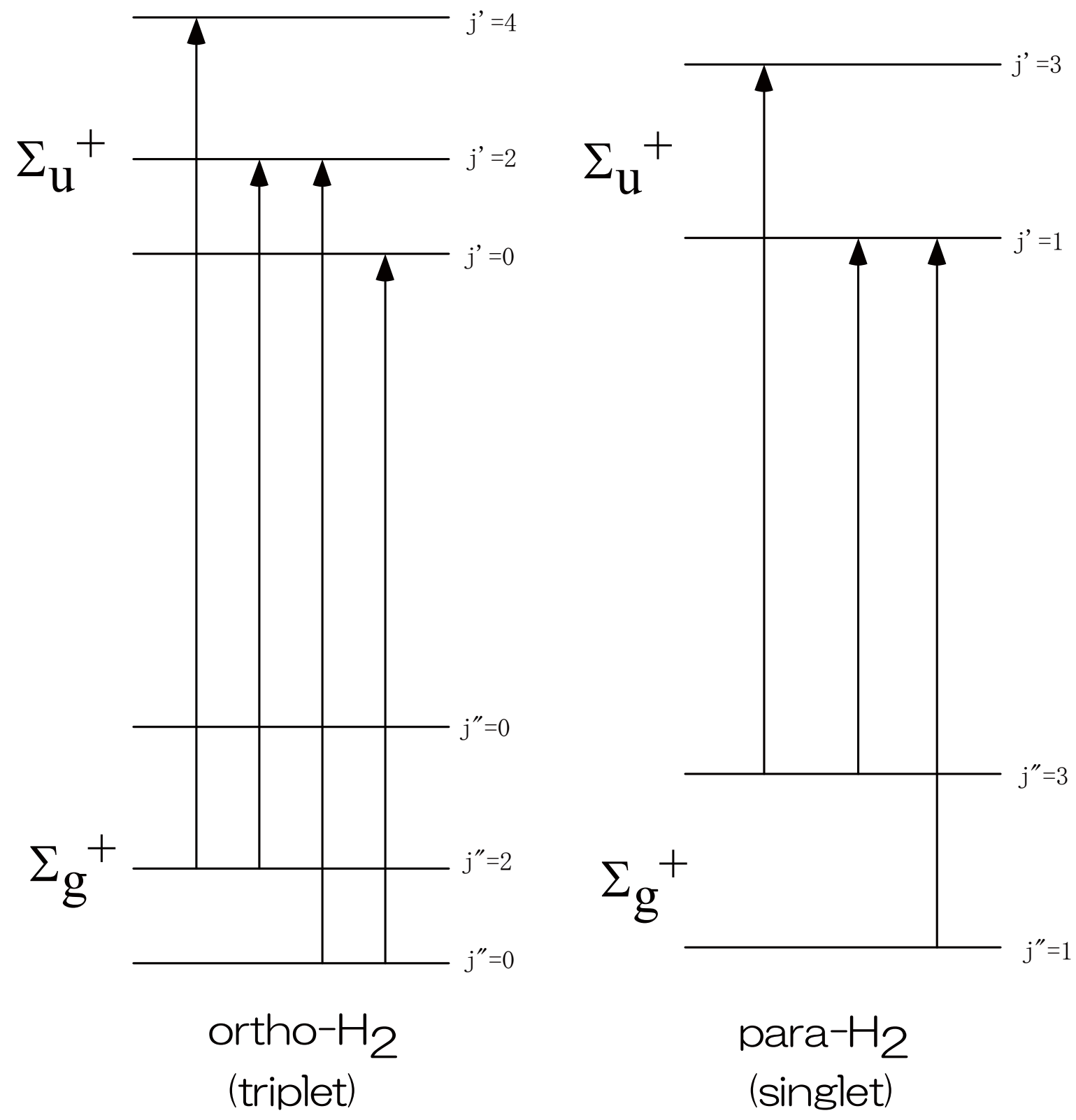

図 15.2.3 o- $\mathrm{H}_{2}$ と $\mathrm{p}-\mathrm{H}_{2}$ の遠紫外スペクトルの回転構造.

$300 \mathrm{~K}$ では o- $\mathrm{H}_{2}$ が p- $\mathrm{H}_{2}$ の 3 倍存在する

ところで, Dennison は熱容量のことをどうやって解決したのだろうか. Dennison はこう考えた。 o- $\mathrm{H}_{2}$ と $\mathrm{p}-\mathrm{H}_{2}$ の間の変換には非常に時間がかかるのではなかろうか. それで常温に長いことおいてあった $\mathrm{H}_{2}$ (それは ortho- $\mathrm{H}_{2}$ と para- $\mathrm{H}_{2}$ の 1 対 3 の割の 
混合物）を極低温に泠却しても熱容量を測定する時間のスケールでは相変わらず $\frac{\left.\text { [ortho } \mathrm{H}_{2}\right]}{\left[\text { para } \mathrm{H}_{2}\right]}$ の比は 3 のままに保たれているのではなかろうか. このように考えると，

ortho- $\mathrm{H}_{2}$ と para- $\mathrm{H}_{2}$ の混合物についてのみかけのモル熱容量は, それぞれの成分のモ 儿熱容量の重みをつけた平均値となる。すなわち,

$$
\left(C_{\mathrm{v}}\right)_{\text {rot }}=\frac{3}{4}\left(C_{\mathrm{v}}\right)_{\text {rot, ortho }}+\frac{1}{4}\left(C_{\mathrm{v}}\right)_{\text {rot, para }}
$$

ここで， $\left(C_{\mathrm{v}}\right)_{\text {rot, ortho }}$ および $\left(C_{\mathrm{v}}\right)_{\mathrm{rot}, \text { para }}$ はそれぞれの partition function

$$
\begin{aligned}
& (p . f .)_{\mathrm{rot}, \text { ortho }}=3 \sum_{j=1,3,5, \ldots . .}(2 j+1) \exp \left\{-\frac{j(j+1) \theta_{\mathrm{rot}}}{T}\right\} \\
& (p . f .)_{\mathrm{rot}, \text { para }}=\sum_{j=0,2,4, \ldots}(2 j+1) \exp \left\{-\frac{j(j+1) \theta_{\mathrm{rot}}}{T}\right\}
\end{aligned}
$$

を式(15.1.10)に従って温度に関して 2 回微分することによって得られる. 念のため書 き下す.

$$
\begin{aligned}
& \left(C_{\mathrm{v}}\right)_{\text {rot, ortho }}=\frac{\partial}{\partial T}\left[R T^{2} \frac{\partial}{\partial T} \ln (p . f .)_{\text {rot, ortho }}\right] \\
& \left(C_{\mathrm{v}}\right)_{\text {rot, para }}=\frac{\partial}{\partial T}\left[R T^{2} \frac{\partial}{\partial T} \ln (p . f .)_{\text {rot, para }}\right]
\end{aligned}
$$

式(15.2.9)および式(15.2.10)に基づいて計算した純粋な ortho- $\mathrm{H}_{2}$ および para- $\mathrm{H}_{2}$ の熱 容量, およびそれらを 3 対 1 の重みをつけて平均したもの（それは通常, "normal- $\mathrm{H}_{2}$ " と呼ばれる）を図 15.2 .4 に示す. 


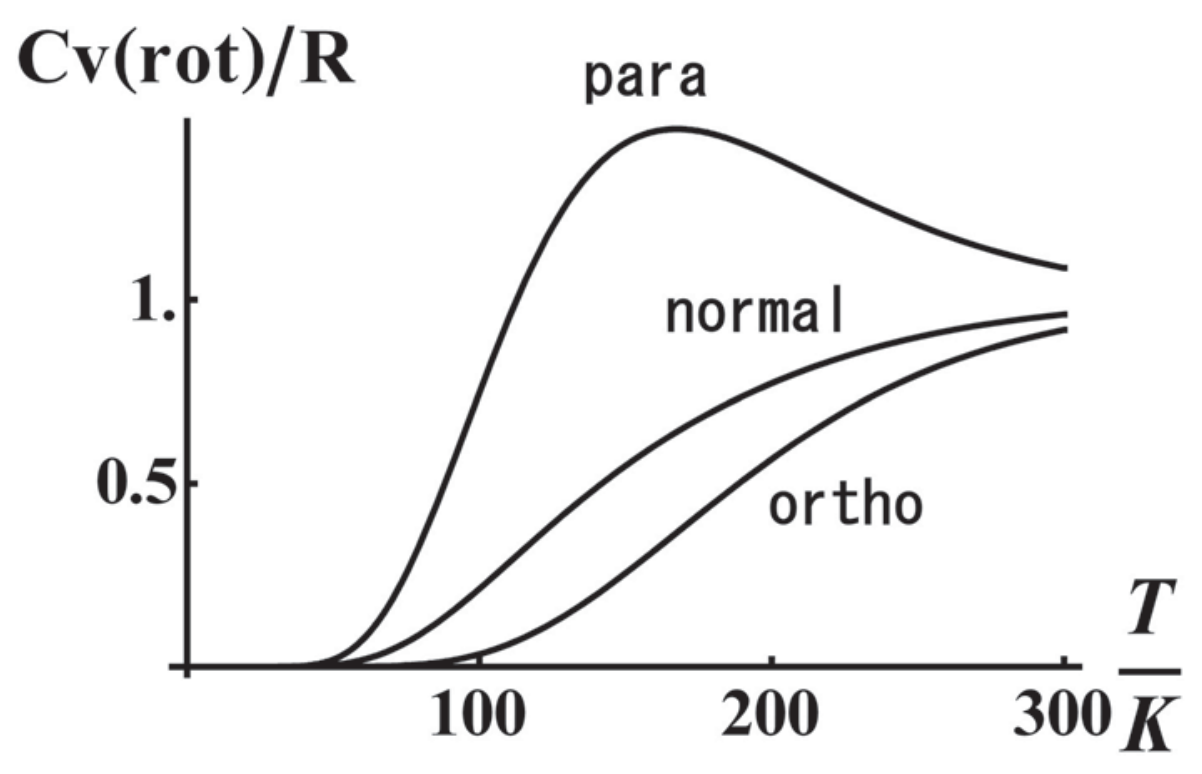

図 15.2.4 $\mathrm{H}_{2}$ の $\left(C_{v}\right)_{r o t}$ の温度変化の理論曲線

"ortho"は o-H $\mathrm{H}_{2}$, "para"は para-H $\mathrm{H}_{2}$, "normal"は o- $\mathrm{H}_{2}$, p- $\mathrm{H}_{2}$ が 3 対 1 の割合で混ざ っているもの. 式(15.2.7)，式(15.2.8)および式(15.2.6)を用いて計算

式(15.2.6)の計算值（すなわち，図 15.2.4 で"normal"と記した曲線）は，実験で得ら れた温度変化を見事に再現した。この一致は Dennison の考えが正しかったことを示

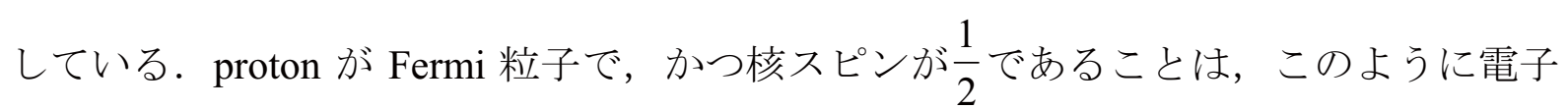
スペクトルと熱容量と両方の立場から実験的に証明された。

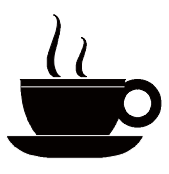

[Coffee Break] Dennison の論文の” Added on Proof"

Dennison の論文は，Proc. Roy. Soc. (London) 115, 483 (1927)に出ているが，題目は"A Note on the Specific Heat of the Hydrogen Molecule"であり，編集委員会が論文を受理し た日として Received June 3, 1927 と記してある．核スピンの発見に相当するこの重大 な論文というのに何と地味な題なのだろうと驚きを感じる．ただ，この論文を書き上 
げた時点では，Dennison は自分の重要な発見に気が付いていなかったように思える. 論文が受理された 1927 年 6 月 3 日から 2 週間の間に Dennison は自分の仕事の重要性 に気がついたようである，というのはこの論文の一番後に追加として次のような文か ら始まる短い文が載っている。

Added June 16, 1927 - It may be pointed out that the ratio of 3 to 1 of the antisymmetrical and symmetrical modifications of hydrogen, as regards the rotation of the molecule, is just what is to be expected from a consideration of the equilibrium at ordinary temperatures if the nuclear spin is taken equal to that of the electron, and only the complete antisymmetrical solution of the Schrödinger wave equation allowed.

この「付け足し」の所で, Dennison は自分の研究は protonの核スピンが電子と同じく $\frac{1}{2}$ であること，および proton が Fermi 粒子である（すなわち，完全反対称）ことを示

していると述べている。この「added...」は，始めの論文から 2 週間後に書いたもので， まだ論文が活字になっていたとは考えられない.だからその気になれば，題の方もも う少し内容を表すもの，例えば「核スピンの存在の実験的証明」といったようなもの に変えられたのではなからうかと私は思うのだが。

なお，この論文の末尾に，Dennison は

I wish to express my thanks to Mr. R. H. Fowler for much helpful criticism and

Prof. T. Hori for the opportunity of seeing the results of his work before their publication.

というふうに Hori に対する謝辞を述べている。このような重要な発見に，日本人が 関与していたということは，実に嬉しいことである. Hori といっしょに謝辞が述べら れているのは, 私が Louisiana State University の大学院学生時代に受けた統計力学の講 義で用いた教科書である Fowler and Guggenheim の Statistical Thermodynamics の著者の 一人であるが，この偉大な著者が Mr. Fowler で，堀健夫先生が Professor Hori という 称号で書かれていることはなんとも考え深い.

[Coffee Break ] Dennison に関する逸話 : $\mathrm{SiO}_{2}$ は気体?

Dennison は上述のように核スピンの存在に関する非常に重大な研究をやったこと でよく知られているが，その他，分子の構造の分野でも多くの優れた功績を残してい る。例えば気体における回転スペクトルから $\mathrm{CO}_{2}$ 分子が直線型であることを始めて 
みつけたのは Dennison である。この発見については 1 つのエピソードが残っている. $\mathrm{CO}_{2}$ の気体で分子が直線であることを見出した彼は，非常に興奮し，同族の $\mathrm{SiO}_{2}$ も 直線ではなからうかと考えた。そこで彼は，助手に言ったという。「君，急いでこの フラスコに $\mathrm{SiO}_{2}$ の気体をつめて来てくれ」と.

\section{【補足】:}

$\mathrm{H}_{2}$ 分子の nuclear spin が singlet のものが"para", triplet のものが"ortho"である.どっ ちがどっちだか，こんがらかってしまいそうである。一般には nuclear spin degeneracy の大きい方（すなわち，高温で多く存在する方）が ortho, nuclear spin degeneracy の小 さい方が paraである。"ortho"は"orthodox"から，"para"は"paradox"から来たらしい。多 重度が大きいとどうしてオーソドックスなのか, などとあまり複雑に考えないで覚え てしまえばよかろう。

ortho- $\mathrm{H}_{2}$, para-H 2 と似ていて, 紛らわしい言葉に, ortho-He, para-Heがある。そ れは $\mathrm{He}$ 原子の電子スピンの問題で, $\mathrm{H}_{2}$ 分子の核スピンの問題と混乱しないようにし てほしい. He の電子スピンの singlet は para, triplet は orthoである。一般に電子スピ ン多重度の異なる状態間の遷移は禁制であるが，スピン軌道相互作用により，多少許 される，学生実験で測定した粼光がその一例である。しかし，He 原子ではこのスピ ン軌道相互作用が極端に小さく（スピン軌道相互作用は原子番号の大きい原子に顕著 であるという一般則がある.), 従って一重項状態と三重項状態とはあたかも異なった 物質のようにみえるのである。 そういう事で, ortho-He, para-He という言葉がついた ものと思われる。

\section{¿ Problem 15.2.1}

上の議論では, proton が Fermi 粒子であるという結論を先取りして熱容量 $\left(C_{\mathrm{v}}\right)_{\mathrm{rot}}$ の 温度変化の理論的計算が実験結果を再現することを示した. しかし, Bose 粒子と考え て計算すると，実験結果とは全然異ることを示さないと不完全である.

ここでは仮に proton が Bose 粒子であると仮定して電子基底状態 $\Sigma_{g}{ }^{+}$における

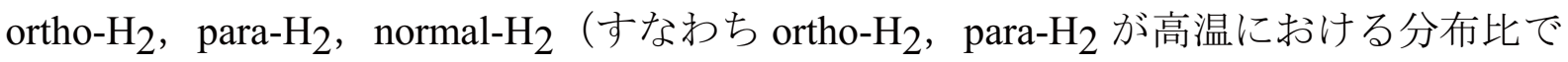
混じり合ったもの）についての $\left(C_{\mathrm{v}}\right)_{\mathrm{rot}}$ の温度変化の理論曲線を描いてみよ. ortho- $\mathrm{H}_{2}$, para-H 2 は上で定義したようにそれぞれ nuclear spin triplet, nuclear spin singlet に相当 する.

全て自分で計算するのが望ましいが computer を用いないとちょっと大変である. 
手を抜きたい場合には，図 15.2.4の Fermi 粒子としての計算結果をグラフから読み取 り，計算すると楽であろう。次のような順序で考えてみよ.

1) triplet spin (ortho), singlet spin（para）のそれぞれについて許される回転量子 数 $j$ はどのように制限されるか.

2) ortho- $\mathrm{H}_{2}$, para- $\mathrm{H}_{2}$ それぞれについて partition function の式を求め Fermi 粒子と しての式(15.2.7), 式(15.2.8)と比べてみよ.

3) 以上のことから図 15.2.4を用いてBose粒子としての理論曲線を求める方法を 考えて実行せよ。結果は図 15.2.4 と同じ目盛の間隔でグラフ用紙にプロット すること．

[Coffee Break] 熱容量と比熱

この節で用いた「熱容量 (heat capacity)」という言葉は昔「比熱（specific heat）」 という言葉で言われたものと深く関係している，その昔使われた「比熱」という言葉 は水の熱容量との比を表し，単位のない物理量であった．最近は（とはいっても数十 年前から）「比熱」という言葉は使ってはいけないことになっているが，それでもこ の間違った言葉が今なお人口に膾多している.

現在では「比 (specific)」という接頭語は「単位質量当り」という意味に用いるこ とに決まっている，例えば比容（specific volume）は単位質量当りの体積のことで $\frac{\mathrm{m}^{3}}{\mathrm{~kg}}$ という単位を持つことになる。もし，仮に比熱というものがあったとすれば，それは 「単位質量当りの熱」という何のことかよく分からないものを指すことになろう.

なお，「比熱容量」（specific heat capacity）という言葉はちやんと定義されている. これは「単位質量当りの熱容量」で $\frac{\mathrm{J}}{\mathrm{K} \cdot \mathrm{kg}}$ という単位を持つことになる。これがその 昔比熱といわれたものを 1000 倍し上記の単位をつけたものである.この節で問題と したモル熱容量は「モル当りの熱容量」で $\frac{\mathrm{J}}{\mathrm{K} \cdot \mathrm{mol}}$ という単位を持つ。言うまでもな いことであるが比熱容量とモル熱容量とは分子量によって関係づけられる。

念のため注意をしておくと, 熱容量は $\frac{\mathrm{J}}{\mathrm{K}}$ という単位をもち, 当然物質の量に依存す る物理量である。化学の分野では 1 モル当りの熱容量を考えることが多い. 単位は $\frac{\mathrm{J}}{\mathrm{K} \cdot \mathrm{mol}}$ で，モル熱容量（molar heat capacity）と呼ばれるが，このモルという接頭語が 
しばしば省略される場合があるので注意する必要がある.

[Coffee Break] 核スピンの発見に重大な役割を果たした Hori

核スピンの発見に深く関係した堀健夫という方は, どういう科学者であったのだろ うか. 伝え聞くところによると, 北海道大学の物理学教室で停年を迎えられたとのこ とである. Bohrの研究室から帰られてから, 日本でどのような研究をされたのだろう か，そのうちに調べてみたいと思っているが，まだチャンスがない.

湯川秀樹博士が「旅人」という本（朝日新聞社刊，昭和 33 年）で自伝を書いてい るが，この本の 201 頁に，湯川博士の旧制三高時代の思い出として次のような文が出 ている.

『三年生になると，学校でも力学を習うことになった．先生は堀健夫博士 であった. 堀先生は分光学の優れた研究者であった. 分光学というのは, 原子や分子から出て来る光のスペクトルを分析して, それから原子や分子 の構造を明らかにしようという学問である. 前期量子論の発展の裏には, スペクトル分析の進歩があった. 今日, 原子核物理学が花形であるように, 当時は分光学が花形であった. 堀先生の力学には新進の学者にふさわしい 活気があった.』

湯川博士が三高の 3 年生であったのは，年表をくくってみると，大正 14 年 $(1925$ 年）のことのようである.この時, 堀先生は三高の先生であったことになる. Dennison の論文も堀先生の論文も共に 1927 年に印刷されているから, 上記の文は, 留学直前 の堀先生のことらしい. 新進の学者にふさわしい活気があった講義 — どういう講義 だったんだろうな，と考えると楽しくなる.

また, 朝永振一郎博士著の「わが師わが友」にも堀博士の話が出て来る. 朝永博士 が高等学校 3 年生の時, 力学を学習したいというところで次のように述心゙られている.

『その力学の先生は，そのときちょうど京都大学の物理科を出たての堀健 夫先生であった。この先生は実験家であったが, 力学の教えかたはなかな かあざやかで, 講義などはいっさいやらず，それは学生の自習にまかせ， 教室では練習問題を解かせるばかりという斬新な方法であった。この先生 は分光学が専門であったので, 新しい量子力学にも関心があり, それに関 することがらをこの先生の口を通じていろいろと聞くことが出来た，電子 が波動であるという考えがあるということ，またマトリックスカ学という， とてつもない新しい理論があるということ, それから, いま日本の大学で やっている物理などは，もはや古くさくてだめだというようなことがこの 
若い先生の言葉からうかがわれた.』

2 人のノーベル物理学賞受賞者から，これほどの賛辞を受けているのであるから， 堀先生の講義というのはよっぽどすばらしかったのだろう。そんな講義を聴いてみた いし，又，自分でもやってみたいものだ.

これほどの功績をあげた先生のことであるから, 北海道大学に行けば当然堀先生の 資料があると思って，理学部などを訪問してみたが，写真 1 枚すら見つけることが出 来なかった。学問の進歩の著しい昨今, いつまでも昔の大教授のことを思い出すのも 問題かもしれないが，功績は残してほしいものだと思う.

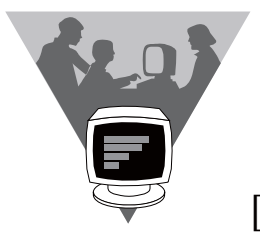

[Let's play with Mathematica] 微分計算がこんなにも簡単に

図 15.2.4 に示したような理論曲線を求めることは難しくはないがけっこう面倒な ものである.まず式(15.2.7)と式(15.2.8)により partition function を温度の関数として表 す（回転の量子数 $j に$ 関する和は無限大まで取ることは勿論出来ないが, exponential の項のために急激に小さくなるから，そう多くの項を足しあわせる必要はなく，この ことについてはなんの問題もない.）この partition function を式(15.1.10)に従って 2 回

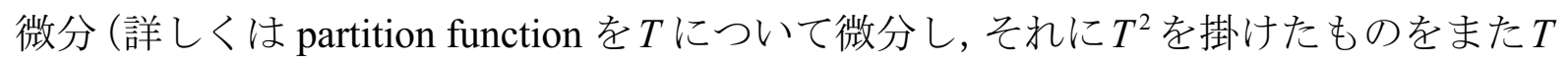
について微分）し，その後でいろいろな温度について数值計算するだけである.

Dennison は computer がない時代にそのような計算をしたわけでここにもなんの難し さもない. しかし，計算をやることを問題として出すと多くの学生は大変苦労するよ うである. 数值計算のプログラムが作れない場合もあるが，微分で間違う場合が非常 に多い，なんともなさけない話であるが，それが悲しい現実である，とはいっても， 数值計算をすることは全くあきらめることは出来ない. 数值計算を実際にやってみて 化学に対する理解が深まるからである. とすると, もっと簡単に数值計算が出来るツ ールを使いこなすことが必要となる。

Mathematica では実に簡単である，以下のようにすればよい.

theta: $=85$;

$g\left[j_{-}, T_{-}\right]:=(2 j+1) \operatorname{Exp}[-j(j+1)$ theta/T];

pfo=3 Sum $[\mathrm{g}[\mathrm{j}, \mathrm{T}],\{\mathrm{j}, 1,9,2\}]$;

$\mathrm{pfp}=\operatorname{Sum}[\mathrm{g}[\mathrm{j}, \mathrm{T}],\{\mathrm{j}, 0,10,2\}]$;

$c v o=D\left[T^{\wedge} 2\right.$ D[Log[pfo],T],T];

cvp $=\mathrm{D}\left[\mathrm{T}^{\wedge} 2 \mathrm{D}[\log [\mathrm{pfp}], \mathrm{T}], \mathrm{T}\right]$;

Lecture Note on Quantum Chemistry by T. Azumi

Chapter 15, Page 25 
$\mathrm{cv}=0.75 \mathrm{cvo}+0.25 \mathrm{cvp}$;

Plot $[\mathrm{cv},\{\mathrm{T}, 0.1,300\}$, PlotRange- $>\{\{0,300\},\{0,1\}\}]$

1 行目は式(15.1.9)で定義した特性温度で，水素分子では $85 \mathrm{~K}$ である. 2 行目は Boltzmann 因子の定義である. 3 行目と 4 行目で orthoおよび para の partition function を定義している．回転の量子数 $j$ につては偶数については $j=10$ まで，奇数につい ては $j=9$ までの和をとっている，その下の 2 行（5 行目および 6 行目）で式(15.2.7)

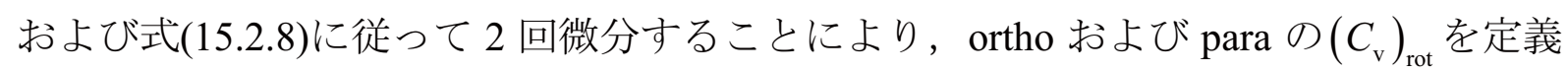
している. D という微分演算子を用いて定義するだけである. 7 行目は式(15.2.6)の平 均值である.そして最後の行でプロットの命令を与えている.（温度については $T=0$ で式(15.2.7)および式(15.28)はそのままでは発散してしまうのでその特異点を避けて $T=0.1 \mathrm{~K}$ からプロットしている.）このように key in してシフトキーを押ながら return すると 2 分位待つことにより（パソコンによって時間は変わる）次のような図 が出て来る.

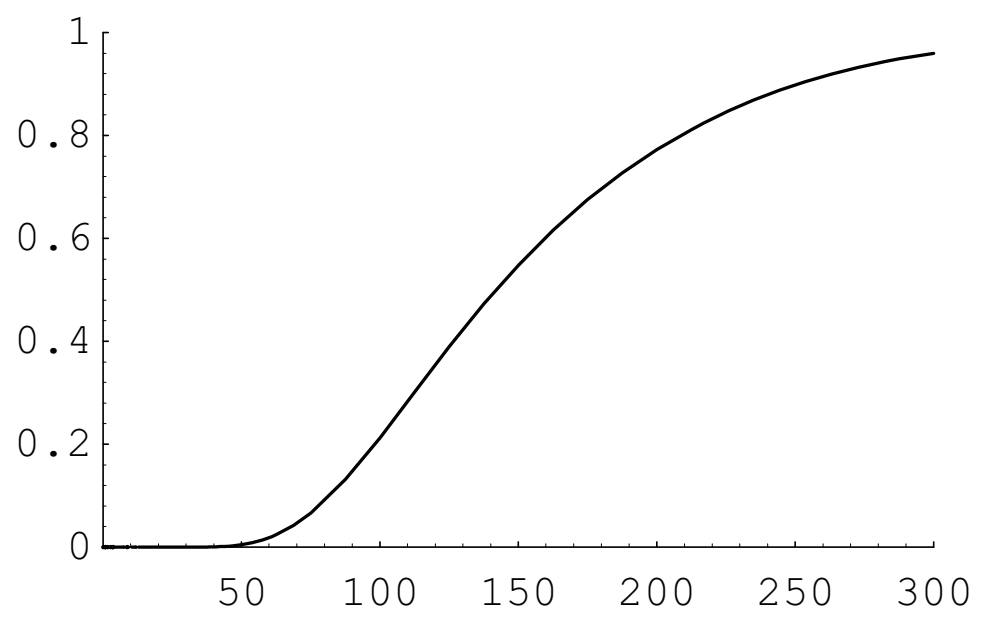

この例で分かるように Fortran とか Basic のような言語を用いて図を描く手間を考 えると信じられないような簡便さである。（もっとも，信じられないような簡便さで 結果が得られるようになるには，普段から Mathematica を使って慣れていることが必 要である.)

\section{3 重水素核の核スピン}

重水素の原子核 deuteron は proton 1 個と neutron 1 個よりなる. proton は Fermi 粒子 
であり，かつ spin $\frac{1}{2}$ を持つことはすでに述べた。 neutronもまた Fermi 粒子であり， $\operatorname{spin} \frac{1}{2}$ を持っている.

では deuteron の核スピンはどうなるであろうか? spin $\frac{1}{2}$ の素粒子 2 つが集まって いるのだから，合成されたスピンは $\frac{1}{2}+\frac{1}{2}=1$ および $\frac{1}{2}-\frac{1}{2}=0$ の 2 つが考えられそうで あるが，実測は deuteronの核スピンが 1 であることを示している. 又，2つの deuteron を交換することは protonの交換と neutronの交換をそれぞれすることに相当する. 全 波動関数はそれぞれの交換に対して antisymmetric. だから結局 $2 つ の$ deuteronの交換 については symmetric ということが出来る。すなわち， deuteron は Bose 粒子である. 重水素についてのモル熱容量については, 水素分子の場合と全く同じようにして考え ることが出来る。それは問題として諸君にやってもらう.

放Problem 15.3.1

$\mathrm{D}_{2}$ 分子の電子基底状態 $\left(\Sigma_{g}^{+}\right)$において, ortho- $\mathrm{D}_{2}$, para- $\mathrm{D}_{2}$ はそれぞれどのよう な回転の量子数 $j$ を持っているか.

\section{is Problem 15.3.2}

deuterium 分子の $\mathrm{D}_{2}$ の電子基底状態 $\left(\Sigma_{g}^{+}\right)$について ortho- $\mathrm{D}_{2}$ と para- $\mathrm{D}_{2}$ の高温に おける存在比を求めよ。

\section{㶦Problem 15.3.3}

上の結果を用い, ortho- $\mathrm{D}_{2}$, para-D 2 およびそれらが高温における存在比で混合し た normal-D 2 について熱容量の温度変化の曲線を描け. Problem 15.2.2 を参考にすべて を計算出来れば望ましいが，手を抜きたい場合には図 15.2.4の $\mathrm{H}_{2}$ についての曲線を 利用するとよい.それには，まず図 15.2.4の横軸を換算温度 $\frac{T}{\theta_{\mathrm{rot}}}$ （ $\theta_{\mathrm{rot}}$ は特性温度）に 直して考え, $\mathrm{H}_{2}$ と $\mathrm{D}_{2}$ における $\theta_{\mathrm{rot}}$ の違いを考慮に入れて, かつ上記 2 つの問題の結 果を用いて計算すればよい，温度範囲に限りがあるのは多少残念であるが，手を抜い た場合にはやむを得ない。 


\section{4 他の核種の核スピン}

水素と重水素の原子核の核スピンはすでに述べたとおりだが他の原子一般に見て みると，核スピンを持っているもの，持っていないもの，又核スピンを持っていると いっても，整数のものと半整数のものとがある．それらはその原子の原子番号（すな わち proton の個数）と質量数（protonの数と中性子の数の和）によって表 15.4.1のよ うに分類される.

表 15.4.1 核スピン

\begin{tabular}{ccc}
\hline atomic number & mass number & nuclear $\operatorname{spin}(I)$ \\
\hline even & even & 0 \\
even & odd & half integer $\left(\frac{1}{2}, \frac{3}{2}, \frac{5}{2}, \ldots\right)$ \\
odd & odd & half integer $\left(\frac{1}{2}, \frac{3}{2}, \frac{5}{2}, \ldots\right)$ \\
odd & even & integer $(1,2, \ldots)$ \\
\hline
\end{tabular}

比較的我々になじみの深い, 原子番号の小さな原子についての核スピンの性質を表 15.4.2 にまとめておく. $g_{\mathrm{N}}$ は, nuclear $\mathrm{g}$ factor と言われるもので， $I$ と $g_{\mathrm{N}}$ と $\mu_{\mathrm{N}}$ との積 が核の磁気モーメントを示している. 表の最後の欄にはこの磁気モーメントの大きさ を,

$$
\mu_{\mathrm{N}}=\frac{e \hbar}{2 m_{\mathrm{p}}}
$$

の単位で示している。この章の冒頭部で, proton が磁気モーメントを持っているとす ると，上式 $\mu_{\mathrm{N}}$ の位の大きさであろうと類推したが，実際にはその 2.79 倍の大きさを 持つのである. 
表 15.4.2 核スピンの性質

\begin{tabular}{|c|c|c|c|c|}
\hline nucleus & $\begin{array}{c}\text { natural } \\
\text { abundance/\% }\end{array}$ & nuclear spin $I$ & $g_{N}$ & $\begin{array}{c}\text { magnetic } \\
\text { moment/ } \mu_{\mathrm{N}}\end{array}$ \\
\hline${ }^{1} \mathrm{H}_{1}$ & 99.9844 & $\frac{1}{2}$ & 5.5854 & 2.7927 \\
\hline${ }^{2} \mathrm{H}_{1}$ & $1.56 \times 10^{-2}$ & 1 & 0.8574 & 0.8574 \\
\hline${ }^{3} \mathrm{H}_{1}$ & - & $\frac{1}{2}$ & 5.9576 & 2.9788 \\
\hline${ }^{3} \mathrm{He}_{2}$ & $10^{-5}-10^{-7}$ & $\frac{1}{2}$ & -4.2548 & -2.1274 \\
\hline${ }^{6} \mathrm{Li}_{3}$ & 7.43 & 1 & 0.82191 & 0.82191 \\
\hline${ }^{7} \mathrm{Li}_{3}$ & 92.57 & $\frac{3}{2}$ & 2.1707 & 3.2560 \\
\hline${ }^{9} \mathrm{Be}_{4}$ & 100 & $\frac{3}{2}$ & -0.7849 & -1.1774 \\
\hline${ }^{10} \mathrm{~B}_{5}$ & 18.83 & 3 & 0.6002 & 1.8006 \\
\hline${ }^{11} \mathrm{~B}_{5}$ & 81.17 & $\frac{3}{2}$ & 1.7920 & 2.6880 \\
\hline${ }^{13} \mathrm{C}_{6}$ & 1.108 & $\frac{1}{2}$ & 1.4044 & 0.7022 \\
\hline${ }^{14} \mathrm{~N}_{7}$ & 99.635 & 1 & 0.4036 & 0.4036 \\
\hline${ }^{15} \mathrm{~N}_{7}$ & 0.365 & $\frac{1}{2}$ & -0.5661 & -0.2830 \\
\hline${ }^{17} \mathrm{O}_{8}$ & $3.7 \times 10^{-2}$ & $\frac{5}{2}$ & -0.7572 & -1.8930 \\
\hline${ }^{19} \mathrm{~F}_{9}$ & 100 & $\frac{1}{2}$ & 5.2546 & 2.6273 \\
\hline
\end{tabular}




\section{5 核スピン関数と核スピン演算子}

electron spin operator $S_{u}$ に対応する nuclear spin operator を $I_{u}$ で表す． $S_{z}$ についての eigenvalue を $m_{s} \hbar$ とたのと同じように， $I_{z}$ についての eigenvalue を $m_{I} \hbar て ゙$ 示す.また $\boldsymbol{S}^{2}$ についての eigenvalue を $S(S+1) \hbar^{2}$ としたものと同じように， $\boldsymbol{I}^{2}$ についての eigenvalue を $I(I+1) \hbar^{2}$ と表す.（このI は，前節で話題となった回転の慣性モーメント でないことは言うまでもない.）

スピンの波動関数も $I_{z}$ および $\boldsymbol{I}^{2} の$ eigenfunction になるように決めておくのが便利 である.その wavefunction を $\gamma\left(I, m_{I}\right)$ と示すことにする.

このスピン関数に対するスピン演算子の作用も電子スピンの場合と全く同様な形 になる。

$$
\begin{aligned}
\boldsymbol{I}^{2} \gamma\left(I, m_{I}\right) & =\hbar^{2} I(I+1) \gamma\left(I, m_{I}\right) \\
I_{z} \gamma\left(I, m_{I}\right) & =\hbar m_{I} \gamma\left(I, m_{I}\right) \\
I_{ \pm} \gamma\left(I, m_{I}\right) & =\hbar \sqrt{\left(I \mp m_{I}\right)\left(I \pm m_{I}+1\right)} \gamma\left(I, m_{I} \pm 1\right) \\
& =\hbar \sqrt{I(I+1)-m_{I}\left(m_{I} \pm 1\right)} \gamma\left(I, m_{I} \pm 1\right)
\end{aligned}
$$

ただし

$$
I_{ \pm}=I_{x} \pm i I_{y}
$$

\section{6 核スピンと磁場との相互作用 - 核スピンについての Zeeman 効果}

電子スピンについての Zeeman 効果があるのと同様，核スピンについてもZeeman 効果がある．核スピンについての Zeeman 効果の Hamiltonian は 


$$
\begin{aligned}
H_{\mathrm{N} . \text { Zeman }} & =-\frac{g_{\mathrm{N}} \mu_{\mathrm{N}} \boldsymbol{B} \boldsymbol{I}}{\hbar} \\
& =-\frac{g_{\mathrm{N}} \mu_{\mathrm{N}}\left(B_{x} I_{x}+B_{y} I_{y}+B_{z} I_{z}\right)}{\hbar}
\end{aligned}
$$

で与えられる. 電子スピンについての Zeeman 効果の Hamiltonian(14.9.4) と同じような 形をしている，負号は核の電荷が電子の電荷と反対であるためについたものである.

$g_{N}$ は核スピンに関する $g$ 值であり，核種によって固有の值を持つ. 代表的な核種につ いては表 15.4.2 に示してある。 $\mu_{\mathrm{N}}$ はすでに式(15.4.1)に示したように

$$
\mu_{\mathrm{N}}=\frac{e \hbar}{2 m_{\mathrm{p}}}
$$

で与えられ， nuclear magneton と言われる。ここで $m_{\mathrm{p}}$ は proton の質量である.すなわ ち, 式(14.9.3)の Bohr magneton $\mu_{\mathrm{B}}$ の定義式の中の electron mass $m_{\mathrm{e}}$ を proton mass $m_{\mathrm{p}}$ で置き換えたものである. nuclear magneton は，昔はしばしば $\beta_{\mathrm{N}}$ という記号で表され た.しかし, IUPAP (International Union of Pure and Applied Physics) や IUPAC （International Union of Pure and Applied Chemistry）の勧告があり，この頃は $\mu_{\mathrm{N}}$ という 記号を用いることになっている. subscript の $\mathrm{N}$ は electron でなくて nucleus という意味 の $\mathrm{N}$ である。

\section{【注意】：}

式(15.6.1)は IUPAP やIUPAC の勧告に従った記号を用いて表しているが，ちょっと 注意をして見る必要がある。この式の中の $\mu_{\mathrm{N}}$ は, 式(15.6.2)で定義したように universal constant である。一方， $g_{\mathrm{N}}$ は核種によって異なった值を持つ. $g_{\mathrm{N}}, \mu_{\mathrm{N}}$ どちらも $\mathrm{N}$ と

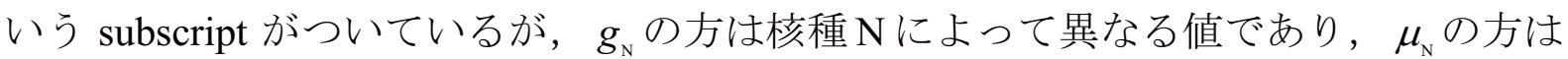
核種によらない constantである。

核スピンについての Zeeman 効果は，すでに Section 14.9 で学習した電子スピンに ついての Zeeman 効果と同様にして，縮退系への摂動論によって簡単に解くことが出 
来る，例えば 1 proton 系については，もし磁場が $z$ 軸にかけられていれば

$$
\left[\begin{array}{ll}
\left\langle\alpha_{\mathrm{N}}\left|H_{\mathrm{NZeeman}}\right| \alpha_{\mathrm{N}}\right\rangle & \left\langle\alpha_{\mathrm{N}}\left|H_{\mathrm{NZZemana}}\right| \beta_{\mathrm{N}}\right\rangle \\
\left\langle\beta_{\mathrm{N}}\left|H_{\mathrm{N} Z \text { Zeeman }}\right| \alpha_{\mathrm{N}}\right\rangle & \left\langle\beta_{\mathrm{N}}\left|H_{\mathrm{N} Z \text { Zeeman }}\right| \beta_{\mathrm{N}}\right\rangle
\end{array}\right]=\left[\begin{array}{cc}
-\frac{g_{\mathrm{N}} \mu_{\mathrm{N}} B_{z}}{2} & 0 \\
0 & \frac{g_{\mathrm{N}} \mu_{\mathrm{N}} B_{z}}{2}
\end{array}\right]
$$

という matrix を対角化すればよい，上式はすでに対角化されているから， spin eigenfunction $\psi_{1}, \psi_{2}$ と eigenvalue $E_{1}, E_{2}$ は次のようになる.

$$
\begin{array}{ll}
\psi_{2}=\beta_{\mathrm{N}}: & E_{2}=E_{0}+\frac{g_{\mathrm{N}} \mu_{\mathrm{N}} B_{z}}{2} \\
\psi_{1}=\alpha_{\mathrm{N}}: & E_{1}=E_{0}-\frac{g_{\mathrm{N}} \mu_{\mathrm{N}} B_{z}}{2}
\end{array}
$$

この結果を式(14.9.7)と比べてみれば，2 種類の Zeeman 効果の類似点と相違点がはっ きりするであろう。

次に，念のため， spin 1 の系（例えば deuteron）の Zeeman 効果をみてみよう。核 スピン $I=1$ であるから $M_{I}=+1,0,-1$ の 3 つ状態が存在する.notation を簡略化して, これらを $|+1\rangle,|0\rangle,|-1\rangle$ と表すことにしよう，Zeeman 効果の結果は， $H_{\mathrm{N}, \mathrm{Zemann}}$ についての 3 次の matrix

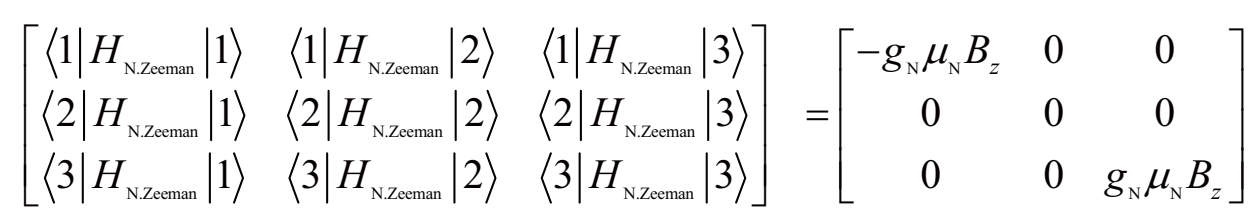

を対角化することによって得られる。ここでも外部磁場は $z$ 軸にかけられているとし ているので, もともと対角化されている. 従って, Zeeman 分裂した状態での spin eigenfunction $\psi_{1}, \psi_{2}, \psi_{3}$ および eigenvalue $E_{1}, E_{2}, E_{3}$ は次のようになる.

$$
\begin{array}{ll}
\psi_{3}=|-1\rangle: & E_{3}=E_{0}+g_{\mathrm{N}} \mu_{\mathrm{N}} B_{z} \\
\psi_{2}=|0\rangle: & E_{2}=E_{0} \\
\psi_{1}=|+1\rangle: & E_{1}=E_{0}-g_{\mathrm{N}} \mu_{\mathrm{N}} B_{z}
\end{array}
$$

$\psi$ および $E$ の subscript は $g_{\mathrm{N}}>0$ の場合, energy の低い方から順番につけるようにして ある。 
放Problem 15.6.1

外部磁場の大きさが $1 \mathrm{~T}$ の場合の（1）Zeeman 分裂の大きさ $\Delta E$ （相当する電磁波 の振動数 $v$ で表すこと）および（2）各状態の Boltzmann populationの比（もつとも多 く存在するものを基準に取ること）を（a）proton（ $I=\frac{1}{2}, g_{\mathrm{N}}=5.5854 ） \quad(\mathrm{~b})$ deuteron ( $\left.I=1, g_{\mathrm{N}}=0.8574\right)$ について求めよ.

¿ 2 Problem 15.6.2

proton の Zeeman 分裂の大きさが, 丁度電磁波の周波数 $100 \mathrm{MHz}$ に相当する時の磁 束密度の大きさを求めよ。

\section{7 核磁気共鳴（NMR）}

Zeeman 分裂した電子スピン準位間の遷移を共鳴法によって観測するのが電子スピ ン共鳴（ESR）であるが，それと同じように，Zeeman 分裂した核スピン準位間の遷 移を共鳴法によって観測するのが核磁気共鳴（Nuclear Magnetic Resonance，通常 NMR と略記）である. 原理は Section 14.10 で学習した ESR と全く同じなので特に改めて 述べることはあまりない，ただ，ESR と比べての大きな違いは，核スピンの Zeeman 分裂の大きさが電子スピンの Zeeman 分裂の大きさの $10^{-3}$ しかないということであ る. ESR の場合，共鳴を起させる電磁波はマイクロ波であったが，NMRの場合には， もちろん磁場の大きさによって異なるが，周波数にして $60 \mathrm{MHz}$ から $600 \mathrm{MHz}$ の電磁 波となり，これはラジオ波の領域となる。（600 MHzの NMR 装置は世界最大，当化 学教室には $60 \mathrm{MHz}$ から $600 \mathrm{MHz}$ までいろいろな種類の NMR spectrometer がある)

現在では，NMR は化学の研究には欠くことの出来ない重要な機器である. 物理化 学者も有機化学者も無機化学者も，いろいろな立場から NMR を手段として用いてい るが，NMR がもつともよく使われている分野はおそらく分子の構造決定であろう。 多くの化合物に含まれている $\mathrm{H}$ の原子核が核スピンを持つということは, その発見に ついてはSection 15.2 で述べたが，化学の発展にとって大変ありがたいことであった. 有機化合物の主構成元素である ${ }^{12} \mathrm{C}$ は, 偶数原子番号の偶数質量数ということで核ス ピンを持たないため，NMR にはかからない。しかし，最近では，天然に存在するご くわずかの（表 15.4.2 を参照） $13 \mathrm{C}$ による NMR が簡単に測定出来るようになった.

じうして NMR が構造決定に用いられるのであろうか?それは, 例えば proton を例 に取ると，一口に $\mathrm{H}$ といっても分子中の環境によって（例えば $\mathrm{H}$ の隣の原子の差異 によって）異なった所に遷移が起るからである。でも，ここまで学習して来た諸君に 
とってそのことは自明ではないというか，むしろ奇異に思われるであろう。Zeeman 分裂の Hamiltonian は式(15.6.1)によって与えられる. 核種が決まれば $g_{\mathrm{N}}$ は決まってし

まうし， $\mu_{\mathrm{N}}$ は universal constant である. 同じ核種が環境によって異なる Hamiltonian を持つということは式(15.6.1)では自明のことではない.このことを理解するには，も う少し立ち入った学習が必要で, その一部については本 lecture note でも扱うが，簡単 に言うと 2 つ効果がある. 1 つは，分子中の電子の存在のために，外部から与えた 磁束密度が少々遮蔽され, 正しくはZeeman 効果の Hamiltonian は次のように書きなお さなければならない.

$$
H_{\mathrm{N} . \mathrm{Zceman}}=-\frac{g_{\mathrm{N}} \mu_{\mathrm{N}} \boldsymbol{B}(1-\sigma) \boldsymbol{I}}{\hbar}
$$

この $\sigma$ が遮蔽定数で, 各核種のおかれている環境によって異なるのである。もう $1 つ$ は, もう少し複雑で, 実は 2 つ上の核種があると, それぞれの核スピン状態間の相 互作用があるために, Hamiltonian はその相互作用をも加えた形で表されることによ る.この相互作用は，既に学習している摂動論又は対角化の方法を用いて容易に取り 入れることが出来る. ごく簡単な例は少し後で学習することにしよう.

ここでNMR の強度についてごく簡単に学習しておこう。NMRの強度は, Section 13.3 および Section 13.4 で学習した遷移確率および遷移に関係した 2 つの準位間の population の差との積でもって与えられる. 状態 $\psi_{1}$ と $\psi_{2}$ との間の遷移確率は遷移モー メント

$$
\left\langle\psi_{1}|V| \psi_{2}\right\rangle \equiv \int \psi_{1} * V \psi_{2} d \sigma
$$

の二乗で与えられる。この式に限り $\sigma$ は遮蔽定数ではなく核スピンの座標である. 正 確にはSection 14.4 で電子スピンの座標について学習したのと同じような不連続な量 であるが，上式では簡単のため積分記号で表している。その意味はあくまで Section 14.4 で学習したと同じことであることを頭に入れておいてほしい.Vは遷移を起す Hamiltonian であり,

$$
\begin{aligned}
V & =-\frac{g_{\mathrm{N}} \mu_{\mathrm{N}} \boldsymbol{B}_{\mathbf{1}} \boldsymbol{I}}{\hbar} \\
& =-\frac{g_{\mathrm{N}} \mu_{\mathrm{N}}\left(B_{1 x} I_{x}+B_{1 y} I_{y}+B_{1 z} I_{z}\right)}{\hbar}
\end{aligned}
$$

で与えられる。ここで $\boldsymbol{B}_{1}$ は subscript 1 がついているように，外部磁場 $\boldsymbol{B}$ とは異なる.

$\boldsymbol{B}_{1}$ は遷移を起させるラジオ波の持っている磁気ベクトルである. 通常は外部磁場 $\boldsymbol{B}$ の 
方向を $z$ 軸とするが, その場合, ラジオ波の磁気ベクトルは $z$ 軸に対して直角の方向, 例えば $x$ 軸方向に取る.（もちろんこれが基本であり，いろいろの modification がある が，それらについては今考えない)，従って，式(15.7.3)は次のように表すことが出来 る.

$$
\begin{aligned}
V & =-\frac{g_{\mathrm{N}} \mu_{\mathrm{N}} B_{1 x} I_{x}}{\hbar} \\
& =-\frac{\frac{1}{2} g_{\mathrm{N}} \mu_{\mathrm{N}} B_{1 x}\left(I_{+}+I_{-}\right)}{\hbar}
\end{aligned}
$$

例として, spin $\frac{1}{2}$ の系（例えば proton）について遷移モーメントを計算してみよう。 spin $\frac{1}{2}$ の系についての Zeeman 分裂した wavefunction と energy については式(15.6.4) に与えられているが念のため再び記す.

$$
\begin{array}{ll}
\psi_{2}=\beta_{\mathrm{N}}: & E_{2}=E_{0}+\frac{g_{\mathrm{N}} \mu_{\mathrm{N}} B_{z}}{2} \\
\psi_{1}=\alpha_{\mathrm{N}}: & E_{1}=E_{0}-\frac{g_{\mathrm{N}} \mu_{\mathrm{N}} B_{z}}{2}
\end{array}
$$

これより遷移モーメントは

$$
\begin{aligned}
\left\langle\psi_{1}\left|H^{\prime}\right| \psi_{2}\right\rangle & =-\frac{\frac{1}{2} g_{\mathrm{N}} \mu_{\mathrm{N}} B_{1 x}\left\langle\alpha_{\mathrm{N}}\left|I_{+}+I_{-}\right| \beta_{\mathrm{N}}\right\rangle}{\hbar} \\
& =-\frac{g_{\mathrm{N}} \mu_{\mathrm{N}} B_{1 x}}{2}
\end{aligned}
$$

遷移確率はこの二乗に比例する.

念のため, spin 1 の場合についても演習してみよう。この系についての Zeeman 分 裂の結果は式(15.6.6)で求めたが再び記す。

$$
\begin{array}{ll}
\psi_{3}=|-1\rangle: & E_{3}=E_{0}+g_{\mathrm{N}} \mu_{\mathrm{N}} B_{z} \\
\psi_{2}=|0\rangle: & E_{2}=E_{0} \\
\psi_{1}=|+1\rangle: & E_{1}=E_{0}-g_{\mathrm{N}} \mu_{\mathrm{N}} B_{z}
\end{array}
$$

3 つ状態があるので, $\psi_{1} \rightarrow \psi_{2}, \psi_{2} \rightarrow \psi_{3}, \psi_{1} \rightarrow \psi_{3}$ の 3 つの遷移が考えられる. これ らの 3 つの遷移について遷移モーメントを計算してみよう。（各自確かめよ！) 結果 は次のようになる。 


$$
\begin{aligned}
& \left\langle\psi_{1}\left|H^{\prime}\right| \psi_{2}\right\rangle=-\frac{\frac{1}{2} g_{\mathrm{N}} \mu_{\mathrm{N}} B_{1 x}\left\langle-1\left|I_{+}+I_{-}\right| 0\right\rangle}{\hbar}=-\frac{g_{\mathrm{N}} \mu_{\mathrm{N}} B_{1 x}}{\sqrt{2}} \\
& \left\langle\psi_{2}\left|H^{\prime}\right| \psi_{3}\right\rangle=-\frac{\frac{1}{2} g_{\mathrm{N}} \mu_{\mathrm{N}} B_{1 x}\left\langle 0\left|I_{+}+I_{-}\right|+1\right\rangle}{\hbar}=-\frac{g_{\mathrm{N}} \mu_{\mathrm{N}} B_{1 x}}{\sqrt{2}} \\
& \left\langle\psi_{1}\left|H^{\prime}\right| \psi_{3}\right\rangle=-\frac{\frac{1}{2} g_{\mathrm{N}} \mu_{\mathrm{N}} B_{1 x}\left\langle-1\left|I_{+}+I_{-}\right|+1\right\rangle}{\hbar}=0
\end{aligned}
$$

このように，準位は 3 つあっても，遷移は $M_{I}$ が 1 つだけ異なる準位間，寸なわち， 隣の準位間のみに起る。そして又, この 2 つ遷移の遷移確率は同じであることが分 かる.

\section{8 スピンスピン結合 -2 つの proton を持つ系を例として}

諸君の大部分の人は, 後半年もすると, 毎日のようにNMR のスペクトルをとって 解析することになろう。 その時, spin-spin coupling についての理解が必要になる. 以 下，もっとも簡単な例として proton が 2 個からなる系について $2 つ の$ proton 間の相互 作用について考えてみよう。

2 つの proton はそれぞれ環境は同じでなく, 遮蔽定数 $\sigma$ が異なるものとする. proton 1 および proton 2 についての Zeeman 効果の Hamiltonian をそれぞれ

$$
\begin{aligned}
& H_{1}=-\frac{g_{\mathrm{N}} \mu_{\mathrm{N}} B_{z}\left(1-\sigma_{1}\right) I_{\mathrm{1z}}}{\hbar} \\
& H_{2}=-\frac{g_{\mathrm{N}} \mu_{\mathrm{N}} B_{z}\left(1-\sigma_{2}\right) I_{\mathrm{Iz}}}{\hbar}
\end{aligned}
$$

とする．ここで外部磁場は $z$ 軸にかけられるとしている．最初に，2つの proton の間 には相互作用がなく，全く独立である場合を考える．この場合，proton 1 についての eigenvalue と eigenfunction は次のようになる。（式(15.6.4)を参）

$$
\begin{array}{ll}
\psi_{12}=\beta_{1}: & E_{12}=\frac{\delta_{1}}{2} \\
\psi_{11}=\alpha_{1}: & E_{11}=-\frac{\delta_{1}}{2}
\end{array}
$$

ただし，

$$
\delta_{1}=g_{\mathrm{N}} \mu_{\mathrm{N}} B_{z}\left(1-\sigma_{1}\right)
$$


ここで $\psi$ および $E$ の subscript のうち, 第 1 の文字は proton の番号, 第 2 の文字は energy の順序を示している．核スピンの wavefunction は $\alpha_{\mathrm{N}}, \beta_{\mathrm{N}}$ と書くべきであるが，ここ では核スピンのみを扱い，電子スピンの $\alpha, \beta$ との混乱の心配もないので，繁雑さを 避けるために subscript の Nを省くことにする.

同様に proton 2 にいては

$$
\begin{array}{ll}
\psi_{22}=\beta_{2}: & E_{22}=\frac{\delta_{2}}{2} \\
\psi_{21}=\alpha_{2}: & E_{11}=-\frac{\delta_{2}}{2}
\end{array}
$$

ただし，

$$
\delta_{2}=g_{\mathrm{N}} \mu_{\mathrm{N}} B_{z}\left(1-\sigma_{2}\right)
$$

従って $2 つ の$ proton を合わせた系の eigenfunction および eigenvalue は次のようになる.

（Hamiltonian は和，従って eigenfunction は積，eigenvalue は和）

$$
\begin{array}{ll}
\psi_{4}=\beta_{1} \beta_{2}: & E_{4}=\frac{1}{2}\left(\delta_{1}+\delta_{2}\right) \\
\psi_{3}=\beta_{1} \alpha_{2}: & E_{3}=\frac{1}{2}\left(\delta_{1}-\delta_{2}\right) \\
\psi_{2}=\alpha_{1} \beta_{2}: & E_{2}=-\frac{1}{2}\left(\delta_{1}-\delta_{2}\right) \\
\psi_{1}=\alpha_{1} \alpha_{2}: & E_{1}=-\frac{1}{2}\left(\delta_{1}+\delta_{2}\right)
\end{array}
$$

式(15.8.3)で $\psi$ および $E$ の subscript は $\delta_{1}>\delta_{2}$ の場合に energy の順になるようにつけた が，本質的なことではない。

次に spin-spin coupling を考える. spin-spin coupling の Hamiltonian は通常

$$
\begin{aligned}
H^{\prime} & =\frac{J \boldsymbol{I}_{1} \boldsymbol{I}_{2}}{\hbar^{2}} \\
& =\frac{J\left(I_{1 z} I_{2 z}+\frac{1}{2} I_{1+1} I_{2-}+\frac{1}{2} I_{1-1} I_{2+}\right)}{\hbar^{2}}
\end{aligned}
$$

の形で表される. 式(15.8.4)で表される状態が spin-spin coupling（式(15.8.5)）によって どのように影響するかは，今まで学習して来たことで簡単に分かる．荒い近似では摂 動論があり，もっと正確に解こうと思えば厳密に対角化をすればいいことになる。こ れらについては，今まで十分に学習して来たはずであるが，格好の演習材料でもある 
ので以下詳しくやってみよう。

\section{（1） 1 次の摂動論}

まずもっとも荒い近似として energy について 1 次の摂動論で, wavefunction につい てはゼロ次近似のままで考えてみよう。いま， $\delta_{1} \neq \delta_{2}$ と考えているので式(15.8.4)には 縮退はない. 従って 1 次の摂動 energy は,

$$
\Delta E_{i}=\left\langle\psi_{i}\left|H^{\prime}\right| \psi_{i}\right\rangle \quad i=1,2,3,4
$$

で与えられる. 式(15.8.4)の $\psi_{1}, \psi_{2}, \psi_{3}, \psi_{4}$ を用いて上式を計算すればいいだけのこと であるが，やみくもに計算を始める前に，式(15.8.6)および Hamiltonian をもう少し眺 めてみよう。まず式(15.8.6)は, 1 次の摂動 energy を与える式であるから, 当然, 同じ wavefunction 同志を $H^{\prime}$ ではさんで，積分するわけである．次に Hamiltonian (15.8.4)の 2 行目の各項を吟味してみよう， $I_{z}$ という operator は $\alpha$ を $\alpha$ に, $\beta$ を一 $\beta$ に変換する $\left(I_{z} \alpha=\frac{\alpha}{2} \hbar, \quad I_{z} \beta=-\frac{\beta}{2} \hbar\right)$ ので, 第 1 項の $I_{1 z} I_{2 z}$ という operator は, 全く同じ spin function 同志間での夕働く operator であることが分かる．第 2 項目の $I_{1+} I_{2-}$ および第 3 項目の $I_{1-} I_{2+}$ という operator は， $\alpha_{1} \beta_{2}$ と $\beta_{1} \alpha_{2}$ とを結びつける operator である. 以上の考察から 明らかなように, 1 次の摂動 energy を求める限り, 式(15.8.5)の第 1 項, 寸なわち

$$
H^{\prime}=\frac{J I_{1 z} I_{2 z}}{\hbar^{2}}
$$

のみを考えていいことになる，結果は，わざわざ計算するまでもなく，直ちに次のよ うに求まる.

$$
\begin{aligned}
\Delta E_{4} & =\frac{\left\langle\beta_{1} \beta_{2}\left|J I_{1 z} I_{2 z}\right| \beta_{1} \beta_{2}\right\rangle}{\hbar^{2}} \\
& =\frac{J\left\langle\beta_{1}\left|I_{1 z}\right| \beta_{1}\right\rangle\left\langle\beta_{2}\left|I_{2 z}\right| \beta_{2}\right\rangle}{\hbar^{2}} \\
& =J\left(-\frac{1}{2}\right)\left(-\frac{1}{2}\right) \\
& =\frac{J}{4}
\end{aligned}
$$




$$
\begin{aligned}
\Delta E_{3} & =\frac{\left\langle\beta_{1} \alpha_{2}\left|J I_{1 z} I_{2 z}\right| \beta_{1} \alpha_{2}\right\rangle}{\hbar^{2}} \\
& =\frac{J\left\langle\beta_{1}\left|I_{1 z}\right| \beta_{1}\right\rangle\left\langle\alpha_{2}\left|I_{2 z}\right| \alpha_{2}\right\rangle}{\hbar^{2}} \\
& =J\left(-\frac{1}{2}\right)\left(+\frac{1}{2}\right) \\
& =-\frac{J}{4}
\end{aligned}
$$

同様に

$$
\begin{aligned}
& \Delta E_{2}=-\frac{J}{4} \\
& \Delta E_{1}=\frac{J}{4}
\end{aligned}
$$

従って, energy について 1 次, wavefunction について 2 次という近似内で結果は次の ようになる。

$$
\begin{array}{ll}
\psi_{4}=\beta_{1} \beta_{2}: & E_{4}=\frac{\delta_{1}+\delta_{2}}{2}+\frac{J}{4} \\
\psi_{3}=\beta_{1} \alpha_{2}: & E_{4}=\frac{\delta_{1}-\delta_{2}}{2}-\frac{J}{4} \\
\psi_{2}=\alpha_{1} \beta_{2}: & E_{2}=-\frac{\delta_{1}-\delta_{2}}{2}-\frac{J}{4} \\
\psi_{1}=\alpha_{1} \alpha_{2}: & E_{1}=-\frac{\delta_{1}+\delta_{2}}{2}+\frac{J}{4}
\end{array}
$$

この結果を図 15.8.1 に schematic に示す. 


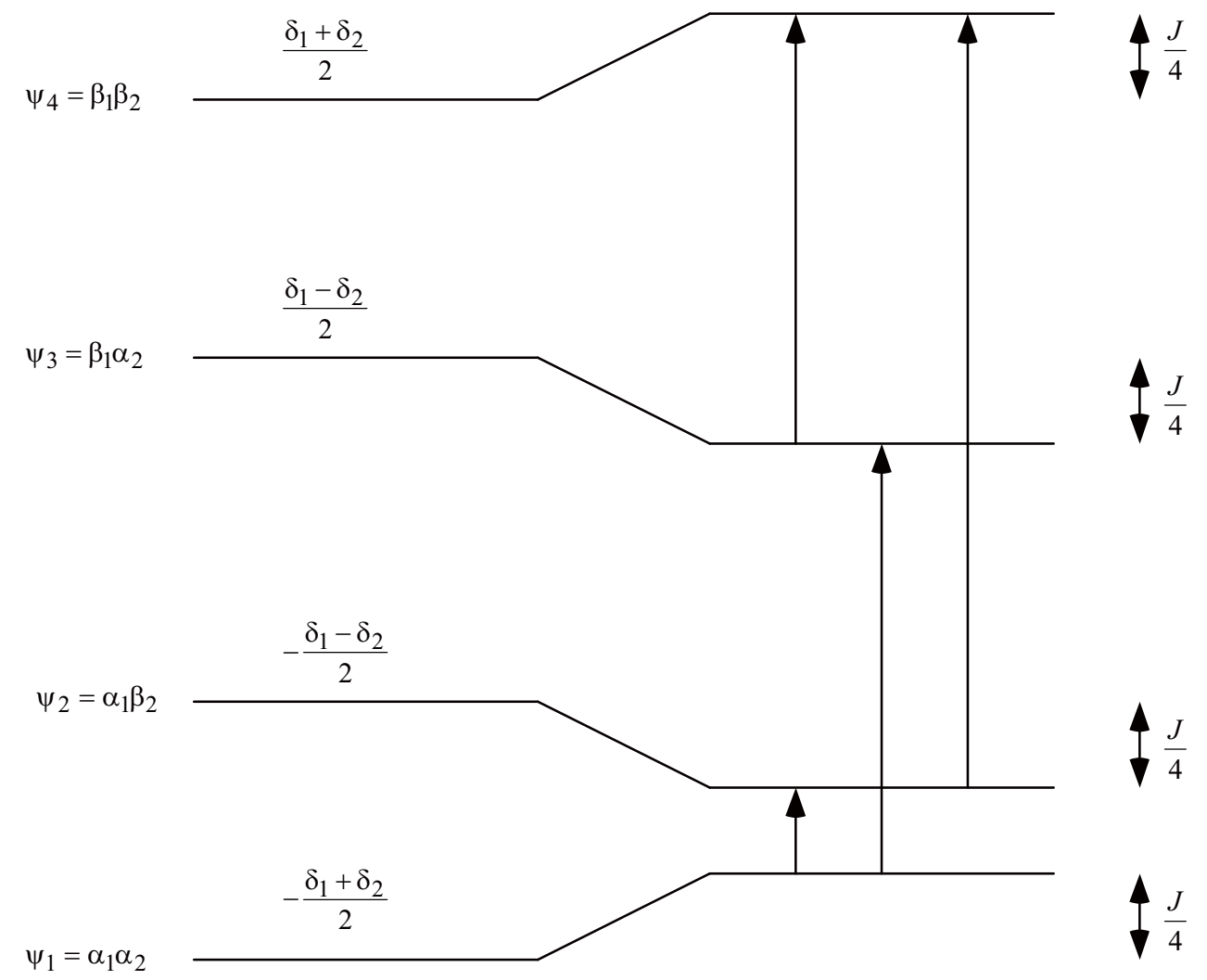

図 15.8.1 2 proton 系の spin-spin coupling energy の 1 次摂動による補正.

困は $J>0$ の場合を想定している.

NMR 遷移は 1 つの proton については同じ spin でもう 1 つの proton についてのみ異な る spin を持つ状態間で起るから，図の中の矢印で示したような遷移が起こる。遷移 energy は次のようになる。

$$
\begin{aligned}
& \psi_{2} \rightarrow \psi_{4}: E_{4}-E_{2}=\delta_{1}+\frac{J}{2} \\
& \psi_{3} \rightarrow \psi_{4}: E_{4}-E_{3}=\delta_{2}+\frac{J}{2} \\
& \psi_{1} \rightarrow \psi_{3}: E_{3}-E_{1}=\delta_{1}-\frac{J}{2} \\
& \psi_{1} \rightarrow \psi_{2}: E_{2}-E_{1}=\delta_{2}-\frac{J}{2}
\end{aligned}
$$

次に各遷移についての遷移モーメントを計算してみよう。この場合, proton が 2 個あ るので，それぞれの proton についての式(15.7.3)の和となる. 


$$
\begin{aligned}
V & =V_{1}+V_{2} \\
& =-\frac{g_{\mathrm{N}} \mu_{\mathrm{N}} B_{1 x}\left\{\left(I_{1+}+I_{1-}\right)+\left(I_{2+}+I_{2-}\right)\right\}}{2 \hbar}
\end{aligned}
$$

$I_{1+}$ 等の最初の subscript 1,2 が proton の番号を示す. 念のため, $B_{1 x}$ の subscript の 1

は protonの番号ではなく, ラジオ波のもっている磁束密度を示すことと混乱しないよ うに注意が必要である。式(15.8.10)を用いて各遷移について遷移モーメントを計算す る.

$$
\begin{aligned}
\left\langle\psi_{2}|V| \psi_{4}\right\rangle & =\left\langle\alpha_{1} \beta_{2}\left|V_{1}+V_{2}\right| \beta_{1} \beta_{2}\right\rangle \\
& =\left\langle\alpha_{1}\left|V_{1}\right| \beta_{1}\right\rangle \\
& =-\frac{g_{\mathrm{N}} \mu_{\mathrm{N}} B_{1 x}}{2} \\
\left\langle\psi_{3}|V| \psi_{4}\right\rangle & =\left\langle\beta_{1} \alpha_{2}\left|V_{1}+V_{2}\right| \beta_{1} \beta_{2}\right\rangle \\
& =\left\langle\alpha_{2}\left|V_{2}\right| \beta_{2}\right\rangle \\
& =-\frac{g_{\mathrm{N}} \mu_{\mathrm{N}} B_{1 x}}{2}
\end{aligned}
$$

同様に

$$
\begin{aligned}
& \left\langle\psi_{1}|V| \psi_{3}\right\rangle=-\frac{g_{\mathrm{N}} \mu_{\mathrm{N}} B_{1 x}}{2} \\
& \left\langle\psi_{1}|V| \psi_{2}\right\rangle=-\frac{g_{\mathrm{N}} \mu_{\mathrm{N}} B_{1 x}}{2}
\end{aligned}
$$

これから，すべての遷移は同じ遷移確率を持つことが結論される，すなわち，NMR は 4 本の等強度の遷移よりなる。このことを図 15.8.2 に schematic に示す。

1 次の摂動論という荒い近似がまあまあ良いという系は, spin-spin coupling が小さ いという系にほかならない. 相互作用の小さい2 つのスピン系の NMR は通常（主と して有機化学者の間に popularな言葉で）AX系のスペクトルといわれている. AX 系 のスペクトルは図 15.8.2に見られるように単純な構造なので解析は容易である. 


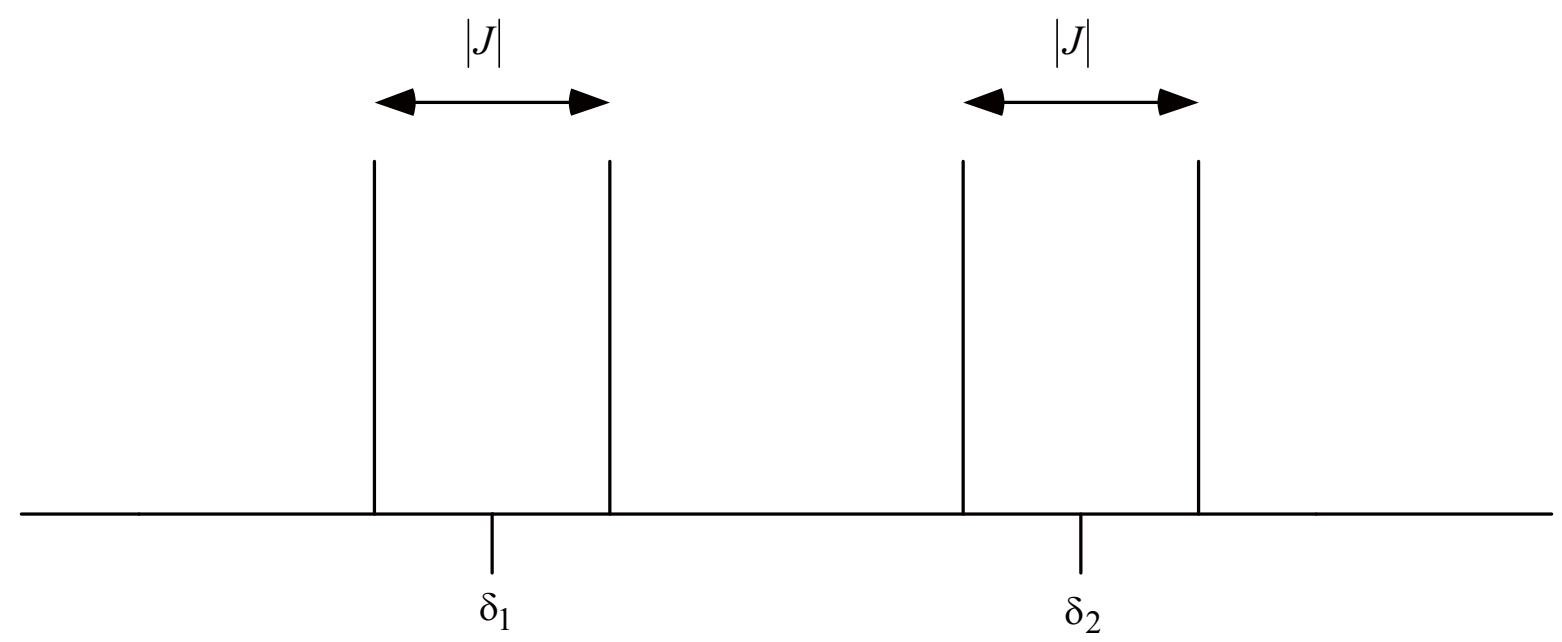

図 15.8.2 2 proton 系, spin-spin coupling energy について 1 次の摂動, wavefunction についてゼロ次の摂動で考えた場合の NMR スペクトル。これはいわゆる AX スピン 系の NMR スペクトルである。

（2） 2 次の摂動論

次に考えられる近似は, spin-spin coupling をwavefunction については 1 次, energy については 2 次まで取り組むことである。これは諸君の演習として残しておこう。

(Problem 15.8.1)

（3）対角化による厳密解

式(15.8.4)に示した 4 つの basis function は，この 4 つで 2 proton 系の完全系をなし ている. 従って全 Hamiltonian について対角化を行えば㛜密な eigenfunction と eigenvalue が求まることになる.全 Hamiltonian はそれぞれの proton についての Zeeman 効果の Hamiltonian と, spin-spin coupling の Hamiltonian との和である.すなおち

$$
H=-\frac{g_{\mathrm{N}} \mu_{\mathrm{N}} B_{1 z}\left(1-\sigma_{1}\right) I_{1 z}}{\hbar}-\frac{g_{\mathrm{N}} \mu_{\mathrm{N}} B_{1 z}\left(1-\sigma_{2}\right) I_{2 z}}{\hbar}+\frac{J\left(I_{1 z} I_{2 z}+\frac{I_{1+} I_{2-}}{2}+\frac{I_{1-} I_{2+}}{2}\right)}{\hbar^{2}}
$$

式(15.8.4)の 4 つの basis function $\psi_{1}, \psi_{2}, \psi_{3}, \psi_{4}$ について $H$ について対角化を行えばい いわけである。ここでも，やみくもに計算を始める前に Hamiltonian 式(15.8.12)の形を 見て見通しをつけておこう。まず, $H$ についての行列要素のうち, 4 個の diagonal term については，ちょっと考えてみれば式(15.8.8)の $E_{1}, E_{2}, E_{3}, E_{4}$ となることが明らかであ 
ろう. off-diagonal term については, Hamiltonian (15.8.12)のうちの最後の 2 項，すなわ ち $I_{1+} I_{2-}+I_{1-} I_{2+}$ によってのみ生きる。このうち， $I_{1+} I_{2-}$ は proton 1 の $M_{I}$ を 1 つげて proton 2 の $M_{I}$ を 1 つ下げる. 寸なわち $\beta_{1} \alpha_{2}$ に作用すると $\alpha_{1} \beta_{2}$ となる。同様に $I_{1-} I_{2+}$ は proton 1 の $M_{I}$ を 1 つ下げ proton 2 の $M_{I}$ を 1 つ上げる. すなわち $\alpha_{1} \beta_{2}$ に作用して $\beta_{1} \alpha_{2}$ を生ずる. 以上のことから, off diagonal term は $\psi_{2}=\alpha_{1} \beta_{2}$ と $\psi_{3}=\beta_{1} \alpha_{2}$ との間だけ值を 持つ，他の off diagonal term はすべてゼロとなる.

念のため, $\psi_{2}$ と $\psi_{3}$ との間の matrix element を計算しておこう.

$$
\begin{aligned}
& \left\langle\psi_{2}|H| \psi_{3}\right\rangle \\
& =\left\langle\alpha_{1} \beta_{2}|H| \beta_{1} \alpha_{2}\right\rangle \\
& =\frac{\left\langle\alpha_{1} \beta_{2}\left|\frac{J I_{1+} I_{2-}}{2}\right| \beta_{1} \alpha_{2}\right\rangle}{\hbar^{2}} \\
& =\frac{J\left\langle\alpha_{1}\left|I_{1+}\right| \beta_{1}\right\rangle\left\langle\beta_{2}\left|I_{1-}\right| \alpha_{2}\right\rangle}{2 \hbar^{2}} \\
& =\frac{J}{2}
\end{aligned}
$$

少々くどいが，同様に

$$
\begin{aligned}
& \left\langle\psi_{3}|H| \psi_{2}\right\rangle \\
& =\left\langle\beta_{1} \alpha_{2}|H| \alpha_{1} \beta_{2}\right\rangle \\
& =\frac{\left\langle\beta_{1} \alpha_{2}\left|\frac{J I_{1-} I_{2+}}{2}\right| \alpha_{1} \beta_{2}\right\rangle}{\hbar^{2}} \\
& =\frac{J\left\langle\beta_{1}\left|I_{1-}\right| \alpha_{1}\right\rangle\left\langle\alpha_{2}\left|I_{2+}\right| \beta_{2}\right\rangle}{2 \hbar^{2}} \\
& =\frac{J}{2}
\end{aligned}
$$

となるが， $\left\langle\psi_{3}|H| \psi_{2}\right\rangle$ が $\left\langle\psi_{2}|H| \psi_{3}\right\rangle$ と同じになることは $H$ が Hermitian で wavefunction が real であることから当然のことである.（分かっていることを検算したことにはな る）かくして，Hについての matrix は次のようになる. 


$$
\begin{aligned}
& \begin{array}{llll}
\psi_{1} & \psi_{2} & \psi_{4}
\end{array} \\
& {\left[\begin{array}{cccc}
\frac{\delta_{1}+\delta_{2}}{2}+\frac{J}{4} & 0 & 0 & 0 \\
0 & \frac{\delta_{1}-\delta_{2}}{2}-\frac{J}{4} & 0 & 0 \\
0 & -\frac{\delta_{1}-\delta_{2}}{2}-\frac{J}{4} & 0 \\
0 & 0 & -\frac{\delta_{1}+\delta_{2}}{2}+\frac{J}{4}
\end{array}\right]}
\end{aligned}
$$

始めにも見通しをつけたように， $\psi_{1}$ および $\psi_{4}$ は他の状態と結合しないから，そのま まで $H$ の eigenfunction になっている.すなわち, 対角化された後の eigenfunctionを $\Psi$ で表すと，

$$
\begin{array}{ll}
\Psi_{4}=\psi_{4}=\beta_{1} \beta_{2}: & E_{4}=\frac{\delta_{1}+\delta_{2}}{2}+\frac{J}{4} \\
\Psi_{1}=\psi_{1}=\alpha_{1} \alpha_{2}: & E_{1}=-\frac{\delta_{1}+\delta_{2}}{2}+\frac{J}{4}
\end{array}
$$

eigenvalue の方は basis function と同じ記号 $E$ を用いているが，混乱しないようにして ほしい. 残りの $\psi_{2}$ と $\psi_{3}$ とはお互いに交じり合うわけで当然,

$$
\left[\begin{array}{cc}
\psi_{2} & \psi_{3} \\
\frac{\delta_{1}-\delta_{2}}{2}-\frac{J}{4} & \frac{J}{2} \\
\frac{J}{2} & -\frac{\delta_{1}-\delta_{2}}{2}-\frac{J}{4}
\end{array}\right]
$$

という 2 次の matrix を対角化すればいいことになる。すなわち,

$$
\left|\begin{array}{cc}
\frac{\delta_{1}-\delta_{2}}{2}-\frac{J}{4}-E & \frac{J}{2} \\
\frac{J}{2} & -\frac{\delta_{1}-\delta_{2}}{2}-\frac{J}{4}-E
\end{array}\right|=0
$$

という secular determinant を解けばよい.ここで例によって, energy の基準を 2 つの diagonal term の平均值にシフトして

$$
E^{\prime}=E+\frac{J}{4}
$$


とすると式(15.8.18)は

$$
\left|\begin{array}{cc}
\frac{\delta_{1}-\delta_{2}}{2}-E^{\prime} & \frac{J}{2} \\
\frac{J}{2} & -\frac{\delta_{1}-\delta_{2}}{2}-E^{\prime}
\end{array}\right|=0
$$

となる。ここで

$$
\begin{aligned}
& \frac{\delta_{1}-\delta_{2}}{2}=W \cos 2 \theta \\
& \frac{J}{2}=W \sin 2 \theta
\end{aligned}
$$

すなわち

$$
W=\sqrt{\left(\frac{\delta_{1}-\delta_{2}}{2}\right)^{2}+\left(\frac{J}{2}\right)^{2}}
$$

とおく。そうすると secular determinantは

$$
\begin{array}{cc}
\psi_{3} & \psi_{2} \\
\left|\begin{array}{cc}
W \cos 2 \theta-E^{\prime} & W \sin 2 \theta \\
W \sin 2 \theta & -W \cos 2 \theta-E^{\prime}
\end{array}\right|=0
\end{array}
$$

となる。解は直ちに求まる。すなわち

$$
\begin{array}{ll}
\Psi_{3}=(\cos \theta) \psi_{3}+(\sin \theta) \psi_{4}: & E_{3}{ }^{\prime}=+W \\
\Psi_{2}=-(\sin \theta) \psi_{3}+(\cos \theta) \psi_{4}: & E_{2}{ }^{\prime}=-W
\end{array}
$$

すなおち

$$
\begin{array}{ll}
\Psi_{3}=(\cos \theta) \beta_{1} \alpha_{2}+(\sin \theta) \alpha_{1} \beta_{2}: & E_{3}=+W-\frac{J}{4} \\
\Psi_{2}=-(\sin \theta) \beta_{1} \alpha_{2}+(\cos \theta) \alpha_{1} \beta_{2}: & E_{2}=-W-\frac{J}{4}
\end{array}
$$

これで厳密な解が求まったわけである。念のため結果をまとめておこう. 


$$
\begin{array}{ll}
\Psi_{4}=\beta_{1} \beta_{2}: & E_{4}=\frac{\delta_{1}+\delta_{2}}{2}+\frac{J}{4} \\
\Psi_{3}=(\cos \theta) \beta_{1} \alpha_{2}+(\sin \theta) \alpha_{1} \beta_{2}: & E_{3}=W-\frac{J}{4} \\
\Psi_{2}=-(\sin \theta) \beta_{1} \alpha_{2}+(\cos \theta) \alpha_{1} \beta_{2}: & E_{2}=-W-\frac{J}{4} \\
\Psi_{1}=\alpha_{1} \alpha_{2}: & E_{1}=-\frac{\delta_{1}+\delta_{2}}{2}+\frac{J}{4}
\end{array}
$$

ここで，

$$
W=\sqrt{\left(\frac{\delta_{1}-\delta_{2}}{2}\right)^{2}+\left(\frac{J}{2}\right)^{2}}
$$

以上から遷移 energy は簡単に次のように求まる.

\section{遷移} 遷移 energy

$$
\begin{array}{ll}
\Psi_{2} \rightarrow \Psi_{4} & \frac{\delta_{1}+\delta_{2}}{2}+W+\frac{J}{2} \\
\Psi_{1} \rightarrow \Psi_{3} & \frac{\delta_{1}+\delta_{2}}{2}+W-\frac{J}{2} \\
\Psi_{3} \rightarrow \Psi_{4} & \frac{\delta_{1}+\delta_{2}}{2}-W+\frac{J}{2} \\
\Psi_{1} \rightarrow \Psi_{2} & \frac{\delta_{1}+\delta_{2}}{2}-W-\frac{J}{2}
\end{array}
$$

次に遷移確率を求めてみよう。例えば $\Psi_{2} \rightarrow \Psi_{4}$ 遷移については

$$
\begin{aligned}
\left\langle\Psi_{2}|V| \Psi_{4}\right\rangle & =-\sin \theta\left\langle\beta_{1} \alpha_{2}|V| \beta_{1} \beta_{2}\right\rangle+\cos \theta\left\langle\alpha_{1} \beta_{2}|V| \beta_{1} \beta_{2}\right\rangle \\
& =-\sin \theta\left\langle\alpha_{2}\left|V_{2}\right| \beta_{2}\right\rangle+\cos \theta\left\langle\alpha_{1}\left|V_{1}\right| \beta_{1}\right\rangle \\
& =-\frac{g_{\mathrm{N}} \mu_{\mathrm{N}} B_{1 x}(-\sin \theta+\cos \theta)}{2}
\end{aligned}
$$

遷移確率はこの二乗に比例する。すなおち 


$$
\begin{aligned}
\left\langle\Psi_{2}|V| \Psi_{4}\right\rangle^{2} & =\left(\frac{g_{\mathrm{N}} \mu_{\mathrm{N}} B_{1 x}}{2}\right)^{2}(1-\sin 2 \theta) \\
& =\left(\frac{g_{\mathrm{N}} \mu_{\mathrm{N}} B_{1 x}}{2}\right)^{2}\left(1-\frac{1}{2} \frac{J}{W}\right)
\end{aligned}
$$

他の 3 つの遷移についても同様に計算出来る。こうして求めた結果を, 遷移 energy および相対的な遷移確率，すなわち NMRの相対強度をまとめて表 15.8 .1 にまとめて おく.

表 15.8.1 AB スピン系の遷移 energy および相対強度.

ただし遷移 energy は $\frac{\delta_{1}+\delta_{2}}{2}$ を基準にして表している.

遷移

遷移 energy

相対強度
$\Psi_{2} \rightarrow \Psi_{4}$
$W+\frac{J}{2}$
$1-\frac{J}{2 W}$
$\Psi_{1} \rightarrow \Psi_{3}$
$W-\frac{J}{2}$
$1+\frac{J}{2 W}$
$\Psi_{3} \rightarrow \Psi_{4}$
$-W+\frac{J}{2}$
$1+\frac{J}{2 W}$
$\Psi_{1} \rightarrow \Psi_{2}$
$-W-\frac{J}{2}$
$1-\frac{J}{2 W}$

$$
W=\sqrt{\left(\frac{\delta_{1}-\delta_{2}}{2}\right)^{2}+\left(\frac{J}{2}\right)^{2}}
$$

この関係を schematic に示すと図 15.8.3のようになる. 有機化学の教科書に出ている $\mathrm{AB}$ 型スペクトルはこのようにして得られるのである.（Problem 15.8.3） 


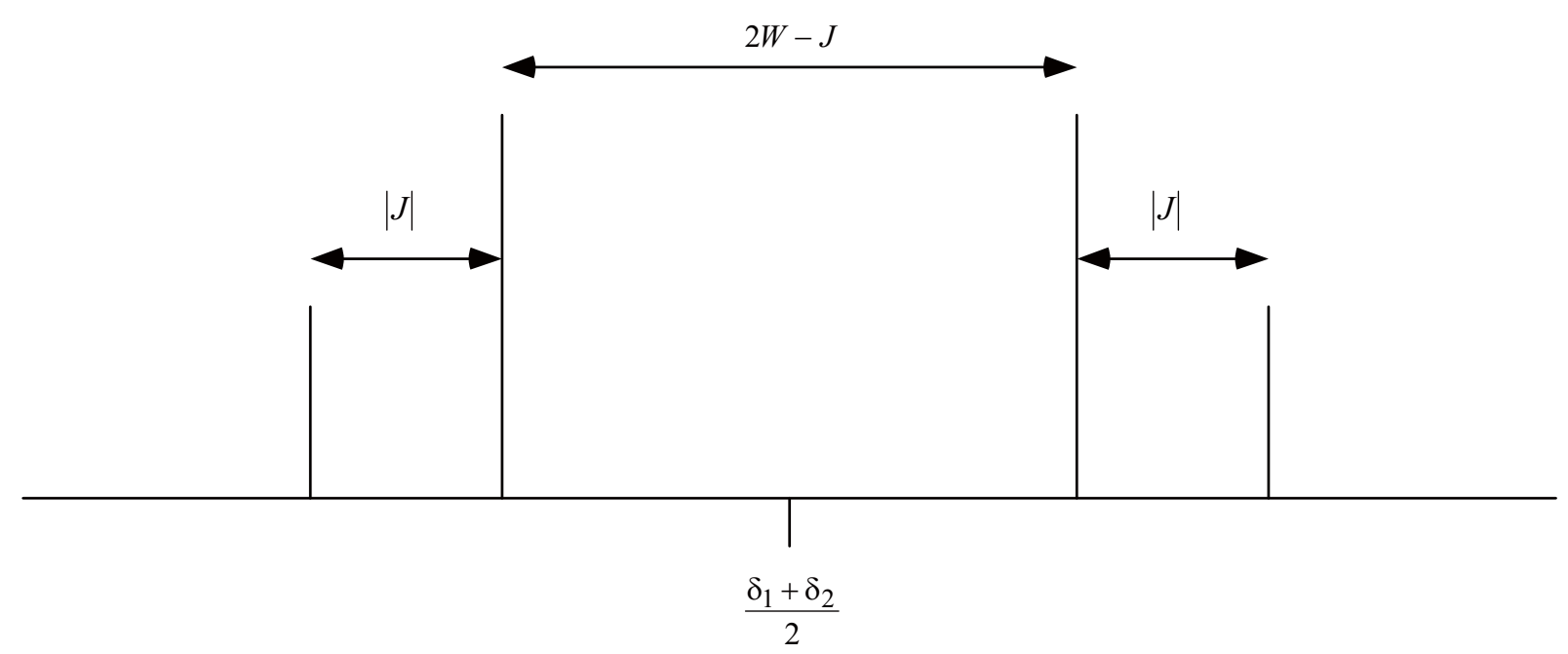

図 15.8.3 AB スピン系のNMR. $\frac{J}{W}>0$ の場合.

図 15.8.3 の結果をもう少し分かり易い形で図示してみよう。上の結果から，NMR のスペクトルおよび強度分布は $J$ と $W$ との比で決まることが分かるが， $W$ が $J$ を含ん でいるので， $J$ と $W$ との比をパラメーターとするのはあまり適切ではなかろう。むし ろ，2つの NMR 線の差 $\delta_{1}-\delta_{2}$ と $J$ との比，すなわち， $\frac{\delta_{1}-\delta_{2}}{J}$ をパラメーターとする のがより適当であろう。このパラメーターをいろいろと変えて NMR のスペクトルを 図示寸るわけであるが，ここで（1）Jを一定とするか，（2） $\delta_{1}-\delta_{2}$ を一定とするか， いずれかに決めて図示するのがより分かり易い. 前者は同一化合物を異なった磁場の もとで（すなわち，異なった spectrometer で）測定することに相当する，一方，後者 は，ある 1 組みの protonについて，結合定数が変化した場合のスペクトルの変化に相 当する. 図 15.8.4 に前者について図示する. 後者については諸君の演習としたい. 


$$
\left(\delta_{1}-\delta_{2}\right) / J=0.0
$$

\begin{tabular}{l|l|l|l}
$\left(\delta_{1}-\delta_{2}\right) / \mathrm{J}=2.0$ & & & $\mid$ \\
\hline
\end{tabular}

\begin{tabular}{l|l|l|l}
$\left(\delta_{1}-\delta_{2}\right) / J=4.0 \quad \mid$ & & & \\
\hline
\end{tabular}

\begin{tabular}{l|l|l|l}
$\left(\delta_{1}-\delta_{2}\right) / J=6.0$ & & & \\
\hline
\end{tabular}

\begin{tabular}{l|l|l|l}
$\left(\delta_{1}-\delta_{2}\right) / J=8.0$ & & & \\
\hline
\end{tabular}

$\left(\delta_{1}-\delta_{2}\right) / J=10.0$

図 15.8.4. $\mathrm{AB}$ スピン系の NMR. J が一定，かつ $\frac{\delta_{1}-\delta_{2}}{J}$ の值が正の場合.

我Problem 15.8.1

2 つの proton 間の相互作用による energy の変化を 2 次の摂動論で計算せよ. 結果を 本 Sectionの（1）の 1 次の摂動論および（3）の峳密解と比較せよ.

动Problem 15.8.2

本 Sectionの（3）の厳密解の energy の式でルートを展開することによって Problem 15.8.1の結果が導かれることを示せ。また，1次の摂動論の結果も吟味すること.

¿ Problem 15.8.3

$\mathrm{AB}$ スピン系の NMR スペクトルの模式図を, 図 15.8.1にならって, $\delta_{1}-\delta_{2}=$ 一定の

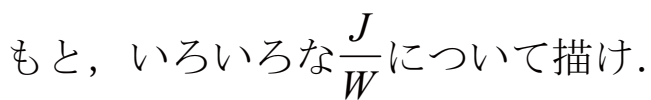

¿ Problem 15.8.4 
水素原子のスピン状態を考える. 電子スピンとして $\alpha_{\mathrm{e}}, \beta_{\mathrm{e}}$ の 2 つの可能性があり，

核スピンとして $\alpha_{\mathrm{N}}, \beta_{\mathrm{N}}$ の 2 つの可能性があるので, 全体として

$\alpha_{\mathrm{e}} \alpha_{\mathrm{N}}, \alpha_{\mathrm{e}} \beta_{\mathrm{N}}, \beta_{\mathrm{e}} \alpha_{\mathrm{N}}, \beta_{\mathrm{e}} \beta_{\mathrm{N}}$ の 4 つのスピン状態が考えられる. 特に相互作用がなければ この 4 つのスピン状態は縮退している. 電子スピンと核スピンとの相互作用があると この縮退は解ける。このありさまを一次の摂動論で吟味せよ．ただし電子スピンと核 スピンとの相互作用の Hamiltonian は次のように取る.

$$
H^{\prime}=a \boldsymbol{S I}=a\left(S_{x} I_{x}+S_{y} I_{y}+S_{z} I_{z}\right)=a\left(\frac{1}{2} S_{+} I_{-}+\frac{1}{2} S_{-} I_{+}+S_{z} I_{z}\right)
$$

なお，これは，ESR スペクトルの超微細構造を計算する演習問題である.

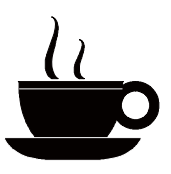

[Coffee Break] NMR の発見について

NMR という, 現在の化学の研究にとって欠くことの出来ない重要な方法を考え出 したのは誰であったろうか. もっとも有名なのは Bloch と Purcell の 2 人で, ほぼ同じ 時期に独立にNMR を見つけることに成功したようである。この 2 人の仕事は，次の 論文に発表されている.

F. Bloch, W. W. Hansen, and M. Packard, Phys. Rev. $\underline{69}, 683$ (1946).

E. M. Purcell, H. C. Torrey, and R. V. Pound, Phys. Rev. $\underline{69}, 37$ (1946).

Bloch と Purcell はこの仕事が認められ，1952 年のノーベル物理学賞を受賞してい る.

しかし，NMR という実験技術を初めて考案したのは Rabi であり，Bloch および Purcell の上述の仕事よりも 8 年も前に次の論文に発表されている.

I. I. Rabi, J. R. Zacharias, S. Millman, and P. Kusch, Phys. Rev., $\underline{53}, 318$ (1938).

Rabi の行った実験というのは，ラジオ波の吸収がある時に，分子線の集まり方が， 大きく変化することを検出することであった. 実は, Section 14.9 の図 14.9.2で示した "resonant" method の一例は, この時の Rabi の仕事であったのである. Rabi はこの仕事 により，すでに 1944 年にノーベル物理学賞を受賞している.

ノーベル賞という大きな賞で報われた Rabi，Bloch，Purcell の他にも，NMR とい う方法に気がついて，それを実験的に見つけようと努力した人がかなりいたであろう と思われる，ただ，そういう悲しい記録というものは，そもそも活字にならないこと 
が多いし，又，仮に記録があったとしてもなかなか人の目につかないものである。し かし，そのまれな記録の一例を紹介しよう。

それは Gorter という人の残念な失敗談であり, Physics Today の 1967 年 1 月号に Gorter 自身が"Bad Luck in Attempts to Make Scientific Discovery"という題の論文に書い ている物語りである。以下，簡単に紹介するが，面白い文なので諸君自ら読んでみる ことを勧めたい.

Gorter は，NMR に関連した緩和現象に関して数多くの優れた功績を残している科 学者である.オランダ人で Chapter 14 のスピン発見のところで紹介した Ehlenfest の研 究室の出身である. Ehlenfest はある時, 現在発展途上のマイクロ波の技術が，科学の 分野でも使われるかもしれないといったことをつぶやいたという。こういう師の言葉 に刺载されたのであろうか，Gorter はNMR を見つけようと考えた。核スピン準位間 にラジオ波の吸収が起れば，系の温度が上昇するであろうから，ラジオ波の周波数を 変えながら系の温度を測定すれば，どこかで急激な温度上昇が見つかるはずであると Gorter は考えた. LiF の結晶を用い, $7 \mathrm{Li}$ の周波数の領域でラジオ波の周波数を変えて みたが，温度上昇を検出することは出来なかった。NMR を見つけることが出来なか ったのは，ラジオ波の吸収が速やかに飽和してしまって（すなわち，2 つのスピン準 位の population が同じになってしまって）それ以上の吸収が起らなかったのであろう と Gorterは報告している.

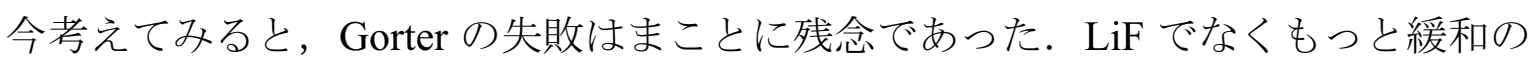
速い，すなわち，飽和の起りにくいものもあったであろう。緩和は結晶中に不純物が 多く入っていると速くなる傾向にあるから，もっと污い結晶を使えば成功していたか もしれない，更に今考えて残念に思うのは，現在の極低温を作る技術があれば，簡単 に温度上昇はみつかったであろうということである。 $300 \mathrm{~K}$ の温度で例えば $10^{-3} \mathrm{~K}$ の

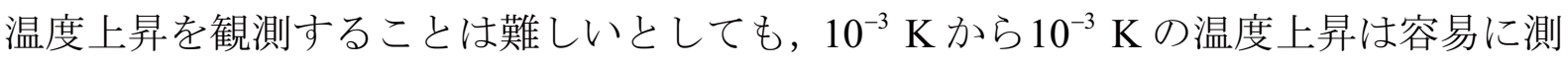
定されるであろう. 現在, $1 \mathrm{mK}$ 程度の極低温の実験をしている人達は, 空中に存在 する色々な電波によって温度が上昇してしまうことに頭を悩ましているのである。そ れで実験室を地下室に作り，しかも部屋全体を何重にも金属でシールしたりするが， それでも完全に電波を遮ることは難しい，そのくらい感度が高いのだから， Gorter が $\mathrm{mK}$ 近辺の極低温を用いることが出来れば，実に容易に温度の上昇を見つけていたで あろう。

以上のようなわけで, Gorterの第一の試みは失敗してしまったが，彼は諦めなかっ た. どうしても NMR を見つけたいという望みを持って，アメリカに渡ったのは 1937 年の夏であった．彼は自分の idea を確かめることが出来る可能性のある場所として 2 つの研究室を考え, そのどちらからも招待されていた. 1 つ上述した Rabi が分子線 の実験をしている Columbia University である. 分子線では, LiF 結晶でNMR の発見 の障害となった飽和というものが起らないであろうから，より適した実験系であると 
考えたのである.もう 1 つは, Michigan State University で, そこでは Cleeton と Williams がマイクロ波分光という新しい spectroscopy を始めており， $\mathrm{NH}_{3}$ のスペクトルなどを 測定していた. Gorterは，ここでマイクロ波を用いれば電子スピン準位間の吸収，す なわち，今の言葉でいう ESR を見つけることが出来るであろうと考えたわけである.

色々考えた末, Michiganに行くことにしたが，それは失敗であったことが後ではっ きりした. Gorter 自身の言葉によると, 秘書が Williamsに Gorter の研究目的を正しく 伝えてくれなかったために, Gorter を丁重に迎えた後, Williams は夏休みの旅行に行 ってしまった。（本当にある種の欧米人は長い長い夏休みを取るのだから！）研究室 に残っていたのは, part timeの technician だけであり, その人は何も知らなかった. それで Gorter はやることがなくなり, 研究は諦め, 丁度 Michigan で行われていた summer school に出席し，Fermi やUhlenbeckなどの lecture を楽しんだ.

さて, 所定の滞在期間が終り, オランダに帰る途中, New York の Rabi の研究室へ 立ち寄り，分子線の装置を見せてもらった，そこで分子線が磁場の中を通過する装置 を見た Gorter は直ちにそこにラジオ波を照射することによってNMRを見つけること が出来るはずであると考えた．Gorter はそのことをRabi に言ったが，Rabi はともか く考えておくと言ったそうである. Gorter はそのうち Rabi が Leiden に訪衩てきて, その計画について，もっと詳しく打ち合せをしてくれるものと思っていたようだ．し かし，そういうこともなく，数力月後に Physical Review でRabi の上述した論文を見 てびっくりしたようである，ノーベル賞受賞の原因となったこの論文の中で Rabi は， この実験を suggest してくれた Gorter に感謝するという謝辞を述べてはいるが，それ でも Gorter としては自分の功績が under evaluate されたような気持ちを捨て去ること は出来なかったみたいである. せっかくいいidea を持っていたにもかかわらず，ちょ っとした偶然のために Gorter はノーベル賞を逸してしまったのである.どんな偉大な 発見にも，このようなことはあるものである。しかし，その本人にとっては相当に残 念なことであったろう。

さて, NMR の発見に関しては, Gorter のことは知られていないにせよ, 少なくと も Rabi, Bloch, Purcell と 3 人のノーベル賞物理学賞者はよく知られている. では, ESR はどうであろうか. ESR の発見については，通常の教科書にはほとんど述べられ ていない，話によると，ロシアの Zaboisky という人が 1945 年頃始めて見つけたとの ことである。しかし，NMR 発見の陰に隠れてしまって，Zaboisky の功績はあまり有 名とはならなかったようである. 


\title{
CHAPTER 16
}

\author{
原子構造
}

この章では， $\mathrm{H}$ 以外の原子，すなわち，電子が 2 個以上ある原子の構造（原子の中 の電子の振る舞いを総称して「原子構造」という言葉で表す）について考える。多く の化学者にとっては原子よりも分子の方がより興味があるであろうが，分子の取り扱 いは原子の取り扱いのほぼ単純な拡張で考えられる場合が多いので原子の問題をち やんと理解しておくと分子への拡張はきわめて容易である.

ところが理論の展開は今まで簡単な系について行って来た理論とはかなり異なる. 今までは，何か解きたい系について Hamiltonian を書き下し，その Hamiltonian の eigenvalue と eigenfunction を正確に求めることを考えた。この方法で, 直線運動をし ている自由粒子（Chapter 6), 円運動をしている自由粒子（Chapter 8), 調和振動子 (Chapter 7)，水素原子（Chapter 9）などについて正確な eigenfunction や eigenvalue を求めて来た。しかし，電子が 2 個以上存在する系については，Hamiltonianの解を正 確に求めることはもはや出来ない，そこで近似的に解くことしかあり得ない。考えら れる近似法としては，変分法と摂動論がある。すでに学習したように，変分法におい ては何等かの trial function を決める必要がある. 摂動論では Hamiltonian の一部を $H_{0}$ として $H_{0}$ の解を求めておく必要がある。いずれの場合も，どういう trial function（変 分法の場合), またはゼロ次の wavefunction（摂動論の場合）から出発すればより正確 な解が得られるであろうか，ということについての化学的なものの見方が要求され る。与えられた Hamiltonian を正確に解くという数学的手法だけでは役立たず，もは や数学者には手の付けられない, 化学者が自分で解決していかなければならない問題 である。

\section{1 原子単位}

原子や分子の問題を取り扱うには原子単位（atomic unit）という単位系を用いると 便利であり，広く用いられている。それで，本論に入る前にこの単位系のことを学習 しておこう。

原子単位系では次のような単位系を採用する.

$$
\hbar=1
$$




$$
\begin{array}{ll}
m_{\mathrm{e}}=1 & \text { (電子の質量を単位とする) } \\
e=1 & \text { (電気素量を単位とする) } \\
4 \pi \varepsilon_{0}=1 &
\end{array}
$$

原子や分子に関するすべての物理量は上述の 4 つの基本単位で表すことが出来る. 例えば Bohr 半径 $a_{0}$ は

$$
a_{0}=4 \pi \varepsilon_{0} \frac{\hbar}{m_{\mathrm{e}}^{2}}=1 \text { atomic unit }
$$

のように表されるが，これが長さに関する原子単位で，しばしば"bohr"という単位で 呼ばれる。水素のイオン化ポテンシャルの 2 倍は，次のようになる.

$$
E=\frac{m_{\mathrm{e}}{ }^{4}}{\left(4 \pi \varepsilon_{0}\right)^{2} \hbar^{2}}=1 \text { atomic unit }
$$

これは，エネルギーに関する原子単位で，しばしば"hartree"と呼ばれる。すなわち， 水素原子の基底状態のエネルギーはー $\frac{1}{2}$ hartree である.

约Exercise 16.1.1

エネルギーの原子単位である hartree を（1） J,（2） $\mathrm{kJ} / \mathrm{mol} ， （ 3 ） \mathrm{~cm}^{-1}$ ，（4） $\mathrm{eV}$ 単 位で表せ。

\section{【解】:}

（1） $m_{\mathrm{e}}, e, \varepsilon_{0}, \hbar$ SI 単位系で表した量

$$
\begin{aligned}
& m_{\mathrm{e}}=9.109534 \times 10^{-31} \mathrm{~kg} \\
& e=1.602189 \times 10^{-19} \mathrm{C} \\
& \varepsilon_{0}=8.954187 \times 10^{-12} \mathrm{~J}^{-1} \mathrm{C}^{2} \mathrm{~m}^{-1} \\
& \hbar=1.05489 \times 10^{-34} \mathrm{Js} \\
& .1 .6) \text { に代入することにより } \\
& 1 \text { hartree }=4.3598 \times 10^{-18} \mathrm{~J}
\end{aligned}
$$

を式(16.1.6)に代入することにより

を得る。

（2）上で求めた值に Avogadro 定数 


$$
N_{0}=6.022045 \times 10^{23} \mathrm{~mol}^{-1}
$$

を掛けることにより

$$
\begin{aligned}
1 \text { hartree } & =\left(4.3598 \times 10^{-18} \mathrm{~J}\right) \times\left(6.022045 \times 10^{23} \mathrm{~mol}^{-1}\right) \\
& =2625 \mathrm{~kJ} / \mathrm{mol}
\end{aligned}
$$

を得る。

（3）J 単位で表されたエネルギーを $\mathrm{cm}^{-1}$ 単位で表すには $c$ と $h$ の積で割ればよい.

$$
\begin{aligned}
& c=2.9979 \times 10^{8} \mathrm{~m} / \mathrm{s} \\
& h=6.626176 \times 10^{-34} \mathrm{Js}
\end{aligned}
$$

より

$$
\begin{aligned}
1 \text { hartree } & =\frac{4.3598 \times 10^{-18} \mathrm{~J}}{\left(2.9979 \times 10^{8} \mathrm{~m} / \mathrm{s}\right) \times\left(6.626176 \times 10^{-34} \mathrm{Js}\right)} \\
& =2.1948 \times 10^{7} \mathrm{~m}^{-1} \\
& =2.1948 \times 10^{5} \mathrm{~cm}^{-1}
\end{aligned}
$$

を得る。

(4) $\mathrm{eV}$ というのは，電気素量 $e$ を持つ電荷を電圧 $V$ に逆らって無限遠に運ぶに要す る仕事である。従って

$$
1 \mathrm{eV}=\left(1.602 \times 10^{-19} \mathrm{C}\right) \times(1 \mathrm{~V})=1.602 \times 10^{-19} \mathrm{~J}
$$

である。この換算因子より

$$
1 \text { hartree }=27.212 \mathrm{eV}
$$

を得る。

\section{2 軌道の概念}

電子が 2 個以上存在すると，どういう所に理論的なむずかしさが生ずるか， He 原 子を例として考えてみよう。言うまでもなく, $\mathrm{He}$ 原子は $Z=+2$ の電荷を持つ原子核 と電子 2 個からなる。原子核の質量は無限大で動かないという近似のもとで Hamiltonian を書き下ろすと次のようになる。

$$
H=-\frac{\hbar^{2}}{2 m_{\mathrm{e}}}\left(\nabla_{1}^{2}+\nabla_{2}^{2}\right)-\frac{1}{4 \pi \varepsilon_{0}} \frac{Z e^{2}}{r_{1}}-\frac{1}{4 \pi \varepsilon_{0}} \frac{Z e^{2}}{r_{2}}+\frac{1}{4 \pi \varepsilon_{0}} \frac{e^{2}}{r_{12}}
$$


ここで $\nabla_{1}$ おび $\nabla_{2}$ は，それぞれ，電子 1 および 2 に関する Laplacian operator， $r_{1}$ およ び $r_{2}$ はこれら電子と原子核との距離， $r_{12}$ は電子 1 と 2 の間の距離を示す. He の場合, 原子核の電荷 $Z$ は当然 2 であるが，後のことを考えてここでは変数のまま $Z$ としてい る. Section 16.1 で導入した原子単位系ではこの Hamiltonian は次のようになる.

$$
H=-\frac{1}{2}\left(\nabla_{1}^{2}+\nabla_{2}^{2}\right)-\frac{Z}{r_{1}}-\frac{Z}{r_{2}}+\frac{1}{r_{12}}
$$

ここで

$$
\begin{aligned}
& H(1)=-\frac{1}{2} \nabla_{1}^{2}-\frac{Z}{r_{1}} \\
& H(2)=-\frac{1}{2} \nabla_{2}^{2}-\frac{Z}{r_{2}}
\end{aligned}
$$

とおくと，

$$
H=H(1)+H(2)+\frac{1}{r_{12}}
$$

となる。ここで $H(1)$ おび $H(2)$ はそれぞれ電子 1 および 2 のみの座標を含む Hamiltonian であるが，それぞれ何を表すかというと， $Z=2$ の電荷を持つ原子核のク 一ロン力を受けて運動している 1 個の電子の Hamiltonian である. すなわち, $\mathrm{He}^{+}$とい う水素類似原子についての Hamiltonian である.もし仮に式(16.2.5)の Hamiltonian のう ち, 第 3 項の $\frac{1}{r_{12}}$, 寸なわち電子反発の項がなければ, Hamiltonian は $2 つ の ~ \mathrm{He}^{+} に つ$ いての Hamiltonian の和であるから， wavefunction は $\mathrm{He}^{+} の$ wavefunction の積である. 電子間反発 $\frac{1}{r_{12}}$ を無視するなんていうことはとても出来ないが，このまま，もう少し 話を進めてみよう。H(1)の eigenfunction は, すでに学習したように, spatial wavefunction の部分が $n, \ell, m$ という量子数で, spin wavefunction の部分が $m_{s}$ という 量子数で表されるから, 合わせて $, n, \ell, m, m_{s}$ という 4 つの量子数でもって表さ れる. $H(2)$ の eigenfunction についても同様である. 従って $H(1)+H(2)$ につての eigenfunction は, 1 つの $\mathrm{He}^{+}$についての量子数のセット $\left(n, \ell, m, m_{s}\right)_{1}$ ともう 1 つの $\mathrm{He}^{+}$ 
についての量子数のセット $\left(n, \ell, m, m_{s}\right)_{2}$ との組み合せとして, 状態を記述出来る.

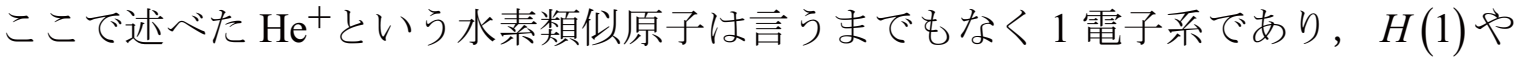
$H(2)$ の eigenfunction は仮想的な 1 電子系についての量子状態を示している.一般に $n$ 電子の原子について, $n-1$ 個の電子を取り去った 1 電子系の水素類似原子の eigenfunction を「軌道」(orbital)という言葉で表す. $\left(n, \ell, m, m_{s}\right)_{1}$ は 1 つの軌道について の量子数のセットであり, $\left(n, \ell, m, m_{s}\right)_{2}$ はもう 1 つの軌道についての量子数のセットで ある、そこで, $\left(n, \ell, m, m_{s}\right)_{1},\left(n, \ell, m, m_{s}\right)_{2}$ という量子数で表される状態を，しばしば， 1 つの電子が $\left(n, \ell, m, m_{s}\right)_{1}$ という軌道に「入り」, もう 1 つの電子が $\left(n, \ell, m, m_{s}\right)_{2}$ という 軌道に「入る」という言葉で表現する。例えば $H(1)$ の eigenfunction が $\left(n, \ell, m, m_{s}\right)_{1}=\left(1,0,0, \frac{1}{2}\right)_{1}=(1 s \alpha)_{1}, \quad H(2)$ の eigenfunction が $\left(n, \ell, m, m_{s}\right)_{2}=\left(1,0,0,-\frac{1}{2}\right)_{2}=(1 s \beta)_{2}$ という状態であったとする. $H(1)+H(2)$ の eigenstate は $(1 s \alpha)_{1}(1 s \beta)_{2}$ と表されることになるが，このような状態を記述するのに， 1 個の電子が $1 s \alpha$ という軌道に入り，もう 1 つの電子が $1 s \beta$ という軌道に入る，という 表し方をする。「軌道」というものはこの概念では，電子を入れる「容れもの」とみ な寸べきものである.

軌道という言葉はすでに Section 9.7 で水素原子のところで導入し, 学習している. そこでは，水素原子の eigenfunction をそのまま軌道であるという言い方をしている. 軌道というのが 1 電子系の wavefunction であるのだから， H 原子についてはその eigenfunction をそのまま軌道といってよかったのである。しかし， H 原子についても 軌道を電子の容れものとみなして，例えば電子が $1 s \alpha$ という軌道に「入っている」と いう言い方をしてもいいのである. どういう言葉使いをしょうとも，水素原子の場合 には，軌道そのものが原子の eigenfunction である。しかし，電子が 2 個以上ある系で は軌道というものは原子の eigenfunction でもないし，それに近いものでもない. $n$ 電 子を持つ原子の場合には， $n-1$ 個の電子を取り去ったイオンについての eigenfunction が「軌道」であり，こうして求めた軌道という容れものに $n$ 個の電子を入れたものが, 
原子の状態を表す eigenfunction に近いものであり，「配置」(configuration)という言葉 で表される。もちろん，これが原子の eigenfunction にはなっていない.というのは， 今までの議論では電子間反発をすべて無視して来たからである。電子間反発を入れ た，正しい eigenfunction は正確には得ることが出来ず，正確な解に出来るだけ近いも のを変分法または摂動論で求めることになろうが, 少なくとも上述したような方法で 求めた configuration は変分法や摂動論の出発点とは使い得るものであろう。

以上，多電子系の原子における「軌道」と「配置」は重要な概念であるからくどい ほど詳しく述べた。十分に理解してほしい.

\section{3 スピン軌道 (spin-orbital)}

前節で，1 電子系の原子についての eigenfunction を軌道と定義した。そしてこの軌 道を表す量子数として $, n, \ell, m, m_{s}$ の 4 つをあげたが，この 4 つの量子数でもつ て 1 つの軌道を表すのか, 又は，スピンの量子数 $m_{s}$ を含めず， $n, \quad \ell, m$ のつのみ で軌道を表すのかという点については，人により場合により微妙に異なる。というよ りは，この 2 つの方法が存在し，それぞれの場合によって記述しやすい方を使うとい うのが正しい言い方かもしれない。もし軌道を $n, \ell, m$ だけで記述する場合には,

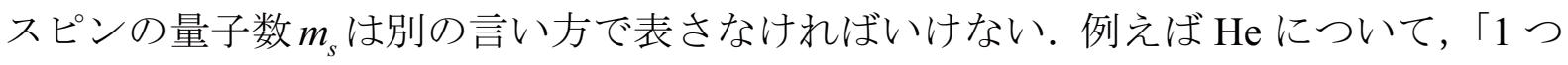
の電子が $1 s \alpha$ という軌道に入り，もう 1 つの電子が $2 s \beta$ という軌道に入る.」という言 い方をする代りに「 $\alpha$ spin を持つ 1 つの電子が $1 s$ という軌道に入り， $\beta$ spin を持つ もう 1 つの電子が $2 s$ という軌道に入る」という言い方をする場合もある．単なる言い まわしのことであるからどちらでもいいのであるが，どちらの方式で表しているの か，といらことがあいまいになると困ることがある.それで，はっきりさせるために， 軌道を表す量子数の中にスピン量子数 $m_{s}$ が含まれている場合に, この軌道のことを 「スピン軌道（spin-orbital）」という特別な言葉で表すことが多い. 単に「軌道」とい うとスピンを含まない場合の方が多いかもしれない. 前節では, Section 14.4 の概念を

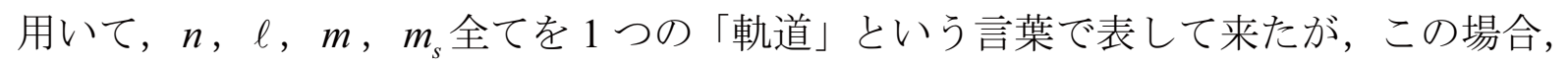

むしろ「スピン軌道」という言葉を用いた方がよかったかもしれない. 本講義でも以 後は, spin 量子数までを含む場合は spin-orbital, 含まない場合についてのみ orbital と いうように使い分けることにする. 


\section{4 パウリ原理とスレーター行列式}

Section 16.2 で述べたように，多電子系の原子の eigenfunction を表すための出発点 として配置（configuration）というものを考えなければならない。この configuration は, Hamiltonian の中の電子間反発を除いたものについての eigenfunction にはなってい るが，全 Hamiltonianの eigenfunction にはなっていないことは繰り返し述べたことで ある. 従って, 正しい eigenfunctionに近いものは変分法または摂動論で求めていくこ とになろう。これに際して, 当然, configuration を数式（この場合も wavefunction と いう言葉を用いる）で表さなければならない，以下このことを考える.

configuration を wavefunction という数式で表す場合の基本的要請が 2 つる. もつ とも大切なことは，2 個以上存在する電子を我々は区別することが出来ないというこ とである. He 原子は電子 2 個を持つが，これが 1 番目の電子でこれが 2 番目の電子， というふうに区別が付けられないわけである。このことを wavefunction の中にどうや って取り込むかが問題である。もう 1 つの基本的な要請は， wavefunction をある種の 演算子の固有関数として選んでおくということである。これは何が何でも絶対そうし なければいけないというわけではないが，そうとっておくと何かと便利である。では じういう演算子の固有関数にするかというと，通常は，全 Hamiltonian $H$ と可換な演 算子 $L^{2}, L_{z}, S^{2}, S_{z}$ の 4 つを選ぶのが普通である. 以上述べた 2 つ要請のうち,

以下ではまず，第 1 の，電子はお互いに区別が付かない，ということを如何にして wavefunction の中に取り入れるかについて学習する. 第 2 の問題は少々後で学習する ことにしよう.

話を簡単にするために再び He 原子を考えよう. Hamiltonian は式(16.2.5), すなわち

$$
H=H(1)+H(2)+\frac{1}{r_{12}}
$$

であるが， configuration は $H(1)+H(2)$ の eigenfunction である. Hamiltonian が $H(1)$ と $H(2)$ の和であるから,この部分の eigenfunction は当然, $H(1)$ の eigenfunction と $H(2)$ の eigenfunction との積となる, と思われる。例えば，電子 1 ，すなわち $H(1)$ の eigenfunction $の$ spin-orbital を $\phi_{a}(1)$, 電子 2 , すなわち $H(2)$ の eigenfunction $の$ spin-orbital を $\phi_{b}(2)$ とする. かっこ内の数字 1 および 2 は電子の番号であり， $\phi$ の subscript とし ての $a$ や $b$ は 4 つの量子数 $n, \ell, m, m_{s}$ の組を表すとする. 結局, $H(1)+H(2)$ に対 
する wavefunction として，

$$
\psi(1,2)=\phi_{a}(1) \phi_{b}(2)
$$

とすればよさそうに思える。しかし，この式は電子 1 と 2 を区別出来ないと意味はな い. 我々は，電子が 2 つることは分かっているが，その 2 つの電子のそれぞれを， これは電子 1 , これは電子 2 , というように区別することは出来ない. 従って式(16.4.2) と

$$
\psi(2,1)=\phi_{a}(2) \phi_{b}(1)
$$

との適当な linear combination を考えなければならない.

この際大切なことは，電子は Fermi 粒子であるということである. Fermi 粒子であ るから，2つの電子の交換によって wavefunction は符号を変えなければいけない.（す なわち，電子の交換に対して antisymmetric でなければいけない.） $\psi(1,2)$ と $\psi(2,1)$ と の組み合せで，このような条件を満たす関数は直ちに分かる．すなわち，規格化定数 まで含めて,

$$
\begin{aligned}
\psi & =\frac{1}{\sqrt{2}}\{\psi(1,2)-\psi(2,1)\} \\
& =\frac{1}{\sqrt{2}}\left\{\phi_{a}(1) \phi_{b}(2)-\phi_{b}(1) \phi_{a}(2)\right\}
\end{aligned}
$$

となる。

2 電子系の場合は簡単であったが，電子の数が多くなると，このような関数を書き 下寸のはそう簡単ではない。例えば Li のような 3 電子系を考える.

$$
\psi(1,2,3)=\phi_{a}(1) \phi_{b}(2) \phi_{c}(3)
$$

とした時, この他に $\psi(1,3,2), \psi(2,1,3), \psi(2,3,1), \psi(3,1,2), \psi(3,2,1)$ の 5 つの関 数があり，都合 6 つの関数の linear combination で，電子 1 と 2 の交換， 1 と 3 の交換， 2 と 3 の交換，いずれの交換についても antisymmetric となるような関数を目の子で書 き下ろすのはそう簡単ではあるまい。電子の数が多くなって，例えば電子 6 個を持つ $\mathrm{C}$ 原子位になると，6!=720 個の関数の linear combination を取らなければならず，書く だけで大変な手間となろう。

どの電子の組をとっても，2つの電子を交換すると符号が変るような関数を簡単に 書き下せないものであろらか?この答は，行列式の性質を思い出せば直ちに求まる．2 電子系の wavefunction である式(16.4.4)は次のような行列式 (determinant) で表される ことに気がつくであろう。 


$$
\psi=\frac{1}{\sqrt{2}}\left|\begin{array}{ll}
\phi_{a}(1) & \phi_{a}(2) \\
\phi_{b}(1) & \phi_{b}(2)
\end{array}\right|
$$

電子 1 と 2 を交換するということは，上の行列式において 2 つ列を交換することに 相当する. 行列式で 2 つ行または 2 つ列を交換すれば符号が反転することはよく 知られている通りである. 従って, wavefunction をこのような行列式で表すと, 電子 が Fermi 粒子であるという要請が自動的に満たされている。この方式に従うと，電子 が何個あっても簡単である. 例えば 3 電子系では,

$$
\psi=\frac{1}{\sqrt{3 !}}\left|\begin{array}{lll}
\phi_{a}(1) & \phi_{a}(2) & \phi_{a}(3) \\
\phi_{b}(1) & \phi_{b}(2) & \phi_{b}(3) \\
\phi_{c}(1) & \phi_{c}(2) & \phi_{c}(3)
\end{array}\right|
$$

となる。一般に $n$ 電子系では

$$
\begin{aligned}
& \psi=\frac{1}{\sqrt{n !}}\left|\begin{array}{lllll}
\phi_{1}(1) & \phi_{1}(2) & \phi_{1}(3) & \ldots \ldots & \phi_{1}(n) \\
\phi_{2}(1) & \phi_{2}(2) & \phi_{2}(3) & \ldots \ldots & \phi_{2}(n) \\
\ldots \ldots \ldots & & & & \\
\ldots \ldots \ldots & & & & \\
\phi_{n}(1) & \phi_{n}(2) & \phi_{n}(3) & \ldots . & \phi_{n}(n)
\end{array}\right| \\
& =\frac{1}{\sqrt{n !}} \sum(-1)^{P} P \phi_{1}(1) \phi_{2}(2) \ldots \phi_{n}(n) \\
& =\left|\phi_{1}(1) \phi_{2}(2) \ldots \phi_{n}(n)\right|
\end{aligned}
$$

となる。式(16.4.8)では，式(16.4.6)や式(16.4.7)で $\phi_{a}, \phi_{b}, \phi_{c}, \ldots$ としたものを $\phi_{1}, \phi_{2}$ ， $\phi_{3}, \ldots$ とした. spin-orbital $\phi$ の番号付けも $1,2,3 \ldots$ と, 電子の番号付けも $1,2,3 \ldots$ のようにしたが，この2つを混乱しないように気をつけてほしい.

式(16.4.8')は行列式の書き表し方の一つである。Pは電子を交換（permutation）す る operator を示す. $\Sigma$ は $n$ !個の可能な permutationすべてについての和を取ることを示 す. $(-1)^{P}$ は偶の permutation については正, 奇の permutation については負の符号を取 ることを示す．また，式(16.4.8")は式(16.4.8)の行列式全体を書くのが面倒なので，そ の対角項のみを書き並べた形として表すという簡便法による表し方である。この場 合, normalization factor の $\frac{1}{\sqrt{n !}}$ は書いてないが，それはミスプリントではない. 式 
(16.4.8")で, normalization factor を含んだ式(16.4.8)および式(16.4.8')と全く同じ内容を 示すことを特に注意しておきたい.

電子の交換に関して antisymmetric な wavefunction を表す上述したような行列式を スレーター行列式（Slater determinant）という.

\section{【注意】：}

原子の波動関数を表すのに，水素類似原子の波動関数の代りに，しばしば"Slater orbital"と言われる関数が使われる. Slater orbital と Slater determinant. どちらもあの有 名な人の名前がついているがこの 2 つは全く別のものである．混乱しないように.

多電子系の原子の wavefunction を Slater determinant で表してみると，もう1つ，非 常に重要なことに気がつく.式(16.4.8)は $n$ 個の電子が $\phi_{1}, \phi_{2}, \ldots, \phi_{n}$ の $n$ 個の spin-orbital に収容されている場合の wavefunction を示しているが，もし2つ（又は2つ以上）の 電子が 1 つの spin-orbital に入るとどうなるであろうか. そうなると Slater determinant の 2 つ又はそれ以上の行が完全に等しいということになる. 行列式において 2 つの行 又は 2 つ列が完全に同じであればその行列式の值はゼロになる．すなわち，2 つ又 は3つ以上の電子が 1 つの spin-orbital に収容されるような configuration は存在しない. このことは「Pauli 原理」(Pauli principle) としてよく知られているが，このことは， 電子が Fermi 粒子である，ということから必然的に導かれるのである．又は，Pauli 原 理というものは，電子が Fermi 粒子であるということと全く同じものである，という ことも出来る.

[Coffee Break] Pauli は実験が苦手?

Pauli 原理の生みのである Pauli は理論家として有名であるが，実験の方は全く出来 なかったという，嘘か本当か全く分からない言い伝えがある．Pauli 自身が実験の能 力がなかっただけでなく，Pauli がそばに来ただけで実験装置が壊れてしまうという 話まで伝わっている。分子軌道法の生みの親である Robert Mulliken が，"Molecular Scientists and Molecular Science: Some Reminiscences"という思い出話を J. Chem. Phys. 43 (1965) S2 に書いている. 国際会議の時の招待講演を印刷したものらしいが，その 中に次のような一節がある。

After that I visited Zürich, where I went to call on Schrödinger. I recall that while I was talking with him his chair collapsed, not for any good reason, this being a type 
of phenomenon that would be associated with the name of Pauli. エピソードのことを何も知らなければ,この" this being a type of phenomenon that would be associated with the name of Pauli"という言葉の意味も分からないだろうが，実は，こ れは Pauli が近くにいたために椅子が壊れたという, Pauli にとっては不名誉な噂のこ とを意味しているのである。

また，小出昭一郎著「量子力学」(裳華房）の 8 頁には「Gamowによれば Pauli が 近くに来ただけでも実験装置が動かなくなることがしばしばあったという」という記 述がある。ささら，この他にも，出典は記憶していないが，ある時どういうわけか実 験装置の調子が突然に悪くなってしまった。後から分かったことは, Pauli が丁度そ の時刻に，汽車に乗ってその町のそばを通ったということである，といった，Pauli にとっては甚だ迷惑な話もある。

こんなたわいのない話であるが，こういうエピソードのこと位知っていないと，上 に例としてあげた Mullikenの話の中の"this being a type of phenomenon that would be associated with the name of Pauli"といった文も何を言っているのか分からない，という ことになってしまう。

\subsection{He の基底状態のエネルギー（ I ）：摂動論による取り扱い}

やっと準備が出来たので，いよいよ具体的な例として He 原子の基底状態を考えて みよう。この節ではまず摂動論を用いた取り扱いを学習し，次の節で変分法を用いる ことにしよう。以下扱うことは，どんな教科書にも必ず出ている基本的なことで，例 えば Atkins の"Molecular Quantum Mechanics"では p.223-229に，また Eyring, Walter, Kimball の"Quantum Chemistry"ではp.102-104 に記述がある。ただ，これら 2 つを含む 多くの教科書では He の基底状態を扱う場合，スピンのことを全然考えていない. 3 電子以上の系では，スピンのことをあらわに考えないと大変なことになるのだが，2 電子系の，しかも $1 s^{2}$ という configuration では，スピンを考えなくても実質的な問題 は出て来ないということで，簡単のためにスピンのことを省いてしまっているらし い.しかし「 $\mathrm{He}$ の基底状態を扱うにはスピンは不要で励起状態を扱うにはスピンを 考慮しないといけない」とか，「He の基底状態ではスピンを考慮しなくていいが $\mathrm{Li}$ の基底状態ではスピンを考慮しなければいけない」といったことを説明されてもそん なことが納得出来るはずはない，理論的に筋道が立つ方法は，やはり，電子数がいく つであろうと，または基底状態であろうと励起状態であろうと，統一的に扱えないと いけないであろう。そういう観点からここでは，首尾一貫してスピンのことを考えて 扱うことにする。 この点について, 本 lecture note は通常の教科書と大きく異なる方式 をとっている. 
He についての Hamiltonian は原子単位系では，すでに式(16.2.2)に示したように，

$$
H=-\frac{1}{2}\left(\nabla_{1}^{2}+\nabla_{2}^{2}\right)-\frac{Z}{r_{1}}-\frac{Z}{r_{2}}+\frac{1}{r_{12}}
$$

となる. 摂動論を適用するにはこの $H$ を $H_{0}$ と $H^{\prime}$ とに分けなくてはいけない. 分ける 際の要請としては，（1） $H_{0}$ の eigenfunction を求め得る，ということと，（2） $H^{\prime}$ の補 正が $H_{0}$ に比べて小さいということである．一般的なこのような要請を両方とも満足 することは至難の業である．ただ， $H_{0}$ の eigenfunction を解くことが出来なければど うにもしようがないので（1）の条件を優先して次のように取ることとしよう.

$$
\begin{aligned}
H_{0} & =\left(-\frac{1}{2} \nabla_{1}^{2}-\frac{Z}{r_{1}}\right)+\left(-\frac{1}{2} \nabla_{2}^{2}-\frac{Z}{r_{2}}\right) \\
& =H(1)+H(2) \\
H^{\prime} & =\frac{1}{r_{12}}
\end{aligned}
$$

こうおいた時 $H^{\prime}$ が小さい補正であるかは大いに疑問である。実際，電子間反発の項 は残りの項とほとんど同じ位の寄与を与える。そういうわけでこのままで摂動論を押 し進めば，あまりいい結果は期待出来ないということは始めからはっきりしている. しかし，摂動論を用いる限り，他の $H_{0}$ の選び方はあり得ないように思われる.

Ho eigenfunction $\psi^{0}(1,2)$ は, Slater determinant を用いて

$$
\begin{aligned}
\psi^{0}(1,2) & =\frac{1}{\sqrt{2}}\left|\begin{array}{ll}
\phi_{1 s \alpha}(1) & \phi_{1 s \alpha}(2) \\
\phi_{1 s \beta}(1) & \phi_{1 s \beta}(2)
\end{array}\right| \\
& \equiv\left|\phi_{1 s \alpha}(1) \phi_{1 s \alpha}(2)\right|
\end{aligned}
$$

となる.ここで $\phi$ は spin-orbital を示す.すなわち

$$
\begin{aligned}
& \phi_{1 s \alpha}(1)=\psi_{1 s}(1) \alpha(1) \\
& \phi_{1 s \beta}(1)=\psi_{1 s}(1) \beta(1)
\end{aligned}
$$

は電子 1 についての spin-orbital で, 電子 2 についてのそれも同様に定義される. $\psi_{1 s}(1)$ および $\psi_{1 s}(2)$ は,それぞれ, 電子 1 および 2 についての $Z=2$ の hydrogen-like atom $\mathrm{He}^{+}$ 
の固有関数（すなわち He 原子の orbital）であり，空間座標 $r$ のみの関数である（ $s$ 軌 道であるから $\theta$ および $\phi$ 依存性はない)。すなおち

$$
\begin{aligned}
& \psi_{1 s}(1)=\sqrt{\frac{Z}{\pi}} e^{-Z r_{1}} \\
& \psi_{1 s}(2)=\sqrt{\frac{Z}{\pi}} e^{-Z r_{2}}
\end{aligned}
$$

摂動計算を始める前に，まず式(16.5.4)の wavefunction が $\boldsymbol{L}^{2}, L_{z}, S^{2}, \quad S_{z}$ すべての operatorの eigenfunction になっていることを確かめておこう。ここで, 上述した operator は 2 電子系の operator であるから，電子 1 の operator と電子 2 の operator の和となる. すなわち，今さら書く必要もないとは思うが，念のため書いておくと，

$$
\begin{aligned}
& \boldsymbol{L}^{2}=L_{z}{ }^{2}+\frac{1}{2} L_{+} L_{-}+\frac{1}{2} L_{-} L_{+} \\
& \boldsymbol{S}^{2}=S_{z}{ }^{2}+\frac{1}{2} S_{+} S_{-}+\frac{1}{2} S_{-} S_{+}
\end{aligned}
$$

において

$$
\begin{aligned}
& L_{z}=L_{z}(1)+L_{z}(2) \\
& L_{+}=L_{+}(1)+L_{+}(2) \\
& L_{-}=L_{-}(1)+L_{-}(2) \\
& S_{z}=S_{z}(1)+S_{z}(2) \\
& S_{+}=S_{+}(1)+S_{+}(2) \\
& S_{-}=S_{-}(1)+S_{-}(2)
\end{aligned}
$$

となるわけである。

例えば， $S_{z}$ を作用してみよう。

$$
\begin{aligned}
& S_{z}\left|\psi_{1 s}(1) \alpha(1) \psi_{1 s}(2) \beta(2)\right| \\
& =\left|\psi_{1 s}(1)\left\{S_{z}(1) \alpha(1)\right\} \psi_{1 s}(2) \beta(2)\right|+\left|\psi_{1 s}(1) \alpha(1) \psi_{1 s}(2)\left\{S_{z}(2) \beta(2)\right\}\right| \\
& =\frac{\hbar}{2}\left|\psi_{1 s}(1) \alpha(1) \psi_{1 s}(2) \beta(2)\right|-\frac{\hbar}{2}\left|\psi_{1 s}(1) \alpha(1) \psi_{1 s}(2) \beta(2)\right| \\
& =0
\end{aligned}
$$


このような計算により, 式(16.5.4)は $S_{z}$ の eigenfunction であり, eigenvalue は 0 と いうことが分かる. $S_{z}$ の eigenvalue が 0 であるから量子数 $M_{s}$ は 0 である.

同様に $S_{-}$を作用してみよう。

$$
\begin{aligned}
& S_{-}\left|\psi_{1 s}(1) \alpha(1) \psi_{1 s}(2) \beta(2)\right| \\
& =\left|\psi_{1 s}(1)\left\{S_{-}(1) \alpha(1)\right\} \psi_{1 s}(2) \beta(2)\right|+\left|\psi_{1 s}(1) \alpha(1) \psi_{1 s}(2)\left\{S_{-}(2) \beta(2)\right\}\right| \\
& =\hbar\left|\psi_{1 s}(1) \beta(1) \psi_{1 s}(2) \beta(2)\right|
\end{aligned}
$$

この結果に更に $S_{+}$を作用してみよう.

$$
\begin{aligned}
& S_{+} \hbar\left|\psi_{1 s}(1) \beta(1) \psi_{1 s}(2) \beta(2)\right| \\
& =\hbar\left|\psi_{1 s}(1)\left\{S_{+}(1) \beta(1)\right\} \psi_{1 s}(2) \beta(2)\right|+\left|\psi_{1 s}(1) \beta(1) \psi_{1 s}(2)\left\{S_{+}(2) \beta(2)\right\}\right| \\
& =\hbar^{2}\left|\psi_{1 s}(1) \alpha(1) \psi_{1 s}(2) \beta(2)\right|+\hbar^{2}\left|\psi_{1 s}(1) \beta(1) \psi_{1 s}(2) \alpha(2)\right| \\
& =0
\end{aligned}
$$

（行列式の性質から分かるように第 2 項は第 1 項の符号を変えたものである）

結局，上の 2 つの計算をまとめると

$$
S_{+} S_{-}\left|\psi_{1 s}(1) \alpha(1) \psi_{1 s}(2) \beta(2)\right|=0
$$

同様に

$$
S_{-} S_{+}\left|\psi_{1 s}(1) \alpha(1) \psi_{1 s}(2) \beta(2)\right|=0
$$

また

$$
S_{z}\left|\psi_{1 s}(1) \alpha(1) \psi_{1 s}(1) \beta(2)\right|=0
$$

この3つより

$$
\begin{aligned}
& \boldsymbol{S}^{2}\left|\psi_{1 s}(1) \alpha(1) \psi_{1 s}(2) \beta(2)\right| \\
& =\left(S_{z}^{2}+\frac{1}{2} S_{+} S_{-}+\frac{1}{2} S_{-} S_{+}\right)\left|\psi_{1 s}(1) \alpha(1) \psi_{1 s}(2) \beta(2)\right| \\
& =0
\end{aligned}
$$

かくして，式(16.5.4)は $\boldsymbol{S}^{2}$ の eigenfunction であり，その eigenvalue は0 あることが分か った. $S^{2}$ の eigenvalue は量子数 $S$ を用いて $S(S+1) \hbar^{2}$ と定義されるから, 量子数 $S$ は 0 ということが分かる，すなわち，多重度 $2 S+1$ は 1 で singlet である. 
同様にして, 式(16.5.4')は $\boldsymbol{L}^{2}$ および $L_{z}$ の固有関数であることが分かる.これは演習 としておこう. (Problem 16.5.1)

では，いよいよ本論に戻って摂動計算を始めよう。ゼロ次のエネルギー $E^{(0)}$ は当然

$$
H_{0} \psi^{0}(1,2)=E^{(0)} \psi^{0}(1,2)
$$

で定義されるように $H_{0}$ の eigenvalue である. 式(16.5.4)，すなわち

$$
\begin{aligned}
\psi^{0}(1,2) & =\frac{1}{\sqrt{2}}\left|\begin{array}{ll}
\psi_{1 s}(1) \alpha(1) & \psi_{1 s}(2) \alpha(2) \\
\psi_{1 s}(1) \beta(1) & \psi_{1 s}(2) \beta(2)
\end{array}\right| \\
& \equiv\left|\psi_{1 s}(1) \alpha(1) \psi_{1 s}(2) \beta(2)\right|
\end{aligned}
$$

に

$$
H_{0}=H(1)+H(2)
$$

を作用してみよう。 $\psi_{1 s}$ は $Z=2$ の hydrogen-like atom の eigenfunction であり, その eigenvalue は atomic unit で- $\frac{Z^{2}}{2}$ である.

すなわち

$$
\begin{aligned}
& H(1) \psi_{1 s}(1)=E_{1 s} \psi_{1 s}(1)=-\frac{Z^{2}}{2} \psi_{1 s}(1) \\
& H(2) \psi_{1 s}(2)=E_{1 s} \psi_{1 s}(2)=-\frac{Z^{2}}{2} \psi_{1 s}(2)
\end{aligned}
$$

$H(1)$ およ゙ $H(2)$ は式(16.5.2)から分かるように空間座標のみを含みスピン座標を含 まないから，スピン関数 $\alpha$ または $\beta$ に作用しても変らない，従って

$$
\begin{aligned}
& H(1) \frac{1}{\sqrt{2}}\left|\begin{array}{ll}
\psi_{1 s}(1) \alpha(1) & \psi_{1 s}(2) \alpha(2) \\
\psi_{1 s}(1) \beta(1) & \psi_{1 s}(2) \beta(2)
\end{array}\right|= \\
& -\frac{Z^{2}}{2 \sqrt{2}}\left|\begin{array}{ll}
\psi_{1 s}(1) \alpha(1) & \psi_{1 s}(2) \alpha(2) \\
\psi_{1 s}(1) \beta(1) & \psi_{1 s}(2) \beta(2)
\end{array}\right|
\end{aligned}
$$

$H(2)$ の作用も全く同じように書ける.すなわち 


$$
\begin{aligned}
H(2) \frac{1}{\sqrt{2}}\left|\begin{array}{ll}
\psi_{1 s}(1) \alpha(1) & \psi_{1 s}(2) \alpha(2) \\
\psi_{1 s}(1) \beta(1) & \psi_{1 s}(2) \beta(2)
\end{array}\right|= \\
-\frac{Z^{2}}{2 \sqrt{2}}\left|\begin{array}{ll}
\psi_{1 s}(1) \alpha(1) & \psi_{1 s}(2) \alpha(2) \\
\psi_{1 s}(1) \beta(1) & \psi_{1 s}(2) \beta(2)
\end{array}\right|
\end{aligned}
$$

かくして

$$
H_{0} \psi^{0}(1,2)=2 E_{1 s} \psi^{0}(1,2)=-Z^{2} \psi^{0}(1,2)
$$

を得る。すなわち，ゼロ次のエネルギーとして

$$
E^{(0)}=2 E_{1 s}=-Z^{2} \quad \text { (atomic unit) }
$$

を得る。

\section{【註】：}

Slater determinant についての operator の作用は， determinant を構成する $n$ !個の項す ベてに operator を作用することになるが，具体的な計算にあたっては diagonal term の み作用すればよいことは次のように考えれば理解出来る。（spin orbital を $\phi_{1}, \phi_{2}, \ldots$ とした場合)

$$
H(1)\left|\phi_{1}(1) \phi_{2}(2) \ldots \phi_{n}(n)\right|=H(1) \sqrt{n !} \sum P(-1)^{P} \phi_{1}(1) \phi_{2}(2) \ldots \phi_{n}(n)
$$

ここで $H(1)$ は permutation $P$ と可換であるから

$$
\begin{aligned}
H(1)\left|\phi_{1}(1) \phi_{2}(2) \ldots \phi_{n}(n)\right| & =\sqrt{n !} \sum P(-1)^{P} H(1) \phi_{1}(1) \phi_{2}(2) \ldots \phi_{n}(n) \\
& =\left|\left\{H(1) \phi_{1}(1)\right\} \phi_{2}(2) \ldots \phi_{n}(n)\right|
\end{aligned}
$$

一次の摂動エネルギーは当然

$$
E^{(1)}=\iint \psi^{0}(1,2)^{*} \frac{1}{r_{12}} \psi^{0}(1,2) d \tau d \sigma
$$

である。ここで積分は空間座標 $\tau$ とスピン座標 $\sigma$ の両方について行う。簡単のために 上式では単に $d \tau$ および $d \sigma$ と記したが正しくはそれぞれが電子 1 と 2 に関するもので ある。

$$
\begin{aligned}
& d \tau=d \tau_{1}+d \tau_{2} \\
& d \sigma=d \sigma_{1}+d \sigma_{2}
\end{aligned}
$$

また 


$$
\begin{aligned}
& d \tau_{1}=r_{1}^{2} \sin \theta_{1} d r_{1} d \theta_{1} d \phi_{1} \\
& d \tau_{2}=r_{2}^{2} \sin \theta_{2} d r_{2} d \theta_{2} d \phi_{2}
\end{aligned}
$$

であるから，式(16.5.13)の積分は $r_{1}, \theta_{1}, \phi_{1}, r_{2}, \theta_{2}, \phi_{2}, \sigma_{1}, \sigma_{2}$ の 8 つの変数につ いての積分である. $H^{\prime}=\frac{1}{r_{12}}$ はスピン関数を含まないから, 式(16.5.13)の展開項のうち， スピン関数が異なるものは直交してゼロとなってしまう，念のため，少及詳しく書き 下してみよう。

$$
\begin{aligned}
E^{(1)} & =\frac{1}{2} \int d \tau_{1} \int d \tau_{2} \int d \sigma_{1} \int d \sigma_{2} \\
& \left\{\begin{array}{l}
\psi_{1 s}{ }^{*}(1) \alpha^{*}(1) \psi_{1 s}{ }^{*}(2) \beta^{*}(2) \frac{1}{r_{12}} \psi_{1 s}(1) \alpha(1) \psi_{1 s}(2) \beta(2) \\
-\psi_{1 s}{ }^{*}(1) \alpha^{*}(1) \psi_{1 s}{ }^{*}(2) \beta^{*}(2) \frac{1}{r_{12}} \psi_{1 s}(1) \beta(1) \psi_{1 s}(2) \alpha(2) \\
-\psi_{1 s}{ }^{*}(1) \beta^{*}(1) \psi_{1 s}{ }^{*}(2) \alpha^{*}(2) \frac{1}{r_{12}} \psi_{1 s}(1) \alpha(1) \psi_{1 s}(2) \beta(2) \\
+\psi_{1 s}{ }^{*}(1) \beta^{*}(1) \psi_{1 s}{ }^{*}(2) \alpha^{*}(2) \frac{1}{r_{12}} \psi_{1 s}(1) \beta(1) \psi_{1 s}(2) \alpha(2)
\end{array}\right\}
\end{aligned}
$$

であるが，スピン関数の直交性より第 2 および第 3 項はゼロとなる，又，それぞれの スピン関数が規格化されていることから， $\sigma_{1}$ と $\sigma_{2}$ についての積分を実行すると

$$
E^{(1)}=\int d \tau_{1} \int d \tau_{2} \psi_{1 s}^{*}(1) \psi_{1 s}^{*}(2) \frac{1}{r_{12}} \psi_{1 s}(1) \psi_{1 s}(2)
$$

となる．これは電子雲 $\psi_{1 s} *(1) \psi_{1 s}(1)$ と電子雲 $\psi_{1 s} *(2) \psi_{1 s}(2)$ との Coulomb 相互作用を 表す項であり，クーロン積分（Coulomb integral）と言われる。しばしば $J$ という記号 で表される． $\psi_{1 s}$ に式(16.5.6)の具体的な形を代入すると

$$
E^{(1)}=\frac{Z^{2}}{\pi^{2}} \int d \tau_{1} \int d \tau_{2} e^{-2 Z r_{1}} \frac{1}{r_{12}} e^{-2 Z r_{2}}
$$

この積分は $\frac{1}{r_{12}}$ という項の存在のため, このままでは変数分離するわけにいかない. $\frac{1}{r_{12}}$ を含む積分が出て来た時の定石は $\frac{1}{r_{12}}$ を球関数で展開する方法である. すなわち, 数学の教科書（又は Eyring, Walter, Kimball, "Quantum Chemistry" p.371）から展開式を 
引用すると

$$
\frac{1}{r_{12}}=\frac{1}{r_{>}} \sum_{l=1}^{\infty} \sum_{m=-l}^{l} \frac{4 \pi}{2 l+1}\left(\frac{r_{<}}{r_{>}}\right)^{l} Y_{l, m}\left(\theta_{1}, \phi_{1}\right) Y_{l, m}\left(\theta_{2}, \phi_{2}\right)
$$

$r_{>}$おび $r_{<}$はそぞれ $r_{1}$ おび $r_{2}$ のうちの大きい方および小さい方を示す.（この式で 再び球関数が使われている。このように球関数は非常に重要な関数である）この式を 式(16.5.18) に代入して $r_{1}, \theta_{1}, \phi_{1}, r_{2}, \theta_{2}, \phi_{2}$ について積分するのであるが，被積分 関数は角度部分 $\theta_{1}, \phi_{1}, \theta_{2}, \phi_{2}$ のいずれも含んでいない. 従って, 式(16.5.18)の積分 が生きる項は式(16.5.19)の展開項のうち, $\quad=0, m=0$ のただ 1 項，すなおち $Y_{0,0}(\theta, \phi)=\sqrt{\frac{1}{4 \pi}}$ のみである. すなわち, 式(16.5.19)の無限項の和のうち， $\ell=m=0$ の 項のみが残り，その項は

$$
\begin{aligned}
& r_{1}>r_{2} \text { において } \frac{1}{r_{12}}=\frac{1}{r_{1}} \\
& r_{1}<r_{2} \text { において } \frac{1}{r_{12}}=\frac{1}{r_{2}}
\end{aligned}
$$

となる。

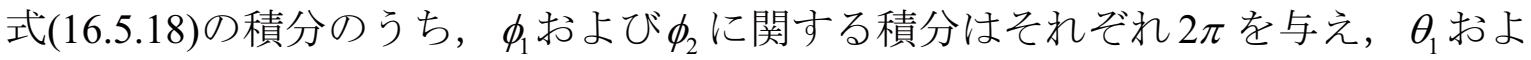
び $\theta_{2}$ に関する積分はそれぞれ 2 となる．それで，角度部分の 4 つの変数について積分 すると，その結果は

$$
E^{(1)}=\frac{Z^{6}}{\pi^{2}}\left(4 \pi^{2}\right) \int r_{1}^{2} d r \int r_{2}^{2} d r e^{-2 Z r_{1}} \frac{1}{r_{12}} e^{-2 Z r_{2}}
$$

となる.ここで式(16.5.20) を用い， $r_{2}$ に関する積分を 0 から $r_{1}$ までの積分と $r_{1}$ からめま での積分とに分ける。そうすると 


$$
\begin{aligned}
E^{(1)} & =16 Z^{2} \int_{0}^{\infty} e^{-2 Z r_{1}}\left(\int_{0}^{r_{1}} \frac{r_{2}^{2}}{r_{1}} e^{-2 Z r_{2}} d r_{2}+\int_{r_{1}}^{r_{1}} \frac{r_{2}^{2}}{r_{2}} e^{-2 Z r_{2}} d r_{2}\right) r_{1}^{2} d r_{1} \\
& =16 Z^{2} \int_{0}^{\infty} e^{-2 Z r_{1}}\left(\frac{1}{r_{1}} \int_{0}^{r_{1}} e^{-2 Z r_{2}} r_{2}^{2} d r_{2}+\int_{r_{1}}^{\infty} e^{-2 Z r_{2}} r_{2} d r_{2}\right) r_{1}^{2} d r_{1} \\
& =4 Z^{3} \int_{0}^{\infty} e^{-2 Z r_{1}}\left\{\frac{1}{r_{1}}-e^{-2 Z r_{1}}\left(Z+\frac{1}{r_{1}}\right)\right\} r_{1}^{2} d r \\
& =\frac{5}{8} Z
\end{aligned}
$$

となる.かくして 1 次の摂動までのエネルギーは

$$
E=E^{(0)}+E^{(1)}=-Z^{2}+\frac{5}{8} Z
$$

となる。これに $Z=2$ を代入して，

$$
E=-2.75 \text { a.u. }=-74.83 \mathrm{eV}
$$

を得る。

$\mathrm{He}$ の基底状態のエネルギーの実験值は $-2.9033 \mathrm{a} . \mathrm{u}=79.00 \mathrm{eV}$ である.すなわち， 1 次の摂動エネルギーの計算值は 5\%ほど実験值と異なっている.

計算の結果はしばしばイオン化エネルギー（ionization energy）（イオン化ポテンシ ヤル, ionization potential という言葉も使われる）でもって議論される. He から 1 個 の電子を取り除いた $\mathrm{He}^{+}$基底状態のエネルギーは上述の議論から明らかなように $-\frac{Z^{2}}{2}$ である. 従ってイオン化エネルギー, すなわち, $\mathrm{He}^{+}$と $\mathrm{He}$ とのエネルギー差は, 1 次の摂動論では式(16.5.23) より

$$
\begin{aligned}
\text { ionization energy } & =E\left(\mathrm{He}^{+}\right)-E(\mathrm{He}) \\
& =-\frac{Z^{2}}{2}-\left(-Z^{2}+\frac{5}{8} Z\right)=\frac{Z^{2}}{2}-\frac{5}{8} Z \\
& =0.75 \text { a.u. }=20.41 \mathrm{eV}
\end{aligned}
$$

これに対してイオン化エネルギーの実験值は 0.9033 a.u. である。実験值と計算值との 差, 0.1537 a.u. $\approx 4 \mathrm{eV}$ は化学結合のエネルギーより大きい位であり，この差は決して 小さくない.これは何と言っても，冒頭に述べたように $\frac{1}{r_{12}}$ を 1 次の攝動論で扱うこ とに大きな無理があるからである。

たとえ $\frac{1}{r_{12}}$ を捸動論で取り入れたとしたとしても，摂動の次数を上げれば実験值と の一致は良くなることと予想される。1963 年の Scheer と Knight の論文（表 16.5.1を 
参照）ではなんと 13 次までの摂動計算を行っている。その結果は

$$
E=-Z^{2}+\frac{5}{8} Z-0.15766254+\frac{0.008698679}{Z}+\frac{0.000888302}{Z^{2}}+\ldots
$$

のような式で表され， $Z=2$ を代入すると $E$ は-2.9037 a.u. となり，実験值の -2.9033 a.u. とほぼ一致している.

$\mathrm{He}$ の基底状態（ $1 s^{2}$ configuration）についての摂動計算のうち代表的なものを表 16.5.1 にまとめておく.

表 16.5.1 He 原子の基底状態のエネルギーの摂動論による取り扱い

\begin{tabular}{lcc}
\hline \hline \multicolumn{1}{c}{ method } & energy/atomic unit & $\begin{array}{c}\text { ionization } \\
\text { energy/atomic unit. }\end{array}$ \\
\hline \hline $\begin{array}{l}\text { Complete neglect of } \\
\text { the electron repulsion }\end{array}$ & -4.00 & 2.00 \\
\hline First order perturbation & -2.75 & 0.75 \\
\hline $\begin{array}{l}\text { Second order perturbation } \\
\text { Thirteenth order }\end{array}$ & -2.91 & 0.91 \\
\hline perturbation ${ }^{\mathrm{a})}$ & -2.90372433 & 0.9037 \\
experimental & -2.9033 & 0.9033 \\
\hline \hline
\end{tabular}

a: C. W. Scheer and R. E. Knight, Rev. Mod. Phys., 35, 426 (1963).

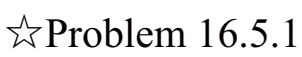

式(16.5.4)は $\boldsymbol{L}^{2}$ および $L_{z}$ の eigenfunction になっていることを証明し，それぞれの固 有值を求めよ.

\subsection{He の基底状態のエネルギー（II）: 変分法による取り扱い}

変分法を用いる場合には言うまでもなく, まずある試行関数を決めなくてはいけな い. 試行関数といっても, Pauli 原理に従って電子の交換に関して antisymmetric でな 
ければならないことは当然である。そこで，この場合も式(16.5.8)と形式的に同じく，

$$
\psi_{\text {trial }}(1,2)=\frac{1}{\sqrt{2}}\left|\begin{array}{ll}
\psi_{1 s}(1) \alpha(1) & \psi_{1 s}(2) \alpha(2) \\
\psi_{1 s}(1) \beta(1) & \psi_{1 s}(2) \beta(2)
\end{array}\right|
$$

としてよさそうである.ただし，ここで $\psi_{1 s}$ の関数形についてもう少し吟味してみよ

う. 摂動論の場合に行ったように $\psi_{1 s}$ を $\mathrm{He}^{+}$の eigenfunction に選ぶとすると，この trial function は，電子間反発を無視した Hamiltonian の固有関数となっているから，こうい う trial function から出発すると, 電子間反発を含めた全 Hamiltonian の解としてはあま り期待出来ない，そこで，数学的にあまり面倒にならず，電子間反発の効果が何とか 取り入れられるような方法はないかどうか考えてみる.

$\psi_{1 s}$ は, 何回も繰り返して述べて来たように $\mathrm{He}^{+}$についての eigenfunction である. すなわち， $Z=+2$ の電荷をもった原子核の周りにただ 1 個の電子がある系である.し かし， He 原子においては，電子は現実に 2 個あるわけである. 1 つの電子の受ける potential は，核からの引力の他に，もう 1 つの電子からの反発もあるはずである. 後 者の存在は前者の効果を弱㻪きをする. 仮に電子 1 が原子核から大きく離れてい て，電子 2 が原子核の近くにあるとすると，電子 1 から見ると，原子核ともう 1 つの 電子がまとまって電荷 $Z=1$ の原子核のように見えるであろう。この時は，電子 1 の 受ける potential は $Z=1$ の原子核からの引力のみとみなせる. 寸なわち, 核の電荷が ある程度遮蔽されている. 実際には電子 1 のみがそれほど遠くに離れているわけでも なく, 又, 電子 2 よりも電子 1 の方が原子核に近いこともあり得る。しかし，こう考 えてみると, 1 電子系についての軌道関数を求める場合, 見かけの核の電荷として 1 と 2 の間の数をとっていると見なすことは出来よう。こういうわけで我々は，遮蔽

（shielding）の効果を考慮した有効核荷電（effective nuclear change）を $Z_{\text {eff }}$ と表すこと にする.ここで $Z_{\text {eff }}$ は

$$
1<Z_{\text {eff }}<2
$$

の範囲にあるであろうことは上述した通りである.こういう考えで $\psi_{1 s}$ の関数形とし ては式(16.5.6)の hydrogen-like wavefunction そのままでなく 


$$
\begin{aligned}
& \phi_{1 s}(1)=\sqrt{\frac{Z_{\text {eff }}}{\pi}} e^{-Z_{\text {eff }} r_{1}} \\
& \phi_{1 s}(2)=\sqrt{\frac{Z_{\text {eff }}}{\pi}} e^{-Z_{\text {effr }}}
\end{aligned}
$$

とする. 式(16.6.1)の $\psi_{1 s}$ をこのような $Z_{\mathrm{eff}}$ を含む形として表しておき，その後， $Z_{\mathrm{eff}}$ を 変分 parameter として Rayleigh ratio $\varepsilon\left(Z_{\text {eff }}\right)$ を最小にするような $Z_{\text {eff }}$ を求めよう，とい うのがもっとも考えやすい簡単な変分法の取り扱いである. 式(16.6.1)はすでに規格化 されているので

$$
\varepsilon\left(Z_{\text {eff }}\right)=\iiint \int \psi^{*}{ }_{\text {trial }}(1,2) H \psi_{\text {trial }}(1,2) d \tau_{1} d \tau_{2} d \sigma_{1} d \sigma_{2}
$$

を求めればよい。 $H$ は言うまでもなく全 Hamiltonian であり, 式(16.5.1)と同じく

$$
H=-\frac{1}{2}\left(\nabla_{1}^{2}+\nabla_{2}^{2}\right)-\frac{Z}{r_{1}}-\frac{Z}{r_{2}}+\frac{1}{r_{12}}
$$

である.（この式の $Z$ は $Z_{\mathrm{eff}}$ ではないことに注意）

計算は前節で行った 1 次の摂動エネルギーの計算と全く同様に行われる.要は $H$ が スピン関数を含まないこと，およびスピン関数の規格直交の性質を用い, $\varepsilon\left(Z_{\mathrm{eff}}\right)$ を空 間座標 $\tau_{1}$ と $\tau_{2}$ のみの積分とする.ここで $\frac{1}{r_{12}}$ を球関数で展開し， $\psi_{1 s}$ が角度部分を含ん でいないということから, 最終的には $\varepsilon\left(Z_{\mathrm{eff}}\right)$ が $r_{1}$ および $r_{2}$ に関する積分として表され る.計算の途中は形式的に前節と全く同様であるので途中を省略して結果だけを記す と,

$$
\begin{aligned}
\varepsilon\left(Z_{\text {eff }}\right) & =-Z_{\text {eff }}^{2}-2 Z_{\text {eff }}\left(Z-Z_{\text {eff }}\right)+\frac{5}{8} Z_{\text {eff }} \\
& =Z_{\text {eff }}^{2}-2 Z_{\text {eff }} Z+\frac{5}{8} Z_{\text {eff }}
\end{aligned}
$$

かくして $\varepsilon\left(Z_{\text {eff }}\right)$ の最小值は上式を $Z_{\text {eff }}$ で微分することにより

$$
Z_{\text {eff }}=Z-\frac{5}{16}
$$

と得られる。これを式(16.6.6)に代入することにより，He の基底状態のエネルギーと して 


$$
E=-\left(Z-\frac{5}{16}\right)^{2}
$$

を得る. $Z=2$ を代入して

$$
E=-\left(\frac{27}{16}\right)^{2}=-2.8477 \text { a.u. . }
$$

となる．実験值は，すでに述べたように-2.9037 a.u. であり，実験と変分計算との差 は約 $2 \%$ である。

実験と計算との差が $2 \%$ しかないとは言ってもこの差の

0.056 a.u.=1.5 eV=145 kJ/mol はほぼ化学結合のエネルギーに相当し, 決して小さいと は言えない.

変分法においては, 変分 parameterの数を多くすればするほどそれだけ Rayleigh ratio は小さくなり，真のエネルギーに近くなる. trial function を電子の交換に対して antisymmetric になるような式(16.6.1)の形に選び，この枠の中で最も良い wavefunction と energy を求めようというのが Hartree-Fock の方法であり, しばらく後で（4 年の講 義で）学習することになろう。一口に Hartree-Fock の方法とはいっても，種々の方法 があるが, Roothaan, Sachs, Weiss によって 1960 年になされた計算 (C. C. J. Roothaan, L. M. Sachs, A. W. Weiss, Rev. Mod. Phys. 32, 186 (1960)） では，基底状態のエネルギー として -2.8617 a.u.が得られている。まだ実験值との差はあるが，実際問題としてか なり満足すべき值とは言えよう。

trial function として，式(16.6.1)のような 2 つの orbital の反対称化された積

(antisymmetrized product) にこだわらずに，もつと一般的な関数形を選ぶことはもち ろん可能である. そして, parameterの数を多くしていけばもっともつと Rayleigh ratio は下がり，実験值に近いものとなることはすぐに想像つく．歴史的に有名なのは Hylleras が 1929 年に行ったもの（E. A. Hylleras, Z. Physik, 54.347 (1957)）であり, trial function として

$$
\psi\left(r_{1}, r_{2}, r_{12}\right)=e^{-Z r_{1}} e^{-Z r_{2}}\left(1+C r_{12}\right)
$$

のように，波動関数を電子 1 および 2 それぞれの座標 $r_{1}, r_{2}$ のみならず， 2 電子間の 距離 $r_{12}$ の関数として表すことにより，計算值として -2.90363 a.u. を得た。大型 computer を駆使すれば parameter の数をどんどん増やすことも可能であり，1959 年の Pekeris の論文 (C. L. Pekeris, Phys. Rev. 105, 1490 (1957))ではなんと 1078 個の parameter を用い，実験值とほとんど一致する結果を得ている. 
このような大がかりの計算の結果は, 変分法をとことんまで行えば実験值を再現す るような計算值が求まるという，すなわち変分法を実際に検証したという見方をすれ ば面白い．しかし，いわば腕力に頼ったこのような計算が，化学の理論としてどの程 度意味があるか，ということになるといろいろ意見は別れるであろう. 1000 個を越え る parameterがあっても，その parameterの1つ1つに物理的な意味付けをすることは ほとんど出来ないであろうし，又，その parameter の值それぞれから，原子の物理的 化学的性質の何が分かるか, というと, どうもはっきりしない. 又, 励起状態への拡 張とかほかの原子一の拡張とかを考えてもあまり発展性があるとは思えない. 理論の 布衍性を考えると，やはり式(16.6.1)の形の antisymmetrized product に基づいた Hartree-Fock 法が優れているように思われる。（ただしこれは，私の個人的な見解であ る.)

\subsection{He 原子の励起状態}

すでに学習したように, He の基底状態は $1 s$ orbital に 2 個の電子が詰まった配置を 取っている． 1 個の電子が $1 s$ orbital から $2 s$ orbital 移れば，この状態は基底状態よ りは energy が高くなり，このような状態は励起状態と言われる。このような励起状態 を，電子 1 と電子 2 の交換について antisymmetric になり，かつ $\boldsymbol{S}^{2}$ おび $S_{z}$ の固有関 数になるものをまず作ってみよう.

2 つの orbital $\psi_{1 s}$ と $\psi_{2 s}$ に $\alpha$ spin または $\beta$ spin が入るわけで $2 \times 2=4$ 通りの configuration の可能性があろう. 図示すると次のようになる（ $\alpha$ スピンを上向き矢印， $\beta$ スピンを下向き矢印で示した)

$2 \mathrm{~s}$

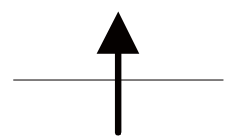

$1 \mathrm{~s}$

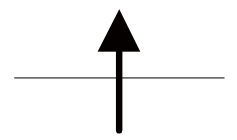

(a)

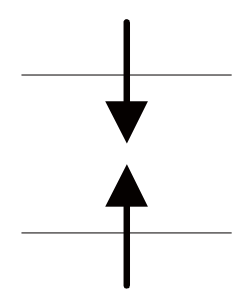

(b)

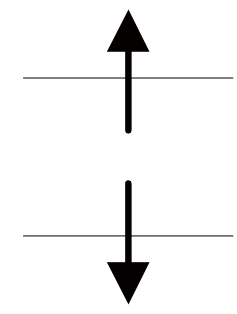

(c)

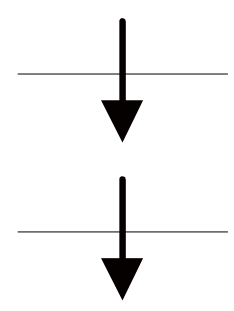

(d)

図 16.7.1 He の励起状態で可能な 4 つの configuration

これら configuration をそれぞれ Slater determinant で表し， $S_{Z}$ を作用してみると結果は 
次のようになりいずれも $S_{z}$ の固有関数となっていることが分かる.

$$
\begin{array}{lc}
\left|\psi_{1 s}(1) \alpha(1) \psi_{2 s}(2) \alpha(2)\right| & \hbar \\
\left|\psi_{1 s}(1) \beta(1) \psi_{2 s}(2) \beta(2)\right| & -\hbar \\
\left|\psi_{1 s}(1) \alpha(1) \psi_{2 s}(2) \beta(2)\right| & 0 \\
\left|\psi_{1 s}(1) \beta(1) \psi_{2 s}(2) \alpha(2)\right| & 0
\end{array}
$$

次に $\boldsymbol{S}^{2}$ を作用させてみると, これらの Slater determinant は必ずしも $\boldsymbol{S}^{2}$ の固有関数 とはなっていないことがわかる。そこで対角化を行い， $\boldsymbol{S}^{2}$ の固有関数を作らなけれ ばならない。それは諸君の演習としておこう (Problem 16.7.1).

結果を, 量子数 $S$ および $M_{s}$ によって $\psi\left(S, M_{s}\right)$ の形式で表すと次のようになる.

$$
\begin{aligned}
& \psi(1,1)=\left|\psi_{1 s}(1) \alpha(1) \psi_{2 s}(2) \alpha(2)\right|=\frac{1}{\sqrt{2}}\left|\begin{array}{ll}
\psi_{1 s} \alpha(1) & \psi_{2 s} \alpha(1) \\
\psi_{1 s} \alpha(2) & \psi_{2 s} \alpha(2)
\end{array}\right| \\
& \psi(1,0)=\frac{1}{\sqrt{2}}\left\{\left|\psi_{1 s}(1) \alpha(1) \psi_{2 s}(2) \beta(2)\right|+\left|\psi_{1 s}(1) \beta(1) \psi_{2 s}(2) \alpha(2)\right|\right\} \\
& =\frac{1}{\sqrt{2}}\left\{\frac{1}{\sqrt{2}}\left|\begin{array}{ll}
\psi_{1 s} \alpha(1) & \psi_{2 s} \beta(1) \\
\psi_{1 s} \alpha(2) & \psi_{2 s} \beta(2)
\end{array}\right|+\frac{1}{\sqrt{2}}\left|\begin{array}{ll}
\psi_{1 s} \beta(1) & \psi_{2 s} \alpha(1) \\
\psi_{1 s} \beta(2) & \psi_{2 s} \alpha(2)
\end{array}\right|\right\} \\
& \psi(1,-1)=\left|\psi_{1 s}(1) \beta(1) \psi_{2 s}(2) \beta(2)\right|=\frac{1}{\sqrt{2}}\left|\begin{array}{ll}
\psi_{1 s} \beta(1) & \psi_{2 s} \beta(1) \\
\psi_{1 s} \beta(2) & \psi_{2 s} \beta(2)
\end{array}\right| \\
& \psi(0,0)=\frac{1}{\sqrt{2}}\left\{\left|\psi_{1 s}(1) \alpha(1) \psi_{2 s}(2) \beta(2)\right|-\left|\psi_{1 s}(1) \beta(1) \psi_{2 s}(2) \alpha(2)\right|\right\} \\
& =\frac{1}{\sqrt{2}}\left\{\frac{1}{\sqrt{2}}\left|\begin{array}{ll}
\psi_{1 s} \alpha(1) & \psi_{2 s} \beta(1) \\
\psi_{1 s} \alpha(2) & \psi_{2 s} \beta(2)
\end{array}\right|-\frac{1}{\sqrt{2}}\left|\begin{array}{ll}
\psi_{1 s} \beta(1) & \psi_{2 s} \alpha(1) \\
\psi_{1 s} \beta(2) & \psi_{2 s} \alpha(2)
\end{array}\right|\right\}
\end{aligned}
$$

式(16.7.1)の 3 つの式はいずれも $S^{2}$ の演算子について $1(1+1) \hbar^{2}$ の固有值を与え, 又 $S_{z}$ 


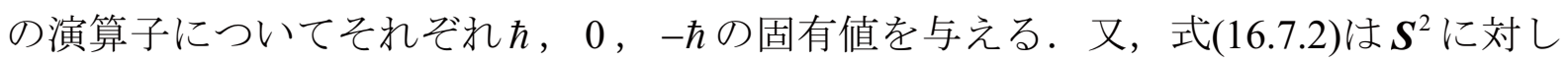
て $0(0+1) \hbar^{2}, S_{z}$ について0の固有值を与える.

これら励起状態のエネルギーも, 本質的には基底状態について行ったのと同じよう にして求めることが出来る．ただ，通常の変分法は，本来，基底状態についてのより 良い解を求めるための方法であるから，励起状態については，ある種の制限下である 種の工夫をして初めて適用することが出来る.しかし，このことについてはかなり専 門的になるのでここでは省略する.

胥Problem 16.7.1

$S^{2}$ について対角化を行い，式(16.7.1)および式(16.7.2)となることを自ら求めよ.

\subsection{Li 原子}

Li は 3 個の電子を持つ. Pauli 原理を満たすような状態のうち，最低の energy を持 つものは

$$
\begin{aligned}
\psi\left(S=\frac{1}{2}, M_{s}=\frac{1}{2}\right) & =\left|\psi_{1 s}(1) \alpha(1) \psi_{1 s}(2) \beta(2) \psi_{2 s}(3) \alpha(3)\right| \\
& =\frac{1}{\sqrt{3 !}}\left|\begin{array}{lll}
\psi_{1 s} \alpha(1) & \psi_{1 s} \beta(1) & \psi_{2 s} \alpha(1) \\
\psi_{1 s} \alpha(2) & \psi_{1 s} \beta(2) & \psi_{2 s} \alpha(2) \\
\psi_{1 s} \alpha(3) & \psi_{1 s} \beta(3) & \psi_{2 s} \alpha(3)
\end{array}\right|
\end{aligned}
$$

および

$$
\begin{aligned}
\psi\left(S=\frac{1}{2}, M_{s}=-\frac{1}{2}\right) & =\left|\psi_{1 s}(1) \alpha(1) \psi_{1 s}(2) \beta(2) \psi_{2 s}(3) \beta(3)\right| \\
& =\frac{1}{\sqrt{3 !}}\left|\begin{array}{lll}
\psi_{1 s} \alpha(1) & \psi_{1 s} \beta(1) & \psi_{2 s} \beta(1) \\
\psi_{1 s} \alpha(2) & \psi_{1 s} \beta(2) & \psi_{2 s} \beta(2) \\
\psi_{1 s} \alpha(3) & \psi_{1 s} \beta(3) & \psi_{2 s} \beta(3)
\end{array}\right|
\end{aligned}
$$

である．外部磁場が存在しない限り，これら2つの状態は縮退している。このような configuration を $1 s^{2} 2 s$ というふうに表す.

$\mathrm{Li}$ では $1 s^{2} 2 s$ configuration が基底状態となる。このちょつと高エネルギーの所に $1 s^{2} 2 p$ という configuration がある。こういうと，水素原子のことをよく勉強した人は

「あれおかしいな」と思うはずである. 水素原子の場合には $2 s$ と $2 p$ とは同じ軌道エ ネルギーを持っていた。 それから考えると $1 s^{2} 2 s$ と $1 s^{2} 2 p$ とは同じエネルギーになりそ 


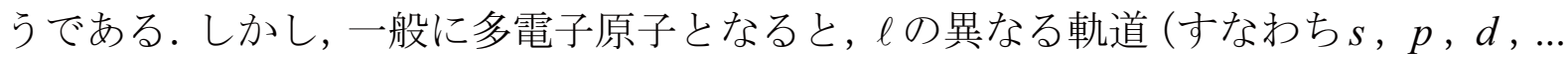
軌道）のエネルギーは同じではなくなる，そのことについては次の Section で学習す る.

\section{9 多電子原子における軌道エネルギーと遮蔽効果}

前節で Li の電子状態を議論する際， $1 s^{2} 2 s$ という configuration configurationよりも energy が低い，ということを述べた。水素類似原子の場合から考 えてこのことはおかしく思われるであろう. Chapter 9 で水素類似原子を学習した時, energy は式(9.6.1), 寸なわち

$$
E_{n}=-\frac{1}{\left(4 \pi \varepsilon_{0}\right)^{2}} \frac{\mu e^{4}}{2 n^{2} \hbar^{2}} Z^{2}
$$

で与えられた. 寸なわち, energy は主量子数 $n$ のみの関数であり $\ell や m$ には依存しな い. 事実, 図 9.3.1 をみても， $2 s$ 軌道と $2 p$ 軌道とは同じ energy になっている。同様 に $3 s, 3 p ， 3 d$ 軌道の energy は等しい. ところが，Li では $2 s の$ energy は $2 p$ の energy よりも低いという。このように，電子を 2 個以上持つ多原子分子では軌道エネルギー

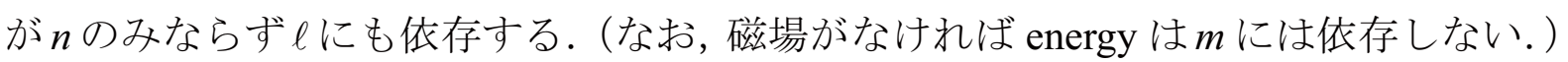
ここでは軌道エネルギーの $\ell$ 依存性の原因を考えてみる.

再び Li を例として $2 s$ の電子と $2 p$ の電子について考えてみよう。これらの電子は,

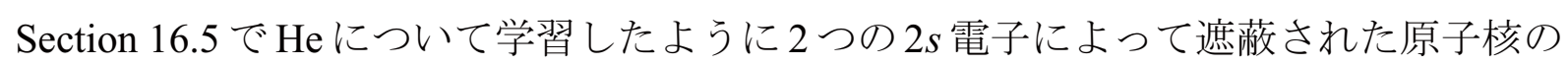
電荷を感じている．この遮蔽の効果は, He について行ったように, 例えば変分法に よっても求めることが出来るが，定性的には次のように考えられよう.

$2 s$ と $2 p$ の存在確率を, 原子核からの距離 $r$ の関数としてみてみよう。 $\ell \neq 0$ の軌道 は球対称ではないから, 電子の存在確率は $r$ のの関数ではなく $\theta$ やの関数でもあ

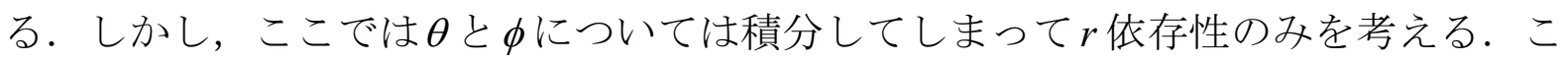
の考え方によると

$$
\int_{0}^{\pi} d \theta \int_{0}^{2 \pi} d \phi R_{n l}(r)^{2} Y_{l, m}(\theta, \phi)^{2} r^{2} \sin \theta=r^{2} R_{n l}(r)^{2}
$$

の $r$ 依存性をみれば良いということになる.これは寸でに図 9.9 .2 に示してあるが，大 分前のことなので，改めて図 16.9.1に図を示すことにしょう. 

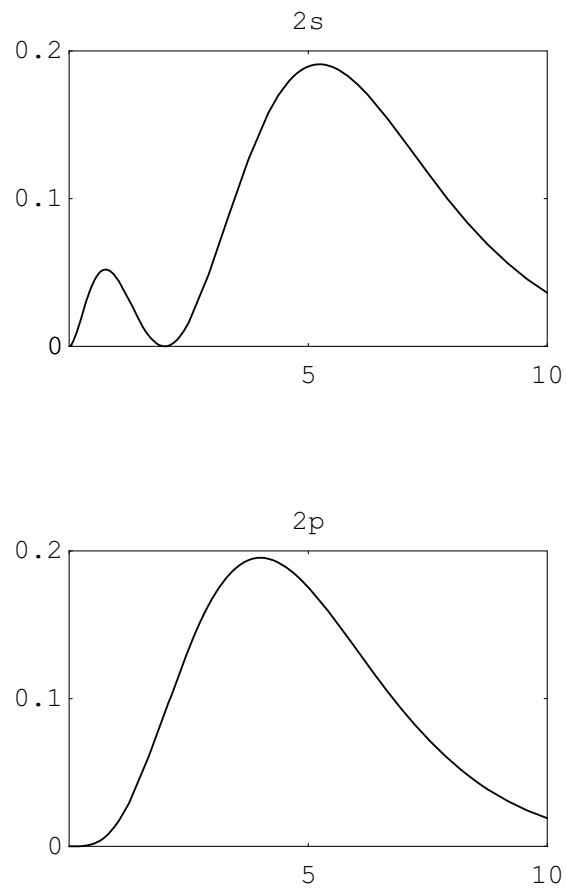

図 16.9.1 $r^{2} R_{2 \ell}(r)^{2}$ の $r / a_{0}$ についてのプロット

図 16.9.1 より分かるように， $2 s$ electron については 2 つのピークがあり，そのう ちの 1 つは $r$ の非常に小さい所（正確には $\frac{r}{a_{0}}=\frac{3-\sqrt{5}}{Z}$ にある.この距離においては $2 p$ electron の存在確率は極めて小さい.このことから分かるように， $2 s$ electron は $2 p$ electron に比べて，より原子核に近く存在する．従って遮蔽の効果は $2 s$ の方が $2 p$ より 小さい. すなわち有効核荷電 $Z_{\text {eff }}$ は $2 s$ の方が $2 p$ よりも大きくなる. 従って式(16.9.1) より明らかなように，軌道エネルギーは $2 s$ の方が低くなる.

$n=3$ の 3 つ軌道についても同様に考えることが出来る. 図 9.9 .2 から $3 s, 3 p, 3 d$ の軌道についてのグラフを取り出して図 16.9.2に示す. 

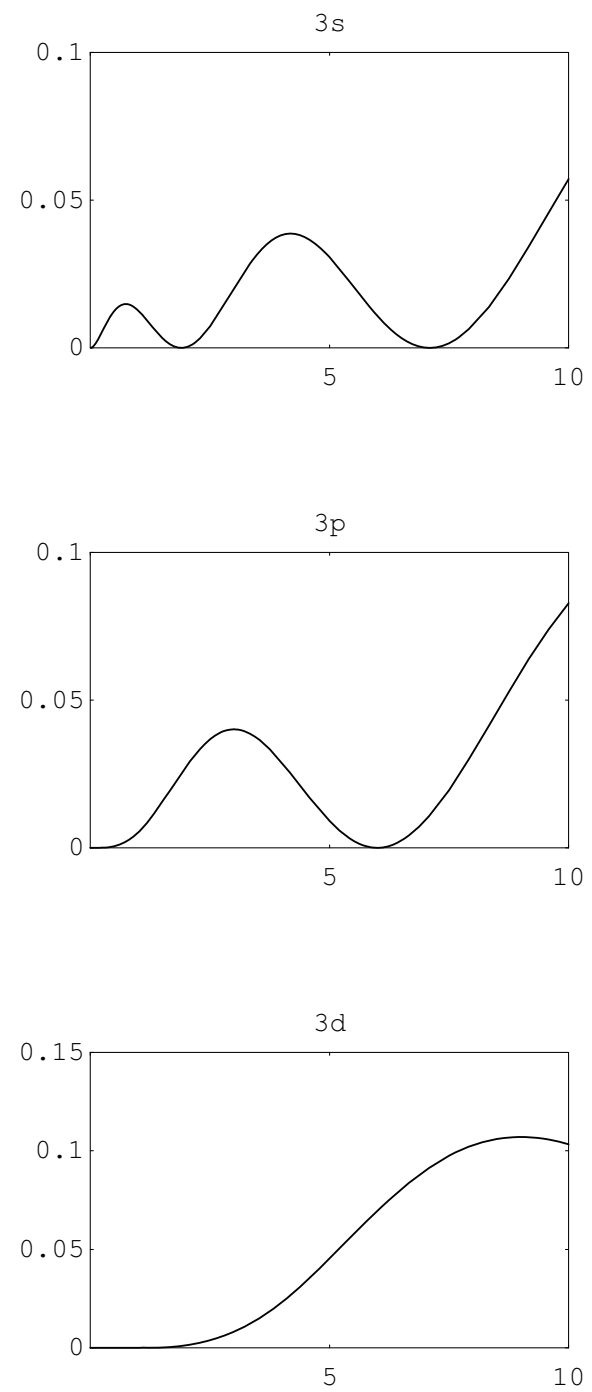

図 16.9.2 $r^{2} R_{3 \ell}(r)^{2}$ の $r / a_{0}$ についてのプロット

この図から分かるように，原子核に近い所の存在確率は $3 s>3 p>3 d$ の順になって いる．従って，遮蔽の効果は $3 s<3 p<3 d$ の順で，軌道エネルギーは $3 s<3 p<3 d$ の順 に高くなっている.

ここでは $n=2$ と $n=3$ の場合のみ吟味したが, $n \geq 4$ の軌道についても同様な吟味を することが出来る。そして一般に，多電子原子では同一の $n$ に対し， $\ell$ のきい軌道 がエネルギーが高くなると結論される。

ある場合には intrashell（ $n$ が同じで $\ell$ が異なる）の準位間のエネルギー差の方が intershell（ $n$ が異なる）準位間のエネルギー差よりも大きくなる．従って， $n$ に関し 
ての準位の逆転が起る. 例えば $4 s$ 準位は $3 d$ 準位よりも低い. 同様に $5 s$ は $4 d$ よりも低 く, $6 s$ は $5 d$ や $f$ よりも低い. 細かいことは原子の種類によっても少しずつは異なる が，大部分の原子について軌道エネルギーはほぼ次のような順序となる。

$1 s<2 s<2 p<3 s<3 p<4 s<3 d<4 p<5 s<4 d<5 p<6 s<4 f<5 d<6 p<7 s \ldots \ldots$

具体的に，どういう原子でこの順とならないかは次の節で述べる.

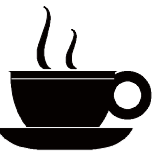

[Coffee Break] atomic orbital energy の順序

式(16.9.2)のような orbital energy の順序は，覚えておくと大変に便利ではあるが， そうかといってやみくもに覚えておくのも芸がないように思える. A. K. Carpenter, J. Chem. Education, 60 (1983), 562 にこの順序を求める面白い方法が載っているので以 下に紹介する．このやり方を覚えていれば，式(16.9.2)の順序を容易に再現出来る。こ の論文によれば，以下のようにして順序を決める.

[Step 1] $7 \times 7$ の matrix を作り，対角項に左上から $1 s ， 2 s ， \ldots 7 s$ の順に記入する.

\begin{tabular}{|l|l|l|l|l|l|l|}
\hline $1 s$ & & & & & & \\
\hline & $2 s$ & & & & & \\
\hline & & $3 s$ & & & & \\
\hline & & & $4 s$ & & & \\
\hline & & & & $5 s$ & & \\
\hline & & & & & $6 s$ & \\
\hline & & & & & & $7 s$ \\
\hline
\end{tabular}

[Step 2] 各 $n s$ から右に向かって $n p, n d, \ldots$ を許されるものについて書き入れる. $n \geq 5$ については，途中までしか箱がないが，書けるところまで書く. 


\begin{tabular}{|l|l|l|l|l|l|l|}
\hline $1 s$ & & & & & & \\
\hline & $2 s$ & $2 p$ & & & & \\
\hline & & $3 s$ & $3 p$ & $3 d$ & & \\
\hline & & & $4 s$ & $4 p$ & $4 d$ & $4 f$ \\
\hline & & & & $5 s$ & $5 p$ & $5 d$ \\
\hline & & & & & $6 s$ & $6 p$ \\
\hline & & & & & & $7 s$ \\
\hline
\end{tabular}

[Step 3］こうして matrix に書き入れたら左上から矢印で示すような順序になる.

\begin{tabular}{|c|c|c|c|c|c|c|}
\hline $1 s$ & $\downarrow$ & $/ \downarrow$ & & & & \\
\hline 1 & $2 s$ & $2 p$ & $/ \downarrow$ & $/ \downarrow$ & & \\
\hline & $\downarrow$ & $3 s$ & $3 p$ & $3 d$ & $/ \downarrow$ & $/ \downarrow$ \\
\hline & & & $4 s$ & $4 p$ & $4 d$ & $4 f$ \\
\hline & & & $\checkmark$ & $5 s$ & $5 p$ & $5 d$ \\
\hline & & & & $\checkmark$ & $6 s$ & $6 p$ \\
\hline & & & & & $\checkmark$ & $7 s$ \\
\hline
\end{tabular}

\subsection{Aufbau 原理}

前節で述べた多電子原子の orbital energy の順序に従って Pauli 原理を満足するよう に下の方から順々に電子を詰めていくことによって原子の基底状態の電子配置 (configuration) が得られる。これがドイツ語で"Aufbau Prinzip"と言われる法則であ る. 英語では"Building-up principle"という言葉もあることはあるが，多くの場合独英 混合の"Aufbau principle"という言葉が用いられている。（Eigen Werte というドイツ語 から eigenvalue という英語を作ってしまったのと似ている）以下，Aufbau principleに 従って，多電子原子の基底電子状態の configuration を調べてみよう。

$n \ell$ という軌道は $m$ の異なるものが $2 \ell+1$ 個あり, それらは磁場がない限り縮退して いる. 従って spin をも含めた spin-orbital は2 $2(2 \ell+1)$ 個あることになる. すなわち Pauli 原理に従うと $s$ orbital には 2 個まで， $p$ orbitalには 6 個まで， $d$ orbital には 10 個ま で電子を詰めることが可能である.

表 16.10.1 に実験から明らかになった configuration を第 3 周期までの原子について 
示す（どういう実験からこういうことが分かるかは大切な問題であるが，ここでは 議論を省略する.）この結果はほぼ Aufbau principle からの予測と一致する．ただし例 外もある. 実験結果が Aufbau principle と一致しないのは原子番号 36 までの原子では $\mathrm{Cr}$ と $\mathrm{Cu}$ のみである.この 2 つの原子については orbital energy の順序が Section 16.9 で述べたものと異なっているのであろう.

この表を上の方から順に見ていこう.原子番号 18 の $\mathrm{Ar}$ までは何の問題もあるまい. 原子番号 19 の $\mathrm{K}$ では新たな電子は $3 d$ に入らず $4 s$ に入っているがこれは $3 p<4 s<3 d<4 p$ という orbital の順序に従っているからである. そして原子番号 20 の $\mathrm{Ca}$ で $4 s$ orbital が詰まってその次の $\mathrm{Sc}$ から $3 d$ orbital に入っていくことになる. $\mathrm{Zn}$ で $3 d$ orbital が完全に詰まってその次の $\mathrm{Ga}$ で始めて $4 p$ orbital に電子が入り始め る.

$\mathrm{Cr}$ と $\mathrm{Cu}$ においては，単純な Aufbau principle から予想される配置とは少々異なり 表に示寸ような配置を取ることが分かっている。こうして得られた $3 d^{5} \quad(\mathrm{Cr}$ の場合） 又は $3 d^{10}(\mathrm{Cu}$ の場合）がより安定であることは他の実験からも言われていることで ある。こういうことも理論的に説明がついているが詳細は省略しよう.

表 16.10 .1 原子の基底状態の電子配置.

\begin{tabular}{ccl}
\hline 原子番号 & 原子 & 配置 \\
\hline 1 & $\mathrm{H}$ & $1 s$ \\
2 & $\mathrm{He}$ & $1 s^{2}$ \\
3 & $\mathrm{Li}$ & $1 s^{2} 2 s$ \\
4 & $\mathrm{Be}$ & $1 s^{2} 2 s^{2}$ \\
5 & $\mathrm{~B}$ & $1 s^{2} 2 s^{2} 2 p$ \\
6 & $\mathrm{C}$ & $1 s^{2} 2 s^{2} 2 p^{2}$ \\
7 & $\mathrm{~N}$ & $1 s^{2} 2 s^{2} 2 p^{3}$ \\
8 & $\mathrm{O}$ & $1 s^{2} 2 s^{2} 2 p^{4}$ \\
9 & $\mathrm{~F}$ & $1 s^{2} 2 s^{2} 2 p^{5}$ \\
10 & $\mathrm{Ne}$ & $1 s^{2} 2 s^{2} 2 p^{6}$ \\
11 & $\mathrm{Na}$ & $1 s^{2} 2 s^{2} 2 p^{6} 3 s$ \\
12 & $\mathrm{Mg}$ & $1 s^{2} 2 s^{2} 2 p^{6} 3 s^{2}$ \\
13 & $\mathrm{Al}$ & $1 s^{2} 2 s^{2} 2 p^{6} 3 s^{2} 3 p$
\end{tabular}




\begin{tabular}{lll}
14 & $\mathrm{Si}$ & $1 s^{2} 2 s^{2} 2 p^{6} 3 s^{2} 3 p^{2}$ \\
15 & $\mathrm{P}$ & $1 s^{2} 2 s^{2} 2 p^{6} 3 s^{2} 3 p^{3}$ \\
16 & $\mathrm{~S}$ & $1 s^{2} 2 s^{2} 2 p^{6} 3 s^{2} 3 p^{4}$ \\
17 & $\mathrm{Cl}$ & $1 s^{2} 2 s^{2} 2 p^{6} 3 s^{2} 3 p^{5}$ \\
18 & $\mathrm{Ar}$ & $1 s^{2} 2 s^{2} 2 p^{6} 3 s^{2} 3 p^{6}$ \\
19 & $\mathrm{~K}$ & $1 s^{2} 2 s^{2} 2 p^{6} 3 s^{2} 3 p^{6} 4 s$ \\
20 & $\mathrm{Ca}$ & $1 s^{2} 2 s^{2} 2 p^{6} 3 s^{2} 3 p^{6} 4 s^{2}$ \\
21 & $\mathrm{Sc}$ & $1 s^{2} 2 s^{2} 2 p^{6} 3 s^{2} 3 p^{6} 4 s^{2} 3 d^{1}$ \\
22 & $\mathrm{Ti}$ & $1 s^{2} 2 s^{2} 2 p^{6} 3 s^{2} 3 p^{6} 4 s^{2} 3 d^{2}$ \\
23 & $\mathrm{~V}$ & $1 s^{2} 2 s^{2} 2 p^{6} 3 s^{2} 3 p^{6} 4 s^{2} 3 d^{3}$ \\
24 & $\mathrm{Cr}$ & $1 s^{2} 2 s^{2} 2 p^{6} 3 s^{2} 3 p^{6} 4 s^{1} 3 d^{5}$ \\
25 & $\mathrm{Mn}$ & $1 s^{2} 2 s^{2} 2 p^{6} 3 s^{2} 3 p^{6} 4 s^{2} 3 d^{5}$ \\
26 & $\mathrm{Fe}$ & $1 s^{2} 2 s^{2} 2 p^{6} 3 s^{2} 3 p^{6} 4 s^{2} 3 d^{6}$ \\
27 & $\mathrm{Co}$ & $1 s^{2} 2 s^{2} 2 p^{6} 3 s^{2} 3 p^{6} 4 s^{2} 3 d^{7}$ \\
28 & $\mathrm{Ni}$ & $1 s^{2} 2 s^{2} 2 p^{6} 3 s^{2} 3 p^{6} 4 s^{2} 3 d^{8}$ \\
29 & $\mathrm{Cu}$ & $1 s^{2} 2 s^{2} 2 p^{6} 3 s^{2} 3 p^{6} 4 s^{1} 3 d^{10}$ \\
30 & $\mathrm{Zu}$ & $1 s^{2} 2 s^{2} 2 p^{6} 3 s^{2} 3 p^{6} 4 s^{2} 3 d^{10}$ \\
31 & $\mathrm{Ga}$ & $1 s^{2} 2 s^{2} 2 p^{6} 3 s^{2} 3 p^{6} 4 s^{2} 3 d^{10} 4 p$ \\
32 & $\mathrm{Ge}$ & $1 s^{2} 2 s^{2} 2 p^{6} 3 s^{2} 3 p^{6} 4 s^{2} 3 d^{10} 4 p^{2}$ \\
33 & $\mathrm{As}$ & $1 s^{2} 2 s^{2} 2 p^{6} 3 s^{2} 3 p^{6} 4 s^{2} 3 d^{10} 4 p^{3}$ \\
34 & $\mathrm{Se}$ & $1 s^{2} 2 s^{2} 2 p^{6} 3 s^{2} 3 p^{6} 4 s^{2} 3 d^{10} 4 p^{4}$ \\
35 & $\mathrm{Br}$ & $1 s^{2} 2 s^{2} 2 p^{6} 3 s^{2} 3 p^{6} 4 s^{2} 3 d^{10} 4 p^{5}$ \\
36 & $\mathrm{Kr}$ & $1 s^{2} 2 s^{2} 2 p^{6} 3 s^{2} 3 p^{6} 4 s^{2} 3 d^{10} 4 p^{6}$ \\
\hline & & \\
\hline 3 & &
\end{tabular}

\subsection{1 炭素原子の基底状態}

どんな原子のどんな電子状態でも Aufbau principleによって wavefunction を作るこ とが出来る. とはいっても, 電子の数が多くなると $\boldsymbol{L}^{2}, L_{z}, \boldsymbol{S}^{2}, S_{z}$ のいずれの演算 
子についても固有関数となるような wavefunction を作るのはちょっと手間がいるよう になる.しかし，いったん wavefunction を作ってしまえば，いかなる物理量をも計算 し得るという立場から考えると, wavefunction を作ることは最初にすべき大切な問題 である。ここでは一例として炭素原子の基底状態について考えてみよう。

炭素原子の基底状態は $1 s^{2} 2 s^{2} 2 p^{2}$ という configuration を持つ。このうち $1 s^{2} 2 s^{2}$ の部 分は閉款になっているから何の問題もない. 問題となるのは, $2 p^{2}$ の部分である. $2 p$ orbital は $2 p_{+1}, 2 p_{0}, 2 p_{-1}$ の 3 つがあり，これに spin 関数の $\alpha$ および $\beta$ を考慮すると

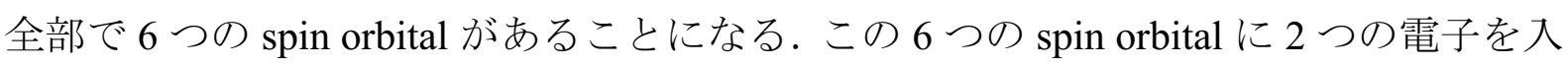
れるわけであるから，電子の入れ方の数は ${ }_{6} C_{2}=15$ 通りあることになる. この 15 通り

の Slater determinant $の$ linear combination として, $\boldsymbol{L}^{2}, L_{z}, \boldsymbol{S}^{2}, S_{z}$ の eigenfunction と なるような wavefunction を作り上げなければならない.

計算を始める前に，量子数 $L$ や $S$ とてどういう可能性があるかをみておこう．2 つの $p$ 電子はそれぞれ $\ell=1$ であるから, その合成として $L=2, L=1, L=0$ の 3 通り が考えられる. 同様に $\operatorname{spin}$ 量子数については $S=\frac{1}{2}$ のスピン 2 つの合成として $S=1$ お よび $S=0$ が得られる. 量子数 $M$ は， $L=2$ については $M=2,1,0,-1,-2$ の 5 通り, $L=1$ については $M=1,0,-1$ の 3 通りの可能性があり, また $L=0$ については必然的に $M=0$ となる．また， $M_{S}$ は， $S=1$ については $M_{S}=1,0,-1$ の 3 通りがあり,$S=0$ に ついては $M_{S}=0$ である.このようにして $L, M, S, M_{S}$ の 4 つの量子数としてどん な值を取り得るかの見通しがたった。ではいよいよ計算にとりかかろう。

いずれの spin-orbital も $L_{z}$ および $S_{z}$ の eigenfunction になっているので, どんな Slater determinant も必ず $L_{z}$ および $S_{z}$ の eigenfunction となっている． $L_{z}$ についての固有值が $M \hbar ， S_{z}$ についての固有値が $M_{S} \hbar$ であことは今まで何回も学習して来たことであ る. 考えられる Slater determinant およびそれぞれの $M$ および $M_{S}$ を以下の表に示す. 


\begin{tabular}{|c|c|c|}
\hline Slater determinant & $M$ & $M_{S}$ \\
\hline$\psi_{1}=\left|p_{+1}(1) \alpha(1) p_{+1}(2) \beta(2)\right|$ & 2 & 0 \\
\hline$\psi_{2}=\left|p_{+1}(1) \alpha(1) p_{0}(2) \alpha(2)\right|$ & 1 & 1 \\
\hline$\psi_{3}=\left|p_{+1}(1) \alpha(1) p_{0}(2) \beta(2)\right|$ & 1 & 0 \\
\hline$\psi_{4}=\left|p_{+1}(1) \beta(1) p_{0}(2) \alpha(2)\right|$ & 1 & 0 \\
\hline$\psi_{5}=\left|p_{+1}(1) \beta(1) p_{0}(2) \beta(2)\right|$ & 1 & -1 \\
\hline$\psi_{6}=\left|p_{+1}(1) \alpha(1) p_{-1}(2) \alpha(2)\right|$ & 0 & 1 \\
\hline$\psi_{7}=\left|p_{+1}(1) \alpha(1) p_{-1}(2) \beta(2)\right|$ & 0 & 0 \\
\hline$\psi_{8}=\left|p_{+1}(1) \beta(1) p_{-1}(2) \alpha(2)\right|$ & 0 & 0 \\
\hline$\psi_{9}=\left|p_{0}(1) \alpha(1) p_{0}(2) \beta(2)\right|$ & 0 & 0 \\
\hline$\psi_{10}=\left|p_{+1}(1) \beta(1) p_{-1}(2) \beta(2)\right|$ & 0 & -1 \\
\hline$\psi_{11}=\left|p_{0}(1) \alpha(1) p_{-1}(2) \alpha(2)\right|$ & -1 & 1 \\
\hline$\psi_{12}=\left|p_{0}(1) \alpha(1) p_{-1}(2) \beta(2)\right|$ & -1 & 0 \\
\hline$\psi_{13}=\left|p_{0}(1) \beta(1) p_{-1}(2) \alpha(2)\right|$ & -1 & 0 \\
\hline$\psi_{14}=\left|p_{0}(1) \beta(1) p_{-1}(2) \beta(2)\right|$ & -1 & -1 \\
\hline$\psi_{15}=\left|p_{-1}(1) \alpha(1) p_{-1}(2) \beta(2)\right|$ & -2 & 0 \\
\hline
\end{tabular}

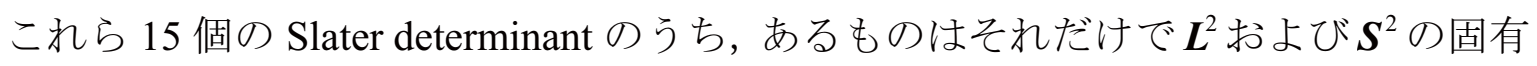
関数になっているが一般にはそうなっていない.そこで $\boldsymbol{L}^{2}$ および $\boldsymbol{S}^{2}$ について対角化 
し，それらの固有関数となるような linear combination を作るわけである。ただし 15 次の対角化は必要でない. というのは， $\boldsymbol{L}^{2}, \boldsymbol{S}^{2}, L_{z}, S_{z}$ がお互いに可換であるから， $M$ または $M_{S}$ の異なる Slater determinant 間では $\boldsymbol{L}^{2}, \boldsymbol{S}^{2}$ いずれの演算子でも相互作用 しないことは明らかである。

従って, 15 個の Slater determinant は次の 11 種類に分類されることになる.
(1) $M=2, \quad M_{S}=0$
$\psi_{1}$
(2) $M=1, \quad M_{S}=1$
$\psi_{2}$
(3) $M=1, \quad M_{S}=0$
$\psi_{3}, \quad \psi_{4}$
(4) $\quad M=1, \quad M_{S}=-1$
$\psi_{5}$
(5) $M=0, \quad M_{S}=1$
$\psi_{6}$
(6) $M=0, \quad M_{S}=0$
$\psi_{7}, \quad \psi_{8}, \psi_{9}$
(7) $M=0, \quad M_{S}=-1$
$\psi_{10}$
(8) $M=-1, \quad M_{S}=1$
$\psi_{11}$
(9) $\quad M=-1, \quad M_{S}=0$
$\psi_{12}, \quad \psi_{13}$
(10) $M=-1, \quad M_{S}=-1$
$\psi_{14}$
(11) $M=-2, \quad M_{S}=0$
$\psi_{15}$

この分類の中で，(1)，（2），(4)，（5），(7)，（8），(10），(11）の8 種類はそれぞ れただ 1 つの wavefunction しかない. 従って, それらはそれぞれ， $\boldsymbol{L}^{2}$ および $\boldsymbol{S}^{2}$ の固 有関数になっているはずである. しかし（3），(6)，（9）の3 種類は 2 つたた 3 つ の wavefunction を含む. そこでこれら 2 つるいは3つの linear combination をとって $\boldsymbol{L}^{2}$ および $\boldsymbol{S}^{2}$ の固有関数とすればよい. 寸なわち，15 次の対角化の代わりに，2 次の 対角化を 2 つ 3 次の対角化を 1 つ行えばよいことになる. 
本講義をここまで学習して来た人にとっては対角化は極めて簡単なはずである.必 要な対角化を行い， $\boldsymbol{L}^{2}, \boldsymbol{S}^{2}, L_{z}, S_{z}$ の eigenfunction となるような wavefunction を作 ることは諸君の演習としておこう。

is Problem 16.11.1

$\psi_{1}$ から $\psi_{15}$ までの linear combination として $\boldsymbol{L}^{2}, \boldsymbol{S}^{2}, L_{z}, S_{z}$ の固有関数となるよう な wavefunction を対角化の方法で作り，量子数 $L, M, S, M_{S}$ で整理せよ。（答えは, 例えば Eyring, Walter, Kimball, Quantum Chemistry の page 142-143 に出ている. ) 


\section{CHAPTER 17}

\section{群論}

今まで，いろいろな量子状態を記述するのにいくつかの量子数を定義して来た. 例 えば，水素原子については $n, \ell, m, m_{S}$ の 4 つの量子数があった。このうち， $n$ は単なる 番号付けであるが，その他の 3 つの量子数は Hamiltonian $H$ と可換なある演算子の固 有值に関連している。具体的に言うと， $\left[H, \boldsymbol{L}^{2}\right]=0$ を満たす演算子 $\boldsymbol{L}^{2}$ の固有值が $\ell(\ell+1) \hbar^{2},\left[H, L_{z}\right]=0$ を満たす演算子 $L_{z}$ の固有值が $m \hbar$ である. 更に, $\left[H, S_{z}\right]=0$ を満

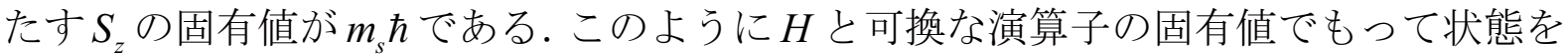
記述することの重要性は今更説明するまでもなからう。これら演算子の固有值が異な る状態間は $H$ によって相互作用しないという量子化学の基本定理があるからである. 例えば $\ell=0$ の $s$ 軌道と $\ell=1 の p$ 軌道とは， $H$ により相互作用することはない. 原子の 場合には，このような量子数の組で状態を分類し，それが理論の更なる発展に便利で ある．ところが分子の場合には，直線分子の場合を除いて，任意の大きさの角度に対 する対称性を有する対称軸が存在しないので， $\ell$ も $m$ も「良い量子数（good quantum number) 」でなくなる.（ $H$ と可換な演算子の固有值でもって量子数が定義出来ないこ とをこういう言葉で表す.）こうなると原子の時に出来たさまざまな系統づけや理論 が分子について使えないことになり，理論の展開にも支障をきたすことになってしま う。しかし，幸いにも，分子の場合には，その形に着目した新しい演算子を考えるこ とが出来るので，その演算子の固有值でもって状態を分類することが出来るのであ る.

上述した分子の形に着目した演算子とは以下に説明する「対称操作（symmetry operation）」のことである. 分子にある種の操作を施した時に形が変らなければその操 作のことを対称操作と言う。例えば正方形の分子があったとして，その対角線を含む 軸で $\pi$ の回転を行えば元と同じ形となる。それでこのような操作は対称操作である.

しかしこの軸のまわりで $\frac{\pi}{4}$ の回転を行ったとすると，もちろん正方形は正方形のま まではあるが，操作を施す前とは異なった位置関係にあり，このような操作は対称操 作ではない.

さて，分子の Hamiltonian を考えてみる．分子中の電子の Hamiltonian は，分子の骨 格を形作る原子核の座標と電子の座標の両方を含む. 分子に対称操作を施す，という 
場合，我々は骨格の原子核の配置のみを考えて，電子がどこにあるかは考えない。し かし，電子の座標を含む Hamiltonian は原子核の相対配置が変らないような対称操作 に対して不変であると考えることが出来る. 従って, 対称操作 $G$ は Hamiltonian $H$ と 可換，すなわち， $[H, \mathrm{G}]=0$ である. そこでこの対称操作 $G$ の固有值でもつて状態を 分類することが出来るわけであり, そのために必要な理論が群論（group theory）であ る.

群論には, 分子を対象とする点群と, 結晶のように無限に連続している系を対象と する空間群があるが，本章では点群のみを扱うことにする.

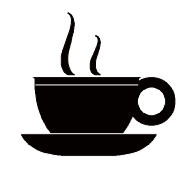

\section{[Coffee Break] "Gruppenpest}

ドイツ語で "Gruppenpest" という言葉がある。このグルッペンペストという病気は 群論をちょっと勉強した人がかかりやすいペストみたいな疫病である.

群論というのは，まじめに勉強を始めるとたまらないほど面白い.それはおそらく， 我々が過去に勉強した数学の分野にはない領域であったからであろう. 群論自体で非 常に面白いし, その上, それを応用すると複雑なスペクトルが実に単純明解に理解出 来るという点に感激し，面白さも倍増する，それであらゆる量子化学的な思考はまず 群論から入らなければいけない, などと考えたりする。こういうことがグルッペンペ ス卜病の 1 つの徴候である. 又, 群論の勉強があまりにも面白く, 本業をほったらか してそればかり勉強する。こうなるとグルッペンペスト病はかなり重症である。とこ ろが, 出来上がった群論を如何に勉強しても, 何も新しいものは出て来ない. 数学者 の目から見て, 群論に何か将来の大きな問題があるのかどうかは分からないが, 化学 の学徒がただ面白いというだけで群論を勉強していても, 何か特別のものが出るわけ がないのである。まあ, 自分の本業を考えて,「勉強はほどほどに」というところで あろうか.

外国語の文献を見ていて, Gruppenpest という言葉にはなかなか出会わないが，1 つの例を次にあげておこう。それは He 原子の理論をやったことで有名な Hylleraas の "Reminiscence from Early Quantum Mechanics of Two-Electron Atoms"という論文[Rev. Mod. Phys. $\underline{35}, 421$ (1963)]の中の一節である.この思い出話の中で Hylleraas は群論に 関して大きな功績のあった Wigner（1963 年ノーベル物理学賞受賞）について次のよ うに述べている.

One thing which I noticed fairly soon was that solutions must exist which depend only on three coordinates, instead of the full number of six, and these were the 
coordinates $r_{1}, r_{2}, \theta$, defining the shape of the electron-nucleus triangle, leaving its orientation in space out of interest. When confronted with this really useful simplification Born asked: "What does that mean? Let us consult Wigner!"

Eugene Wigner was already at that time a central person among the young Göttingen pioneers. He was suspected to be familiar with some kind of black magic, called group theory. This was several years before the culmination of the so-called "Gruppenpest", when every paper on wave mechanics in order to be taken seriously had to start by stating the "Group character" of its subject. Those who know Wigner will not hesitate to guess that he at once gave the correct answer: "Those states", he said, "are the S states", i.e., states with zero angular momentum.

また, 山内恭彦著「雑叢, 一物理屋の随想」(岩波書店, 昭和 45 年) の中に Gruppenpest のことが書いてある。以下その一部を抜粋する。前章で原子構造を学習した諸君は， ここに書いてあることがよく理解出来るであろう。

『さて盛者必滅は世の慣ひとか，人類発生以来暴威を振つた疫病にも今や絶 滅に瀕してみるものが少なくない，遥に伝聞する所によれば，欧米の文明国に 於いてはコレラ，チブス等は最早骨董的存在であるといふ。併しこの逆に滅ぶ ものあれば又生ずるものありで，今迄聞いたこともない病気が篤学な医者先生 により続々と発見されるのは薄気味が悪いことである。こ〉に述べようする Gruppenpest もこの種の「新病」の一つである。但し旧い病の今日に残ったもの は中々手剛いが，こんな新米の病気は百戦錬磨の現代医術にか〉つては一溜も ない，見る見る中に脆くも撲滅されてしまつたことは甚だ鮮やかな且つ有難い ことであつた。その上発生地が遠い欧洲であつた為本邦では幸ひ余りその禍を 蒙らずに済んだのはいつもながらとお国自慢をしたい処であるが，不覚にも流 行遅れの時期に本病に取り附かれた甚だ気のきかない奴が日本にも居る。それ が本文の筆者なのであるからお話に「なる」のである.

抑々本病の起りは量子力学が創設された直後Heisenberg が He の一重項と三重 項の存在を同種個体の共鳴現象として説明したのに始まる。そんな馬鹿々々し い病気があるもんかなど〉言はないで暫く言ふ処を聞き給へ。世の中にはさう いふこともあるのだ。この理論を任意の原子や分子に拡張しようとすることは 誰しも思ひ附くことであらうが，こ〉でハタと難関にぶつかつた．Heのやうに 電子二箇の場合には，波動函数の対称性が対称か反対称に限られるが，電子数 が多くなるとさう簡単には片附かない。こ〉に対称群の表現論といふ面倒なも のが必要になつて来た。これは元来 Frobenius, Schur 等の手で純粋数学的に発展 した代数学の一分科で，これが創設者にしても物理に応用される日があらうと 
は夢想もしなかつただらうと思はれるやうな抽象的な理論なのである.さなき だに量子力学の発展に伴つて行列算法, 固有值問題, ヒルベルト空間論と不馴 れの数学に苦しめられてみる所へ, この新手の勁敵に士気弥益した強剛の士も あらうが，又悲鳴を上げた贏弱者も少しはあつたらうと思はれる．喜んだ（?） のは Neumann, Wigner, Weyl のやうな数学と物理の両棲学者で, 続々としてむ づかしい論文を発表する。純粋物理学者にも Heitler-London, Heisenberg のやう に勇敢にも之を駆使して夫々分子化合の一般論, 強磁性体の基礎論を樹立寸る 人もある. つぶいて Weyl, Wigner, Waerden の群論と量子力学に関する書物が 出版される. といふ有様で理論物理学者たるもの群を語り得ざれば人に非ずと もまさか言はなかつたらうが，兔に角追随者を多く生じて正に一世を風靡する

（大げさに言つてですぞ）大流行を来たした．然るに群論（特に対称群の表現 論）が果して量子力学の数学的形式に不可欠か否かを疑った人々（或は邪推を すればこんな七面倒臭いものを勉強するのに閉口した人）はこの流行を快く思 はずこれに Gruppenpest なる有難からぬ名前を奉つたものと思はれる。（こつで 白状するが，あまりはつきりした事情は筆者も実はよく知らないのである.）殊 に Weyl の著書(この本の序文に Gruppenpest の語がある) は, 著者が Halbeinfache Gruppe の表現論に関する大研究を完成した直後丁度待つてみましたと言はんば かりの機会だつたので, 内容豊富, 該博なる知識を織込んだ名著であるが，そ れだけ難解な点もあつて悪くすると一部の人々は一層厭気を増させる原因にな つたかも知れない.

さて本病の流行一度猖獗と見るや, 腕に覚えの名医連がその侭にほつて置く 筈がない. 早速その療法を案出した. 先づ Dirac は置換を波動函数に施される演 算子と考へて, 全然量子力学的考察から群論から導かれるのと同等な結果を導 き出すことに成功した。併しこれは悪く云へば全く群論的方法の焼直しで，対 症療法の域を出ない.もつと䚑面の根治療法を発見したのはSlaterであつた. 彼 の方法ではスピン函数を含めて最初から反対称の波動函数（所謂 Slater determinant)のみを用みるから対称群の表現論は全然不要である.一度この Slater determinant なる特効薬が知れてからは, さしも流行のペストも下火となり，今 日では之になやまされるものも殆ど後を断つに至つた。

以上がこの奇病の消長の大略で，かやうな病があつたことは聞き及ばれた方 もあらうと思ふが，

追記.このペストは戦後原子核理論に，ついで素粒子の対称性に関して大流 行をした。 今日でも罹病者は後を断たない.』（引用終り） 


\section{1 対称操作（symmetry operation）}

すべての対称操作は proper rotation $C_{n}$ と improper rotation $S_{n}$ のいずれかに属する.

a) Proper rotation

proper rotation はある軸のまわりの $\frac{2 \pi}{n}$ の回転で, 記号 $C_{n}$ で示す. 対称操作 $C_{n}$ の軸 を $C_{n}$ 軸という言葉で表す. 1 つの分子に複数個の $C_{n}$ 軸があることはしばしばある。こ の場合，最も大きな $n$ を持つ $C_{n}$ 軸を主軸（principal axis）という.

例として $\mathrm{NH}_{3}$ 分子の $C_{3}$ 軸および $\mathrm{H}_{2} \mathrm{O}$ 分子の $C_{2}$ 軸を図 17.1.1 に示す.
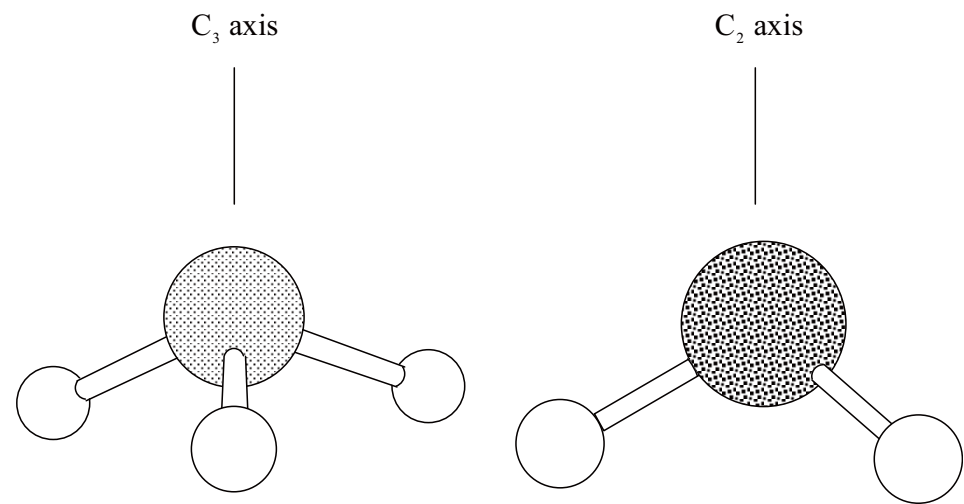

図 17.1.1 $\mathrm{NH}_{3}$ の $C_{3}$ 軸および $\mathrm{H}_{2} \mathrm{O}$ の $C_{2}$ 軸

b) Improper rotation

improper rotation は proper rotation $C_{n}$ を行った後 $C_{n}$ 軸に垂直な面での面対称操作で ある鏡映 (reflection) を行う操作で $S_{n}$ という記号で表す。例として $\mathrm{CH}_{4}$ 分子の $S_{4}$ 軸 を図 17.1.2 に示す。 


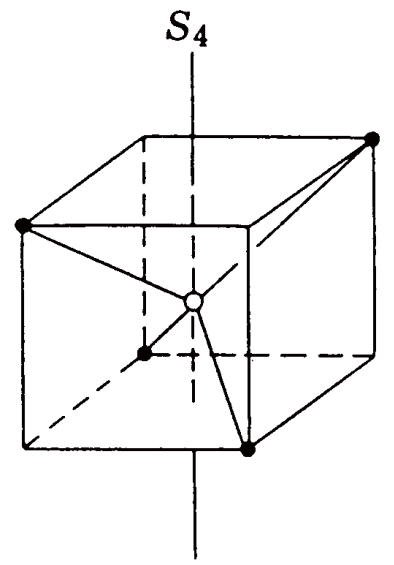

図 17.1.2 $\mathrm{CH}_{4}$ 分子の $S_{4}$ 軸

冒頭で述べたように，全ての対称操作は $C_{n}$ 又は $S_{n}$ のいずれかに属する. しかし， そのうちのいくつかについては，特別な名称が与えられている．それについて述べよ う。

$E=C_{1}=C_{\infty}$ : identity（恒等操作）すなわち「何もしない」という対称操作である. 実空間では $2 \pi$ の回転 $C_{1}$ は何もしないことと同じである。何もしないという「操作」 を対称操作の中に加えなければならない理由はおいおい明らかとなるであろう。な お， $E$ はドイツ語の Einheit から取ったものである。（注：Eを $2 \pi$ の回転と考えると $\frac{2 \pi}{2 \pi}=1$ よりその操作は $C_{1}$ と表される. また， $E$ をゼ口度の回転と考えると $\frac{2 \pi}{0}=\infty$ よ りその操作は $C_{\infty}$ と表される.)

$\sigma=S_{1}=S_{\infty}$ : reflection（鏡映）. 1 つの平面についての面対称操作である.もし $\sigma$ の 他に $C_{n}$ があった場合，主軸を含む面での reflection を $\sigma_{v}$ （subscript の $\mathrm{v}$ は"vertical"の 意)，主軸に垂直な面での reflection を $\sigma_{h}$ （subscript の h は"horizontal"の意）というよ うに，"v"または"h"の subscript が付けられる場合がある。主軸を空間上垂直（vertical） にとって考えれば, vertical と horizontal の意味は明かであろう。また dihedral plane に 
よる reflection $\sigma_{d}$ がある場合もある。これは， $\sigma_{v}$ の特殊な場合であり，2つの $C_{2}$ 軸を 2 分寸るような面での reflection である. 図 17.1.3 に例に $\mathrm{H}_{2} \mathrm{O}$ 分子の $2 つ の \sigma$ 面を示 す. なお， $\sigma$ はドイツ語の Spiegelung の頭文字 S をギリシャ文字で表したものである.

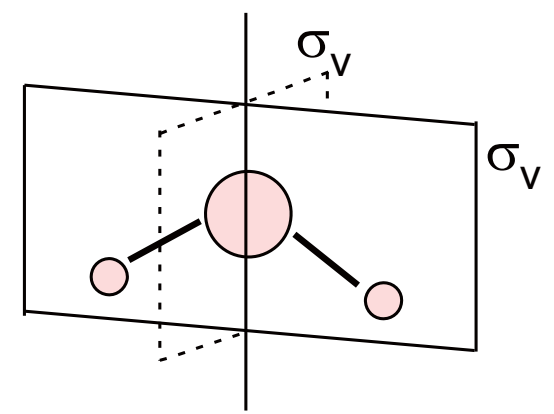

図 17.1.3 (a) $\mathrm{H}_{2} \mathrm{O}$ 分子の 2 つの $\sigma_{v}$ 面

$i=S_{2}$ : inversion. 対称中心（center of inversion）について点対称な点への対称操作 である。図 17.1.4 に 6 座配位の錯体 $\mathrm{MX}_{6}$ についての center of inversion を示す.

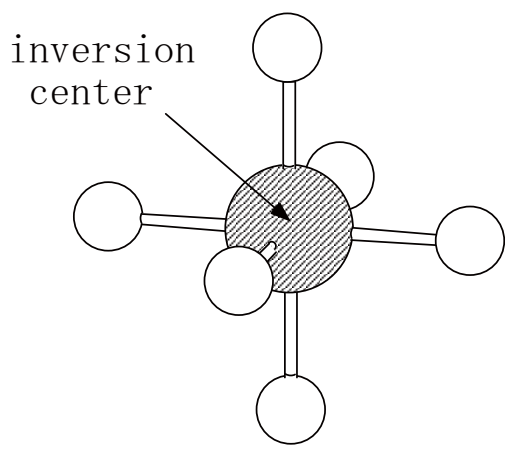

図 17.1.4 $\mathrm{MX}_{6}$ イオンの対称中心

ここで記号について一言. 本 lecture note では，対称操作（symmetry operation）を イタイック体で示すことにする. 


\section{2 分子の形の対称性による分類}

ある分子がどのような対称操作の組を持っているかということで分子を分類しよ うというのがここで考えることである。例えば $\mathrm{H}_{2} \mathrm{O}$ 分子は identity $E, \pi$ の回転 $C_{2}$, および 2 種類の鏡映 $\sigma$, 計 4 つの対称操作を持っている. $\mathrm{H}_{2} \mathrm{~S}$ もこれと同じ 4 つの対 称操作を持っている。この 2 つの分子の形は同じではない. $\mathrm{H}-\mathrm{O}-\mathrm{H}$ の角度と $\mathrm{H}-\mathrm{S}$ - $\mathrm{H}$ の角度は異なるし， $\mathrm{H}-\mathrm{O}$ の長さと $\mathrm{H}-\mathrm{S}$ の長さも異なる.しかし，この 2 つの 分子は, 全く同じ 4 つの対称操作を持つということで, 同じ仲間とみなすわけである. 一方，同じ 3 原子分子でも $\mathrm{CO}_{2}$ は 3 つの原子が直線的に並んでいるので，持ってい る対称操作が異なり， $\mathrm{H}_{2} \mathrm{O}$ や $\mathrm{H}_{2} \mathrm{~S}$ とは異なった仲間となる. 分子の形をこのような 観点から分類するのであるが，それぞれに以下に示すような約束で名前をつけてお く.この分類を, 点群という言葉で表現している.

(A) $\mathrm{C}_{n}$ 軸を 1 個持つ場合

1) $\mathrm{C}_{1}$ : identity operation $E$ のみしか持たない場合.

2) $\mathrm{C}_{\mathrm{s}}=\mathrm{C}_{1 \mathrm{~h}}: \quad E$ と $\sigma$ のつの symmetry operation を持つ場合

$\mathrm{C}_{\mathrm{S}}$ の例 :

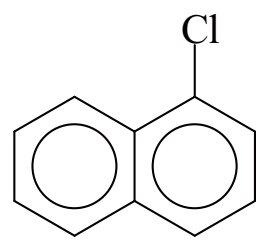

3) $\mathrm{C}_{\mathrm{i}}=\mathrm{S}_{2}: \quad E$ と inversion $i$ を持つ場合.

$\mathrm{C}_{\mathrm{i}}$ の例 :<smiles>FC(Cl)CCl</smiles>

4) $\mathrm{C}_{\mathrm{n}}$ : $E$ と $C_{n}$ を持つ場合.

$\mathrm{C}_{\mathrm{n}}$ という記号が点群を表す場合と symmetry operation を表す場合とがある が，この 2 つが混同することはあまりないことと思われる. 本や論文として印刷する 
場合には，点群を表す $\mathrm{C}_{\mathrm{n}}$ はローマンの書体に, symmetry operation を表す $C_{n}$ はイタリ ックの書体で表して，区別している場合もある. 本 lecture note でもおおむねはそのよ うに区別を付けるようにしているつもりではある。

$\mathrm{C}_{3}$ の例 :

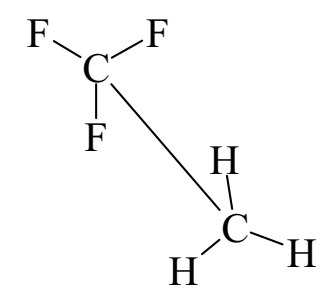

5) $\mathrm{C}_{\mathrm{nv}}$ : $E, C_{n}, n$ 個の $\sigma_{\mathrm{v}}$ を持つ場合.

$$
\begin{aligned}
& \mathrm{C}_{2 \mathrm{v}} \text { の例 : } \\
& \mathrm{C}_{2 \mathrm{v}} \text { の例 : }
\end{aligned}
$$$$
\mathrm{H}^{\prime} \mathrm{O}^{\prime} \mathrm{H}
$$$$
\mathrm{H}_{2} \mathrm{O}
$$

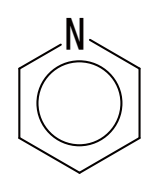

pyridine

$\mathrm{C}_{2 \mathrm{v}}$ の例 :

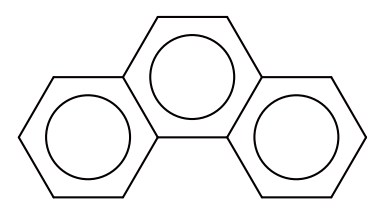

phenanthrene

$\mathrm{C}_{3 \mathrm{v}}$ の例 :

$$
\mathrm{H}_{\mathrm{H}}^{--\mathrm{N}} \mathrm{H}
$$

$\mathrm{NH}_{3}$ 
$\mathrm{C}_{4 \mathrm{v}}$ の例 :

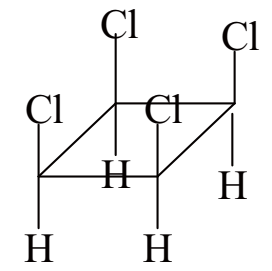

tetrachlorocyclohexane

6) $\mathrm{C}_{\mathrm{nh}}: E, C_{n}, \sigma_{h}$ を持つ場合.

ある symmetry operation があると，自動的に他の symmetry operation が存在す る場合もある。例えば $\mathrm{C}_{2} \mathrm{~h}$ では，対称操作 $C_{2}$ と $\sigma$ の組み合せで inversion も存在する ことになる。

$\mathrm{C}_{2 \mathrm{~h}}$ の例 :<smiles>Cl/C=C/Cl</smiles>

trans-dichloroethylene

$\mathrm{C}_{3 \mathrm{~h}}$ の例 :<smiles>OB(O)O</smiles>

$\mathrm{B}(\mathrm{OH})_{3}$

7) $\mathrm{D}_{\mathrm{n}}: E, C_{n}$, および $C_{n}$ 軸に垂直な $n$ 個の $C_{2}$ 軸を持つ場合.

\section{【注意】 :}

Eyring, Walter, Kimball 著"Quantum Chemistry"の p. 377 では， $C_{2}$ 軸の数を $2 n$ 個とし ているが，これは間違いで，上述のように $n$ 個であるべきである)

8） $\mathrm{D}_{\mathrm{nh}}$ ： $\mathrm{D}_{\mathrm{n}}$ に含まれる symmetry operation の他に $\sigma_{h}$ を 1 つ持つ場合.

$$
\mathrm{D}_{2 \mathrm{~h}} \text { の例 : }
$$

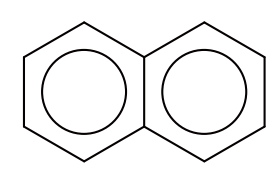

naphthalene 
$\mathrm{D}_{2 \mathrm{~h}}$ の例 :<smiles>C=C</smiles>

ethylene

$\mathrm{D}_{3 \mathrm{~h}}$ の例 :<smiles>CC</smiles>

ethane (eclipsed)<smiles>[2H]C(O)O</smiles>

$\mathrm{CO}_{3}{ }^{2-}$

$\mathrm{D}_{4 \mathrm{~h}}$ の例 :<smiles></smiles>

$\left[\mathrm{PtCl}_{4}\right]^{2-}$

$\mathrm{D}_{4 \mathrm{~h}}$ の例 :

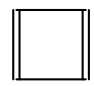

cyclobutadine

D6h の例 :<smiles>c1ccccc1</smiles>

benzene

$\mathrm{D}_{3 \mathrm{~h}}$ の例 :

$$
\left[\mathrm{PlCl}_{4}\right]^{2-}
$$

(注 : 左の図の ethane 分子では, 奥 の $\mathrm{H}$ 原子，手前の $\mathrm{H}$ 原子，観測者が 一直線上にある.あたかも日食にお いて，太陽，月，観測者が一直線上 に並ぶのと似ていることから，この ような ethane を eclipsed 構造と呼ば れている.)

9） $\mathrm{D}_{\mathrm{nd}}$ ： $\mathrm{D}_{\mathrm{n}}$ に含まれる symmetry operation に加えて 2 つの $C_{2}$ 軸を 2 分する軸を含 む面での reflection $\sigma_{d}$ を $n$ 個を持つ場合. 


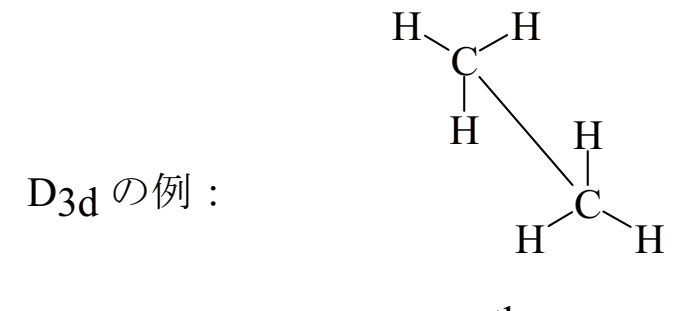

ethane

(staggered conformation)

$\mathrm{D}_{5 \mathrm{~d}}$ の例 :

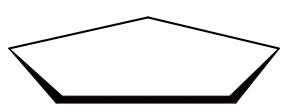

$\mathrm{Fe}$

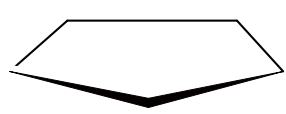

ferocene

10） $\mathrm{S}_{2 n}$ ： $E, C_{n}$ の他に $S_{2 n}$ を持つ場合.

$\mathrm{S}_{4}$ の例 :

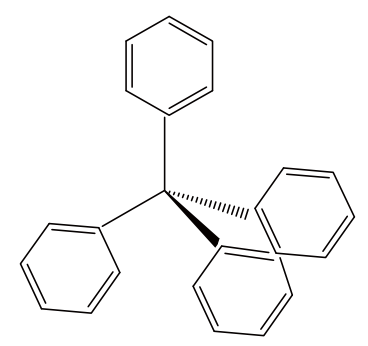

tetraphenylmethane

（B） $C_{n}$ 軸が 2 個以上ある場合.

対称操作を羅列するよりも具体的な分子の例を示した方が分かりやすいであ ろう。 


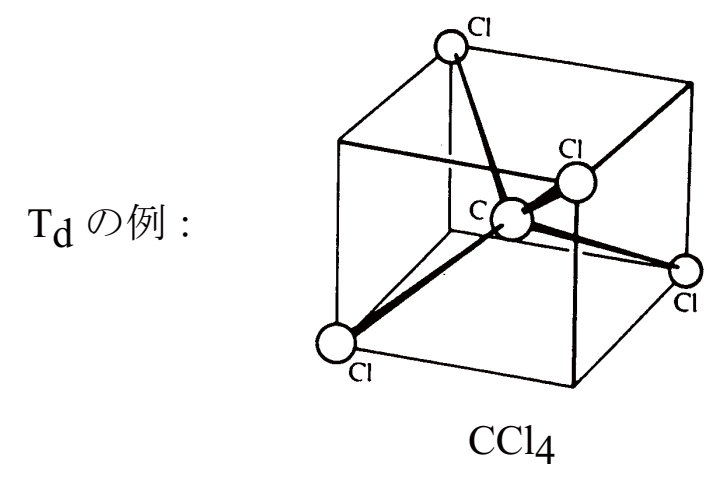

$\mathrm{O}_{\mathrm{h}}$ の例 :

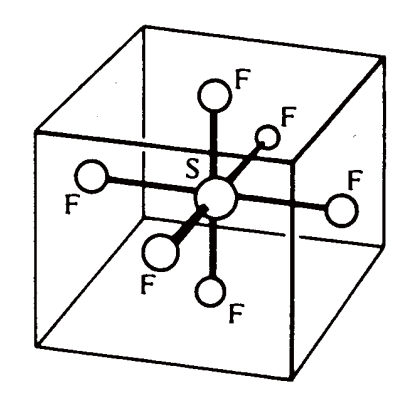

$\mathrm{SF}_{6}$

$\mathrm{I}_{\mathrm{h}}$ の例 :

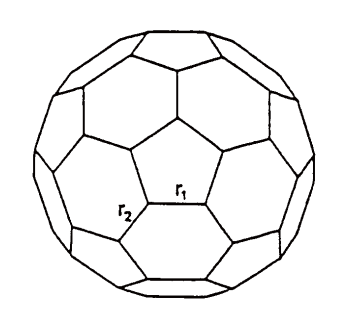

$\mathrm{C}_{60}$

(炭素 60 個からなるクラスター)

上述したようにいろいろの点群がある．1つの分子の形が与えられたら，どのよう な対称操作が存在するかを注意深く吟味し，その結果を見ながらどの点群に属するか を判断すればよい，慣れて来ると直ちに分かるようになるが，始めのうちはなかなか 大変であろう。

群論の教科書には，点群を systematic に求めるための flow chart が出ており，それ らを注意深く検討すれば求める点群が求まることになるが，むしろ，素人には分かり にくいみたいである，上に述べた例を見ながら，後は，指標表（後述）と比べてみる のが手っ取り早いように思う.

记Problem 17.2.1

次のものの点群を述べよ. 
1）六角柱の鉛筆

2） 1）の鉛筆を削ったもの

3） 円柱の鉛筆

4） 3）の鉛筆を削ったもの

5）人間の体

6） 3 枚バネのプロペラ

7）サイコロ

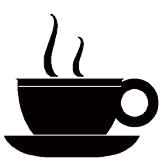

[Coffee Break] 戦国武将の紋章

日本の紋章には, 対称性の良いものが多い.ヨーロッパの貴族の紋と比べると著し い特徴であると思う。

紋には立体的な模様を描いたものもあるが，すべて図に忠実に平面と考えると，必 ず $\sigma$ という対称操作を持つわけで, $\mathrm{C}_{2} \mathrm{v}, \mathrm{C}_{n \mathrm{~h}}, \mathrm{D}_{n \mathrm{~h}}$ の点群が考えられる.

$n=2,3,4,5,6,8,9,10$ についてはかなりの例があり, もっと $n$ の大きいものも，たまに はある。中村吾郎「戦国武将の紋章」という論文に出ていた 77 種の紋章を点群によ って分類してみた．次頁以降に示寸ように， $\mathrm{C}_{2 \mathrm{v}}$ のものがもっとも多いが， $\mathrm{D}_{12 \mathrm{~h}}$ や $\mathrm{D}_{\infty \mathrm{h}}$ のような対称性の高いものもある. 
$\mathrm{C}_{2 \mathrm{~V}}$
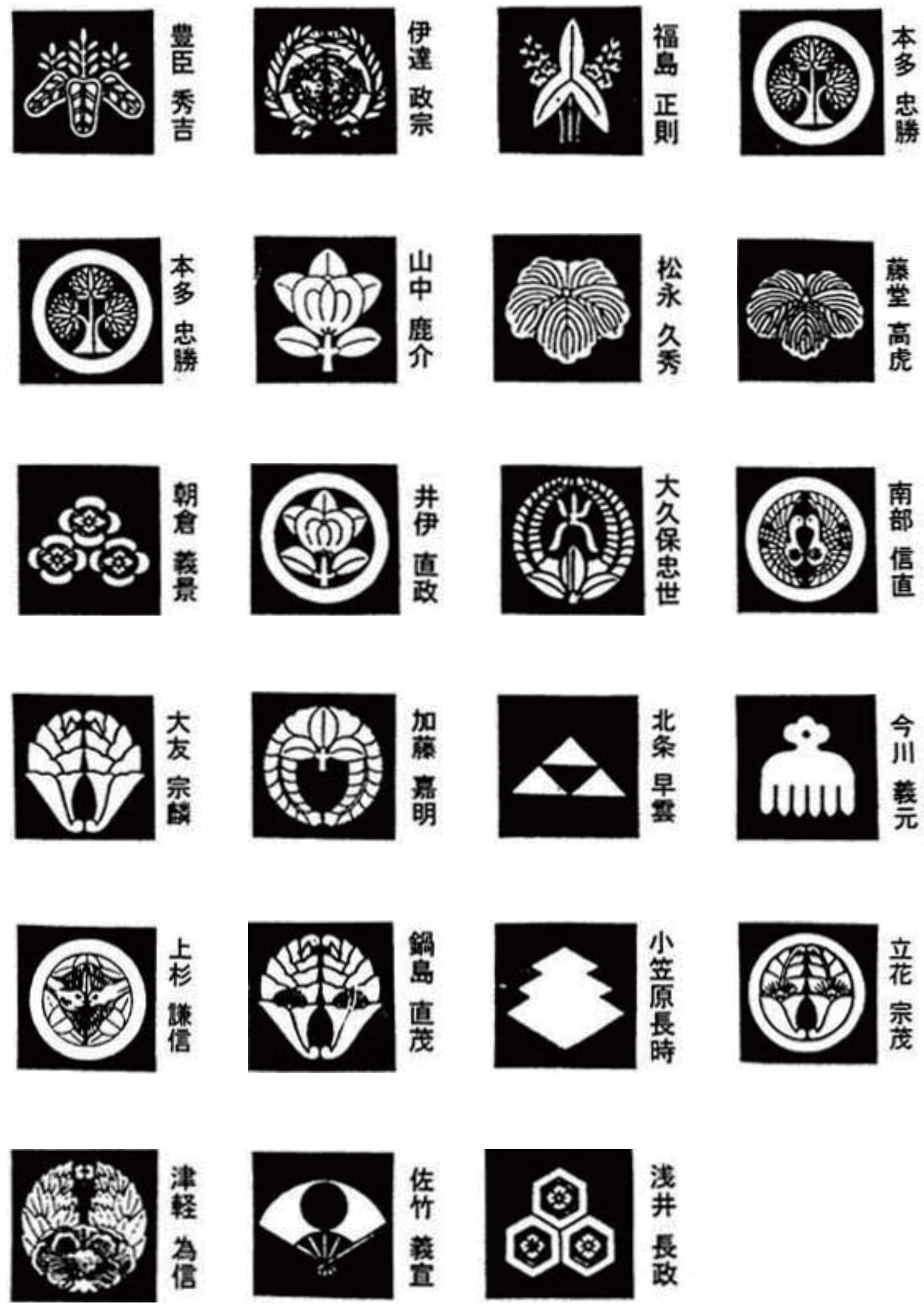
$\mathrm{C}_{1 \mathrm{~h}}=\mathrm{Cs}$
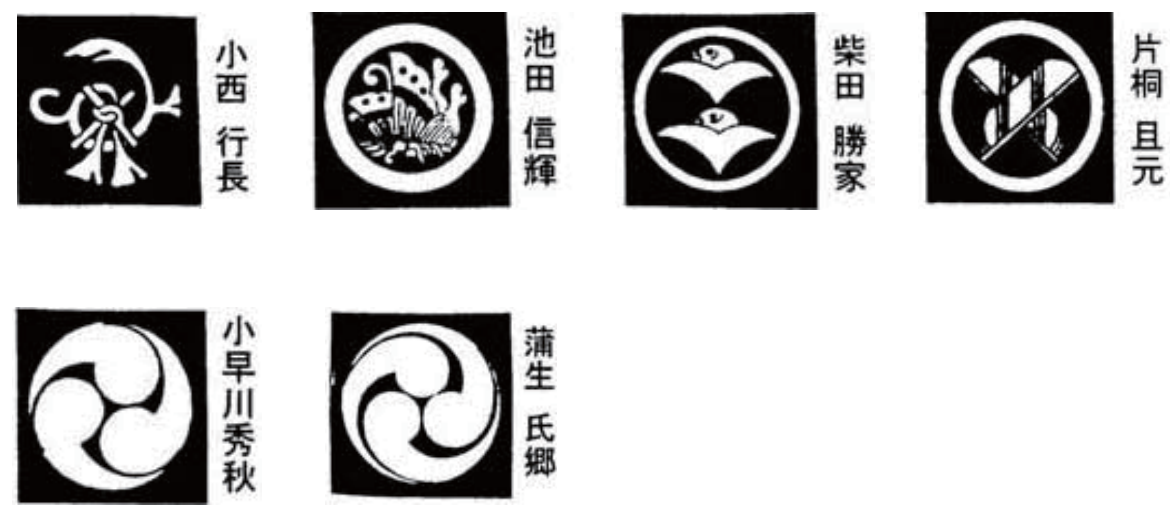

$\mathrm{C}_{3 \mathrm{~h}}$

$\mathrm{C}_{4 \mathrm{~h}}$

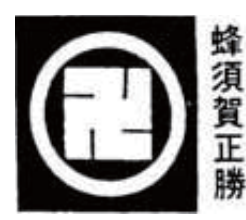

$\mathrm{D}_{2 \mathrm{~h}}$
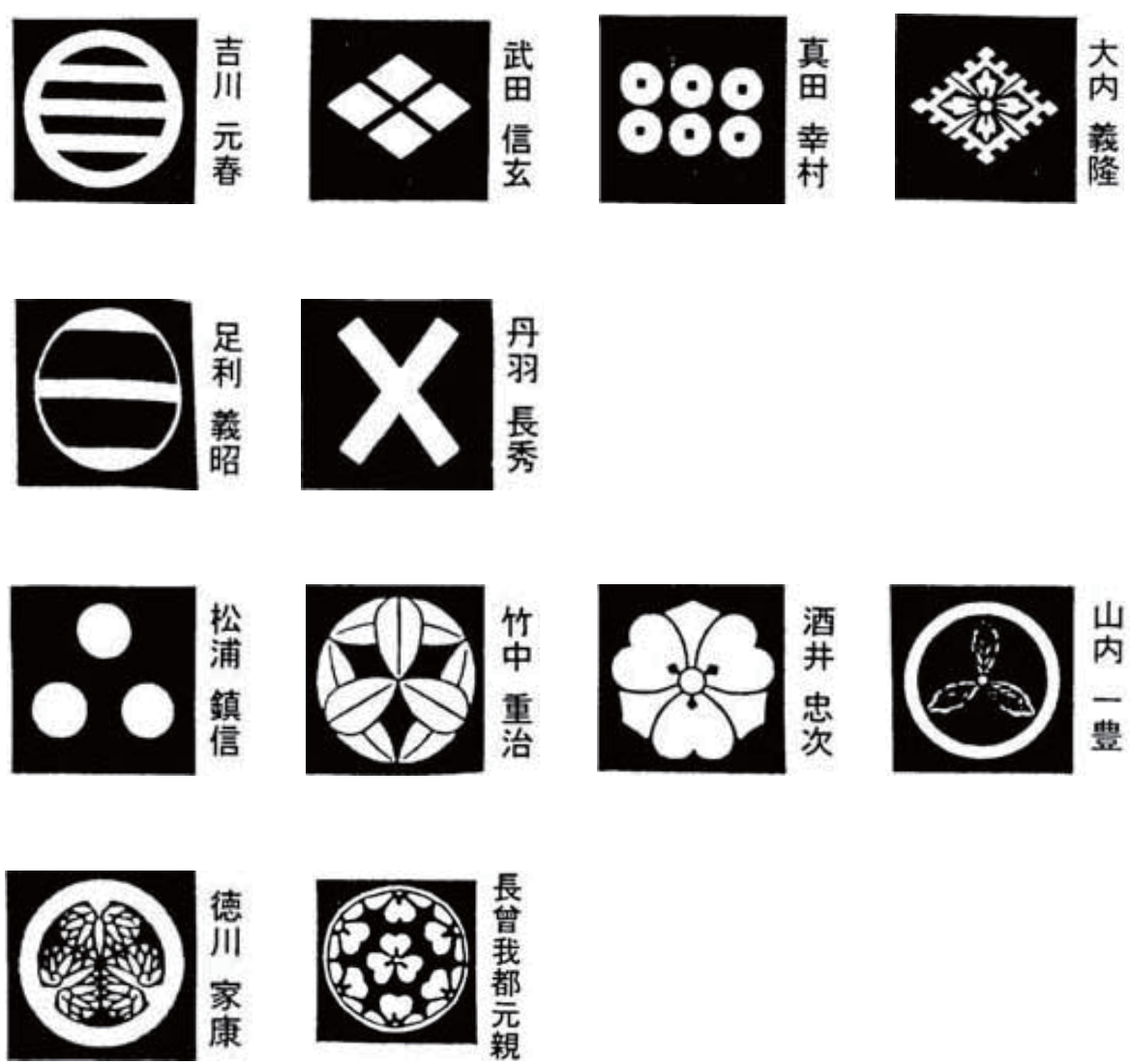
$\mathrm{D}_{4 \mathrm{~h}}$
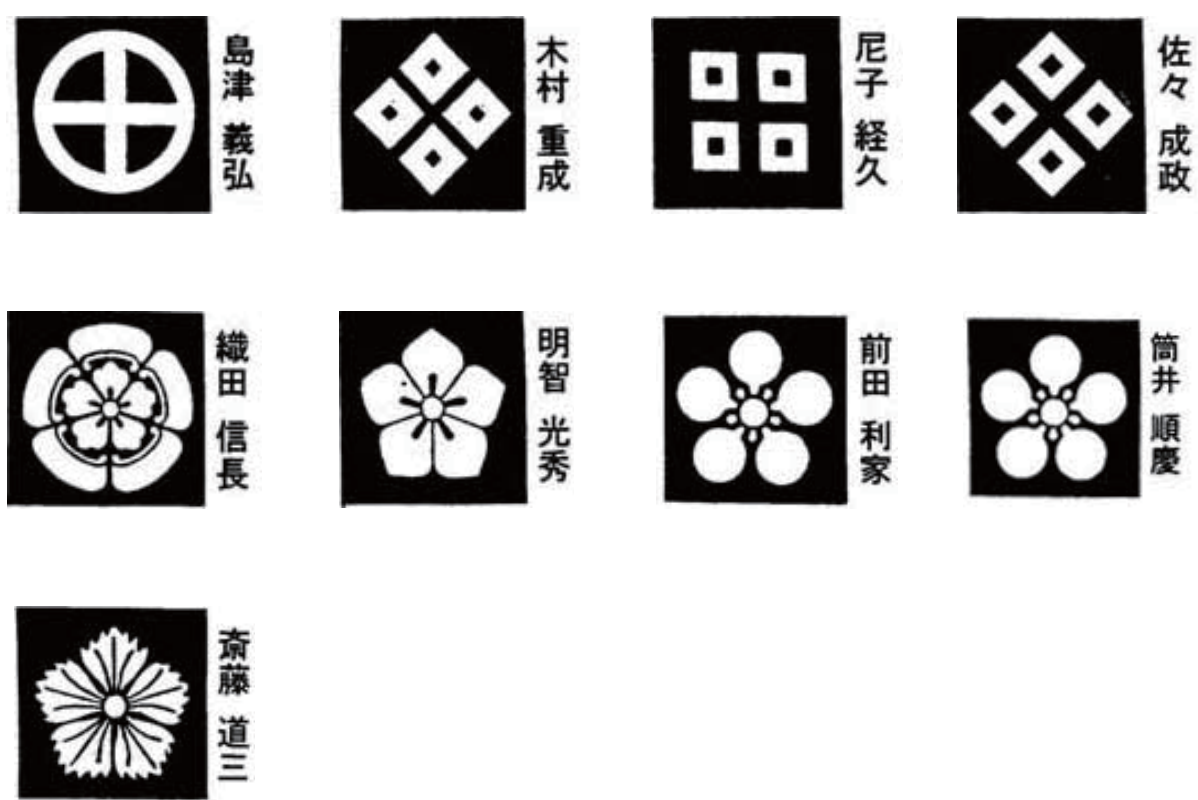

$\mathrm{D}_{6 \mathrm{~h}}$
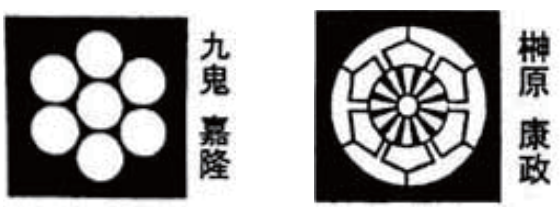

$\mathrm{D}_{8 \mathrm{~h}}$
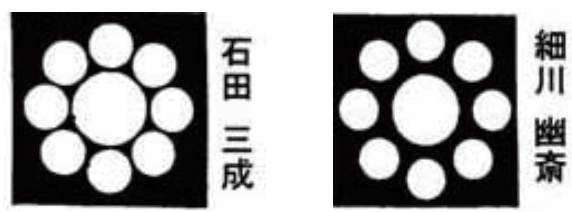

$\mathrm{D}_{12 \mathrm{~h}}$

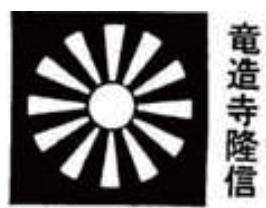

$\mathrm{D}_{\infty \mathrm{h}}$
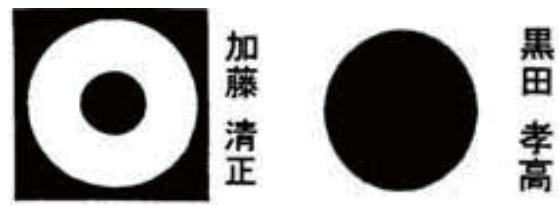


\section{3 群}

このChapterに入ってから今まで「群論」という言葉を用いたことはあっても，実 際は対称操作の話しかして来なかった. どうして群論という言葉が用いられるのかと いうと，「1つの分子について可能な対称操作を全て取り上げると，それが群となる」 からである。以下，このことを説明しよう。

例として $\mathrm{NH}_{3}$ 分子を考える。この分子の持つ対称操作は $E$ の他に $C_{3}$ および $\sigma_{\mathrm{v}}$ であ り, 分子は $\mathrm{C}_{3 \mathrm{v}}$ の点群に属する. $C_{3}$ は正の方向へ $\frac{2 \pi}{3}$ の回転と, 負の方向へ $\frac{2 \pi}{3}$ の回 転があり，それらを例えば $C_{3}^{+}, C_{3}^{-}$などと記す場合もある。しかし，回転が正の方向， 負の方向と両方考えるのは時としてややこしくなるので, 本講義では一貫して, 正の 方向の回転のみを考える.そうすると, 可能な回転は $C_{3}$ (正の方向へ $\frac{2 \pi}{3}$ の回転) と $C_{3}^{2}$ （正の方向へ $\frac{2 \pi}{3} \times 2$ の回転，すなおち，負の方向へ $\frac{2 \pi}{3}$ の回転と同じこと）と 2 つあ ることになる， reflection $\sigma$ は， $\mathrm{N}$ 原子と 1 つの $\mathrm{H}$ 原子を通る面で行うので都合 3 種 類ある. 結局対称操作は, $E, 2$ 種類の $C_{3}, 3$ 種類の $\sigma$ と, 合わせて 6 つあることに なる.念のため, 図 17.3.1に対称操作の結果を模式的に示した. 

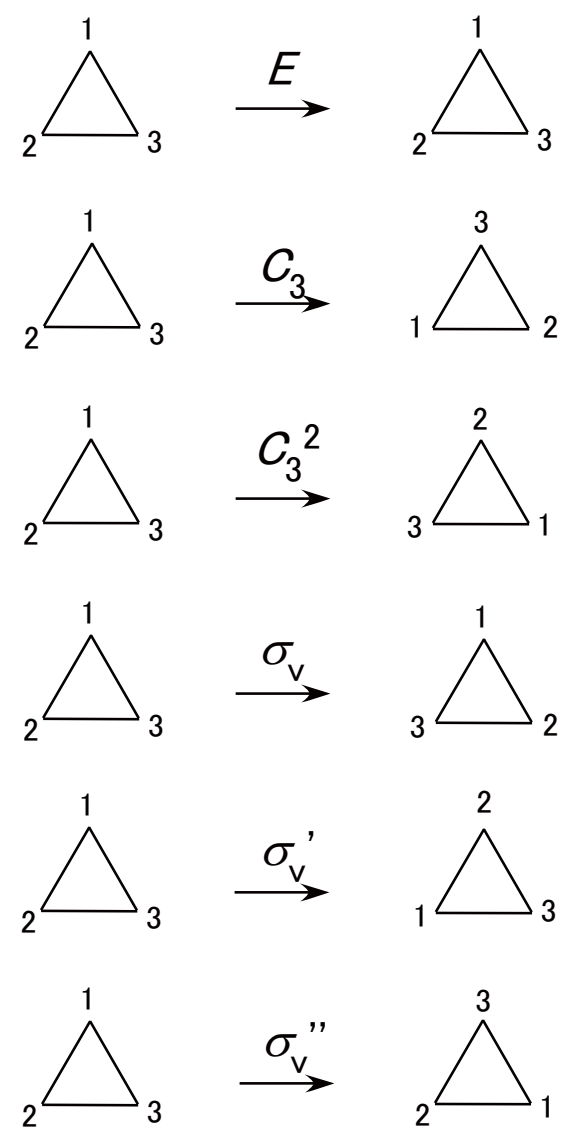

図 17.3.1 $\mathrm{NH}_{3}\left(\mathrm{C}_{3 \mathrm{~V}}\right)$ における対称操作. 1，2，3 は 3 つの $\mathrm{H}$ 原子を示寸. 三角形の上に平面からはずれて $\mathrm{N}$ 原子が存在している.

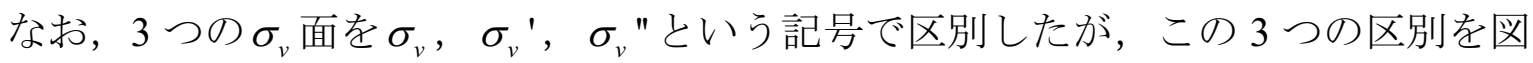
17.3.1b に模式的に表す.
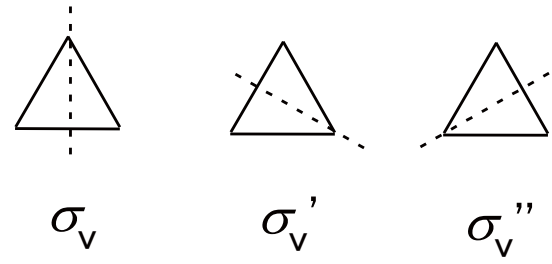

図 17.3.1b 3 つの $\sigma_{v}$ 面

次に対称操作を 2 回繰り返すことを考えてみよう。例えば $C_{3} \sigma_{v}$ は，始めに $\sigma_{v}$ を行 
い, 次に $C_{3}$ を行うということであり, 図 17.3.2 のようになり，始めから $\sigma_{v}{ }^{\prime}$ を行った ことと同じことになる.
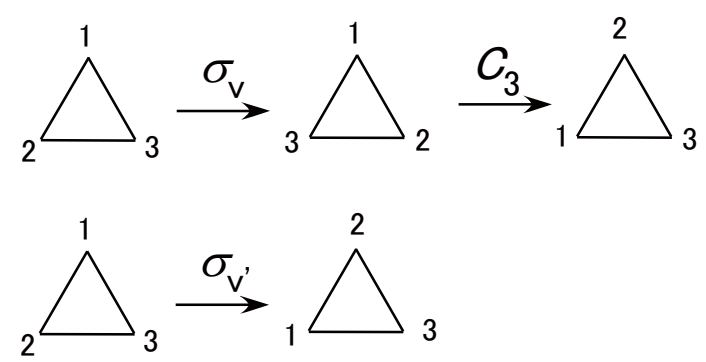

図 17.3.2 $C_{3} \sigma_{v}$ の対称操作

このようにして, 対称操作を 2 回行った結果がどうなるかを表 17.3 .1 にまよめてみる.

表 17.3.1 $\mathrm{C}_{3 \mathrm{v}}$ における 2 つの対称操作の積

\begin{tabular}{|c|cccccc|}
\hline & $E$ & $C_{3}$ & $C_{3}{ }^{2}$ & $\sigma_{v}$ & $\sigma_{v}{ }^{\prime}$ & $\sigma_{v}{ }^{\prime \prime}$ \\
\hline$E$ & $E$ & $C_{3}$ & $C_{3}{ }^{2}$ & $\sigma_{v}$ & $\sigma_{v}{ }^{\prime}$ & $\sigma_{v}{ }^{\prime \prime}$ \\
$C_{3}$ & $C_{3}$ & $C_{3}{ }^{2}$ & $E$ & $\sigma_{v}{ }^{\prime}$ & $\sigma_{v}{ }^{\prime \prime}$ & $\sigma_{v}$ \\
$C_{3}{ }^{2}$ & $C_{3}{ }^{2}$ & $E$ & $C_{3}$ & $\sigma_{v}{ }^{\prime}$ & $\sigma_{v}$ & $\sigma_{v}{ }^{\prime}$ \\
$\sigma_{v}$ & $\sigma_{v}$ & $\sigma_{v}{ }^{\prime \prime}$ & $\sigma_{v}{ }^{\prime}$ & $E$ & $C_{3}{ }^{2}$ & $C_{3}$ \\
$\sigma_{v}{ }^{\prime}$ & $\sigma_{v}{ }^{\prime}$ & $\sigma_{v}$ & $\sigma_{v}{ }^{\prime}$ & $C_{3}$ & $E$ & $C_{3}{ }^{2}$ \\
$\sigma_{v}{ }^{\prime \prime}$ & $\sigma_{v}{ }^{\prime \prime}$ & $\sigma_{v}{ }^{\prime}$ & $\sigma_{v}$ & $C_{3}{ }^{2}$ & $C_{3}$ & $E$ \\
\hline
\end{tabular}

表 17.3.1の結果は,「いかなる 2 つの対称操作の積（2つの対称操作を続けて行う こと）もある 1 つの対称操作となる」ことを示している．また，表 17.3.1のどの列を 
見ても必ず identity $E$ を含んでいる。これは『1つの対称操作 $G$ には，必ず，それに掛 けて $E$ となる「逆対称操作」 $G^{-1}$ が存在する』ことを示している. 例えば $C_{3}^{-1}$ は $C_{3}^{2}$ で

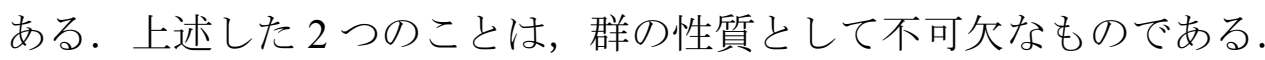

一般に，何個かの「要素 (element)」の組 $\left\{g_{1}, g_{2}, g_{3}, \ldots\right\}$ が次に示す 4 つの性質を持 っている時，この組は群を構成するという。この4つの性質とは，

（1） 2 つの要素の積 $g_{i} g_{j}$ が組の中の 1 つの要素となる.

(2) identity $E$ が組の中に含まれる.すなわち, $E g_{i}=g_{i} E=g_{i}$ が組の中の全ての要素 $g_{i}$ について成り立つ.

（3）積の結合則（associative law）が成り立つ.すなわち $\left(g_{i} g_{j}\right) g_{k}=g_{i}\left(g_{j} g_{k}\right)$

（4）すべての要素 $g_{i}$ はその逆要素 $g_{i}^{-1}$ を持つ。ここで $g_{i}^{-1}$ というのは, $g_{i}^{-1} g_{i}=g_{i} g_{i}^{-1}=E$ が成り立つような要素のことである.

上述の記述の中の「要素」という数学的な言葉は分かりにくいかもしれないが, 我々 の場合は，それは「対称操作」そのものと考えてよい.

再び $\mathrm{C}_{3 \mathrm{v}}$ の例に戻ろう. 6 つの対称操作 $E, \mathrm{C}_{3}, \mathrm{C}_{3}{ }^{2}, \sigma_{v}, \sigma_{v}{ }^{\prime}, \sigma_{v}{ }^{\prime}$ の組が群を 作ることは簡単に証明することが出来る.

（1）まず 2 つの対称操作の積がある 1 つの対称操作となる，という第 1 の要請は 既に表 17.3.1 で確かめている.

(2) identity $E$ は含まれている.

（3）積の結合則については，まだ吟味しなかった。一例を示そう。3つの対称操 作の積 $\sigma_{v} C_{3} \sigma_{v}$ を考えよう。表 17.3.1 を用いて次の結果を得る.

$$
\begin{aligned}
& \left(\sigma_{v} C_{3}\right) \sigma_{v}=\sigma_{v}{ }^{\prime} \sigma_{v}=C_{3}{ }^{2} \\
& \sigma_{v}\left(C_{3} \sigma_{v}\right)=\sigma_{v} \sigma_{v}{ }^{\prime}=C_{3}{ }^{2}
\end{aligned}
$$

このように，少なくともこの組については結合則が成り立つ。他の組については諸君 自ら吟味してほしい。

（4）最後に，逆要素であるが，これも表 17.3.1 より，全ての対称操作についてそ の逆要素を次のように求めることが出来る. 


$$
\begin{aligned}
& (E)^{-1}=E \\
& \left(C_{3}\right)^{-1}=C_{3}^{2} \\
& \left(C_{3}^{2}\right)^{-1}=C_{3} \\
& \left(\sigma_{v}\right)^{-1}=\sigma_{v} \\
& \left(\sigma_{v}\right)^{-1}=\sigma_{v}{ }^{\prime} \\
& \left(\sigma_{v}{ }^{\prime \prime}\right)^{-1}=\sigma_{v}{ }^{\prime}
\end{aligned}
$$

以上のように，(結合則についての証明は不十分であったけれども），6つの対称操作 の組が群を作ることは証明された。

なお，2つの対称操作の積において， $g_{i} g_{j}$ は $g_{j} g_{i}$ と一致するとは限らない.すなわ ち対称操作は交換可能とは限らない，例えば表 17.3.1 から分かるように

$$
\begin{aligned}
& C_{3} \sigma_{v}=\sigma_{v}{ }^{\prime} \\
& \sigma_{v} C_{3}=\sigma_{v}{ }^{\prime \prime}
\end{aligned}
$$

となり 2 つの結果は一致しない，仮に，群の中の全ての要素の組について $g_{i} g_{j}=g_{j} g_{i}$ が成り立つ場合，その群をAbel 群と言う。

群を構成する要素の数を「位数（order）」と言う。上述の $\mathrm{C}_{3 \mathrm{v}}$ の例は, 対称操作が 6 個あるわけでそれを「位数は 6」と表現する.

\section{【補遺】 :}

表 17.3.1の multiplication table を見ると，どの列にも，また，どの行にも，1つの対 称操作は 1 回しか出て来ない。このことは multiplication table に関する重要な定理で ある。この定理の証明は簡単である。

\section{【証明】：}

仮に, 要素 $B$ についての行の中に要素 $F$ が 2 回出て来たとする. 寸なわち, $D \neq G$ として, multiplication tableの中に次のような部分があるとする.

\begin{tabular}{|l|lllll|}
\hline & $\cdots$ & $D$ & $\cdots$ & $G$ & $\cdots$ \\
\hline$B$ & $\cdots$ & $F$ & $\cdots$ & $F$ & $\cdots$ \\
\hline
\end{tabular}




$$
\begin{aligned}
& B D=F \\
& B G=F
\end{aligned}
$$

この 2 つの式に $B^{-1}$ を作用する

$$
\begin{aligned}
& B^{-1} B D=B^{-1} F \\
& B^{-1} B G=B^{-1} F
\end{aligned}
$$

すなわち

$$
\begin{aligned}
& D=B^{-1} F \\
& G=B^{-1} F
\end{aligned}
$$

$B^{-1} F$ は 1 つ要素であるから, $D=G$ と結論しなければならない.しかしこれは $D \neq G$ という前提と矛盾する。（Q.E.D.）

次に群の multiplication tableについて，少々抽象的に吟味してみよう.

位数 1 の群の場合には，ただ 1 個の要素は当然 identity operationのEでなければな らない. multiplication table は当然次のようになる.

\begin{tabular}{|c|c|}
\hline & $E$ \\
\hline$E$ & $E$ \\
\hline
\end{tabular}

位数 2 の群の場合は, 次の表が唯一の可能性である.

\begin{tabular}{|l|ll|}
\hline & $E$ & $A$ \\
\hline$E$ & $E$ & $A$ \\
$A$ & $A$ & $E$ \\
\hline
\end{tabular}

この表が得られる理由は次の通りである。 $E E=E, E A=A, A E=A$ は当然である. 残りは $A A$ のである. 群が閉じていることからこれは $E$ または $A$ である。しかしも しも $A A=A$ とすると 1 つの行に, 又, 1 つの列に $A$ が 2 回表れることになる. 従って $A A=A$ ということはあり得ず, $A A=E$ と結論せざるを得ない.

位数 3 の群については, 次の表が唯一の可能性である. 


\begin{tabular}{|l|lll|}
\hline & $E$ & $A$ & $B$ \\
\hline$E$ & $E$ & $A$ & $B$ \\
$A$ & $A$ & $B$ & $E$ \\
$B$ & $B$ & $E$ & $A$ \\
\hline
\end{tabular}

位数 4 の群の場合には, 2 つの異なった multiplication table が存在する. それは諸 君の演習としよう。(Problem 17.3.2)

¿̦Problem 17.3.1

位数 3 の group について multiplication table が表 17.3.3のようになることを証明せ よ.

¿̧ Problem 17.3.2

位数 4 の group について $2 つ の$ 可能な multiplication tableを求めよ. (element は $E$, $A, B, C$ とし，ここで $E$ を identity operation とせよ.)

¿3roblem 17.3.2

以下に示す, 要素の数が 4 である点群を上 Problem 17.3.2 で求めた multiplication table の型で分類せよ.

$$
\begin{aligned}
& \mathrm{C}_{2 \mathrm{v}}: \quad E, \quad C_{2}, \quad \sigma(x z), \quad \sigma(y z) \\
& \mathrm{C}_{2 \mathrm{~h}}: \quad E, \quad C_{2}, \quad i, \quad \sigma_{h} \\
& \mathrm{D}_{2}: \quad E, \quad C_{2}(z), \quad C_{2}(y), \quad C_{2}(x) \\
& \mathrm{C}_{4}: \quad E, \quad C_{4}, C_{2}, C_{4}^{3}
\end{aligned}
$$

¿ Problem 17.3.3 
5 つの要素について次のような multiplication table がある.

\begin{tabular}{|l|lllll|}
\hline & $E$ & $A$ & $B$ & $C$ & $D$ \\
\hline$E$ & $E$ & $A$ & $B$ & $C$ & $D$ \\
$A$ & $A$ & $E$ & $D$ & $B$ & $C$ \\
$B$ & $B$ & $C$ & $E$ & $D$ & $A$ \\
$C$ & $C$ & $D$ & $A$ & $E$ & $B$ \\
$D$ & $D$ & $B$ & $C$ & $A$ & $E$ \\
\hline
\end{tabular}

$5 つ の$ 要素は群を構成するかどうかを吟味せよ。

放Problem 17.3.4

$\mathrm{H}_{2} \mathrm{O}$ 分子を考える. 分子平面を $y z$ 面, $\mathrm{O}$ 原子を通る対

称軸を $z$ 軸とする.4 つの対称操作 $E, C_{2}(z), \sigma(x z), \sigma(y z) \mathrm{H}^{\prime}{ }^{0} \mathrm{H}$

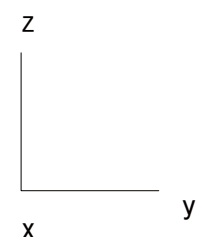

が群を作っていることを証明せよ。

¿ 2 Problem 17.3.5

allene $\left(\mathrm{H}_{2} \mathrm{C}=\mathrm{C}=\mathrm{CH}_{2}\right)$ は $\mathrm{D}_{2} \mathrm{~d}$ 点群に属する. 以下の図に示した 8 つの symmetry operation について積の表を作り，この 8 つの operation が群を作ることを示せ．ただ し, associate law が成り立つかどうかはいくつかの組みを選んで確かめればよい. 

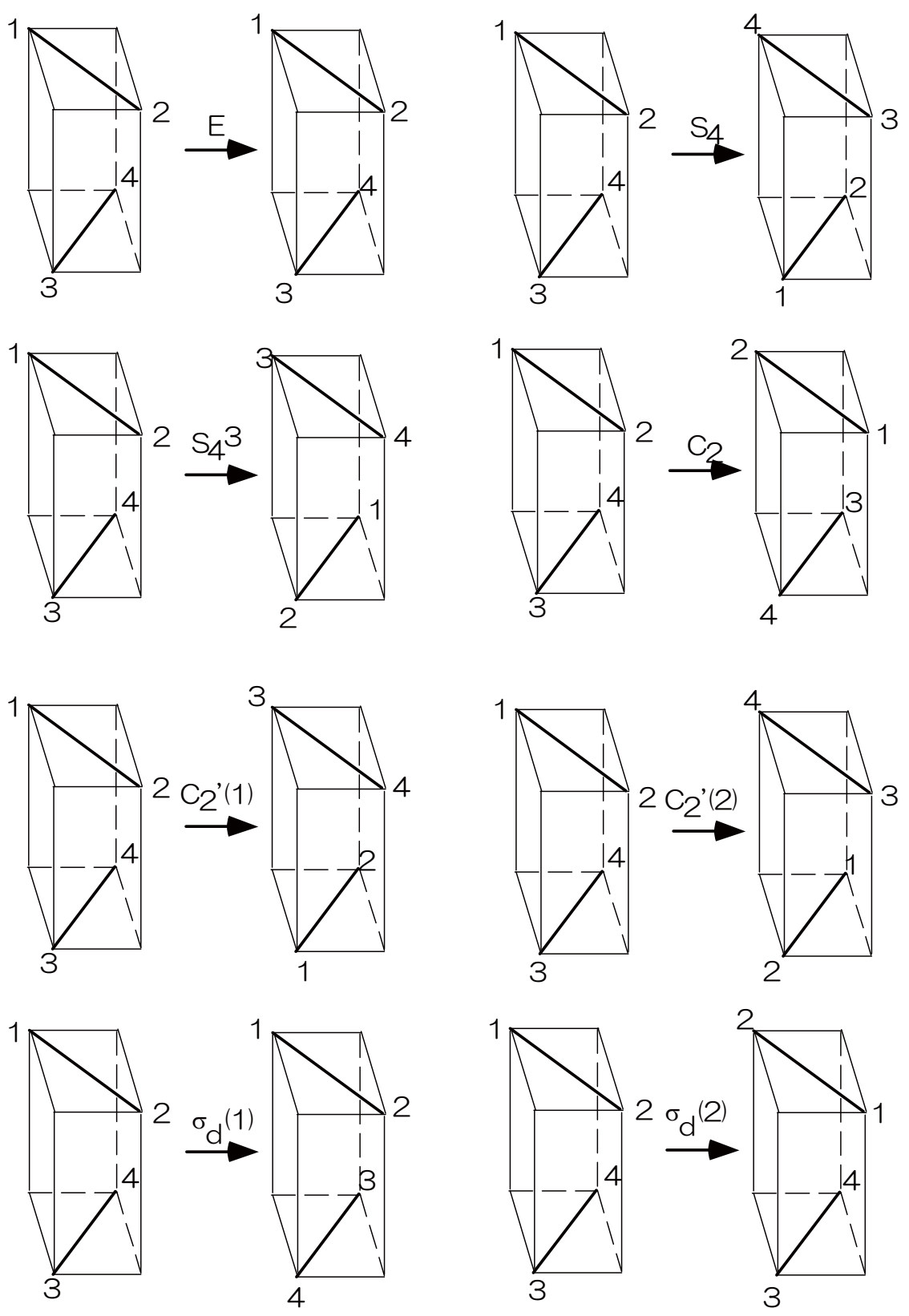

図 17.3.3 $\mathrm{D}_{2 \mathrm{~d}}$ における 8 つの対称操作

\section{4 類 (class)}

群はいくつかの対称操作のセットであることを上で学習したが，これら対称操作 を，ある約束に従って分類したものが「類（class）」である。「ある約束」については 以下にきちんと述べるが，大雑把には，「同じ種類の対称操作は同じ類に属する」，と 考えてよいであろう。再び $\mathrm{C}_{3 \mathrm{v}}$ 点群を例にとろう. 6 つの対称操作 $E, C_{3}, C_{3}{ }^{2}, \sigma_{v}$, 
$\sigma_{v}{ }^{\prime}, \sigma_{v}{ }^{\prime \prime}$ のちち, $C_{3}$ と $C_{3}{ }^{2}$ とが同じ分類に, $\sigma_{v}, \sigma_{v}{ }^{\prime}, \sigma_{v}{ }^{\prime \prime}$ の 3 つがそれとは別の分 類に分けられるであろうことは容易に想像出来よう。事実, $\mathrm{C}_{3 \mathrm{~V}}$ では $E$ が 1 つで 1 つ の類をなし， $C_{3}$ と $C_{3}{ }^{2}$ の 2 つが 1 つの類, そして, $\sigma_{v}, \sigma_{v}{ }^{\prime}, \sigma_{v}{ }^{\prime \prime}$ の 3 づ 1 つの類 となり，全部で 3 つの類がある．以下もう少しきちんと定義しよう.

群 $G=\left\{g_{1}, g_{2}, \ldots, g_{h}\right\}$ の要素 $g_{i}$ を同じ群の要素 $g_{j}(j=1,2, \ldots, h)$ を用いて similarity transformation によって変形した $g_{j} g_{i} g_{j}^{-1}$ を $g_{i}$ に共役な要素という。例えば $g_{i}$ とて $\sigma_{v}, g_{j}$ として $C_{3}$ を考えてみる. $C_{3}^{-1}=C_{3}^{2}$ であるから, 表 17.3.1 を用いて

$$
C_{3} \sigma_{v}\left(C_{3}\right)^{-1}=C_{3} \sigma_{v} C_{3}^{2}=C_{3} \sigma_{v}{ }^{\prime}=\sigma_{v}{ }^{\prime}
$$

となることになる.すなわち $\sigma_{v} "$ は $\sigma_{v}$ と共役である. 要素 $g_{i}$ に共役なすべての要素の 集合を $g_{i}$ の共役類，又は単に類（class）と言う．1つの類に属する要素は，例えばあ る $g_{i}$ について $g_{j} g_{i} g_{j}^{-1}$ を群の中の全ての要素について求めればよい. こうして計算し たものの中には重複しているものもあるが，この中から重複しないものだけを拾い出 せばその集まりが類となる，具体的に $g_{i}$ として $C_{3}$ をとり，群のすべての要素をもと に similarity transformationを行ってみよう。

$$
\begin{aligned}
& E C_{3}(E)^{-1}=C_{3} \\
& C_{3} C_{3}\left(C_{3}\right)^{-1}=C_{3} \\
& C_{3}^{2} C_{3}\left(C_{3}^{2}\right)^{-1}=C_{3} \\
& \sigma_{v} C_{3}\left(\sigma_{v}\right)^{-1}=\sigma_{v} C_{3} \sigma_{v}=\sigma_{v} \sigma_{v}{ }^{\prime}=C_{3}^{2} \\
& \sigma_{v}{ }^{\prime} C_{3}\left(\sigma_{v}{ }^{\prime}\right)^{-1}=\sigma_{v}{ }^{\prime} C_{3} \sigma_{v}{ }^{\prime}=\sigma_{v}{ }^{\prime} \sigma_{v}{ }^{\prime \prime}=C_{3}^{2} \\
& \sigma_{v}{ }^{\prime \prime} C_{3}\left(\sigma_{v}{ }^{\prime \prime}\right)^{-1}=\sigma_{v}{ }^{\prime \prime} C_{3} \sigma_{v}{ }^{\prime \prime}=\sigma_{v}{ }^{\prime \prime} \sigma_{v}=C_{3}^{2}
\end{aligned}
$$


この結果により， $C_{3}$ と $C_{3}^{2}$ の 2 つが 1 つの類を構成することが分かる. 同じようにし て $g_{i}$ として $\sigma_{v}$ を選んで similarity transformation を行ってみよう.

$$
\begin{aligned}
& E \sigma_{v}(E)^{-1}=\sigma_{v} \\
& C_{3} \sigma_{v}\left(C_{3}\right)^{-1}=\sigma_{v}{ }^{\prime} \\
& C_{3}{ }^{2} \sigma_{v}\left(C_{3}^{2}\right)^{-1}=\sigma_{v}{ }^{\prime} \\
& \sigma_{v} \sigma_{v}\left(\sigma_{v}\right)^{-1}=\sigma_{v} \\
& \sigma_{v}{ }^{\prime} \sigma_{v}\left(\sigma_{v}{ }^{\prime}\right)^{-1}=\sigma_{v}{ }^{\prime} \\
& \sigma_{v}{ }^{\prime \prime} \sigma_{v}\left(\sigma_{v}{ }^{\prime \prime}\right)^{-1}=\sigma_{v}{ }^{\prime}
\end{aligned}
$$

この結果により， $\sigma_{v} ， \sigma_{v}{ }^{\prime}, \sigma_{v}{ }^{\prime}$ の 3 つが 1 つの類を構成することが分かる. 残りは $E$ についての similarity transformation であるが，Eはすべての対称操作と可換であるか ら，すべての $g_{j}$ について

$$
g_{j} E g_{j}^{-1}=g_{j} g_{j}^{-1} E=E
$$

のようになる，すなわち，Eはそれ 1 つだけで 1 つの類を構成することが分かる。こ うして, $\mathrm{C}_{3 \mathrm{v}}$ の 6 つの対称操作は $\{E\},\left\{\sigma_{v}, \sigma_{v}{ }^{\prime}, \sigma_{v}{ }^{\prime}\right\}$ のように 3 つの類に分類される, という naive な感覚から想像したのと同じ結果がきちんと得られたわけである.

聍Problem 17.4.1

Problem 17.3.1 で扱っている 4 つの対称操作を類に分類せよ. 


\section{5 表現（representation）および指標}

群論が分子の量子力学に重要である理由は，この章の冒頭で述べたように，分子の 状態を表す波動関数が対称操作という演算子に対してどういうふうに変換されるか ということが, 丁度各種の量子数を定義したのと同じ意味で重要な情報となるからで ある. 分子の波動関数の表し方にはいろいろな方法があるが，いずれにしても，分子 中のいろいろな場所に局在している関数の組み合せで表されることは，どの方法でも 共通であろう。それで, 分子の波動関数が対称操作によってどう変換されるかを知る には，まず，分子中のある場所に局在化しているある関数が，対称操作によってどう 変るかということを知ることが必要となって来る．上で，「分子のある場所に局在化 している関数」と述べたが，それは，ある場合には原子に局在化した atomic orbital であったり，又，ある場合には，結合に局在化した bond orbital であったりする。こ ういう関数の変換の二三の例を以下取り扱ってみよう.

再び $\mathrm{C}_{3 \mathrm{~V}}$ 点群として $\mathrm{NH}_{3}$ 分子を考える. 3 つの水素を仮りに $\mathrm{H}_{1}, \mathrm{H}_{2}, \mathrm{H}_{3}$ と名付け

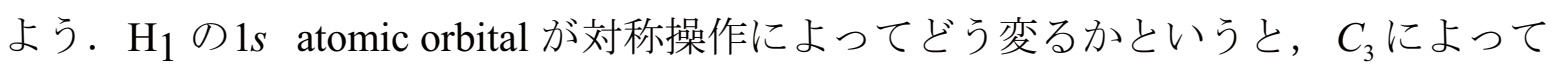

$\mathrm{H}_{2}$ の $1 s$ atomic orbital に，また $C_{3}^{2}$ によって $\mathrm{H}_{3}$ の 1s atomic orbital に変換される.す なわち, $\mathrm{H}_{1}$ の $1 s$ atomic orbital のみでは, 変換のありさまを記述することが出来ない. $\mathrm{H}_{1}, \mathrm{H}_{2}, \mathrm{H}_{3} 3$ つの原子それぞれの $1 s$ orbital をセットとして取り上げて始めて変換を 記述出来る。このようなセットを基底（basis）という。簡単のため $\mathrm{H}_{1}, \mathrm{H}_{2}, \mathrm{H}_{3}$ それ ぞれの $1 s$ atomic orbital を $s_{1}, s_{2}, s_{3}$ と表すことにしよう。 $\mathrm{C}_{3 \mathrm{~V}}$ の 6 つの symmetry operationの結果は次のような 3 次の matrix を含む式で表される.

$$
\begin{aligned}
& E\left[\begin{array}{lll}
s_{1} & s_{2} & s_{3}
\end{array}\right]=\left[\begin{array}{lll}
s_{1} & s_{2} & s_{3}
\end{array}\right]\left[\begin{array}{lll}
1 & 0 & 0 \\
0 & 1 & 0 \\
0 & 0 & 1
\end{array}\right] \\
& C_{3}\left[\begin{array}{lll}
s_{1} & s_{2} & s_{3}
\end{array}\right]=\left[\begin{array}{lll}
s_{1} & s_{2} & s_{3}
\end{array}\right]\left[\begin{array}{lll}
0 & 0 & 1 \\
1 & 0 & 0 \\
0 & 1 & 0
\end{array}\right] \\
& C_{3}^{2}\left[\begin{array}{lll}
s_{1} & s_{2} & s_{3}
\end{array}\right]=\left[\begin{array}{lll}
s_{1} & s_{2} & s_{3}
\end{array}\right]\left[\begin{array}{lll}
0 & 1 & 0 \\
0 & 0 & 1 \\
1 & 0 & 0
\end{array}\right]
\end{aligned}
$$




$$
\begin{aligned}
& \sigma_{v}\left[\begin{array}{lll}
s_{1} & s_{2} & s_{3}
\end{array}\right]=\left[\begin{array}{lll}
s_{1} & s_{2} & s_{3}
\end{array}\right]\left[\begin{array}{lll}
1 & 0 & 0 \\
0 & 0 & 1 \\
0 & 1 & 0
\end{array}\right] \\
& \sigma_{v}{ }^{\prime}\left[\begin{array}{lll}
s_{1} & s_{2} & s_{3}
\end{array}\right]=\left[\begin{array}{lll}
s_{1} & s_{2} & s_{3}
\end{array}\right]\left[\begin{array}{lll}
0 & 1 & 0 \\
1 & 0 & 0 \\
0 & 0 & 1
\end{array}\right] \\
& \sigma_{v}{ }^{\prime \prime}\left[\begin{array}{lll}
s_{1} & s_{2} & s_{3}
\end{array}\right]=\left[\begin{array}{lll}
s_{1} & s_{2} & s_{3}
\end{array}\right]\left[\begin{array}{lll}
0 & 0 & 1 \\
0 & 1 & 0 \\
1 & 0 & 0
\end{array}\right]
\end{aligned}
$$

ここに示した各式に表される 3 次の matrix はそれぞれの symmetry operation の内容を 表しており，表現行列（representation matrix）又は単に表現（representation）と言う. 以下, symmetry operation $G$ に対する表現を $\boldsymbol{D}(G)$ と記すことにする.

表現行列の大切な性質は， symmetry operationの積が表現行列の積で表すことが出 来るということである。例えば

$$
\begin{aligned}
D\left(\sigma_{v}\right) D\left(C_{3}\right) & =\left[\begin{array}{lll}
1 & 0 & 0 \\
0 & 0 & 1 \\
0 & 1 & 0
\end{array}\right]\left[\begin{array}{lll}
0 & 0 & 1 \\
1 & 0 & 0 \\
0 & 1 & 0
\end{array}\right]=\left[\begin{array}{lll}
0 & 0 & 1 \\
0 & 1 & 0 \\
1 & 0 & 0
\end{array}\right] \\
& =D\left(\sigma_{v}{ }^{\prime \prime}\right)
\end{aligned}
$$

この関係は，表 17.3.1 から分かる symmetry operation の積

$$
\sigma_{v} C_{3}=\sigma_{v}^{\prime \prime}
$$

と同じ関係になっている。 $\sigma_{v}$ と $C_{3}$ の積に限らず，どんな 2 つの symmetry operation の 組をとっても，表現行列の積が symmetry operation の積となっている.

各表現行列の trace，すなわち，対角項の和を指標（character）と言う。本講義では

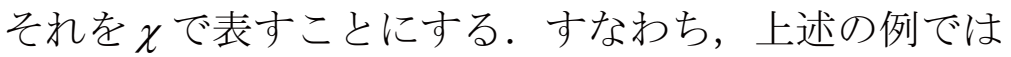

$$
\begin{aligned}
& \chi(E)=3 \\
& \chi\left(C_{3}\right)=0 \\
& \chi\left(C_{3}^{2}\right)=0 \\
& \chi\left(\sigma_{v}\right)=1 \\
& \chi\left(\sigma_{v}{ }^{\prime}\right)=1 \\
& \chi\left(\sigma_{v}{ }^{\prime \prime}\right)=1
\end{aligned}
$$


character の重要な性質は「同じ類に属する symmetry operation は同じ character を持つ」 ということである。上の例は確かにそうなっている.

上に例として述べた表現は，言うまでもなく， basis $\left(s_{1}, s_{2}, s_{3}\right)$ についてである. 他 の basis をとれば当然結果は異なって来る. 例えば $\mathrm{N}$ 原子の $p_{x}$ orbital と $p_{y}$ orbital を basisとしてみよう。
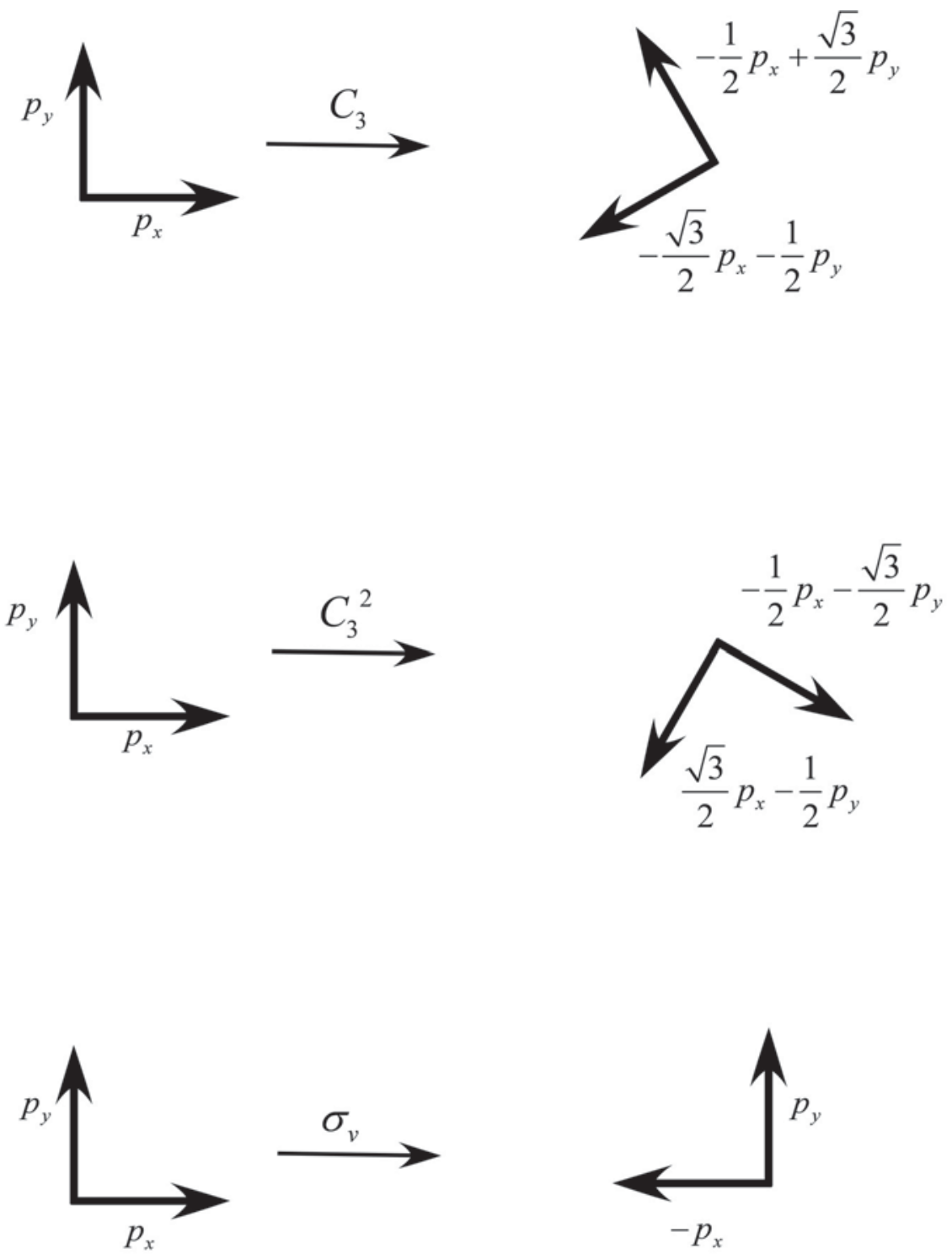

困 17.5.1 $\left[\begin{array}{ll}p_{x} & p_{y}\end{array}\right]$ basis set $\sim の$ symmetry operation $の$ 例 
図 17.5.1に一部を例として示したようになるが，表現行列の形で書き下寸と，次の ようになる。

$$
\begin{aligned}
& E\left[p_{x} p_{y}\right]=\left[p_{x} p_{y}\right]\left[\begin{array}{ll}
1 & 0 \\
0 & 1
\end{array}\right] \\
& C_{3}\left[p_{x} p_{y}\right]=\left[p_{x} p_{y}\right]\left[\begin{array}{ll}
-\frac{1}{2} & -\frac{\sqrt{3}}{2} \\
\frac{\sqrt{3}}{2} & -\frac{1}{2}
\end{array}\right] \\
& C_{3}^{2}\left[p_{x} p_{y}\right]=\left[p_{x} p_{y}\right]\left[\begin{array}{cc}
-\frac{1}{2} & \frac{\sqrt{3}}{2} \\
-\frac{\sqrt{3}}{2} & -\frac{1}{2}
\end{array}\right] \\
& \sigma_{v}\left[p_{x} p_{y}\right]=\left[p_{x} p_{y}\right]\left[\begin{array}{ll}
-1 & 0 \\
0 & 1
\end{array}\right] \\
& \sigma_{v}^{\prime}\left[p_{x} p_{y}\right]=\left[p_{x} p_{y}\right]\left[\begin{array}{cc}
\frac{1}{2} & -\frac{\sqrt{3}}{2} \\
-\frac{\sqrt{3}}{2} & -\frac{1}{2}
\end{array}\right] \\
& \sigma_{v}^{\prime \prime}\left[p_{x} p_{y}\right]=\left[p_{x} p_{y}\right]\left[\begin{array}{cc}
\frac{1}{2} & \frac{\sqrt{3}}{2} \\
\frac{\sqrt{3}}{2} & -\frac{1}{2}
\end{array}\right]
\end{aligned}
$$

従って character は次のようになる。

$$
\begin{aligned}
& \chi(E)=2 \\
& \chi\left(C_{3}\right)=-1 \\
& \chi\left(C_{3}^{2}\right)=-1 \\
& \chi\left(\sigma_{v}\right)=0 \\
& \chi\left(\sigma_{v}{ }^{\prime}\right)=0 \\
& \chi\left(\sigma_{v}{ }^{\prime}\right)=0
\end{aligned}
$$

以上が $\left[p_{x} p_{y}\right]$ を basis set とした場合の表現および指標である.これは前に求めた

$\left[\begin{array}{lll}s_{1} & s_{2} & s_{3}\end{array}\right]$ を basis set とした場合とは全く異なるものであることは言うまでもない。こ のように，表現および指標はあくまで basis の選び方によるのである.

なお，basis set の数は，2 個以上であるとは限らない。もし 1 個の basis のみで symmetry operation の結果を表すことが出来ればその 1 個を basis とする. 例えば $\mathrm{NH}_{3}$ 
において, $\mathrm{N}$ 原子の $2 s$ orbital を $s_{\mathrm{N}}$ と示すと,

$$
\begin{aligned}
& E s_{N}=s_{N} \\
& C_{3} s_{N}=s_{N} \\
& C_{3}^{2} s_{N}=s_{N} \\
& \sigma_{v} s_{N}=s_{N} \\
& \sigma_{v}{ }^{\prime} s_{N}=s_{N} \\
& \sigma_{v}{ }^{\prime} s_{N}=s_{N}
\end{aligned}
$$

のようには $\mathrm{C}_{3 \mathrm{v}}$ のすべての symmetry operation に対して不変 (invariant) である.この basis については, representation matrix は, すべての operation について単なる数字の 1 ということになるが，一次元の matrix とみなすことが出来るわけである.

さて，だいぶ長々と具体的な例をあげて説明して来たが，以上のことをもう少し数 式的に扱ってみよう. basis set $\mathbf{f}=\left[f_{1} f_{2} \ldots\right]$ に symmetry operation $G$ を作用した結果は 式(17.5.1)，式(17.5.4)，式(17.5.6)などを一般化した形として

$$
G \mathbf{f}=\mathbf{f D}(G)
$$

または，これを成分で表すと

$$
G f_{i}=\sum_{k} f_{k} D_{k i}(G)
$$

ただし $D_{k i}(G)$ は matrix $\mathbf{D}(G)$ の $k i$ 成分である. symmetry operation $G$ に対する

character $\chi(G)$ は

$$
\chi(G)=\sum_{k} D_{k k}(G)
$$

で表される.

同じ class に属する symmetry operation については, character が等しいということを 上で例で示したがそのことを証明しよう.その前に, 3 つの matrix $\mathbf{A} ， \mathbf{B}, \mathbf{C} の$ 積の trace

（すなわち character）は， $\mathbf{A} ， \mathbf{B}, \mathbf{C}$ を循環的に置換したものの trace と同じ，すなわち

$$
\operatorname{tr}(\mathbf{A B C})=\operatorname{tr}(\mathbf{B C A})=\operatorname{tr}(\mathbf{C A B})
$$

ということを証明しておこう。 


$$
\begin{aligned}
\operatorname{tr}(\mathbf{A B C}) & =\sum_{i}(\mathbf{A B C})_{i i} \\
& =\sum_{i} \sum_{j} \sum_{k} A_{i j} B_{j k} C_{k i} \\
& =\sum_{j} \sum_{k} \sum_{i} B_{j k} C_{k i} A_{i j} \\
& =\sum_{i}(\mathbf{B C A})_{j j} \\
& =\operatorname{tr}(\mathbf{B C A})
\end{aligned}
$$

式(17.5.10)の 2 番目の等式も明らかであろう。ささて 式(17.5.11)において $\mathbf{C}=\mathbf{A}^{-1}$ とお $<$ と

$$
\operatorname{tr}\left(\mathbf{A} \mathbf{B} \mathbf{A}^{-1}\right)=\operatorname{tr}\left(\mathbf{B} \mathbf{A}^{-1} \mathbf{A}\right)=\operatorname{tr}(\mathbf{B})
$$

となる.上式の左辺は右辺を similarity transformation したものである.すなおち, matrix の trace は similarity transformation によって不変である.かくして，同じ類に属する symmetry operation の character は等しいということが証明された.

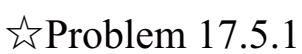

関数 $x, y, z$ の組についての表現行列を次の各対称操作（回転の主軸を $z$ 軸とするこ と）について求め、character（指標）と共に示せ。

$$
\begin{aligned}
& E\left[\begin{array}{lll}
x & y & z
\end{array}\right]=\left[\begin{array}{lll}
x & y & z
\end{array}\right]\left[\begin{array}{lll}
1 & 0 & 0 \\
0 & 1 & 0 \\
0 & 0 & 1
\end{array}\right] \quad \chi(E)=3 \\
& C_{2}\left[\begin{array}{lll}
x & y & z
\end{array}\right]=\left[\begin{array}{lll}
x & y & z
\end{array}\right]\left[\quad \chi\left(C_{2}\right)=\right. \\
& C_{4}\left[\begin{array}{lll}
x & y & z
\end{array}\right]=\left[\begin{array}{lll}
x & y & z
\end{array}\right]\left[\quad \chi\left(C_{4}\right)=\right.
\end{aligned}
$$




$$
\begin{aligned}
& i\left[\begin{array}{lll}
x & y & z
\end{array}\right]=\left[\begin{array}{lll}
x & y & z
\end{array}\right][\quad \chi(i)= \\
& S_{1}\left[\begin{array}{lll}
x & y & z
\end{array}\right]=\left[\begin{array}{lll}
x & y & z
\end{array}\right]\left[\quad \chi\left(S_{1}\right)=\right. \\
& S_{4}\left[\begin{array}{lll}
x & y & z
\end{array}\right]=\left[\begin{array}{lll}
x & y & z
\end{array}\right]\left[\quad \chi\left(S_{4}\right)=\right.
\end{aligned}
$$

\section{敄Problem 17.5.2}

Problem 17.5.1 の一般形として $C_{n}$ （すなわち $\frac{2 \pi}{n}$ の回転）および $S_{n}$ （すなわち $C_{n}$ を 操作して後 $C_{n}$ 軸に垂直な面で $\sigma$ を操作する）についての表現行列と character を求め よ。

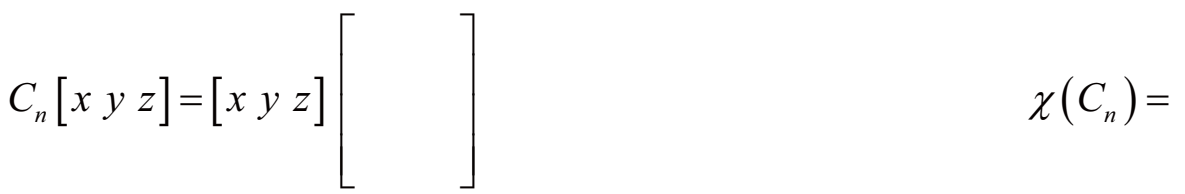

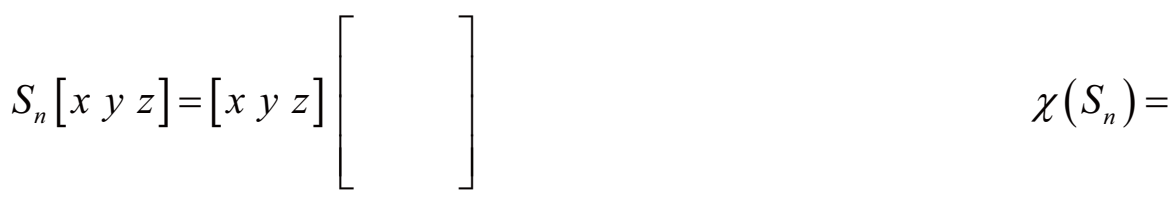

以上の結果を用いて以下の表現行列および character を求めよ。 


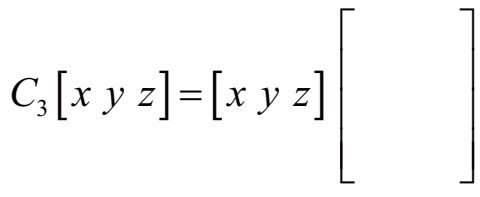

$$
\begin{aligned}
& \chi\left(C_{3}\right)=
\end{aligned}
$$

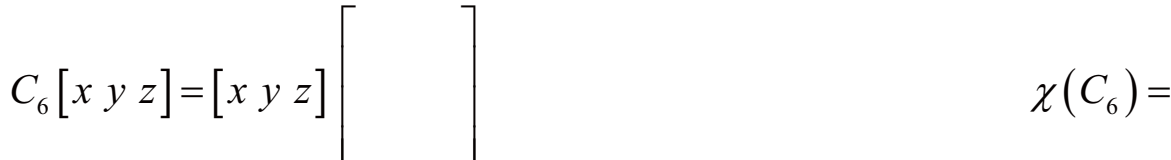

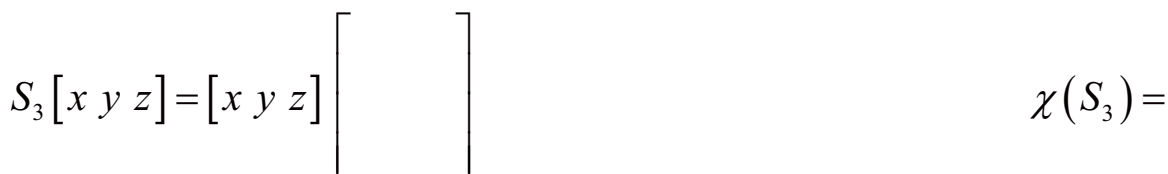

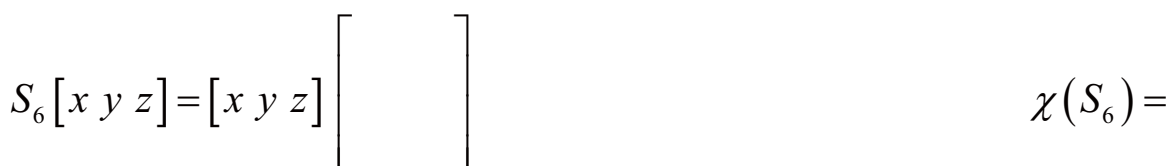

なお、以上の結果は以降使うことが多いので次の表にまとめて記入しておくと便利で ある。各自記入しておくように。 
表 17.5.1 関数 $x, y, z$ の組についての表現行列

\begin{tabular}{|c|c|c|c|}
\hline \multicolumn{2}{|c|}{ Proper rotation } & \multicolumn{2}{c|}{ Improper rotation } \\
\hline operation & character & operation & character \\
\hline$E$ & & $\sigma=S_{1}$ & \\
\hline$C_{2}$ & & $i=S_{2}$ & \\
\hline$C_{3}$ & & $S_{3}$ & \\
\hline$C_{4}$ & & $S_{4}$ & \\
\hline$C_{6}$ & & $S_{6}$ & \\
\hline
\end{tabular}

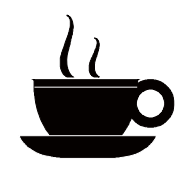

[Coffee Break] 縦ベクトルか横ベクトルか?

representation matrix を定義するにあたって，ここではbasis set を横ベクトル（row vector）で表しているが，そのことは非常に大切なことである. 群論の教科書の中に は，それを縦ベクトル（column vector）で表しているものがけっこうある。いったい， row vector で表すのと, column vector で表すのと何が違うのだろうか?

式(17.5.1)のような関係を， column vector を用いて表すことはもちろん可能である. そのこと自体何の不都合もない. 念のため, 式(17.5.1)を column vector を用いて書き 直してみよう。 


$$
\begin{aligned}
& E\left[\begin{array}{l}
s_{1} \\
s_{2} \\
s_{3}
\end{array}\right]=\left[\begin{array}{lll}
1 & 0 & 0 \\
0 & 1 & 0 \\
0 & 0 & 1
\end{array}\right]\left[\begin{array}{l}
s_{1} \\
s_{2} \\
s_{3}
\end{array}\right] \\
& C_{3}\left[\begin{array}{l}
s_{1} \\
s_{2} \\
s_{3}
\end{array}\right]=\left[\begin{array}{lll}
0 & 1 & 0 \\
0 & 0 & 1 \\
1 & 0 & 0
\end{array}\right]\left[\begin{array}{l}
s_{1} \\
s_{2} \\
s_{3}
\end{array}\right] \\
& C_{3}^{2}\left[\begin{array}{l}
s_{1} \\
s_{2} \\
s_{3}
\end{array}\right]=\left[\begin{array}{lll}
0 & 0 & 1 \\
1 & 0 & 0 \\
0 & 1 & 0
\end{array}\right]\left[\begin{array}{l}
s_{1} \\
s_{2} \\
s_{3}
\end{array}\right] \\
& \sigma_{v}\left[\begin{array}{l}
s_{1} \\
s_{2} \\
s_{3}
\end{array}\right]=\left[\begin{array}{lll}
1 & 0 & 0 \\
0 & 0 & 1 \\
0 & 1 & 0
\end{array}\right]\left[\begin{array}{l}
s_{1} \\
s_{2} \\
s_{3}
\end{array}\right] \\
& \sigma_{v}{ }^{\prime}\left[\begin{array}{l}
s_{1} \\
s_{2} \\
s_{3}
\end{array}\right]=\left[\begin{array}{lll}
0 & 1 & 0 \\
1 & 0 & 0 \\
0 & 0 & 1
\end{array}\right]\left[\begin{array}{l}
s_{1} \\
s_{2} \\
s_{3}
\end{array}\right] \\
& \sigma_{v}^{\prime \prime}\left[\begin{array}{l}
s_{1} \\
s_{2} \\
s_{3}
\end{array}\right]=\left[\begin{array}{lll}
0 & 0 & 1 \\
0 & 1 & 0 \\
1 & 0 & 0
\end{array}\right]\left[\begin{array}{l}
s_{1} \\
s_{2} \\
s_{3}
\end{array}\right]
\end{aligned}
$$

式(17.5.1)も式(17.5.13)もどちらも transformation propertyを示していることには違い ない. どちらの表し方をとっても同じことであるし，どちらかというと，式(17.5.1) のような row vector を用いると，しばしばノートがいっぱいになって書けなくなるの で，何となく式(17.5.13)のような column vector で表したくなる.

しかし，式(17.5.13)のように column vectorで表した時の matrix は，transformation matrix ではあっても representation matrix ではない.というのは，この場合， transformation matrix の積が symmetry operation の積とはならないからである。このこ とをはっきりするために，式(17.5.2)と同じように $\sigma_{v}$ に対する transformation matrix と $C_{3}$ に対する transformation matrix の積を求めてみよう.

$$
\left[\begin{array}{lll}
1 & 0 & 0 \\
0 & 0 & 1 \\
0 & 1 & 0
\end{array}\right]\left[\begin{array}{lll}
0 & 1 & 0 \\
0 & 0 & 1 \\
1 & 0 & 0
\end{array}\right]=\left[\begin{array}{lll}
0 & 1 & 0 \\
1 & 0 & 0 \\
0 & 0 & 1
\end{array}\right]
$$

右辺の transformation matrix は式(17.5.13)をみると $\sigma_{v}{ }^{\prime}$ のものである. $\sigma_{v}{ }^{\prime}$ のものではな い. すなわち， column vector で表した時の transformation matrix の積は symmetry 
operation $の$ 積

$$
\sigma_{v} C_{3}=\sigma_{v} "
$$

と同じ関係にならないのである，representation matrix の定義は row vector を用いなけ ればならないことはこの例からも明らかであろう。注意してほしい。 


\section{6 既約表現 （irreducible representation）}

表現行列 $\mathbf{D}(G)$ に similarity transformation $\mathbf{C}^{-1} \mathbf{D}(G) \mathbf{C}$ を行うことによって，次に示 すように matrix がいくつかの block に分けられるということが全ての symmetry operation $G$ について成り立つとする. すなわち，

$$
\begin{aligned}
\mathbf{D}^{\prime}(G) & =\mathbf{C}^{-1} \mathbf{D}(G) \mathbf{C} \\
& =\left[\begin{array}{ccc}
\mathbf{D}^{(1)} & 0 & 0 \\
0 & \mathbf{D}^{(2)} & 0 \\
0 & 0 & \mathbf{D}^{(3)}
\end{array}\right]
\end{aligned}
$$

ここで, 対角の各ブロックは值を持つが，このブロック以外の全ての要素はゼロと なることを示している。このようなことが可能であれば, 表現 $\mathbf{D}(G)$ は可約 (reducible) であると言い，この手続きを簡約（reduction）と言う。このようなことが出来ない表 現行列を，既約表現（irreducible representation）と言う。（註：日本語と英語とで微妙 に言い方が異なるのは面白い.日本語では「既に簡約されたもの」という言い方をす るのに対し，英語では「簡約し得ないもの」という言い方をしている.）

可約表現の一例として，式(17.5.1)に現れる $\left(s_{1}, s_{2}, s_{3}\right)$ をbasis set とした場合の $\mathrm{C}_{3 \mathrm{v}}$ の表現行列を取り上げよう。念のため，各表現行列を再び示すと次のようになる.

$$
\begin{aligned}
& \mathbf{D}(E)=\left[\begin{array}{lll}
1 & 0 & 0 \\
0 & 1 & 0 \\
0 & 0 & 1
\end{array}\right] \\
& \mathbf{D}\left(C_{3}\right)=\left[\begin{array}{lll}
0 & 0 & 1 \\
1 & 0 & 0 \\
0 & 1 & 0
\end{array}\right] \\
& \mathbf{D}\left(C_{3}^{2}\right)=\left[\begin{array}{lll}
0 & 1 & 0 \\
0 & 0 & 1 \\
1 & 0 & 0
\end{array}\right]
\end{aligned}
$$




$$
\begin{aligned}
& \mathbf{D}\left(\sigma_{v}\right)=\left[\begin{array}{lll}
1 & 0 & 0 \\
0 & 0 & 1 \\
0 & 1 & 0
\end{array}\right] \\
& \mathbf{D}\left(\sigma_{v}{ }^{\prime}\right)=\left[\begin{array}{lll}
0 & 1 & 0 \\
1 & 0 & 0 \\
0 & 0 & 1
\end{array}\right] \\
& \mathbf{D}\left(\sigma_{v}{ }^{\prime \prime}\right)=\left[\begin{array}{lll}
0 & 0 & 1 \\
0 & 1 & 0 \\
1 & 0 & 0
\end{array}\right]
\end{aligned}
$$

例えば

$$
\mathbf{C}=\left[\begin{array}{ccc}
\frac{1}{\sqrt{3}} & \frac{\sqrt{2}}{\sqrt{3}} & 0 \\
\frac{1}{\sqrt{3}} & -\frac{1}{\sqrt{6}} & \frac{1}{\sqrt{2}} \\
\frac{1}{\sqrt{3}} & -\frac{1}{\sqrt{6}} & -\frac{1}{\sqrt{2}}
\end{array}\right]
$$

とすると，その逆行列は

$$
\mathbf{C}^{-1}=\left[\begin{array}{ccc}
\frac{1}{\sqrt{3}} & \frac{1}{\sqrt{3}} & \frac{1}{\sqrt{3}} \\
\frac{2}{\sqrt{6}} & -\frac{1}{\sqrt{6}} & -\frac{1}{\sqrt{6}} \\
0 & \frac{1}{\sqrt{2}} & -\frac{1}{\sqrt{2}}
\end{array}\right]
$$

となる。これにより similarity transformation を行う。

$$
\begin{aligned}
& \mathbf{D}^{\prime}(E)=\mathbf{C}^{-1} \mathbf{D}(E) \mathbf{C}=\left[\begin{array}{lll}
1 & 0 & 0 \\
0 & 1 & 0 \\
0 & 0 & 1
\end{array}\right] \\
& \mathbf{D}^{\prime}\left(C_{3}\right)=\mathbf{C}^{-1} \mathbf{D}\left(C_{3}\right) \mathbf{C}=\left[\begin{array}{ccc}
1 & 0 & 0 \\
0 & -\frac{1}{2} & -\frac{\sqrt{3}}{2} \\
0 & \frac{\sqrt{3}}{2} & -\frac{1}{2}
\end{array}\right]
\end{aligned}
$$




$$
\begin{aligned}
& \mathbf{D}^{\prime}\left(C_{3}^{2}\right)=\mathbf{C}^{-1} \mathbf{D}\left(C_{3}^{2}\right) \mathbf{C}=\left[\begin{array}{ccc}
1 & 0 & 0 \\
0 & -\frac{1}{2} & \frac{\sqrt{3}}{2} \\
0 & -\frac{\sqrt{3}}{2} & -\frac{1}{2}
\end{array}\right] \\
& \mathbf{D}^{\prime}\left(\sigma_{v}\right)=\mathbf{C}^{-1} \mathbf{D}\left(\sigma_{v}\right) \mathbf{C}=\left[\begin{array}{ccc}
1 & 0 & 0 \\
0 & 1 & 0 \\
0 & 0 & -1
\end{array}\right] \\
& \mathbf{D}^{\prime}\left(\sigma_{v}{ }^{\prime}\right)=\mathbf{C}^{-1} \mathbf{D}\left(\sigma_{v}{ }^{\prime}\right) \mathbf{C}=\left[\begin{array}{ccc}
1 & 0 & 0 \\
0 & -\frac{1}{2} & \frac{\sqrt{3}}{2} \\
0 & \frac{\sqrt{3}}{2} & \frac{1}{2}
\end{array}\right] \\
& \mathbf{D}^{\prime}\left(\sigma_{v}{ }^{\prime \prime}\right)=\mathbf{C}^{-1} \mathbf{D}\left(\sigma_{v}{ }^{\prime \prime}\right) \mathbf{C}=\left[\begin{array}{ccc}
1 & 0 & 0 \\
0 & -\frac{1}{2} & -\frac{\sqrt{3}}{2} \\
0 & -\frac{\sqrt{3}}{2} & \frac{1}{2}
\end{array}\right]
\end{aligned}
$$

以上のように，すべての symmetry operation について representation は 1 次の matrix と 2 次の matrix とに block out される.これが簡約である. 簡約によって分けられた 2 次 の matrix は，もはや，いかなる $\mathbf{C}$ を持って来てもこれ以上簡約することは出来ない. このように，これ以上簡約することが出来ない表現が，上述した既約表現である.

このように，3 次の可約表現行列が 1 次と 2 次の既約表現とに簡約されたわけであ るが, 念のため, それを改めて書いておこう.まず 1 次の既約表現行列および character は，次の通りになる。 


$$
\begin{aligned}
& \mathbf{D}^{\left(A_{1}\right)}(E)=[1] \\
& \mathbf{D}^{\left(A_{1}\right)}\left(C_{3}\right)=[1] \\
& \mathbf{D}^{\left(A_{1}\right)}\left(C_{3}{ }^{2}\right)=[1] \\
& \mathbf{D}^{\left(A_{1}\right)}\left(\sigma_{v}\right)=[1] \\
& \mathbf{D}^{\left(A_{1}\right)}\left(\sigma_{v}^{\prime}\right)=[1] \\
& \mathbf{D}^{\left(A_{1}\right)}\left(\sigma_{v}{ }^{\prime \prime}\right)=[1] \\
& \chi^{\left(A_{1}\right)}(E)=1 \\
& \chi^{\left(A_{1}\right)}\left(C_{3}\right)=1 \\
& \chi^{\left(A_{1}\right)}\left(C_{3}^{2}\right)=1 \\
& \chi^{\left(A_{1}\right)}\left(C_{3}^{2}\right)=1 \\
& \chi^{\left(A_{1}\right)}\left(\sigma_{v}\right)=1 \\
& \chi^{\left(A_{1}\right)}\left(\sigma_{v}^{\prime}\right)=1 \\
& \chi^{\left(A_{1}\right)}\left(\sigma_{v}{ }^{\prime \prime}\right)=1
\end{aligned}
$$

Dの superscript のかっこ内に示した $A_{1}$ というのは，この既約表現の「呼び名」である.

このことは後で Section 17.8 の指標表のところで改めて述べる. 同様に, 2 次の既約表 現行列および character を次に示す.Dの superscript の括弧内の $E$ は，やはりこの既約 表現の呼び名である.

$$
\begin{aligned}
& \mathbf{D}^{(E)}(E)=\left[\begin{array}{ll}
1 & 0 \\
0 & 1
\end{array}\right] \\
& \mathbf{D}^{(E)}\left(C_{3}\right)=\left[\begin{array}{ll}
-\frac{1}{2} & -\frac{\sqrt{3}}{2} \\
\frac{\sqrt{3}}{2} & -\frac{1}{2}
\end{array}\right] \\
& \mathbf{D}^{(E)}\left(C_{3}{ }^{2}\right)=\left[\begin{array}{cc}
-\frac{1}{2} & \frac{\sqrt{3}}{2} \\
-\frac{\sqrt{3}}{2} & -\frac{1}{2}
\end{array}\right] \\
& \mathbf{D}^{(E)}\left(\sigma_{v}\right)=\left[\begin{array}{cc}
1 & 0 \\
0 & -1
\end{array}\right]
\end{aligned}
$$




$$
\begin{aligned}
& \mathbf{D}^{(E)}\left(\sigma_{v}{ }^{\prime}\right)=\left[\begin{array}{ll}
-\frac{1}{2} & \frac{\sqrt{3}}{2} \\
\frac{\sqrt{3}}{2} & \frac{1}{2}
\end{array}\right] \\
& \mathbf{D}^{(E)}\left(\sigma_{v}^{\prime \prime}\right)=\left[\begin{array}{cc}
-\frac{1}{2} & -\frac{\sqrt{3}}{2} \\
-\frac{\sqrt{3}}{2} & \frac{1}{2}
\end{array}\right] \\
& \chi^{(\mathrm{E})}(E)=2 \\
& \chi^{(\mathrm{E})}\left(C_{3}\right)=-1 \\
& \chi^{(\mathrm{E})}\left(C_{3}{ }^{2}\right)=-1 \\
& \chi^{(\mathrm{E})}\left(\sigma_{v}\right)=0 \\
& \chi^{(\mathrm{E})}\left(\sigma_{v}{ }^{\prime}\right)=0 \\
& \chi^{(\mathrm{E})}\left(\sigma_{v}^{\prime \prime}\right)=0
\end{aligned}
$$

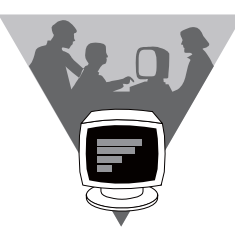

[Let's play with Mathematica] 逆行列

式(17.6.4)で逆行列を求めたが，高校で 2 次の行列の逆行列を学習しているわけで あるから大学生になったら 3 次の逆行列位寸らすらと求めてほしいものである.

とは言うものの, computer を用いて簡単に解が得られる現在, そういう道具を積極 的に使い, computerには出来ない化学の研究に集中寸るという方針も悪くはない.

Mathematica では行列や逆行列は次のように扱う.

例として式(17.6.3)の行列の逆行列を求めてみよう。まず，式(17.6.3)の行列を定義

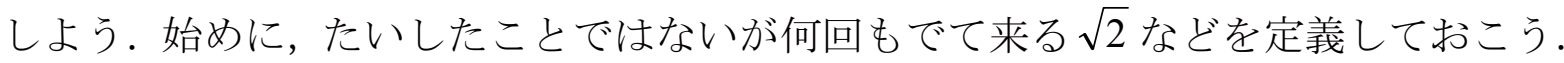
$\mathrm{rt2}:=\operatorname{Sqrt}[2]$ 
$\mathrm{rt3}:=$ Sqrt $[3]$

rt6:=Sqrt[6]

行列は次のようにリストとして定義する.

$\mathrm{c}:=\{\{1 / \mathrm{rt} 3, \mathrm{rt} 2 / \mathrm{rt} 3,0\},\{1 / \mathrm{rt} 3,-1 / \mathrm{rt} 6,1 / \mathrm{rt} 2\},\{1 / \mathrm{rt} 3,-1 / \mathrm{rt} 6,-1 / \mathrm{rt} 2\}\}$

これで十分用は足りるのであるが通常の行列の形に表した方が分かりやすいかもし れない。

\section{MatrixForm[c]}

結果は次のようになる。

$\begin{array}{ccc}1 & 2 & \\ ------ & \text { Sqrt[-] } & 0 \\ \text { Sqrt[3] } & 3 & 1 \\ 1 & 1 & ------ \\ ------ & -(------) & \text { Sqrt[2] } \\ \text { Sqrt[3] } & \text { Sqrt[6] } & 1 \\ 1 & 1 & -(-----) \\ ------ & -(------) & \text { Sqrt[2] }\end{array}$

式(17.6.3)が与えられていることが分かる。では，逆行列を行列の形式で出力してみよ う.

MatrixForm[Inverse[c]]

直ちに次のような結果が得られる. 


$\begin{array}{ccc}1 & 1 & 1 \\ ----- & ----- & ---- \\ \text { Sqrt[3] } & \text { Sqrt[3] } & \text { Sqrt[3] } \\ 2 & 1 & 1 \\ \text { Sqrt[-] } & -(-----) & -(-----) \\ 3 & \text { Sqrt[6] } & \text { Sqrt[6] } \\ & 1 & 1 \\ 0 & (------) & -(----) \\ & \text { Sqrt[2] } & \text { Sqrt[2] }\end{array}$

当然のことであるが式(17.6.4)が再現されている.

\section{7 表現行列の直交性}

位数（order） $h$ の群において, symmetry operation $G$ についての $d$ 次元の irreducible representation の matrix を $\mathbf{D}^{(\ell)}(G)$ とする.ここで superscript の $(\ell)$ は既約表現を示す.

ここでは $\mathbf{D}^{(t)}(G)$ は unitary matrix と仮定する.すべての有限群の representation matrix は similarity transformation によって unitary matrix に変換出来るので，この仮定は何の 制限にもならない。この representation matrix には次に示寸直交関係がある.

$$
\sum_{G} \mathbf{D}^{(\ell)}{ }_{i, j}(G) * \mathbf{D}^{\left(\ell^{\prime}\right)}{ }_{i^{\prime} j^{\prime}}(G)=\frac{h}{d} \delta_{\ell, \ell^{\prime}} \delta_{i, i^{\prime}} \delta_{j, j^{\prime}}
$$

左辺の和は寸べての symmetry operation についての和である．上式の証明は，ここで は省略するので，物足りない人は群論の本を見て学習してほしい（例えば， Eyring， Walter, Kimball, "Quantum Chemistry", page 371; 犬井鉄郎，田辺行人，小野寺嘉孝，「応 用群論」, page 62 等.) 式(17.7.1)は"Great Orthogonality Theorem"と言われている.

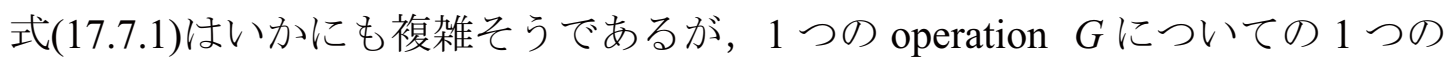
representation matrix のある要素と, 同じ operation についての同じまたは他の representation matrix のある要素との積をとり，それをすべての symmetry operation に ついて和をとったものが左辺である．例えば，式(17.6.7a)に示した 2 次元の representation matrix において, $\ell=\ell^{\prime}, i=i^{\prime}=1, j=j^{\prime}=2$ とする. 寸なわち, 6 つの matrix

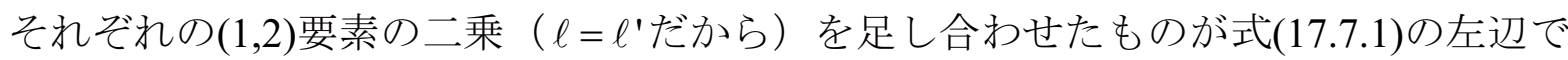
ある。すなわち

$$
\sum_{G} \mathbf{D}_{1,2}^{(t)}(G) * \mathbf{D}_{1,2}^{(t)}(G)=0^{2}+\left(-\frac{\sqrt{3}}{2}\right)^{2}+\left(\frac{\sqrt{3}}{2}\right)^{2}+0^{2}+\left(\frac{\sqrt{3}}{2}\right)^{2}+\left(-\frac{\sqrt{3}}{2}\right)^{2}=3
$$


一方， $h=6, d=2$ であるから式(17.7.1)の右辺は $\frac{6}{2}=3$ となり，たしかに等号が成立す る.

式(17.7.1)の特殊な場合として $i=j, \quad i^{\prime}=j^{\prime}$ の場合を考えよう。この場合式(17.7.1) は

$$
\sum_{G} \mathbf{D}_{i, i}^{(\ell)}(G) * \mathbf{D}^{\left(e^{\prime}\right)}{ }_{i, i^{\prime}}(G)=\frac{h}{d} \delta_{\ell, \ell^{\prime}} \delta_{i, i^{\prime}}
$$

となるが，両辺について $i, i^{\prime}$ についての和をとる。すなわち

$$
\sum_{i} \sum_{i^{\prime}} \sum_{G} \mathbf{D}_{i, i}^{(e)}(G) * \mathbf{D}^{\left(e^{\prime}\right)}{ }_{i, i^{\prime}}(G)=\sum_{i} \sum_{i^{\prime}} \frac{h}{d} \delta_{\ell, \ell^{\prime}} \delta_{i, i^{\prime}}
$$

左辺は

$$
\sum_{G}\left(\sum_{i} \mathbf{D}_{i, i}^{(e)}(G) *\right)\left(\sum_{i^{\prime}} \mathbf{D}^{(e)}{ }_{i, i^{\prime}}(G)\right)=\sum_{G} \chi^{(\ell)}(G)^{*} \chi^{(())}(G)
$$

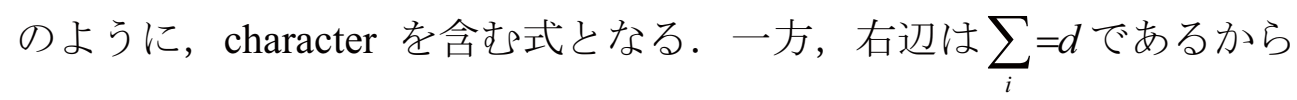

$$
\sum_{i} \frac{h}{d} \delta_{\ell, \ell^{\prime}}=h \delta_{\ell, \ell^{\prime}}
$$

となるので，結局

$$
\sum_{G} \chi^{(\ell)}(G)^{*} \chi^{(e)}(G)=h \delta_{\ell, \ell^{\prime}}
$$

すなわち，「異なる表現間で指標は直交する」という定理が得られる。この指標間の 直交性は, 「指標の第 1 種直交性」とも言われる. 1 つの class の中の全ての symmetry operation について character は等しいから, 上式は次のようにも表される.

$$
\sum_{c-1}^{n_{c}} g(c) \chi^{(\ell)}(c)^{*} \chi^{(e)}(c)=h \delta_{\ell, \ell^{\prime}}
$$

ここで $g(c)$ は class $c$ に属する symmetry operation の数であり， $\sum_{c}$ はすべての class についての和である.

式(17.7.3)は以下のように, ベクトルの内積とみなすことが出来る.すなわち

$$
V^{(t)}(c)=\sqrt{g(c)} \chi^{(\theta)}(c)
$$

とおくと，これはべクトル $\mathbf{V}^{(t)}$ の成分とみなせる. 従って式(17.7.3)は

$$
\sum_{c} V^{(t)}(c) * V^{(e)}(c)=\mathbf{V}^{(t)} * \mathbf{V}^{(e)}=h \delta_{\ell, \ell^{\prime}}
$$

となり，これは2つのベクトル $\mathbf{V}^{(t)} と \mathbf{V}^{(e)}$ の直交性を示す．そして(17.7.2)の左辺は 2 つのベクトルの内積にほかならない. 一般に, $n_{c}$ 次元空間で互いに直交するべクトル 
はたかだか $n_{c}$ 個しか存在しないから， ベクトルの個数（すなわち既約表現の個数） $n_{r}$ は $n_{c}$ 以下でなければならない.すなおち,

$$
n_{r} \leq n_{c}
$$

ベクトルの成分の数 $n_{c}$ は $c$ の数, 寸なわち, 類の数である.

もう 1 つ，証明は省略するが，「指標の第 2 種直交性」と言われる直交性がある.

$$
\sum_{\ell=1}^{n_{r}} \chi^{(\ell)}\left(c_{i}\right)^{*} \chi^{(\ell)}\left(c_{j}\right)=\delta_{i j} \frac{h}{g\left(c_{i}\right)}
$$

ここで右辺の分母の $g\left(c_{i}\right)$ は類 $c_{i}$ に属する symmetry operation の数である. 右辺の分子 の hは群の位数（order）である.上の議論と同様に，

$$
\left\{\chi^{(1)}\left(c_{i}\right), \chi^{(2)}\left(c_{i}\right), \ldots, \chi^{\left(n_{r}\right)}\left(c_{i}\right)\right\}
$$

を $n_{r}$ 次元のベクトルと見れば, 式(17.7.6)はベクトルの内積が直交することを示してい る. $n_{r}$ 次元空間で互いに直交するべクトルの個数は $n_{r}$ 以下でなければならない. すな わち，

$$
n_{c} \leq n_{r}
$$

式(17.7.6)および式(17.7.7)2つの要請から

$$
n_{r}=n_{c}
$$

が結論される．かくして次のような重要な定理が導かれる.

定理： 既約表現の数は類の数に等しい

又，ここでは証明は省略するが，表現 $\mathbf{D}^{(t)}$ の次元を $d_{\ell}$ とすると式(17.7.1)から，次のよ うな定理が導かれる。

$$
\sum d_{\ell}^{2}=h
$$

これは重要な定理である。 
定理： 各既約表現の次元の二乗の和は群の位数 $h$ に等しい.

\section{8 指標表（character table）}

前節で既約表現行列のことを学習したが, 群論の便利な点は, 多くの場合, 表現行 列全体を扱う必要はなく, その character のみで十分であるということである. そこで, 群の既約表現の characterのみをまとめた character table というものが，非常に有用と なって来る。

再び $\mathrm{C}_{3 \mathrm{v}}$ の例を考えよう。すでに繰り返し学習しているように，この群は 6 つの symmetry operation を持ち, それは 3 つの class に分類される. すなわち, operation $E$ がただ 1 つで 1 つの class に, $C_{3}$ およ゙ $C_{3}{ }^{2}$ のつが 1 つの classに, そして $\sigma_{v}, \sigma_{v}{ }^{\prime}, \sigma_{v}{ }^{\prime \prime}$ の3つが 1 つの classに属する.これらの class のそれぞれを記号で分類しておくのが 便利であろう. symmetry operation $E$ の属する class をやはり同じ記号 $E$ で表す.

symmetry operation $C_{3}$ と $C_{3}{ }^{2}$ が属する class を $C_{3}$ で表す. 同様に symmetry operation $\sigma_{v}, \sigma_{v}{ }^{\prime}, \sigma_{v}{ }^{\prime \prime}$ の つが属する class を $\sigma_{v}$ で表す。このように, symmetry operation の代 表的な記号でもって同時に class をも表すのが普通である.

次に既約表現についても，ある約束に従って名前をつけておく．現在は Mulliken によって考案された命名法がもっとも popularである. 1 次元の既約表現は $A$ および $B, 2$ 次元のそれは $E, 3$ 次元のそれは $T$ (または $F$ ) で表す. 1 次元の既約表現のう ち，主軸の回転により invariant なものを $A$, 符号を変えるものを $B$ とする. そして主 軸の回転以外の symmetry operation によって $A_{1}, A_{2}, \ldots$ とか $B_{1}, B_{2}, \ldots$ のように subscript をつけて区別する，E，Tについても同様に $E_{1}, E_{2}, \ldots$ とか $T_{1}, T_{2}, \ldots$ のように subscript をつけて区別する，更にすべての既約表現について，inversionについて符号が変らな いか変るかで $g$ （ドイツ語の gerade に由来する）または $u$ (同じくドイツ語の ungerade に由来する）の subscript をつける.

$\mathrm{C}_{3 \mathrm{v}}$ の場合は, class の数が 3 つであるから, 既約表現の数も 3 つである. 各既約 表現の次数を $d_{1}, d_{2}, d_{3}$ とすると, 式(17.7.7)から

$$
d_{1}^{2}+d_{2}^{2}+d_{3}^{2}=6
$$


となる. 未知数 3 つあって方程式は 1 つかないから解けないと思われるが，実は， $d$ が整数であることを考えると，解は 1 つに決まってしまう。すなわち

$$
1^{2}+1^{2}+2^{2}=6
$$

のみが許される解であり， 1 次元の既約表現が 2 つ, 2 次元の既約表現が 1 つあと いうことが分かる。この 3 つの既約表現を $A, B, E$ という名前で区別する.

$\mathrm{C}_{3 \mathrm{v}}$ の character table は次のように与えられる.

表 17.8.1 $\mathrm{C}_{3 \mathrm{~V}}$ の指標表

\begin{tabular}{|c||c|c|c||}
\hline $\mathrm{C}_{3 \mathrm{v}}$ & $E$ & $2 C_{3}$ & $3 \sigma_{\mathrm{v}}$ \\
\hline \hline$A_{1}$ & 1 & 1 & 1 \\
\hline$A_{2}$ & 1 & 1 & -1 \\
\hline$E$ & 2 & -1 & 0 \\
\hline
\end{tabular}

最上段が class と operation を示していて，例えば $2 C_{3}$ というのは， $C_{3}$ に属する operation が 2 つることを示している．この character table は, character の規格直交 性より容易に導かれるが，その導出法はここでは省略する。（よっぽど特殊な点群を 考えない限り, character table は多くの教科書に与えてあるので, character table の作り 方を知らなくても実質上の不便はなからう。)

指標表は，たいていの量子化学の教科書に Appendix として出ている. どの本の表 を見ても本質的に変りはないが，並べ方や記号の用い方などが微妙に異なるので，毎 回異なったものを見るとちよっとまごつく場合もある。むしろ使いやすいような「自 分の」 character table を作っておくことが望ましい.

它Problem 17.8.1

character table の表をみて，与えられているすべての点群について

1. 類 (class) の数が既約表現の数と等しいかを吟味せよ.

2. 式(17.7.7)が成り立つかを吟味せよ。

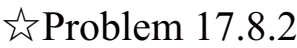

すべての symmetry operation がお互いに可換であるような群を Abel 群と言う. Abel 群においては，それぞれの symmetry operation がそれ自体で class をなしていることを 
証明せよ。

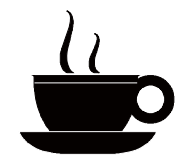

[Coffee Break] 指標表の間違い

character table は多くの教科書に Appendix として代表的なものが載っている. しか し，そういう character table には間違いが必ずあるものだ，位に考えるのが安全であ る.色々な間違いがあるが, 大部分の場合は単純な misprintであろうと思われる.Atkins の "Molecular Quantum Mechanics", page 440 の $\mathrm{D}_{\infty \mathrm{h}}$ の character table も 1 箇所符号が間 違っている。こういう misprint を完全に除くことは，本 lecture note の misprint を完全 になくすことと同様に至難の業である. 各自が気をつけるしかない. 防御のためには, 自分の為の character table を持つ，ということである。十分に吟味して間違いのない ものに訂正した上で，それのみを信用して用いるようにすればよい.

このような，単純な misprint は我慢出来るが，たまには著者の勘違いでとんだ character table が印刷されていることがある。こういう間違いは, 実に困ったものだが， character table をみて,a）既約表現の数と類の数が一致しているか, すなわち, character table が正方行列の形になっているか，b）既約表現の次元の二乗の和が対称操作の数 と等しくなっているか.の 2 点に注意しただけでもかなり間違いを見つけることが出 来る.

一例をあげよう。 H. H. Jaffe and M. Orchin 著"Symmetry in Chemistry" (John Wiley) と いう本がある。日本語訳もあり，「群論入門一化学における対称」（東京化学同人）と いう本で学生にも人気のある本である。この本のp.160（訳本ではp.165）に $\mathrm{C}_{3}$ の character table が次のように間違って与えられている. 
間違つている指標表の一例

\begin{tabular}{||c||c|c||}
\hline $\mathrm{C}_{3}$ & $E$ & $2 C_{3}$ \\
\hline \hline$A$ & 1 & 1 \\
\hline$E$ & 2 & -1 \\
\hline
\end{tabular}

この表によると，既約表現の数は 2 つ, 類の数が 2 つで上述したa）の条件は満た しているようにみえる。それでb）の条件を吟味してみる. 次元の二乗の和は， $1^{2}+2^{2}=5$, 一方, 対称操作の数は 3 つである. 明らかにおかしい. どこがおかしい のであろうか?

$\mathrm{C}_{3}$ という点群は, $E, C_{3}, C_{3}^{2}$ の 3 つの対称操作を持っている. このような回転 操作同志はお互いに可換であることは明らかであろう。すなわち $\mathrm{C}_{3}$ という点群では 全ての対称操作はお互いに可換である.そのような群を一般に Abel 群というが, Abel 群においては1つ1つの対称操作がそれ自身で類をなすことは similarity transformation を行ってみれば明らかであろう。(Problem 17.8.2) 従って, $\mathrm{C}_{3}$ 点群においては類の数 が 3 つ， 1 次元の既約表現の数が 3 つ，ということが分かる. Eyring, Walter, Kimball の "Quantum Chemistry" p.383-388 の character table は間違いだらけであるが， C 3 のそ れは間違ってなく, 次のように正しい character table が与えられている.

\begin{tabular}{||c||c|c|c||}
\hline \hline $\mathrm{C}_{3}$ & $E$ & $C_{3}$ & $C_{3}{ }^{2}$ \\
\hline \hline \multirow{2}{*}{$A$} & 1 & 1 & 1 \\
\hline \multirow{2}{*}{$E$} & 1 & $\omega$ & $\omega^{2}=\omega^{*}$ \\
\cline { 2 - 4 } & 1 & $\omega^{2}=\omega^{*}$ & $\omega$ \\
\hline
\end{tabular}

ここで $\omega=\exp \left(\frac{2 \pi}{3} i\right)$ である.

この指標表から分かるように, 既約表現の数も類の数も 3 つる. また, 次元の二 
乗の和は $1^{2}+1^{2}+1^{2}=3$ で, 対称操作の数とも一致している.

この character table は正しいが，それを間違って解釈する研究者がかなり多いこと も注意しないといけない. Eyring, Walter, Kimball の教科書では, 1 次元の既約表現 2 つをまとめて $E$ と示している。一般に $E$ というのは，2 次元の既約表現を表すので， この 2 つをまとめて, 2 次元の既約表現 1 つといううに勘違いしてしまうのである. 上述した Jaffe, Orchin の教科書の間違いもそういう勘違いに基づいているものと思わ れる。

同様な間違いは $\mathrm{C}_{4}, \mathrm{C}_{5}, \mathrm{C}_{6}, \ldots$ および $\mathrm{S}_{4}$ の character table にしばしば見られる. 生意気な言い方をすれば, character table を見ればそれぞれの著者の群論に対する理解 度が分かるといらものだ。

もつとも，上述した， 1 次元の既約表現 2 つををまとめて 2 重縮退の既約表現と勘 違いしてしまう理由は理解できないことではない，上に例としてあげた $\mathrm{C}_{3}$ の点群の $E$ のそれぞれの成分を，仮に， $E_{1}$ および $E_{2}$ と表すとすると，上述の指標表からも分 かるように， $E_{1}$ の指標と $E_{2}$ の指標はお互いに複素共役となっている. 既約表現 $E_{1}$ に 属する波動関数を $\psi\left(E_{1}\right)$, 既約表現 $E_{2}$ に属する波動関数を $\psi\left(E_{2}\right)$ とすると, Hermitian かつ real な operator $A$ についての期待值について

$$
\left\langle\psi\left(E_{1}\right)|A| \psi\left(E_{1}\right)\right\rangle=\left\langle\psi\left(E_{2}\right)|A| \psi\left(E_{2}\right)\right\rangle
$$

という関係が成り立つ。すなわち, Hermitian かつ real な普通の Hamiltonian $H$ につい てのエネルギーは等しくなる。だから縮退なんだ，という話は理解はできる。しかし，

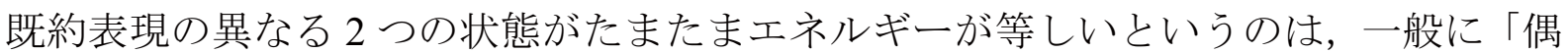
然縮退」と言って，縮退とは言わないのが普通である。また，考える演算子がいつも

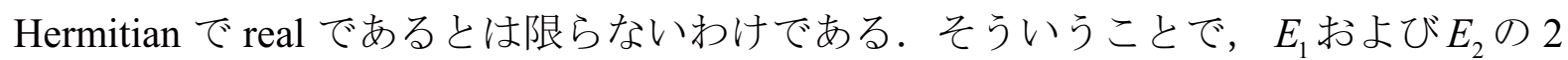
つの成分を縮退とみなすべきではないと思っている.

论Exercise 17.8.1

$\mathrm{H}_{2} \mathrm{O}$ の分子軌道を CNDO 法によって求めた結果は以下の表の通りである. 
EIGENVALUES AND EIGENVECTORS OF $\mathrm{H}_{2} \mathrm{O}$

\begin{tabular}{|c|c|c|c|c|c|c|c|c|}
\hline \multicolumn{2}{|c|}{ EIGENVALUES------- } & & -1.4714 & -.7964 & -.6959 & -.6516 & .3144 & .3608 \\
\hline & & & 1 & 2 & 3 & 4 & 5 & 6 \\
\hline 1 & 0 & $S$ & 8676 & .0000 & 2910 & 0000 & .4032 & 0000 \\
\hline 1 & 0 & $P Z$ & -.0555 & .0000 & 8625 & 0000 & .5031 & 0000 \\
\hline 1 & 0 & PY & 0000 & .7496 & 0000 & 0000 & .0000 & -.6619 \\
\hline 1 & 0 & $P X$ & 0000 & .0000 & 0000 & 1.0000 & .0000 & 0000 \\
\hline 2 & H & $S$ & 3494 & .4680 & -.2928 & 0000 & -.5405 & 5301 \\
\hline 3 & $\mathrm{H}$ & $S$ & 3494 & -.4680 & -.2928 & 0000 & -.5405 & -.530 \\
\hline
\end{tabular}

CNDO 法という分子軌道法についてはずっと後に学習するので詳しいことはここで は省略するが，ここで大切なことはCNDO 法においては， molecular orbital（MO）を atomic orbital（AO）の linear combination で表し，この場合の basis set として各原子の valence atomic orbital（電子が詰まっている atomic orbital）を取るということである. すなわち $\mathrm{H}_{2} \mathrm{O}$ の場合, $\mathrm{O}$ の $2 s, 2 p_{z}, 2 p_{y}, 2 p_{x}$ の各 $\mathrm{AO}, 1$ つの $\mathrm{H}$ の $1 s \mathrm{AO}$ ，もう 1 つの $\mathrm{H}$ の $1 s \mathrm{AO}$ と計 6 個の $\mathrm{AO}$ の組を basis set とする. 従って MO の数は basis set を構成する AO の数と等しく6 個ある.

さて，上の表の見方であるが，最上段の行は各 MO の orbital energy を hartree 単位 で表したものである.2 段目の行は MO の番号付けで energy の低い方から 1,2, .., 6 と番号を付けている. それぞれの MO における $\mathrm{AO}$ の係数を各列に示している.もつ とも左の列の $1,2,3$ という数字は単に原子に番号を付けたものである.ここでは $\mathrm{O}$ を 1，2つの $\mathrm{H}$ （仮りに $\mathrm{H}_{\mathrm{A}}, \mathrm{H}_{\mathrm{B}}$ とする）をそれぞれ 2,3 と番号を付けたまでである. 左 から 2 番目の列が原子を示し, 3 番目の列が $\mathrm{AO}$ を示す.いちいち断らなくても 0 の $2 s$ $\mathrm{AO}$ は単に $\mathrm{S}$ と示し, $\mathrm{H}$ の $1 s \mathrm{AO}$ も同様に単に $\mathrm{S}$ と示している.例えば, もっとも energy の低い MO の $\psi_{1}$ につては

$$
\psi_{1}=0.8676 \phi_{\mathrm{O}, 2 s}-0.055 \phi_{\mathrm{O}, 2 p_{z}}+0.3494\left(\phi_{\mathrm{H}_{\mathrm{A}}, 1 s}+\phi_{\mathrm{H}_{\mathrm{B}}, 1 s}\right)
$$

という LCAOで示されることを示している。ここで中はAOを示す．なお，座標は $\mathrm{H}_{2} \mathrm{O}$ の分子面を $y z$ 面に, かつ, 分子の $C_{2}$ 軸を $z$ 軸にとっている（Section 17.9 で述べ る Mulliken recommendationに従っている).

Lecture Note on Quantum Chemistry by T. Azumi Chapter 17, Page 54 
問題 : 各 $\mathrm{MO}$ の属する既約表現を求めよ.

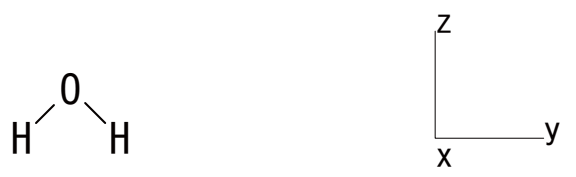

\section{【解】:}

まず分子の属する点群が $\mathrm{C}_{2 \mathrm{v}}$ であることに着目する。 $\mathrm{C}_{2 \mathrm{v}}$ の character table は次の 表で与えられる.

表 $\quad 17.8 .2 \quad \mathrm{C}_{2 \mathrm{v}}$ の指標表

\begin{tabular}{||c||c|c|c|c||}
\hline $\mathrm{C}_{2 \mathrm{v}}$ & $E$ & $C_{2}$ & $\sigma(x z)$ & $\sigma(y z)$ \\
\hline \hline$A_{1}$ & 1 & 1 & 1 & 1 \\
\hline$A_{2}$ & 1 & 1 & -1 & -1 \\
\hline$B_{1}$ & 1 & -1 & 1 & -1 \\
\hline$B_{2}$ & 1 & -1 & -1 & 1 \\
\hline
\end{tabular}

各 $\mathrm{MO}$ の transformation property を求めるに当り, 各 $\mathrm{AO}$ の分子面（zy 面）につい ての reflection $\sigma(z y)$ に対する対称性を考慮する必要がある. 各 AO の形を思い出し てみれば $\sigma(y z)$ について symmetric なものは $\mathrm{O} の 2 p_{z}, 2 p_{y}$ および各 $\mathrm{H} の 1 s \mathrm{AO}$ ま た, antisymmetric なものは $\mathrm{O} の 2 p_{x} \mathrm{AO}$ である. 以上のことを考慮しつつ, 各 $\mathrm{MO}$ の transformation property を求めると次の表のようになる. 


\begin{tabular}{||c||c|c|c|c||c||}
\hline \hline $\mathrm{C}_{2 \mathrm{v}}$ & $E$ & $C_{2}(z)$ & $\sigma(x z)$ & $\sigma(y z)$ & 既約表現 \\
\hline \hline$\psi_{1}$ & 1 & 1 & 1 & 1 & $A_{1}$ \\
\hline$\psi_{2}$ & 1 & -1 & -1 & 1 & $B_{2}$ \\
\hline$\psi_{3}$ & 1 & 1 & 1 & 1 & $A_{1}$ \\
\hline$\psi_{4}$ & 1 & -1 & 1 & -1 & $B_{1}$ \\
\hline$\psi_{5}$ & 1 & 1 & 1 & 1 & $A_{1}$ \\
\hline$\psi_{6}$ & 1 & -1 & -1 & 1 & $B_{2}$ \\
\hline \hline
\end{tabular}

この表と character table を比較することにより，各 MO の既約表現は表のもつとも右 の列に示したようになることが分かる.

拧Exercise 17.8.2

アンモニア $\mathrm{NH}_{3}$ 分子の分子軌道を CNDO 法によって求めた結果を次の表に示す. $C_{3}$ 軸を $z$ 軸にとっている. $\mathrm{NH}_{3}$ は Section 17.3 から何回も出て来たように $\mathrm{C}_{3 \mathrm{v}}$ の点群 に属する. 分子軌道（MO） $\psi_{1}, \ldots, \psi_{7}$ の既約表現を求めよ.

\section{EIGENVALUES AND EIGENVECTORS OF $\mathrm{NH}_{3}$}

\begin{tabular}{rrrrrrrrrr} 
EIGENVALUES----- & & -1.3636 & -.7433 & -.7433 & -.5991 & .3274 & .3486 & .3486 \\
& & & 1 & 2 & 3 & 4 & 5 & 6 & \multicolumn{1}{l}{7} \\
1 & $\mathrm{~N}$ & $\mathrm{~S}$ & -.7851 & .0000 & .0000 & .3157 & .5329 & .0000 & .0000 \\
1 & $\mathrm{~N}$ & $\mathrm{PX}$ & .0000 & .7333 & .0010 & .0000 & .0000 & .0032 & -.6800 \\
1 & $\mathrm{~N}$ & $\mathrm{PY}$ & .0000 & -.0010 & .7333 & .0000 & .0000 & -.6800 & -.0032 \\
1 & $\mathrm{~N}$ & $\mathrm{PZ}$ & .0809 & .0000 & .0000 & .9052 & -.4171 & .0000 & .0000 \\
& & & & & & & & & \\
2 & $\mathrm{H}$ & $\mathrm{S}$ & -.3545 & -.0008 & .5552 & -.1642 & -.4251 & .5987 & .0029
\end{tabular}




$$
\begin{array}{llllllllll}
3 & \text { H } & \text { S } & -.3545 & -.4804 & -.2783 & -.1642 & -.4251 & -.2969 & -.5199 \\
4 & \text { H } & \text { S } & -.3545 & .4812 & -.2769 & -.1642 & -.4251 & -.3018 & .5171
\end{array}
$$

\section{【解】：}

3 つの $\mathrm{H}$ の $1 s$ 軌道に着目するのが便利であろう. $\psi_{1}, \psi_{4}, \psi_{5}$ の 3 つの orbital につい てはいずれも 3 つの $s$ orbital が同符号の線形結合となっている. 表 17.8.1の $\mathrm{C}_{3 \mathrm{v}}$ の character table と比較してみると，これらの MO はいずれも $A_{1}$ の既約表現（全対称表 現）を持つことが分かる。この結論は $\mathrm{N} の p$ 軌道を見ても矛盾しない. $\psi_{1}, \psi_{4}, \psi_{5}$ の すべてについて $p_{x}, p_{y}$ orbital の寄与がゼロになっている.これらがゼロでなければ 全対称にはなりえないことは明らかである.こういうことについて $\psi_{1}, \psi_{4}, \psi_{5}$ のつ の MO の既属は直ちに分かる.しかし， $\psi_{2}$ や幽を見ると一見分からない. すなわち 3 つの $s$ orbital のみに着目すると， $\psi_{2}, \psi_{3}$ は次のようになっている.

$$
\begin{aligned}
& \psi_{2}=-0.0008 s_{1}-0.4804 s_{2}+0.4812 s_{3} \\
& \psi_{3}=+0.5552 s_{1}-0.2783 s_{2}-0.2769 s_{3}
\end{aligned}
$$

この結果はあたかも $C_{3}$ の symmetry operation を持たないかのようにみえる.このこと は $\psi_{2}$ または $\psi_{3}$ それ自体では $C_{3}$ の symmetry operation を持たない(すなわち, $\psi_{2} も \psi_{3}$ も $C_{3}$ の eigenfunction になっていない）ということである。実はこの 2 つの MO は縮退 している. (eigenvalue を見ればどちらも同じになっていることが分かるであろう.) それで， $\psi_{2}$ と $\psi_{3}$ の 2 つのセットとして $C_{3}$ の eigenfunction になっている.

少々ややこしいかもしれないが大切なことであるからもう少し詳しく述べよう。 $\psi_{2}, \psi_{3}$ に $C_{3}$ を作用すると次のようになることは明らかであろう.

$$
\begin{aligned}
& C_{3} \psi_{2}=+0.4812 s_{1}-0.0008 s_{2}-0.4804 s_{3} \\
& C_{3} \psi_{3}=-0.2769 s_{1}+0.5552 s_{2}-0.2783 s_{3}
\end{aligned}
$$


この右辺を $\psi_{2}, \psi_{3}$ で表すと次のようになる.

$$
\begin{aligned}
& C_{3} \psi_{2}=-0.5000 \psi_{2}+0.8660 \psi_{3} \\
& C_{3} \psi_{3}=-0.8660 \psi_{2}-0.5000 \psi_{3}
\end{aligned}
$$

行列で表せば

$$
C_{3}\left[\psi_{2} \psi_{3}\right]=\left[\psi_{2} \psi_{3}\right]\left[\begin{array}{ll}
-0.5000 & -0.8660 \\
+0.8660 & -0.5000
\end{array}\right]
$$

すなわち, 行列

$$
\left[\begin{array}{ll}
-0.5000 & -0.8660 \\
+0.8660 & -0.5000
\end{array}\right]
$$

が $\psi_{2} ， \psi_{3}$ を basis とした場合の representation であり， character は-1となる。同様な

ことを $\mathrm{C}_{3 \mathrm{v}}$ の他の symmetry operation について行い， character table と比較してみれば $\psi_{2} ， \psi_{3}$ が既約表現 $E$ に属することが分かるであろう.

以上をまとめて， $\psi_{1}$ から $\psi_{7}$ までの既約表現をまとめると次のようになる.

$$
\begin{array}{ll}
\psi_{1} & : \mathrm{A}_{1} \\
\left(\psi_{2}, \psi_{3}\right): \mathrm{E} \\
\psi_{4}: \mathrm{A}_{1} \\
\psi_{5}: \mathrm{A}_{1} \\
\left(\psi_{6}, \psi_{7}\right): \mathrm{E}
\end{array}
$$

\section{خP Problem 17.8.1}

naphthalene（ $\mathrm{D}_{2} \mathrm{~h}$ 点群）の $\pi$ 分子軌道のうちいくつかを図に示した．ここで各分子 軌道を形成する $2 p \pi$ 原子軌道の大きさと符号を模式的に示している．黒丸は係数が 正，白丸は係数が負であることを示している． $2 p \pi$ 原子軌道は， naphthalene の分子の 上下で符号が変わることを考慮して，分子軌道 $\mathrm{A}, \mathrm{B}, \mathrm{C}, \mathrm{D}$ の既約表現を求めよ.

ただし，ここで軸は分子の長軸を $x$ 軸，短軸を $y$ 軸，分子面に垂直な軸を $z$ 軸とせ よ。（答えはそれぞれの図の下に記入する.） 

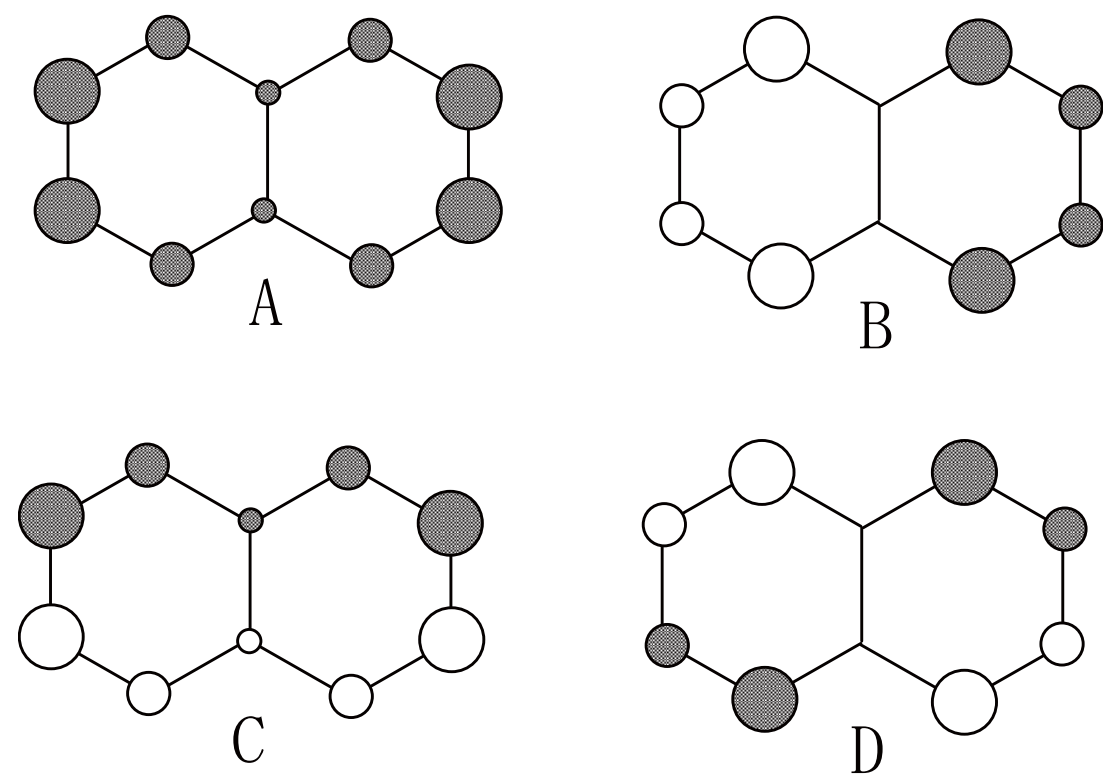

放Problem 17.8.2

$\mathrm{H}_{2} \mathrm{O}$ 分子 $\left(\mathrm{C}_{2} \mathrm{v}\right.$ 点群) の分子振動を模式的に表わしたのが下の図である. 原子の 運動の方向を矢印で示している，A，B，C，Dそれぞれについて既約表現を求めよ. ただし，分子平面を $y z$ 面，分子面に垂直な軸を $x$ 軸とすること.

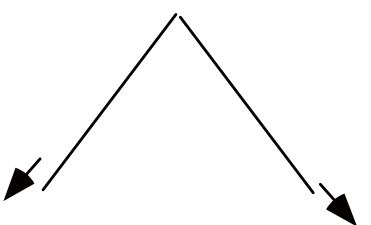

A

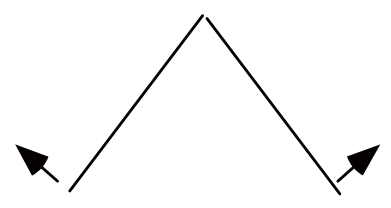

$\mathrm{B}$

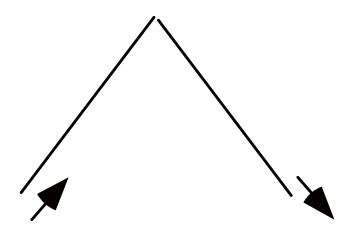

C

\section{岤Problem 17.8.3}

$\mathrm{H}_{2} \mathrm{O}_{2}$ 分子の分子軌道を CNDO 法によって求めた結果を次の表に示す. 軸はO-Oを結ぶ軸を $z$ 軸としている。

1）この分子の属する点群は何か

2） $\mathrm{MO}, \psi_{1}, \ldots \psi_{10}$ の既約表現を求めよ.

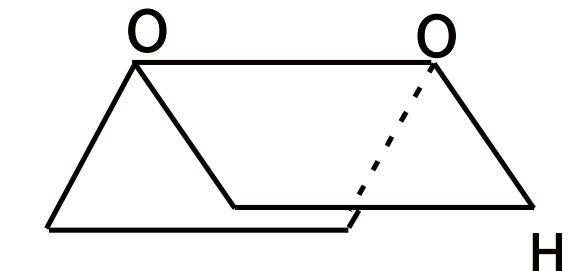

$\mathrm{H}$ 
EIGENVALUES AND EIGENVECTORS OF $\mathrm{H}_{2} \mathrm{O}_{2}$

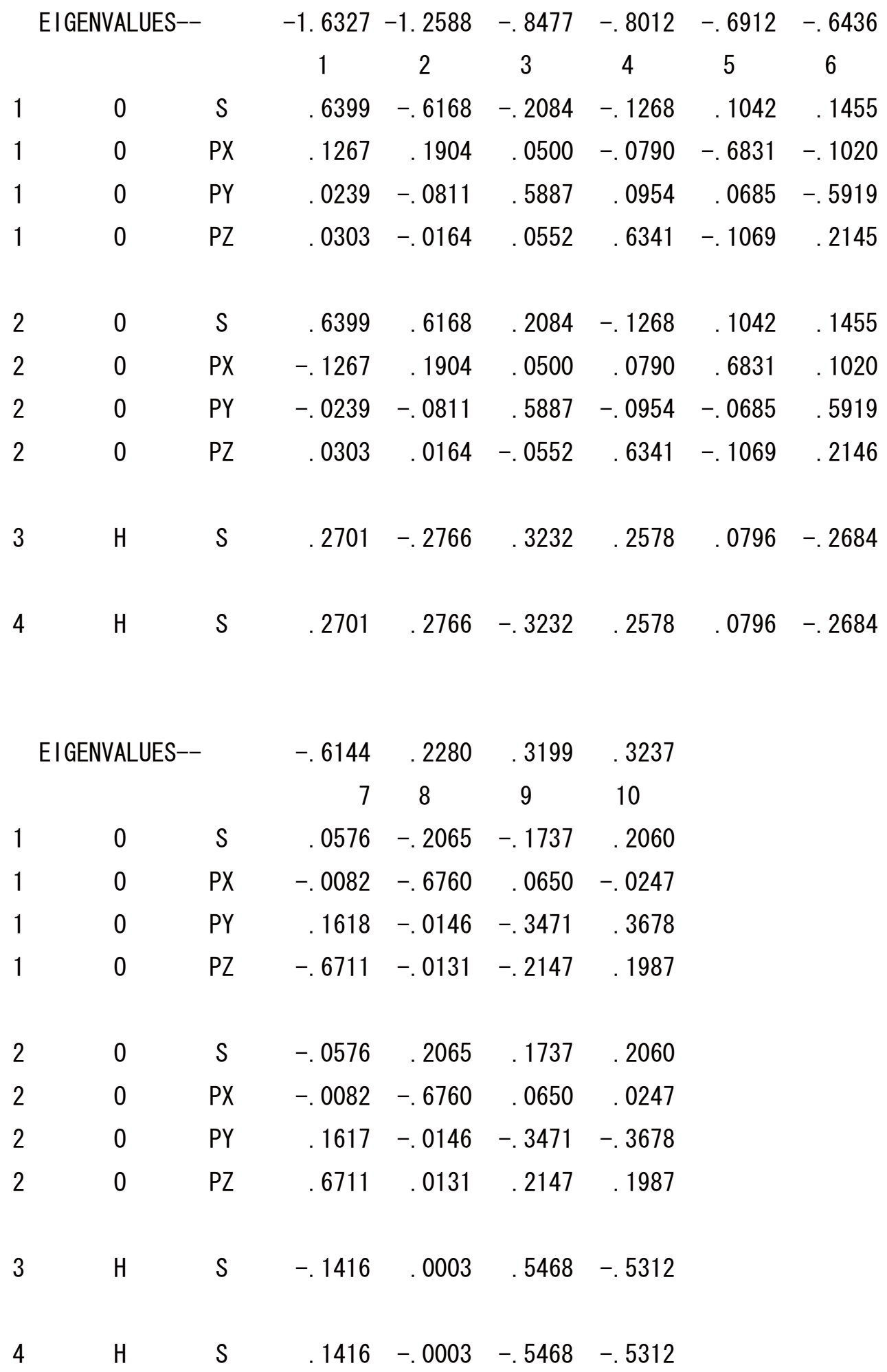


放Problem 17.8.4

ethylene 分子の分子軌道を CNDO 法によって求めた結果を次の表に示す．軸は

Mulliken recommendation に従い，分子面を $y z$ 面に，C-C 軸を $z$ 軸とする．原子の番号 は図のようにとる.

1）この分子の属する点群は何か.

2）各 $\mathrm{MO}, \psi_{1}, \ldots \psi_{12}$ の属する既約表現を求めよ.

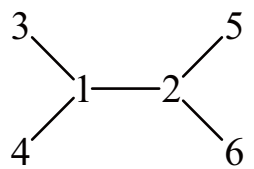

\section{EIGENVALUES AND EIGENVECTORS OF ETHYLENE}

\begin{tabular}{|c|c|c|c|c|c|c|c|c|}
\hline \multicolumn{3}{|c|}{ EIGENVALUES----------- } & \multicolumn{2}{|c|}{$-1.4347-1.0103$} & \multirow{2}{*}{$\begin{array}{c}-.9221 \\
3\end{array}$} & \multirow{2}{*}{$\begin{array}{c}-.7042 \\
4\end{array}$} & \multirow{2}{*}{$\begin{array}{c}-.5904 \\
5\end{array}$} & \multirow{2}{*}{$\begin{array}{c}-.5809 \\
6\end{array}$} \\
\hline & & & 1 & 2 & & & & \\
\hline 1 & $C$ & $S$ & .5962 & -.4133 & .0000 & .0004 & 0000 & 0000 \\
\hline 1 & $C$ & PX & .0000 & 0000 & .0000 & .0000 & -.7071 & 0000 \\
\hline 1 & $C$ & PY & .0000 & 0000 & -.5459 & .0000 & 0000 & -.4211 \\
\hline 1 & $C$ & $\mathrm{PZ}$ & 2012 & 3334 & 0000 & -.6003 & 0000 & 0000 \\
\hline 2 & $C$ & $S$ & 5962 & 4133 & .0000 & .0004 & 0000 & 0000 \\
\hline 2 & $C$ & PX & .0000 & 0000 & .0000 & .0000 & -.7071 & 0000 \\
\hline 2 & $C$ & PY & .0000 & 0000 & -.5459 & .0000 & 0000 & 4211 \\
\hline 2 & C & $\mathrm{PZ}$ & -. 2012 & 3334 & .0000 & .6003 & 0000 & 0000 \\
\hline 3 & $\mathrm{H}$ & $S$ & 2280 & -.3301 & -.3178 & .2643 & 0000 & -.4017 \\
\hline 4 & $\mathrm{H}$ & $S$ & 2280 & -.3301 & .3178 & .2643 & .0000 & 4017 \\
\hline 5 & $\mathrm{H}$ & $S$ & 2280 & 3301 & -.3178 & .2643 & .0000 & 4017 \\
\hline 6 & $\mathrm{H}$ & $S$ & 2280 & 3301 & 3178 & .2643 & 0000 & -.4017 \\
\hline
\end{tabular}




\begin{tabular}{|c|c|c|c|c|c|c|c|c|}
\hline \multicolumn{3}{|c|}{ EIGENVALUES---------- } & 1960 & .2763 & 2816 & 3115 & 4287 & 4942 \\
\hline & & & 7 & 8 & 9 & 10 & 11 & 12 \\
\hline 1 & C & $S$ & .0000 & .4763 & 0000 & 3801 & .0000 & -.3198 \\
\hline 1 & $\mathrm{C}$ & $P X$ & -.7071 & .0000 & .0000 & 0000 & .0000 & .0000 \\
\hline 1 & C & PY & .0000 & .0000 & -.4494 & 0000 & .5680 & .0000 \\
\hline 1 & C & $\mathrm{PZ}$ & .0000 & -.1214 & .0000 & -.3150 & .0000 & -.6116 \\
\hline 2 & C & $S$ & .0000 & -.4763 & .0000 & 3801 & .0000 & .3198 \\
\hline 2 & $\mathrm{C}$ & $P X$ & .7071 & .0000 & .0000 & .0000 & .0000 & .0000 \\
\hline 2 & C & PY & .0000 & .0000 & -.4494 & .0000 & -.5680 & .0000 \\
\hline 2 & C & $\mathrm{PZ}$ & .0000 & -.1214 & .0000 & .3150 & .0000 & -.6116 \\
\hline 3 & $\mathrm{H}$ & $S$ & .0000 & -.3595 & .3860 & -.3580 & -.2978 & -.1086 \\
\hline 4 & $\mathrm{H}$ & $S$ & .0000 & -.3595 & -.3860 & -.3580 & .2978 & -.1086 \\
\hline 5 & $\mathrm{H}$ & $S$ & .0000 & .3595 & 3860 & -.3580 & .2978 & .1086 \\
\hline 6 & $\mathrm{H}$ & $S$ & .0000 & .3595 & -.3860 & -.3580 & -.2978 & .1086 \\
\hline
\end{tabular}

$\mathrm{D}_{2 \mathrm{~h}}$ の character table を表 17.8.3 に示す. 
表 17.8.3 $\mathrm{D}_{2 \mathrm{~h}}$ の character table

\begin{tabular}{||c||c|c|c|c|c|c|c|c||}
\hline \hline $\mathrm{D}_{2 \mathrm{~h}}$ & $E$ & $\sigma(x y)$ & $\sigma(x z)$ & $\sigma(y z)$ & $i$ & $C_{2}(z)$ & $C_{2}(y)$ & $C_{2}(x)$ \\
\hline \hline$A_{g}$ & 1 & 1 & 1 & 1 & 1 & 1 & 1 & 1 \\
\hline$A_{u}$ & 1 & -1 & -1 & -1 & -1 & 1 & 1 & 1 \\
\hline$B_{1 g}$ & 1 & 1 & -1 & -1 & 1 & 1 & -1 & -1 \\
\hline$B_{1 u}$ & 1 & -1 & 1 & 1 & -1 & 1 & -1 & -1 \\
\hline$B_{2 g}$ & 1 & -1 & 1 & -1 & 1 & -1 & 1 & -1 \\
\hline$B_{2 u}$ & 1 & 1 & -1 & 1 & -1 & -1 & 1 & -1 \\
\hline$B_{3 g}$ & 1 & -1 & -1 & 1 & 1 & -1 & -1 & 1 \\
\hline$B_{3 u}$ & 1 & 1 & 1 & -1 & -1 & -1 & -1 & 1 \\
\hline \hline
\end{tabular}

\section{9 群論を分子に適用する場合の軸の選び方および二三の取り決め}

対称操作を軸でもって定義することが多いが，まず約束ごととして

主軸を $z$ 軸と選ぶ

ということがある。回転軸 $C_{n}$ が 1 つしかない時はそれが主軸である。回転軸 $C_{n}$ が 2 つ以上ある場合には $n$ のもつとも大きい軸が主軸である.

この取り決めだけでは決められない場合がある.同じ $n$ を持つ $C_{n}$ 軸が 2 つ上㙂 場合である，例えば naphthalene 分子については，分子平面の長軸，短軸，および分 
子平面に垂直な軸の 3 つの 2 回軸がある.どれも $n=2$ であるから, そのうちの $1 つ$ が主軸というわけにはいかず, $z$ 軸の選び方に 3 つの方法があることになってしまう. こういうあいまいさがあると，後の議論が面倒である。

又, ある場合には，主軸がはっきり決まったとしても他の軸の選び方にあいまいさ があって困ることもある。一例として, 図 17.9.1 で考えてみる. 図は $\mathrm{H}_{2} \mathrm{O}$ 分子の 2 つの水素原子の $1 s$ 軌道の符号を示している. 図の白い所と黒い所で wavefunction の符 号が反対になっていると考える.

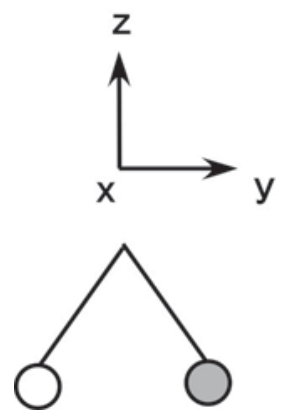

\begin{tabular}{|c|c|c|c|c|}
\hline$E$ & $C_{2}(z)$ & $\sigma(x z)$ & $\sigma(y z)$ & \\
\hline+1 & -1 & -1 & +1 & $B_{2}$ \\
\hline
\end{tabular}

(a)

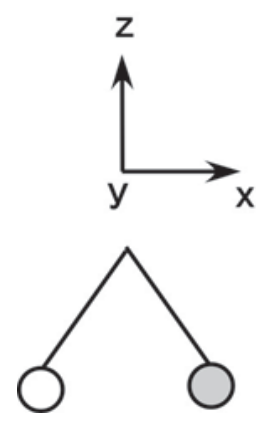

\begin{tabular}{|c|c|c|c|c|}
\hline$E$ & $C_{2}(z)$ & $\sigma(x z)$ & $\sigma(y z)$ & \\
\hline+1 & -1 & +1 & -1 & $B_{1}$ \\
\hline
\end{tabular}

(b)

図 17.9.1 $\mathrm{C}_{2 \mathrm{v}}$ における2つの軸の取り方

$C_{2}$ 軸は 1 つしかないから $z$ 軸はユニークに決まる. 残りの 2 つの軸のうちどちらを $x$

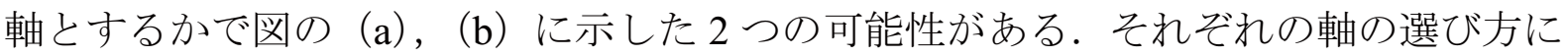
ついて, 図に示したような wavefunction が対称操作によって符号が変るか変らないか を図中に示してある. $\mathrm{C}_{2 \mathrm{~V}}$ の character table と比べてみると（a）の場合は既約表現 $B_{2}$ に，(b) の場合は $B_{1}$ に属寸ることが分かる．ある決められた wavefunction が，軸の選 び方によって $B_{1}$ になったり $B_{2}$ になったりするのである．このことは，始めに軸の選 
び方がきちんと定義さえしてあればことさら問題にはならない，現に，多少なりとも まぎらわしい可能性がある時は, 軸をきちんと定義することが, 研究論文の場合でも 習慣となっている，だからといって混乱がないわけではない．軸の選び方に差がある ために全く同じものを，ある人は $B_{1}$ といい，他の人は $B_{2}$ といったのでは，やはりや やこしい.

もう 1 つまぎらわしいことがある. それは主軸に垂直な 2 回軸が 2 種類ある時，そ れを $C_{2}{ }^{\prime}$ および $C_{2}{ }$ とするが, この 2 つの区別をどうやってつけるか, ということで ある、同じように $\sigma_{v}$ と $\sigma_{d}$ の区別もあいまいである.

こういうあいまいさを残さないように，軸の選び方や対称操作をきちんと決めて， 全ての人がその約束に従えば混乱はなからう。そういう気運が高まって Mulliken があ る案を提唱した。これはJ. Chem. Phys. 23, 1997 (1955) にまとめられており，一般に Mulliken recommendation として知られている. ところが何とも奇異なことに，この大 切な論文の中にも $\mathrm{D}_{4 \mathrm{~h}}$ について 1 つの間違いがあり, この間違いのために, ますます ややこしくなってしまっている. 以下，この間違いを訂正したうえ，代表的なものに ついての約束ごとをまとめておく.

(1) 軸の選び方について

1. $\mathrm{C}_{2 \mathrm{~V}}$ の平面分子では $x$ 軸を分子面に垂直にとる.
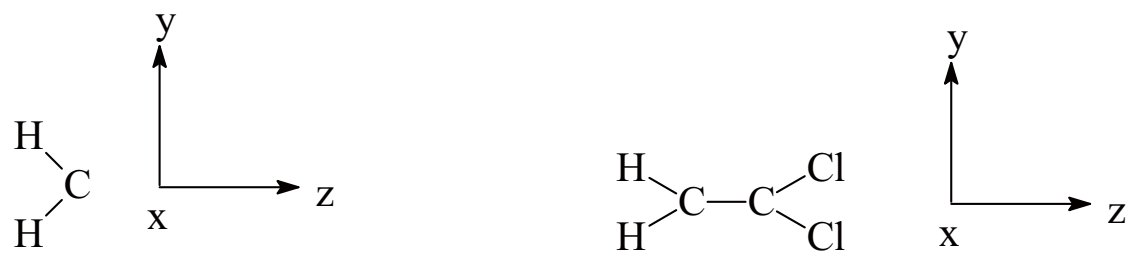

図 17.9.2 $\mathrm{C}_{2 \mathrm{v}}$ における軸の取り方

2. $\mathrm{D}_{2 \mathrm{~h}}$ の平面分子では， $x$ 軸は分子面に垂直に選ぶ. $z$ 軸はなるべく多くの原子を通 るように選ぶ。この原理では決められない場合にはなるべく多くの結合を切るように 
選ぶ.
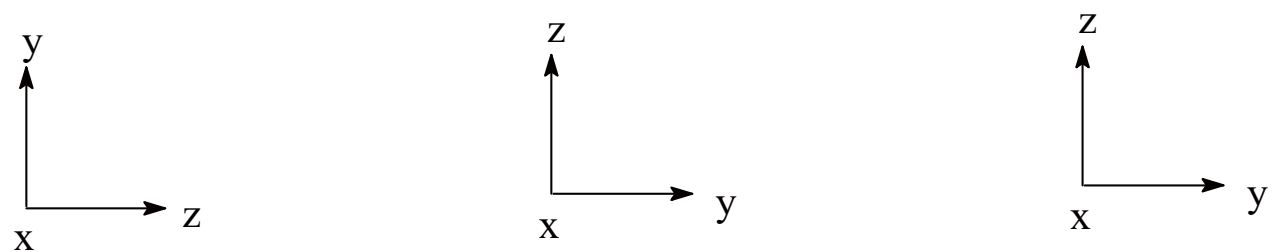

$\mathrm{H}_{\searrow}^{\mathrm{H}} \succ \mathrm{C}-\mathrm{C}_{\succ}^{-\mathrm{H}}$
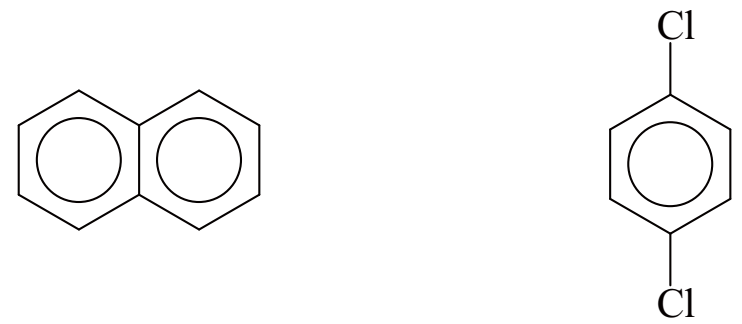

図 17.9.3 $\mathrm{D}_{2 \mathrm{~h}}$ における軸の取り方の例

(2) $\sigma_{v}$ と $\sigma_{d}$ の区別，および $C_{2}{ }^{\prime}$ と $C_{2}{ }^{\prime}$ の区別

1. $\mathrm{C}_{4 \mathrm{v}}, \mathrm{D}_{4 \mathrm{~h}}$

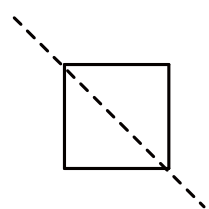

$\sigma_{v}, C_{2}{ }^{\prime}$

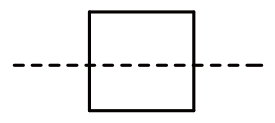

$\sigma_{d}, C_{2} "$

図 17.9.4 $\mathrm{D}_{4 \mathrm{~h}}$ および $\mathrm{C}_{4 \mathrm{v}}$ における軸の取り方の例 
2. $\mathrm{C}_{6 \mathrm{v}}, \mathrm{D}_{6 \mathrm{~h}}$
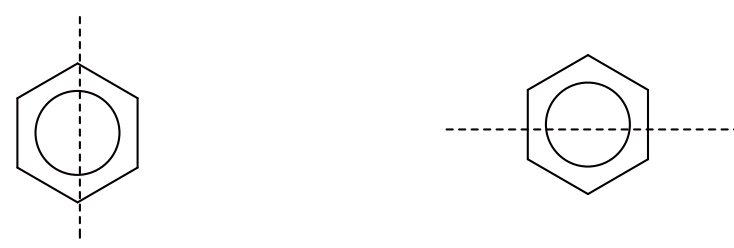

$\sigma_{v}, C_{2}{ }^{\prime}$

$\sigma_{d}, C_{2} "$

図 17.9.5 $\mathrm{D}_{6 \mathrm{~h}}$ および $\mathrm{C}_{6 \mathrm{v}}$ における対称操作の区別の例

\subsection{0 既約表現への簡約}

Section 17.6で，ある表現行列 $\mathbf{D}(G)$ を, similarity transformation によっていくつか の既約表現に簡約することを学習した。すなおち

$$
\mathbf{D}^{\prime}(G) \stackrel{\text { similarity transformation }}{\longrightarrow}\left[\begin{array}{ccc}
\mathbf{D}^{(1)} & 0 & 0 \\
0 & \mathbf{D}^{(2)} & 0 \\
0 & 0 & \mathbf{D}^{(3)}
\end{array}\right]
$$

ここでは， $\mathbf{D}(G)$ そのものでなく，その character が与えられた時，どのような既約表 現に簡約されるかを求める方法を述べる. 今まで繰り返し述べて来たように，多くの 場合，表現行列すべてを扱うことは不必要でその character だけで事がすむので，この 方法は大切である。

さて，式(17.10.1)のような reduction が出来たとする. character は similarity transformation によって不変であるから, 式(17.10.1)両辺それぞれの character について

$$
\chi(G)=\sum_{\ell} a_{\ell} \chi^{(\ell)}(G)
$$

と表される，係数 $a_{\ell}$ は，既約表現 $\mathbf{D}^{(\ell)}$ がいくつあるかを示している．この $a_{\ell}$ が，すべ

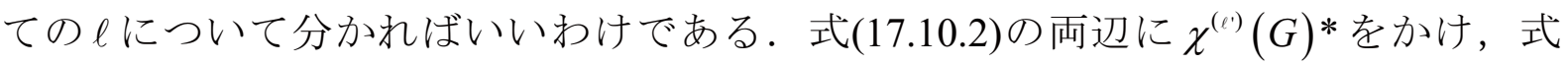
(17.7.2)を用いると 


$$
\begin{aligned}
\sum_{G} \chi^{(())}(G) * \chi(G) & =\sum_{G} \sum_{\ell} a_{\ell} \chi^{(())}(G)^{*} \chi^{(\ell)}(G) \\
& =\sum_{\ell} a_{\ell} h \delta_{\ell \ell^{\prime}} \\
& =h a_{\ell}
\end{aligned}
$$

となる. 寸なわち, 求むべき係数 $a_{\ell}$ は

$$
a_{\ell}=\frac{1}{h} \sum_{G} \chi^{(\ell)}(G) * \chi(G)
$$

で与えられる. 又, 1 つの class に属する既約表現は同じ character を持つので,

$$
a_{\ell}=\frac{1}{h} \sum_{c} g(c) \chi^{(\theta)}(c) * \chi(c)
$$

と書くことも出来る.

例として式(17.6.2)にあげた $\mathrm{C}_{3 \mathrm{v}}$ の可約表現がどのような既約表現に簡約されるか

\begin{tabular}{|c|c|c|c|c|}
\hline $\mathrm{C}_{3 \mathrm{v}}$ & $E$ & $2 C_{3}$ & $3 \sigma_{v}$ & \\
\hline$A_{1}$ & 1 & 1 & 1 & \\
\hline$A_{2}$ & 1 & 1 & -1 & \\
\hline$E$ & 2 & -1 & 0 & \\
\hline$\chi$ & 3 & 0 & 1 & $A_{1}+E$ \\
\hline
\end{tabular}
を求めてみよう。こういう場合, 面倒のようでも，まず character tableを書いて，そ の最下段に可約表現の character を書いて考えるのが間違いの少ない方法である.すな わち，次のように行う。

表 17.10 .1

この場合, character table を見れば， $\chi$ は $A_{1}$ と $E$ との和であることが直ちに分かるであ ろう。こういう場合には，式(17.10.4)又は式(17.10.5)の公式を使う必要はない．しか

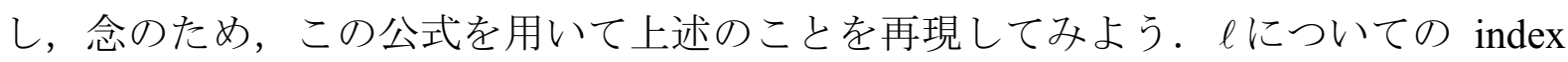
は $\mathrm{C}_{3 \mathrm{v}}$ の場合 $A_{1}, A_{2}$ および $E$ である. $h=6$ であるから 


$$
\begin{aligned}
& a\left(A_{1}\right)=\frac{1}{6}(1 \times 1 \times 3+2 \times 1 \times 0+3 \times 1 \times 1)=1 \\
& a\left(A_{2}\right)=\frac{1}{6}\{1 \times 1 \times 3+2 \times 1 \times 0+3 \times(-1) \times 1\}=0 \\
& a(E)=\frac{1}{6}\{1 \times 2 \times 3+2 \times(-1) \times 0+3 \times 0 \times 1\}=1
\end{aligned}
$$

のようになる．得られた係数は上の表の 1 番下の右端のセルのように，1つのセルを 作って書いておくのが分かり易い.

もう 1 つ, $\mathrm{T}_{\mathrm{d}}$ 点群の例を示そう. $\mathrm{CH}_{4}$ 分子の 4 つの $\mathrm{H}$ の $1 s$ orbital のセットが, どのような既約表現になるかを調べてみよう。H の $1 s$ orbital は球対称であるから， symmetry operation によって位置が変らなければ, character のの寄与は 1 となる.すな わち, symmetry operation によって位置を変えない $\mathrm{H}$ 原子の数が $\chi(G)$ となる.上の例 と同じように，まず $\mathrm{T}_{\mathrm{d}}$ の character table を書いて，その最下段に $\chi(G)$ を書くのがよ い.

表 17.10.2

\begin{tabular}{||c||c|c|c|c|c||}
\hline \hline $\mathrm{T}_{\mathrm{d}}$ & $E$ & $8 C_{3}$ & $3 C_{2}$ & $6 S_{4}$ & $6 \sigma_{d}$ \\
\hline \hline$A_{1}$ & 1 & 1 & 1 & 1 & 1 \\
\hline$A_{2}$ & 1 & 1 & 1 & -1 & -1 \\
\hline$E$ & 2 & -1 & 2 & 0 & 0 \\
\hline$T_{1}$ & 3 & 0 & -1 & 1 & -1 \\
\hline$T_{2}$ & 3 & 0 & -1 & -1 & 1 \\
\hline \hline$\chi(G)$ & 4 & 1 & 0 & 0 & 2 \\
$A_{1}+T_{2}$ \\
\hline
\end{tabular}

表の一番下段の右側のセルの結果は次のようにして計算したものである. 


$$
\begin{aligned}
& a\left(A_{1}\right)=\frac{1}{24}(1 \times 1 \times 4+8 \times 1 \times 1+3 \times 1 \times 0+6 \times 1 \times 0+6 \times 1 \times 2)=1 \\
& a\left(A_{2}\right)=\frac{1}{24}\{1 \times 1 \times 4+8 \times 1 \times 1+3 \times 1 \times 0+6 \times(-1) \times 0+6 \times(-1) \times 2\}=0 \\
& a(E)=\frac{1}{24}\{1 \times 2 \times 4+8 \times(-1) \times 1+3 \times 2 \times 0+6 \times 0 \times 0+6 \times 0 \times 2\}=0 \\
& a\left(T_{1}\right)=\frac{1}{24}\{1 \times 3 \times 4+8 \times 0 \times 1+3 \times(-1) \times 0+6 \times 1 \times 0+6 \times(-1) \times 2\}=0 \\
& a\left(T_{2}\right)=\frac{1}{24}\{1 \times 3 \times 4+8 \times 0 \times 1+3 \times(-1) \times 0+6 \times(-1) \times 0+6 \times 1 \times 2\}=1
\end{aligned}
$$

かくして，与えられた表現は， $A_{1}$ と $T_{2}$ とに簡約されることが分かる.

\section{【注意】：}

Eyring et al., “Quantum Chemistry” p. 388 にある $\mathrm{T}_{\mathrm{d}}$ の character table は， $T_{1}, T_{2}$ の表現 の $S_{4}$ およ゙ $\sigma_{d}$ についての character が間違っている.上記の表が正しい.

放Exercise 17.10.1

原点に存在する $x, y, z \quad 3$ つの vector function を basis としたとき, proper rotation $C_{n}$ に対する representation および character を求めよ。

\section{【解】:}

$C_{n}$ というのは $\frac{2 \pi}{n}$ の回転のことである. 回転軸として $z$ 軸を考えると $C_{n}$ の結 果は次の式で表される.

$$
C_{n}\left[\begin{array}{lll}
x & y & z
\end{array}\right]=\left[\begin{array}{lll}
x & y & z
\end{array}\right]\left[\begin{array}{ccc}
\cos \frac{2 \pi}{n} & -\sin \frac{2 \pi}{n} & 0 \\
\sin \frac{2 \pi}{n} & \cos \frac{2 \pi}{n} & 0 \\
0 & 0 & 1
\end{array}\right]
$$

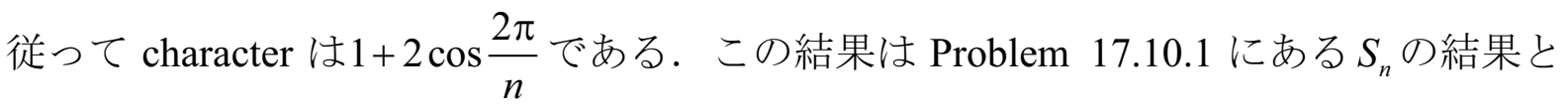
合わせて記憶しておくとなにかと便利である。（表 17.5.1 ですでに学習したもの）

诂Problem 17.10.1 
原点に存在する $x, y, z \quad 3$ つの vector function を basis としたとき, improper rotation $S_{n}$ に対する representation および character を求めよ。

¿ 2 Problem 17.10.2

$\mathrm{C}_{2 \mathrm{v}}$ 点群のもとで， $x, y, z$ vector はいかなる既約表現に属するか.

خ Problem 17.10.3

$\mathrm{C}_{3 \mathrm{v}}$ 点群のもとで, $x, y, z$ vector はいかなる既約表現に属するか.

放Problem 17.10.4

$\mathrm{D}_{2 \mathrm{~h}}$ 点群のもとで， $x, y, z$ vector はいかなる既約表現に属するか.

¿ 2 Problem 17.10.5

$\mathrm{T}_{\mathrm{d}}$ 点群のもとで, $x, y, z$ vector はいかなる既約表現に属するか.

¿ Problem 17.10.6

benzene の 6 つの $\mathrm{H}$ の $1 s$ 軌道を basis set とした場合の表現はどのような既約表現に 簡約されるか.

\subsection{1 既約表現の基底となるような関数の作り方}

前節で引用した例で， $\mathrm{CH}_{4}$ の 4 つの $\mathrm{H}$ の $1 s$ 軌道は $A_{1}$ および $T_{2}$ 表現に属することが 分かった。しからば， $A_{1}$ となるような wavefunction はこの 4 つの $\mathrm{H}$ の $1 s$ 軌道のどの ような線形結合で表されるのであろうか. 同様に， $T_{2}$ となるような wavefunction の組 はどのように表されるであろうか。以下，ある既約表現の基底となるような wavefunction をどのようにして作るかその方法を考えてみる.

ここでは, 式の導出を省略して結果のみを述べるとにする.ある wavefunction (例 えば，ある atom に局在している atomic orbital と考えればよい）を $\phi_{i}$ とすと

$$
\psi^{(\ell)}=\sum_{G} \chi^{(\ell)}(G) * G \phi_{i}
$$

で表される linear combination は $\ell$ 番目の既約表現の基底となっている．群論では規格 化因子は考えていないから，それは別に定めればよい.

具体例として $\mathrm{NH}_{3}$ について 3 つの $\mathrm{H}$ の $1 s$ 軌道 $s_{1}, s_{2}, s_{3}$ を考えよう。このうちの 1 
つ，例えば $s_{1}$ を式(17.11.1)の $\phi_{i}$ に選ぶ. $\mathrm{C}_{3 \mathrm{~V}}$ の 6 つの symmetry operation のすべての $G$ について $G s_{1}$ を行う。前節で我々は $\mathrm{H} の 1 s$ orbital からは $A_{1}$ 及び $E$ 表現が得られるこ

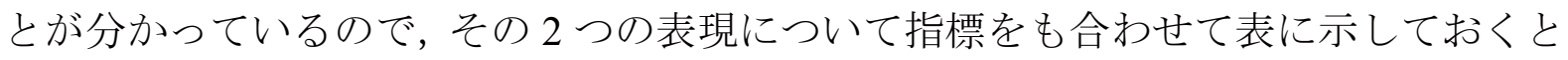
便利である。

\begin{tabular}{|c|c|c|c|c|c|c|}
\hline & $E$ & $C_{3}$ & $C_{3}{ }^{2}$ & $\sigma_{\mathrm{v}}$ & $\sigma_{\mathrm{v}}{ }^{\prime}$ & $\sigma_{\mathrm{v}}{ }^{\prime}$ \\
\hline$\chi\left(A_{1}\right)$ & 1 & 1 & 1 & 1 & 1 & 1 \\
\hline$\chi(E)$ & 2 & -1 & -1 & 0 & 0 & 0 \\
\hline$G s_{1}$ & $s_{1}$ & $s_{2}$ & $s_{3}$ & $s_{1}$ & $s_{3}$ & $s_{2}$ \\
\hline$G s_{2}$ & $s_{2}$ & $s_{1}$ & $s_{3}$ & $s_{3}$ & $s_{1}$ & $s_{2}$ \\
\hline
\end{tabular}

この結果より $A_{1}$ に属する wavefunction は，上の表の $\chi\left(A_{1}\right)$ と $G s_{1}$ の各項をかけて $G に$ ついて足し合わせればよい。すなわち，

$$
s_{1}+s_{2}+s_{3}+s_{1}+s_{3}+s_{2}=2\left(s_{1}+s_{2}+s_{3}\right)
$$

従って, normalization factor を除いて

$$
\psi\left(A_{1}\right)=s_{1}+s_{2}+s_{3}
$$

と求まる.

$\phi_{i}$ として $s_{1}$ の代りに $s_{2}$ を選んでみる. 上表の最下段に示すようになるので,

$$
\psi\left(A_{1}\right)=s_{1}+s_{2}+s_{3}
$$

と， $s_{1}$ の場合と同じ結果が得られる. 同様にして, 既約表現 $E$ の基底となるような wavefunction は， $\phi_{i}$ として $s_{1}$ を選んだ場合には

$$
\psi(E)=2 s_{1}-s_{2}-s_{3}
$$

もしも $\phi_{i}$ として $s_{2}$ を選ぶと 


$$
\psi(E)=2 s_{2}-s_{1}-s_{3}
$$

のようになる。 $A_{1}$ の場合と異なり，今回は異なった wavefunction が得られたが，この 2 つが縮退表現 $E$ の基底となるわけである．もしも， $\phi_{i}$ として $s_{3}$ を選ぶと

$$
\psi(E)=2 s_{3}-s_{1}-s_{2}
$$

となる。このように， $S_{1}, S_{2}, S_{2}$ のどれを $\phi_{i}$ として選ぶかによって一見異なった結果が 得られるが，この中の任意の 2 つをとればよい. 残りはこの 2 つの線形結合で表され る。とにかく，結果をまとめると，

$$
\begin{aligned}
& \psi\left(A_{1}\right)=N\left(s_{1}+s_{2}+s_{3}\right) \\
& \psi(E)_{(1)}=N\left(2 s_{1}-s_{2}-s_{3}\right) \\
& \psi(E)_{(2)}=N\left(s_{1}-2 s_{2}+s_{3}\right)
\end{aligned}
$$

ただし，N はそれぞれについて異なる normalization factor である.

\section{【註】：}

normalization factor を求めることは群論の問題ではない. しかし，念のため以 下にその求め方を述べておく。上で求めたように

$$
\psi\left(A_{1}\right)=N\left(s_{1}+s_{2}+s_{3}\right)
$$

であるが， normalization condition は

$$
\int \psi\left(A_{1}\right) * \psi\left(A_{1}\right) d \tau=1
$$

従って

$$
\frac{1}{N^{2}}=3+2\left\{\left\langle\mathrm{~s}_{1} \mid \mathrm{s}_{2}\right\rangle+\left\langle\mathrm{s}_{1} \mid \mathrm{s}_{3}\right\rangle+\left\langle\mathrm{s}_{3} \mid \mathrm{s}_{2}\right\rangle\right\}
$$

ここで，例えば， overlap integral を

$$
\left\langle s_{1} \mid s_{2}\right\rangle=\int s_{1} s_{2} d \tau=S
$$

のように $S$ とおくと

$$
\frac{1}{N^{2}}=3(1+2 S)
$$

となる。従って 


$$
N=\frac{1}{\sqrt{3(1+2 S)}}
$$

$S$ は，ある距離だけ離れた $2 つ の 1 s$ 軌道の重なりであるから，当然ある值を持つ。し かし，いわゆる Hückel 分子軌道では，しばしばこの $S$ をゼロと近似している。同様

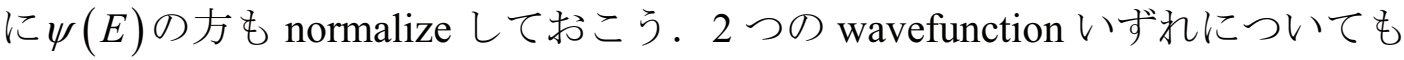
normalization factor は共通で

$$
\frac{1}{N^{2}}=6-6 S=6(1-S)
$$

従って

$$
N=\frac{1}{\sqrt{6(1-S)}}
$$

結局，結果をまとめると，

$$
\begin{gathered}
\psi\left(A_{1}\right)=\frac{1}{\sqrt{3(1+2 S)}}\left(s_{1}+s_{2}+s_{3}\right) \\
\psi(E)_{(1)}=\frac{1}{\sqrt{6(1-S)}}\left(2 s_{1}-s_{2}-s_{3}\right) \\
\psi(E)_{(2)}=\frac{1}{\sqrt{6(1-S)}}\left(s_{1}-2 s_{2}+s_{3}\right)
\end{gathered}
$$

この結果でいっこう差し支えないが, 縮退している wavefunction の取り方は無限通 りの可能性があるということは今まで再三指摘して来たが，お互いに直交するように 選んでおくと何かと都合がよい。二重縮退の場合，お互いに直交させるのは簡単で， normalize された wavefunction 同志の和および差を求めればよい（Problem 17.11.1）. ということで，規格化は改めて行い,

$$
\begin{aligned}
& \psi(E)_{(1)}=\frac{1}{\sqrt{2(1-S)}}\left(s_{1}-s_{2}\right) \\
& \psi(E)_{(2)}=\frac{1}{\sqrt{6(1-S)}}\left(s_{1}+s_{2}-2 s_{3}\right)
\end{aligned}
$$

というふうにしておく，繰り返しになるが，念のため述べると，縮退している wavefunctionの組についてはそのあらゆる linear combination を取り得るわけで, 式 (17.11.9)の $\psi(E)$ でも式(17.11.10)の $\psi(E)$ でも，どちらでもいいのである.ただし，す 
ベての wavefunction が直交するように選んでおくと後の計算が何かと便利である，と いうだけのことである.

もう 1 つの例として, cyclopropenyl の $\pi$ 分子軌道（ $\pi \mathrm{MO} ）$ を求めることを試みて みよう。

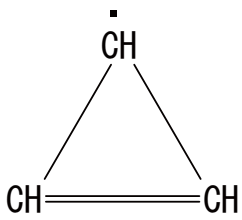

$\pi \mathrm{MO}$ は 3 つの $\mathrm{C}$ 原子上の $2 p_{z}$ atomic orbital の linear combination として表される. $\pi$ 電子が非局在化していることを考慮するとこの分子は $\mathrm{D}_{3 \mathrm{~h}}$ 点群に属する．まず，3つ の $2 p_{z}$ atomic orbital を $\phi_{1}, \phi_{2}, \phi_{3}$ とし, この3つの basis setからどのような既約表現が 得られるか前の Section で学習した方法で求めてみよう.

\begin{tabular}{||c||c|c|c|c|c|c||}
\hline \hline $\mathrm{D}_{3 \mathrm{~h}}$ & $E$ & $2 C_{3}$ & $3 C_{2}{ }^{\prime}$ & $\sigma_{h}$ & $2 S_{3}$ & $3 \sigma_{v}$ \\
\hline \hline$A_{1}{ }^{\prime}$ & 1 & 1 & 1 & 1 & 1 & 1 \\
\hline$A_{2}{ }^{\prime}$ & 1 & 1 & -1 & 1 & 1 & -1 \\
\hline$E^{\prime}$ & 2 & -1 & 0 & 2 & -1 & 0 \\
\hline$A_{1}{ }^{\prime \prime}$ & 1 & 1 & 1 & -1 & -1 & -1 \\
\hline$A_{2}{ }^{\prime \prime}$ & 1 & 1 & -1 & -1 & -1 & 1 \\
\hline$E^{\prime \prime}$ & 2 & -1 & 0 & -2 & 1 & 0 \\
\hline \hline & 3 & 0 & -1 & -3 & 0 & 1 \\
\hline
\end{tabular}

この結果により，既約表現 $A_{2}$ "と $E "$ がそれぞれ 1 つずつ得られることが分かる.そこ で次にこれら既約表現の basis となるような wavefunction を求めてみる. 


\begin{tabular}{|c|c|c|c|c|c|c|}
\hline & $E$ & $\sigma_{\mathrm{h}}$ & \multicolumn{2}{|c|}{$C_{3}$} & \multicolumn{2}{|c|}{$S_{3}$} \\
\hline & & & $\wedge$ & & $\widehat{\wedge}$ & $\widehat{\triangle}$ \\
\hline$\chi\left(A_{2}^{\prime \prime}\right)$ & 1 & -1 & \multicolumn{2}{|c|}{1} & \multicolumn{2}{|c|}{-1} \\
\hline$\chi\left(E^{\prime \prime}\right)$ & 2 & -2 & \multicolumn{2}{|c|}{-1} & \multicolumn{2}{|c|}{1} \\
\hline$G \phi_{1}$ & $\phi_{1}$ & $-\phi_{1}$ & $\phi_{2}$ & $\phi_{3}$ & $-\phi_{2}$ & $-\phi_{3}$ \\
\hline$G \phi_{2}$ & $\phi_{2}$ & $-\phi_{2}$ & $\phi_{3}$ & $\phi_{1}$ & $-\phi_{3}$ & $-\phi_{1}$ \\
\hline
\end{tabular}

\begin{tabular}{|c|c|c|c|c|c|c|}
\hline & \multicolumn{3}{|c|}{$C_{2}{ }^{\prime}$} & \multicolumn{3}{|c|}{$\sigma_{v}$} \\
\hline & 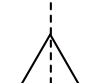 & $A$ & 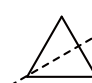 & & $\ldots$ & \\
\hline$\chi\left(A_{2} "\right)$ & \multicolumn{3}{|c|}{-1} & \multicolumn{3}{|c|}{1} \\
\hline$\chi\left(E^{\prime \prime}\right)$ & \multicolumn{3}{|c|}{0} & \multicolumn{3}{|c|}{0} \\
\hline$G \phi_{1}$ & $-\phi_{1}$ & $-\phi_{2}$ & $-\phi_{3}$ & $\phi_{1}$ & $\phi_{2}$ & $\phi_{3}$ \\
\hline$G \phi_{2}$ & $-\phi_{3}$ & $-\phi_{1}$ & $-\phi_{2}$ & $\phi_{3}$ & $\phi_{1}$ & $\phi_{2}$ \\
\hline
\end{tabular}

かくして, normalization factor 無視すると

$$
\begin{aligned}
& \psi\left(A_{2} "\right)=\phi_{1}+\phi_{2}+\phi_{3} \\
& \psi\left(E^{\prime \prime}\right)_{(1)}=2 \phi_{1}-\phi_{2}-\phi_{3} \\
& \psi\left(E^{\prime \prime}\right)_{(2)}=\phi_{1}-2 \phi_{2}+\phi_{3}
\end{aligned}
$$

という結果が得られる。

放Problem 17.11.1

$\psi_{1}$ と $\psi_{2}$ がいずれも normalize されているが，お互いに直交していない時に， 
$\frac{1}{\sqrt{2(1+S)}}\left(\psi_{1}+\psi_{2}\right)$ と $\frac{1}{\sqrt{2(1-S)}}\left(\psi_{1}-\psi_{2}\right)$ はお互いに orthonormal であることを証明せ よ.

خ 2 Problem 17.11.2

(1)： cyclobutadiene の $\pi$ molecular orbital (MO) を各炭素上の $2 p_{z}$ atomic orbital (AO) （ $z$ 軸は分子面に垂直な軸とする）を basis set として，それらの linear combination として表すことにする.

(1-a) $\pi$ MO の属する既約表現を求めよ.

(1-b) 群論を用いて, 各 $\pi \mathrm{MO}$ の具体的な関数形を表せ. 以下, notation を簡約化して, 炭素 $r(r=1,2,3,4)$ の $2 p_{z} \mathrm{AO}$ を $z_{r}$ と示すことにする. (すなわち, $i$ 番 目の MOを $c_{i 1} z_{1}+c_{i 2} z_{2}+c_{i 3} z_{3}+c_{i 4} z_{4}$ と表す.) この問 題は， $c_{i r}$ を $i, r$ のすべてについて求めることであ

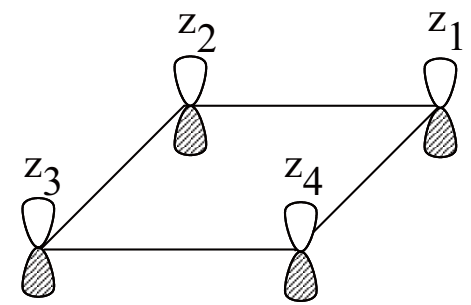
る。

(1-c) すべての MO をお互いに orthonormal になるようにすることななお， cyclobutadiene の炭素骨格は，正方形であると仮定せよ。

(2)：(1)と同様なことを $\sigma \mathrm{MO}$ について試みよ。ここでは $\sigma \mathrm{MO}$ を各炭素上の $2 p_{x}$ および $2 p_{y}$ AO の linear combination として表すことにする. 前問と同様に, $r$ 番目の炭素の $2 p_{x} \mathrm{AO}$ を $x_{r}, 2 p_{y} \mathrm{AO}$ を $y_{r}$ と示すことにする. 

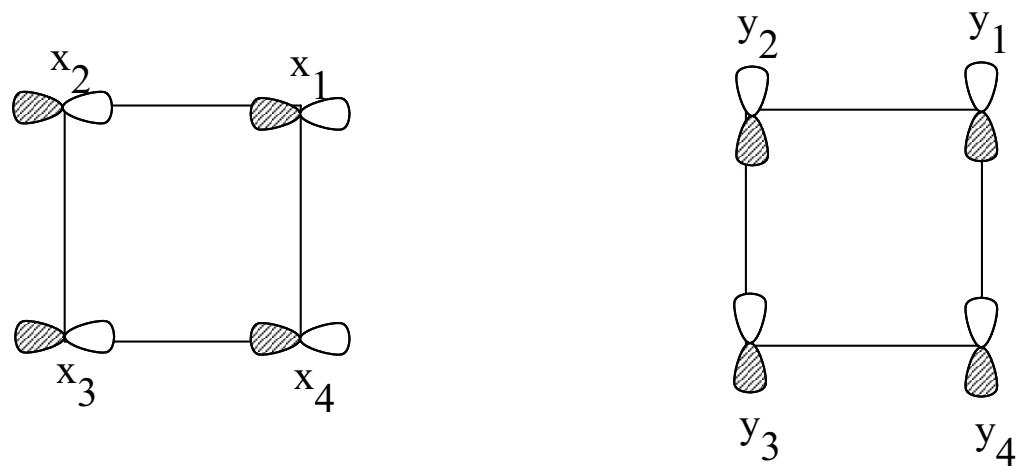

（2-a） MO の属する既約表現を求めよ.

(2-b) 各 MO の具体的な形を求めよ.

(2-c) すべての MO をお互いに orthonormalになるようにすること.

なお $\mathrm{D}_{4 \mathrm{~h}}$ の character table を次に示す. 
表 17.11.1 $\quad \mathrm{D}_{4 \mathrm{~h}}$ の character table

\begin{tabular}{|c|c|c|c|c|c|c|c|c|c|c|c|}
\hline $\mathrm{D}_{4 \mathrm{~h}}$ & $E$ & $2 C_{4}$ & $C_{2}$ & $2 C_{2}{ }^{\prime}$ & $2 C_{2} "$ & $i$ & $2 S_{4}$ & $\sigma_{h}$ & $2 \sigma_{v}$ & $2 \sigma_{d}$ & \\
\hline$A_{1 g}$ & 1 & 1 & 1 & 1 & 1 & 1 & 1 & 1 & 1 & 1 & $x^{2}+y^{2}, z^{2}$ \\
\hline$A_{2 g}$ & 1 & 1 & 1 & -1 & -1 & 1 & 1 & 1 & -1 & -1 & $R_{z}$ \\
\hline$B_{1 g}$ & 1 & -1 & 1 & 1 & -1 & 1 & -1 & 1 & 1 & -1 & $x^{2}-y^{2}$ \\
\hline$B_{2 g}$ & 1 & -1 & 1 & -1 & 1 & 1 & -1 & 1 & -1 & 1 & $x y$ \\
\hline$E_{g}$ & 2 & 0 & -2 & 0 & 0 & 2 & 0 & -2 & 0 & 0 & $\begin{array}{l}\left(R_{x}, R_{y}\right) \\
(x z, y z)\end{array}$ \\
\hline$A_{1 u}$ & 1 & 1 & 1 & 1 & 1 & -1 & -1 & -1 & -1 & -1 & \\
\hline$A_{2 u}$ & 1 & 1 & 1 & -1 & -1 & -1 & -1 & -1 & 1 & 1 & $z$ \\
\hline$B_{1 u}$ & 1 & -1 & 1 & 1 & -1 & -1 & 1 & -1 & -1 & 1 & \\
\hline$B_{2 u}$ & 1 & -1 & 1 & -1 & 1 & -1 & 1 & -1 & 1 & -1 & \\
\hline$E_{u}$ & 2 & 0 & -2 & 0 & 0 & -2 & 0 & 2 & 0 & 0 & $(x, y)$ \\
\hline
\end{tabular}

放Problem 17.11.3

式(17.11.11)を orthonormal になるようにせよ. 


\subsection{2 直積 (direct product)}

仮りに， $f_{1}^{(\ell)} ， f_{2}^{(\ell)} ， \ldots, f_{m}^{(\ell)}$ という $m$ 個の function が，ある既約表現 $\Gamma_{\ell}$ の basis であるとする。同様に $f_{1}^{\left(\ell^{\prime}\right)}, f_{2}^{\left(\ell^{\prime}\right)}, \ldots, f_{n}^{\left(\ell^{\prime}\right)}$ という $n$ 個の function が，既約表現 $\Gamma_{\ell^{\prime}}$ の basis であるとする.すなわち

$$
\begin{aligned}
& G f_{i}^{(\ell)}=\sum f_{j}^{(\ell)} D_{j i}{ }^{(\ell)}(G) \\
& G f_{i^{\prime}}^{\left(\ell^{\prime}\right)}=\sum{f_{j}}^{\left(\ell^{\prime}\right)} D_{j^{\prime} i^{\prime}}{ }^{\left({ }^{\prime}\right)}(G)
\end{aligned}
$$

これら 2 つの basis set の $m n$ 個の積,

$$
f_{1}^{(\ell)} f_{1}^{\left(\ell^{\prime}\right)}, \ldots, f_{m}^{(\ell)} f_{n}^{\left(\ell^{\prime}\right)}
$$

は次のように transform される.

$$
G f_{i}^{(\ell)} f_{i^{\prime}}^{\left(\ell^{\prime}\right)}=\sum_{j} \sum_{j^{\prime}} f_{j}^{(\ell)} f_{j^{\prime}}^{\left(\ell^{\prime}\right)} D_{j i}{ }^{(\ell)}(G) D_{j^{\prime} i^{\prime}}{ }^{\left({ }^{\prime}\right)}(G)
$$

すなわち， $m n$ 個の積はある表現の basis となっていることが分かる.

この表現を直積表現（direct product representation）という。ではこの直積表現は可 約であろうか，既約であろうか?もし可約であるとするとどういうふうに簡約される であろうか?

$m n$ 個の basis についての表現行列の要素は, $D_{j i}{ }^{\left({ }^{\ell}\right)}(G) D_{j^{\prime} i^{\prime}}{ }^{\left({ }^{\prime}\right)}(G)$ であるが, ここで $j j^{\prime}$

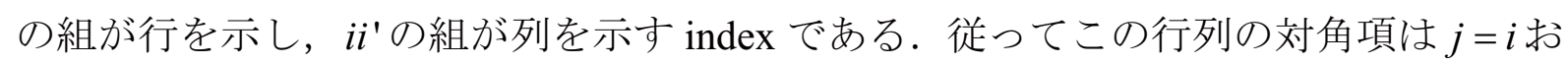
よび $j^{\prime}=i^{\prime}$ とおいたものである。その character は

$$
\begin{aligned}
\chi(G) & =\sum_{i} \sum_{i^{\prime}} D_{i i}{ }^{(\ell)}(G) D_{i^{\prime} i^{\prime}}{ }^{\left(\ell^{\prime}\right)}(G) \\
& =\left\{\sum_{i} D_{i i}^{(\ell)}(G)\right\}\left\{\sum_{i^{\prime}} D_{i^{\prime} i^{\prime}}{ }^{\left({ }^{\prime}\right)}(G)\right\} \\
& =\chi^{(\ell)}(G) \chi^{\left(\ell^{\prime}\right)}(G)
\end{aligned}
$$

このように非常に簡単な結果が得られた。 すなわち, 積の basisについての character は，もとの basis の character の積である。

再び $\mathrm{C}_{3 \mathrm{v}}$ 群の場合を例として考えよう. Section 17.5 で示したように, $\{x, y\}$ という basis set は既約表現 $E$ に属する. 従って $\{x, y\}$ と $\{x, y\}$ の積を basis set とした $\left\{x^{2}, x y, y x, y^{2}\right\}$ についは character は，Eの character の二乗で与えられる.その簡約 
を次の表で行う.

\begin{tabular}{|c|c|c|c|}
\hline $\mathrm{C}_{3 \mathrm{v}}$ & $E$ & $2 C_{3}$ & $3 \sigma_{v}$ \\
\hline$A_{1}$ & 1 & 1 & 1 \\
\hline$A_{2}$ & 1 & 1 & -1 \\
\hline$E$ & 2 & -1 & 0 \\
\hline$\chi(E)^{2}$ & 4 & 1 & 0 \\
\hline
\end{tabular}

この結果をしばしば次のように表す。

$$
E \times E=A_{1}+A_{2}+E
$$

このように $\left\{x^{2}, x y, y x, y^{2}\right\}$ の basis set は既約表現, $A_{1}, A_{2}$, および $E の 3 つ に$ 簡約さ れる，それぞれがどのような関数形で表されるかは，前節のような方法で求めること が出来る。

\subsection{3 群の直積}

Section 17.12 では，既約表現間の直積，もう少し正確にいうと既約表現に属してい る basis set 間の直積を問題にした。ここで取り上げるのは，それと似ているが，群の 対称操作間の直積である.

2 つの群 $A$ および $B$ を考える.

群 $A$ の element は $R_{i} \quad\left(i=1,2, \ldots, g_{A}\right), \quad$ order は $g_{A}$

群 $B$ の element は $S_{j} \quad\left(j=1,2, \ldots, g_{B}\right), \quad$ order は $g_{B}$

この element 間の積 $R_{i} S_{j}\left(g_{A} \times g_{B}\right.$ 個ある $)$ の集合 $C$ が群を作る時，もし $R_{i} S_{j}=S_{j} R_{i}$ が すべての $C$ について成り立つなら，群 $C$ は，群 $A$ と群 $B$ との直積（direct product）と 言い, 
$C=A \times B$

と示す。この場合，次のことが成り立つ.

$C$ の order $=A$ の order $\times B$ order

$C$ の class の数 $=A$ の class $の$ 数 $\times B$ の class の数

$C$ の character $=A$ の character $\times B$ の character

\section{【例】 :}

群 $A$ として $\mathrm{S}_{2}=\mathrm{C}_{\mathrm{i}}$, 群 $B$ として $\mathrm{D}_{2}$ を考える. それぞれの character table を次に 示す.

\begin{tabular}{||c||c|c|}
\hline \hline $\mathrm{S}_{2}$ & $E$ & $i$ \\
\hline \hline$A_{g}$ & 1 & 1 \\
\hline$A_{u}$ & 1 & -1 \\
\hline
\end{tabular}

order $=2$

class の数 $=2$

\begin{tabular}{||c||c|c|c|c|}
\hline \hline $\mathrm{D}_{2}$ & $E$ & $C_{2}(z)$ & $C_{2}(y)$ & $C_{2}(x)$ \\
\hline \hline$A_{1}$ & 1 & 1 & 1 & 1 \\
\hline$B_{1}$ & 1 & 1 & -1 & -1 \\
\hline$B_{2}$ & 1 & -1 & 1 & 1 \\
\hline$B_{3}$ & 1 & -1 & -1 & -1 \\
\hline
\end{tabular}

order $=4$

class $の$ 数 $=4$

2 つの群の element（すなわち symmetry operation）の積を計算する. commute する

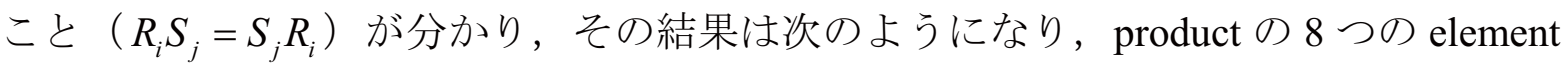
は再び group を作ることが分かる。（このことを Section 17.3 で学習した群を作ること 
の条件より吟味せよ.)

\begin{tabular}{|c|c|c|c|c|c|}
\hline & & \multicolumn{4}{|c|}{$\mathrm{D}_{2}$} \\
\hline & & $E$ & $C_{2}(z)$ & $C_{2}(y)$ & $C_{2}(x)$ \\
\hline \multirow[b]{2}{*}{$\mathrm{S}_{2}$} & $E$ & $E$ & $C_{2}(z)$ & $C_{2}(y)$ & $C_{2}(x)$ \\
\hline & $i$ & $i$ & $\begin{array}{l}i C_{2}(z) \\
=C_{2}(z) i \\
=\sigma(x y)\end{array}$ & $\begin{array}{l}i C_{2}(y) \\
=C_{2}(y) i \\
=\sigma(x z)\end{array}$ & $\begin{array}{l}i C_{2}(x) \\
=C_{2}(x) i \\
=\sigma(y z)\end{array}$ \\
\hline
\end{tabular}

このことから分かるように $\mathrm{D}_{2} \times \mathrm{S}_{2}$ は 1 つの群である。このような群を $\mathrm{D}_{2} \mathrm{~h}$ と名付け， $\mathrm{D}_{2 \mathrm{~h}}=\mathrm{D}_{2} \times \mathrm{S}_{2}$

と記す. Eyring, et al., "Quantum Chemistry"では，上式の代りに

$\mathrm{D}_{2 \mathrm{~h}}=\mathrm{D}_{2 \times \mathrm{i}}$

のように表しているが同じことである.

このような直積の character table は，それぞれの群の character table が与えられてい れば直ちに作ることが出来る，直ちに作ることが出来るので，多くの教科書では頁数 を減らすためか，そういう群についての character table はしばしば省略されていて載 っていない，それで自分で character table を作る方法を知っておく必要がある。

では直積の群の character table の作り方を述べる. 具体的に $\mathrm{D}_{2 \mathrm{~h}}$ の場合を例にとっ て考えよう。

element の数は $2 \times 4=8$

class の数は $2 \times 4=8$

class の数が 8 だから, 既約表現の数も 8 でなければならない. 各既約表現の dimension を $\ell_{1}, \ell_{2}, \ldots, \ell_{8}$ と表すと，

$$
\ell_{1}^{2}+\ell_{2}^{2}+\ell_{3}^{2}+\ell_{4}^{2}+\ell_{5}^{2}+\ell_{6}^{2}+\ell_{7}^{2}+\ell_{8}^{2}=8
$$

この解は, 


$$
\ell_{1}=\ell_{2}=\ell_{3}=\ell_{4}=\ell_{5}=\ell_{6}=\ell_{7}=\ell_{8}=1
$$

すなわち, 1 次元の既約表現が 8 個あることになる.

character table を作る場合, representationの記号としては， $\mathrm{D}_{2}$ の $A_{1}, B_{1}, B_{2}, B_{3}$ に $\mathrm{S}_{2}$ の $A_{g}$ を掛けたものをそれぞれ $A_{1 g}, B_{1 g}, B_{2 g}, B_{3 g}$ と名付け， $\mathrm{S}_{2}$ の $A_{u}$ を掛けたも のを同様に， $A_{1 u}, B_{1 u}, B_{2 u}, B_{3 u}$ と名付ける. 後は,

character of $D_{2 h}=$ character of $D_{2} \times$ character of $S_{2}$

の式より直ちに求まる。結果は次のようになる，各自確かめてみよ.

\begin{tabular}{||c||c|c|c|c||c|c|c|c||}
\hline \hline $\mathrm{D}_{2 \mathrm{~h}}$ & $E$ & $C_{2}(z)$ & $C_{2}(y)$ & $C_{2}(x)$ & $i$ & $\sigma(x y)$ & $\sigma(x z)$ & $\sigma(y z)$ \\
\hline \hline$A_{1 g}$ & 1 & 1 & 1 & 1 & 1 & 1 & 1 & 1 \\
\hline$B_{1 g}$ & 1 & 1 & -1 & -1 & 1 & 1 & -1 & -1 \\
\hline$B_{2 g}$ & 1 & -1 & 1 & -1 & 1 & -1 & 1 & -1 \\
\hline$B_{3 g}$ & 1 & -1 & -1 & 1 & 1 & -1 & -1 & 1 \\
\hline \hline$A_{1 u}$ & 1 & 1 & 1 & 1 & -1 & -1 & -1 & -1 \\
\hline$B_{1 u}$ & 1 & 1 & -1 & -1 & -1 & -1 & 1 & 1 \\
\hline$B_{2 u}$ & 1 & -1 & 1 & -1 & -1 & 1 & -1 & 1 \\
\hline$B_{3 u}$ & 1 & -1 & -1 & 1 & -1 & 1 & 1 & -1 \\
\hline \hline
\end{tabular}

この character table は既に表 17.8.3 に示したものと同じであることは比べてみれば明 らかであるう。 


\subsection{4 対称積と反対称積}

Section 17.12で $\{x, y\}$ という basis function 自身の直積として $\left\{x^{2}, x y, y x, y^{2}\right\}$ が得られ， $\mathrm{C}_{3 \mathrm{v}}$ ではそれが $E \times E=A_{1}+A_{2}+E$ となるということを例として述べた．しかし， $x y$ と $y x$ とはお互いに独立ではない.もし $\left\{x_{1}, y_{1}\right\}$ という basis と $\left\{x_{2}, y_{2}\right\}$ という basis の直積 を考えると， $x_{1} y_{2}$ と $y_{1} x_{2}$ の 2 つのいずれも群の既約表現の基底になっていないことに 容易に気づく.ちょっとした考察から，むしろ $x_{1} y_{2}+y_{1} x_{2}$ と $x_{1} y_{2}-y_{1} x_{2}$ が既約表現の基 底になっていることが分かる.もしも， $\left\{x_{1}, y_{1}\right\}$ と $\left\{x_{2}, y_{2}\right\}$ が全く同じで $\{x, y\}$ 自身の直 積を考えるならば $x y$ と $y x$ は同じものである。(「全く同じ」ということは順序に関係 ないということ).こういう場合, 我々は, $\left\{x^{2}, x y, y x, y^{2}\right\}$ についではなく, $\left\{x^{2}, x y, y^{2}\right\}$ がどういう既約表現に属するかを知る必要がある。

一般には，1つの縮退表現に属している 2 つの要素 $f_{i}^{\ell}$ と $f_{j}^{\ell}$ にいて，関数

$\frac{1}{2}\left\{f_{i}^{\ell} f_{j}^{\ell}+f_{j}^{\ell} f_{i}^{\ell}\right\}$ を $f_{i}^{\ell}$ と $f_{j}^{\ell}$ との対称積 (symmetric product), また $\frac{1}{2}\left\{f_{i}^{\ell} f_{j}^{\ell}-f_{j}^{\ell} f_{i}^{\ell}\right\}$ を反 対称積 (antisymmetric product) と言う. 対称積および反対称積の character は次の式で 求まる。ここでは証明は省略する。

対称積 : $\quad \chi_{S}(G)=\frac{1}{2}\left\{\chi^{(\ell)}(G)^{2}+\chi^{(\ell)}\left(G^{2}\right)\right\}$

反対称積 : $\quad \chi_{A}(G)=\frac{1}{2}\left\{\chi^{(\ell)}(G)^{2}-\chi^{(\ell)}\left(G^{2}\right)\right\}$

例として, 再び $\mathrm{C}_{3 \mathrm{v}}$ を考えよう。縮退表現 $E$ について $E \times E$ の対称積と反対称積を 求めてみよう。 


\begin{tabular}{|c||c|c|c||}
\hline \hline $\mathrm{C}_{3 \mathrm{v}}$ & $E$ & $2 C_{3}$ & $3 \sigma_{v}$ \\
\hline \hline$A_{1}$ & 1 & 1 & 1 \\
\hline$A_{2}$ & 1 & 1 & -1 \\
\hline$E$ & 2 & -1 & 0 \\
\hline$\chi^{(E)}(G)^{2}$ & 4 & 1 & 0 \\
\hline$\chi^{(E)}\left(G^{2}\right)$ & 2 & -1 & 1 \\
\hline$\chi_{S}(G)$ & 3 & 0 & -1 \\
\hline$\chi_{A}(G)$ & 1 & 1 & $A_{1}+A_{2}$ \\
\hline
\end{tabular}

この表で $\chi^{(E)}(G)^{2}$ は簡単である. $\chi^{(E)}(G)$ を単に二乗するだけである. 一方， $\chi^{(E)}\left(G^{2}\right)$ についてはある $G$ につて $G^{2}$ が何かを求めないといけない，それを以下に考えてみ よう.まず $E$ の欄であるが $E^{2}=E$ であるから $\chi^{(E)}\left(E^{2}\right)=\chi^{(E)}(E)=2$ となる. 次に $C_{3}$ で あるが $\left(C_{3}\right)^{2}=C_{3}^{2}$ で, $C_{3}^{2}$ の character は $C_{3}$ のそれと同じである. 従って $\chi^{(E)}\left(\left(C_{3}\right)^{2}\right)=\chi^{(E)}\left(C_{3}\right)=-1$ である. 最後に $\sigma_{v}$ については $\left(\sigma_{v}\right)^{2}=E$ より

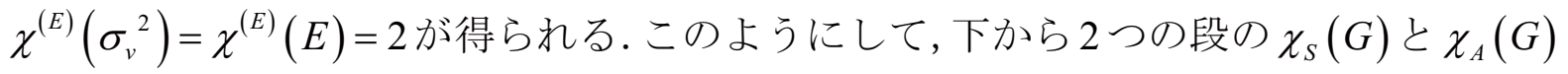
が得られる。かくして，結果をまとめると

$$
\begin{aligned}
& (E \times E)_{\text {symmetric }}=A_{1}+E \\
& (E \times E)_{\text {antisymmetric }}=A_{2}
\end{aligned}
$$


このような，対称積，反対称積はいたるところに応用例がある．以下，ほんの二三 の例をあげるだけとしょう。

1 つの例は，上で引用したものと全く同じ $\{x, y\}$ 自身の直積である. この場合，反 対称積は $x y-y x=0$ となってしまうから, 対称積のみしか意味をなさない，それで， 対称積のみをとり, basis $\left\{x^{2}, x y, y^{2}\right\}$ は $A_{1}+E$ に属寸ることが分かる. 多くの character table には主な関数形が属する既約表現が示されているので，そういう表をみると $x^{2}+y^{2}$ が $A_{1}$ に $\quad x y$ が $E$ に属するとなっている．このことは上のことから納得がいく であろう。

次に，もう 1 つの例として basis $\{x, y\}$ と basis $\left\{\frac{\partial}{\partial x}, \frac{\partial}{\partial y}\right\}$ の 2 つの直積を考える.こ れはどちらも同じ既約表現に属することは当然である. $\mathrm{C}_{3 \mathrm{v}}$ の場合にはどちらも $E$ に 属する.もし演算子 $L_{z}=-i \hbar\left(x \frac{\partial}{\partial y}-y \frac{\partial}{\partial x}\right)$ を考えると, これは $E$ と $E$ の反対称積である. $\mathrm{C}_{3 \mathrm{v}}$ では反対称積は $A_{2}$ であることを上で求めた. かくして, 角運動量演算子 $L_{z}$ は $\mathrm{C}_{3 \mathrm{v}}$ で $A_{2}$ に属することが分かる. 上の演算子は, $z$ 軸まわりの回転と同じである. character

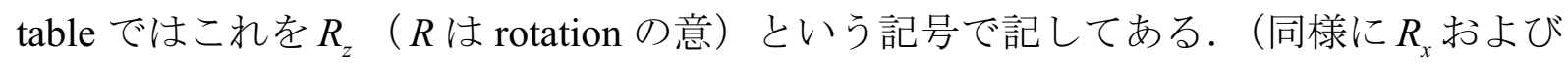
$R_{y}$ はそれぞれ $x$ および $y$ 軸まわりの回転). $\mathrm{C}_{3 \mathrm{v}}$ の character table で $A_{2}$ のところに $R_{z}$ と 示してあるのはこのことである.

上で $\mathrm{C}_{3 \mathrm{v}}$ で行ったのと全く同じことを $\mathrm{D}_{4}$ 点群で行ってみよう．basis $\{x, y\}$ は既約 表現 $E$ に属する. 従って basis $\left\{x^{2}, x y, y^{2}\right\}$ は $E \times E$ の対称積に，また $L_{z}=-i \hbar\left\{y \frac{\partial}{\partial x}-x \frac{\partial}{\partial y}\right\}$ は $E \times E$ の反対称積に属することが分かる. 念のため, 以下の表 で確かめてみよう。 


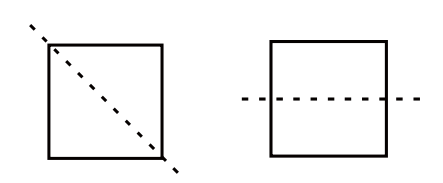

\begin{tabular}{||c||c|c|c|c|c||}
\hline $\mathrm{D}_{4}$ & $E$ & $C_{2}$ & $2 C_{4}$ & $2 C_{2}{ }^{\prime}$ & $2 C_{2}{ }^{\prime}$ \\
\hline \hline$A_{1}$ & 1 & 1 & 1 & 1 & 1 \\
\hline$A_{2}$ & 1 & 1 & 1 & -1 & -1 \\
\hline$B_{1}$ & 1 & 1 & -1 & 1 & -1 \\
\hline$B_{2}$ & 1 & 1 & -1 & -1 & 1 \\
\hline$E$ & 2 & -2 & 0 & 0 & 0 \\
\hline \hline$\chi^{(E)}(G)^{2}$ & 4 & 4 & 0 & 0 & 0 \\
\hline$\chi^{(E)}\left(G^{2}\right)$ & 2 & 2 & -2 & 2 & 2 \\
\hline \hline$\chi_{S}(G)$ & 3 & 3 & -1 & 1 & -1 \\
\hline$\chi_{A}(G)$ & 1 & 1 & 1 & -1 & $A_{1}+B_{1}+B_{2}$ \\
\hline \hline
\end{tabular}

かくして， $L_{z}$ は既約表現 $A_{2}$ に属することが分かる. また $\left\{x^{2}, x y, y^{2}\right\}$ は $A_{1}+B_{1}+B_{2}$ に属 すということが分かる。そう思ってためしに Eyring, Walter, Kimball の"Quantum Chemistry"の p. 386 の $\mathrm{D}_{4}$ の character table を見てみると, $x^{2}+y^{2}$ が $A_{1}, x^{2}-y^{2}$ と $x y$ と が $E$ に属することになっている，ということは対称積が $A_{1}+E$ ということになる.

$\left\lceil\mathrm{C}_{3 \mathrm{v}}\right.$ の場合と同じだな.では，上の取り扱いのどこが間違ったのだろう.」と悩んで しまう。

実はこれも Eyring et al. の教科書の character table の大きな間違いの 1 つである.ち やんとやってみると,$x^{2}+y^{2}$ が $A_{1}$ に,$x^{2}-y^{2}$ が $B_{1}$ に,$x y$ が $B_{2}$ に属することが分る 
すなわち，対称積が $A_{1}+B_{1}+B_{2}$ という，上で求めた結果は正しかったのである.

この例でも分かるように，市販されている教科書に記載されている character table には間違いが非常に多い. 自分で十分に納得して使う必要があることを強調しておき たい.

対称積, 反対称積のもう 1 つ例として, 二重に縮退した軌道に 2 つの電子が入る 場合を考えてみよう. 電子が 2 つるから, spin は singlet と triplet のいずれかとなる. では，空間部分はどういう既約表現になろうか? 縮退した軌道の 2 つの成分をそれぞ

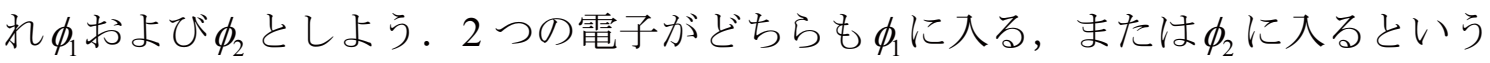

configuration $\phi_{1}(1) \phi_{1}(2)$ および $\phi_{2}(1) \phi_{2}(2)$ は Pauli principle から singlet に限られる.1つ の電子が $\phi_{1}$ にう $1 つ か ゙ ~ \phi_{2}$ に入るという configuration は singlet または triplet のいずれ かであるが，wavefunction は

$$
\begin{array}{ll}
\text { singlet: } & \sqrt{\frac{1}{2}}\left\{\phi_{1}(1) \phi_{2}(2)+\phi_{2}(1) \phi_{1}(2)\right\} \\
\text { triplet: } & \sqrt{\frac{1}{2}}\left\{\phi_{1}(1) \phi_{2}(2)-\phi_{2}(1) \phi_{1}(2)\right\}
\end{array}
$$

である。こう考えると, singlet の wavefunction は $E \times E の$ symmetric product, triplet は その antisymmetric product ということになる.

例として $\mathrm{O}_{2}$ 分子 $\left(\mathrm{D}_{\infty \mathrm{h}}\right.$ 点群) を考える。この分子では縮退した $\Pi_{g}$ 軌道に 2 個の 電子がつまっている，従って $\Pi_{g} \times \Pi_{g}$ の symmetric product が singlet, $\Pi_{g} \times \Pi_{g}$ の antisymmetric product が triplet ということになる. Atkins "Molecular Quantum Mechanics" p. 44 の $\mathrm{D}_{\infty \mathrm{h}}$ の character table は間違っているので, 正しい character table に従って symmetric product と antisymmetric product を求めてみよう. 


\begin{tabular}{|c|c|c|c|c|c|c|}
\hline $\mathrm{D}_{\infty \mathrm{h}}$ & $E$ & $2 C_{\phi}$ & $\infty \sigma_{v}$ & $i$ & $2 S_{\phi}$ & $\infty C_{2}^{\prime}$ \\
\hline$\Sigma_{g}^{+}$ & 1 & 1 & 1 & 1 & 1 & 1 \\
\hline$\Sigma_{g}^{-}$ & 1 & 1 & -1 & 1 & 1 & -1 \\
\hline$\Pi_{g}$ & 2 & $2 \cos \phi$ & 0 & 2 & $-2 \cos \phi$ & 0 \\
\hline$\Delta_{g}$ & 2 & $2 \cos 2 \phi$ & 0 & 2 & $2 \cos 2 \phi$ & 0 \\
\hline$\Sigma_{u}^{+}$ & 1 & 1 & 1 & -1 & -1 & -1 \\
\hline$\Sigma_{u}^{-}$ & 1 & 1 & -1 & -1 & -1 & 1 \\
\hline$\Pi_{u}$ & 2 & $2 \cos \phi$ & 0 & -2 & $2 \cos \phi$ & 0 \\
\hline$\Delta_{u}$ & 2 & $2 \cos 2 \phi$ & 0 & -2 & $-2 \cos \phi$ & 0 \\
\hline$\chi^{\left(\Pi_{g}\right)}(G)^{2}$ & 4 & $4 \cos ^{2} \phi$ & 0 & 4 & $4 \cos ^{2} \phi$ & 0 \\
\hline$\chi^{\left(\Pi_{g}\right)}\left(G^{2}\right)$ & 2 & $2 \cos 2 \phi$ & 2 & 2 & $2 \cos 2 \phi$ & 2 \\
\hline$\chi_{S}(G)$ & 3 & $2 \cos 2 \phi+1$ & 1 & 3 & $2 \cos 2 \phi+1$ & 1 \\
\hline$\chi_{A}(G)$ & 1 & 1 & -1 & 1 & 1 & -1 \\
\hline
\end{tabular}

かくして, $\mathrm{O}_{2}$ の $\Pi_{g}$ 軌道に 2 個電子が詰まった configuration からは ${ }^{3} \Sigma_{g}{ }^{-},{ }^{1} \Sigma_{g}{ }^{+},{ }^{1} \Delta_{g}$ の 3 つの state が得られることが分かる．このうち， ${ }^{3} \Sigma_{g}{ }^{-}$が基底状態である（ $\mathrm{O}_{2}$ の基底 状態は常磁性であることはよく知られている). 残りの 2 つの singlet state は, 低エネ ルギーの 2 つの励起状態であり, singlet oxygen として, 反応などに重要な役割を持つ 酸素としてよく話題になるものである. 
最後にもう 1 つだけ例をあげよう. 分子の持っている規準振動のうち, どの既約表 現に属する振動が赤外線吸収スペクトルに現れるか（すなわち赤外 active か）, 又, どの既約表現に属する振動がラマン散乱に現れるか（すなわち Raman active か）を知 ることは大切である. 赤外 active な振動は, 変数 $x, y, z$ と同じように transform 寸 る既約表現に属する．たいていの character table では変数 $x, y, z$ がどの既約表現に 属するかが示されているから character tableを見ただけで直ちに分かる. 一方, Raman active な振動は, 変数 $x, y, z$ 同志の積と同じように transform 寸る既約表現に属寸 る.この積については character table に示されてない場合が多い，そういう場合は自 分で直積を求めれば良い， $x, y, z$ が縮退していない時は簡単であるので何も改め て言うことはない. 縮退がある場合にはその対称積をとらなければならないことは上 の議論で明らかであろう。

以下一例として点群 O (立方対称群) における Raman active な既約表現を求めてみ よう.

$\mathrm{O}$ 点群においては $x, y, z$ はすべて既約表現 $T_{1}$ に属する. 従って $T_{1} \times T_{1}$ の対称積を 求めるのが以下行うべきことである。例によって，点群 $\mathrm{O}$ の character table をそのま ま書き写寸ことから始めて，以下の表のようにして対称積を得る。 


\begin{tabular}{||c||c|c|c|c|c||}
\hline \hline $\mathrm{O}$ & $E$ & $8 C_{3}$ & $3 C_{2}$ & $6 C_{2}{ }^{\prime}$ & $6 C_{4}$ \\
\hline \hline$A_{1}$ & 1 & 1 & 1 & 1 & 1 \\
\hline$A_{2}$ & 1 & 1 & 1 & -1 & -1 \\
\hline$E$ & 2 & -1 & 2 & 0 & 0 \\
\hline$T_{1}$ & 3 & 0 & -1 & -1 & 1 \\
\hline$T_{2}$ & 3 & 0 & -1 & 1 & -1 \\
\hline \hline$\chi^{\left(T_{1}\right)}(G)$ & 3 & 0 & -1 & -1 & 1 \\
\hline$\chi^{\left(T_{1}\right)}(G)^{2}$ & 9 & 0 & 1 & 1 & 1 \\
\hline$\chi^{\left(T_{1}\right)}\left(G^{2}\right)$ & 3 & 0 & 3 & 3 & -1 \\
\hline \hline$\chi_{S}(G)$ & 6 & 0 & 2 & 2 & 0 \\
\hline \hline
\end{tabular}

ここで $\chi^{\left(T_{1}\right)}\left(G^{2}\right)$ を求めるにあたっては,

$$
\begin{aligned}
& E^{2}=E \\
& C_{2}^{2}=E \\
& C_{4}^{2}=C_{2}
\end{aligned}
$$

ということに着目した。

この表より， $T_{1} \times T_{1}$ の対称積は $A_{1}+E+T_{2}$ ということが分かる. すなわち $A_{1}, E, T_{2}$ が Raman active ということになる. Raman active か Raman inactive かは, Eyring, Walter, Kimball, "Quantum Chemistry"の character table では「Active」とか「Inactive」として 示される.この character table の Oの所を見ると, なんと, $A_{1}, E, T_{2}$ に加えて, $T_{1}$ も 
Raman active ということになっている。これも, Eyring et al. の character table の間違 いの一例であるが，これは，単なる misprint ではなさそうである. どうやら Eyring 先 生は， $T_{1} \times T_{1}$ の単なる直積をとって $T_{1} \times T_{1}=A_{1}+E+T_{1}+T_{2}$ のすべてが Raman active であ ると思っていたようである。この本が出版された 1933 年には，まだ対称積，反対称 積のことが化学者にまでは理解されていなかったのかもしれない. なお, Eyring et al. の教科書での同様な間違いは点群 $\mathrm{T}_{\mathrm{d}}$ においてもみられる.

乞2 Problem 17.14.1

$\mathrm{T}_{\mathrm{d}}$ 点群における Raman active な既約表現を求め, Eyring et al. の本の character table の間違いを訂正せよ. 


\subsection{5 積分值がゼロになるかどうかの判定}

量子力学では，期待值（平均值）が積分で表されるから，積分がゼロになるかどう か，数值計算をする前に判断出来れば大変に都合がよい. 群論を用いるとそれが可能 となる．もっとも，ある積分が，ゼロになるかどうかの判断は，高等学校の数学でお なじみのことである。すなわち，被積分関数 $f(x)$ が奇関数であれば，すなわち $f(x)=-f(x)$ であれば， $f(x)$ をー $a$ から $+a$ まで積分するとゼロになるわけである

この場合には, $f(x)$ を $y$ 軸についての $C_{2}$ または $y z$ 平面についての $\sigma$ を作用した時に 符号が反対になるから，積分はゼロになる，ということである。こういう考え方こそ， 群論の考え方である. 被積分関数が偶関数の場合には積分は值を持ち得る.しかし， 絶対にゼロにはならない，とはいい切れない。例えば $f(x)=3 x^{2}-1$ の時

$$
\int_{-1}^{+1} f(x) d x=\int_{-1}^{+1}\left(3 x^{2}-1\right) d x=0
$$

となるように，たまたまゼロになってしまうことはあり得る，このように，群論では， 積分がゼロになるか，又は值を持ち得るかどうかを判定することが出来るが，後者の 場合でも，絶対にゼロにならないとは結論出来ない.

上では一変数のみの関数の例を考えたが, 一般的に拡張すると, 次のように言うこ とが出来る。すなわち

定理： 被積分関数が全対称表現を含まない限り，積分はゼロである

ここで，もちろん，積分範囲は，座標の正負の領域について対称の位置まで考えるも のとしている.ここで全対称表現というのは，すべての operation に対して +1の character を与える表現で, 通常は, character table のもつとも上段に示されている表現 である. 又,「全対称表現を含む」といった言い方をしているのは，被積分関数の表 現が可約である場合のことを考えていて，この可約表現を簡約した時に全対称表現が 含まれているかどうかで判定するわけである.例えば $\mathrm{C}_{3 \mathrm{v}}$ の分子の wavefunction $\psi_{1}$ と $\psi_{2}$ との積の積分 $\int \psi_{1}{ }^{*} \psi_{2} d \tau$ を考える. $\psi_{1}$ が $A_{1}$ 表現, $\psi_{2}$ が $A_{2}$ 表現であれば $A_{1} \times A_{2}=A_{2}$ で 
あり，これは全対称表現ではないから積分はゼロである。もし， $\psi_{1} も \psi_{2}$ も $A_{2}$ 表現に 属すれば $A_{2} \times A_{2}=A_{1}$ となり, 全対称既約表現そのものとなり, 積分は值を持ち得る.

もう 1 つの例として, $\psi_{1}$ も $\psi_{2}$ も $E$ 表現であったとする.この場合 $E \times E=A_{1}+A_{2}+E$ で $A_{1}$ を含むので, この積分は值を持ち得ることが分かる.

论Exercise 17.15.1

$d$ 電子を持つ金属が配位子により $\mathrm{C}_{4 \mathrm{v}}$ の場にあるとする。 $d$ 軌道間の積分 $\int d_{x y} z d_{x^{2}-y^{2}} d \tau$ は值を持つか否かを吟味せよ。

\section{【解】：}

まず, 与えられた $2 つ の d$ 軌道がどのような既約表現に属するかを求める必要があ る。それを求めるのは容易であるが幸いにもたいていの character table には， $p$ 関数 と $d$ 関数についてはどの既約表現に属しているかが示されている. $\mathrm{C}_{4 \mathrm{v}}$ の character table を見ると， $d_{x y}$ は $B_{2} ， d_{x^{2}-y^{2}}$ は $B_{1}$ に属することが分かる．また $z$ は $A_{1}$ である．従 って integrand 全体の表現は $B_{2} \times A_{1} \times B_{1}=A_{2}$ となり，全対称表現を含まない. 従って積 分はゼロとなる.

弥 Exercise 17.15.2

上の例題の場合 $\int d_{x y} L_{z} d_{x^{2}-y^{2}} d \tau$ の積分について吟味せよ.

\section{【解】 :}

$L_{z}$ は $z$ 軸まわりの回転に相当する $x, y, z$ 軸のまわりの回転の属寸る既約表現 は， character table において， $R_{x}, R_{y}, R_{z}$ の記号で記されている. $\mathrm{C}_{4 \mathrm{v}}$ の場合， $L_{z}$ は $A_{2}$ に属することが分かる. 従って integrand 全体として $B_{2} \times A_{2} \times B_{1}=A_{1}$ のように全対称 
表現 $A_{1}$ となるので，積分は值を持つ可能性がある.

\subsection{6 原子軌道関数の既約表現}

ある原子のおかれている環境がある点群で表わされる場合, その原子の原子軌道関 数がその点群におけるどの既約表現に属するかを知りたい場合がよくある。ここでは この問題を考えてみよう。原子軌道関数としては，とりあえず， $s$ 軌道， 3 つの $p$ 軌 道 $\left(p_{x}, p_{y}, p_{z}\right)$ ，および 5 つの $d$ 軌道 $\left(d_{z^{2}}, d_{x^{2}-y^{2}}, d_{x y}, d_{y z}, d_{z x}\right)$ を考えよう. $f$ 軌道が必要なこともあるが，考え方は同じなので考え方さえ分かっていれば特に問 題はなからう.

ある特定の点群についての具体的な例を学習する前に, まず, 一般論として考えて みよう。量子数 $n, \ell, m$ で規定される原子軌道関数は

$$
\begin{aligned}
\psi_{n, \ell, m} & =R_{n, \ell}(r) \Theta_{\ell, m}(\theta) \Phi_{m}(\phi) \\
& =\sqrt{\frac{1}{2 \pi}} R_{n, \ell}(r) \Theta_{\ell, m}(\theta) \exp (i m \phi)
\end{aligned}
$$

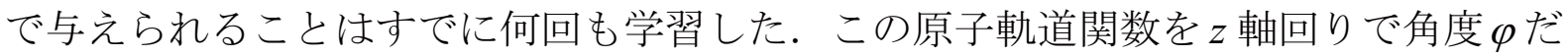
け回転することを考える。この演算子を $C_{\varphi}(z)$ と表すと

$$
\begin{aligned}
C_{\varphi}(z) \psi_{n, \ell, m} & =\sqrt{\frac{1}{2 \pi}} R_{n, \ell}(r) \Theta_{\ell, m}(\theta) \exp \{i m(\phi-\varphi)\} \\
& =\exp (-i m \varphi) \psi_{n, \ell, m}
\end{aligned}
$$

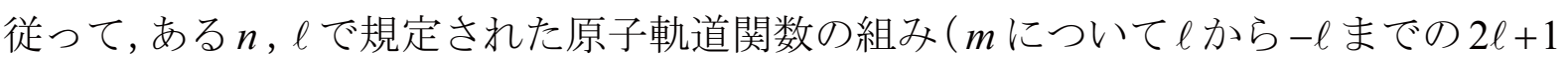
個の組夕）についての回転は次の式で表される.

$$
\begin{aligned}
& C_{\varphi}(z)\left[\begin{array}{lllll}
\psi_{n, \ell, \ell} & \psi_{n, \ell, \ell-1} & \cdots & \cdots & \psi_{n, \ell,-\ell}
\end{array}\right] \\
& =\left[\begin{array}{lllll}
\psi_{n, \ell, \ell} & \psi_{n, \ell, \ell-1} & \cdots & \cdots & \psi_{n, \ell,-\ell}
\end{array}\right]\left[\begin{array}{ccccc}
e^{-i \ell \varphi} & 0 & \cdots & \cdots & 0 \\
0 & e^{-i(\ell-1) \varphi} & 0 & \cdots & 0 \\
& & \ddots & & \\
& & & \ddots & \\
0 & 0 & \cdots & \cdots & e^{+i \ell \varphi}
\end{array}\right]
\end{aligned}
$$

従ってこの回転操作の character は 


$$
\chi\left(C_{\varphi}\right)=\sum_{m=-\ell}^{+\ell} e^{-i m \varphi}=\left\{\begin{array}{cc}
2 \ell+1 \quad(\varphi=0) \\
\frac{\sin \left(\ell+\frac{1}{2}\right) \varphi}{\sin \frac{1}{2} \varphi} & (\varphi \neq 0)
\end{array}\right.
$$

（character をとると，回転軸の取り方に無関係となるので軸の指定をしていない.） こうして proper rotation に関しては簡単に character が求まった。 improper rotationを作 用すると上述した $\phi \rightarrow \phi-\varphi$ の変換に更に $\theta \rightarrow \pi-\theta$ という変換も加わるのでいささか 複雑になるのでここでは省略しよう。

式(17.16.4)を用いて $\ell=0$ の $s$ 軌道， $\ell=1 の p$ 軌道， $\ell=2 の d$ 軌道について代表的な proper rotation の character を表 17.16.1 にまとめておく.

表 17.16.1 原子軌道関数 $\psi_{n, \ell}$ についての回転の指標： $\chi\left(C_{n}\right)$

\begin{tabular}{||c||c|c|c||}
\hline & $s$ 軌道 & $p$ 軌道 & $d$ 軌道 \\
\hline \hline$E$ & 1 & 3 & 5 \\
\hline$C_{2}$ & 1 & -1 & -1 \\
\hline$C_{3}$ & 1 & 0 & -1 \\
\hline$C_{4}$ & 1 & 1 & 1 \\
\hline$C_{6}$ & 1 & 2 & 1 \\
\hline
\end{tabular}

表 17.16.1 から回転群（対称操作が回転のみの群）の場合には簡単に結果が得られ る．例えば $\mathrm{D}_{4}$ 点群を例として考えよう。 


\begin{tabular}{|c||c|c|c|c|c||c||}
\hline $\mathrm{D}_{4}$ & $E$ & $C_{2}$ & $2 C_{4}$ & $2 C_{2}{ }^{\prime}$ & $2 C_{2} "$ & \\
\hline \hline$A_{1}$ & 1 & 1 & 1 & 1 & 1 & \\
\hline$A_{2}$ & 1 & 1 & 1 & -1 & -1 & -1 \\
\hline$B_{1}$ & 1 & 1 & -1 & 1 & 1 & \\
\hline$B_{2}$ & 1 & 1 & -1 & -1 & 0 & $A_{1}$ \\
\hline$E$ & 2 & -2 & 0 & 0 & $A_{2}+E$ \\
\hline \hline$S$ 軌道 & 1 & 1 & 1 & 1 & -1 & $A_{1}+B_{1}+B_{2}+E$ \\
\hline$p$ 軌道 & 3 & -1 & 1 & -1 & 1 & \\
\hline$d$ 軌道 & 5 & 1 & -1 & 1 & & \\
\hline \hline
\end{tabular}

表 17.16.1 または表 17.16.2 から分かるように $s$ 軌道はすべての proper rotation に対 して不変である.improper rotation をも含めてすべての対称操作に対して不変であるこ とは関数形を思い浮かべれば明らかであろう。こういうわけで「 $s$ 軌道は必ず全対称 (totally symmetric）表現に属する」ということが分かる.

こうして原子軌道の属する既約表現を求める方法は分かったが, この方法では具体 的な軌道, 例えば $p_{x}$ 軌道はどの既約表現に属するかは分からない. それを知るには具 体的にそれぞれの原子軌道に対称操作をほどこしてみる必要がある.

では具体的な例についていくつか考えてみよう。

放Exercise 17.16.1

$\mathrm{H}_{2} \mathrm{O}$ 分子の $\mathrm{O}$ 原子の $p$ 軌道および $d$ 軌道の属する既約表現を求めよ. 


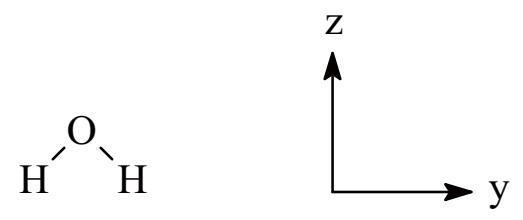

\section{【解】 :}

$\mathrm{H}_{2} \mathrm{O}$ 分子の $\mathrm{O}$ 原子は $\mathrm{C}_{2 \mathrm{v}}$ 点群にある. 軸を図のように取り, 関数 $x, y, z$ の transformation を調べると次のようになっている.

\begin{tabular}{||c||c|c|c|c||}
\hline \hline & $E$ & $C_{2}$ & $\sigma(x z)$ & $\sigma(y z)$ \\
\hline \hline$x$ & $x$ & $-x$ & $x$ & $-x$ \\
\hline$y$ & $y$ & $-y$ & $-y$ & $z$ \\
\hline$z$ & $z$ & $z$ & $z$ & $z$ \\
\hline
\end{tabular}

この結果を $\mathrm{C}_{2 \mathrm{v}}$ の character table と見比べることにより関数 $x, y, z$ ，すなわち $3 つ$ の $p$ 軌道 $p_{x} ， p_{y} ， p_{z}$ はそれぞれ次の既約表現に属することが分かる.

$$
\begin{aligned}
& p_{x}: B_{1} \\
& p_{y}: B_{2} \\
& p_{z}: A_{1}
\end{aligned}
$$

次に $d$ 軌道について考えよう. 関数 $x, y, z$ の変換が求まればそれらの積の変換も 容易に求まり，直ちに次の表の結果が得られる. 


\begin{tabular}{||c||c|c|c|c||}
\hline & $E$ & $C_{2}(z)$ & $\sigma(x z)$ & $\sigma(y z)$ \\
\hline \hline$z^{2}$ & $z^{2}$ & $z^{2}$ & $z^{2}$ & $z^{2}$ \\
\hline$x^{2}-y^{2}$ & $x^{2}-y^{2}$ & $x^{2}-y^{2}$ & $x^{2}-y^{2}$ & $x^{2}-y^{2}$ \\
\hline$x y$ & $x y$ & $x y$ & $-x y$ & $-x y$ \\
\hline$y z$ & $y z$ & $-y z$ & $-y z$ & $y z$ \\
\hline$z x$ & $z x$ & $-z x$ & $z x$ & $-z x$ \\
\hline
\end{tabular}

この表を $\mathrm{C}_{2 \mathrm{v}}$ の character table と比べることにより次のような結果が得られる.

$$
\begin{aligned}
& d_{z^{2}}: A_{1} \\
& d_{x^{2}-y^{2}}: A_{1} \\
& d_{x^{2}-y^{2}}: A_{2} \\
& d_{y z}: B_{2} \\
& d_{z x}: B_{1}
\end{aligned}
$$

放Exercise 17.16.2

$\mathrm{CuCl}_{4}$ 2-における $\mathrm{Cu}$ 原子の $p$ および $d$ 軌道の属する既約表現を求めよ.

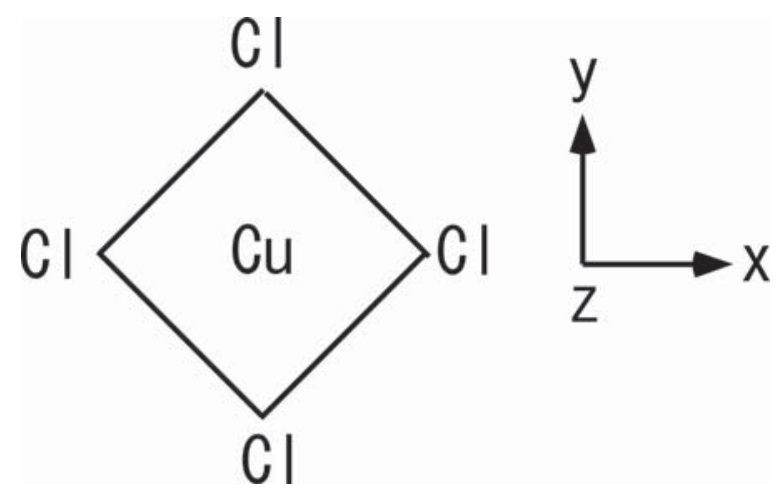




\section{【解】 :}

$\mathrm{Cu}$ 原子は $\mathrm{D}_{4 \mathrm{~h}}$ 点群にある. $\mathrm{D}_{4 \mathrm{~h}}$ における $x, y, z$ 関数の変換を求めると次の表 のようになる.
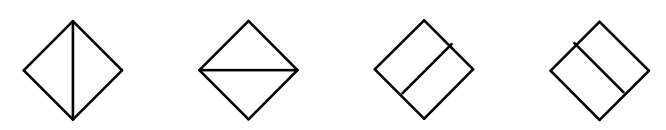

\begin{tabular}{|c||c|c|c|c|c|c|c|c|}
\hline \hline & $E$ & $C_{4}$ & $C_{4}{ }^{3}$ & $C_{2}$ & $C_{2}{ }^{\prime}$ & $C_{2}{ }^{\prime}$ & $C_{2}{ }^{\prime \prime}$ & $C_{2}{ }^{\prime \prime}$ \\
\hline \hline$x$ & $x$ & $y$ & $-y$ & $-x$ & $-x$ & $x$ & $y$ & $-y$ \\
\hline$y$ & $y$ & $-x$ & $x$ & $-y$ & $y$ & $-y$ & $x$ & $-x$ \\
\hline$z$ & $z$ & $z$ & $z$ & $z$ & $-z$ & $-z$ & $-z$ & $-z$ \\
\hline \hline
\end{tabular}
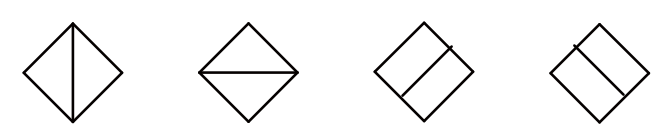

\begin{tabular}{|c||c|c|c|c|c|c|c|c||}
\hline \hline & $i$ & $S_{4}$ & $S_{4}{ }^{3}$ & $\sigma_{h}$ & $\sigma_{v}$ & $\sigma_{v}$ & $\sigma_{d}$ & $\sigma_{d}$ \\
\hline \hline$x$ & $-x$ & $y$ & $-y$ & $x$ & $-x$ & $x$ & $y$ & $-y$ \\
\hline$y$ & $-y$ & $-x$ & $x$ & $y$ & $y$ & $-y$ & $x$ & $-x$ \\
\hline$z$ & $-z$ & $-z$ & $-z$ & $-z$ & $z$ & $z$ & $z$ & $z$ \\
\hline
\end{tabular}

この表より $p$ 軌道については次の結果が得られる.

$$
\begin{array}{ll}
\left(p_{x}, p_{y}\right): & E_{u} \\
p_{z}: & A_{2 u}
\end{array}
$$


次に $d$ 軌道であるが，上の表をもとにして次の表が容易に得られる.

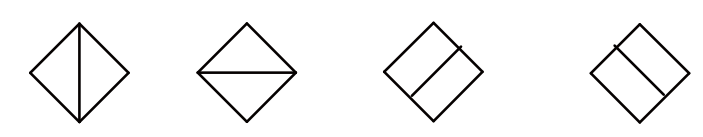

\begin{tabular}{|c||c|c|c|c|c|c|c|c||}
\hline \hline & $E$ & $C_{4}$ & $C_{4}{ }^{3}$ & $C_{2}$ & $C_{2}{ }^{\prime}$ & $C_{2}{ }^{\prime}$ & $C_{2}{ }^{\prime}$ & $C_{2}{ }^{\prime \prime}$ \\
\hline$z^{2}$ & $z^{2}$ & $z^{2}$ & $z^{2}$ & $z^{2}$ & $z^{2}$ & $z^{2}$ & $z^{2}$ & $z^{2}$ \\
\hline$x^{2}-y^{2}$ & $x^{2}-y^{2}$ & $-\left(x^{2}-y^{2}\right)$ & $-\left(x^{2}-y^{2}\right)$ & $x^{2}-y^{2}$ & $x^{2}-y^{2}$ & $x^{2}-y^{2}$ & $-\left(x^{2}-y^{2}\right)$ & $-\left(x^{2}-y^{2}\right)$ \\
\hline$x y$ & $x y$ & $-x y$ & $-x y$ & $x y$ & $-x y$ & $-x y$ & $x y$ & $x y$ \\
\hline$y z$ & $y z$ & $-z x$ & $z x$ & $-y z$ & $-y z$ & $y z$ & $-z x$ & $z x$ \\
\hline$z x$ & $z x$ & $y z$ & $-y z$ & $-z x$ & $z x$ & $-z x$ & $-y z$ & $y z$ \\
\hline \hline
\end{tabular}




\section{$\triangleright$
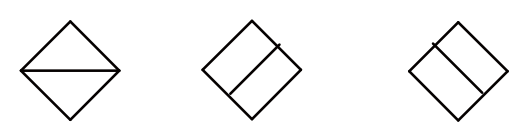

\begin{tabular}{||c||c|c|c|c|c|c|c|c||}
\hline \hline$z^{2}$ & $i$ & $S_{4}$ & $S_{4}{ }^{2}$ & $\sigma_{h}$ & $\sigma_{v}$ & $\sigma_{v}$ & $\sigma_{d}$ & $\sigma_{d}$ \\
\hline \hline$x^{2}-y^{2}$ & $z^{2}-y^{2}$ & $-\left(x^{2}-y^{2}\right)$ & $-\left(x^{2}-y^{2}\right)$ & $x^{2}-y^{2}$ & $x^{2}-y^{2}$ & $x^{2}-y^{2}$ & $-\left(x^{2}-y^{2}\right)$ & $-\left(x^{2}-y^{2}\right)$ \\
\hline$x y$ & $x y$ & $-x y$ & $-x y$ & $x y$ & $-x y$ & $-x y$ & $x y$ & $x y$ \\
\hline$y z$ & $y z$ & $z x$ & $-z x$ & $-y z$ & $y z$ & $-y z$ & $z x$ & $-z x$ \\
\hline$z x$ & $z x$ & $-y z$ & $y z$ & $-z x$ & $-z x$ & $z x$ & $y z$ & $-y z$ \\
\hline \hline
\end{tabular}

この表より $d$ 軌道として次の結果を得る.

$$
\begin{array}{ll}
d_{z^{2}}: & A_{1 g} \\
d_{x^{2}-y^{2}}: & B_{1 g} \\
d_{x y}: & B_{2 g} \\
\left(d_{z x}, d_{y z}\right): & E_{g}
\end{array}
$$

$p$ 軌道, $d$ 軌道の属寸る既約表現は以上のようにして, 簡単に求まる. 手続きは簡単 ではあるが，ある程度の手数はかかる。この手数を省くために，たいていの character table には, $p$ 関数と $d$ 関数の属する既約表現が示されている. 


\subsection{7 混成軌道}

前節で求めた原子軌道関数の属する既約表現の知識をもとに混成軌道についての 知見を得ることが出来る. それにはまず, 注目している原子のまわりの結合軌道がど のような既約表現に属するかを調べる。これが分かれば $s, p, d$ 軌道関数の線形結 合としてその結合軌道がどのように表わされるかが直ちに分かる．以下，いくつかの 具体的な例を考えてみよう.

\section{㶦Exercise 17.17.1}

平面構造の $\mathrm{AB}_{3}$ 型の分子（すなわち $\mathrm{D}_{3 \mathrm{~h}}$ 点群）について, $\mathrm{A}$ 原子のまわりの結合 としてはどのような混成軌道が考えられるか. 可能な混成軌道の型すべてを挙げよ.

\section{【解】 :}

まず 3 つの A-B 結合軌道がどのような既約表現として表わされるかを求めよう. 例によって character table をそっくりそのまま写すことから始めるが， $s, p, d$ 各関 数の属する既約表現もはっきり分かるように character table に書き込んでおこう

\begin{tabular}{||c|c|c|c|c|c|c||c||}
\hline $\mathrm{D}_{3 h}$ & $E$ & $2 C_{3}$ & $3 C_{2}{ }^{\prime}$ & $\sigma_{h}$ & $2 S_{3}$ & $3 \sigma_{v}$ & \\
\hline \hline$A_{1}{ }^{\prime}$ & 1 & 1 & 1 & 1 & 1 & 1 & $s, d_{z^{2}}$ \\
\hline$A_{2}{ }^{\prime}$ & 1 & 1 & -1 & 1 & 1 & -1 & \\
\hline$E^{\prime}$ & 2 & -1 & 0 & 2 & -1 & 0 & $\left(p_{x}, p_{y}\right)$ \\
\hline$A_{1}{ }^{\prime \prime}$ & 1 & 1 & 1 & -1 & -1 & -1 & $\left(d_{x^{2}-y^{2}}, d_{x y}\right)$ \\
\hline$A_{2}{ }^{\prime \prime}$ & 1 & 1 & -1 & -1 & -1 & 1 & $p_{z}$ \\
\hline$E^{\prime \prime}$ & 2 & -1 & 0 & -2 & 1 & 0 & $\left(d_{x z}, d_{y z}\right)$ \\
\hline \hline$\chi_{A-B}$ & 3 & 0 & 1 & 3 & 0 & 1 & $A_{1}{ }^{\prime}+E^{\prime}$ \\
\hline \hline
\end{tabular}


この表から分かるように $3 つ の ~ \mathrm{~A}-\mathrm{B}$ 結合の属する既約表現は $A_{1}{ }^{\prime}+E^{\prime}$ である. $\mathrm{A}$ 原 子の atomic orbital のうち $A_{1}{ }^{\prime}$ に属するものは $s$ 軌道および $d_{z^{2}}$ 轨道, 縮退表現 $E^{\prime}$ に属す るものは $\left(p_{x}, p_{y}\right)$ 軌道および $\left(d_{x^{2}-y^{2}}, d_{x y}\right)$ 軌道ということになる. 結局, 可能な混成の 型をすべて羅列すると

$$
\begin{array}{ll}
s+\left(p_{x}, p_{y}\right): & s p^{2} \text { 混成 } \\
s+\left(d_{x^{2}-y^{2}}, d_{x y}\right): & s d^{2} \text { 混成 } \\
d_{z^{2}}+\left(p_{x}, p_{y}\right): & d p^{2} \text { 混成 } \\
d_{z^{2}}+\left(d_{x^{2}-y^{2}}, d_{x y}\right): & d^{3} \text { 混成 }
\end{array}
$$

の 4 種類である.

ここで，例えば $s p^{2}$ 混成の $s+\left(p_{x}, p_{y}\right)$ という式は， $s$ 軌道， $p_{x}$ 軌道， $p_{y}$ 軌道の適当 な線形結合で混成軌道を表すという意味で, この場合の線形結合の係数をどうやって 決定するかはすぐ下に例を示す．(たとえば，後述の式(17.17.20).)

これら 4 種類の混成軌道はすべて同じ表現を持つのでお互いに混じり合い,この中 の 1 つのみの混成ということは原理的にあり得ない，しかし，ある分子を考えたとき にはどの混成がもっとも重要であるかは簡単に分かる. 例えば炭素原子を中心とする 混成軌道の場合には $2 s$ および $2 p$ 軌道に比べて $3 d$ 軌道はずっと高いエネルギーを持 つので $3 d$ 軌道の関与寸る混成はほとんど寄与しないはずである。そういうわけで炭 素原子の場合には $s p^{2}$ 混成のみと考えてほぼよいことになる。一方，遷移金属の錯体 の場合には $d$ 軌道の関与はより重要になることは容易に分かる.

诂Exercise 17.17.2

tetrahedral 構造の $\mathrm{AB}_{4}$ 型の分子について, A 原子のまわりの結合としてはどのよう な混成軌道が考えられるか. 可能な混成軌道の型すべてを挙げよ. 
【解】 :

表 17.17 .2

\begin{tabular}{||c||c|c|c|c|c||c||}
\hline \hline$T_{\mathrm{d}}$ & $E$ & $8 C_{3}$ & $3 C_{2}$ & $6 S_{4}$ & $6 \sigma_{d}$ & \\
\hline \hline$A_{1}$ & 1 & 1 & 1 & 1 & 1 & $s$ \\
\hline$A_{2}$ & 1 & 1 & 1 & -1 & -1 & \\
\hline$E$ & 2 & -1 & 2 & 0 & 0 & $\left(d_{z^{2}}, d_{x^{2}-y^{2}}\right)$ \\
\hline$T_{1}$ & 3 & 0 & -1 & 1 & -1 & \\
\hline$T_{2}$ & 3 & 0 & -1 & -1 & 1 & $\begin{array}{c}\left(p_{x}, p_{y}, p_{z}\right) \\
\left(d_{x y}, d_{y z}, d_{z x}\right)\end{array}$ \\
\hline \hline$\chi_{A-B}(G)$ & 4 & 1 & 0 & 0 & 2 & $A_{1}+T_{2}$ \\
\hline \hline
\end{tabular}

この表から分かるように 4 つの $\mathrm{A}-\mathrm{B}$ 結合の属する既約表現は $A_{1}+T_{2}$ である. $\mathrm{A}$ 原子 の atomic orbital のうち $A_{1}$ に属するものは $s$ 軌道, $T_{2}$ に属するものは $p_{x}, p_{y}, p_{z}$ 軌道 または $d_{x y}, d_{y z}, d_{z x}$ 軌道ということになる，結局，可能な混成の型は

$$
\begin{array}{ll}
s+\left(p_{x}, p_{y}, p_{z}\right): & s p^{3} \text { 混成 } \\
s+\left(d_{x y}, d_{y z}, d_{z x}\right): & s d^{3} \text { 混成 }
\end{array}
$$

の 2 種類である.

论Exercise 17.17.3

平面構造の $\mathrm{AB}_{4}$ 型分子について, $\mathrm{A}$ のまわりの結合として可能な混成軌道を全て 求めよ.

\section{【解】：}




\begin{tabular}{|c|c|c|c|c|c|c|c|c|c|c|c|}
\hline $\mathrm{D}_{4 h}$ & $E$ & $2 C_{4}$ & $C_{2}$ & $2 C_{2}{ }^{\prime}$ & $2 C_{2} "$ & $i$ & $2 S_{4}$ & $\sigma_{h}$ & $2 \sigma_{v}$ & $2 \sigma_{d}$ & \\
\hline$A_{1 g}$ & 1 & 1 & 1 & 1 & 1 & 1 & 1 & 1 & 1 & 1 & $s, d_{z^{2}}$ \\
\hline$A_{2 g}$ & 1 & 1 & 1 & -1 & -1 & 1 & 1 & 1 & -1 & -1 & \\
\hline$B_{1 g}$ & 1 & -1 & 1 & 1 & -1 & 1 & -1 & 1 & 1 & -1 & $d_{x^{2}-y^{2}}$ \\
\hline$B_{2 g}$ & 1 & -1 & 1 & -1 & 1 & 1 & -1 & 1 & -1 & 1 & $d_{x y}$ \\
\hline$E_{g}$ & 2 & 0 & -2 & 0 & 0 & 2 & 0 & -2 & 0 & 0 & $\left(d_{y z}, d_{z x}\right)$ \\
\hline$A_{1 u}$ & 1 & 1 & 1 & 1 & 1 & -1 & -1 & -1 & -1 & -1 & \\
\hline$A_{2 u}$ & 1 & 1 & 1 & -1 & -1 & -1 & -1 & -1 & 1 & 1 & $p_{z}$ \\
\hline$B_{1 u}$ & 1 & -1 & 1 & 1 & -1 & -1 & 1 & -1 & -1 & 1 & \\
\hline$B_{2 u}$ & 1 & -1 & 1 & -1 & 1 & -1 & 1 & -1 & 1 & -1 & \\
\hline$E_{u}$ & 2 & 0 & -2 & 0 & 0 & -2 & 0 & 2 & 0 & 0 & $\left(p_{x}, p_{y}\right)$ \\
\hline$\chi_{A-B}(G)$ & 4 & 0 & 0 & 2 & 0 & 0 & 0 & 4 & 2 & 0 & $A_{1 g}+B_{1 g}+E_{\imath}$ \\
\hline
\end{tabular}

この表より可能な混成軌道の型は次の通りであることが分かる.

$$
\begin{aligned}
& s+d_{x^{2}-y^{2}}+\left(p_{x}, p_{y}\right): d s p^{2} \text { 混成 } \\
& d_{z^{2}}+d_{x^{2}-y^{2}}+\left(p_{x}, p_{y}\right): d^{2} p^{2} \text { 混成 }
\end{aligned}
$$


以上で混成軌道の種類を求める方法を学習したが, 分子軌道的な考えで何かを計算 しようとすれば混成軌道の具体的な関数形が必要となる。 そこで, 以下，混成軌道の 関数形を求める方法を学習しよう.

理屈をいろいろと述べるよりも具体的な例から入るのが分かりやすいであろう.例 として， $s p^{2}$ 混成軌道について考えてみよう. $3 つ の ~ s p^{2}$ 混成軌道を $\Phi_{1}, \Phi_{2}, \Phi_{3}$ と表 すことにしよう。これらの混成軌道を $s$ 軌道, $p_{x}$ 軌道, および $p_{y}$ 軌道の線形結合とし て表すわけである。すなわち,

$$
\Phi_{i}=a_{i} s+b_{i} p_{x}+c_{i} p_{y}
$$

をiについて 1 から 3 まで求めることになる.

まず, 1 つの混成軌道例えば $\Phi_{1}$ は $x$ 軸の方向にあるとしよう。この場合, 当然 $p_{y}$ 軌

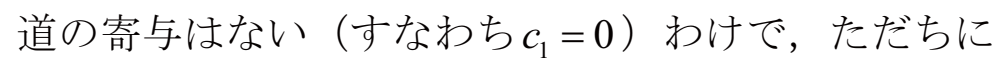

$$
\Phi_{1}=a_{1} s+b_{1} p_{x}
$$

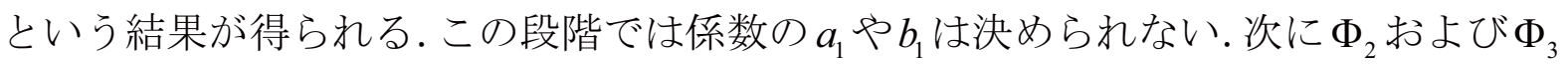
を求めるのであるが， $\Phi_{2}$ は $\Phi_{1}$ に対称操作 $C_{3}$ を作用したものと考える. そうすれば $\Phi_{3}$ は $\Phi_{1}$ に $C_{3}^{2}$ を作用したものとなる，まず， $\Phi_{2}$ を考えよう，当然

$$
\Phi_{2}=a_{2} s+b_{2} p_{x}+c_{2} p_{y}
$$

であるが上述したように

$$
\Phi_{2}=C_{3} \Phi_{1}
$$

に着目する。

$$
\begin{aligned}
& C_{3} s=s \\
& C_{3} p_{x}=-\frac{1}{2} p_{x}+\frac{\sqrt{3}}{2} p_{y}
\end{aligned}
$$

であるから（例えば図 17.5.1ですでに求めている.） 


$$
\begin{aligned}
\Phi_{2} & =C_{3}\left(a_{1} s+b_{1} p_{x}\right) \\
& =a_{1} s+b_{1}\left(-\frac{1}{2} p_{x}+\frac{\sqrt{3}}{2} p_{y}\right) \\
& =a_{1} s+\left(-\frac{1}{2} b_{1}\right) p_{x}+\left(\frac{\sqrt{3}}{2} b_{1}\right) p_{y}
\end{aligned}
$$

従って

$$
\begin{aligned}
& a_{2}=a_{1} \\
& b_{2}=-\frac{1}{2 .} b_{1} \\
& c_{2}=\frac{\sqrt{3}}{2} b_{1}
\end{aligned}
$$

のような関係が得られる。

$\Phi_{3}$ についも同様に $\Phi_{1}$ に $C_{3}{ }^{2}$ を作用して係数の関係を求めることが出来るが，こ こではもっと簡単に， $\Phi_{3}$ は $\Phi_{2}$ に $x z$ 面を含む $\sigma$ を作用することによっても得られるこ とに着目しよう。

$$
\begin{aligned}
& \sigma s=s \\
& \sigma p_{x}=p_{x} \\
& \sigma p_{y}=-p_{y}
\end{aligned}
$$

であるから

$$
\begin{aligned}
\Phi_{3} & =a_{3} s+b_{3} p_{x}+c_{3} p_{y} \\
& =\sigma\left(a_{2} s+b_{2} p_{x}+c_{2} p_{y}\right) \\
& =a_{2} s+b_{2} p_{x}-c_{2} p_{y}
\end{aligned}
$$

となる。結局

$$
\begin{aligned}
& a_{3}=a_{2} \\
& b_{3}=b_{2} \\
& c_{3}=-c_{2}
\end{aligned}
$$

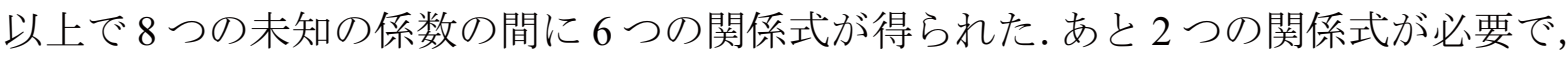
混成軌道同士が規格直交系をなしているという条件から適当に 2 つを選べばよい. 例 えば $\Phi_{2}$ の normalization condition

$$
a_{2}^{2}+b_{2}^{2}+c_{2}^{2}=1
$$


および $\Phi_{2}$ と $\Phi_{3}$ とが直交するという条件

$$
a_{2} a_{3}+b_{2} b_{3}+c_{2} c_{3}=0
$$

を加える. こうして 8 つの未知数に対して 8 つの関係式が得られ，8つの未知数す心゙ てを決めることが出来る。こうして混成軌道は以下のように求まる.

$$
\begin{aligned}
& \Phi_{1}=\sqrt{\frac{1}{3}} s+\sqrt{\frac{2}{3}} p_{x} \\
& \Phi_{2}=\sqrt{\frac{1}{3}} s-\sqrt{\frac{1}{6}} p_{x}+\sqrt{\frac{1}{2}} p_{y} \\
& \Phi_{3}=\sqrt{\frac{1}{3}} s-\sqrt{\frac{1}{6}} p_{x}-\sqrt{\frac{1}{2}} p_{y}
\end{aligned}
$$


is Problem 17.17.1

平面構造の $\mathrm{AB}_{5}$ 型分子（ $\mathrm{D}_{5 \mathrm{~h}}$ 点群）について $\mathrm{A}$ のまわりの結合として可能な混成 軌道の全てを求めよ.

\section{$\mathrm{D}_{5 \mathrm{~h}}$ の指標表}

\begin{tabular}{|c|c|c|c|c|c|c|c|c|c|}
\hline $\mathrm{D}_{5 \mathrm{~h}}$ & $E$ & $2 C_{5}$ & $2 C_{5}^{2}$ & $5 C_{2}$ & $\sigma_{h}$ & $2 S_{5}$ & $2 S_{5}^{3}$ & $5 \sigma_{v}$ & \\
\hline$A_{1}^{\prime}$ & 1 & 1 & 1 & 1 & 1 & 1 & 1 & 1 & $x^{2}+y^{2}, z^{2}$ \\
\hline$A_{2}^{\prime}$ & 1 & 1 & 1 & -1 & 1 & 1 & 1 & -1 & $R_{z}$ \\
\hline$E_{1}^{\prime}$ & 2 & $2 \cos \theta$ & $2 \cos 2 \theta$ & 0 & 2 & $2 \cos \theta$ & $2 \cos 2 \theta$ & 0 & $(x, y)$ \\
\hline$E_{2}^{\prime}$ & 2 & $2 \cos 2 \theta$ & $2 \cos \theta$ & 0 & 2 & $2 \cos 2 \theta$ & $2 \cos \theta$ & 0 & $\left(x^{2}-y^{2}, x y\right)$ \\
\hline$A_{1}^{\prime \prime}$ & 1 & 1 & 1 & 1 & -1 & -1 & -1 & -1 & \\
\hline$A_{2}^{\prime \prime}$ & 1 & 1 & 1 & -1 & -1 & -1 & -1 & 1 & $z$ \\
\hline$E_{1}^{\prime \prime}$ & 2 & $2 \cos \theta$ & $2 \cos 2 \theta$ & 0 & -2 & $-2 \cos \theta$ & $2 \cos 2 \theta$ & 0 & \\
\hline$E_{2}^{\prime \prime}$ & 2 & $2 \cos 2 \theta$ & $2 \cos \theta$ & 0 & -2 & $-2 \cos 2 \theta$ & $-2 \cos \theta$ & 0 & $\begin{array}{l}\left(R_{x}, R_{y}\right) \\
(x z, y z)\end{array}$ \\
\hline
\end{tabular}

$\theta=2 \pi / 5=72^{\circ}$

交Problem 17.17.2

Exercise 17.17.3 で求めた混成軌道の具体的な関数形を求めよ. 


\subsection{8 規準振動}

この節では分子の規準振動（normal vibration）がどういう既約表現に属するかを求 める方法を学習する. 分子の振動状態のありさまは赤外線吸収スペクトルおよびラマ ン散乱スペクトル（単に「ラマンスペクトル」とも言う）の測定により理解出来るが, この解析の際，規準振動の既約表現を知ることは，最初に行わなければならない基本 的なステップである.

1 つの分子が $n$ 個の原子から構成されているとしよう. 1 つの原子が $x, y, z$ の 3 方向に動く可能性があるので, $n$ 個の原子では $3 n$ 個の運動の自由度がある.このうち, すべての原子が同じ方向に動けば，それは分子全体が形を変えないで，並進運動をし たことになり，分子内の振動にはならない。こういう分子全体の振動が 3 個あり, 更 に，分子全体の回転が 3 個ある。（分子が直線であれば，その直線の回りの回転は無 意味だから回転の自由度は 2 つである）従って，これら分子全体の並進と回転を除い て，3n-6 個の振動モードがあることになる。すなわち，3n-6個の規準振動（直線 分子の場合には $3 n-5$ 個の規準振動）がある。（本来ならば「規準振動」の定義から学 習しなければいけないのであるが，ここでは群論の応用という観点に重きをおいて， 規準振動そのものの学習を省略する.)

規準振動の持つ既約表現を求めるには，まず， $3 n$ 個の 運動全てについて求め, その後, 並進および回転の部分 を差し引くのが便利であろう。例として $\mathrm{C}_{2 \mathrm{v}}$ に属する $\mathrm{H}_{2} \mathrm{O}$ 分子の振動について考えよう. 分子平面を $y z$ 面とす 1

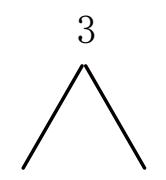

2

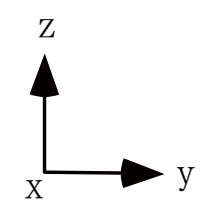
る. 2 つの水素原子をそれぞれ 1 および 2 と番号を付け, 酸素原子を 3 とする. 原子 1 の $x$ 軸, $y$ 軸, $z$ 軸方向への微小変位をそれぞれ $x_{1}, y_{1}$, $z_{1}$ とする. 原子 2 については $x_{2}, y_{2}, z_{2}$, 原子 3 についても同様に $x_{3}, y_{3}, z_{3}$ とす る。まず，分子の対称操作によって，これらが如何に変換されるかを調べよう。例え ば， $C_{2}$ によって，

$$
\begin{aligned}
& C_{2} x_{1}=-x_{2} \\
& C_{2} y_{1}=-y_{2} \\
& C_{2} z_{1}=z_{2}
\end{aligned}
$$

のように変換される.このようなことを，すべての対称操作について行うと次のよう な結果が得られる。 


$$
\begin{aligned}
& E\left[\begin{array}{lllllllll}
x_{1} & y_{1} & z_{1} & x_{2} & y_{2} & z_{2} & x_{3} & y_{3} & z_{3}
\end{array}\right] \\
& =\left[\begin{array}{lllllllllll}
x_{1} & y_{1} & z_{1} & x_{2} & y_{2} & z_{2} & x_{3} & y_{3} & z_{3}
\end{array}\right]\left[\begin{array}{llllllllll}
1 & 0 & 0 & 0 & 0 & 0 & 0 & 0 & 0 \\
0 & 1 & 0 & 0 & 0 & 0 & 0 & 0 & 0 \\
0 & 0 & 1 & 0 & 0 & 0 & 0 & 0 & 0 \\
0 & 0 & 0 & 1 & 0 & 0 & 0 & 0 & 0 \\
0 & 0 & 0 & 0 & 1 & 0 & 0 & 0 & 0 \\
0 & 0 & 0 & 0 & 0 & 1 & 0 & 0 & 0 \\
0 & 0 & 0 & 0 & 0 & 0 & 1 & 0 & 0 \\
0 & 0 & 0 & 0 & 0 & 0 & 0 & 1 & 0 \\
0 & 0 & 0 & 0 & 0 & 0 & 0 & 0 & 1
\end{array}\right]
\end{aligned}
$$

$$
\begin{aligned}
& C_{2}\left[\begin{array}{lllllllll}
x_{1} & y_{1} & z_{1} & x_{2} & y_{2} & z_{2} & x_{3} & y_{3} & z_{3}
\end{array}\right]
\end{aligned}
$$

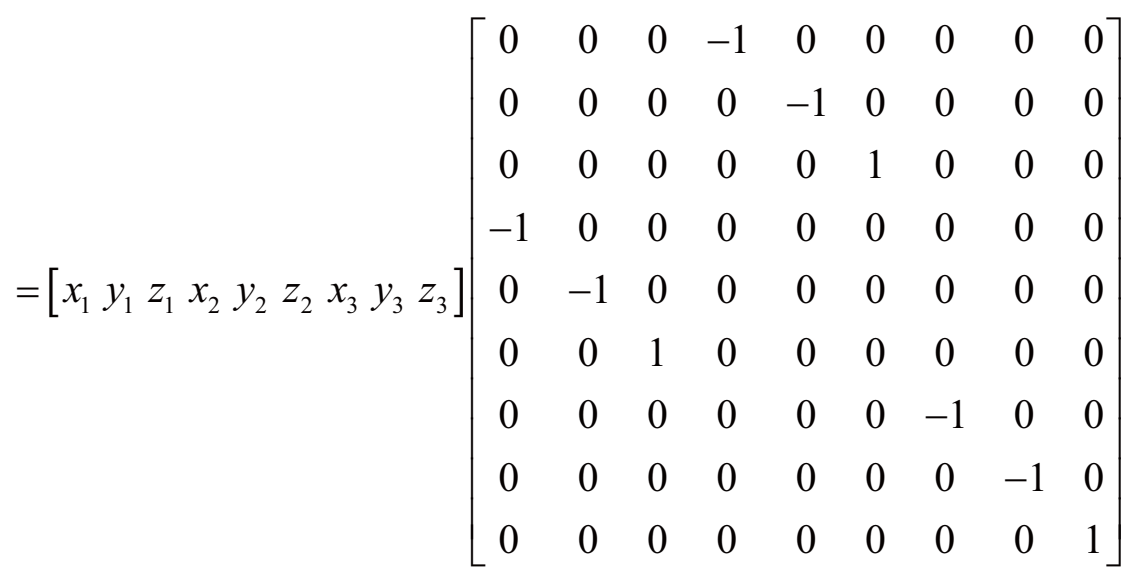

$$
\begin{aligned}
& \sigma(x z)\left[\begin{array}{lllllllll}
x_{1} & y_{1} & z_{1} & x_{2} & y_{2} & z_{2} & x_{3} & y_{3} & z_{3}
\end{array}\right]
\end{aligned}
$$

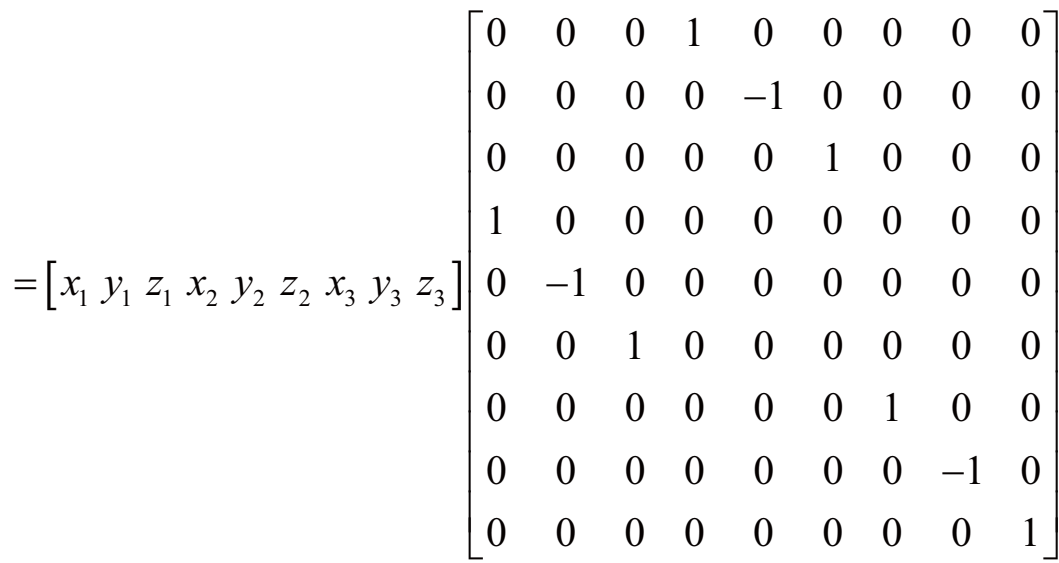




$$
\begin{aligned}
& \sigma(y z)\left[\begin{array}{lllllllll}
x_{1} & y_{1} & z_{1} & x_{2} & y_{2} & z_{2} & x_{3} & y_{3} & z_{3}
\end{array}\right]
\end{aligned}
$$

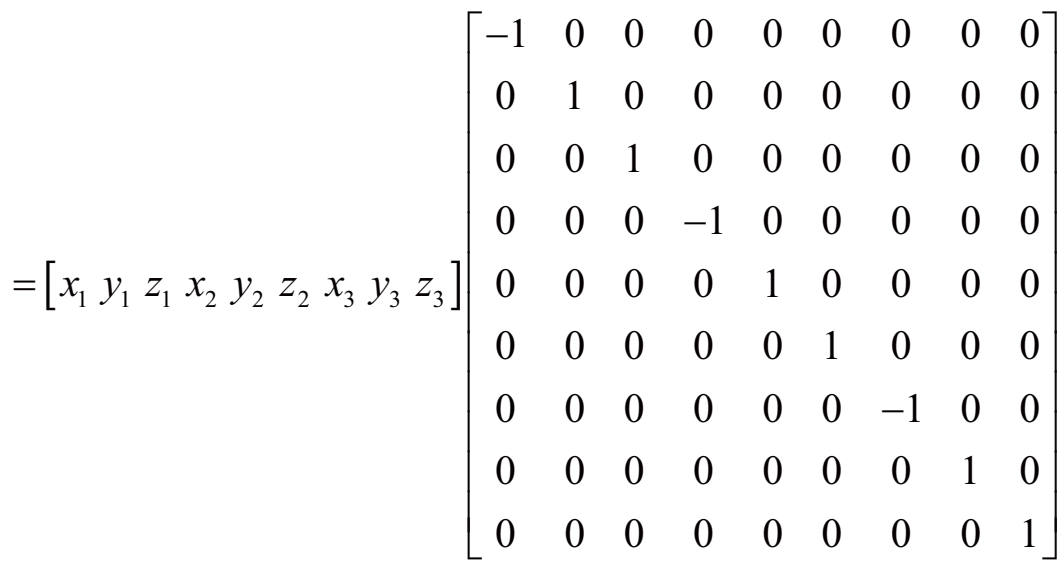

各表現行列の対角項の和をとることにより character は次のようになる.

$$
\begin{aligned}
& \chi(E)=9 \\
& \chi\left(C_{2}\right)=-1 \\
& \chi(\sigma(x z))=1 \\
& \chi(\sigma(y z))=3
\end{aligned}
$$

さて, 今まで学習して来たように, 表現行列を正しい形で求めなくても多くの場合 にはその characterのみで十分である。この場合もまさしくそうで, characterだけを求 めれば当面の役に立つ。では，表現行列を求めないで character を求めるにはどうした らいいであろうか。

式(17.18.1)をみれば分かるように，対角項に 0 以外の值が表れるためには，少なく とも, 対称操作によって原子の位置が変わらないことが必要である. そしてその原子 上の $x, y, z$ 方向の変位が対称操作によりどういうふうに変換されるかを調べれば よいことが分かる. すなわち, 分子中の全ての原子の運動についての character $\chi_{\text {motion }}$ は，対称操作によって位置を変えない原子の数に，その原子上の変位 $x, y, z$ につ いての character を掛けたものとなる。すなおち，

$$
\begin{gathered}
\chi_{\text {motion }}=(\text { number of atoms unchanged by symmetry operation }) \\
\times(\text { character for } x, y, z)
\end{gathered}
$$

第 1 項の対称操作によって位置を変えない原子の数は直ちに求まるであろう. 第 2 項 の $x, y, z$ についての character もたいていの場合はすぐ分かるであろうが， $\frac{2 \pi}{3}$ の回 転とか $\frac{2 \pi}{6}$ の回転の場合にはちょっとばかり厄介かもしれない.そのために，実は本 
lecture noteでは繰り返しこれを求めて来たわけである. 例えば, Problem 17.5.2を行 った人は結果が表 17.5.1 にまとめてあるはずである. 式(17.18.3)に基づいて, $\mathrm{H}_{2} \mathrm{O}$ を 構成する原子の運動を解析してみよう。例によって, character tableをそのまま写し, その下の行に必要なものを記入していくのが間違いをなくすコツである.

まず式(17.18.3)に従って $\chi_{\text {motion }}$ を計算する．間違いをなくすには，表のように「対 称操作によって変わらない原子の数」と「 $x, y, z$ を基底とした時の表現行列の character（仮に $\chi_{x y z}$ と表す）」を表に記入し，この 2 つの掛算から $\chi_{\text {motion }}$ を計算するの がよかろう。これは既約表現の和として表わす。この結果を $\chi_{\text {motion }}$ を記入した行の右 側に書いておこう。表に記入してあるように

$$
\Gamma_{\text {motion }}=3 A_{1}+A_{2}+2 B_{1}+3 B_{2}
$$

次にこの中から分子全体の並進と回転の寄与を差し引かなければならない。並進 （translation）に関する既約表現は，既に記入してある $\chi_{x y z}$ を既約表現の和として表わ してもよいが（どうしてそうなるか考えよ）, もっとも手っ取り早いのは, character table の右の欄に記入してある $x, y, z$ の所をみればよい. そこで直ちに

$$
\Gamma_{\text {trans }}=A_{1}+B_{1}+B_{2}
$$

であることが分かる．次に回転（rotation）であるが，これは character table に $R_{x}, R_{y}$ ， $R_{z}$ と書いてあるのがそれぞれ $x$ 軸, $y$ 軸, $z$ 軸まわりの回転ということであるから

$$
\Gamma_{\text {rot }}=A_{2}+B_{1}+B_{2}
$$

結局

$$
\begin{aligned}
\Gamma_{\text {vib }} & =\Gamma_{\text {motion }}-\Gamma_{\text {trans }}-\Gamma_{\text {rot }} \\
& =2 A_{1}+B_{2}
\end{aligned}
$$

すなわち，規準振動は $A_{1}$ 既約表現が 2 つ， $B_{2}$ 既約表現が 1 つあるということが分か る。 


\begin{tabular}{||c||c|c|c|c||c||}
\hline & $E$ & $C_{2}(z)$ & $\sigma(x z)$ & $\sigma(y z)$ & \\
\hline \hline$A_{1}$ & 1 & 1 & 1 & 1 & $R_{z}$, \\
\hline$A_{2}$ & 1 & 1 & -1 & -1 & $x, R_{y}$ \\
\hline$B_{1}$ & 1 & -1 & 1 & -1 & $y, R_{x}$ \\
\hline$B_{2}$ & 1 & -1 & -1 & 1 & 3 \\
\hline \hline 不変原子の数 & 3 & 1 & 1 & 3 & $3 A_{1}+A_{2}+2 B_{1}+3 B_{2}$ \\
\hline$\chi_{x y z}$ & 3 & -1 & 1 & 1 & 3 \\
\hline \hline$\chi_{\text {motion }}$ & 9 & -1 & 1 & \multicolumn{1}{|c||}{} \\
\hline \hline
\end{tabular}

この章を終わるにあたり，ここで用いた「規準振動」という言葉について述べる. ここでは，「規準振動」という言葉を用いたが，「基準振動」が正しいと主張する学者 もいる．ただ，私にとっては，英語の normal vibration の翻訳としては「規準振動」の 方がふさわしいという感じを捨てきれない。

斿Problem 17.18.1

cis- $\mathrm{C}_{2} \mathrm{H}_{2} \mathrm{Cl}_{2}\left(\mathrm{C}_{2 \mathrm{v}}\right)$ の規準振動の既約表現を求めよ。(ここで分子面を $y z$ 面とする $)$ それらのうち赤外活性振動、ラマン活性振動それぞれの既約表現を示せ。 
$\mathrm{C}_{2 \mathrm{v}}$ の指標表

\begin{tabular}{||c||c|c|c|c||c||}
\hline $\mathrm{C}_{2 \mathrm{v}}$ & $E$ & $C_{2}$ & $\sigma(x z)$ & $\sigma(y z)$ & \\
\hline \hline$A_{1}$ & 1 & 1 & 1 & 1 & $z, x^{2}, y^{2}, z^{2}$ \\
\hline$A_{2}$ & 1 & 1 & -1 & -1 & $R_{z}, \quad x y$ \\
\hline$B_{1}$ & 1 & -1 & 1 & -1 & $x, R_{y}, \quad x z$ \\
\hline$B_{2}$ & 1 & -1 & -1 & 1 & $y, R_{x}, \quad y z$ \\
\hline \hline 不変原子の数 & & & & \\
\hline$\chi_{x y z}$ & & & & \\
\hline$\chi_{\text {motion }}$ & & & & \\
\hline \hline
\end{tabular}

㶦Problem 17.18.2

$\mathrm{C}_{2} \mathrm{H}_{6} （ \mathrm{D}_{3 \mathrm{~d}}$ ）の規準振動の既約表現を求めよ。それらのうち赤外活性振動、ラマ ン活性振動それぞれの既約表現を示せ。 


\section{$\mathrm{D}_{3 \mathrm{~d}}$ の指標表}

\begin{tabular}{||c||c|c|c|c|c|c||c||}
\hline $\mathrm{D}_{3 \mathrm{~d}}$ & $E$ & $2 C_{3}$ & $3 C_{2}$ & $i$ & $2 S_{6}$ & $3 \sigma_{d}$ & \\
\hline \hline$A_{1 g}$ & 1 & 1 & 1 & 1 & 1 & 1 & $\begin{array}{c}x^{2}+y^{2} \\
z^{2}\end{array}$ \\
\hline$A_{2 g}$ & 1 & 1 & -1 & 1 & 1 & -1 & $R_{z}$ \\
\hline$E_{g}$ & 2 & -1 & 0 & 2 & -1 & 0 & $\begin{array}{c}\left(R_{x}, R_{y}\right) \\
\left(x^{2}-y^{2}, x y\right) \\
(x z, y z)\end{array}$ \\
\hline$A_{1 u}$ & 1 & 1 & 1 & -1 & -1 & -1 & $z$ \\
\hline$A_{2 u}$ & 1 & 1 & -1 & -1 & -1 & 1 & $(x, y)$ \\
\hline$E_{u}$ & 2 & -1 & 0 & -2 & 1 & 0 & \\
\hline \hline 不変原子の数 & & & & & & & \\
\hline$\chi_{x y z}$ & & & & & & & \\
\hline$\chi_{\text {motion }}$ & & & & & & & \\
\hline \hline
\end{tabular}

¿ 2 Problem 17.18.3

$\mathrm{SiF}_{6}\left(\mathrm{O}_{\mathrm{h}}\right)$ の規準振動の既約表現を求めよ。それらのうち赤外活性振動、ラマン 活性振動それぞれの既約表現を示せ。 
$\mathrm{O}_{\mathrm{h}}$ の指標表

\begin{tabular}{||c||c|c|c|c|c|c|c|c|c|c||c||}
\hline \hline $\mathrm{O}_{\mathrm{h}}$ & $E$ & $8 C_{3}$ & $3 C_{2}$ & $6 C_{2}{ }^{\prime}$ & $6 C_{4}$ & $i$ & $8 S_{6}$ & $3 \sigma_{h}$ & $6 \sigma_{d}$ & $6 S_{4}$ & \\
\hline \hline$A_{1 g}$ & 1 & 1 & 1 & 1 & 1 & 1 & 1 & 1 & 1 & 1 & $x^{2}+y^{2}+z^{2}$ \\
\hline$A_{2 g}$ & 1 & 1 & 1 & -1 & -1 & 1 & 1 & 1 & -1 & -1 & \\
\hline$E_{g}$ & 2 & -1 & 2 & 0 & 0 & 2 & -1 & 2 & 0 & 0 & $\left(x^{2}+y^{2}-2 z^{2}, x^{2}-y^{2}\right)$ \\
\hline$T_{1 g}$ & 3 & 0 & -1 & -1 & 1 & 3 & 0 & -1 & -1 & 1 & $\left(R_{x}, R_{y}, R_{z}\right)$ \\
\hline$T_{2 g}$ & 3 & 0 & -1 & 1 & -1 & 3 & 0 & -1 & 1 & -1 & $(x y, y z, z x)$ \\
\hline$A_{1 u}$ & 1 & 1 & 1 & 1 & 1 & -1 & -1 & -1 & -1 & -1 & \\
\hline$A_{2 u}$ & 1 & 1 & 1 & -1 & -1 & -1 & -1 & -1 & 1 & 1 & \\
\hline$E_{u}$ & 2 & -1 & 2 & 0 & 0 & -2 & 1 & -2 & 0 & 0 & \\
\hline$T_{1 u}$ & 3 & 0 & -1 & -1 & 1 & -3 & 0 & 1 & 1 & -1 & $(x, y, z)$ \\
\hline$T_{2 u}$ & 3 & 0 & -1 & 1 & -1 & -3 & 0 & 1 & -1 & 1 & \\
\hline \hline & & & & & & & & & & & \\
\hline & & & & & & & & & & & \\
\hline & & & & & & & & & & & \\
\hline \hline
\end{tabular}


¿2 Problem 17.18.4

ベンゼン（D $6 h ）$ の規準振動の既約表現を求めよ。それらのうち赤外活性振動、ラ マン活性振動それぞれの既約表現を示せ。 
$\mathrm{D}_{6 \mathrm{~h}}$ の指標表

\begin{tabular}{|c|c|c|c|c|c|c|c|c|c|c|c|c|c|}
\hline $\mathrm{D}_{6 \mathrm{~h}}$ & $E$ & $2 C_{6}$ & $2 C_{6}^{2}$ & $C_{6}{ }^{3}$ & $3 C_{2}^{\prime}$ & $3 C_{2} "$ & $\sigma_{h}$ & $3 i C_{2} "$ & $3 i C_{2}^{\prime}$ & $2 S_{6}$ & $2 S_{3}$ & $i$ & \\
\hline$A_{1 g}$ & 1 & 1 & 1 & 1 & 1 & 1 & 1 & 1 & 1 & 1 & 1 & 1 & $\begin{array}{c}x^{2}+y^{2} \\
z^{2}\end{array}$ \\
\hline$A_{1 u}$ & 1 & 1 & 1 & 1 & 1 & 1 & -1 & -1 & -1 & -1 & -1 & -1 & \\
\hline$A_{2 g}$ & 1 & 1 & 1 & 1 & -1 & -1 & 1 & -1 & -1 & 1 & 1 & 1 & $R_{z}$ \\
\hline$A_{2 u}$ & 1 & 1 & 1 & 1 & -1 & -1 & -1 & 1 & 1 & -1 & -1 & -1 & $z$ \\
\hline$B_{1 g}$ & 1 & -1 & 1 & -1 & 1 & -1 & -1 & -1 & 1 & 1 & -1 & 1 & \\
\hline$B_{1 u}$ & 1 & -1 & 1 & -1 & 1 & -1 & 1 & 1 & -1 & -1 & 1 & -1 & \\
\hline$B_{2 g}$ & 1 & -1 & 1 & -1 & -1 & 1 & -1 & 1 & -1 & 1 & -1 & 1 & \\
\hline$B_{2 u}$ & 1 & -1 & 1 & -1 & -1 & 1 & 1 & -1 & 1 & -1 & 1 & -1 & \\
\hline$E_{1 g}$ & 2 & 1 & -1 & -2 & 0 & 0 & -2 & 0 & 0 & -1 & 1 & 2 & $\begin{array}{l}\left(R_{x}, R_{y}\right) \\
(y z, z x)\end{array}$ \\
\hline$E_{1 u}$ & 2 & 1 & -1 & -2 & 0 & 0 & 2 & 0 & 0 & 1 & -1 & -2 & $(x, y)$ \\
\hline$E_{2 g}$ & 2 & -1 & -1 & 2 & 0 & 0 & 2 & 0 & 0 & -1 & -1 & 2 & $\left(x^{2}-y^{2}, x y\right)$ \\
\hline$E_{2 u}$ & 2 & -1 & -1 & 2 & 0 & 0 & -2 & 0 & 0 & 1 & 1 & -2 & \\
\hline & & & & & & & & & & & & & \\
\hline & & & & & & & & & & & & & \\
\hline & & & & & & & & & & & & & \\
\hline
\end{tabular}




\title{
CHAPTER 18
}

\author{
断熱近似
}

分子の電子状態を取り扱う場合, 原子の場合に比べて厄介なのは原子核が 2 個以上 あるといらことである。それで分子の電子状態は，正確には原子核の座標にも依存す ることになる。もつとも，原子，すなわち原子核が 1 個の場合でも，電子状態は原子 核の座標に依存しているわけである。しかし，この場合は，座標の変換を行い，かつ， 換算質量を導入することによってあたかも原子核は静止しているように取り扱うこ とが出来た。しかし，原子核が 2 個以上存在すると，もうそういうことにはならない. この場合, Schrödinger equation を正確に解くことは，ほとんど不可能になってしまう. そこで第一近似として, 原子核は動かないと考え, 電子についての Schrödinger equation を解くことを試みる。この近似を一般的に「断熱近似」と呼ぶ. 分子の問題に入る前 に, この近似のことについて学習しておく必要があり, 本章でそれらを試みる. Section 18.1 では，まず水素分子について簡単な考察を行い, Section 18.2 でもう少し正確に取 り扱ってみる.

本論に入る前に，このChapter の意義について一言述べておきたい．量子化学の入 門書では，多くの場合，断熱近似についてほんのわずか述べるに留まっているようで ある。現に，原子核の質量と電子の質量には 2000 倍以上の差があるので，断熱近似 はもっともらしい近似とみなされやすく，断熱近似の破れに言及することは非常に細 かいことを議論しているように思われるかもしれない.しかし, 現在の化学において, 興味ある現象の多くが断熱近似の破れによって引き起こされているという事実を忘 れてはならない.

諸君は 3 年生後半から卒業研究を始めることになるが，ひとたび研究を始めると， 「光化学反応」,「無輻射遷移」,「Vironic coupling（振電相互作用）」, 「電子移動反応」 などの言葉を日常的に聞いたり話したりするようになる。これらの興味ある現象は断 熱近似の敗れに依存しているわけであるが, 残念ながら, 本化学教室のカリキュラム では，それらを理解するための基礎理論について必ずしも十分な教育がなされていな い.このChapter は，他のChapter に比べて多少難解であり，現時点ではわかりにく いところがあるかもしれないが，基礎教育と研究レベルとのギャップを埋める 1 つの 試みと思ってもらいたい. 


\section{1 水素分子における断熱近似，初歩的な考察}

水素分子についての Hamiltonian は次のように与えられる.

$$
\begin{aligned}
H= & -\frac{\hbar^{2}}{2 M}\left(\nabla_{A}^{2}+\nabla_{B}^{2}\right)-\frac{\hbar^{2}}{2 m_{\mathrm{e}}}\left(\nabla_{1}^{2}+\nabla_{2}^{2}\right) \\
& +\frac{1}{4 \pi \varepsilon_{0}}\left(-\frac{e^{2}}{r_{1 A}}-\frac{e^{2}}{r_{1 B}}-\frac{e^{2}}{r_{2 A}}-\frac{e^{2}}{r_{2 B}}+\frac{e^{2}}{r_{12}}+\frac{e^{2}}{R}\right)
\end{aligned}
$$

ここで水素の原子核を $\mathrm{A}$ および $\mathrm{B}$ ，電子を 1 および 2 と名付ける， $M$ は水素の原子 核の質量， $m_{\mathrm{e}}$ は電子の質量である。その他の記号は明らかであろう。式(18.1.1)のよ うな Hamiltonian の固有值を求めることは大変にむずかしい。そこで，しばしば原子 核は動いていない，という近似を採用する。そうすると， $\nabla_{A}$ およ゙ $\nabla_{B}$ の項がなくな るので Hamiltonian は次のようになる.

$$
\begin{aligned}
H= & -\frac{\hbar^{2}}{2 m_{e}}\left(\nabla_{1}^{2}+\nabla_{2}^{2}\right) \\
& +\frac{1}{4 \pi \varepsilon_{0}}\left(-\frac{e^{2}}{r_{1 A}}-\frac{e^{2}}{r_{1 B}}-\frac{e^{2}}{r_{2 A}}-\frac{e^{2}}{r_{2 B}}+\frac{e^{2}}{r_{12}}+\frac{e^{2}}{R}\right)
\end{aligned}
$$

又は，原子単位系では

$$
H=-\frac{1}{2}\left(\nabla_{1}^{2}+\nabla_{2}^{2}\right)-\frac{1}{r_{1 A}}-\frac{1}{r_{1 B}}-\frac{1}{r_{2 A}}-\frac{1}{r_{2 B}}+\frac{1}{r_{12}}+\frac{1}{R}
$$

このような近似は，しばしば「断熱近似」とか「Born-Oppenheimerの断熱近似」と言 われる。

核の運動を考えないという近似は, 原子核が電子に比べて十分に重いということか ら一見良さそうに思われる。しかし，核が動いていないということが間違いであるこ とは，分子の振動スペクトルが観測されることからも明らかである．断熱近似という のは，本当のところ，核が動いていないと仮定しているのではないのである．電子の 運動と核の運動とを分けて，別々に取り扱おうという近似なのである，従って，核の 運動を単純に止めてしまうわけにはいかない。ではいったいどういうことなのか. 多 原子分子についての断熱近似の取り扱いを，もう少し正確に次の Section で取り扱っ てみよう。 


\section{2 電子の運動と核の運動の分離}

前の section で簡単に説明した断熱近似という近似は，平たく言うと，原子核が動 くと電子はほとんど瞬間的に新しい核配置に適応寸るように動く, という考えに基づ いた近似である，従って，電子の運動を考える時には核は動いていないと考えてよい ことにもなる.ただ，こういう文学的な表現を用いての記述でははっきりしないし， またしばしば誤解を招くことにもなる，そこで以下，式を用いてこの近似をもう少し 厳密に取り扱っておきたい.

なお，以下の記述は，大筋において，T. Azumi，K. Matsuzaki，Photochemistry and Photobiology, 25 (1977), 315 の"What Does the Term 'Vibronic Coupling' Mean?"からの引 用である.ちゃんとした学術雑誌に, 依頼されて書いた review articleであるから, 学 部の学生のレベルでは少々むずかしいかもしれない，どうしても理解出来ない人は, とりあえずここを省略し，4 年生になってから読みなおす，ということもやむを得な い.

断熱近似に関しては, 何といっても, Born と Oppenheimer の原論文 (M. Born and R. Oppenheimer, Ann. Phys. 84 (1927), 457）が重要である.この論文では, 正しい wavefunction を電子の質量と核の質量の比 $\frac{m_{\mathrm{e}}}{M}$ の power series として展開していて, ど ういう項が $\frac{m_{\mathrm{e}}}{M}$ の何乗で効いて来るかということを理解するには非常に都合がよい. しかし全般的にむずかしいこともあり，以下ではこの原論文とは全く異なる取り扱い を行う。

分子の全ハミルトニアンは次のように表される.

$$
H_{\text {total }}(r, Q)=T_{\mathrm{e}}(r)+T_{\mathrm{N}}(Q)+U(r, Q)+V(Q)
$$

ここで $r$ は電子の座標を， $Q$ は核の座標をまとめて表す，括弧内に示したのは，それ ぞれの operator が $r, Q$ いずれの関数であるかを示したものである. $T_{\mathrm{e}}(r)$ は電子の運 動量演算子

$$
T_{\mathrm{e}}(r)=-\frac{\hbar^{2}}{2 m_{\mathrm{e}}} \sum_{i} \frac{\partial^{2}}{\partial r_{i}^{2}}
$$

である.また $T_{\mathrm{N}}(Q)$ は核の運動量演算子

$$
T_{\mathrm{N}}(Q)=-\frac{\hbar^{2}}{2} \sum_{n} \frac{\partial^{2}}{\partial Q_{n}^{2}}
$$

である. $Q_{n}$ は核の絶対座標ではなく, 分子の $n$ 番目の規準振動の, 平衡位置からの変 
位に，よくなされるように核の質量の補正を入れたものとである。（注：この初歩的 な量子化学の講義では, 規準振動については述べていないので,「核の質量の補正を 入れた振動座標」というものの理解は難しいかもしれないが，ここではとりあえず， 式(18.2.2)に含まれている質量が式(18.2.3)では一見含まれていないように見えるのは その為だ,くらいに理解しておいてほしい. ) $U(r, Q)$ は電子と電子との potential energy と電子と核との potential energy の項を含む. 最後に $V(Q)$ は核と核との potential energy を示すものとする. 系の Schrödinger equation

$$
\left(H_{\text {total }}-E_{t}\right) \Psi_{t}(r, Q)=0
$$

は, $r$ と $Q$ の 2 種類の変数を分離することが出来ず正確には解くことが出来ない. そ こで次のような工夫をする. 寸なわち, 全八ミルトニアンの中, 電子の座標 $r$ を含む ものだけを取り出して，それを electronic Hamiltonian $H_{\text {elec }}(r, Q)$ とする.

$$
H_{\text {elec }}(r, Q)=T_{\mathrm{e}}(r)+U(r, Q)
$$

そして $H_{\text {elec }}(r, Q)$ についての Schrödinger equation を定義することが出来る.

$$
\left\{T_{\mathrm{e}}(r)+U(r, Q)-\varepsilon_{i}(Q)\right\} \psi_{i}(r, Q)=0
$$

これは, 核座標が $Q$ に固定された系についての Schrödinger equation とみなすことが出 来る. 固有值は当然 $Q$ の関数であり, $i$ 番目の固有値を $\varepsilon_{i}(Q)$ で示している. 固有関数 $\psi_{i}(r, Q)$ は, 一般的には, 多電子からなる分子全体を示す wavefunction であり, 少な くともそう簡単には解けそうもない。電子 2 個を持つ He 原子についてさえ, 正確に は解けず，何等かの近似法を用いざるを得なかった．ただ，ともかく， He の場合に は, 式(16.5.4)のような Slater determinant をいくつか重祮合わせた形として近似的に表 されるであろう. He の原子でさえそれほど大変なのであるから, 分子の場合にはと てつもなく大変な問題であろうことは容易に想像がつく. 現に, 式(18.2.6)を出来るだ け正確に解こうと多くの科学者が努力をして来たし，これからもその努力が続けられ ることになろうが，それは今問題としていることではない．ここで言いたいことは， たとえ式(18.2.6)が正確に解けたとしても，それは式(18.2.4)で定義される系の固有関 数とは全く質的に異なるものである, ということである. そこで, 議論をはっきりさ せるために，ここでは，式(18.2.6)が正確に解けたと仮定しょう。もし，式(18.2.6)の 
固有関数がすべて求まれば，それは完全系をなしている．任意の関数は完全系をなす 関数でもって展開することが出来るわけであるから, 系の正しい固有関数 $\Psi_{t}(r, Q)$ を 次のように完全系 $\left\{\psi_{i}(r, Q)\right\}$ でもって展開して表そう.

$$
\Psi_{t}(r, Q)=\sum_{i} \psi_{i}(r, Q) \chi_{i t}(Q)
$$

ここで $\chi_{i t}(Q)$ は展開係数であり, 核座標 $Q$ の関数である. 式(18.2.7)を式(18.2.4)に代 入し, $\frac{\partial^{2}}{\partial Q^{2}}\{\psi(r, Q) \chi(Q)\}=\frac{\partial^{2} \psi(r, Q)}{\partial Q^{2}} \chi(Q)+2 \frac{\partial \psi(r, Q)}{\partial Q} \frac{\partial \chi(Q)}{\partial Q}+\psi(r, Q) \frac{\partial^{2} \chi(Q)}{\partial Q^{2}}$ などの 関係式を用い, 左から $\psi_{j}(r, Q)$ * を掛けて電子座標 $r$ について積分すると, 展開係数 $\chi_{i t}(Q)$ は次に示寸微分方程式のセットの解として与えられる.

$$
\begin{aligned}
& \left\{T_{\mathrm{N}}(Q)+V(Q)+\varepsilon_{j}(Q)+\left\langle\psi_{j}(r, Q)\left|T_{\mathrm{N}}(Q)\right| \psi_{j}(r, Q)\right\rangle-E_{t}\right\} \chi_{j t}(Q) \\
& +\sum_{i \neq j} \hbar^{2}\left\{\begin{array}{l}
\left\langle\psi_{j}(r, Q)\left|T_{\mathrm{N}}(Q)\right| \psi_{i}(r, Q)\right\rangle \\
-\sum_{n}\left\langle\psi_{j}(r, Q)\left|\frac{\partial}{\partial Q_{n}}\right| \psi_{i}(r, Q)\right\rangle \frac{\partial}{\partial Q_{n}}
\end{array}\right\} \chi_{i t}(Q)=0
\end{aligned}
$$

ここでブラケット〈｜｜〉は電子の座標 $r$ について積分を示す.

この微分方程式を解いて，すべての $\chi_{i t}(Q)$ を求めることが出来れば，式(18.2.7)を 用いて正しい固有関数が求まるということになる.しかし，一般的には，この連立微 分方程式は解けない，そこであきらめて，ここで1つの近似を採用することにする. もしも上式の $\sum$ の項すべてがゼロであれば，すなわち，もし，

$$
\left\langle\psi_{j}(r, Q)\left|T_{\mathrm{N}}(Q)\right| \psi_{i}(r, Q)\right\rangle=0 \quad \text { for } i \neq j
$$

および

$$
\left\langle\psi_{j}(r, Q)\left|\frac{\partial}{\partial Q_{n}}\right| \psi_{i}(r, Q)\right\rangle=0 \quad \text { for } i \neq j
$$

が成り立つとすると, 式(18.2.7)の展開はただ 1 項のみで表されることになる.

$$
\Psi_{j t}(r, Q)=\psi_{j}(r, Q) \chi_{j t}(Q)
$$


ここで, 左辺の subscriptにも新しくjをつけ加えて,この wavefunction が electronic state $\psi_{j}(r, Q)$ と関係することを陽に示すこととする.ここで，係数 $\chi_{j t}(Q)$ は

$$
\left\{\begin{array}{c}
T_{N}(Q)+V(Q)+\varepsilon_{j}(Q)+ \\
\left\langle\psi_{j}(r, Q)\left|T_{\mathrm{N}}(Q)\right| \psi_{j}(r, Q)\right\rangle-E_{j t}
\end{array}\right\} \chi_{j t}(Q)=0
$$

という Schrödinger equation の解として与えられる.これは, chapter 7 で学習した振動 に関する Schrödinger equationの一般形と見なすことが出来る。こういうことから， $\chi_{j t}(Q)$ は, 電子状態 $j$ についての振動波動関数と考えてよいことになる. 式(18.2.7) では $\chi_{i t}(Q)$ は単なる展開係数であったが, 式(18.2.11)においてはそれが振動波動関数 という意味を持つことになる，かくして，式(18.2.11)の意味するところは，全波動関 数が, 電子状態の波動関数 $\psi_{j}(r, Q)$ と振動の波動関数 $\chi_{j t}(Q)$ の単なる積として表され るということである。これはあくまで式(18.2.9)および式(18.2.10)の 2 つの近似が成り 立つ時の近似であり, これが「断熱近似」である。

上述したように断熱近似は, 式(18.2.9)および式(18.2.10)の 2 つの近似に基づいてい る.すなわち $\frac{\partial}{\partial Q}$ および $\frac{\partial^{2}}{\partial Q^{2}}$ の 2 つの演算子に対する非対角要素がゼロであることが 要求される. 電子状態の波動関数 $\psi_{j}(r, Q)$ の $Q$ 座標依存性が小さければこの近似はほ ぼ成り立つと考えてよさそうである.

\section{【註】：}

なお，一口に断熱近似といっても，微妙に異なるいくつかの近似がある. 多くの教 科書や研究論文でその微妙な定義の違いのために無用の混乱が生じている。一例をあ げると，上述したような $\frac{\partial}{\partial Q}$ および $\frac{\partial^{2}}{\partial Q^{2}}$ の 2 つの演算子に対する非対角要素をゼロと した場合の断熱近似を「Born-Huang 断熱近似」, $\frac{\partial^{2}}{\partial Q^{2}}$ の対角要素までをもゼロとした 場合の断熱近似を「Born-Oppenheimer の断熱近似」というように異なった名前をつけ て区別している人もいる。このあたりのことは，上に引用した Photochemistry and 
Photobiologyの review articleにまとめてあるので, 関心のある人は参考にしてほしい.

خ Problem 18.2.1

式(18.2.5)の $U(r, Q)$ を, 平衡核配置 $Q_{0}$ における值 $U\left(r, Q_{0}\right)$ と残りとに分け

$$
H_{\text {elec }}(r, Q)=T_{e}(r)+U\left(r, Q_{0}\right)+\Delta U(r, Q)
$$

とおくことが出来る。そして，式(18.2.6)の代りに

$$
\left\{T_{e}(r)+U\left(r, Q_{0}\right)-\varepsilon_{i}(Q)\right\} \psi_{i}^{0}\left(r, Q_{0}\right)=0
$$

という Schrödinger equation を定義する. $\psi_{i}^{0}\left(r, Q_{0}\right)$ は当然に完全系を成すから，式 (18.2.7)の代りに

$$
\Psi_{t}(r, Q)=\sum_{i} \psi_{i}^{0}\left(r, Q_{0}\right) \chi_{i t}(Q)
$$

のような展開も可能である. 式(18.2.15)に基づいて, 式(18.2.8)に相当する $\chi_{i t}(Q)$ を表 す式を求めよ.

完Problem 18.2.2

式(18.2.9)の仮定を，もし，k=j についても拡張すると，それ以降の式はどうなる か.

必Problem 18.2.3

式(18.2.12)の，振動についての Schrödinger equation において，どのような近似（仮 定）を採用すると， harmonic oscillator の wavefunction が得られるか?

なお，Problem 18.2.1-18.2.1 の答えは，T. Azumi, K. Matsuzaki, Photochemistry and Photobiology, 25 (1977), 315 の Review Article に載っている. 


\title{
CHAPTER 19
}

\author{
水素分子
}

分子の問題の第一段階として，この章では水素分子について少々詳しく学習する. 分子の問題を扱うには大きく分けて 2 つの方法がある. 1 つは分子軌道法（molecular orbital method）で，もう1つは原子価結合法（valence bond method）である。原子の 問題と同じような取り扱いで分子の問題も取り扱おうというのが分子軌道法であり， Chapter 16 で原子を学習した後は，非常に分かりや寸い方法である．一方，原子価結 合法は，分子というものは原子から構成されている，という考えを陽に出した取り扱 いであり，「分子は原子から構成されている」という化学者特有の見方をしている人 には分かりやすい概念である. 分子軌道法, 原子価結合法, いずれも分子を扱う重要 な理論であるので，水素分子を例として 2 つ方法を学習することにしよう.

なお，以下の各章において，特に断らない限り，Chapter 18 で学習した断熱近似の 枠内で考える.

\section{1 分子軌道法}

分子軌道（molecular orbital）の方法というのは，上述したように，原子の取り扱い と同じように分子も取り扱おうという考えに基づいている．多電子原子において，ま ず，1 電子系の原子について atomic orbital を定め，その atomic orbital に Pauli 原理を 満たすように Aufbau principle に従って電子を詰めていった。それと全く同じように， 分子についても，まず 1 電子の軌道があると考えて, それを分子軌道 (molecular orbital) と名付ける．どうやって分子軌道を求めるかについてはすぐ後から考えるが，とにか く，分子軌道が得られたら，それに Pauli 原理を満足するように電子を詰めていくわ けである，すなわち，原子の場合の Aufbau principle と同様な考え方に基づいて電子 を詰めていく.

では，分子軌道を如何にして求めるかを考えてみよう。原子の場合，電子 1 個のみ を考えて，水素類似型の原子の波動関数を得て，それを atomic orbital としたわけで， それと同じような方法を分子についても適用してみたらどうなるであろうか. 分子の 場合には原子核が 2 個以上あるから Hamiltonian は複雑になる.その複雑な Hamiltonian の解を求めることは事実上不可能である。そこで我々は, 最初の段階から, 近似を導 入して，その近似の枠内で，出来るだけ良い波動関数を求めることで我慢をする。こ の近似の代表的なものが，すでに学習した線形変分法に基づくものである.すなわち， 
まずいくつかの有限個の basis function を決め, 変分原理で決めたそれらの線形結合で もって molecular orbital を表そうとするわけである. この中でも，もつともよく使わ れ，またよく発展したのは以下に述べる LCAO の方法である.

LCAO の方法とは分子軌道を表す basis function を, 分子を構成する各原子の原子軌 道とする方法である. 分子軌道 (molecular orbital, しばしばMO と略記する) を atomic orbital（しばしばAO と略記する）の linear combination で表す，すなわち Linear Combination of Atomic Orbital（LCAO）の方法である.こうして得られた MO を LCAO MOと言う.

今仮に， $\mathrm{AB}$ という 2 原子分子を考えよう。この分子の MO はどんな形をしている か分からないが，Aの原子の近くではA原子の $\mathrm{AO}\left(\phi_{A}\right)$ に近い形をしていると考え ていいであろう。同様に B の原子の近くでは B 原子の $\mathrm{AO}\left(\phi_{B}\right)$ に近い形をしている であろう。そこでMOを

$$
\psi_{i}=c_{i A} \phi_{A}+c_{i B} \phi_{B}
$$

のような linear combination で表すことはそう悪い近似ではなさそうである。これがも っとも簡単な形の LCAO MO である.

もっとも， $\mathrm{AO} \phi_{A}$ と $\phi_{B}$ とが線形結合するためには二三の条件が必要である。それ らは

（1） $\phi_{A}$ と $\phi_{B}$ とは $\mathrm{A}-\mathrm{B}$ の結合軸について同じ対称性を持たなければいけない.

（2） $\phi_{A}$ と $\phi_{B}$ の軌道エネルギーはあまり大きく離れていてはいけない.

これらの条件を理解するために, まず式(19.1.1)の係数 $c_{i A}, c_{i B}$ および $\psi_{i}$ の energy $E_{i}$ を形式的に求めることを考えてみよう。すでに学習した linear variation theory を用い るわけであり，当然次の secular determinant を解くことになる.

$$
\left|\begin{array}{cc}
H_{A A}-E & H_{A B}-S_{A B} E \\
H_{B A}-S_{B A} E & H_{B B}-E
\end{array}\right|=0
$$

$H_{A A}, H_{B B}, H_{A B}, H_{B A}$ は分子の全 Hamiltonian についての行列要素であり $S_{A B}, S_{B A}$ は 重なり積分である.もしも $\phi_{A}$ と $\phi_{B}$ が分子の持っているある対称操作に対して異なっ た対称性を持つならば（すなわち異なった既約表現に属するならば） $H_{A B}$ および $S_{A B}$ は 
どちらもゼロとなる.こういう場合には式(19.1.1)のような linear combination は有り得 ないことになる．また， $\phi_{A}, \phi_{B}$ の energy が大きく異なると， $H_{A A}$ と $H_{B B}$ とが大きく 異なることになり，実質的に式(19.1.1)は $\phi_{A}$ または $\phi_{B}$ いずれかに大きく片寄ったもの となってしまうわけである。

以上で molecular orbital についてのおおまかな説明が終ったので，以下，二三の具 体的な例について考えてみる.

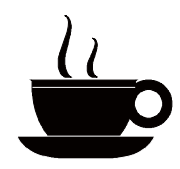

[Coffee Break] orbital という言葉

"orbital"という言葉は，日本語では「軌道」と訳されている。一方"orbit"も「軌道」 であるから，日本語では"orbital"も"orbit"も同じ言葉に訳されてしまっていてどうも具 合がわるい. "orbital"という英語はもともとは"orbit"の形容詞である。（例えば"orbital motion"とか"orbital function"のように）それを，現在用いられているような意味で名詞 として用いたのは，分子軌道法の生みの親ともいうべき Robert S. Mulliken である. Mullikenの分子軌道論は, 1932 年から 33 年にわたって書かれた"Electronic Structures of Polyatomic Molecules and Valence"という題で書かれた 14 編のシリーズの論文で大成し たわけだが，このシリーズの第 2 報（Phys. Rev. 41 (1932) 49-71）で始めて"orbital" と いう言葉が導入された。この所はこの論文では次のように書かれている.

From here on, one-electron orbital wavefunctions will be referred to for brevity as orbitals. The method followed here will be to describe unshared electrons always in terms of atomic orbitals but to use molecular orbitals for shared electrons.

この論文の記述で atomic orbital と molecular orbital の区別がきちんと説明されていて 面白いが， orbital という言葉を始めて導入した著者の考え方や背景についてはあまり よく分からない。この点については Mulliken 自身の自伝, "Life of a Scientist", R. S. Mulliken, Springer-Verlag (1989)の p. 90 に次のように書いてある.

In the second paper, I introduced the noun "orbital" and defined atomic orbitals and molecular orbitals as something like the orbits of Bohr's theory, but very different in some ways because of the radically new viewpoint of quantum mechanics. One feature is that the form of an orbital (when squared) tells only the probability of finding an electron in any particular position in space.

このように"orbital"という形容詞を"something like the orbit"という意味の名詞として導 入したということである。このように，orbital という言葉は，orbit とは異なるものを 
示すために新たに Mullikenによって導入されたわけだが，上述したように，日本語は orbit も orbital もどちらも「軌道」という言葉になってしまったことは残念である.

\section{2 水素分子イオン $\mathrm{H}_{2}{ }^{+}$の分子軌道論}

ここでは電子 1 個の水素分子イオン $\mathrm{H}_{2}{ }^{+}$の分子軌道を LCAO の方法で考えてみよ う。この場合, basis set として考えられるのは 1 つの水素原子 A についての atomic orbital $1 s, 2 s, 2 p, \ldots$ およびもう 1 つの水素原子 B についての atomic orbital $1 s, 2 s$, $2 p ， \ldots$ 等々無限個あるが, basis set $の$ 数が多くなると計算がやっかいであるし，第一， 無限個の basis set があったのでは計算出来ない. そこでどこかで打ち切るわけである が，考えられるもっとも簡単なモデルでは，低エネルギーの状態を考える限り，2つ の水素原子それぞれについて $1 s$ atomic orbital のみを考える，ということである. $2 s$ 以 上の AO の寄与は energy が離れるに従って小さくなるので, とりあえず考えないこと にするわけである。この近似により， $i$ 番目の MO $\psi_{i}$ は

$$
\psi_{i}=c_{i a} \phi_{a}+c_{i b} \phi_{b}
$$

となる. $\phi_{a} お よ ひ ゙ \phi_{b}$ はそれぞれの $\mathrm{H} の 1 s$ AO である. linear variation theory により orbital energy $E$ は

$$
\left|\begin{array}{cc}
H_{a a}-E & H_{a b}-S_{a b} E \\
H_{b a}-S_{b a} E & H_{b b}-E
\end{array}\right|=0
$$

を解くことによって得られる。ここで

$$
\begin{aligned}
& H_{a a}=\int \phi_{a} * H \phi_{a} d \tau \\
& H_{b b}=\int \phi_{b} * H \phi_{b} d \tau \\
& H_{a b}=\int \phi_{a}^{*} H \phi_{b} d \tau \\
& S_{a b}=\int \phi_{a}^{*} \phi_{b} d \tau
\end{aligned}
$$

積分は分子全体の座標について行う。今の場合 $\phi_{a} お よ ひ ゙ \phi_{b}$ はどちらも $1 s$ orbitalであ るから

$$
H_{a a}=H_{b b}
$$


である．また Hamiltonian $H$ は当然 Hermitian であり， $1 s$ orbital は real であるから

$$
\begin{aligned}
& H_{a b}=H_{b a} \\
& S_{a b}=S_{b a}
\end{aligned}
$$

が成り立つ. 従って式(19.2.2)の解は

$$
E_{ \pm}=\frac{H_{a a} \pm H_{a b}}{1 \pm S_{a b}}
$$

となる.係数 $c_{a}$ および $c_{b}$ は, 今まで何回も繰り返し学習して来たように secular equation のもとになっている式，例えば

$$
c_{a}\left(H_{a a}-E\right)+c_{b}\left(H_{a b}-E S_{a b}\right)=0
$$

において $E$ に $E_{+}$または $E_{-}$のいずれかを代入し, 規格化条件(この場合係数 $c_{a}$ および $c_{b}$ はいずれも realであるから）

$$
c_{a}^{2}+2 c_{a} c_{b} S_{a b}+c_{b}^{2}=1
$$

と合わせて求めるわけである。こうして molecular orbital およびその energy（orbital energy と言う）が次のように求まる.

$$
\begin{array}{ll}
\psi_{+}=\frac{1}{\sqrt{2\left(1+S_{a b}\right)}}\left(\phi_{a}+\phi_{b}\right): & E_{+}=\frac{H_{a a}+H_{a b}}{1+S_{a b}} \\
\psi_{-}=\frac{1}{\sqrt{2\left(1-S_{a b}\right)}}\left(\phi_{a}-\phi_{b}\right): & E_{+}=\frac{H_{a a}-H_{a b}}{1-S_{a b}}
\end{array}
$$

この式の中の積分 $H_{a a}, H_{a b}, S_{a b}$ は, atomic orbital と Hamiltonian の形が与えられて いるから正確に計算出来る，以下，それを行ってみよう. Hamiltonianは atomic unit で

$$
H=-\frac{1}{2} \nabla^{2}-\frac{1}{r_{a}}-\frac{1}{r_{b}}+\frac{1}{R}
$$

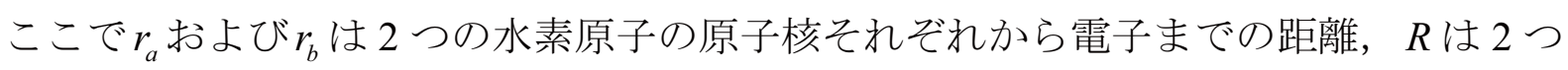
の原子核間の距離である， $\phi_{a} お よ ひ ゙ \phi_{b}$ にいての Schrödinger equation は 


$$
\begin{aligned}
& \left(-\frac{1}{2} \nabla^{2}-\frac{1}{r_{a}}\right) \phi_{a}=E_{1 s} \phi_{a} \\
& \left(-\frac{1}{2} \nabla^{2}-\frac{1}{r_{b}}\right) \phi_{b}=E_{1 s} \phi_{b}
\end{aligned}
$$

で与えられる。 $E_{1 s}$ は $1 s$ orbital energy で具体的には Chapter 9 で求めた. 式(19.2.7) を考慮して，式(19.2.6)より

$$
\begin{aligned}
& H \phi_{a}=\left(E_{1 s}-\frac{1}{r_{b}}+\frac{1}{R}\right) \phi_{a} \\
& H \phi_{b}=\left(E_{1 s}-\frac{1}{r_{a}}+\frac{1}{R}\right) \phi_{b}
\end{aligned}
$$

を得る.これらの式に左から $\phi_{a}$ *をかけて全空間について積分すると次式を得る.

$$
\begin{aligned}
& H_{a a}=E_{1 s}+\frac{1}{R}-\varepsilon_{a a} \\
& H_{a b}=\left(E_{1 s}+\frac{1}{R}\right) S_{a b}-\varepsilon_{a b}
\end{aligned}
$$

ここで

$$
\begin{aligned}
\varepsilon_{a a} & =\int \frac{\phi_{a}^{*} \phi_{b}}{r_{b}} d \tau \\
\varepsilon_{a b} & =\int \frac{\phi_{a}^{*} \phi_{b}}{r_{a}} d \tau
\end{aligned}
$$

式(19.2.9)を式(19.2.4)に代入することによって, orbital energy として次式を得る.

$$
\begin{aligned}
& E_{+}=E_{1 s}+\frac{1}{R}-\frac{\varepsilon_{a a}+\varepsilon_{a b}}{1+S_{a b}} \\
& E_{-}=E_{1 s}+\frac{1}{R}-\frac{\varepsilon_{a a}-\varepsilon_{a b}}{1-S_{a b}}
\end{aligned}
$$

ここで $\varepsilon_{a a}, \varepsilon_{a b}$, および $S_{a b}$ は $R$ の関数であるから， $\phi_{a} お よ ひ ゙ \phi_{b}$ の関数形が与えられ れば以下のようにして具体的な值を求めることが出来る.

一般に式(19.2.10)のような，2つの原子軌道を含む積分は，それぞれの原子核の位 置を焦点とする楕円座標を用いて簡単に值を求めることが出来る. 数学的なテクニッ クの問題ではあるが, こういう計算は, 分子の計算でもっとも一般的なもので非常に 重要であるので, 以下，具体的に計算してみよう。 
楕円座標では $\mu, v, \phi$ のつの座標を用いる.ここで

$$
\begin{gathered}
\mu=\frac{r_{a}+r_{b}}{R} \\
\nu=\frac{r_{a}-r_{b}}{R}
\end{gathered}
$$

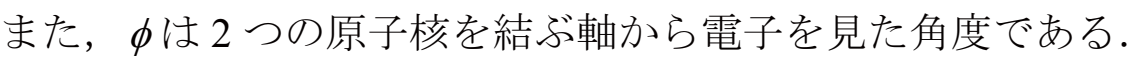

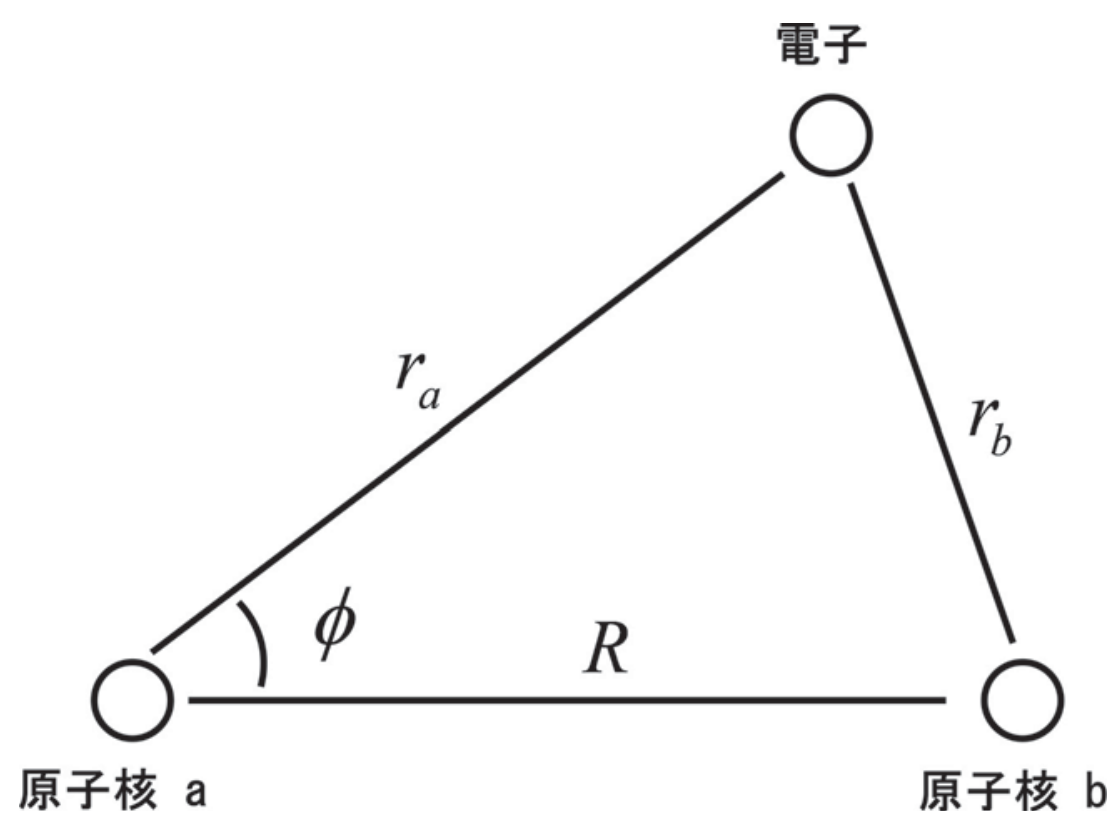

図 19.2.1 楕円座標

各座標の範囲は

$$
\begin{aligned}
& 1 \leq \mu \leq \infty \\
& -1 \leq \nu \leq 1 \\
& 0 \leq \phi \leq 2 \pi
\end{aligned}
$$

また volume element $d \tau$ は

$$
d \tau=\frac{R^{3}}{8}\left(\mu^{2}-v^{2}\right) d \mu d v d \phi
$$

となる。

atomic orbital $\phi_{a}$ および $\phi_{b}$ としては水素原子の $1 s$ wavefunction であるから，

$$
\begin{aligned}
& \phi_{a}=\frac{1}{\sqrt{\pi}} \exp \left(-r_{a}\right) \\
& \phi_{b}=\frac{1}{\sqrt{\pi}} \exp \left(-r_{b}\right)
\end{aligned}
$$


と表される.（ここで，距離は atomic unit で表されていることに注意.）

では，まず，重なり積分 $S_{a b}$ を計算しよう。

$$
\begin{aligned}
S_{a b} & =\int \phi_{a}{ }^{*} \phi_{b} d \tau \\
& =\frac{1}{\pi} \int \exp \left\{-\left(r_{a}+r_{b}\right)\right\} d \tau \\
& =\frac{R^{3}}{8 \pi} \int_{1}^{\infty} d \mu \int_{-1}^{1} d v \int_{0}^{2 \pi} \exp (-R \mu)\left(\mu^{2}-v^{2}\right) \\
& =\frac{R^{3}}{4} \int_{1}^{\infty} d \mu \int_{-1}^{1} d v \exp (-R \mu)\left(\mu^{2}-v^{2}\right) \\
& =\frac{R^{3}}{2} \int_{1}^{\infty} \mu^{2} \exp (-R \mu) d \mu-\frac{R^{3}}{6} \int_{1}^{\infty} \exp (-R \mu) d \mu \\
& =\frac{R^{3}}{2} A_{2}(R)-\frac{R^{3}}{6} A_{0}(R)
\end{aligned}
$$

ここで $A_{0}(R)$ および $A_{2}(R)$ は, 通常, $A$ integral と呼ばれているものの一部で, 一般 的には次式で与えられる.

$$
\begin{aligned}
A_{n}(R) & =\int_{1}^{\infty} x^{n} \exp (-R x) d x \\
& =\frac{n ! \exp (-R)}{R^{n+1}} \sum_{k=0}^{n} \frac{R^{k}}{k !}
\end{aligned}
$$

具体的に $n=0$ と $n=2$ については次のようになる.

$$
\begin{aligned}
& A_{0}(R)=\frac{\exp (-R)}{R} \\
& A_{2}(R)=\frac{2 \exp (-R)}{R^{3}}\left(1+R+R^{2}\right)
\end{aligned}
$$

従って式(19.2.15)は次のようになる.

$$
S_{a b}=\frac{1+R+R^{2}}{3} \exp (-R)
$$

$\varepsilon_{a a}$ および $\varepsilon_{a b}$ も同じように計算出来る. 途中は諸君の演習に残しておこう（Problem 19.2.1). 結果は

$$
\varepsilon_{a a}=\frac{1-(1+R) \exp (-2 R)}{R}
$$




$$
\varepsilon_{a b}=(1+R) \exp (-R)
$$

かくして, 式(19.2.11)に表れるすべての積分が $R$ の関数として求まった.

$R$ は水素分子イオン $\mathrm{H}_{2}{ }^{+}$における 2 つの原子核間距離で，実験によると $R=106 \mathrm{pm}=2.00 \mathrm{bohr}$ が平衡核間距離であり，この近辺の $R$ で式(19.2.11) を計算す心゙

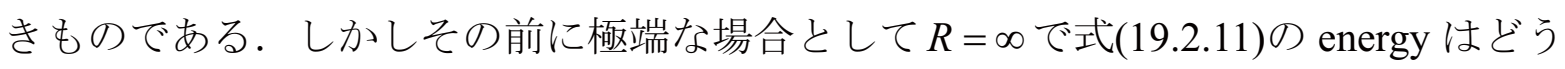
なるかを吟味してみよう。この場合, 式(19.2.15)を見るまでもなく $S_{a b}=0$. また, 式 (19.2.18)および式(19.2.19)より $\varepsilon_{a a}=\varepsilon_{a b}=0$. 従って $E_{+}=E_{-}=E_{1 s}$ となる. すなわち， $R=\infty$ における $\mathrm{H}_{2}+$ の orbital energy は $E_{1 s}$ に等しく二重に縮退していて, 当然そうなる べきものである.従って少なくとも $R=\infty$ の極限では式(19.2.11)は真実を表しているこ とは間違いない。

有限の $R$ の值では， $E_{+}<E_{-}$となることが式(19.2.11)より直ちに分かる。 $E_{+}$および $E_{-}$を $R$ の関数としてプロットすると図 19.2.2 のようになる. $R=\infty て ゙ E_{+}$も $E_{-}$も共に

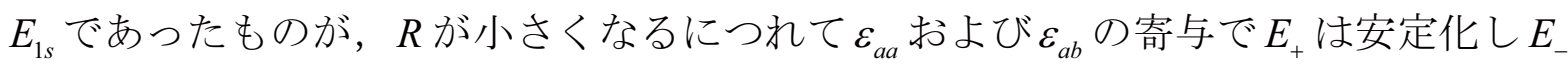
は不安定化する. $R$ の小さい所では $\frac{1}{R}$ の項が大きくなり， $E_{+}$も $E_{-}$も急に立ち上がる ようになる，従って $E_{+}$の方には，極小值が生ずる．この図から， $\mathrm{H}_{2}+$ は 2 つの $\mathrm{H}$ 原 子がばらばらに存在するよりは安定であることも分かる. 


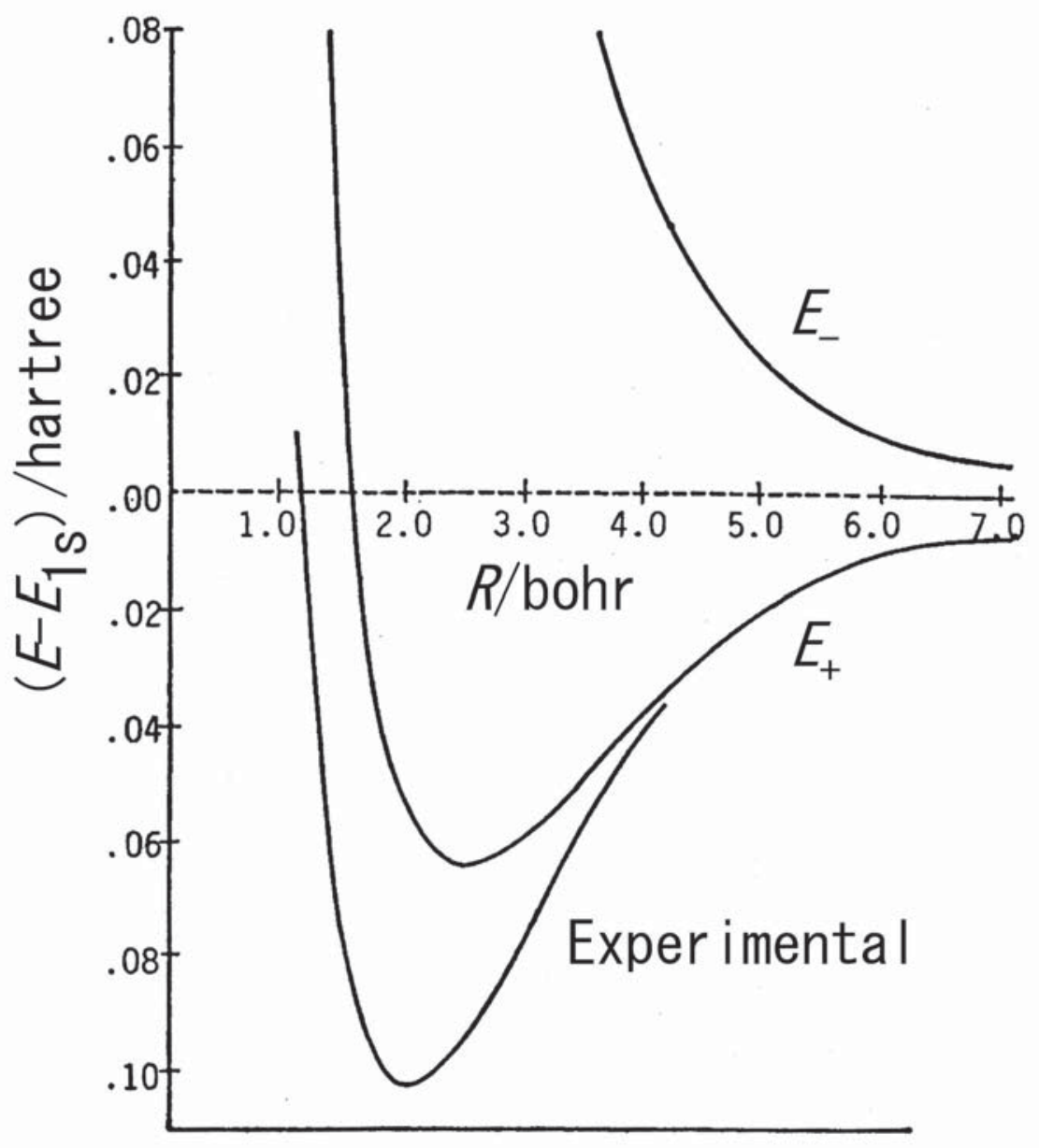

図 19.2.2 $\mathrm{H}_{2}{ }^{+}$の分子軌道のエネルギー.

横軸は核間距離，縦軸は $E_{1 s}$ を基準としたエネルギー。いずれも atomic unit.

(Eyring, Walter, Kimball, "Quantum Chemistry", page 199 の図を加工修正)

図 19.2.2には，実験から求まったエネルギー值も示してある. 定性的には $E_{+}$の傾 向と似てはいるが，極小の $R$ の位置もそのエネルギーもかなり異なっている. 理論と 実験との一致は，理論を改良することによってどんどん良くなるが，考えられる最も 単純な分子軌道を用いて，むしろ定性的にせよ，これだけ実験と一致する結果が得ら 
れることに意義を見出すべきであろう。

さて, molecular orbital の orbital energy ばかりに着目して来たが, 最後に wavefunction の方にも目を向けてみよう. wavefunction は式(19.2.5)に与えたが，それ以来

wavefunctionの形については吟味しなかった。 まず, これらが群のどのような既約表 現に属するかを見てみよう. 水素分子も水素分子イオンも $\mathrm{D}_{\infty \mathrm{h}}$ の点群に属する. そ こでまず $\phi_{a}$ および $\phi_{b}$ が $\mathrm{D}_{\infty \mathrm{h}}$ の各 operation によりどのように transform するかを求め, その結果に基づき，式(19.2.5)の $\psi_{+}$および $\psi_{-}$がどのような既約表現に属するかを調べ よう．例によって $\mathrm{D}_{\infty \mathrm{h}}$ の character table を写すところから始める. 
表 19.2.1 $\mathrm{H}_{2}{ }^{+}$における $\mathrm{AO} \phi_{a}, \phi_{b}$, および $\mathrm{MO} \psi_{+}, \psi_{-}$の transformation property

\begin{tabular}{|c|c|c|c|c|c|c|}
\hline $\mathrm{D}_{\infty \mathrm{h}}$ & $E$ & $2 C_{\phi}$ & $\sigma_{v}$ & $i$ & $2 i C_{\phi}$ & $i \sigma_{v}$ \\
\hline$\Sigma_{g}^{+}$ & 1 & 1 & 1 & 1 & 1 & 1 \\
\hline$\Sigma_{u}^{+}$ & 1 & 1 & 1 & -1 & -1 & -1 \\
\hline$\Sigma_{g}^{-}$ & 1 & 1 & -1 & 1 & 1 & -1 \\
\hline$\Sigma_{u}^{-}$ & 1 & 1 & -1 & -1 & -1 & 1 \\
\hline$\Pi_{g}$ & 2 & $2 \cos \phi$ & 0 & 2 & $2 \cos \phi$ & 0 \\
\hline$\Pi_{u}$ & 2 & $2 \cos \phi$ & 0 & -2 & $-2 \cos \phi$ & 0 \\
\hline$\Delta_{g}$ & 2 & $2 \cos 2 \phi$ & 0 & 2 & $2 \cos 2 \phi$ & 0 \\
\hline$\Delta_{u}$ & 2 & $2 \cos 2 \phi$ & 0 & -2 & $-2 \cos 2 \phi$ & 0 \\
\hline$\phi_{a}$ & $\phi_{a}$ & $\phi_{a}$ & $\phi_{a}$ & $\phi_{b}$ & $\phi_{b}$ & $\phi_{b}$ \\
\hline$\phi_{b}$ & $\phi_{b}$ & $\phi_{b}$ & $\phi_{b}$ & $\phi_{a}$ & $\phi_{a}$ & $\phi_{a}$ \\
\hline$\psi_{+}$ & $\psi_{+}$ & $\psi_{+}$ & $\psi_{+}$ & $\psi_{+}$ & $\psi_{+}$ & $\psi_{+}$ \\
\hline$\psi_{-}$ & $\psi_{-}$ & $\psi_{-}$ & $\psi_{-}$ & $-\psi_{-}$ & $-\psi_{-}$ & $-\psi$ \\
\hline
\end{tabular}

この結果を $\mathrm{D}_{\infty \mathrm{h}}$ の character table と比較することにより， $\psi_{+}$は $\Sigma_{g}{ }^{+}$に, また $\psi_{-}$は $\Sigma_{u}{ }^{+}$に 属することが分かる． $\mathrm{D}_{\infty \mathrm{h}}$ の点群における既約表現は以上の通りであるが，一般に 2 原子分子の分子軌道を $\mathrm{D}_{\infty \mathrm{h}}$ （等核 2 原子分子）または $\mathrm{C}_{\infty \mathrm{V}}$ （異核 2 原子分子）の群 論に基づいて molecular orbital をおおざっぱに分類することが行われている.まずこ れら 2 つの MO はいずれも $\sigma_{v}$ に対して symmetric である. $\mathrm{D}_{\infty \mathrm{h}}$ や $\mathrm{C}_{\infty \mathrm{v}}$ ではそのよう 
な性質を持つ既約表現を $\Sigma$ と表しているが，これの小文字を用い，reflection $\sigma_{v}$ に対 して symmetric な MOを $\sigma$-orbital と言う. $\mathrm{D}_{\infty \mathrm{h}}$ の場合には inversion による対称性 $g$ または $u$ をつけ，この場合には $\psi_{+} を \sigma_{g}$ 軌道， $\psi_{-}$を $\sigma_{u}$ 軌道と名付ける.また， $\psi_{-}$は, もともとの $E_{1 s}$ よりも高いエネルギーを持つということで antibonding orbital と言われ る. antibonding orbital にはしばしばアステリスク「*」をつける。こういう約束事に より， $\psi_{+}$は $\sigma_{g}$ 軌道， $\psi_{-}$は $\sigma_{u}$ *軌道というふうに名付けられる.

放Problem 19.2.1

式(19.2.18) および式(19.2.19) を導け.

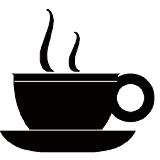

[Coffee Break] molecular orbital を表す記号 $\sigma, \pi, \delta$ の由来

この節で紹介した molecular orbital を表す記号， $\sigma, \pi, \delta$ などを対称性に基づいて 命名するという方法は，現在一般に用いられているが，このような命名法は，分子軌 道法を発展させた 2 人の先駆者, Hund と Mulliken が 1929 年, 学会に行く時に汽車の 中で相談し，他の人々の賛成を得たということである. 1988 年 5 月シカゴ大学で行わ れた Mulliken Memorial Lecture において，Hund が"Recollection of Robert S. Mulliken" という題で行った speech がある。（実は Hund は高齢のためこの会に出席出来ずビデ オテープでの speech が披露されたということである）この speech の中で Hund が，上 述した nomenclature について次のように述べている.

At this time it became urgent to establish a unitary nomenclature for molecules, the symbols $\sigma, \pi, \delta$ for orbitals, capital $\Sigma, \Pi, \Delta$ for terms, g, u for symmetry etc.

Mulliken and I discussed the possibilities in the long train trip between Chicago and New York; then other colleagues agreed. A picture I took during a meeting of American Physical Society in Washington shows Morse, Crawford, Mulliken, and Dennison, and has the note "Einigung über die Bezeichnung der Molekülzustände". 


\section{3 水素分子の分子軌道法による取り扱い}

水素分子は, 前節で学習した水素分子イオンと異なり, 電子が 2 個存在するという ところがむずかしい. 電子が 2 個以上存在する分子の分子軌道法的取り扱いは, 丁度, 電子が 2 個以上存在寸る原子の取り扱いと全く同様である.もう少し具体的に見てみ よう. $\mathrm{He}$ 原子の場合には $\mathrm{He}^{+}$という電子 1 個の系について解いた原子軌道（atomic orbital，AO）に電子を 2 個詰める，そして，例えば Hartree-Fock 法では，基底電子配 置 (すなわち $1 \mathrm{~s} \mathrm{AO} に 2$ 個の電子が詰まった配置)の energy (すなわち, 全 Hamiltonian に対する期待値）を最小にするように AO を決める. 多電子原子についてのこのよう な取り扱い方法をそのまま分子にも適用しようとするのが分子軌道法である. 原子の 場合，電子を入れる「容れ物」は原子軌道（AO）であった，分子の場合には，その 類推で，電子を入れる「容れ物」は分子軌道（molecular orbital，MO）と呼ばれる.

$\mathrm{H}_{2}$ 分子の場合の $\mathrm{MO}$ は $\mathrm{H}_{2}+$ について解いた $\mathrm{MO}$ を用いるのが最も適当である. ( $\mathrm{He}$ 原子の場合 $\mathrm{He}^{+}$について解いた $\mathrm{AO}$ に電子を詰めたのと同じように. ) $\mathrm{H}_{2}+$ の分子軌道 はすでに前節で求めてある，念のため，結果を再び掲げよう。

$$
\begin{array}{ll}
\sigma_{u}=\frac{1}{\sqrt{2\left(1-S_{a b}\right)}}\left(\phi_{a}-\phi_{b}\right): & E\left(\sigma_{u}\right)=E_{1 s}+\frac{1}{R}-\frac{\varepsilon_{a a}-\varepsilon_{a b}}{1-S_{a b}} \\
\sigma_{g}=\frac{1}{\sqrt{2\left(1+S_{a b}\right)}}\left(\phi_{a}+\phi_{b}\right): & E\left(\sigma_{g}\right)=E_{1 s}+\frac{1}{R}-\frac{\varepsilon_{a a}+\varepsilon_{a b}}{1+S_{a b}}
\end{array}
$$

ここで $\phi_{a}$ おび $\phi_{b}$ はそれぞれ，水素原子 $a$ および $b$ の $1 \mathrm{~s} \mathrm{AOである.} S_{a b}, \varepsilon_{a a}, \varepsilon_{a b}$ は 式(19.2.17), 式(19.2.18), 式(19.2.19)に与えられている. 水素分子の持つ様々な「状態

(state)」を, この, $\mathrm{H}_{2}+$ について求めた分子軌道（MO）に電子を 2 個詰めたもので 表現しようとするのが, 電子を 2 個以上持つ分子についての分子軌道理論の考え方で ある.式(19.3.1)に示した $2 つ の \mathrm{MO}, \sigma_{g}$ と $\sigma_{u}$ に $2 つ の$ 電子を詰める場合の数は図 19.3.1 に示すように3つある。 


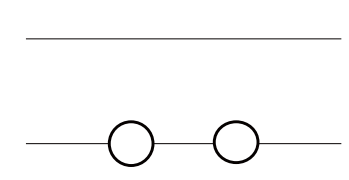

(a) 基底配置

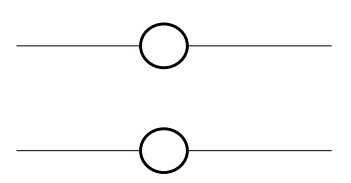

(b) 励起配置

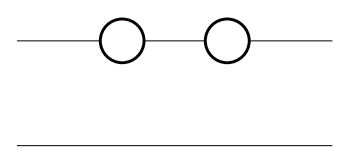

(c) 励起配置

図 $19.3 .1 \quad \mathrm{H}_{2}$ 分子の配置

$\mathrm{H}_{2}$ 分子の基底状態（ground state）（すなわち，もつともエネルギーの低い状態）は， 図 19.3.1の（a）に示した基底配置（ground configuration）でもって表されると考える. 後で詳しく述べるが， state（状態）と configuration（配置）とは全く別のものである. しかしここでは，もつとも簡単な考え方として，とりあえず ground state を ground configurationでもって表すという「近似」を採用するのである.

$\mathrm{H}_{2}$ の基底状態 $\Psi_{0}$ は， $\sigma_{g} \mathrm{MO}$ に 2 個の電子が詰まった配置とみなすわけであるか ら, 次のような Slater determinant で表される.

$$
\begin{aligned}
\Psi_{0} & =\left|\sigma_{g} \alpha(1) \quad \sigma_{g} \beta(2)\right| \\
& =\sqrt{\frac{1}{2}}\left|\begin{array}{ll}
\sigma_{g} \alpha(1) & \sigma_{g} \beta(1) \\
\sigma_{g} \alpha(2) & \sigma_{g} \beta(2)
\end{array}\right| \\
& =\left\{\sigma_{g}(1) \sigma_{g}(1)\right\} \sqrt{\frac{1}{2}}\{\alpha(1) \beta(2)-\beta(1) \alpha(2)\}
\end{aligned}
$$

ここで重要なことは式(19.3.2)のような state wavefunction は $\mathrm{H}_{2}$ 分子全体の Hamiltonian の固有関数にはなっていないということである。（このことについては，すぐ後で吟 味する).もし仮に，式(19.3.2)の代りに全 Hamiltonian の固有関数が与えられれば，そ れに全 Hamiltonian を作用することによって直ちに固有值が求まる．量子化学の勉強 を始めてからずっと, 多くの場合, 系の固有関数を求めて（場合によっては変分法や 摂動論を用いることはあっても）その固有值を求めることに努力して来た。しかし， なんとも残念なことに，もつとも簡単な，2 電子系分子の $\mathrm{H}_{2}$ 分子においてその基本 方針をあきらめなければならないのである! そこで, 系の固有值を求める代りに, 式 (19.3.2)で与えた state wavefunction について, 全 Hamiltonian $H$ の期待值をとることで 我慢をすることにする。 なんともおかしな理論とも思われるが， state wavefunctionを 出来るだけ $H$ の固有関数に近いものとすることで改良出来るであろうと楽観視して, この方針で先に進むことにする.

以上の方針によると，基底状態の「energy」 $E_{0}$ は 


$$
\begin{aligned}
E_{0} & =\left\langle\Psi_{0}|H| \Psi_{0}\right\rangle \\
& =\int \Psi_{0} * H \Psi_{0} d \tau
\end{aligned}
$$

で与えられる. total Hamiltonian $H$ は（atomic unit で)

$$
H=-\frac{1}{2} \nabla_{1}^{2}-\frac{1}{2} \nabla_{2}^{2}-\frac{1}{r_{a 1}}-\frac{1}{r_{b 1}}-\frac{1}{r_{a 2}}-\frac{1}{r_{b 2}}+\frac{1}{r_{12}}+\frac{1}{R}
$$

ここで $r$ のつきの $a$ および $b$ は原子核を，また， $r$ の下つきの 1 および 2 は電子を示 す。 $R$ は原子核間の距離である。（図 19.3.2）

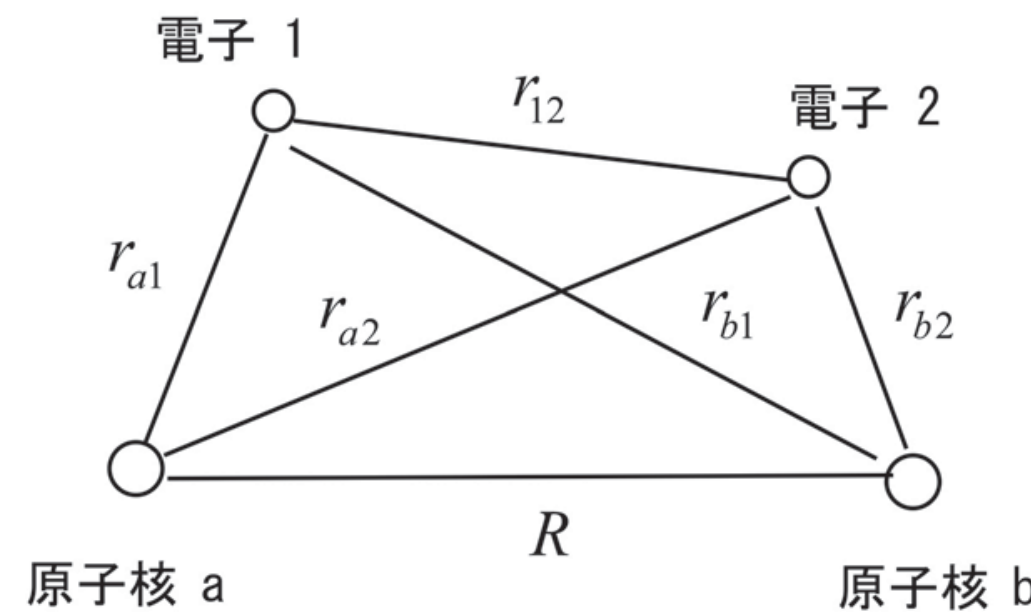

図 19.3.2 $\mathrm{H}_{2}$ 分子の座標系

ここで

$$
\begin{aligned}
& h(1)=-\frac{1}{2} \nabla_{1}^{2}-\frac{1}{r_{a 1}}-\frac{1}{r_{b 1}}+\frac{1}{r_{12}}+\frac{1}{R} \\
& h(2)=-\frac{1}{2} \nabla_{2}^{2}-\frac{1}{r_{a 2}}-\frac{1}{r_{b 2}}+\frac{1}{r_{12}}+\frac{1}{R}
\end{aligned}
$$

とおくと，h(1)およびh(2)は，式(19.2.6)で与えたもの，すなわち，それぞれ電子 1 および電子 2 についての Hamiltonian である。すなわち

$$
\begin{aligned}
& h(1) \sigma_{g}(1)=E\left(\sigma_{g}\right) \sigma_{g}(1) \\
& h(2) \sigma_{g}(2)=E\left(\sigma_{g}\right) \sigma_{g}(2)
\end{aligned}
$$


従って, 全 Hamiltonian $H$ は

$$
H=h(1)+h(2)+\frac{1}{r_{12}}-\frac{1}{R}
$$

となる. 式(19.3.7)で与えられた全 Hamiltonian $H$ を state wavefunction に作用してみよ う。この場合, 式(19.3.7)の Hamiltonian はすべて空間座標のみの関数でスピンの座標 を含んでいないので， $\Psi_{0}$ は式(19.3.2)の 3 行目の式を用いるのが便利であろう.

$$
\begin{aligned}
H \Psi_{0} & =\left\{h(1)+h(2)+\frac{1}{r_{12}}-\frac{1}{R}\right\} \sigma_{g}(1) \sigma_{g}(2) \frac{1}{\sqrt{2}}\{\alpha(1) \beta(2)-\beta(1) \alpha(2)\} \\
& =\left\{2 E\left(\sigma_{g}\right)-\frac{1}{R}+\frac{1}{r_{12}}\right\} \sigma_{g}(1) \sigma_{g}(2) \frac{1}{\sqrt{2}}\{\alpha(1) \beta(2)-\beta(1) \alpha(2)\} \\
& =\left\{2 E\left(\sigma_{g}\right)-\frac{1}{R}\right\} \Psi_{0}+\frac{1}{r_{12}} \Psi_{0}
\end{aligned}
$$

上式の最後の式で, もしも仮に, 最後の $\frac{1}{r_{12}}$ を含む項がなければ, state wavefunction $\Psi_{0}$ は $H$ の固有関数であるということになるが，現実には $\frac{1}{r_{12}}$ の項の存在のため， $\Psi_{0}$ は $H$ の固有関数ではない。むしろ，電子反発の寄与はかなり大きいから， $\Psi_{0}$ は $H$ の固有 関数からは大きくはずれていると見なすべきであろう.

これではあまりにもひどいということで， $\Psi_{0}$ を改良する試みは多くある. 1 つの 方法は 1 電子演算子 $h(1)$ と $h(2)$ の中に, なんとかして $\frac{1}{r_{12}}$ の項を部分的にでも取り込 んでしまおうという考えである。これが Hartree の方法であり，後に Hartree-Fock の 方法へと発展し, 大きな成功をおさめた方法である. しかし, 本質的に 2 電子の座標 を含む $\frac{1}{r_{12}}$ という項を 1 電子の座標 2 つで表すことは原理的に無理な話であり，たと え, Hartree-Fock 法を用いたとしても，依然として, state wavefunction は全 Hamiltonian の固有関数とは成り得ないのである. この問題は, 多電子系の量子化学の永遠の問題 であり，「電子相関（electron correlation）」という言葉で代表される概念の基となって おり，歴史的にも数多くの優れた理論があるが，こういう問題は，学部での講義のレ ベルを超えるものであるので，これ以上つっこんだ話はここでは出来ない.

式(19.3.8) を用いて，式(19.3.3)を計算すると次式が得られる. 


$$
E_{0}=2 E\left(\sigma_{g}\right)+J\left(\sigma_{g}, \sigma_{g}\right)-\frac{1}{R}
$$

ここで

$$
J\left(\sigma_{g}, \sigma_{g}\right)=\iint \sigma_{g} *(1) \sigma_{g} *(2) \frac{1}{r_{12}} \sigma_{g}(1) \sigma_{g}(2) d \tau_{1} d \tau_{2}
$$

は, 分子軌道に関する Coulomb 積分である. 式(19.3.1)の $E\left(\sigma_{g}\right)$ を代入すると式(19.3.9) は

$$
E_{0}=2 E_{1 s}-\frac{2\left(\varepsilon_{a a}-\varepsilon_{a b}\right)}{1-S_{a b}}+J\left(\sigma_{g}, \sigma_{g}\right)+\frac{1}{R}
$$

この式の右辺の第 2 項以降はすべて核間距離 $R$ の関数である. $\varepsilon_{a a}, \varepsilon_{a b}, S_{a b}$ の $R$ 依 存性についてはすでに前節で求めた. $J\left(\sigma_{g}, \sigma_{g}\right)$ は, 分子軌道についての Coulomb 積 分であるが，MO の形，式(19.3.1)を代入することによって AO に関する 2 電子積分の 和の形に表す。すなわち

$$
J\left(\sigma_{g}, \sigma_{g}\right)=\frac{1}{4\left(1+S_{a b}\right)^{2}}\left(\begin{array}{c}
2\langle a a \mid a a\rangle+2\langle a a \mid b b\rangle \\
+8\langle a a \mid a b\rangle+4\langle a b \mid a b\rangle
\end{array}\right)
$$

ここで，〈ab $|a b\rangle$ などは原子軌道に関する 2 電子積分で，一般的には次のように定義 されている。

$$
\langle p q \mid r s\rangle=\iint \phi_{p}(1) \phi_{q}(1) \frac{1}{r_{12}} \phi_{r}(2) \phi_{s}(2) d \tau_{1} d \tau_{2}
$$

(式(19.3.13)のような notation は, atomic orbital はすべて real の場合に用いられる. 従 って $\phi_{p}{ }^{*}=\phi_{p}$ などが成り立ち， conjugate を取る記号を省いている.）具体的には

$$
\begin{aligned}
\langle a a \mid a a\rangle & =\iint \phi_{a}(1) \phi_{a}(1) \frac{1}{r_{12}} \phi_{a}(2) \phi_{a}(2) d \tau_{1} d \tau_{2} \\
& =J(a, a) \\
\langle a a \mid b b\rangle & =\iint \phi_{a}(1) \phi_{a}(1) \frac{1}{r_{12}} \phi_{b}(2) \phi_{b}(2) d \tau_{1} d \tau_{2} \\
& =J(a, b) \\
\langle a a \mid a b\rangle & =\iint \phi_{a}(1) \phi_{a}(1) \frac{1}{r_{12}} \phi_{a}(2) \phi_{b}(2) d \tau_{1} d \tau_{2}
\end{aligned}
$$




$$
\begin{aligned}
\langle a b \mid a b\rangle & =\iint \phi_{a}(1) \phi_{b}(1) \frac{1}{r_{12}} \phi_{a}(2) \phi_{b}(2) d \tau_{1} d \tau_{2} \\
& =K(a, b)
\end{aligned}
$$

これら 4 つの 2 電子積分のうち, 式(19.3.14)の $\langle a a \mid a a\rangle$ は $\phi_{a}$ 軌道のみで与えられ, 1 中 心 2 電子積分と言われる. その他は $\phi_{a}$ と $\phi_{b}$ の 2 つの軌道を用いるので 2 中心 2 電子積 分と言われる．上式で定義される $J(a, a)$ および $J(a, b)$ は原子軌道に関する Coulomb 積分， $K(a, b)$ は原子軌道に関する交換積分であり，すでに Section 16.5 で定義したも のである. 2 中心積分は, 2 つの原子間の距離によって変り, 距離が大きくなるにつ れて積分の值は小さくなる. 3 つの型の 2 中心積分は, それぞれ, 原子間距離 $R$ に対 寸る関数形として求めることが出来る. 1 中心積分の值も計算で求めることが出来る. これら積分の具体的な形は, 大分複雑になるので,ここで計算することは省略するが, 結果は多くの教科書に載っている. かくして $J\left(\sigma_{g}, \sigma_{g}\right)$ の值を, それてひいては式 (19.3.9)の $E_{0}$ の值を $R$ の関数として求めることが出来る. 計算結果は図 19.3 .3 の破線 曲線（2つある破線曲線のうち下の方）のようになる. 


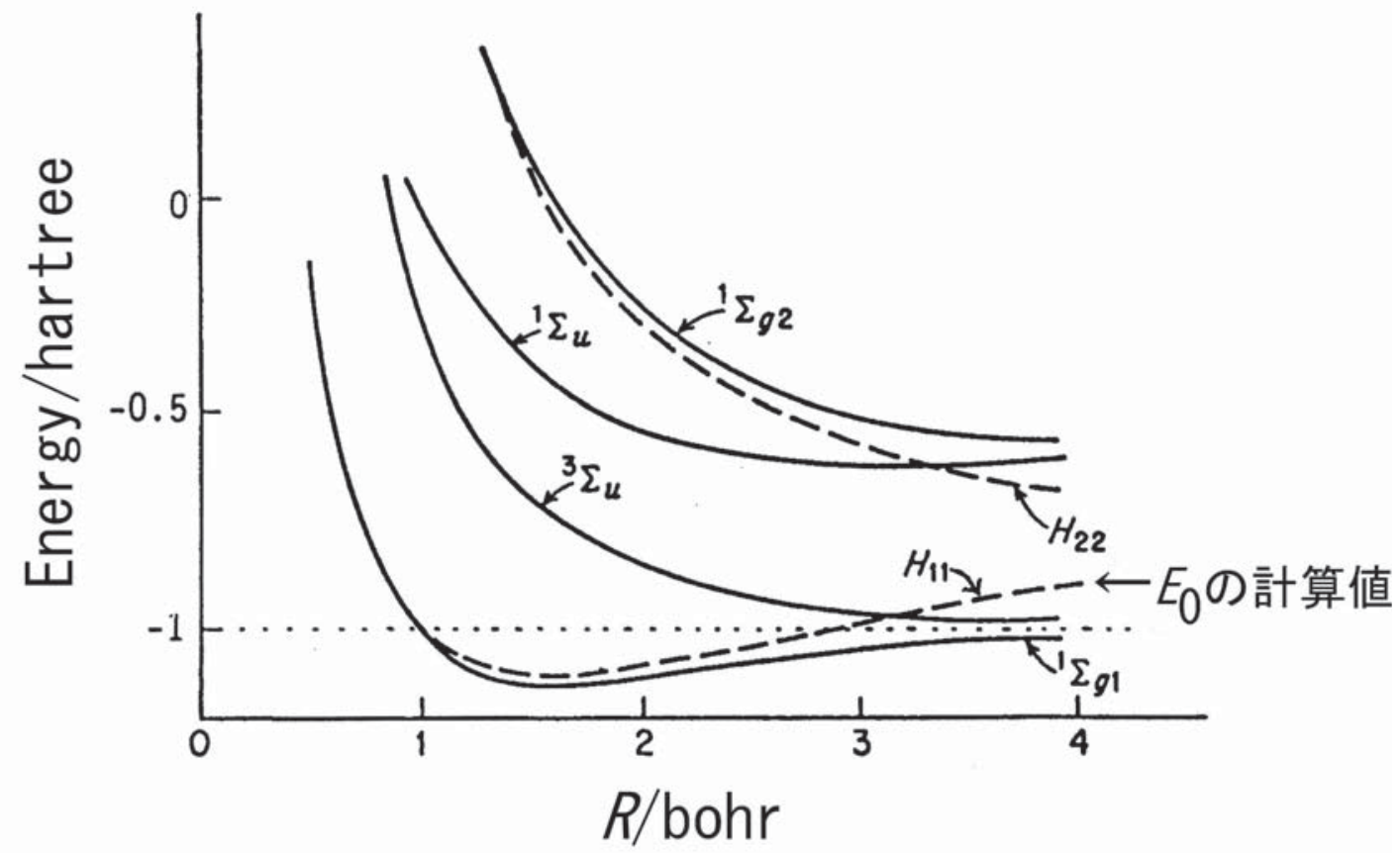

困 19.3.3 $\mathrm{H}_{2}$ 分子の energy の分子軌道法による計算值.

(J. Slater, "Quantum Theory of Molecules and Solids", Volume 1, page 67 の図を加工 修正). 式(19.3.9)の $E_{0}$ は，2つの破線曲線のうちの下の方. 実線の曲線は, 配置 間相互作用を入れた計算結果で，Section 19.5 で述べる. 基底状態は ${ }^{1} \Sigma_{g 1}$ と示し ている. 励起状態 $\left({ }^{3} \Sigma_{u},{ }^{1} \Sigma_{u},{ }^{1} \Sigma_{g 2}\right.$ と示したもの) についての計算結果も示さ れているが，ここでは問題としない.

計算結果では極小值は $R=84.0 \mathrm{pm}=1.59 \mathrm{bohr}$ の所にある. $\mathrm{H}_{2}$ 分子の原子間距離の 実測值は74.0 pm=1.40 bohr で，計算值と実験值の差は大きいと見るか小さいと見る かは考え方によるが，モデルが簡単な割にはよく合っているとみなせるような気がす る.図 19.3.3の計算結果は，上述したように，エネルギーの極小における $R$ の值につ いてはまあまあの結果と思えるが，定性的に見ても不都合なことは， $R$ が大きい所で $1 s$ の energy (すなわち $-\frac{1}{2}$ hartree ) の 2 倍よりも $E_{0}$ が大きくなってしまうことである. 
本来なら，Rが大きくなるにつれて，2 $E_{1 s}$ に収束しなければいけないはずであるのに。 このことを吟味するために，式(19.3.11)を $R \rightarrow \infty に$ 外挿してみよう. 式(19.2.18), 式 (19.2.19)，式(19.2.17)の $\varepsilon_{a a} ， \varepsilon_{a b} ， S_{a b}$ はいずれも $R \rightarrow \infty て ゙ 0$ となる.また式(19.3.12) の $J\left(\sigma_{g}, \sigma_{g}\right)$ は $R \rightarrow \infty て ゙ \frac{1}{2}\langle a a \mid a a\rangle$ となる. 従って

$$
E_{0}(R \rightarrow \infty)=2 E_{1 s}+\frac{1}{2}\langle a a \mid a a\rangle
$$

となってしまう。これは明らかにおかしい。 寸なわち, この節で述べた形の分子軌道 法は, 原子間距離の大きい所では定性的にも非常に悪いということになる. 従って解 離エネルギーの計算值も望ましいものとはほど遠いということになる.

以上のことは, 分子軌道法そのものが悪い, ということではない. ここで述べたよ うな, もっとも簡単な取り扱いでは不十分であるということである. 分子軌道法の改 良方法をこれから考えなければならないが，まずその前に，このSection で行った取 り扱い法の要点をまとめておこう.

本節で取り上げたのは, MO theory として考えられるいろいろな方法のうち, もう, これ以上単純な仮定はあり得ない，というような取り扱いである. 取り上げた仮定を まとめておく.

仮定 1： ground state は ground configuration で表すと仮定する. [式(19.3.2)]

仮定 2： molecular orbital $\sigma_{g}$ は2つの水素原子の $1 \mathrm{~s}$ atomic orbital $\phi_{a}$ および $\phi_{b}$ の linear combination として表す. [式(19.3.1)]

仮定 3： $\phi_{a}$ および $\phi_{b}$ を表す $1 s$ atomic orbital は H 原子のそれをそのまま用い る。すなわち, shielding の効果はないとしている. [式(19.2.14)]

これらの仮定のうち，もつとも重要なのが仮定 1 である. ground configuration が全 Hamiltonian の固有関数でないということが如何に深刻な問題であり, その解決は永遠 の問題であるということを上でも強調したところである. そのむずかしい解決策への 1 つの approach については Section 19.5 で学習することにする.

仮定 1 を保ちながら, 仮定 2 と仮定 3 を改良していく試みは今までも多くの人によ ってなされた。 それらのうち, Coulsonによる試みを表 19.3.1 に紹介寸る. 
表 19.3.1 MO method における $\sigma_{g}$ MO の改良

\begin{tabular}{|c|c|c|}
\hline$\sigma_{g}$ orbital & 結合 energy/eV & 変分 parameter \\
\hline$e^{-r_{a}}+e^{-r_{b}}$ & 2.681 & \\
\hline$e^{-Z r_{a}}+e^{-Z r_{b}}$ & 3.470 & $Z=1.197$ \\
\hline$e^{-Z R \mu}\left(1+a v^{2}\right)$ & 3.096 & $\begin{array}{l}Z=0.535 \\
a=0.23342 \\
R=1.40 \mathrm{bohr}\end{array}$ \\
\hline $\begin{array}{c}e^{-Z R \mu}\left(\begin{array}{l}1+a v^{2}+b \mu+c \mu^{2} \\
+d \mu v^{2}\end{array}\right) \\
\left(\mu=\frac{r_{a}+r_{b}}{R}, v=\frac{r_{a}-r_{b}}{R}\right)\end{array}$ & 3.603 & $\begin{array}{l}Z=0.535 \\
a=0.2787 \\
b=-0.12863 \\
c=0.012503 \\
d=-0.039589 \\
R=1.40 \mathrm{bohr}\end{array}$ \\
\hline 実験值 & 4.745 & \\
\hline
\end{tabular}

（文献）: C. A. Coulson, Trans. Faraday Soc. 33 (1937), 1479; Proc. Cambridge Phil. Soc. 34 (1938), 204

なお，MO の normalization factor は省略している. 表の 1 行目はこの Section で述べた ものである. 2 行目は shielding の効果として effective nuclear charge $の ~ Z$ を導入し, そ の $Z$ は変分原理によって求めている。結合エネルギーは $3.470 \mathrm{eV}$ となり，大分改良 されている. 3 行目と 4 行目はMO の形自身が原子核間距離 $R$ の関数として表されて いる. 3 行目は，変分 parameter の数が 3 個に増えているにもかかわらず，結合エネル ギーの計算值はより悪くなっている．やはり MO の関数形としては，2 つの AO の LCAO で表すというのが，定性的にはかなり良いということを示しているように思え る.しかし，3 行目の MO も，変分 parameter の数を更に多くすると結合エネルギー は大分改善される。しかし，それでも，実測の $4.745 \mathrm{eV}$ にはほど遠い。こうしてみる と，やはり，近似 1 をどうにかしないと，根本的な解決にはならないであろうことが 予想出来る.

最後に，本節で扱った基底状態 $\Psi_{0}$ が分子のどのような既約表現に属するかを調べ 
ておこう．MO $\sigma_{g}$ の transformation property については表 19.2.1 で既に調べてあるが

（表 19.2.1 では $\sigma_{g}$ のことを $\psi_{+}$と表している）念のため再び掲げる.

\begin{tabular}{|c|cccccc|c|}
\hline & $E$ & $2 C_{\phi}$ & $\sigma_{v}$ & $i$ & $2 i C_{\phi}$ & $i \sigma_{v}$ & 既約表現 \\
\hline$\sigma_{g}$ & $\sigma_{g}$ & $\sigma_{g}$ & $\sigma_{g}$ & $\sigma_{g}$ & $\sigma_{g}$ & $\sigma_{g}$ & $\Sigma_{g}{ }^{+}$ \\
\hline
\end{tabular}

すなおち，すべての operation によって

$$
R \sigma_{g}=\sigma_{g}
$$

が成り立つ.それに基づいて式(19.3.2)の $\Psi_{0}$ の transformation property を求めてみよう. 再び $R$ を $\mathrm{D}_{2 \mathrm{~h}}$ 点群の全ての operation として

$$
\begin{aligned}
& R \Psi_{0}=R\left|\sigma_{g} \alpha(1) \quad \sigma_{g} \beta(2)\right| \\
& =\left|\left(R \sigma_{g}\right) \alpha(1) \quad\left(R \sigma_{g}\right) \beta(2)\right| \\
& =\left|\sigma_{g} \alpha(1) \quad \sigma_{g} \beta(2)\right|
\end{aligned}
$$

となる.すなわち，すべての symmetry operation について $\Psi_{0}$ は invariant である.これ は totally symmetric（全対称）な表現であり， character table をみればそれは $\Sigma_{g}^{+}$である ことが分かる。

式(19.3.20)では Slater determinant 全体に symmetry operation を作用したが, operation $R$ が spin function には作用しないということで式(19.3.2)の最後の式に $R$ を作用させて もよい. この場合,

$$
R \sigma_{g}(1) \sigma_{g}(2)=\left(R \sigma_{g}\right)(1)\left(R \sigma_{g}\right)(2)=\sigma_{g}(1) \sigma_{g}(2)
$$

より，やはり totally symmetric ということが分かる．また，もっと簡便に， $\sigma_{g} \mathrm{MO}$ 自 体が $\Sigma_{g}{ }^{+}$に属することが分かっているから，

$$
\Sigma_{g}^{+} \times \Sigma_{g}^{+}=\Sigma_{g}^{+}
$$


のように, $\Sigma_{g}{ }^{+}$同志の直積を求めてもよい. いずれにしても, どんな点群においても, 縮退していない MO に 2 個の電子がつまれば，必ず totally symmetric となることは以 上の議論からはっきりしたであろう。

\section{4 水素分子の原子価結合法による取り扱い. Heiter-London の方法}

分子軌道の方法と並んで，もう1つの重要な取り扱いは原子価結合法 (valence bond method）である. 化学者は一般的に「分子は原子より構成される」という概念を持っ ており, valence bond method（VB method）はそのような考え方を素直に取り入れた理 論であるため，化学者にとっては，VB method の方が molecular orbital method（MO method）に比べるとより理解しやすいと思う.

MO method では，まず，原子から電子を取り除き，核同志をある程度の距離まで 近付けて，そうして作られた molecular orbital に電子を詰めていく．それに対し，VB method では，電子を持った原子をある程度の距離まで近付けて分子を作るのである. 原子間の距離が十分に大きければ独立した原子となる. 前節の最後で, MO method で は，原子間距離を無限大にした時，全エネルギーが 2 つの原子のエネルギーの和より も大きくなってしまうという不都合があることを学習したが，VB methodにはそのよ うな不都合はない。

2 つの $\mathrm{H}$ 原子が遠く離れている場合を考えよう.それぞれは基底状態にあると考え てよい，基底状態の $\mathrm{H}$ 原子は $1 s$ atomic orbital（AO）に電子が入ったものである． A という $\mathrm{H}$ 原子の $1 s \mathrm{AO}$ を $\phi_{a}$ とすると, 例えば電子 1 が $\phi_{a}$ に入った状態は $\phi_{a}(1)$ と表さ れる。もう 1 つの $\mathrm{H}$ 原子 $\mathrm{B}$ の $1 s \mathrm{AO}$ を $\phi_{b}$ として，その $\mathrm{H}$ 原子の基底状態は $\phi_{b}(2)$ と 表される. 2 つの H が無限遠に離れていれば $\phi_{a}(1)$ と $\phi_{b}(2)$ はお互いに独立であるが， 距離がある程度近づくと, $\mathrm{H}_{2}$ 分子の状態は $\phi_{a}(1) \phi_{b}(2)$ と $\phi_{a}(2) \phi_{b}(1)$ の線形結合として 表される.この場合, 2 つの電子のスピンの相対的向きによって, $\mathrm{H}_{2}$ 分子全体として singlet（ $S=0 ）$ または triplet（ $S=1 ）$ のいずれかの可能性がある.

singlet $の$ wave function ${ }^{1} \Psi$ は次のような Slater determinant で表される. 


$$
\begin{aligned}
& { }^{1} \Psi=\frac{1}{\sqrt{2\left(1+S_{a b}^{2}\right)}}\left(\frac{1}{\sqrt{2}}\left|\begin{array}{ll}
\phi_{a} \alpha(1) & \phi_{b} \beta(1) \\
\phi_{a} \alpha(2) & \phi_{b} \beta(2)
\end{array}\right|-\frac{1}{\sqrt{2}}\left|\begin{array}{ll}
\phi_{a} \beta(1) & \phi_{b} \alpha(1) \\
\phi_{a} \beta(2) & \phi_{b} \alpha(2)
\end{array}\right|\right) \\
& =\frac{1}{\sqrt{2\left(1+S_{a b}^{2}\right)}}\left(\begin{array}{ll}
\phi_{a} \alpha & \phi_{b} \beta
\end{array}|-| \phi_{a} \beta \quad \phi_{b} \alpha \mid\right) \\
& =\frac{1}{\sqrt{2\left(1+S_{a b}^{2}\right)}}\left\{\phi_{a}(1) \phi_{b}(2)+\phi_{b}(1) \phi_{a}(2)\right\} \frac{1}{\sqrt{2}}\{\alpha(1) \beta(2)-\beta(1) \alpha(2)\}
\end{aligned}
$$

式(19.4.1a)の最後の式では, Slater determinant で表される state wavefunction が，空間部 分の波動関数（spatial wavefunction）とスピンの波動関数（spin wavefunction）との積 で表されている。電子の数が 2 個の時には，このように， state wavefunction が spatial wavefunction と spin wavefunction との単純な積としても表すことが出来て, 何かと便 利である。一方, triplet の wavefunction は $S_{z}$ の固有值がちの場合, 0 の場合, $-\hbar$ の場 合，それぞれ次のようになる.

$$
\begin{aligned}
& { }^{3} \Psi_{+1}=\frac{1}{\sqrt{2\left(1-S_{a b}^{2}\right)}}\left|\begin{array}{ll}
\phi_{a} \alpha(1) & \phi_{b} \alpha(1) \\
\phi_{a} \alpha(2) & \phi_{b} \alpha(2)
\end{array}\right| \\
& =\frac{1}{\sqrt{2\left(1-S_{a b}^{2}\right)}}\left|\phi_{a} \alpha \quad \phi_{b} \alpha\right| \\
& =\frac{1}{\sqrt{2\left(1-S_{a b}^{2}\right)}}\left\{\phi_{a}(1) \phi_{b}(2)-\phi_{b}(1) \phi_{a}(2)\right\}\{\alpha(1) \alpha(2)\} \\
& { }^{3} \Psi_{0}=\frac{1}{\sqrt{2\left(1-S_{a b}^{2}\right)}}\left(\frac{1}{\sqrt{2}}\left|\begin{array}{ll}
\phi_{a} \alpha(1) & \phi_{b} \beta(1) \\
\phi_{a} \alpha(2) & \phi_{b} \beta(2)
\end{array}\right|+\frac{1}{\sqrt{2}}\left|\begin{array}{ll}
\phi_{a} \beta(1) & \phi_{b} \alpha(1) \\
\phi_{a} \beta(2) & \phi_{b} \alpha(2)
\end{array}\right|\right) \\
& =\frac{1}{\sqrt{2\left(1+S_{a b}^{2}\right)}}\left(\begin{array}{ll}
\mid \phi_{a} \alpha & \phi_{b} \beta
\end{array}|+| \phi_{a} \beta \quad \phi_{b} \alpha \mid\right) \\
& =\frac{1}{\sqrt{2\left(1+S_{a b}^{2}\right)}}\left\{\phi_{a}(1) \phi_{b}(2)-\phi_{b}(1) \phi_{a}(2)\right\} \frac{1}{\sqrt{2}}\{\alpha(1) \beta(2)+\beta(1) \alpha(2)\}
\end{aligned}
$$




$$
\begin{aligned}
{ }^{3} \Psi_{-1} & =\frac{1}{\sqrt{2\left(1-S_{a b}^{2}\right)} \mid}\left|\begin{array}{ll}
\phi_{a} \beta(1) & \phi_{b} \beta(1) \\
\phi_{a} \beta(2) & \phi_{b} \beta(2)
\end{array}\right| \\
& =\frac{1}{\sqrt{2\left(1-S_{a b}^{2}\right)}}\left|\phi_{a} \beta \quad \phi_{b} \beta\right| \\
& =\frac{1}{\sqrt{2\left(1-S_{a b}^{2}\right)}}\left\{\phi_{a}(1) \phi_{b}(2)-\phi_{b}(1) \phi_{a}(2)\right\}\{\beta(1) \beta(2)\}
\end{aligned}
$$

ここで $\Psi$ の subscript は， $\frac{S_{z}}{\hbar}$ についての固有值，すなわち $M_{S}$ を示す.

state wavefunction が与えられたので，エネルギーを計算する前に，まず，これらの state wavefunction がどのような既約表現に属するかを調べておこう. atomic orbital $\phi_{a}$ および $\phi_{b}$ が $\mathrm{D}_{\infty \mathrm{h}}$ 点群の operation に対してどのように transform するかはすでに表 19.2.1に示してあるが，念のため再び載せる.

\begin{tabular}{|c|c|c|c|c|c|c|}
\hline & $E$ & $2 C_{\phi}$ & $\sigma_{v}$ & $i$ & $2 i C_{\phi}$ & $i \sigma_{v}$ \\
\hline$\phi_{a}$ & $\phi_{a}$ & $\phi_{a}$ & $\phi_{a}$ & $\phi_{b}$ & $\phi_{b}$ & $\phi_{b}$ \\
\hline$\phi_{b}$ & $\phi_{b}$ & $\phi_{b}$ & $\phi_{b}$ & $\phi_{a}$ & $\phi_{a}$ & $\phi_{a}$ \\
\hline
\end{tabular}

これを用いて，式(19.4.1)に示した state wavefunction がじのように transform するかを 調べればよい.

上の表をみると, operation $E, C_{\phi}$, および $\sigma_{v}$ については $\phi_{a} お よ ひ ゙ \phi_{b}$ はもとのまま, また, operation $i, i C_{\phi}$, および $i \sigma_{v}$ については $\phi_{a}$ と $\phi_{b}$ とが交換することが分かる. そ こで以下，簡単のために，前者の operation をまとめて $R$, 後者の operation をまとめ て $S$ と示すことにしよう。すなわち

$R=E, \quad C_{\phi}, \quad \sigma_{v}$ の場合 


$$
\begin{aligned}
& R \phi_{a}=\phi_{a} \\
& R \phi_{b}=\phi_{b}
\end{aligned}
$$

$S=i, \quad i C_{\phi}, i \sigma_{v}$ の場合

$$
\begin{aligned}
R \phi_{a} & =\phi_{b} \\
R \phi_{b} & =\phi_{a}
\end{aligned}
$$

そこで，例えば， singlet の state function ${ }^{1} \Psi$ そ および $S$ を作用してみよう.

$$
\begin{aligned}
R^{1} \Psi & =\frac{1}{\sqrt{2\left(1+S_{a b}^{2}\right)}} R\left(\begin{array}{lll}
\mid \phi_{a} \alpha & \phi_{b} \beta|-| \phi_{a} \beta & \phi_{b} \alpha
\end{array}\right) \\
& =\frac{1}{\sqrt{2\left(1+S_{a b}^{2}\right)}}\left(\mid \begin{array}{lll}
\left.R \phi_{a}\right) \alpha & \left(R \phi_{b}\right) \beta|-|\left(R \phi_{a}\right) \beta \quad\left(R \phi_{b}\right) \alpha
\end{array}\right) \\
& =\frac{1}{\sqrt{2\left(1+S_{a b}^{2}\right)}}\left(\begin{array}{lll}
\mid \phi_{a} \alpha & \phi_{b} \beta|-| \phi_{a} \beta & \phi_{b} \alpha
\end{array}\right) \\
& ={ }^{1} \Psi
\end{aligned}
$$

同様に， ${ }^{1} \Psi$ $S$ を作用してみよう。

$$
\begin{aligned}
& S^{1} \Psi=\frac{1}{\sqrt{2\left(1+S_{a b}^{2}\right)}} S\left(\left|\phi_{a} \alpha \quad \phi_{b} \beta\right|-\left|\phi_{a} \beta \quad \phi_{b} \alpha\right|\right)
\end{aligned}
$$

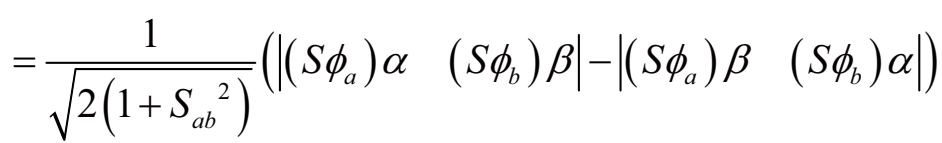

$$
\begin{aligned}
& =\frac{1}{\sqrt{2\left(1+S_{a b}^{2}\right)}}\left(\begin{array}{ll}
\mid \phi_{b} \alpha & \phi_{a} \beta
\end{array}|-| \phi_{b} \beta \quad \phi_{a} \alpha \mid\right) \\
& ={ }^{1} \Psi
\end{aligned}
$$

ここで 2 行目から 3 行目の変換では行列のある 2 つの列を交換すると符号が反転する という行列の性質を用いている.

同様な操作を ${ }^{3} \Psi_{0}$ についても行ってみる. 


$$
\begin{aligned}
& R^{3} \Psi_{0}=\frac{1}{\sqrt{2\left(1-S_{a b}^{2}\right)}} R\left(\begin{array}{ll}
\mid \phi_{a} \alpha & \phi_{b} \beta
\end{array}|+| \phi_{a} \beta \quad \phi_{b} \alpha \mid\right) \\
& =\frac{1}{\sqrt{2\left(1-S_{a b}^{2}\right)}}\left(\mid \begin{array}{ll}
\left.\left.R \phi_{a}\right) \alpha \quad\left(R \phi_{b}\right) \beta|+|\left(R \phi_{a}\right) \beta \quad\left(R \phi_{b}\right) \alpha \mid\right)
\end{array}\right. \\
& =\frac{1}{\sqrt{2\left(1-S_{a b}^{2}\right)}}\left(\begin{array}{ll}
\mid \phi_{a} \alpha & \phi_{b} \beta
\end{array}|+| \phi_{a} \beta \quad \phi_{b} \alpha \mid\right) \\
& ={ }^{3} \Psi_{0} \\
& S^{3} \Psi_{0}=\frac{1}{\sqrt{2\left(1-S_{a b}^{2}\right)}} S\left(\begin{array}{ll}
\mid \phi_{a} \alpha & \phi_{b} \beta
\end{array}|+| \phi_{a} \beta \quad \phi_{b} \alpha \mid\right)
\end{aligned}
$$

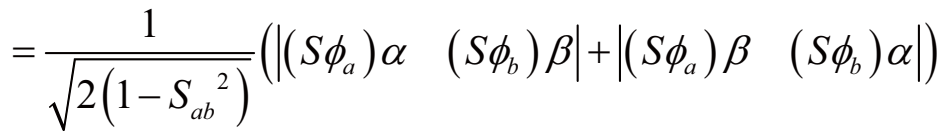

$$
\begin{aligned}
& =\frac{1}{\sqrt{2\left(1-S_{a b}^{2}\right)}}\left(\begin{array}{ll}
\mid \phi_{b} \alpha & \phi_{a} \beta
\end{array}|+| \phi_{b} \beta \quad \phi_{a} \alpha \mid\right) \\
& =\frac{1}{\sqrt{2\left(1-S_{a b}^{2}\right)}}\left(-\left|\phi_{a} \beta \quad \phi_{b} \alpha\right|-\left|\phi_{a} \alpha \quad \phi_{b} \beta\right|\right) \\
& =-{ }^{3} \Psi_{0}
\end{aligned}
$$

以上まとめると transformation property は次のようになる.

\begin{tabular}{|c|cccccc|c|}
\hline & $E$ & $2 C_{\phi}$ & $\sigma_{v}$ & $i$ & $2 i C_{\phi}$ & $i \sigma_{v}$ & 既約表現 \\
\hline${ }^{1} \Psi$ & ${ }^{1} \Psi$ & ${ }^{1} \Psi$ & ${ }^{1} \Psi$ & ${ }^{1} \Psi$ & ${ }^{1} \Psi$ & ${ }^{1} \Psi$ & $\Sigma_{g}{ }^{+}$ \\
\hline${ }^{3} \Psi_{0}$ & ${ }^{3} \Psi_{0}$ & ${ }^{3} \Psi_{0}$ & ${ }^{3} \Psi_{0}$ & $-{ }^{3} \Psi_{0}$ & $-{ }^{3} \Psi_{0}$ & $-{ }^{3} \Psi_{0}$ & $\Sigma_{u}{ }^{+}$ \\
\hline
\end{tabular}

$\mathrm{D}_{\infty \mathrm{h}}$ の character table と比較することにより， ${ }^{1} \Psi$ は $\Sigma_{g}{ }^{+}$の既約表現に，また， ${ }^{3} \Psi_{0}$ は $\Sigma_{u}{ }^{+}$の既約表現に属することが分かる.上の表の右端の列にそのことをも書き入れて 
ある.なお，ここでは， tripletの 3 つの関数のうちただ $1{ }^{3} \Psi_{0}$ のみを扱った. ${ }^{3} \Psi_{1}$ と ${ }^{3} \Psi_{-1}$ については諸君の演習に残しておこう。（Problem 19.4.1）

以上の取り扱いでは, 群論の練習になると思って, Slater determinantに直接 symmetry operation を作用した。 しかし，以下のようにすることも可能である.

式(19.4.1)に示すように, state wavefunction が spatial wavefunction と spin wavefunction との積になっている。仮に, spatial wavefunction をФで表すと, singlet stateについて は

$$
{ }^{1} \Phi=\frac{1}{\sqrt{2\left(1+{S_{a b}}^{2}\right)}}\left\{\phi_{a}(1) \phi_{b}(2)+\phi_{b}(1) \phi_{a}(2)\right\}
$$

また， triplet stateについては

$$
{ }^{3} \Phi=\frac{1}{\sqrt{2\left(1-S_{a b}^{2}\right)}}\left\{\phi_{a}(1) \phi_{b}(2)-\phi_{b}(1) \phi_{a}(2)\right\}
$$

これらの spatial wavefunction に直接 symmetry operation を作用しても上で求めたのと 同じ結果になるはずである。試みてみよ。(Problem 19.4.2)

こうして state を示す wavefunction が得られた。この state wavefunction は以下に示 す全 Hamiltonian の固有関数にはなっていない（Problem 19.4.1）。そこで，ここでも， $H$ に対する期待值を計算してそれを"energy"とする，という方針で我慢をする。かく して, 各 state の"energy"は

$$
E_{i}=\int \Psi_{i} * H \Psi_{i} d \tau
$$

で与えられる.ここで壮は式(19.4.1) に示した 4 つの wavefunction のいずれかである.

Hamiltonian は（再び原子単位系で）

$$
\begin{aligned}
H & =-\frac{1}{2} \nabla_{1}^{2}-\frac{1}{2} \nabla_{2}^{2}-\frac{1}{r_{a 1}}-\frac{1}{r_{a 2}}-\frac{1}{r_{b 1}}-\frac{1}{r_{b 2}}+\frac{1}{r_{12}}+\frac{1}{R} \\
& =h(1)+h(2)-\frac{1}{r_{a 2}}-\frac{1}{r_{b 1}}+\frac{1}{r_{12}}+\frac{1}{R}
\end{aligned}
$$

ここで

$$
\begin{aligned}
& h(1)=-\frac{1}{2} \nabla_{1}^{2}-\frac{1}{r_{a 1}} \\
& h(2)=-\frac{1}{2} \nabla_{2}^{2}-\frac{1}{r_{b 2}}
\end{aligned}
$$


は

$$
\begin{aligned}
& h(1) \phi_{a}(1)=E_{1 s} \phi_{a}(1) \\
& h(2) \phi_{b}(2)=E_{1 s} \phi_{b}(2)
\end{aligned}
$$

で表されるように， $\phi_{a}$ および $\phi_{b}$ にいての Hamiltonian である.

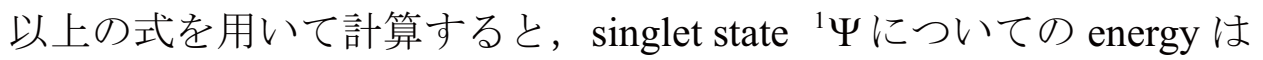

$$
E\left({ }^{1} \Psi\right)=2 E_{1 s}+\frac{J}{1+S_{a b}^{2}}+\frac{K}{1+S_{a b}^{2}}
$$

また， triplet state についての energy は，3つの state $\left({ }^{3} \Psi_{1},{ }^{3} \Psi_{0},{ }^{3} \Psi_{-1}\right)$ とも共通に

$$
E\left({ }^{3} \Psi\right)=2 E_{1 s}+\frac{J}{1-S_{a b}^{2}}-\frac{K}{1-S_{a b}^{2}}
$$

となる，ここで $J$ は，通常，Coulomb integral と呼ばれ次の式で表される.

$$
\begin{aligned}
J & =\iint \phi_{a} *(1) \phi_{b} *(2)\left(-\frac{1}{r_{a 2}}-\frac{1}{r_{b 1}}+\frac{1}{r_{12}}+\frac{1}{R}\right) \phi_{a}(1) \phi_{b}(2) d \tau_{1} d \tau_{2} \\
& =-2 \varepsilon_{a a}+\frac{1}{R}+\iint \phi_{a} *(1) \phi_{b} *(2)\left(\frac{1}{r_{12}}\right) \phi_{a}(1) \phi_{b}(2) d \tau_{1} d \tau_{2} \\
& =-2 \varepsilon_{a a}+\frac{1}{R}+\langle a a \mid b b\rangle
\end{aligned}
$$

2 行目，および 3 行目の式の第 3 項は，式(19.3.15)ですでに定義したもので，「atomic orbital に関する Coulomb integral」と言われる。この式全体で示されるJは，「valence bond theory における Coulomb integral」である. 同じ $J$ という記号が用いられるが，原 子を扱う理論の時の Coulomb integral [式(19.4.16)の第 3 項目］と valence bond theory における Coulomb integral [式(19.4.16)全体］とは多少異なったものである．更に molecular orbital theoryにおける Coulomb integral [例えば式(19.3.10)］とも異なるもの である。名前が同じなだけに注意しないといけない.

又, $K$ は exchange integral と呼ばれ, 次式で定義される.

$$
\begin{aligned}
K & =\iint \phi_{a} *(1) \phi_{b} *(2)\left(-\frac{1}{r_{a 2}}-\frac{1}{r_{b 1}}+\frac{1}{r_{12}}+\frac{1}{R}\right) \phi_{b}(1) \phi_{a}(2) d \tau_{1} d \tau_{2} \\
& =\frac{S_{a b}^{2}}{R}-2 S_{a b} \varepsilon_{a b}+\iint \phi_{a} *(1) \phi_{b} *(2)\left(\frac{1}{r_{12}}\right) \phi_{b}(1) \phi_{a}(2) d \tau_{1} d \tau_{2} \\
& =\frac{S_{a b}^{2}}{R}-2 S_{a b} \varepsilon_{a b}+\langle a b \mid a b\rangle
\end{aligned}
$$


2 行目, および 3 行目の式の第 3 項目は, 寸でに式(19.3.17)で定義した交換積分であ る. 寸なわち, 式(19.4.17)の全体が VB theory でいう所の exchange integral であり，そ のうちの一部に MO theory でいう所の exchange integral が含まれている. 式(19.4.16) の $J$ によ，式(19.4.17)の $K$ にせよ，Coulomb integral とか exchange integral という同 じ言葉が，いろいろと異なった意味で使われているので注意が必要である.

さて, 式(19.4.17)の $K$ の符号を考えてみる. 第 1 項 $\left(\frac{S_{a b}{ }^{2}}{R}\right)$ と第 3 項 $(\langle a b \mid a b\rangle)$

は正である. 第 2 項 $\left(-2 S_{a b} \varepsilon_{a b}\right)$ に現れる重なり積分は, 軌道の種類と原子間距離に よって少々異なるが，少なくとも $2 つ の s$ 軌道の場合には，あらゆる原子間距離で正 である. 従って第 2 項全体としては負である. そこで $K$ 全体として正であるか負であ るかは，一般の分子についてはもう少し定量的に大きさを吟味しないといけないが， 少なくとも水素分子の場合には, 第 2 項の寄与が大きく, $K$ 全体として負となる.

以上の考察をもとに singlet state ${ }^{1} \Psi$ と triplet state ${ }^{3} \Psi$ とのエネルギーを比較してみ よう。式(19.4.15)と式(19.4.14)との差をとると

$$
\begin{aligned}
E\left({ }^{3} \Psi\right)-E\left({ }^{1} \Psi\right) & =J\left(\frac{1}{1-S_{a b}{ }^{2}}-\frac{1}{1+S_{a b}{ }^{2}}\right)+K\left(\frac{1}{1-S_{a b}{ }^{2}}+\frac{1}{1+S_{a b}{ }^{2}}\right) \\
& =\frac{2\left(S_{a b}{ }^{2} J+K\right)}{1-S_{a b}{ }^{4}}
\end{aligned}
$$

この式の值および符号は，もちろん， $S_{a b}$ の大きさにもよるが，通常の 2 原子分子位 の距離では $S_{a b}{ }^{2}<<1$ と考えてよく, 式(19.4.18)の符号はほぼ $K$ の符号で決まり， $K<0$ であるから式(19.4.18)も負であるといい得る．従って

$$
E\left({ }^{3} \Psi\right)>E\left({ }^{1} \Psi\right)
$$

すなわち, triplet state の方が singlet state よりもエネルギーが高いという結論が得られ る.このことは, 非常に重要な結論の 1 つである. なお, この節の Coffee Break を参 考にしてほしい.

結局, $E\left({ }^{3} \Psi\right)$ および $E\left({ }^{1} \Psi\right)$ は $S_{a b}, \varepsilon_{a a}, \varepsilon_{a b}, E_{1 s},\langle a a \mid b b\rangle,\langle a b \mid a b\rangle$ 等の $\mathrm{AO}$ に関 する積分でもって表すことが出来る. AO が $\exp (-r)$ という, 水素原子と同じ形で与 えられる場合は，これら積分值の関数形はすでに前節で与えてある.

図 19.4.1に，こうして求めた $E\left({ }^{3} \Psi\right)$ および $E\left({ }^{1} \Psi\right)$ の計算值を核間距離 $R$ の関数と 
して示した.

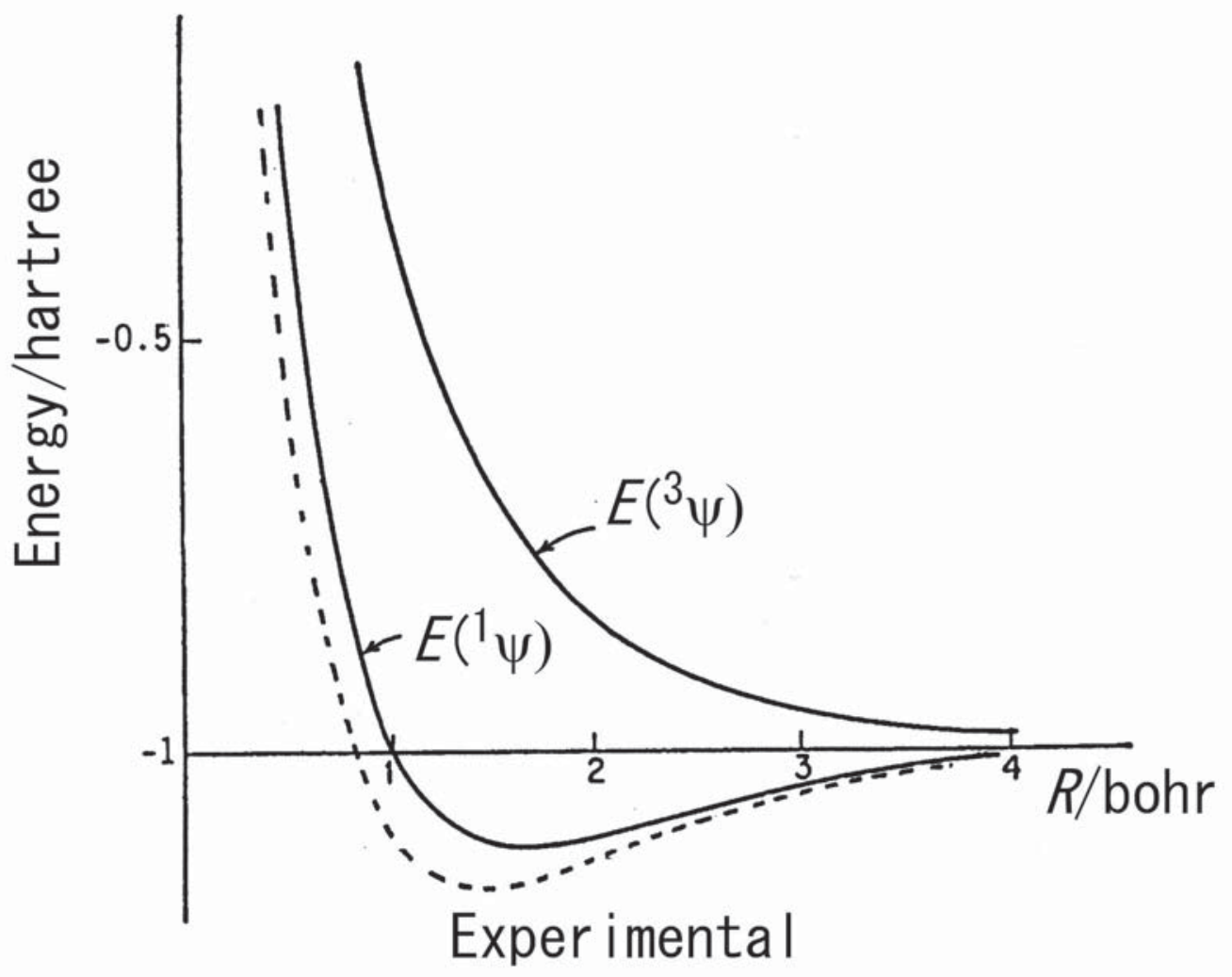

図 19.4.1 Heitler-London model による $\mathrm{H}_{2}$ 分子のエネルギー $\left(E\left({ }^{3} \Psi\right)\right.$ および $\left.E\left({ }^{1} \Psi\right)\right)$ の計算值（実線）。破線は実験から得られる基底状態のエネルギー.

基底状態 ${ }^{1} \Psi$ は $R=1.64 \mathrm{bohr}$ でもつとも安定で, この距離が平衡核間距離の計算值 である．解離エネルギーの計算值は，この時のエネルギーと $R \rightarrow \infty$ の時のエネルギー との差で 0.1160 hartree $=3.14 \mathrm{eV}$ となる．実験によると平衡核間距離は $1.4006 \mathrm{bohr}$, 解離エネルギーは 0.174 hartree と求まっている。計算と実験とは，それほど正確には 合っているとは必ずしも言えないが，むしろ，これだけ簡単なモデルで，よくまあ合 っているものだ，とも考えられる.

図 19.4.1の計算結果は，あくまで，AO を $\exp (-r)$ という， shielding の効果を考え 
ない水素原子の $1 s$ 波動関数を用いた時の計算值である. state wavefunction はあくまで 式(19.4.1)のように表しておいた上で，AOの関数形を改良することも可能である．そ れらの試みのうちのいくつかを表 19.4.1 に示す. 1 行目は上述した Heitler-London 法 である. 2 行目は shielding の効果を入れて, effective nuclear charge $Z$ を変分パラメー ターとしたものである. 3 行目は $\phi_{a}$ を $1 s$ 軌道と $2 p_{z}$ 軌道との linear combination として 表したものである。こういう方式での AO の改良はきりがなく, parameter の数を増す に従って結合エネルギーは実験值に近くなる。そういう試みは沢山あるが，かなり専 門的な話になるので，ここではこれ以上詳しくは述べないことにする.

表 19.4.1 VB methodにおける AO $\left(\phi_{a}\right.$ およ゙ $\left.\phi_{b}\right)$ の改良

\begin{tabular}{ccc}
\hline $\mathrm{AO} \phi_{a}$ & 結合 energy/eV & 変分 parameter \\
\hline $\exp \left(-r_{a}\right)$ & 3.14 & \\
$\exp \left(-Z r_{a}\right)$ & 3.76 & $Z=1.166$ \\
$\exp \left(-Z r_{a}\right)\left(1+a Z r_{a} \cos \theta_{a}\right)$ & 4.02 & $Z=1.17$ \\
実験值 & 4.745 & $a Z_{a}=0.123$ \\
\hline
\end{tabular}

式(19.4.16)および式(19.4.17)から明らかなように， $J$ も $K$ も $R \rightarrow \infty$ で0に収束する. このことはAO の形によらない，従って式(19.4.14)および式(19.4.15)より分かるよう に, VB theory では $R \rightarrow \infty$ で $E\left({ }^{1} \Psi\right)$ も $E\left({ }^{3} \Psi\right)$ もどちらも $2 E_{1 s}=-1$ hartree に収束してい る.すなわち，距離無限大では正しくエネルギーを与えており，この意味で，距離の 大きいところで定性的にも正しくない結果を与える MO theory とは大きく異なる.

では VB theory と MO theory は，どこが同じでじこが異なるのであろうか.それを 次の Sectionで学習しよう. 
[Coffee Break] 一重項状態と三重項状態と，どちらがエネルギーが高い

か?

式(19.4.19)で，原子価結合方では，三重項状態が相当する一重項状態よりもエネル ギーが高いことを示したが，分子軌道論に慣れ親しんだ学生さんの中には，ここで述 べたことが理解しにくくて悩む人が多いようである. Hund の法則に従うと，三重項 状態が一重項状態よりも低エネルギーに存在する. 多くの分子について（例外もある ことに注意！), 三重項状態からの発光である燐光スペクトルが一重項状態からの発 光である蛍光スペクトルよりも長波長にあることが Hund の法則で説明されている. そこでこんがらかってしまうらしい，これは，原子価結合法と分子軌道法法の違いの せいなのである．原子価結合法でも分子軌道法でも，一重項状態のエネルギーマイナ ス三重項状態のエネルギーは，大杂他把には交換積分の 2 倍になるが，この交換積分の 符号が，原子価結合法では負，分子軌道法では正になることが両方法の違いである.

经Problem 19.4.1

式(19.4.1)で定義される ${ }^{3} \Psi_{1}$ および ${ }^{3} \Psi_{-1}$ の属する既約表現を求めよ.

放Problem 19.4.2

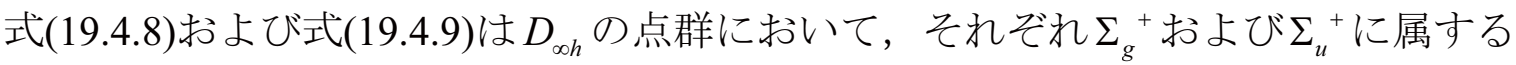
ことを示せ。

弥Problem 19.4.3

式(19.4.1)に示した $4 つ の$ state wavefunction は, いずれも式(19.4.11)の全 Hamiltonian の固有関数となっていないことを示せ.

\section{5 分子軌道法と原子価結合法との比較}

Section 19.4 と Section 19.5 で，分子を扱う 2 つの代表的な方法である分子軌道法

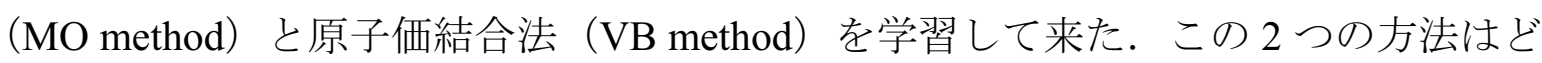

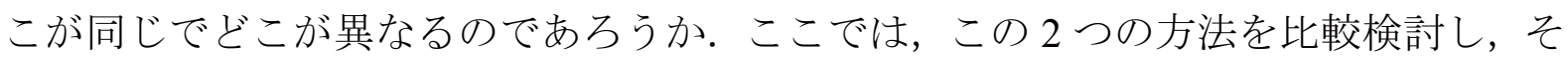
の差異を明らかにした上で, MO method と VB method それぞれの方法の改良方法を考 
えてみることにする.

ただ，2つの方法を比較するといっても，それぞれの方法の枠内でのいろいろな改 良を紹介して来たわけで, それらのうちのどれとどれとを比較したらいいのかが問題 となる. MO method および VB method それぞれの特徽がもっともよく現れているの は，それぞれについてもっとも単純な方法である. 寸なわち, MO methodにおいては， 表 19.3.1の 1 番上の行に記してある形の MO に基づく方法で, Section 19.3 の大部分 を用いて詳述した方法を取り上げる. VB methodでも，もっとも簡単なものはやはり 表 19.4.1 の最上の行にある Heitler-London の方法であり，Section 19.4 の大部分を用い て詳述した方法を取り上げる，なんといっても，これら 2 つは，それぞれ MO method およびVB method を代表するものであり, それぞれの方法の特徴がもっともよく現れ ていると思われる。

この 2 つの方法それぞれで, $\mathrm{H}_{2}$ 分子の基底状態 $\left({ }^{1} \Sigma_{g}{ }^{+}\right)$がどのような wavefunction で表現されているかを吟味してみよう，MO theoryにおける state function は式(19.3.2) に示した。一方，VB theoryにおける state function は式(19.4.1)に示した。 これらの式 をみると，いずれも共通の spin function $\frac{1}{\sqrt{2}}\{\alpha(1) \beta(2)-\beta(1) \alpha(2)\}$ を含んでいる.そ れで, 2 つの方法の比較は spatial wavefunction について行えばよいことになる.また， normalization factor は wavefunction の意味を吟味寸る場合にはなくてもいいのでそれ を省略し, normalization factor 除いた spatial wavefunction で比較を行ってみよう. 以下， spatial wavefunction をФで表すことにする. MO method では，式(19.3.2)および 式(19.3.1)より,

$$
\begin{aligned}
\Phi_{\text {MO }} & =\sigma_{g}(1) \sigma_{g}(2) \\
& =\left\{\phi_{a}(1)+\phi_{b}(1)\right\}\left\{\phi_{a}(2)+\phi_{b}(2)\right\} \\
& =\left\{\phi_{a}(1) \phi_{b}(2)+\phi_{b}(1) \phi_{a}(2)\right\}+\left\{\phi_{a}(1) \phi_{a}(2)+\phi_{b}(1) \phi_{b}(2)\right\}
\end{aligned}
$$

一方 VB theory では式(19.4.1)より

$$
\Phi_{\mathrm{VB}}=\phi_{a}(1) \phi_{b}(2)+\phi_{b}(1) \phi_{a}(2)
$$

この 2 つの式を比べてみると， $\Phi_{\mathrm{MO}}$ の第 1 項目と $\Phi_{\mathrm{vB}}$ とは全く同じであることが分か

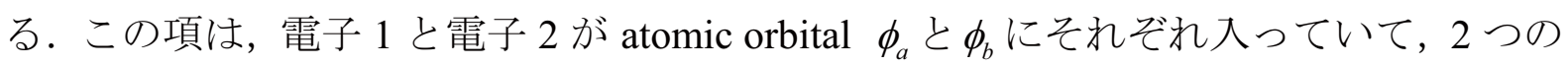
$\mathrm{H}$ 原子が共有結合した状態 $\mathrm{H}-\mathrm{H}$ （covalent structure）を表している． $\Phi_{\text {мо }}$ に表れる 第 2 項目は, 2 つの電子が共に $\phi_{a}, \phi_{b}$ いずれかの atomic orbitalに占有されている状態 
を表し，これは $\mathrm{H}^{+}-\mathrm{H}^{-}$というイオン結合した状態（ionic structure）を表している。す なわち, MO method では, covalent structure と ionic structure とが 1 対 1 の割合で混じ り合っている状態を表し, VB method では純粋に covalent structure のみを表している. このことを模式的に書くと次のようになろう.

$$
\begin{aligned}
& \Phi_{\mathrm{MO}}=(\mathrm{H}-\mathrm{H})+\left(\mathrm{H}^{+}-\mathrm{H}^{-}\right) \\
& \Phi_{\mathrm{VB}}=(\mathrm{H}-\mathrm{H})
\end{aligned}
$$

化学結合に covalent なものと ionic なものがある程度ずつ混じり合っているという 概念は化学者にとって常識となっているであろう.HF のような ionic structure の大き い分子でも少しは covalent structure が入っているであろうし，そして， $\mathrm{H}_{2}$ のように covalent structure の大きい分子でも少しは ionic structure の寄与がある，ということは， 無機化学の講義でも学習していることであろう。その意味では MO method は化学の 常識に合っているようにも思える。しかし，だからといって， $\mathrm{H}_{2}$ 分子のような等核 2 原子分子において, ionic structure の寄与が丁度 2 分の 1 だけあるかというと, とても そんなことはあり得ないというのも，これまた，化学の常識であろう。真実は, 式 (19.5.1)と式(19.5.2)との間位にあるのであろう。すなわち， covalent structure の寄与の 方が大きく，それに多少の ionic structure の寄与を混ぜる。すなわち， schematicに書 けば,

$$
\Phi=(\mathrm{H}-\mathrm{H})+\lambda\left(\mathrm{H}^{+}-\mathrm{H}^{-}\right) \quad(|\lambda|<1)
$$

というのがより真実に近いと思われる. 以上の考察より2つの方法の特徴は明らかで ある。すなわち，MO methodでは ionic structureの寄与を overestimate し，一方，VB method では ionic structure の寄与を全然考えていない（すなわち underestimate してい る）ということになる。

以上の議論から，それぞれの方法をどういう方向で改良していったらいいかが分か る. MO method では ionic structure の寄与を小さくし，一方，VB method では ionic structure の寄与を取り込めば良い。こう考えてみると，表 19.3.1および表 19.4.1に示 したいくつかの「改良」は必ずしももつとも適切な方向へ向いていたとは言えないこ とにも気がつく.

VB method の改良は容易である。式(19.5.2)に ionic structure の寄与を加えるだけで ある。すなわち，式(19.5.5)に忠実に

$$
\begin{aligned}
\Phi_{\mathrm{VB}}=\left\{\phi_{a}(1) \phi_{b}(2)+\phi_{b}(1) \phi_{a}(2)\right\} & \\
& +\lambda\left\{\phi_{a}(1) \phi_{b a}(2)+\phi_{b}(1) \phi_{b}(2)\right\} \quad(|\lambda|<1)
\end{aligned}
$$

とすればよい.もちろん, state wavefunction としての正しい形にするには, spin function 
を掛け，かつ， normalization factor をも考慮しなければいけないが，そのことは簡単 なことなので，諸君の演習に残しておこう。ここで，入を決めるには，trial な wavefunction を式(19.5.6)のようにして，入を parameter として変分法を適用すればよ i.

MO theory の改良は, 式(19.5.1)の ionic structure を減少させるようにすればいいわけ である。どうしたら ionic structure の寄与を減らせるだろうか. 次のように考えてみよ う。式(19.5.1)では図 19.3.1の（a）に示した $\sigma_{g}(1) \sigma_{g}(2)$ という configuration について 計算したが，同様なことを，図 19.3.1の（c）に示した $\sigma_{u}(1) \sigma_{u}(2)$ という configuration について計算してみる。そうすると, 式(19.5.1)と同じように covalent structure と ionic structure とが 1 対 1 で混じり合った wavefunction となるが，式(19.5.1)と異なり，両者 の符号が反対になる，従って， $\sigma_{g}(1) \sigma_{g}(2)$ という configuration と $\sigma_{u}(1) \sigma_{u}(2)$ という

configuration を適当な比率でまぜ合わせれば, covalent structure と ionic structure との任 意の比率の混じり合いの状態が得られることになる.すなわち, 式(19.5.1)の代りに

$$
\Phi_{\mathrm{MO}}=\left\{\sigma_{g}(1) \sigma_{g}(2)\right\}+k\left\{\sigma_{u}(1) \sigma_{u}(2)\right\}
$$

とすればよい.（ここでも normalization factor を除いている.）もっとも，ここで示し たような混じり合いが起るためには 2 つ configuration が群の同じ既約表現に属して いないといけない. $\sigma_{g}(1) \sigma_{g}(2)$ という configuration については，すでにみたように

$$
\Sigma_{g}^{+} \times \Sigma_{g}^{+}=\Sigma_{g}^{+}
$$

から $\Sigma_{g}{ }^{+}$となる。一方， $\sigma_{u}(1) \sigma_{u}(2)$ については $\sigma_{u}$ が $\Sigma_{u}{ }^{+}$に属することから（表 19.2.1）

$$
\Sigma_{u}^{+} \times \Sigma_{u}^{+}=\Sigma_{g}^{+}
$$

から $\Sigma_{g}^{+}$となる.このように，2つの configuration, $\sigma_{g}(1) \sigma_{g}(2)$ と $\sigma_{u}(1) \sigma_{u}(2)$ は同じ 既約表現 $\Sigma_{g}{ }^{+}$に属する. 従って式(19.5.7)のような混じり合いが可能なのである.この ような，2つ以上の configuration が混じり合うことは配置間相互作用（configuration interaction）と言われる.

configuration interaction と言われる混じり合いを考えなければならない理由は，1 つ 1 つの configuration が全 Hamiltonian の固有関数でないということにある.1つ1つ 
の configuration が全 Hamiltonian の固有関数 になっていないので，そういう

configuration をいくつか集め，それらをbasis set として，その linear combination を trial function とし, linear variation theory でもつて真の wavefunction（すなわち全 Hamiltonian の固有関数）に近い wavefunction を得よう，というのが configuration interaction の考 え方である。

以上，VB method の改良と MO method の改良の方法を述べた．まとめとして繰り 返すと, VB method の改良は式(19.5.6)に示すように ionic structure の寄与を加える. 一方，MO method の改良は，式(19.5.7)のように，configuration interaction を行う。こ の改良を行う限り，MO method とVB method は完全に同じものとなる．そのことを見 るために，式(19.5.7)を書き直してみよう。

$$
\begin{aligned}
\Phi_{\mathrm{MO}}= & \left\{\sigma_{g}(1) \sigma_{g}(2)\right\}+k\left\{\sigma_{u}(1) \sigma_{u}(2)\right\} \\
= & \left\{\phi_{a}(1)+\phi_{b}(1)\right\}\left\{\phi_{a}(2)+\phi_{b}(2)\right\} \\
& +k\left\{\phi_{a}(1)-\phi_{b}(1)\right\}\left\{\phi_{a}(2)-\phi_{b}(2)\right\} \\
=(1-k) & \left\{\phi_{a}(1) \phi_{b}(2)+\phi_{b}(1) \phi_{a}(2)\right\} \\
& +(1+k)\left\{\phi_{a}(1) \phi_{a}(2)+\phi_{b}(1) \phi_{b}(2)\right\}
\end{aligned}
$$

従って

$$
\lambda=\frac{1+k}{1-k}
$$

とおけば式(19.5.8)すなわち式(19.5.7)は式(19.5.6)と全く同じ式となる.すなわち，MO method で configuration interaction を考えるということと，VB method で ionic structure の寄与を加えるということは全く同等なのである.MO method と VB method とは, それぞれのもっとも naive な形のものでは異なった理論のように思われるが，上述し たような改良によって同じものとなる。

MO method による configuration interaction の効果は, 図 19.3.3 に示してある.この 図で，破線で示した $H_{11}$ および $H_{22}$ が，それぞれ $\sigma_{g}(1) \sigma_{g}(2)$ および $\sigma_{u}(1) \sigma_{u}(2)$ の

"energy"であり, configuration interaction という変分の結果が実線で示してある.上述 したように, VB method から出発して ionic structure の寄与を入れても全く同じことで あるから，全く同じ計算結果が得られる，念のため，改良した方法による計算結果を 図 19.5.1 に改めて示す。 


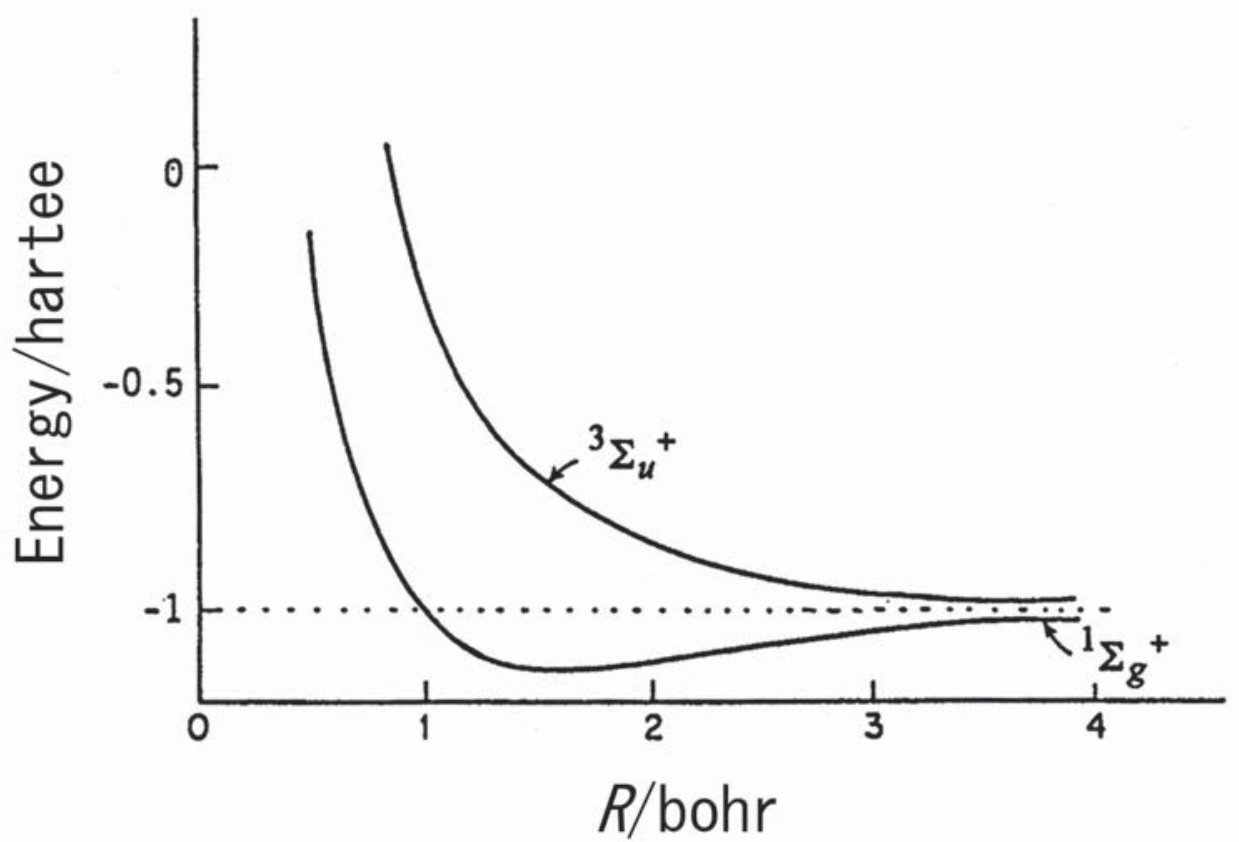

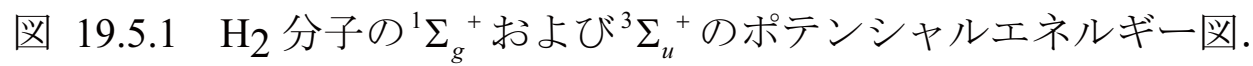
式(19.5.6)または式(19.5.7)に基づく計算値.

Section 19.3 の MO method では, $R$ の大きい所で基底状態 ${ }^{1} \Sigma_{g}{ }^{+}$の energy が $2 E_{1 s}$ より も大きくなってしまうという不都合があったが, configuration interaction によってその ような不都合はなくなる. configuration interaction の結果, 結合エネルギーとして 3.21 $\mathrm{eV}$ という結果が得られている。実験值の $4.745 \mathrm{eV}$ にはほど遠いが，もっとも naive な MO method での $2.681 \mathrm{eV}$ (表 19.3.1)，もっとも naive な VB method での $3.14 \mathrm{eV}$ (表 19.4.1）のいずれよりもよくなっている．もちろん，もとの atomic orbital を良くする につれて（例えば表 19.4.1の 2 段目以降），式(19.5.8)はどんどん改良される。しかし， 後は計算力（または computer による計算時間）との闘いであるから，ここでは述べる 必要もあるまい。

しかし，どんな方法を用いたとて，定性的には，図 19.5.1 のような potential curve が得られることには変りはない. 寸なわち, 基底状態 ${ }^{1} \Sigma_{g}{ }^{+}$の potential は $R$ のある值で 極小值をとり， $R \rightarrow \infty$ で，エネルギーの低い方から $E_{1 s}$ に収束する，一方，第一励起 
三重項状態 ${ }^{3} \Sigma_{u}{ }^{+}$は $R$ のいたる所で解離的な potential を示す. 寸なわち， $R$ が大きくな

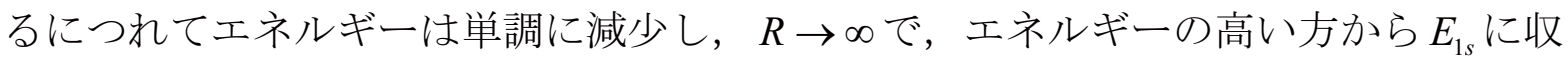
束する. この事実は，水素分子の結合を切った時の反応を考える時にも重要である. すなわち, $\mathrm{H}-\mathrm{H}$ という分子の結合を何らかの方法で切ったとする.もし基底状態 ${ }^{1} \Sigma_{g}{ }^{+}$ の分子が切れれば，切れた所から potential curve の低い方へと行くから，結局は再び 結合が生じ，もとの $\mathrm{H}_{2}$ 分子になる。一方，もし三重項励起状態 ${ }^{3} \Sigma_{u}{ }^{+}$の分子の結合が 切れれば, potential に沿って移動し，結局 2 つの $\mathrm{H}$ 原子一解離することになる.

以上の話は， $\mathrm{H}_{2}$ 分子に限った話ではあるが，どんな結合を切断した時もほぼ同じ ようなことが成り立つ. 例えば $\mathrm{R}_{1}-\mathrm{R}_{2}$ （ $\mathrm{R}_{1}$ および $\mathrm{R}_{2}$ はそれぞれアルキル基とする） という分子を, 光または熱で解離すると $\mathrm{R}_{1}$ ・というラジカルと $\mathrm{R}_{2} ・$ というラジカルが 出来るが，この 2 つのジカルはお互いに相互作用し， $\left[R_{1} ・ ・ R_{2}\right]$ というラジカル対 となっている。これはあたかも 2 つの・が対を作っている $\mathrm{H}_{2}$ 分子と同様に考えるこ とが出来る. 寸なわち, このラジカル対は基底状態が一重項, 励起状態が三重項とな

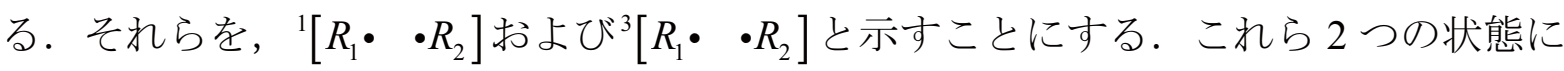
ついても図 19.5.1 とほぼ同じような potential 曲線が得られる. 従って ${ }^{1}\left[R_{1} ・ ・ R_{2}\right]$ はや がて $\mathrm{R}_{1}-\mathrm{R}_{2}$ へ行くという再結合過程をたどるし，一方， ${ }^{3}\left[R_{1} ・ ・ R_{2}\right]$ は解離して $\mathrm{R}_{1} ・$ と $\mathrm{R}_{2}$ ・となる，解離したラジカルは，拡散過程を経て様々な反応過程をとる．このよう に，ラジカル対のスピン状態によって，その後の反応経路が異なる。このことは，多 くの化学反応で知られていることである.

[Coffee Break］分子軌道法と原子価結合法それぞれの特徵を示す比喻 
分子軌道法と原子価結合法それぞれの特徵をはっきりさせようとして古来からい ろいろな比喻が用いられて来た. 比喻であるからなかなか完全に両方法の特徵を示し ているというわけにはいかないが，初心者の理解には役立つかもしれない.

以下, 西村肇, 山口兆, 吉田元二著「コンピューターはいい化学者」というやさし い解説書の中から，一つのパラグラフを引用させていただく.

『ちょっと問題があるかもしれませんが，あえて比喻を使うと，原子価結合 法は，男と女がそれぞれ一人ずつ子供を連れて結婚し，新しい家庭をつくる ようなものです，この場合，最後までお父さんの子，お母さんの子という意 識は残るでしょう。これに対し，分子軌道法は，結婚した後二人の子供が出 来たようなものです．この場合子供は完全に二人の子供です。お父さん子， お母さん子というのもあるかもしれませんが，これはお父さんの子，お母さ んの子とは違います。その証拠に離婚となると子供が困ってしまいます.』

\section{6 水素分子に関する究極の計算}

前節ではMO method およびVB method それぞれのもっとも naive な方法から出発 してそれを効果的に改良する方法を述べた。 その結果として, 結合エネルギーの計算 值として $3.21 \mathrm{eV}$ が得られ，もとの方法よりはかなり改善されたものの，実験值の $4.7 \mathrm{eV}$ にはだまだほど遠い. 変分法を駆使してがむしゃらに計算を行えばどんどん 改良されるということを今まで何回も述べているが，果してどこまで改良されるであ ろうか?このような「究極」の計算を行ったところで, 水素分子の結合がより完全に 理解出来るようになるとは必ずしも思われないが，量子力学の方法論がどの位正しい かの計算実験としては興味がある。

1960 年あたりから computer がどんどん発達し, 理論の方も大きく進歩した．それ と同時に実験の精度も向上した．実験の進歩が理論計算を刺激し，理論計算の進歩が また実験を刺激し，ついに実験と計算とは，非常に良く一致するようになった。この あたりのことについては，G. Herzberg が"Experimental Tests of the Quantum Theory of Molecular Hydrogen"という論文にまとめている. (この論文の邦訳が大野公男教授によ ってなされている. [日本化学会編, 化学総説 10,「化学における精密測定」]）以下， そのエッセンスを紹介する.

$\mathrm{H}_{2}$ の解離エネルギー $D_{e}$ についての実験值と理論值は 1960 年に表 19.6.1 の如く であった.この頃になると理論も発展してきて $D_{e}$ と $D_{0}$ を区別して議論出来るよう 
になった。（図 19.6.1に示したように，電子的にも振動的にも回転的にもすべて 基底状態にある分子を構成原子の基底状態に解離させるのに要するエネルギーが $D_{0}$ ．それに基底状態の振動のゼロ点エネルギーを加えたものが $D_{e}$ である．）

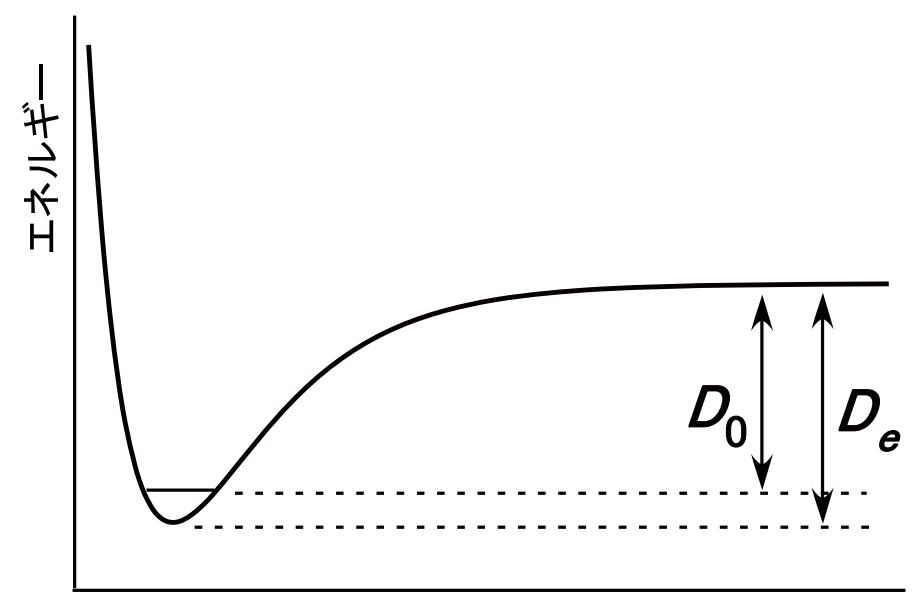

原子間距離

図 19.6.1 2 種類の解離エネルギー， $D_{0}$ と $D_{e}$

表 19.6.1 $\mathrm{H}_{2}$ の $\frac{D_{e}}{h c} \quad(1960$ 年 $)$

実験值（Herzberg, Monfils）

$38292.3 \pm 0.5 \mathrm{~cm}^{-1}$

実験值を核の質量無限大へ外挿した值

$38287.0 \pm 0.8 \mathrm{~cm}^{-1}$

計算值（Kolos, Roothaan）

$38283.9 \mathrm{~cm}^{-1}$

(文献)

実験 : G. Herzberg and A. Monfils, J. Mol. Spectroscopy 5, 482 (1960)

計算：W. Kolos and C. C. J. Roothaan, Revs. Mod. Phys., 32, 219 (1960) 
表 19.6.1 の計算は Born-Oppenheimer の断熱近似に基づいているので, 実験值と比較 するには実験值を核の運動がない質量無限大へ外挿したものと比べるのがよい. 実験 值と計算值との差の $0.1 \mathrm{~cm}^{-1}$ は $D_{e}$ のわずか $3 \times 10^{-6}$ ，すなわち $3 \mathrm{ppm}$ に相当し，実験誤 差よりも小さな誤差である. $3 \mathrm{ppm}$ の誤差は, 富士山の高さを $1 \mathrm{~cm}$ 以内の誤差で見積 もることに相当する。すなわち，計算と実験は完全に一致したと考えられた.

ところがそれから 8 年たって理論計算が更に進歩すると, 解離エネルギーが以前の 計算より大きくなり，実験值との間には， $\mathrm{H}_{2}, \mathrm{HD}, \mathrm{D}_{2}$ すべてについて系統的な差が 見られるようになった。（表 19.6.2）更にこの計算では， $D_{e}$ ではなく， $D_{0}$ を計算して いるので実験と直接比べ得る.

表 19.6.2 $\mathrm{H}_{2}, \mathrm{HD}, \mathrm{D}_{2}$ の $\frac{D_{0}}{h c} \quad(1968$ 年 $)$

\begin{tabular}{ccc}
\hline 分子 & 実験 & 計算 \\
\hline $\mathrm{H}_{2}$ & $36113.6 \pm 0.3 \mathrm{~cm}^{-1}$ & $36117.4 \mathrm{~cm}^{-1}$ \\
$\mathrm{HD}$ & $36399.9 \pm 1.0 \mathrm{~cm}^{-1}$ & $36405.2 \mathrm{~cm}^{-1}$ \\
$\mathrm{D}_{2}$ & $36743.6 \pm 0.5 \mathrm{~cm}^{-1}$ & $36748.0 \mathrm{~cm}^{-1}$ \\
\hline
\end{tabular}

(文献)

実験： G. Herzberg, and A. Monfils, J. Mol. Spectroscopy 5, 482 (1960)

計算： W. Kolos and L. Wolniewicz, J. Chem. Phys. 49, 404 (1948)

すなわち，すべての同位体分子について 4 5 $\mathrm{cm}^{-1}$ の差が見られる。これはわずか $0.01 \%$ 誤差に過ぎないとしても気になることである.

通常, このように計算值と実験值が一致しなかった時, どちらが正しいと考えるで あろうか? 実験屋は計算值が間違いだと思うのではなかろうか. 計算屋はどうであろ うか. 実験が間違いだと言い得るほど自信があるであろうか. Herzberg が偉かったの は，優れた実験家でありながら計算が悪いと決めつけないで，今までの実験は間違っ 
ているのではないかと疑い，実験をやりなおしたことである.さすがにノーベル賞を 受賞するような人は違うものだ.

Herzberg は 2 つ点に注意して実験をやり直した. 1960 年の時に用いた焦点距離 $3 \mathrm{~m}$ の分光器の代りに $10 \mathrm{~m}$ のものを使用することによって分解能を更に 3 倍上げた. もう 1 つは回転的に励起された状態からの吸収との重りを避けるために液体窒素温度 （77 K）で測定した.（G. Herzberg, J. Mol. Spectroscopy, 33, 147 (1970)）

一方, 理論の方ももう少し進んで, 以前の計算で仮定した断熱近似からのずれをも 補正することが出来た。（P. R. Bunker, J. Mol. Spectroscopy, 42, 478 (1972)）

以上の結果, 理論と実験との対応は 1972 年には表 19.6.3のようになった.

表 19.6.3 $\mathrm{H}_{2}, \mathrm{HD}, \mathrm{D}_{2}$ の $\frac{D_{0}}{h c} \quad(1972$ 年 $)$

\begin{tabular}{ccc}
\hline 分子 & 実験 & 計算 \\
\hline $\mathrm{H}_{2}$ & $<36118.3 \mathrm{~cm}^{-1}$ & $36117.9 \mathrm{~cm}^{-1}$ \\
& $>36116.3 \mathrm{~cm}^{-1}$ & \\
$\mathrm{HD}$ & $<36406.6 \mathrm{~cm}^{-1}$ & $36405.2 \mathrm{~cm}^{-1}$ \\
& $>36405.8 \mathrm{~cm}^{-1}$ & \\
$\mathrm{D}_{2}$ & $36748.9 \pm 0.4 \mathrm{~cm}^{-1}$ & $36748.2 \mathrm{~cm}^{-1}$ \\
\hline
\end{tabular}

この表で見るように, 理論計算は, 実験の誤差範囲で完全に実験結果と一致している.

$\mathrm{H}_{2}$ 分子に関する以上の歴史を振り返ってみると，量子力学的な計算をとことんま でやれば，我々は真実に到達し得るということで我々を勇気づけてくれる．理論計算 と実験が一致しない時，実験をやりなおす必要があると判断出来るほど正確な計算が 出来るのは，まだ水素分子位の小さな分子で，しかも電子的に励起されていない基底 状態の解離エネルギーに限られるが，後何年かすれば， benzene みたいな大きな分子 の，しかも励起状態の問題が，上述した程度の精度で計算されるようになるかもしれ ない.ただ, そうなったとしたら, それがどの程度, 化学の学問の理解に役立つかは, 改めて考えなければならない問題ではある. 


\section{APPENDIX 01}

\section{SI 単位}

化学の分野における世界的な機構である IUPAC（International Union of Pure and Applied Chemistry）で単位に関しては SI 単位系を用いようという約束ごとが決まって から久しい，日本化学会でもこの取り決めに従い，日本化学会の刊行物などは全て SI 単位系を用いないといけないことになっている.しかし，このような取り決めの意 義は必ずしも広く理解されてはいないように思える.

SI 単位系のことは，多くの教科書の付録などに大まかな説明が出ているので，大 体のことは理解されているようではある，例えば，エネルギーの単位は ergではなく て, joule であるというようなことが書いてある。エネルギーの単位としては，従来， erg や joule の他に $\mathrm{eV}, \mathrm{kcal} / \mathrm{mol}$ などがあり，更に， $\mathrm{cm}^{-1}$ など，本来は，エネルギー の単位でないものまで色々使われていた。 それは長さを表すのに meter，寸，尺，間， inch，yard，mile といった，色々な単位が同時に使われるのと同じく，しばしば単位 間の換算を必要とした。それでこれらがすべて統一されればそれにこしたことはな い.エネルギーの単位がすべて joule に統一されれば，その意味で便利である。しか し,私の考えでは,このような単位の間には 1 対 1 の関係があり,例えば, $1 \mathrm{erg}=10^{-7} \mathrm{~J}$, $1 \mathrm{eV}=1.6 \times 10^{-19} \mathrm{~J}$ といったようにして，難無く換算出来るので，それほど大きな問題 はもともとなかった，単位系に関して我々を悩ましてきたのは，むしろ電磁気学にお ける cgs Gauss 単位系, cgs esu 単位系, MKS 単位系といった単位系の間の換算であ る.どのような単位系を用いるかによってある量を表す式が異なるということが面倒 な, 又, 多くの人にとっては難解な問題であった。これを統一して用いようというこ とがSI 単位系を用いることの最も本質的な意義であると私は考える。単位系が $1 つ$ に統一されると如何に便利かということは以下に説明するが，ここで 1 つだけ例をあ げておこう。

2 つの電荷 $Q$ および $Q^{\prime}$ が距離 $r$ だけ離れて存在する時の相互作用のエネルギー $U$ は，ある教科書では

$$
U=\frac{Q Q^{\prime}}{r}
$$

と書かれており，又ある教科書では，

$$
U=\frac{1}{4 \pi \varepsilon_{0}} \frac{Q Q^{\prime}}{r}
$$

となっている. 前者は cgs Gauss 単位系の式であり, 後者は SI 単位系の式である. こ のように，用いる単位系によって式が異なるのである。このような式の違いの為に， 我々が如何に苦労して来たことであろうか. まさに，電磁気学の難しさはここにあっ 
たと言えそうである.SI 単位系に全てが統一されればそのような面倒な事は全くなく なり，電磁気学は，もっと SImple な科目となるであろう。

SI 単位系を用いることの上述したような意義は，学生諸君のみならず，化学者達 にも必ずしも十分には理解されていないように思える. 例えば, $U=\frac{Q Q^{\prime}}{r}$ という $\operatorname{cgs}$ Gauss 単位系の式を与えておいて, 結果だけ joule で表すといったことは最近出版され ている本でもしばしばみかける．50 年位たてばすっかり統一されるかもしれないが， 過渡期にある現在はどうしてもこのような混乱は避けられない，そういうわけで，教 科書や論文を正しく理解するには, 単位系に関するある程度の理解力を持つことは必 要である.この Appendix 1 では，そのための基礎を簡単に述べることにする.

\section{A1.1 電磁気学の単位}

古典力学では基礎単位として, length, mass, timeの3つを用いている. そしてす べての物理量をこれらの結合で表すことにしている. 例えば,

$$
\text { [volume }]=[\text { length }]^{3}
$$

のように決めている.（ここで[...]性理量の dimension を表す.）しかし，このように 決める必然性は必ずしもなかったわけである.

$$
\text { [volume }]=k[\text { length }]^{3}
$$

のようにして, もう 1 つの基礎単位を導入し，この $k$ を $k=1$ ではなく, 例えば, $k=c$

( $c$ は光速度) と定義して, 体積の次元を $[\text { length }]^{4}\left[\mathrm{time}^{-1}\right.$ と決めてもいっこうに差し 支えなかったはずである.しかし, 敢えてそんな面倒なことはしなかったのは， $k=1$ として（すなわち第 4 の基礎単位を用いなくても）何の不便もなかったからである.

しかし，電磁気学では電気的特質と磁気的性質とを結び付けるのにどうしても，も う 1 つの基礎単位を定義することが必要となってくる.この時，この第 4 の基礎単位 の選び方により, 色々な単位系が考えられ用いられて来た. 電磁気学の復習になるが, 電荷 $Q$ および $Q^{\prime}$ または磁荷 $Q_{m}$ および $Q_{m}{ }^{\prime}$ がそれぞれ $r$ の距離に存在する時の力 (真空 中） $F$ を考えてみる.

(1) cgs esu 単位系

$$
\begin{aligned}
& F=\frac{Q Q^{\prime}}{r^{2}} \\
& F=c^{2} \frac{Q_{m} Q_{m}{ }^{\prime}}{r^{2}}
\end{aligned}
$$


(ここで $c$ は光速度である). $Q=Q^{\prime}$ として $r=1 \mathrm{~cm}$ の時の $F$ が 1 dyne の時の電荷 $Q$ を $1 \mathrm{esu}$ という.また， $Q_{m}=Q_{m}{ }^{\prime}$ として $r=1 \mathrm{~cm}$ の時の $F$ が $c^{2}$ dyne の時の磁極 $Q_{m}$ を $1 \mathrm{emu}$ という。

(2) cgs emu 単位系

$$
\begin{aligned}
& F=c^{2} \frac{Q Q^{\prime}}{r^{2}} \\
& F=\frac{Q_{m} Q_{m}{ }^{\prime}}{r^{2}}
\end{aligned}
$$

(3) cgs Gauss 単位系

$$
\begin{aligned}
& F=\frac{Q Q^{\prime}}{r^{2}} \\
& F=\frac{Q_{m} Q_{m}{ }^{\prime}}{r^{2}}
\end{aligned}
$$

（4） MKS 単位系

$$
\begin{aligned}
& F=\frac{1}{4 \pi \varepsilon_{0}} \frac{Q Q^{\prime}}{r^{2}} \\
& F=\frac{1}{4 \pi \mu_{0}} \frac{Q_{m} Q_{m}{ }^{\prime}}{r^{2}}
\end{aligned}
$$

ここで

$$
\varepsilon_{0}=\frac{1}{\mu_{0} c^{2}}
$$

また

$\varepsilon_{0}:$ permittivity of vacuum,

$\mu_{0}:$ permeability of vacuum

これらの単位系はそれぞれ特徴があり, merit と demerit の両方を持っている.たと えば cgs esu 単位系は，電気的性質を表わす時は簡単だが，磁気的性質を表わすとき に $c^{2}$ という余計なものがついてしまう。cgs emu 単位系は, 反対に磁気的性質を扱う 場合には都合がいいが電気的性質を表わすときに $c^{2}$ という余計なものがついてしま う. 
化学の分野の教科書では主として, cgs Gauss 単位系が用いられて来た。この単位 系では， $F$ を表わす式はどちらの単位系でも簡単だが, 電気的性質と磁気的性質とを 結び付けることが面倒になってくる．MKS 単位系は，昔は実用単位系とも言われ， 基礎科学の分野ではあまり用いられなかった。しかし, 最近は MKS 単位系を使う電 磁気学の教科書が多くなってきた.

なお，一口に MKS 単位系といっても, magnetic field flux density $\boldsymbol{B}$, magnetic field $\boldsymbol{H}$, magnetization $\boldsymbol{M}$ などの間の関係式がつぎに示すように 2 通りあり, 混乱の原因 となっている.

$$
\begin{array}{ll}
\boldsymbol{B}=\mu_{0}(\boldsymbol{H}+\boldsymbol{M}) & (\boldsymbol{E} \boldsymbol{B} \text { 対応 }) \\
\boldsymbol{B}=\mu_{0} \boldsymbol{H}+\boldsymbol{M} & (\boldsymbol{E} \boldsymbol{H} \text { 対応 })
\end{array}
$$

この点をすっきりさせることも SI 単位系導入の大きな理由であった.

\section{A1.2 SI 単位}

このようないろいろな単位系を用いると面倒であるし, 更に, 色々と間違いの元に もなるので単位系を統一寸ることになり，SI 単位系が誕生した. SI という名前はフラ ンス語の

\section{Le Systéme International d'Unites}

による、英語では，

The International System of Units

であるが，英語でも，IS 単位系と言わないで，世界的に SI 単位系と言うことになっ ている.

ここで決められた約束は,

1. 単位系としては, MKS 単位系の中の $\boldsymbol{E} \boldsymbol{B}$ 対応を用いる.

2. 単位は基本的には MKS 単位を用いる.

ということである，以下の節でその説明をする.

\section{A1.3 基本的な物理量}

SI 単位系の基本単位は次の 7 つである. 


\begin{tabular}{ccc}
\hline \hline physical quantity & name of unit & symbol \\
\hline \hline length & meter & $\mathrm{m}$ \\
mass & kilogram & $\mathrm{kg}$ \\
time & second & $\mathrm{s}$ \\
electric current & ampere & $\mathrm{A}$ \\
temperature & kelvin & $\mathrm{K}$ \\
luminous intensity & candela & $\mathrm{cd}$ \\
amount of substance & mole & $\mathrm{mol}$ \\
\hline \hline
\end{tabular}

amount of substance（物質の量）というものが基本単位の中に入れられたのは，ご く最近のことであるが，これは非常に重要なことである。今まで長い間にわたってモ ルという単位は使われてはいたが，それが物質の量を表わす単位であるという概念は 必ずしもはっきりとはしていなかった。それで「モル数」などというおかしな言葉が 用いられた.「モル数」という言葉は,「気圧数」,「リットル数」,「メートル数」など の言葉がおかしいのと同様な意味でおかしく，使ってはいけない言葉である.

物質の量を 1 つの基本単位と認めることで，物理定数の表わし方も変更がなされ た。たとえば昔は，「アボガドロ数」（Avogadro Number）として $N=6.022 \times 10^{23}$ という ように単位のない数として定義されてきた. 現在は 1 モル当たりの数というわけで, $N=6.022 \times 10^{23} \mathrm{~mol}^{-1}$ のように $\mathrm{mol}^{-1}$ という単位がつき，「アボガドロ定数」（Avogadro Constant）というようになった。 これによって Avogadro constant も Boltzmann constant, Planck constant などのように物理量の仲間として認められるようになったわけであ る.なお，上記の単位の表わし方について，二三の注意事項をまとめておこう.

（1）科学の論文では，単位には原則として記号（symbol）を用いる．上の表で name of unit と symbol とを混同しないように注意すること．例えば，5メートルというの は，新聞などの一般文章では「5 meters」（イギリスでは「5 metres」）と書くであろう が，科学の論文では「5 m」と書く.同様に「モル」という単位の記号は「mole」で はなくて「mol」である. mol という単位の記号を mole と書くことは現実に広く見ら れる間違いである。 $\mathrm{NaOH} 5$ モルというのを新聞に書くとしたら，「5 moles of $\mathrm{NaOH}$ となる．科学の論文では「5 $\mathrm{mol}$ of $\mathrm{NaOH} 」$ とる。新聞であれ科学の論文であれ，「5

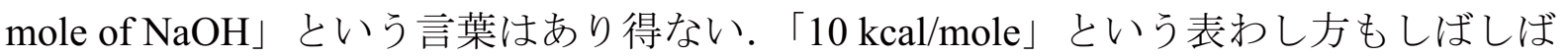
見かけるが，間違いである．新聞で敢えて表わすなら，「10 kilocalories/mole」と書く

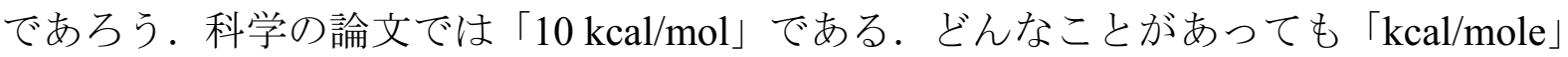
と表わすことはない.

（2）秒は昔は「sec」と書いたが，今は「s」と書くことになっている. 
（3）アンペアも昔は「Amp」とか「amp」と書いたことはあったが，今は「A」であ る.

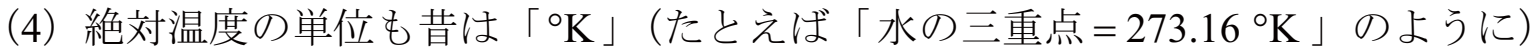
と書いたが，今は「K」と書くことになっている。（たとえば「水の三重点 $=273.16 \mathrm{~K} 」$ のように）（もし，温度を「 ${ }^{\circ} \mathrm{K} 」$ と書くなら，長さも $「{ }^{\circ} \mathrm{m} 」$, 体積も $\left\lceil{ }^{\circ} \mathrm{m}^{3}\right\lrcorner$ のう にしなければいけないであろう。）ただし現在は過渡期としてセルシウス温度の「 ${ }^{\circ} \mathrm{C} 」$ というのは認められている。(「C」はクーロンであるので，同じ字を使うわけにもい かないからであろらか.）

\section{乞 Problem A1.3.1}

G. M. Barrow, "Physical Chemistry, Third Edition"には gas constant として $R=8.3143 \mathrm{~J} \cdot \mathrm{deg}^{-1} \cdot \mathrm{mol}^{-1}$ と与えられている. 間違いを訂正せよ.（Hint: deg という単 位はない.）

[Coffee Break] 摂氏温度を英語でなんと言う？

摂氏の温度を英語で何と言うのだろうか。その昔，学校では「centigrade」という 言葉を教わった.「20 ${ }^{\circ} \mathrm{C} 」 は 「$ twenty centigrade」というように.アメリカではもつ ぱら華氏温度が用いられるのでこういう言葉を現地では聞かなかったが，国際線の飛 行機の中で機長が「到着地の温度は,」と言って華氏と摂氏の温度を紹介する時は 「centigrade」と言っていた。しかし，これは明らかに間違いである。「centi」という のは 100 分の 1 ということだから，「20 centigrade」は 100 分の 20 度ということにな ってしまう。正しい言い方では「20 ${ }^{\circ} \mathrm{C} 」 は$ twenty Celsius である。最近は，国際線の 飛行機でも「Celsius」という単位を用いて到着地の気温を紹介している。もつとも， こうなるまではかなりの年月が必要であった。もう20 年以上も前のことであるが, 日本航空の国際線で，機長が到着地の気温を紹介寸る時に centigrade という単位を用 いていた。 それで，日本航空に，「centigrade は昔々の言葉で，もう50 年位前から， Celsius と言わなければいけないことになっています」という趣旨の手紙を書いた。し ばらくして，日本航空から手紙が来たが，それは，「そういう話もあるのかもしれま せんが，私達はあくまで centigrade を使います」という内容であった。しかし，上述 したように，いつの間にか，日本航空もCelsius という単位を使うようになったよう である。 


\section{A1.4 ある種の SI 誘導単位に対する特別の名称と記号}

ある種の SI 誘導単位には特別な名称と記号が与えられている.

\begin{tabular}{|c|c|c|c|}
\hline 物理量 & SI 単位の名称 & $\begin{array}{c}\text { SI 単位の } \\
\text { 記号 }\end{array}$ & SI 単位の定義 \\
\hline 力 & ニュートン & $\mathrm{N}$ & $\mathrm{m} \cdot \mathrm{kg} \cdot \mathrm{s}^{-2}$ \\
\hline 圧力, 応力 & パスカル & $\mathrm{Pa}$ & $\mathrm{m}^{-1} \cdot \mathrm{kg} \cdot \mathrm{s}^{-2}\left(=\mathrm{N} \cdot \mathrm{m}^{-2}\right)$ \\
\hline エネルギー & ジュール & $\mathrm{J}$ & $\mathrm{m}^{-2} \cdot \mathrm{kg} \cdot \mathrm{s}^{-2}$ \\
\hline 仕事率 & ワット & $\mathrm{W}$ & $\mathrm{m}^{2} \cdot \mathrm{kg} \cdot \mathrm{s}^{-3}\left(\mathrm{~J} \cdot \mathrm{s}^{-1}\right)$ \\
\hline 電荷 & クーロン & $\mathrm{C}$ & $\mathrm{s} \cdot \mathrm{A}$ \\
\hline 電位差 & ボルト & $\mathrm{V}$ & $\mathrm{m}^{2} \cdot \mathrm{kg} \cdot \mathrm{s}^{-3} \cdot \mathrm{A}^{-1}\left(=\mathrm{J} \cdot \mathrm{A}^{-1} \cdot \mathrm{s}^{-1}\right)$ \\
\hline 電気抵抗 & オーム & $\Omega$ & $\mathrm{m}^{2} \cdot \mathrm{kg} \cdot \mathrm{s}^{-3} \cdot \mathrm{A}^{-2}\left(=\mathrm{V} \cdot \mathrm{A}^{-1}\right)$ \\
\hline 伝導度 & ジーメンス & S & $\mathrm{m}^{-2} \cdot \mathrm{kg}^{-1} \cdot \mathrm{s}^{3} \cdot \mathrm{A}^{2}\left(=\mathrm{A} \cdot \mathrm{V}^{-1}=\Omega^{-1}\right)$ \\
\hline 電気容量 & ファラッド & $\mathrm{F}$ & $\mathrm{m}^{-2} \cdot \mathrm{kg}^{-1} \cdot \mathrm{s}^{4} \cdot \mathrm{A}^{2}\left(=\mathrm{A} \cdot \mathrm{s} \cdot \mathrm{V}^{-1}\right)$ \\
\hline 磁束 & ウェーバ & $\mathrm{Wb}$ & $\mathrm{m}^{2} \cdot \mathrm{kg} \cdot \mathrm{s}^{-2} \cdot \mathrm{A}^{-1}(=\mathrm{Vs})$ \\
\hline インダクタンス & ヘンリー & $\mathrm{H}$ & $\mathrm{m}^{2} \cdot \mathrm{kg} \cdot \mathrm{s}^{-2} \cdot \mathrm{A}^{-2}\left(=\mathrm{V} \cdot \mathrm{A}^{-1} \cdot \mathrm{s}\right)$ \\
\hline 磁束密度 & テスラ & $\mathrm{T}$ & $\mathrm{kg} \cdot \mathrm{s}^{-2} \cdot \mathrm{A}^{-1}\left(=\mathrm{V} \cdot \mathrm{s} \cdot \mathrm{m}^{-2}\right)$ \\
\hline 光束 & ルーメン & $\operatorname{lm}$ & $\mathrm{cd} \cdot \mathrm{sr}$ \\
\hline 照度 & ルックス & $1 \mathrm{x}$ & $\mathrm{m}^{-2} \cdot \mathrm{cd} \cdot \mathrm{sr}$ \\
\hline 周波数 & ヘルツ & $\mathrm{Hz}$ & $\mathrm{s}^{-1}$ \\
\hline
\end{tabular}


[Coffee Break] Meter という単位の由来はご婦人の名前から？

単位の中では人の名前に由来するものが少なくない.「J」はJoule,「A」は Ampere, $\lceil\mathrm{V} 」$ はolta，「K」は Lord Kelvin に由来する, ...といったように.

オランダのEindhoven という所にある科学博物館はこういった単位のもととなった 人々の肖像画と共に説明が出ているらしい，それらの中に，「Milli Meter」という名前 の美しい婦人の肖像画と共に，この美しさの故に，メートルの名前が残ったという説 明が出ているとのことである. [J. Chem. Education, 53, 291 (1976)] この学術雑誌によ ると，美しいご婦人の絵の下に次のような説明があるとのことである.

Milli Meter: Daughter of an Alsatian woodcutter. Attracted the attention of a passing general and spent several years at court in Paris. Renowned for her beauty. Fell into disgrace after Napoleon's downfall, and died penniless, in Menton, 1794-1892.

言うまでもなくこんなことが本当であるはずはない. 博物館側のちよつとしたユー モアで, 堅苦しい科学博物館の中でちよっと息抜きを，という配慮から考えたらしい．

（日本の博物館でそういう圥談は許されるであろうか? 多分，日本ではこういう企画 はたちどころにお各めを受けるように思われる.）なお，この博物館の圥談を載せた J. Chem. Education の記事では，「圥談としてもこのご婦人の美しい身体のどの部分の 長さをメートルの起源としたというのであろうか?」とはなはだ不謹慎なコメントを 付けている。

[Coffee Break] エールステッドの偶然の発見

磁界の単位は SI 単位系では $\mathrm{Am}^{-1}$ であるが，cgs Gauss 単位系ではエールステッド である。これは磁気研究に功績のあったデンマークの科学者 Oersted の名をとったも のである. 彼は 1820 年電流の通じている針金のまわりに磁界が生ずることを発見し たが，それについては1つのエピソードが伝えられている.

彼は電流によって磁界が生じないかと思って実験してみたが, 結果は否定的であっ たらしく，そのことを学生に講義実験でやって見せたという。その当時，彼はもし電 流によって磁界が生ずるとすれば，電流と同じ方向であろうと考えた。それで，その 
ような磁界に感ずるように，磁針を「正確に」電流と直角方向に配置したので磁針は 動かなかったのである，講義が終わり，装置を片付けようとして磁針をちょっと動か した時，磁針は突然回転した．エールステッドはそれを見逃さなかったので，この大 発見となったわけであるが，もし彼が磁針を動か寸前に電流を切っていたら何も見つ けなかったかもしれない。しかし，もし彼がはじめから磁針をいいかげんな位置にお いておれば，もっと早くこのことを発見し得たであろう.

実験というものはいつも正確であればいいということでもないようである。時に は，いいかげんな実験も必要かもしれない.

\section{A1.5 計算の例}

冒頭に述べたように，最近まではいろいろな単位系が混在していた．どうして多く の単位系が存在したのかというと, おそらく, それぞれの単位系にそれなりの merit があるからであろう．人による好みの問題もあろう．多くの人にとっては，学生時代 に習った単位系がもっとも親しみやすいということもあろう。

しかし, 物理や化学の分野ではSI 単位系に統一寸ることに決まってしまった現在 では，何とかして SI 単位系に慣れないといけない，ある程度慣れると，SI 単位系は かなり使いやすく, 多くの場合, 与えられた式にただ数を代入するだけでいとも簡単 に結果が得られる，以下，二三の例をあげよう。

\section{放Exercise A1.5.1}

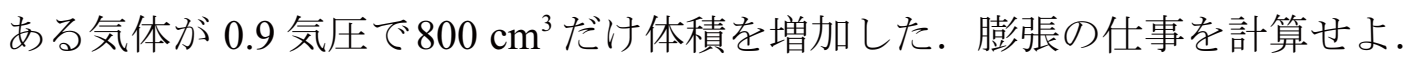

(1) cgs Gauss 単位系

$$
\begin{aligned}
-W & =p \Delta V \\
& =(0.9 \mathrm{~atm}) \times 800 \mathrm{~cm}^{3}
\end{aligned}
$$

ここで

$$
1 \mathrm{~atm}=1013 \mathrm{mbar}=\left(1013 \times 10^{-3}\right) 10^{6} \mathrm{dyne} / \mathrm{cm}^{2}
$$

であるが，仮にこの值を知らないとして計算してみよう，ただし，1 atm は水銀柱で $76.00 \mathrm{~cm}$ ということは当然分かっているとする. 水銀柱の底面積を，仮に（結果には 影響しない） $1 \mathrm{~cm}^{2}$ とする.

水銀の密度 $d_{\mathrm{Hg}}=13.5951 \mathrm{~g} / \mathrm{cm}^{3}$

重力の加速度 $g=980.655 \mathrm{~cm} / \mathrm{s}^{2}$ 
を用い，

$$
\begin{aligned}
1 \mathrm{~atm} & =\frac{\text { 水銀 } 76.00 \mathrm{~cm}^{3} \text { の重量 }}{\text { 底面積 } 1 \mathrm{~cm}^{2}} \\
& =\frac{76.00 \mathrm{~cm}^{3} \times d_{\mathrm{Hg}} \times g}{1 \mathrm{~cm}^{2}} \\
& =\frac{76.00 \mathrm{~cm}^{3} \times 13.5951 \mathrm{~g} / \mathrm{cm}^{3} \times 980.655 \mathrm{~cm} / \mathrm{s}^{2}}{1 \mathrm{~cm}^{2}} \\
& =1.013 \times 10^{6} \frac{\mathrm{g} \mathrm{cm} / \mathrm{s}^{2}}{\mathrm{~cm}^{2}} \\
& =1.013 \times 10^{6} \frac{\mathrm{dyne}}{\mathrm{cm}^{2}} \quad\left(\because \text { dyne }=\mathrm{g} \mathrm{cm} / \mathrm{s}^{2}\right)
\end{aligned}
$$

従って,

$$
\begin{aligned}
-W & =0.9 \mathrm{~atm} \times 800 \mathrm{~cm}^{3} \\
& =0.9 \times 1.013 \times 10^{6} \frac{\text { dyne }}{\mathrm{cm}^{2}} \times 800 \mathrm{~cm}^{3} \\
& =7.3 \times 10^{8} \mathrm{erg} \quad(\because \text { dyne } \times \mathrm{cm}=\mathrm{erg})
\end{aligned}
$$

(2) SI 単位系

$\mathrm{SI}$ 単位系では圧力の単位は $\mathrm{Pa}$ であり,

$$
1 \mathrm{~atm}=1013 \mathrm{hPa}=1013 \times 10^{2} \mathrm{~Pa}
$$

であるが，上と同様，この值を知らないとして水銀の密度を用いて計算してみよう。

水銀の密度 $d_{\mathrm{Hg}}=13.5951 \times 10^{3} \mathrm{~kg} / \mathrm{m}^{3}$

重力の加速度 $g=9.80655 \mathrm{~m} / \mathrm{s}^{2}$

を用い，

$$
\begin{aligned}
1 \mathrm{~atm} & =\frac{\text { 水銀76.00 } \mathrm{cm}^{3} \text { の重量 }}{\text { 底面積 } 1 \mathrm{~cm}^{2}} \\
& =\frac{76.00 \times 10^{-6} \mathrm{~m}^{3} \times d_{\mathrm{Hg}} \times g}{10^{-4} \mathrm{~m}^{2}} \\
& =\frac{76.00 \times 10^{-6} \mathrm{~m}^{3} \times 13.5951 \times 10^{3} \mathrm{~kg} / \mathrm{m}^{3} \times 9.80655 \mathrm{~m} / \mathrm{s}^{2}}{10^{-4} \mathrm{~m}^{2}} \\
& =1.013 \times 10^{5} \frac{\mathrm{kg} \mathrm{m} / \mathrm{s}^{2}}{\mathrm{~m}^{2}} \\
& =1.013 \times 10^{5} \frac{\mathrm{N}}{\mathrm{m}^{2}}\left(\because \mathrm{N}=\mathrm{kg} \mathrm{m} / \mathrm{s}^{2}\right)
\end{aligned}
$$

従って, 


$$
\begin{aligned}
-W & =P \Delta V \\
& =\left(0.9 \times 1.013 \times 10^{5}\right) \frac{\mathrm{N}}{\mathrm{m}^{2}} \times 800 \times 10^{-6} \mathrm{~m}^{3} \\
& =73 \mathrm{~N} \mathrm{~m}=73 \mathrm{~J} \quad(\because \mathrm{N} \mathrm{m}=\mathrm{J})
\end{aligned}
$$

この例は, 単純な力学系の計算で電気的あるいは磁気的な物理量を含まないので, cgs Gauss 単位系, SI 単位系どちらの方法も本質的に変わりはない. そして,

$$
10^{7} \mathrm{erg}=\mathrm{J}
$$

という換算が分かっていれば，一方の計算結果から直ちに他方の結果が得られる。す なわち, こういう計算では特に SI 単位系のありがたみは感じられない.

\section{Exercise A1.5.2}

2 つの電子が真空中で 2.00 オングストローム離れている時の potential energy $U$ を 求めよ.

(1) cgs Gauss 単位系

potential energy $U$ の cgs Gauss 単位系での式は

$$
U=\frac{e^{2}}{r}
$$

である。

物理定数の表より

$$
e=4.8032 \times 10^{-10} \mathrm{esu}
$$

従って,

$$
U=\frac{e^{2}}{r}=\frac{\left(4.8032 \times 10^{-10} \mathrm{esu}\right)^{2}}{\left(2.00 \times 10^{-8} \mathrm{~cm}\right)}=1.15 \times 10^{-11} \frac{(\mathrm{esu})^{2}}{\mathrm{~cm}}
$$

であるが，esu という単位をどういうふうに換算したらいいかが分からないとこれ以 上どうにもならない。ここで，Section A1.1 で述べた定義（式(A1.1.2)）

$$
F=\frac{Q Q^{\prime}}{r^{2}}
$$

を思い出せば

$$
\text { dyne }=\frac{(\mathrm{esu})^{2}}{\mathrm{~cm}^{2}}
$$

であることに気が付く，従って，式(A1.5.11)の単位は

$$
\frac{(\mathrm{esu})^{2}}{\mathrm{~cm}}=\text { dyne } \times \mathrm{cm}=\mathrm{erg}
$$


かくして

$$
U=1.15 \times 10^{-11} \mathrm{erg}
$$

が得られる。

このように, cgs Gauss 単位系の場合には，電磁気学の基本的な式を理解していな いと単位の換算が出来ないことがある。

（2）SI 単位系

potential energy $U$ のSI 単位系での式は

$$
U=\frac{1}{4 \pi \varepsilon_{0}} \frac{e^{2}}{r}
$$

である。

物理定数の表より

$$
\begin{aligned}
& e=1.6021 \times 10^{-19} \mathrm{C} \\
& \varepsilon_{0}=8.854 \times 10^{-12} \mathrm{~J}^{-1} \cdot \mathrm{C}^{2} \cdot \mathrm{m}^{-1}
\end{aligned}
$$

従って

$$
\begin{aligned}
U & =\frac{1}{4 \pi \varepsilon_{0}} \frac{e^{2}}{r} \\
& =\frac{\left(1.6021 \times 10^{-19} \mathrm{C}\right)^{2}}{4 \times 3.14 \times\left(8.854 \times 10^{-12} \mathrm{~J}^{-1} \cdot \mathrm{C}^{2} \cdot \mathrm{m}^{-1}\right) \times\left(2.00 \times 10^{-10} \mathrm{~m}\right)} \\
& =1.15 \times 10^{-18} \mathrm{~J}
\end{aligned}
$$

このように，物理定数表に与えられている值をただ代入するだけで全く機械的に結果 が得られる。

定Exercise A1.5.3

Bohr Magneton $\mu_{\mathrm{B}}$ をcgs Gauss 単位系では erg/gauss 単位で，SI 単位系では J/T 単 位で計算せよ。

(1) cgs Gauss 単位系

$\mu_{\mathrm{B}}$ は cgs Gauss 単位系で次のように定義される。（Section A1.6 を参照）

$$
\mu_{\mathrm{B}}=\frac{e h}{4 \pi m_{\mathrm{e}} c}
$$

ここで

Lecture Note on Quantum Chemistry by T. Azumi Appendix 01: Page 12 


$$
\begin{aligned}
& e=4.8032 \times 10^{-10} \mathrm{esu} \\
& h=6.626 \times 10^{-27} \mathrm{erg} \cdot \mathrm{s} \\
& m_{\mathrm{e}}=9.110 \times 10^{-28} \mathrm{~g} \\
& c=2.9979 \times 10^{10} \mathrm{~cm} \cdot \mathrm{s}^{-1}
\end{aligned}
$$

これだけ与えられていて, 何も見ないで計算がすぐ出来る人がいたら, 化学の学生と してはかなり電磁気学がわかっている人であろう。まず,

$$
\begin{aligned}
\mu_{\mathrm{B}} & =\frac{\left(4.8032 \times 10^{-10}\right) \times\left(6.626 \times 10^{-27}\right)}{4 \times 3.14159 \times\left(9.110 \times 10^{-28}\right) \times 2.9979 \times 10^{10}} \frac{\mathrm{esu} \cdot \mathrm{erg} \cdot \mathrm{s}}{\mathrm{g} \cdot \mathrm{cm} \cdot \mathrm{s}^{-1}} \\
& =9.27 \times 10^{-21} \mathrm{esu} \frac{\mathrm{erg}}{\mathrm{dyne}}
\end{aligned}
$$

とここまでは簡単である.しかし，ここから先どうしていいかわからなくなって途方 にくれる人が多いのではないだろうか. $\frac{\mathrm{erg}}{\mathrm{dyne}}=\mathrm{cm}$ に着目して, esu·cm という単位に したところでその後どうしたらいいかわからない.また, Exercise A1.5.2 で求めた esu とdyneまたは erg の関係式（式(A1.5.11)または式(A1.5.12)）を用いてもますます混乱 するばかりである. 何か別の電磁気学の公式を思い出さないといけない.

そこで，例えば，磁場中を運動する電子に作用する力，すなわち，ローレンツ力は $\frac{e}{c} \boldsymbol{v} \times \boldsymbol{B}$ で与えられることを思い出せばよい. $c$ と $\boldsymbol{v}$ との dimension はキャンセルする から

$$
\text { dyne }=\text { esu } \cdot \text { gauss }
$$

という関係のあることが分かる。これを用いて

$$
\mu_{\mathrm{B}}=9.27 \times 10^{-21} \mathrm{esu} \frac{\mathrm{erg}}{\mathrm{dyne}}=9.27 \times 10^{-21} \mathrm{erg} / \text { gauss }
$$

を得る。

このように，ある程度電磁気学の知識がないと単位の換算は必ずしも容易ではな い.

(2) SI 単位系

$\mu_{\mathrm{B}}$ は SI 単位系で次のように定義される。（Section A1.6 を参照）

$$
\mu_{\mathrm{B}}=\frac{e h}{4 \pi m_{e}}
$$

ここで 


$$
\begin{aligned}
& e=1.602 \times 10^{-19} \mathrm{C} \\
& h=6.626 \times 10^{-34} \mathrm{~J} \cdot \mathrm{s} \\
& m_{e}=9.110 \times 10^{-31} \mathrm{~kg}
\end{aligned}
$$

を用いて

$$
\begin{aligned}
\mu_{\mathrm{B}} & =\frac{\left(1.602 \times 10^{-19}\right) \times\left(6.626 \times 10^{-34}\right)}{4 \times 3.14159 \times\left(9.110 \times 10^{-31}\right)} \frac{\mathrm{C} \cdot \mathrm{J} \cdot \mathrm{s}}{\mathrm{kg}} \quad\left(\because \mathrm{T}=\frac{\mathrm{kg}}{\mathrm{C} \cdot \mathrm{s}}\right) \\
& =9.27 \times 10^{-24} \mathrm{~J} / \mathrm{T}
\end{aligned}
$$

のように $\mathrm{T}$ という単位の定義さえ知っていれば（Section A1.4の表を参照）直ちに結 果が得られる. 電磁気学の公式を知らなくても機械的に計算出来るのはありがたい.

ここで個人的な感想を述べてみたい.SI 単位系が他の単位系に比べて使いやすい かどうか, 正直なところよくわからない。 しかし，上述したように，物理や化学の学 問の世界で SI 単位系を使いましょうと決められた以上，なんとかしてその単位系に 慣れないといけない。このような考え方でいくつかの計算例を上に示したわけである が，SI 単位系では，電磁気学のことをあまり知らなくても機械的に結果が導かれるの はありがたい。上述した cgs Gauss 単位系の計算例では，Exercise A1.5.2 では

$$
\begin{aligned}
(\mathrm{esu})^{2} & =\mathrm{erg} \cdot \mathrm{cm} \\
& =\mathrm{g} \cdot \mathrm{cm}^{3} / \mathrm{s}^{2}
\end{aligned}
$$

という換算を用い，一方 Exercise A1.5.3 では

$$
\begin{aligned}
\text { esu } & =\frac{\text { dyne }}{\text { gauss }} \\
& =\frac{\mathrm{g} \cdot \mathrm{cm} \cdot \mathrm{s}^{-2}}{\mathrm{gauss}}
\end{aligned}
$$

という換算を用いた。このような，換算式の一覧表がどこかにあれば便利なのかもし れないが，不勉強のため，そういう表は見た覚えがない。こういう状態では，SI 単位 系の方がずっと使いやすいというのが正直な気持ちである.

\section{A1.6 電磁気学における代表的ないくつかの式}

上の例で分かるように，ある物理量を計算するのに，式が SI 単位系で与えられて いる限り，その式に SI 単位で表わされた各量を代入するだけで，何も考えなくても きちんと結果が出て, dimensionが合うわけである. だから, 当然のことながら, 式 はSI 単位系で示されなければいけない. IUPACで決めた「SI 単位系を用いよう」と 
いうことはこういうことではあるまいか.このことがしばしば誤解されているように 思える. 長さは $\mathrm{cm}$ でなく $\mathrm{m}$, 質量は $\mathrm{g}$ でなく $\mathrm{kg}$, エネルギーは erg でなく $\mathrm{J} を$ 用い ることが SI 単位系の本質であると考えている人が多い. しかしこういったことは第 二義的なことである．大切なことは，式自体をSI 単位系で書くということである.

表 A1.7.1 に, 我々が量子化学の問題でしばしば用いる式の代表的なものについて, cgs Gauss 単位系とSI 単位系の両単位系の式をまとめておいた。このような表は, 電 磁気学の教科書に多少は載っているが, 化学科の学生にはあまり見慣れないものであ るかもしれない，電磁気学の基礎をきちんと勉強した人にとっては，ごく少数の基本 だけを理解出来ればそれで十分なのだろうが，我々化学をする者はあまりきちんと電 磁気学を勉強していないことも事実であろう。そのような場合に役立つよう，なるべ く多くの式を挙げておいた.

現在, 電磁気学の本はMKS 単位系がかなり使われている. しかし, 量子力学の本 は大部分がまだ cgs Gauss 単位系で書かれている。私の知る限り, SI 単位系を用いて 書かれた量子力学や量子化学の本は Atkins の本位である. 日本の出版社でも SI 単位 系を用いることになっているようであるが，現実にはいろいろな単位系が混じってい ることが多い. 同一著者の書いたある 1 つの章の中にも potential energy を $\frac{1}{4 \pi \varepsilon_{0}} \frac{e^{2}}{r}$ と いうSI 単位系の式と $\frac{e^{2}}{r}$ という cgs Gauss 単位系が混じっている例はかなり多い. 統一 のとれていないことは実にわかりにくいことで, 多分読者を悩ましているのではなか ろうか. それだけに電磁気学の入った式は，まず疑ってみる必要があるし，又，当分 の間, 式の変換は自分で考えやらなくてはならないだろう。しかし, それがかえって よい勉強になるであろうが. 
表 A1.6.1 いくつかの電磁気学の式について cgs Gauss 単位系と SI 単位系との比較

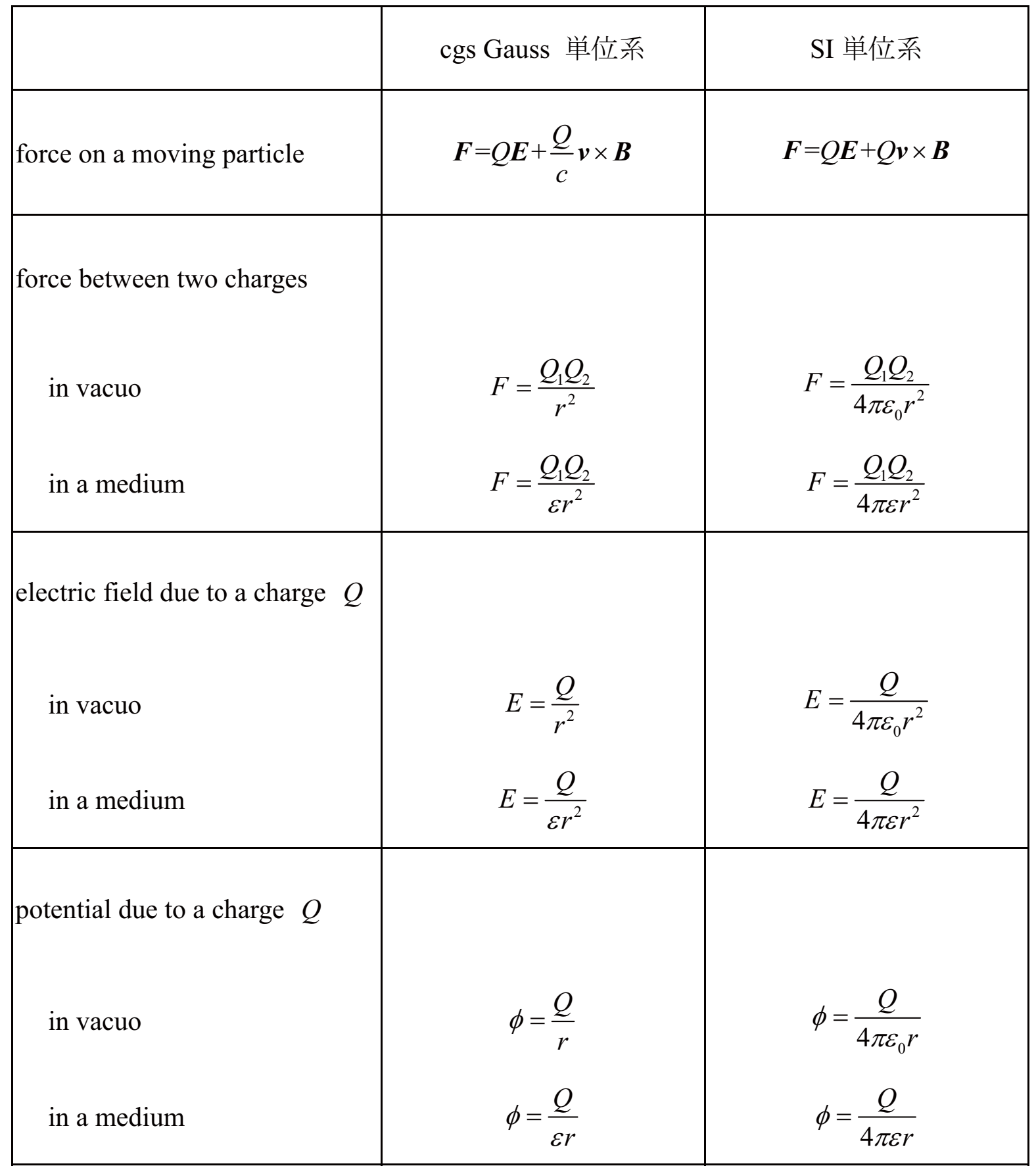




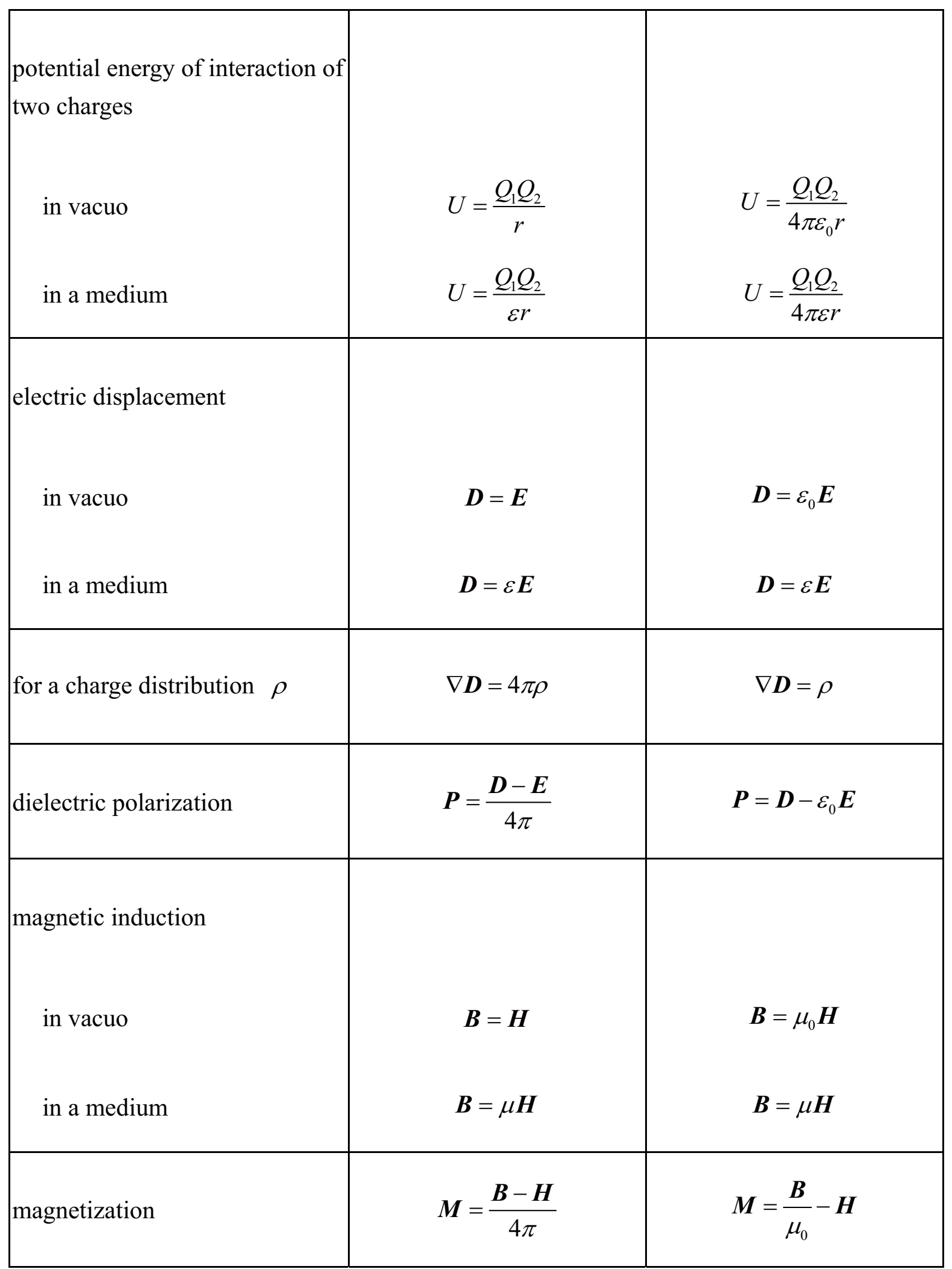




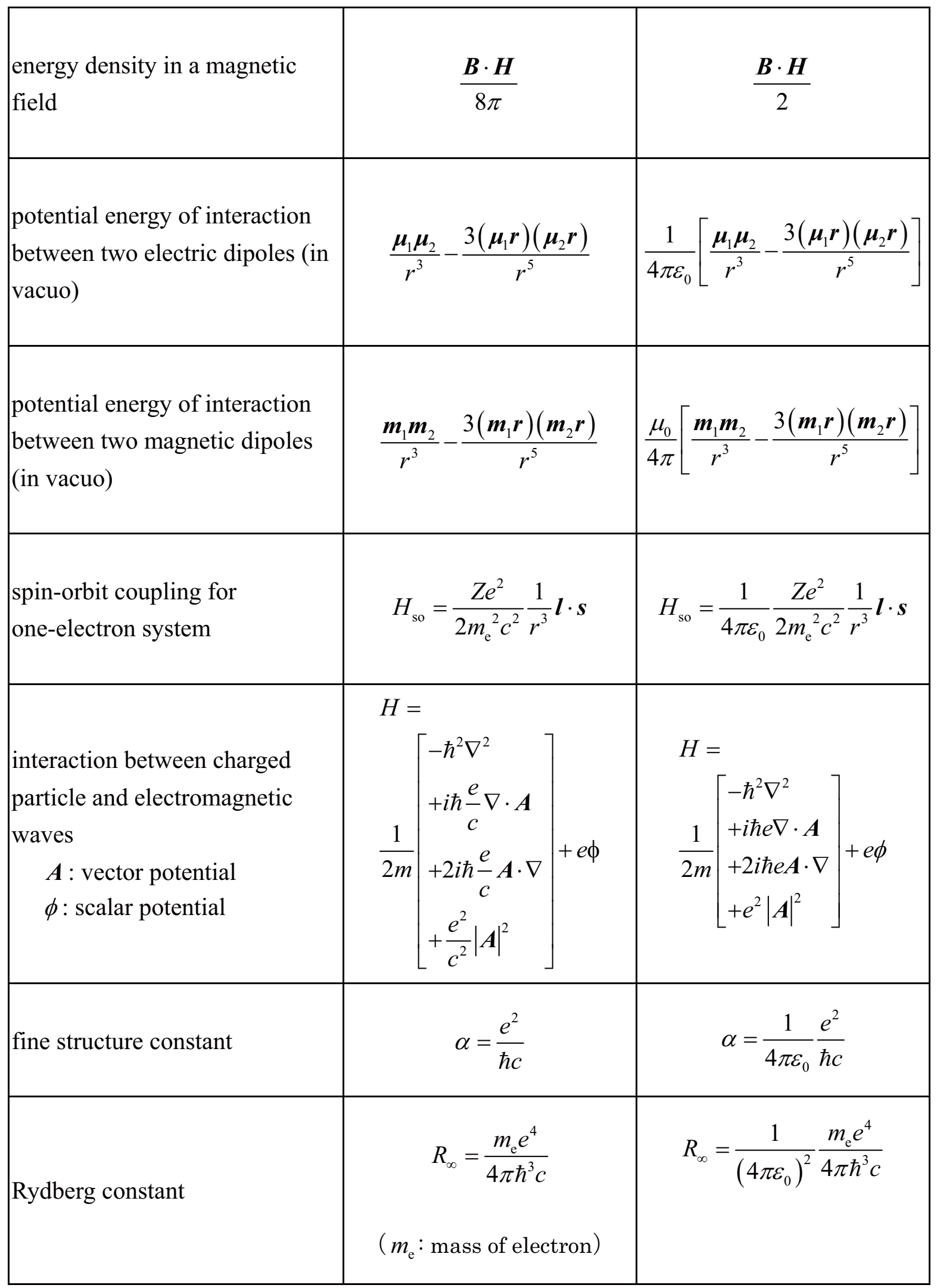




\begin{tabular}{|l|c|c|}
\hline Bohr radius & $a_{0}=\frac{\hbar^{2}}{m_{\mathrm{e}} e^{2}}$ & $a_{0}=4 \pi \varepsilon_{0} \frac{\hbar^{2}}{m_{\mathrm{e}} e^{2}}$ \\
\hline Bohr magneton & $\mu_{\mathrm{B}}=\frac{e \hbar}{2 m_{\mathrm{e}} c}$ & $\mu_{\mathrm{B}}=\frac{e \hbar}{2 m_{\mathrm{e}}}$ \\
\hline nuclear magneton & $\mu_{\mathrm{N}}=\frac{e \hbar}{2 m_{\mathrm{p}} c}$ & $\mu_{\mathrm{N}}=\frac{e \hbar}{2 m_{\mathrm{p}}}$ \\
\hline
\end{tabular}

خ? Problem A1.6.1

Eyring, Walter, Kimball の"Quantum Chemistry"の 83 頁に Bohr radius $a_{0}=\frac{h^{2}}{4 \pi^{2} \mu e^{2}}$ の 導出が cgs Gauss 単位系で書かれている。この導出に用いられるそれぞれの式が SI 単 位系でどうなるかを明らかにしつつ，SI 単位系における Bohr radius を求めよ。（答え は上の表を見れば分かる.）導出に必要な全ての式について，左側に SI 単位系，右側 に cgs Gauss 単位系で書いて比較しつつ， $a_{0}$ の最終結果を求めよ。ここに挙げた表に 加えて，ごく初歩的な電磁気学の知識があれば出来るはずである。忘れていれば電磁 気学を思い出してみよう。

¿ 2 Problem A1.6.2

Eyring, Walter, Kimball の"Quantum Chemistry"の Chapter 7 にinstein's A coefficient $A_{m n}$ の導出が cgs Gauss 単位系で導出されている. 上の問題と同様に, これを SI 単位 系で導出し直してみよ。（答えは，例えば，本 lecture noteの Chapter 13, Section 13.7 を見れば分かる.） 


\section{APPENDIX 02}

\section{行列の対角化}

量子化学およびその関連分野での論文, 会話などにしばしば「このマトリックスを 対角化して...」という言葉が出てくる．ちょっとオーバーな言い方かもしれないが， それさえわかっただけで量子化学の大半のことは理解出来るとも言い得る. しかしこ の大切な数学的手法は必ずしも全ての学生諸君に習得されていないみたいである. そ れで問題が出てくると, 昔学習した数学の教科書を出して来て勉強しようとするが, これがまた必ずしも容易ではないらしい.そこで Appendix 2 では，このような学生諸 君の為に, この重要な数学的手法について, 数学の教科書を見ないでもすむ位簡単に 説明したい，自分の手で演算しつつ，読んでいけばよく分かると思う.

$\mathbf{A 2 . 1}$ 行列の固有值と固有ベクトル

$$
\mathbf{H}=\left[\begin{array}{cccc}
H_{11} & H_{12} & \ldots & H_{1 n} \\
H_{21} & H_{22} & \ldots & H_{2 n} \\
\ldots & \ldots & \ldots & \ldots \\
H_{n 1} & H_{n 2} & \ldots & H_{n n}
\end{array}\right]
$$

という matrix と

$$
\mathbf{c}_{i}=\left[\begin{array}{c}
c_{1 i} \\
c_{2 i} \\
\cdots \\
\cdots \\
c_{n i}
\end{array}\right]
$$

という vector (column matrix)との間に

$$
\mathbf{H c}_{i}=E_{i} \mathbf{c}_{i}
$$

すなおち

$$
\left(\mathbf{H}-\mathbf{I} E_{i}\right) \mathbf{c}_{i}=0
$$

という関係がある時， $E_{i}$ は matrix $\mathbf{H}$ の eigenvalue（固有值）， $\mathbf{c}_{i}$ を matrix $\mathbf{H}$ の 
eigenvector（固有ベクトル）という.

式(A2.1.4)でIは unit matrix で

$$
\mathbf{I}=\left[\begin{array}{cccccc}
1 & 0 & 0 & \ldots & \ldots & 0 \\
0 & 1 & 0 & \ldots & \ldots & 0 \\
0 & 0 & 1 & \ldots & \ldots & 0 \\
\ldots & \ldots & \ldots & \ldots & \ldots & \ldots \\
\ldots & \ldots & \ldots & \ldots & \ldots & \ldots \\
0 & 0 & 0 & \ldots & 0 & 1
\end{array}\right]
$$

のように対角要素は 1 , それ以外は 0 であるような matrix である.ここで, vector $\mathbf{c}_{i}$ に ついては

$$
\left|c_{1 i}\right|^{2}+\left|c_{2 i}\right|^{2}+\ldots+\left|c_{n i}\right|^{2}=1
$$

のように normalize しておくのが普通である。n次の matrix Hについて，式(A2.1.3) または式(A2.1.4)を満たす $E_{i}$ と $\mathbf{c}_{i}$ の組は $n$ 個ある.すなわち, $i=1,2, \ldots, n . \mathbf{H}$ が与え られた時その eigenvalue $E_{i}$, eigenvector $\mathbf{c}_{i}$ を求めることがしばしば必要となる.以 下にその方法を説明する.

マトリックス表示に馴れていない人もいるかもしれないので，式(A2.1.4)を次のよ うに書き直しておく。

$$
\begin{aligned}
& \left(H_{11}-E_{i}\right) c_{1 i}+H_{12} c_{2 i}+H_{13} c_{3 i}+\ldots+H_{1 n} c_{n i}=0 \\
& H_{21} c_{1 i}+\left(H_{22}-E_{i}\right) c_{2 i}+H_{23} c_{3 i}+\ldots+H_{2 n} c_{n i}=0 \\
& H_{31} c_{1 i}+H_{31} c_{2 i}+\left(H_{33}-E_{i}\right) c_{3 i}+\ldots+H_{3 n} c_{n i}=0 \\
& \ldots \ldots \ldots \ldots . . . \\
& \ldots \ldots \ldots \ldots \ldots . . . \\
& H_{n 1} c_{1 i}+H_{n 2} c_{2 i}+H_{n 3} c_{3 i}+\ldots+\left(H_{n n}-E_{i}\right) c_{n i}=0
\end{aligned}
$$

この連立方程式を解いて，例えば $c_{1 i}$ を求めてみると常法によって， 


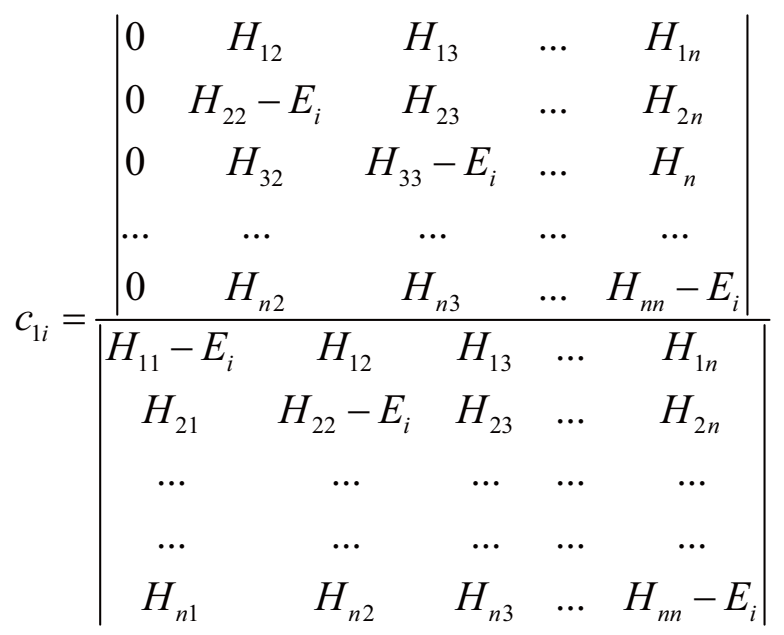

を得る．上式の分子は明らかにゼロである， $c_{2 i}, c_{3 i} \ldots$ すべてについても同様な式が 得られる. すなわち，もし式(A2.1.8)の分母がゼロでないならば $c_{1 i}, c_{2 i}, \ldots, c_{n i}$ のす ベてがゼロになってしまう。これは解とは言っても意味のない解で，そういう解を trivial solution と言う。我々はそれ以外の解，すなわち，non-trivial solution を求めない といけない，そのためには式(A2.1.8)の分母もまたゼロでなくてはいけない。すなわ ち,

$$
\left|\begin{array}{ccccc}
H_{11}-E_{i} & H_{12} & H_{13} & \ldots & H_{1 n} \\
H_{21} & H_{22}-E_{i} & H_{23} & \ldots & H_{2 n} \\
\ldots & \ldots & \ldots & \ldots & \ldots \\
\ldots & \ldots & \ldots & \ldots & \ldots \\
H_{n 1} & H_{n 2} & H_{n 3} & \ldots & H_{n n}-E_{i}
\end{array}\right|=0
$$

が必要になる。(A2.1.9)を通常は簡単に

$$
\left|\mathbf{H}-\mathbf{I} E_{i}\right|=0
$$

という式で表わす。式(A2.1.9)または，式(A2.1.10)は $E_{i}$ につての $n$ 次方程式となる. この方程式を永年方程式 (secular equation) という. 従って, $n$ 個の解 $E_{1}, E_{2}, \ldots, E_{n}$ が得られる。次にそれぞれの eigenvalue について, eigenvector を求めないといけない. それには $E_{i}$ を式(A2.1.7)に代入して $c_{1 i}, c_{2 i}, \ldots, c_{n i}$ について連立方程式を立てる.未 知数が $n$ 個であり，方程式の数も $n$ 個あるので一見よさそうであるが，実は式(A2.1.7) 
の全てが独立ではなく， $n-1$ 個の独立な式しか得られない，それに，式(A2.1.6)の規 格化条件を入れて, 合計 $n$ 個の式とし, それをもとに $n$ 個の未知数 $c_{1 i}, c_{2 i}, \ldots, c_{n i}$ を 求める.

以下，二三の例を述べよう。

¿tzercise A2.1.1

$$
\mathbf{H}=\left[\begin{array}{ll}
1 & 1 \\
1 & 1
\end{array}\right] \text { の eigenvalue, eigenvector を求めよ. }
$$

\section{【解】 :}

式(A2.1.9)の secular determinant

$$
\left|\begin{array}{cc}
1-E_{i} & 1 \\
1 & 1-E_{i}
\end{array}\right|=0
$$

のように書ける。すなわち

$$
\left(1-E_{i}\right)^{2}-1=0
$$

これを解いて

$$
E_{i}=0,2
$$

を得る． $E_{i}$ の番号はどう付けてもいいが，ここでは， $E_{i}$ の小さいものから順に $i=1,2, \ldots$ と番号を付けることにする. すなわち,

$$
\begin{aligned}
& E_{1}=0 \\
& E_{2}=2
\end{aligned}
$$

次に eigenvector を求める. 式(A2.1.7)はこの場合

$$
\begin{aligned}
& \left(1-E_{i}\right) c_{1 i}+c_{2 i}=0 \\
& c_{i}+\left(1-E_{i}\right) c_{2 i}=0
\end{aligned}
$$

となる．まずを $E_{1}=0$ 上式に代入すると，2つの式は共に

$$
\begin{array}{r}
c_{11}+c_{21}=0 \\
\text { となる. すなわち, } \\
c_{21}=-c_{11}
\end{array}
$$

規格化条件は

$$
\left|c_{11}\right|^{2}+\left|c_{21}\right|^{2}=1
$$


すなわち，

$$
\left|c_{11}\right|^{2}+\left|c_{11}\right|^{2}=1
$$

従って,

$$
\left|c_{11}\right|^{2}=\frac{1}{2}
$$

を得る.この解 $c_{11}$ は無限個ある. すなわち $\sqrt{\frac{1}{2}}$ でも- $\sqrt{\frac{1}{2}}$ でもいいし, 又ごく一般的 に任意の $\theta$ にいて $\sqrt{\frac{1}{2}} e^{i \theta}$ が式(A2.1.15)の解となる.この無限個のうちのどれをとつ てもよい. 通常はわざわざ面倒な式にする必要はないから, もっとも簡単に, $c_{11}=\sqrt{\frac{1}{2}}$ とすればよい，すなわち，解は，式(A2.1.14)を用いて

$$
\begin{aligned}
c_{11} & =\sqrt{\frac{1}{2}} \\
c_{12} & =-\sqrt{\frac{1}{2}}
\end{aligned}
$$

従って, 求めるべき eigenvector は

$$
\mathbf{c}_{1}=\left[\begin{array}{c}
\sqrt{\frac{1}{2}} \\
-\sqrt{\frac{1}{2}}
\end{array}\right]=\sqrt{\frac{1}{2}}\left[\begin{array}{c}
1 \\
-1
\end{array}\right]
$$

となる.

次に $E_{2}=2$ に対する eigenvector を求めよう. 式(A2.1.13)に代入し，

$$
c_{12}-c_{22}=0
$$

これより規格化条件は,

$$
\left|c_{12}\right|^{2}+\left|c_{22}\right|^{2}=1
$$

すなわち

$$
\left|c_{12}\right|^{2}+\left|c_{12}\right|^{2}=1
$$

これより， 


$$
\begin{aligned}
& c_{12}=\sqrt{\frac{1}{2}} \\
& c_{22}=\sqrt{\frac{1}{2}}
\end{aligned}
$$

を得る. 求めるべく eigenvector は

$$
\mathbf{c}_{2}=\left[\begin{array}{l}
\sqrt{\frac{1}{2}} \\
\sqrt{\frac{1}{2}}
\end{array}\right]=\sqrt{\frac{1}{2}}\left[\begin{array}{l}
1 \\
1
\end{array}\right]
$$

これですべてが求まったわけである，解はまとめて次のように表わせばよからう. $E_{1}=0$ について

$$
\mathbf{c}_{1}=\left[\begin{array}{c}
\sqrt{\frac{1}{2}} \\
-\sqrt{\frac{1}{2}}
\end{array}\right]
$$

$E_{2}=2$ について

$$
\mathbf{c}_{2}=\left[\begin{array}{l}
\sqrt{\frac{1}{2}} \\
\sqrt{\frac{1}{2}}
\end{array}\right]
$$

¿xercise A2.1.2

$$
\mathbf{H}=\left[\begin{array}{ccc}
-3 & 1 & 0 \\
2 & -3 & 2 \\
0 & 1 & -3
\end{array}\right] \text { の eigenvalue, eigenvector を求めよ. }
$$

\section{【解】:}

secular determinant は

$$
\left|\begin{array}{ccc}
-3-E_{i} & 1 & 0 \\
2 & -3-E_{i} & 2 \\
0 & 1 & -3-E_{i}
\end{array}\right|=0
$$

すなわち 


$$
\begin{aligned}
& \left(-3-E_{i}\right)^{3}-2\left(-3-E_{i}\right)-2\left(-3-E_{i}\right)=0 \\
& \left(-3-E_{i}\right)\left\{\left(-3-E_{i}\right)^{2}-4\right\}=0 \\
& \left(-3-E_{i}\right)\left(-3-E_{i}+2\right)\left(-3-E_{i}-2\right)=0
\end{aligned}
$$

これより

$$
\begin{aligned}
& E_{1}=-5 \\
& E_{2}=-3 \\
& E_{3}=-1
\end{aligned}
$$

(i) $E_{1}=-5$ について

$$
\begin{aligned}
& 2 c_{11}+c_{21}=0 \\
& 2 c_{11}+2 c_{21}+2 c_{31}=0 \\
& c_{21}+2 c_{31}=0
\end{aligned}
$$

(1)より

$$
c_{21}=-2 c_{11}
$$

(4)を(2)に代入

$$
c_{31}=-c_{11}-c_{21}=-c_{11}-\left(-2 c_{11}\right)=c_{11}
$$

規格化条件より

$$
\begin{aligned}
1 & =c_{11}{ }^{2}+c_{21}{ }^{2}+c_{31}{ }^{2} \\
& =c_{11}{ }^{2}\left\{1+(-2)^{2}+1\right\} \\
& =6 c_{11}^{2}
\end{aligned}
$$

従って

$$
\begin{aligned}
& c_{11}=\sqrt{\frac{1}{6}} \\
& c_{21}=-2 \sqrt{\frac{1}{6}} \\
& c_{21}=\sqrt{\frac{1}{6}}
\end{aligned}
$$

(ii) $E_{2}=-3$ について 


$$
\begin{aligned}
& c_{22}=0 \\
& 2 c_{12}+2 c_{32}=0
\end{aligned}
$$

(5),(6)より

$$
\begin{aligned}
& c_{32}=-c_{12} \\
& c_{22}=0
\end{aligned}
$$

規格化条件より

$$
\begin{aligned}
1 & =c_{12}{ }^{2}+c_{22}{ }^{2}+c_{32}{ }^{2} \\
& =c_{12}{ }^{2}\left\{1+0+(-1)^{2}\right\} \\
& =2 c_{12}{ }^{2}
\end{aligned}
$$

従って

$$
\begin{aligned}
& c_{12}=\sqrt{\frac{1}{2}} \\
& c_{22}=0 \\
& c_{32}=-\sqrt{\frac{1}{2}}
\end{aligned}
$$

(iii) $E_{3}=-1$ にいて

$$
\begin{aligned}
& -2 c_{13}+c_{23}=0 \\
& 2 c_{13}-2 c_{23}+2 c_{33}=0 \\
& c_{23}-2 c_{33}=0
\end{aligned}
$$

(7)より

$$
c_{23}=2 c_{13}
$$

8に代入

$$
\begin{aligned}
c_{33} & =-c_{13}+c_{23} \\
& =-c_{13}+2 c_{13} \\
& =c_{13}
\end{aligned}
$$

規格化条件より

$$
\begin{aligned}
1 & =c_{13}{ }^{2}+c_{23}{ }^{2}+c_{33}{ }^{2} \\
& =c_{13}{ }^{2}\left\{1+2^{2}+1\right\} \\
& =6 c_{12}{ }^{2}
\end{aligned}
$$


従って

$$
\begin{aligned}
c_{13} & =\sqrt{\frac{1}{6}} \\
c_{23} & =2 \sqrt{\frac{1}{6}} \\
c_{33} & =\sqrt{\frac{1}{6}}
\end{aligned}
$$

結果をまとめて

$$
\begin{aligned}
& \mathbf{c}_{1}=\left[\begin{array}{c}
\sqrt{\frac{1}{6}} \\
-2 \sqrt{\frac{1}{6}} \\
\sqrt{\frac{1}{6}}
\end{array}\right] \\
& \mathbf{c}_{2}=\left[\begin{array}{c}
\sqrt{\frac{1}{2}} \\
0 \\
-\sqrt{\frac{1}{2}}
\end{array}\right] \\
& E_{2}=-3 \text { について } \\
& \mathbf{c}_{3}=\left[\begin{array}{c}
\sqrt{\frac{1}{6}} \\
2 \sqrt{\frac{1}{6}} \\
\sqrt{\frac{1}{6}}
\end{array}\right]
\end{aligned}
$$

放Exercise A2.1.3

$$
\mathbf{H}=\left[\begin{array}{cc}
1 & i \\
-i & 1
\end{array}\right] \text { の eigenvalue, eigenvector を求めよ. }
$$

\section{【解】 :}

secular determinant は

$$
\left|\begin{array}{cc}
1-E & i \\
-i & 1-E
\end{array}\right|=0
$$


これより

$$
E=0,2
$$

(i) $E_{1}=0$ の時，式(A2.1.7)は，

$$
\begin{aligned}
& c_{11}(1-0)+c_{21} i=0 \\
& c_{11}(-i)+c_{21}(1-0)=0
\end{aligned}
$$

(1)より

$$
\begin{aligned}
& c_{11}=-c_{21} i \\
& c_{11} *=c_{21} * i
\end{aligned}
$$

規格化条件より

$$
\begin{aligned}
1 & =c_{11} * c_{11}+c_{21} * c_{21} \\
& =\left(c_{21} * i\right)\left(-c_{21} i\right)+c_{21} * c_{21} \\
& =c_{21} * c_{21}(1+1) \\
& =2 c_{21} * c_{21} \\
c_{21} & =\sqrt{\frac{1}{2}}
\end{aligned}
$$

従って

$$
c_{11}=-\sqrt{\frac{1}{2}} i
$$

すなわち

$$
\mathbf{c}_{1}=\left[\begin{array}{c}
-\sqrt{\frac{1}{2}} i \\
\sqrt{\frac{1}{2}}
\end{array}\right]
$$

(ii) $E_{2}=2$ の時, 式(A2.1.7)は

$$
\begin{aligned}
& c_{12}(1-2)+c_{22} i=0 \\
& c_{12}(1-i)+c_{22}(1-2)=0
\end{aligned}
$$

(3)より

$$
\begin{aligned}
& c_{12}=c_{22} i \\
& c_{12} *=-c_{22} * i
\end{aligned}
$$


規格化条件より

$$
\begin{aligned}
1 & =c_{12} * c_{12}+c_{22} * c_{22} \\
& =\left(-c_{22} * i\right)\left(-c_{22} i\right)+c_{22} * c_{22} \\
& =c_{22} * c_{22}(1+1) \\
& =2 c_{22} * c_{22}
\end{aligned}
$$

これより

$$
c_{22}=\sqrt{\frac{1}{2}}
$$

従って

$$
c_{12}=\sqrt{\frac{1}{2}} i
$$

すなわち

$$
\mathbf{c}_{2}=\left[\begin{array}{l}
\sqrt{\frac{1}{2}} i \\
\sqrt{\frac{1}{2}}
\end{array}\right]
$$

結果をまとめて

$$
\begin{aligned}
E_{1}=0 \text { について } & \mathbf{c}_{1}=\left[\begin{array}{c}
-\sqrt{\frac{1}{2}} i \\
\sqrt{\frac{1}{2}}
\end{array}\right] \\
E_{2}=2 \text { について } & \mathbf{c}_{2}=\left[\begin{array}{c}
\sqrt{\frac{1}{2}} i \\
\sqrt{\frac{1}{2}}
\end{array}\right]
\end{aligned}
$$

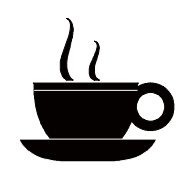

[Coffee Break] secular equation の"secular"とは?

"secular equation"の secular は「長く続く」という意味である.どうしてこういう言 葉が用いられたのだろう. 次数の高い secular equation を解こうとすると大変厄介であ り, 長い時間がかかる. 今のように, computer のない時には十数次のものを解くのに 1 ケ月近くもかかってしまったものだ.だから secularなのだというのは攵談にしても， computer のない時代に手回しの計算機で対角化を行って来た古い世代の人には実感 
のある言葉である．惑星の secular perturbation（永年摂動）を解く時に，この方程式が 用いられたので，それから secular equation という言葉が定着したらしい.

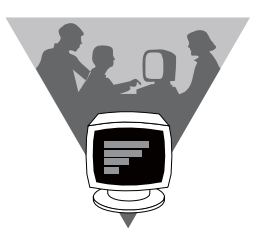

[Let's play with Mathematica] Mathematica を用いた対角化

対角化は, 量子化学の計算に必須なものであるから, 種々の言語でそのプログラム が開発されている，たとえば，Jacobi 法という方法を用いた Fortran 言語のプログラム などは，もっとも popularなものの 1 つである.

Mathematica でも対角化は非常に簡単に行うことが出来る.

以下，一例として， Exercise A2.1.2 で扱った

$$
\mathbf{H}=\left[\begin{array}{ccc}
-3 & 1 & 0 \\
2 & -3 & 2 \\
0 & 1 & -3
\end{array}\right]
$$

という行列の対角化を試みる.

まず，行列を定義しよう。

$\mathrm{h}=$ Table $[\{\{-3,1,0\},\{2,-3,2\},\{0,1,-3\}\}]$

これを通常の行列形式で表すには

\section{MatrixForm[h]}

とすればよい。その結果は,

$$
\begin{aligned}
& \left(\begin{array}{lll}
-3 & 1 & 0 \\
2 & -3 & 2 \\
0 & 1 & -3
\end{array}\right) \\
& \text { という見慣れた形になる. }
\end{aligned}
$$


固有值を求めるには, Eigenvalues という関数を用いる.

\section{Eigenvalues[h]}

計算結果は，

$\{-5,-3,-1\}$

となる．固有べクトルを求めるには Eivenectors という関数を用いる.

\section{Eigenvectors[h]}

結果は,

$\{\{1,-2,1\},\{-1,0,1\},\{1,2,1\}\}$

となる。

行列の形で示したければ

MatrixForm[\%]

とすれば，結果は，

$$
\left(\begin{array}{lll}
1 & -2 & 1 \\
-1 & 0 & 1 \\
1 & 2 & 1
\end{array}\right)
$$

となる。ただし，Eivenvectors の結果は規格化されていない.

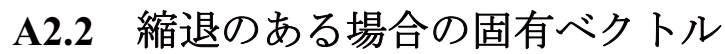

eigenvalue の中に同じもの，すなおち degeneracy がある場合には eigenvector は一義 的には求まらない。通常の場合には式(A2.1.7)から $n-1$ 個の独立な関係式が得られ, それと normalization condition と合わせて $n$ 個の未知数 $c_{1 i}, c_{2 i}, \ldots, c_{n i}$ が求まる. しかし 
degeneracy がある場合には eigenvector を求めるだけの独立な方程式が得られない.す なわち, 解は unique には求まらない. 与えられた方程式を満足する無限個の解があり, そのどれをとってよいことになる。

Exercise A2.2.1

$$
\mathbf{H}=\left[\begin{array}{lll}
0 & 1 & 1 \\
1 & 0 & 1 \\
1 & 1 & 0
\end{array}\right]
$$

の eigenvalue, eigenvector を求めよ.

\section{【解】 :}

secular determinant は

$$
\left|\begin{array}{ccc}
-E & 1 & 1 \\
1 & -E & 1 \\
1 & 1 & -E
\end{array}\right|=0
$$

これより

$$
\begin{aligned}
& E^{3}-3 E-2=0 \\
& (E+1)^{2}(E-2)=0
\end{aligned}
$$

eigenvalue は,

$$
E_{1}=-1, E_{2}=-1, E_{3}=2 \text { となって }, E_{1}=-1, E_{2}=-1 \text { は degenerate している } .
$$

non-degenerate の場合，すなわち， $E_{3}=2$ の場合は問題ない。この場合，式(A2.1.7)は

$$
\begin{aligned}
& -2 c_{13}+c_{23}+c_{33}=0 \\
& c_{13}-2 c_{23}+c_{33}=0 \\
& c_{13}+c_{23}-2 c_{33}=0
\end{aligned}
$$

となるが，このうち 1 つは他の 2 つから導かれるから，このうち 2 つもう $1 つ$ normalization condition, すなわち, $\left|c_{13}\right|^{2}+\left|c_{23}\right|^{2}+\left|c_{33}\right|^{2}=1$ より, 3 つの未知数が求まる. すなわち, 


$$
\mathbf{c}_{3}=\left[\begin{array}{l}
\sqrt{\frac{1}{3}} \\
\sqrt{\frac{1}{3}} \\
\sqrt{\frac{1}{3}}
\end{array}\right]
$$

しかし，縮退している $E_{1}=-1$ の場合には式(A2.1.7)の 3 つの方程式はすべて

$$
c_{11}+c_{21}+c_{31}=0
$$

となってしまう。

$$
\left|c_{11}\right|^{2}+\left|c_{21}\right|^{2}+\left|c_{31}\right|^{2}=1
$$

の規格化条件を合わせても 3 つの未知数に対し 2 つの式しか得られない. こういう場 合は，この 2 つの満足するどんな組み合わせでもいいわけで，1つの係数 $c$ を勝手に 決めてしまう。この決め方は無限個あるわけで，そのうちのどれをとってもいいわけ である．例えば， $c_{31}=0$ とおくと，

$$
c_{11}=-c_{21}=\sqrt{\frac{1}{2}}
$$

となり, eigenvector は

$$
\mathbf{c}_{1}=\left[\begin{array}{c}
\sqrt{\frac{1}{2}} \\
-\sqrt{\frac{1}{2}} \\
0
\end{array}\right]
$$

となる.しかし，たとえば $c_{31}=c_{21}$ と決めてもいい。この場合には，

$$
\begin{aligned}
& c_{21}=c_{31}=\sqrt{\frac{1}{6}} \\
& c_{11}=2 \sqrt{\frac{1}{6}}
\end{aligned}
$$

となり 


$$
\mathbf{c}_{1}=\left[\begin{array}{l}
2 \sqrt{\frac{1}{6}} \\
-\sqrt{\frac{1}{6}} \\
-\sqrt{\frac{1}{6}}
\end{array}\right]
$$

という一見異なった結果となる。こういう決め方はいくらでもあり，たとえば，あま りありそうな例ではないが， $c_{11}=0.12345$ と勝手に決めてしまうと

$$
\mathbf{c}_{1}=\left[\begin{array}{c}
0.12345 \\
0.63725 \\
-0.76070
\end{array}\right]
$$

となるが，わざわざこんな複雑な形にしないのが普通である.

次に縮退しているもう1つの eigenvector $\mathbf{c}_{2}$ を求めなくてはいけない。これについ ても $E_{2}=-1$ を代入することにより，式(A2.1.7)は

$$
c_{12}+c_{22}+c_{32}=0
$$

と $\mathbf{c}_{1}$ の場合と全く同じ形の式が得られることは当然である. 従って $\mathbf{c}_{1}$ を求めた時と同 じように 1 つの条件を勝手に決めてよい. ただその場合， $\mathbf{c}_{2}$ はすでに求めた $\mathbf{c}_{1}$ とは異 なっていなければならない.(一般に $n$ 次の縮退の場合には，1つの eigenvector が残り の $n-1$ 個の eigenvector の線形結合で表わされるようであってはいけない) その条件内 で,どのような eigenvector を選んでもよいが, お互いに直交するように選んでおくと， なにかと便利である。すなわち，この場合には，

$$
\mathbf{c}_{2}^{\dagger} \mathbf{c}_{1}=\left[\begin{array}{lll}
c_{12} * & c_{21} * & c_{32} *
\end{array}\right]\left[\begin{array}{l}
c_{11} \\
c_{21} \\
c_{31}
\end{array}\right]=0
$$

のような条件で解く. そうすると, 上で求めた $\mathbf{c}_{1}$ のそれぞれについて， $\mathbf{c}_{2}$ が一義的に 決まる。例えば 


$$
\mathbf{c}_{1}=\left[\begin{array}{c}
\sqrt{\frac{1}{2}} \\
-\sqrt{\frac{1}{2}} \\
0
\end{array}\right]
$$

$$
\mathbf{c}_{2}=\left[\begin{array}{c}
\sqrt{\frac{1}{6}} \\
\sqrt{\frac{1}{6}} \\
-2 \sqrt{\frac{1}{6}}
\end{array}\right]
$$

又は

$$
\mathbf{c}_{1}=\left[\begin{array}{c}
2 \sqrt{\frac{1}{6}} \\
-\sqrt{\frac{1}{6}} \\
-\sqrt{\frac{1}{6}}
\end{array}\right] \quad \mathbf{c}_{2}=\left[\begin{array}{c}
0 \\
\sqrt{\frac{1}{2}} \\
-\sqrt{\frac{1}{2}}
\end{array}\right]
$$

又は

$$
\mathbf{c}_{1}=\left[\begin{array}{c}
0.12345 \\
0.63725 \\
-0.76070
\end{array}\right] \quad \mathbf{c}_{2}=\left[\begin{array}{c}
0.80711 \\
-0.51047 \\
-0.29664
\end{array}\right]
$$

といった形になる.どの組をとってもよいわけである.

خ Problem A2.2.1

$$
\mathbf{H}=\left[\begin{array}{ll}
1 & 3 \\
4 & 2
\end{array}\right] \text { の eigenvalue と eigenvector を求めよ. }
$$

胥Problem A2.2.2

$$
\mathbf{H}=\left[\begin{array}{cc}
5 & -2 \\
-2 & 2
\end{array}\right] \text { の eigenvalue と eigenvector を求めよ. }
$$

预Problem A2.2.3 


$$
\mathbf{H}=\left[\begin{array}{cc}
8 & 4 i \\
-4 i & 2
\end{array}\right] \text { の eigenvalue と eigenvector を求めよ. }
$$

¿̦Problem A2.2.4

$$
\mathbf{H}=\left[\begin{array}{ccc}
0 & \sqrt{\frac{1}{2}} & 0 \\
\sqrt{\frac{1}{2}} & 0 & \sqrt{\frac{1}{2}} \\
0 & \sqrt{\frac{1}{2}} & 0
\end{array}\right] \text { の eigenvalue と eigenvector を求めよ. }
$$

¿3Problem A2.2.5

$$
\mathbf{H}=\left[\begin{array}{ccc}
0 & \sqrt{\frac{1}{2}} i & 0 \\
-\sqrt{\frac{1}{2}} i & 0 & \sqrt{\frac{1}{2}} i \\
0 & -\sqrt{\frac{1}{2}} i & 0
\end{array}\right] \text { の eigenvalue と eigenvector を求めよ. }
$$

\section{A2.3 あるハミルトニアンの固有関数を完全系をなす波動関数の線形結合で表す}

系の Hamiltonian を $H$ として，その eigenvalue $E_{i}$ と eigenfunction $\varphi_{i}$ を求めること を考えよう。

$$
H \varphi_{i}=E_{i} \varphi_{i}
$$

多くの場合, analytical に解くことはできない.そこでしばしば次のような方法がとら れる。

$n$ 個の orthonormal wavefunction $\phi_{1}, \phi_{2}, \ldots, \phi_{n}$ がすでに定義されており，それが完全 系をなしているとする。この wavefunction（basis function という）は完全系であれば 
何でもよく，一般には $H$ の eigenfunction ではない. 従って当然のことながら，

$$
\left[\begin{array}{cccc}
H_{11} & \ldots & \ldots & H_{1 n} \\
H_{21} & \ldots & \ldots & H_{2 n} \\
\ldots & \ldots & \ldots & \ldots \\
H_{n 1} & \ldots & \ldots & H_{n n}
\end{array}\right]=\left[\begin{array}{cccc}
\left\langle\phi_{1}|H| \phi_{1}\right\rangle & \ldots & \ldots & \left\langle\phi_{1}|H| \phi_{n}\right\rangle \\
\left\langle\phi_{2}|H| \phi_{1}\right\rangle & \ldots & \ldots & \left\langle\phi_{2}|H| \phi_{n}\right\rangle \\
\ldots & \ldots & \ldots & \ldots \\
\left\langle\phi_{n}|H| \phi_{1}\right\rangle & \ldots & \ldots & \left\langle\phi_{n}|H| \phi_{n}\right\rangle
\end{array}\right]
$$

の matrix の off-diagonal term はゼロというわけにはいかない，そこで，これらの basis function $\phi_{1}, \phi_{2}, \ldots, \phi_{n}$ の linear combination として $H$ の eigenfunction $\varphi_{1}, \varphi_{2}, \ldots, \varphi_{n}$ を表 わすことを考える. $\left(\phi_{1}, \phi_{2}, \ldots, \phi_{n}\right.$ が完全系であればいかなる wavefunction もその linear combination として表わされる) 寸なわち，

$$
\left[\begin{array}{llll}
\varphi_{1} & \varphi_{2} & \ldots & \varphi_{n}
\end{array}\right]=\left[\begin{array}{llll}
\phi_{1} & \phi_{2} & \ldots & \phi_{n}
\end{array}\right]\left[\begin{array}{cccc}
c_{11} & c_{12} & \ldots & c_{1 n} \\
c_{21} & c_{22} & & c_{2 n} \\
\ldots & \ldots & \ldots & \ldots \\
c_{n 1} & c_{n 2} & \ldots & c_{n n}
\end{array}\right]
$$

ここで, 右辺の matrix $\mathbf{c}$ は求むべき unitary matrix である.

こうして作られる $\varphi_{1}, \varphi_{2}, \ldots, \varphi_{n}$ を basis として $H$ の matrix を作ると, 式(A2.3.1)の定 義から

$$
\left[\begin{array}{cccc}
\left\langle\varphi_{1}|H| \varphi_{1}\right\rangle & \ldots & \ldots & \left\langle\varphi_{1}|H| \varphi_{n}\right\rangle \\
\left\langle\varphi_{2}|H| \varphi_{1}\right\rangle & \ldots & \ldots & \left\langle\varphi_{2}|H| \varphi_{1}\right\rangle \\
\ldots & \ldots & \ldots & \ldots \\
\left\langle\varphi_{n}|H| \varphi_{1}\right\rangle & \ldots & \ldots & \left\langle\varphi_{n}|H| \varphi_{n}\right\rangle
\end{array}\right]=\left[\begin{array}{cccc}
E_{1} & \ldots & \ldots & 0 \\
0 & E_{2} & \ldots & 0 \\
\ldots & \ldots & \ldots & \ldots \\
0 & \ldots & \ldots & E_{n}
\end{array}\right]
$$

のように，対角項のみ残る。すなわち，式(A2.3.2)が「対角化（diagonalized）」された わけである.この操作を diagonalization という。このような eigenfunction (A2.3.3)を求 めるには次のようにする. 式(A2.3.4)を式(A2.3.3)を用いて書き直す. 


$$
\begin{aligned}
& {\left[\begin{array}{cccc}
c_{11} * & c_{21} * & \ldots & c_{n 1} \\
c_{12} * & c_{22} & \ldots & c_{n 2} \\
\ldots & \ldots & \ldots & \ldots \\
c_{1 n} * & c_{2 n} * & \ldots & c_{n n}
\end{array}\right]\left[\begin{array}{cccc}
H_{11} & \ldots & \ldots & H_{1 n} \\
H_{21} & \ldots & \ldots & H_{2 n} \\
\ldots & \ldots & \ldots & \ldots \\
H_{n 1} & \ldots & \ldots & H_{n n}
\end{array}\right]\left[\begin{array}{cccc}
c_{11} & c_{12} & \ldots & c_{1 n} \\
c_{21} & c_{22} & \ldots & c_{2 n} \\
\ldots & \ldots & \ldots & \ldots \\
c_{n 1} & c_{n 2} & \ldots & c_{n n}
\end{array}\right]} \\
& =\left[\begin{array}{cccc}
E_{1} & \ldots & \ldots & 0 \\
0 & E_{2} & \ldots & 0 \\
\ldots & \ldots & \ldots & \ldots \\
0 & \ldots & \ldots & E_{n}
\end{array}\right]
\end{aligned}
$$

上式より

$$
\begin{aligned}
& {\left[\begin{array}{cccc}
H_{11} & \ldots & \ldots & H_{1 n} \\
H_{21} & \ldots & \ldots & H_{2 n} \\
\ldots & \ldots & \ldots & \ldots \\
H_{n 1} & \ldots & \ldots & H_{n n}
\end{array}\right]\left[\begin{array}{cccc}
c_{11} & c_{12} & \ldots & c_{1 n} \\
c_{21} & c_{22} & \ldots & c_{2 n} \\
\ldots & \ldots & \ldots & \ldots \\
c_{n 1} & c_{n 2} & \ldots & c_{n n}
\end{array}\right] } \\
&= {\left[\begin{array}{cccc}
c_{11} & c_{12} & \ldots & c_{1 n} \\
c_{21} & c_{22} & \ldots & c_{2 n} \\
\ldots & \ldots & \ldots & \ldots \\
c_{n 1} & c_{n 2} & \ldots & c_{n n}
\end{array}\right]\left[\begin{array}{cccc}
E_{1} & \ldots & \ldots & 0 \\
0 & E_{2} & \ldots & 0 \\
\ldots & \ldots & \ldots & \ldots \\
0 & \ldots & \ldots & E_{n}
\end{array}\right] }
\end{aligned}
$$

式(A2.3.6)の matrix の product の各列を比べると，

$$
\left[\begin{array}{cccc}
H_{11} & \ldots & \ldots & H_{1 n} \\
H_{21} & \ldots & \ldots & H_{2 n} \\
\ldots & \ldots & \ldots & \ldots \\
H_{n 1} & \ldots & \ldots & H_{n n}
\end{array}\right]\left[\begin{array}{c}
c_{1 i} \\
c_{21} \\
\ldots \\
c_{n i}
\end{array}\right]=E_{i}\left[\begin{array}{c}
c_{1 i} \\
c_{21} \\
\ldots \\
c_{n i}
\end{array}\right]
$$

が得られる。これは式(A2.1.3)で述べたように, matrix の eigenvalue, eigenvector の関係 である. そしてこの eigenvector の各 element は $\varphi_{i}$ の展開における $\phi_{n}$ の係数となってい る.

以上で明らかなように，式(A2.3.3)の eigenfunction を求めるには $\mathbf{H} の$ matrix の eigenvalue と eigenvector を求め, その eigenvector を各 column に並べた matrix を作れ ばよいことが分かる. eigenfunction は式(A2.3.3)のような表示をしておくとわかりやす い.

放Exercise A2.3.1

orthonormal な $3 つ の$ wavefunction $\phi_{1}, \phi_{2}, \phi_{3}$ を basis function とした時, Hamiltonian 
$H$ について

$$
\begin{aligned}
& \left\langle\phi_{1}|H| \phi_{1}\right\rangle=\left\langle\phi_{2}|H| \phi_{2}\right\rangle=\left\langle\phi_{3}|H| \phi_{3}\right\rangle=0 \\
& \left\langle\phi_{1}|H| \phi_{2}\right\rangle=\left\langle\phi_{2}|H| \phi_{1}\right\rangle=1 \\
& \left\langle\phi_{1}|H| \phi_{3}\right\rangle=\left\langle\phi_{3}|H| \phi_{1}\right\rangle=0 \\
& \left\langle\phi_{2}|H| \phi_{3}\right\rangle=\left\langle\phi_{3}|H| \phi_{2}\right\rangle=1
\end{aligned}
$$

が成り立つとする。 $H$ の eigenfunction を $\phi_{1}, \phi_{2}, \phi_{3}$ の linear combination として表わせ.

\section{【解】：}

$H$ についての行列要素は次のようになる.

$$
\mathbf{H}=\left[\begin{array}{lll}
0 & 1 & 0 \\
1 & 0 & 1 \\
0 & 1 & 0
\end{array}\right]
$$

この matrix の eigenvalue, eigenvector は Section A2.2 の方法で次のようになる. (各自確 かめよ)

$$
\begin{aligned}
E_{1}=-\sqrt{2} \text { に対して } & \mathbf{c}_{1}=\left[\begin{array}{c}
\frac{1}{2} \\
-\sqrt{\frac{1}{2}} \\
\frac{1}{2}
\end{array}\right] \\
E_{2}=0 \text { に対して } & \mathbf{c}_{2}=\left[\begin{array}{c}
\sqrt{\frac{1}{2}} \\
0 \\
-\sqrt{\frac{1}{2}}
\end{array}\right] \\
E_{3}=\sqrt{2} \text { に対して } & {\left[\begin{array}{c}
\frac{1}{2} \\
\sqrt{\frac{1}{2}} \\
\frac{1}{2}
\end{array}\right] }
\end{aligned}
$$

従って, この問題の解としては, 次の結果が得られる.

$$
E=\left[\begin{array}{lll}
-\sqrt{2} & 0 & \sqrt{2}
\end{array}\right]
$$




$$
\left[\begin{array}{lll}
\varphi_{1} & \varphi_{2} & \varphi_{3}
\end{array}\right]=\left[\begin{array}{lll}
\phi_{1} & \phi_{2} & \phi_{3}
\end{array}\right]\left[\begin{array}{ccc}
\frac{1}{2} & \sqrt{\frac{1}{2}} & \frac{1}{2} \\
-\sqrt{\frac{1}{2}} & 0 & \sqrt{\frac{1}{2}} \\
\frac{1}{2} & -\sqrt{\frac{1}{2}} & \frac{1}{2}
\end{array}\right]
$$

¿tsercise A2.3.2

orthonormal な $2 つ の$ wavefunction $\phi_{1}, \phi_{2}$ を basis function とした時, Hamiltonian $H$ について

$$
\begin{aligned}
& \left\langle\phi_{1}|H| \phi_{1}\right\rangle=\left\langle\phi_{2}|H| \phi_{2}\right\rangle=1 \\
& \left\langle\phi_{1}|H| \phi_{2}\right\rangle=i \\
& \left\langle\phi_{2}|H| \phi_{1}\right\rangle=-i
\end{aligned}
$$

が成り立つとする。 $H$ についての eigenfunction を求めよ.

\section{【解】:}

Hについての行列要素は

$$
\mathbf{H}=\left[\begin{array}{cc}
1 & i \\
-i & 1
\end{array}\right]
$$

この matrix の eigenvalue, eigenvector は Exercise A2.1.3 で求めている. その結果を参照 すると，直ちに次の結果が得られる。

$$
\begin{aligned}
& E=\left[\begin{array}{ll}
0 & 2
\end{array}\right] \\
& {\left[\begin{array}{ll}
\varphi_{1} & \varphi_{2}
\end{array}\right]=\left[\begin{array}{ll}
\phi_{1} & \phi_{2}
\end{array}\right]\left[\begin{array}{ll}
-\sqrt{\frac{1}{2}} i & \sqrt{\frac{1}{2}} i \\
\sqrt{\frac{1}{2}} & \sqrt{\frac{1}{2}}
\end{array}\right]}
\end{aligned}
$$

\section{A2.4 線形変分原理}

non-orthogonal basis function $\phi_{1}, \phi_{2}, \ldots, \phi_{n}$ の linear combination としてある state $\varphi_{i}$ を 
表わす。

$$
\varphi_{i}=\sum_{r} c_{r i} \phi_{r}
$$

この条件のもとで, 正しい wavefunction にもっとも近い wavefunction を変分法 （variational method）により求めることを考えよう. 寸なわち，展開係数 $c_{r i}$ を variation principle で求めるわけである。この方法では, total Hamiltonian を $H$ とした時,

$$
E_{i}=\frac{\left\langle\varphi_{i}|H| \varphi_{i}\right\rangle}{\left\langle\varphi_{i} \mid \varphi_{i}\right\rangle}
$$

を minimumにするように， $c_{r i}$ を選ぶ。すなわち，

$$
\frac{\partial E_{i}}{\partial c_{r i}}=0 \quad \frac{\partial E_{i}}{\partial c_{r i}{ }^{*}}=0
$$

式(A2.4.1)と式(A2.4.2)より

$$
E_{i} \sum_{r} \sum_{\mathrm{s}} c_{r i} * c_{\mathrm{si}} S_{r \mathrm{~s}}=\sum_{r} \sum_{\mathrm{s}} c_{r i} * c_{\mathrm{si}} H_{r \mathrm{~s}}
$$

ここで

$$
\begin{aligned}
& S_{r \mathrm{~s}}=\left\langle\phi_{r} \mid \phi_{\mathrm{s}}\right\rangle \\
& H_{r \mathrm{~s}}=\left\langle\phi_{r}|H| \phi_{\mathrm{s}}\right\rangle
\end{aligned}
$$

式(A2.4.4)を $c_{t i}$ *で微分する. $\frac{\partial E_{i}}{\partial c_{t i}{ }^{*}}=0$ を用いて

$$
\sum_{\mathrm{s}} c_{\mathrm{s} i}\left(H_{t \mathrm{~s}}-E_{i} S_{t \mathrm{~s}}\right)=0
$$

この式の non-trivial solution は

$$
\left|\mathbf{H}-E_{i} \mathbf{S}\right|=0
$$

という secular equationより求められる.

もしも，basis setが直交していると，overlap matrix $\mathbf{S}$ は unit matrix I となる。この 場合(A2.5.8)は

$$
\left|\mathbf{H}-E_{i} \mathbf{I}\right|=0
$$

となり，これは式(A2.1.10)ですでに出てきた secular equation である.すなわち， overlap $=0$ の場合には， matrix $\mathbf{H}$ の対角化の問題と等価となる. Section A2.3 で述べ 
たことと Section A2.4 で述べたことは，どちらも数学的には $\mathbf{H}$ とう matrix の対角化 であり，一見似ているように思うかもしれない。しかし，その物理的意味は全く異な ることに注意しないといけない. Section A2.3で述べたことは，ある $H$ の eigenfunction を complete setをなす wavefunction の linear combination で表わそうということで， complete set の wavefunction がある限り，峳密な解が得られる。これはどんな関数も complete set をなす関数で展開出来るという定理に基づいている. 一方, Section A2.4 で行ったことは，ある勝手に選んだ $\phi_{1}, \phi_{2}, \ldots, \phi_{n}$ をもとにして，この linear combination の中でエネルギーが極值を取るものを求めていたにすぎない.すなわち， $\phi_{1}, \phi_{2}, \ldots, \phi_{n}$ の選び方がよくないと正しい wavefunctionからは大きくはずれたものしか得られない わけである.そして如何なる場合には正しい wavefunction が得られることはない. basis functionをよくしていくと，だんだんに正しいものに近づいていくということだけで ある。

[Coffee Break] 極值が最小值になっているか?

賢明な諸君は，もう気付かれていることと思うが，式(A2.4.3)は極值を求めただけ で，エネルギー最小の点を求めたわけではない．量子化学の分野の大部分の変分計算 はそのようにして求められていることは注意しないといけない. 原子や分子の計算で 最も信頼されている Hartree-Fock の方法でも，その点は同じである.式(A2.5.3)により， ひょっとしたら最小值でなく，ある極大值を求めているのではないかという疑問はあ る限られた数の理論家にとってのみ問題にされているだけで, 大部分の人は最小が得 られるのだという信仰を持っているみたいである。 